ES/ESH-31/V1

\title{
OAK RIDGE RESERVATION ENVIRONMENTAL REPORT FOR 1992
}

VOLUME 1: NARRATIVE

\author{
Project director \\ F. C. Kornegay \\ Project coordinator \\ D. C. West \\ Technical coordinators \\ L. W. McMahon \\ Oak Ridge Y-12 Plant \\ J. B. Murphy \\ Oak Ridge National Laboratory \\ Coordinating editor \\ W. S. Koncinski \\ L. G. Shipe \\ Oak Ridge K-25 Site
}

Date Published: September 1993

\author{
Prepared by \\ Environmental, Safety, and Health Compliance \\ and \\ Environmental Management Staffs \\ of the \\ Oak Ridge Y-12 Plant, Oak Ridge National Laboratory, \\ and Oak Ridge K-25 Site \\ managed by \\ MARTIN MARIETTA ENERGY SYSTEMS, INC. \\ P.O. Box 2008 \\ Oak Ridge, Tennessee 37831-6285 \\ for the \\ U.S. DEPARTMENT OF ENERGY \\ under Contract No. DE-AC05-84OR21400
}




\section{Contents}

Page

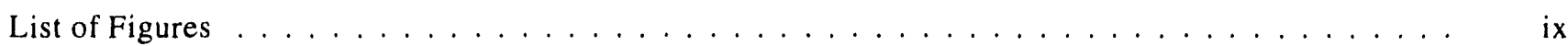

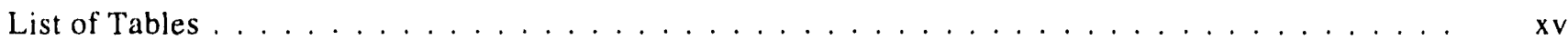

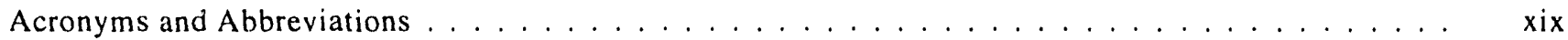

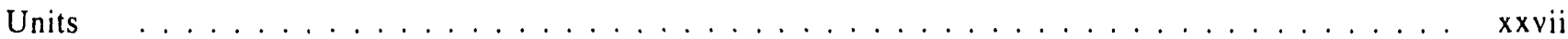

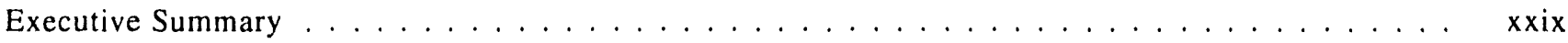

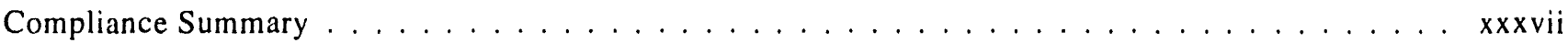

1. Reservation Description and Setting

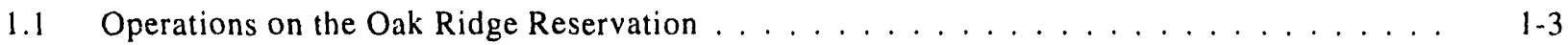

$1.1 .1 \quad$ Y-12 Plant . . . . . . . . . . . . . . . . . . . . . . $1-5$

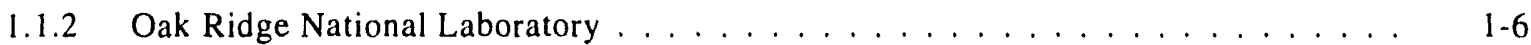

$1.1 .3 \quad$ K-25 Site . . . . . . . . . . . . . . . . . . . . . . . $1-6$

1.1.4 Oak Ridge Institute for Science and Education $\ldots \ldots \ldots \ldots \ldots \ldots \ldots \ldots$

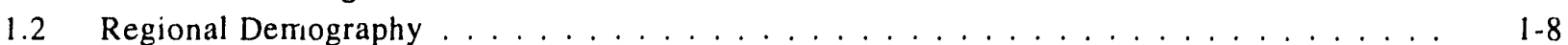

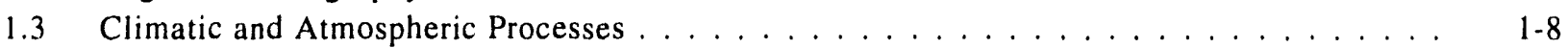

1.3.1 Temperature . . . . . . . . . . . . . . . . . . . . . . . . 1-9

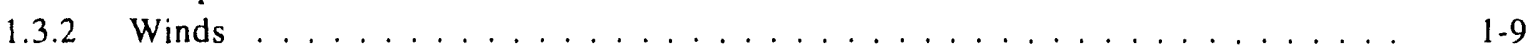

1.3 .3 Precipitation . . . . . . . . . . . . . . . . . . . . . 1.9

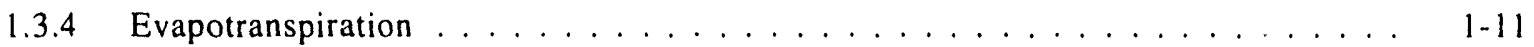

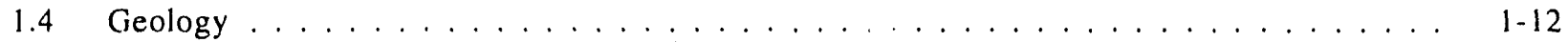

1.4 .1 Stratigraphy . . . . . . . . . . . . . . . . . . . $1-12$

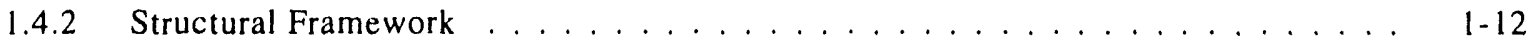

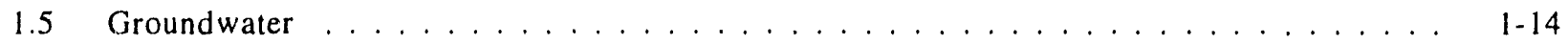

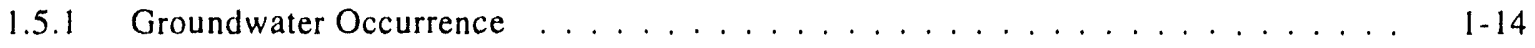

1.5.2 Groundwater Use . . . . . . . . . . . . . . . . . . . . . . . . . 1-15

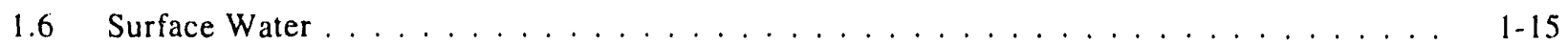

1.6.1 Stream Classification . . . . . . . . . . . . . . . . . . . 1-16

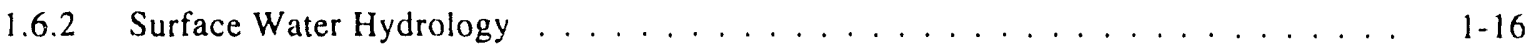

1.6.3 Watershed Characteristics ....................... 1-17

1.6 .4 Water Use . . . . . . . . . . . . . . . . . . . . . . . . 1-17 


\section{Environmental Report Vol. 1, Oak Ridge}

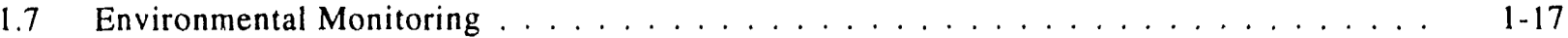

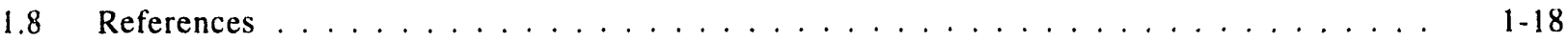

2. Potential Radiation and Chemical Dose to the Public

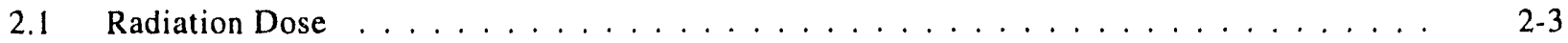

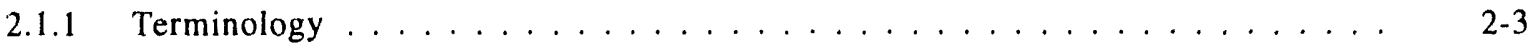

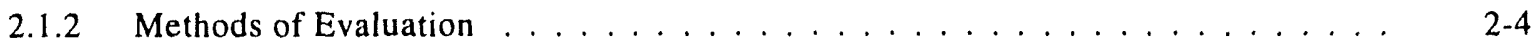

2.1.3 Doses to Aquatic Biota . . . . . . . . . . . . . . . . . . . . 2-11

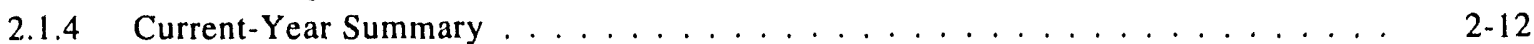

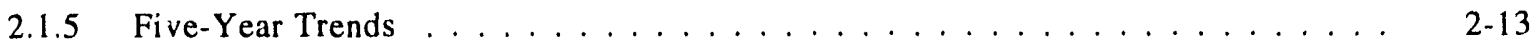

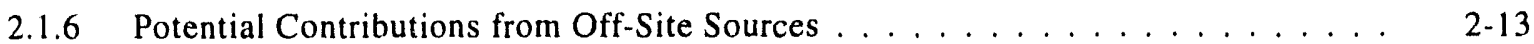

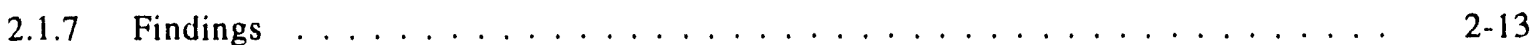

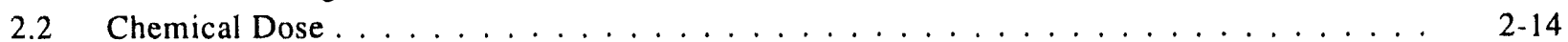

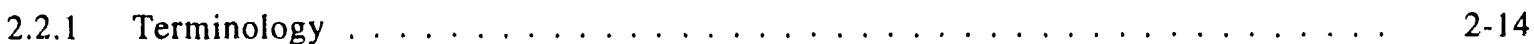

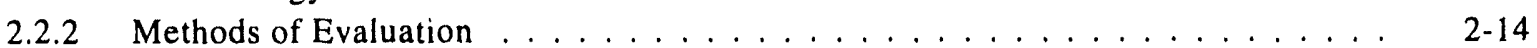

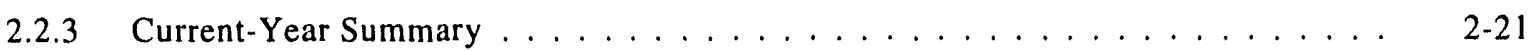

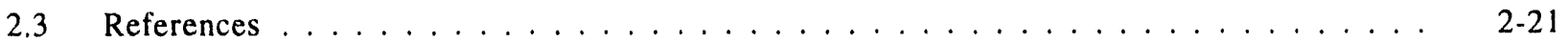

3. Airborne Discharges, Ambient Air Monitoring, Meteorological Monitoring, and External

Gamma Radiation

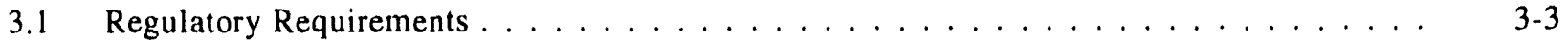

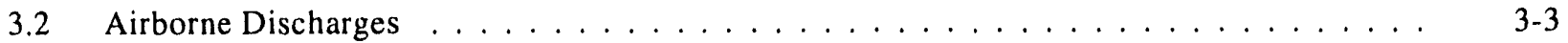

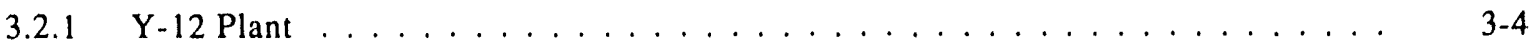

3.2 .2 Oak Ridge National Laboratory . . . . . . . . . . . . . . . . . . . . 3-7

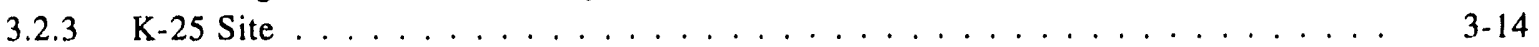

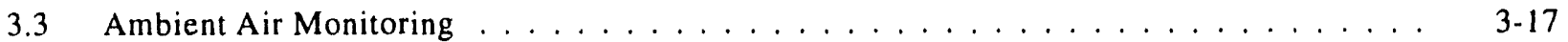

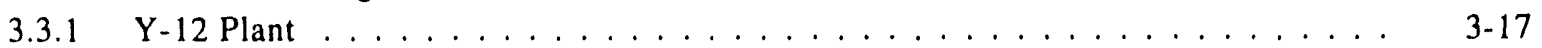

3.3.2 Oak Ridge National Laboratory . . . . . . . . . . . . . . . . . . . . . . . 3-23

$3.3 .3 \quad$ K-25 Site . . . . . . . . . . . . . . . . . . . . . . . . . 3-29

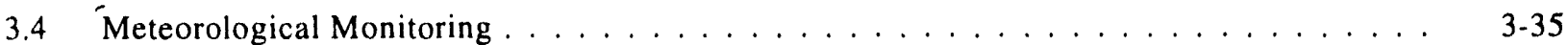

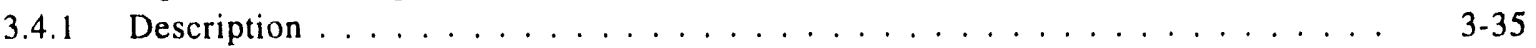

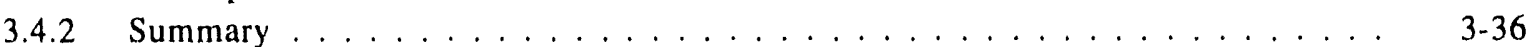

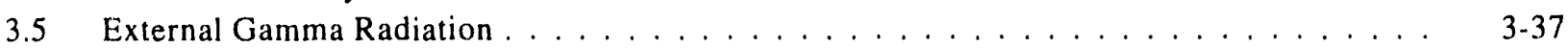

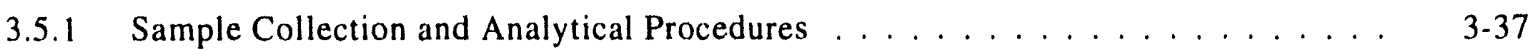

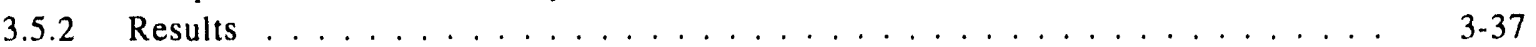

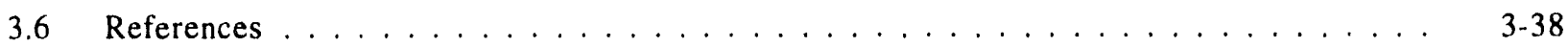

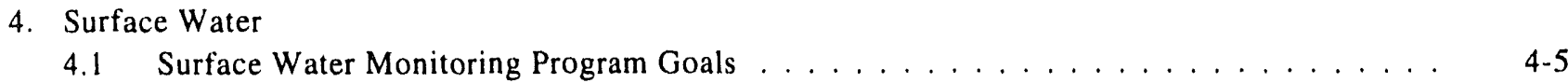

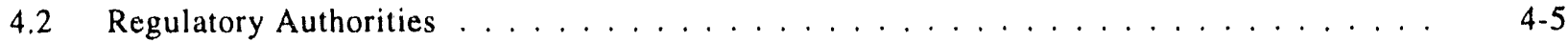

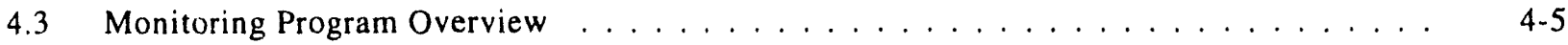

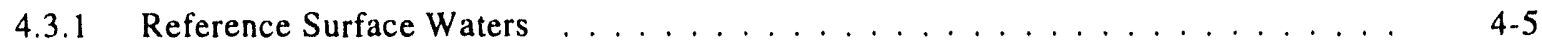

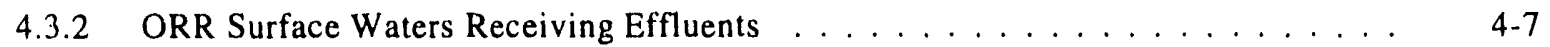

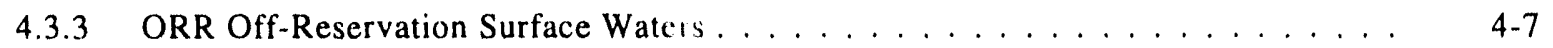

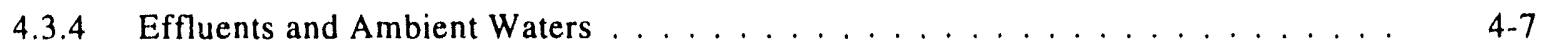

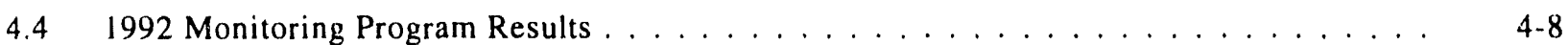

$4.4 .1 \quad$ Y-12 Plant . . . . . . . . . . . . . . . . . . . . . . . . 4-8

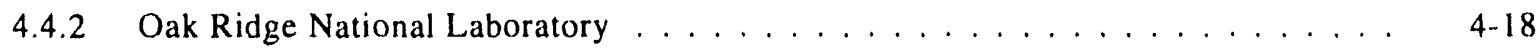




\section{Environmental Report Vol. 1, Oak Ridge}

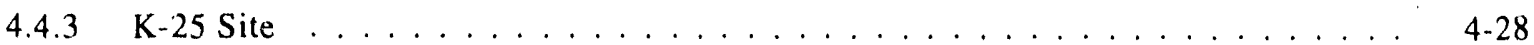

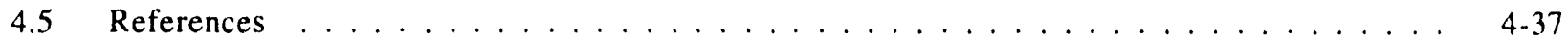

5. Groundwater

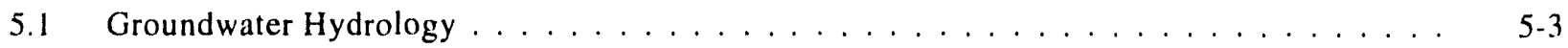

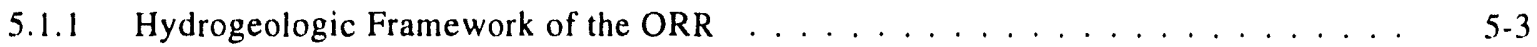

5.1 .2 Groundwater Flow . . . . . . . . . . . . . . . . . . . $5-7$

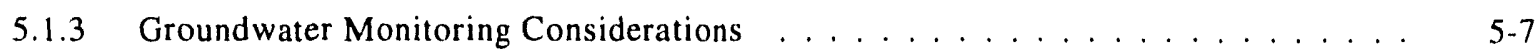

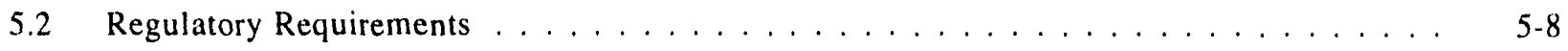

5.2.1 Comprehensive Environmental Response, Compensation, and

Liability Act (CERCLA) . . . . . . . . . . . . . . . . . . . 5 5-8

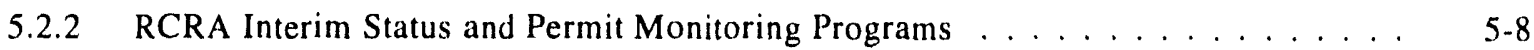

5.2 .3 RCRA $3004(\mathrm{u})$ Monitoring Program . . . . . . . . . . . . . . . . . 5-10

5.2.4 Groundwater Surveillance Monitoring Program on the ORR . . . . . . . . . . 5-10

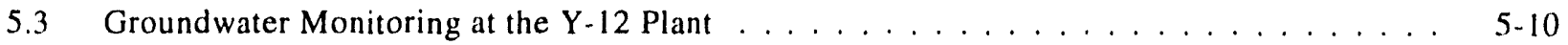

5.3.1 Upper East Fork Poplar Creek Hydrogeologic Regime . . . . . . . . . . . . . . . 5-20

5.3.2 Bear Creek Hydrogeologic Regime . . . . . . . . . . . . . . . . . . . . 5-31

5.3.3 Chestnut Ridge Hydrogeologic Regime . . . . . . . . . . . . . . . . . . 5-39

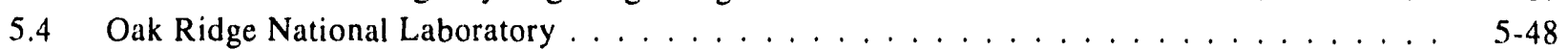

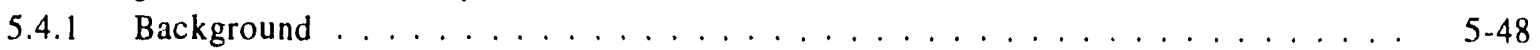

5.4.2 ORNL 1992 Groundwater Quality Well Installation, Development,

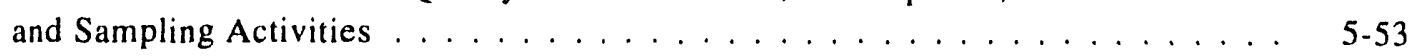

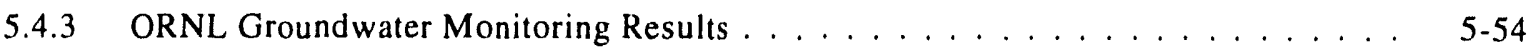

5.4 .4 Future ORNL Groundwater Quality Monitoring Activities . . . . . . . . . . 5-59

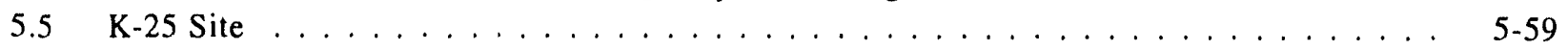

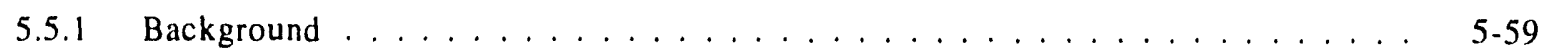

$5.5 .2 \quad$ K-25 Site Hydrogeology . . . . . . . . . . . . . . . . . . 5-61

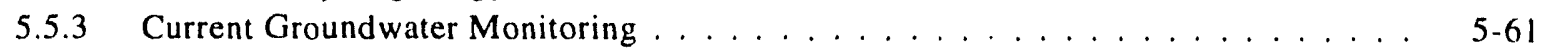

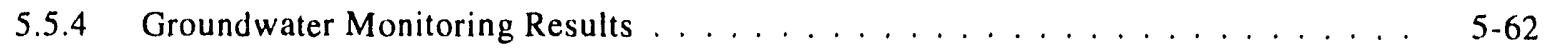

5.5.5 Future K-25 Site Groundwater Program Activities . . . . . . . . . . . . . . 5-68

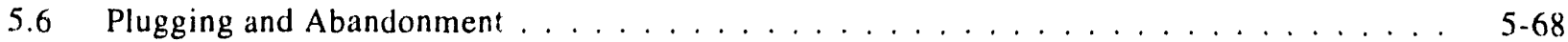

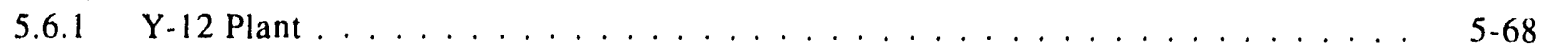

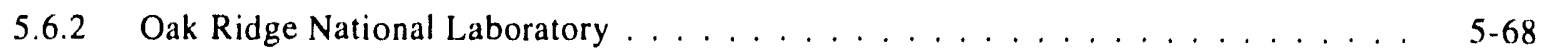

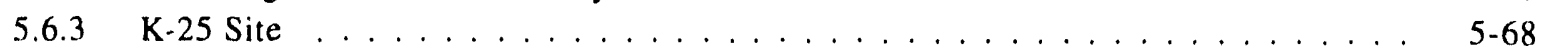

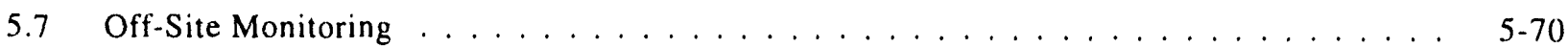

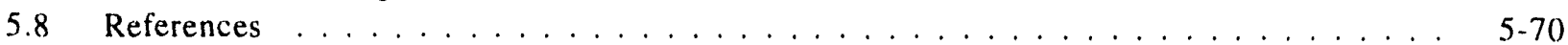

6. Biological Monitoring

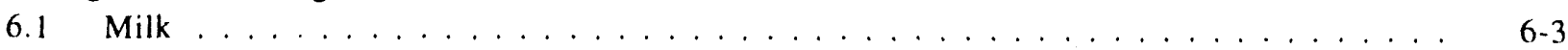

6.1.1 Sample Collection and Analytical Procedures . . . . . . . . . . . . . $6-3$

6.1 .2 Results ............................ 6-3

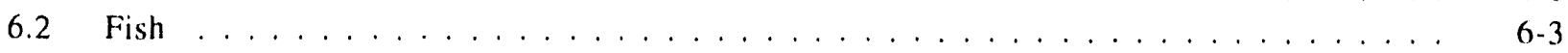

6.2 .1 Sample Collection and Analytical Procedures . . . . . . . . . . . . $6-3$

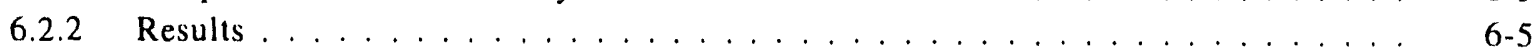

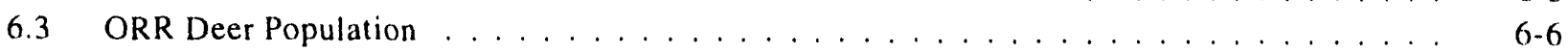

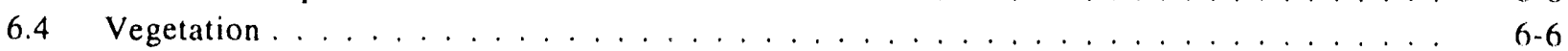

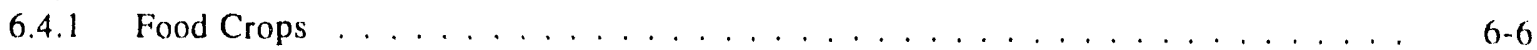

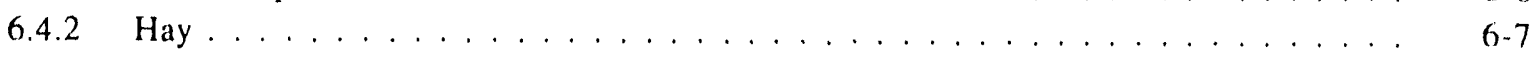




\section{Environmental Report Vol. 1, Oak Ridge}

6.5 Biological Monitoring and Abatement Programs (BMAPs) $\ldots \ldots \ldots \ldots \ldots \ldots$. . . . . .

6.5.1 Monitoring Contaminant Concentrations . . . . . . . . . . . . . . 6-7

6.5.2 Indications of Ecological Recovery in Three Receiving Streams near DOE Oak Ridge Facilities . . . . . . . . . . . . . . . . . . . 6 6-14

6.5.3 Effects of Effluent Dechlorination on Clams in East Fork Poplar Creek . . . . . . 6-17

6.5.4 Changes in Trace Element Concentrations in Largemouth Bass Following Elimination of Fly Ash Discharge to Rogers Quarry . . . . . . . . . . . . . . 6-17

6.5.5 Radioactivity in Largemouth Bass from White Oak Lake . . . . . . . . . . . . . . 6-19

6.5.6 Radioactivity in Resident Canada Geese . . . . . . . . . . . . . . . . . . 6-20

6.6 References . . . . . . . . . . . . . . . . . . . . . . . . . . . 6-20

7. Soil and Sediment Monitoring

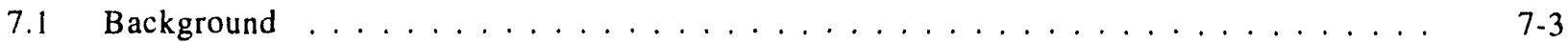

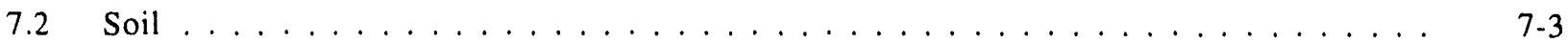

7.2 .1 The Oak Ridge Reservation . . . . . . . . . . . . . . . . . . . . . . . . . . . . . . .

7.2 .2 Soil Sampling at the K-25 Site . . . . . . . . . . . . . . . . . . . . . . 7-4

7.3 Sediment . . . . . . . . . . . . . . . . . . . . . . . . 7.4

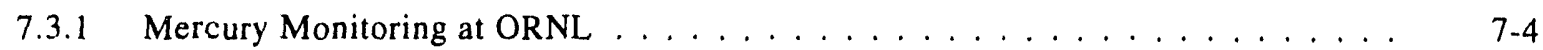

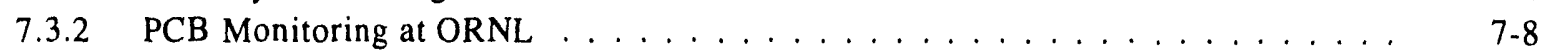

7.3.3 Sediment Sampling at the K-25 Site . . . . . . . . . . . . . . . . . . . . . . . 7-8

7.4 Soil Management Plan ............................ . . . . . . . . . . .

8. Special Studies

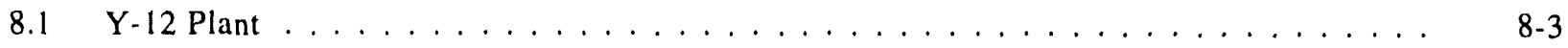

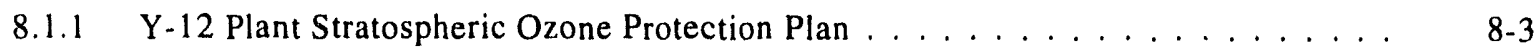

8.1.2 Y-12 Plant Voluntary Reduction of Hazardous Air Pollutants . . . . . . . . . 8 8

8.1.3 Y-12 Plant Stack 62 Emission Event . . . . . . . . . . . . . . . $8-4$

8.1 .4 Accidental Release of Hydrogen Fluoride . . . . . . . . . . . . . . . . . . . . . . 8.4

8.1.5 Visible Emission Evaluations Conducted at the Y-12 Plant . . . . . . . . . . . . . 8-4

8.1 .6 Historical PCB Spills . . . . . . . . . . . . . . . . . . . . . . . . . . . . . . . .

8.1 .7 Dechlorination Work at Y-12 Plant . . . . . . . . . . . . . . . . . . . . . . . . . .

8.1.8 Non-Point-Source Pollution Control . . . . . . . . . . . . . . . . . . . . . 8-6

8.1 .9 Water Corrective Action Program . . . . . . . . . . . . . . . . . . . . . . . . . . . . . . . .

8.2 Oak Ridge National Laboratory . . . . . . . . . . . . . . . . . . . . . . . . . . 8.7

8.2.1 ORNL Waste Area Groupings Ranked According to Human Health Risks . . . . . . 8-7

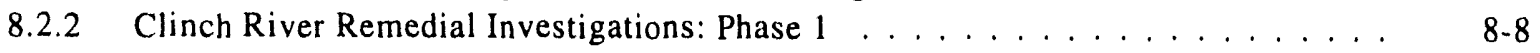

8.2.3 Mapping Soil Contaminated with Heavy Metals . . . . . . . . . . . . . . . . . . 8-8

8.2.4 Contaminated-Sediment Transport in the White Oak Creek Catchment

During Floods . . . . . . . . . . . . . . . . . . . . . . . . . 8-8

8.2.5 Co-Metabolic Techniques Bioreactor Demonstration Project . . . . . . . . . . . . . . 8-9

8.2 .6 Environmental Restoration .......................... 8-10

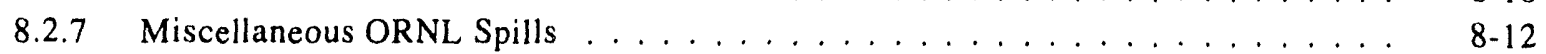

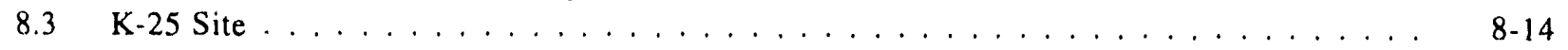

8.3.1 Dechlorination in Mitchell Branch . . . . . . . . . . . . . . . . . $8-14$

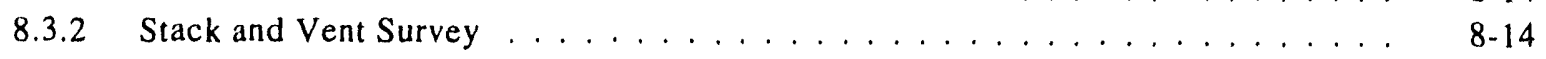

8.3.3 TSCA Air Monitoring Station Relocation . . . . . . . . . . . . . . . . . . . . . . . . . . .

8.3 .4 CFC Equipment Replacement Plan . . . . . . . . . . . . . . . . . . . . . . . . . . . .

8.3.5 Pond Waste Management Program Air Emissions . . . . . . . . . . . . . . . . . . 8-15 


\section{Environmental Report Vol. 1, Oak Ridge}

\subsubsection{K-25 Site Ambient Air Monitoring Program Review Against DOE Order}

and Regulatory Requirements . . . . . . . . . . . . . . . . . . 8-16

8.3.7 K-25 Site PM10 Ambient Air Monitoring Program Review . . . . . . . . . . 8 8-16

8.3.8 Oak Ridge K-25 Site Ambient Air Monitoring Semiannual Report,

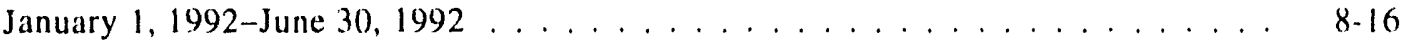

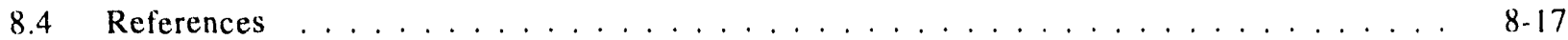

9. Solid Waste Management Program

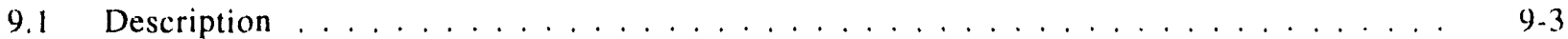

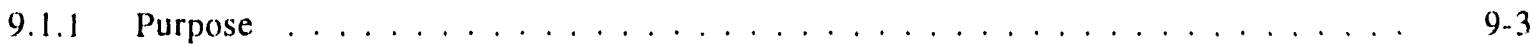

9.1.2 Types of Wastes Generated . . . . . . . . . . . . . . . . . . . . 9 9-3

9.1 .3 Regulations and Guidance . . . . . . . . . . . . . . . . . . . . . . 9 9-4

9.1 .4 Compliance Activities . . . . . . . . . . . . . . . . . . . . . . . 9-5

9.1 .5 Program Strategy . . . . . . . . . . . . . . . . . . . . . . . . . 9 9-6

9.2 Waste-Generating Activities $\ldots \ldots \ldots \ldots \ldots \ldots \ldots \ldots$

$9.2 .1 \quad$ Y-12 Plant . . . . . . . . . . . . . . . . . . . . . . . . 9-13

9.2 .2 Oak Ridge National Laboratory . . . . . . . . . . . . . . . . . . . . . . . . . . 9-14

$9.2 .3 \quad$ K-25 Site . . . . . . . . . . . . . . . . . . . . . . . 9-15

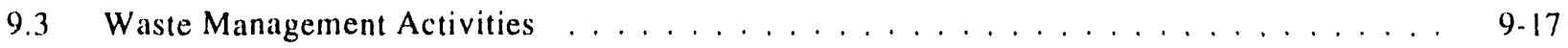

9.3.1 Waste Management System . . . . . . . . . . . . . . . . . . 9.17

9.3 .2 Waste Management Facilities . . . . . . . . . . . . . . . . . . 9.17

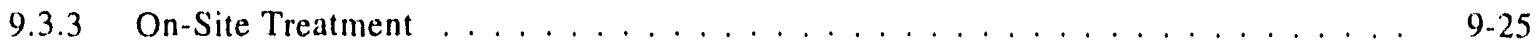

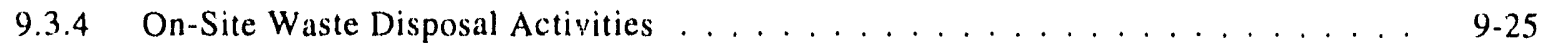

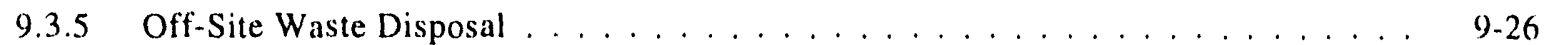

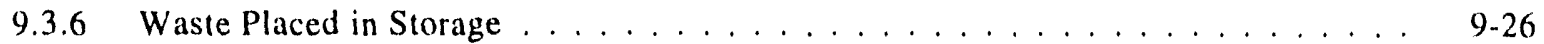

9.4 References . . . . . . . . . . . . . . . . . . . . . . . . 9-27

10. Quality Assurance

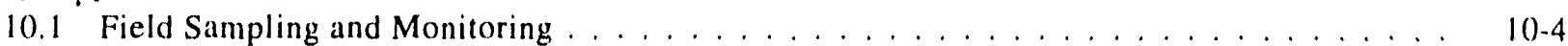

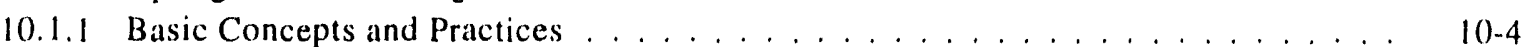

10.1 .2 Air Monitoring . . . . . . . . . . . . . . . . . . . . 10-5

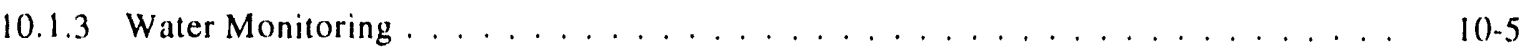

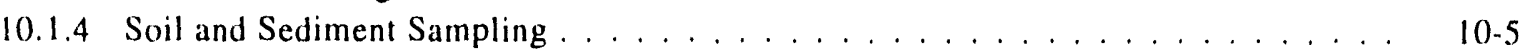

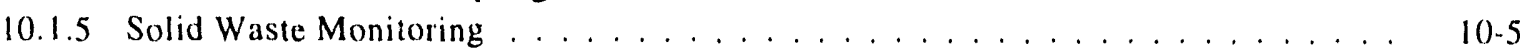

1.0.1.6 Biological Monitoring . . . . . . . . . . . . . . . . . . . . . . . 10-6

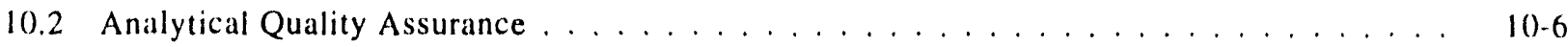

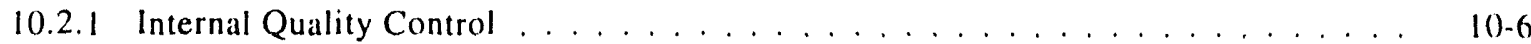

10.2.2 External Quality Control . . . . . . . . . . . . . . . . . . . 10-7

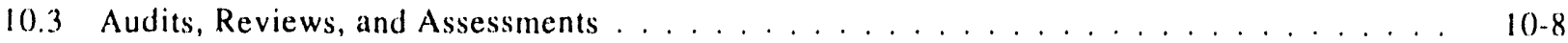

10.3.1 Y-12 Plant . . . . . . . . . . . . . . . . . . . . . . 10-8

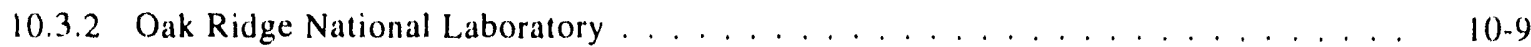

10.3 .3 K-25 site . . . . . . . . . . . . . . . . . . . . . . . 10-10

Appendixes

A: $\quad$ Chemical Releases of the Oak Ridge

Reservation Facilities, 1992 Environmental Report . . . . . . . . . . . . . . . A A-3

B: Errata for Oak Ridge Reservation

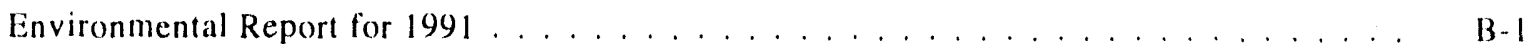

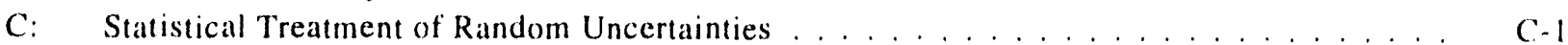




\section{List of Figures}

Figure

Page

1 Map showing location of Oak Ridge and the Oak Ridge Reservation in relation to

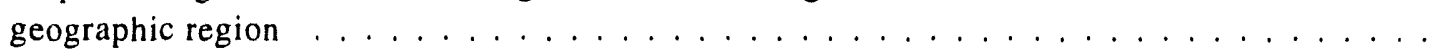

$\mathrm{XXX}$

2 Map showing the Oak Ridge Reservation and the location of the three

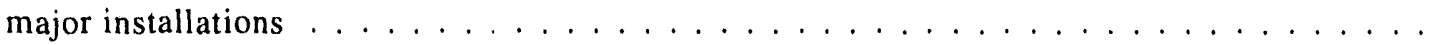

Typical annual radiation doses from various sources $\ldots \ldots \ldots \ldots \ldots$

$x \times x i$

4 The collective effective dose equivalent of the entire population within $80 \mathrm{~km}$

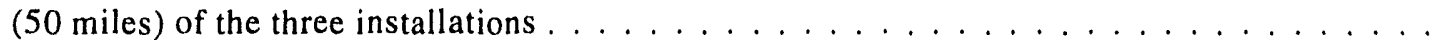

5 Estimated maximum effective dose equivalent to the maximally exposed members

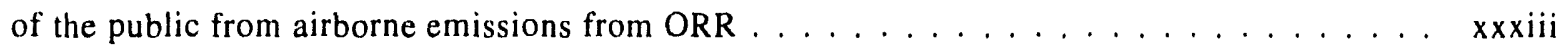

6 Maximum calculated 50-year committed effective dose equivalent from drinking

water from the Gallaher water plant $\ldots \ldots \ldots \ldots \ldots \ldots \ldots \ldots \ldots$

1.1 Map showing location of Oak Ridge and the Oak Ridge Reservation in relation to

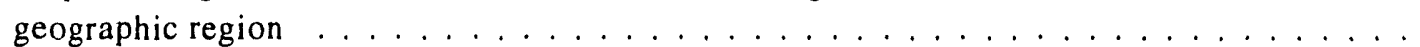

1.2 Map showing the Oak Ridge Reservation and the location of the three major installations

1.3 Oak Ridge $\mathrm{Y}-12$ Plant (view looking northwest) $\ldots \ldots \ldots \ldots \ldots$

1.4 Oak Ridge National Laboratory $($ view looking west $) \ldots \ldots \ldots \ldots \ldots \ldots$

1.5 Oak Ridge $\mathrm{K}-25$ Site $($ view looking northwest) $\ldots \ldots \ldots \ldots \ldots \ldots$

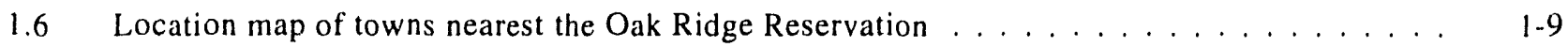

1.7 Projected 1992 population densities within $16 \mathrm{~km}$ ( 10 miles) of the center of the Oak Ridge Reservation, based on 1990 census data (U.S. Department of

Commerce 1991) . . . . . . . . . . . . . . . . . . . . . . . . . . 


\section{Environmental Report Vol. 1, Oak Ridge}

1.8 Projected 1992 population densities within $80 \mathrm{~km}$ (50 miles) of the Oak Ridge

Reservation, based on 1990 census data (U.S. Department of Commerce 1991) . . . . . . . .

1.9 Annual precipitation history of the Oak Ridge area $\ldots \ldots \ldots \ldots \ldots \ldots$

1.10 Genlogy of the southern Appalachians $\ldots \ldots \ldots \ldots \ldots \ldots \ldots$

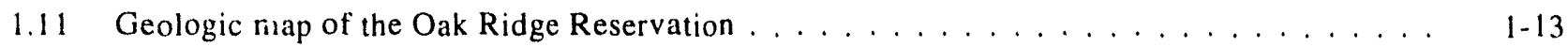

1.12 Geologic cross section of the Oak Ridge Reservation . . . . . . . . . . . . . . . 1-14

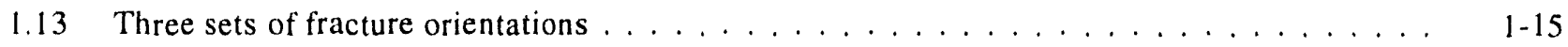

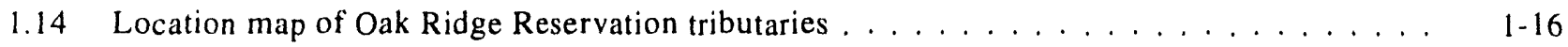

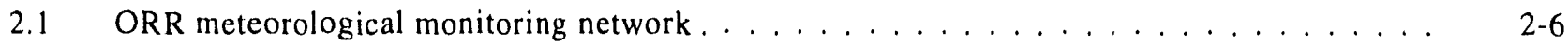

3.1 Total curie discharges of uranium from the Y-12 Plant to the atmosphere,

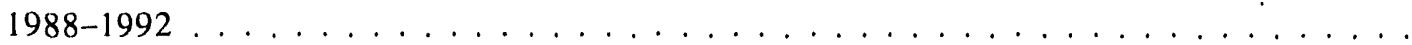

3.2 Total kilograms of uranium discharged from the Y-12 Plant to the atmosphere,

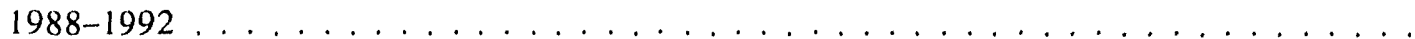

3.3 Locations of major stacks (emission points) at ORNL $\ldots \ldots \ldots \ldots \ldots$

3.4 Total discharges of ${ }^{3} \mathrm{H}$ from ORNL to the atmosphere, $1988-1992 \ldots \ldots \ldots$. $\ldots \ldots$

3.5 Total discharges of ${ }^{133} \mathrm{Xe}$ from ORNL to the atmosphere, $1988-1992 \ldots \ldots \ldots 3-13$

3.6 Total discharges of ${ }^{85} \mathrm{Kr}$ from ORNL to the atmosphere, $1988-1992 \ldots \ldots$. . . . . . . .

3.7 Total discharges of ${ }^{131}$ I from ORNL to the atmosphere, $1988-1992 \ldots \ldots \ldots$. . . . . . . $\ldots 3$

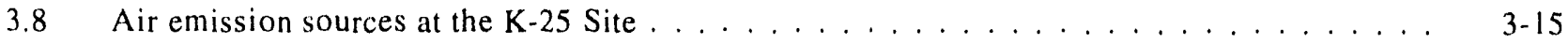

3.9 Air pollution control program at the $\mathrm{K}-25$ Site $\ldots \ldots \ldots \ldots \ldots \ldots \ldots$

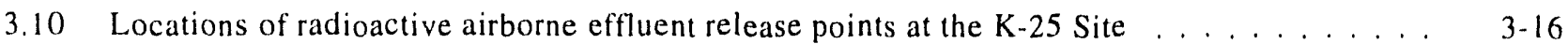

3.11 Total curie discharges of uranium from the K-25 Site to the atmosphere,

3.12 Total kilograms of uranium discharged from the K-25 Site to the atmosphere, $1988-1992$

3.13 Total curie discharges of technetium from the K-25 Site to the atmosphere, 


\section{Environmental Report Vol. 1, Oak Ridge}

3.14 Total kilograms of technetium discharges from the K-25 Site to the atmosphere, 1988-1992

3.15 Ambient air monitoring stations at the $\mathrm{Y}-12$ Plant $\ldots \ldots \ldots \ldots \ldots$

3.16 Time trends in mercury vapor concentrations for five monitoring sites at the Y-12 Plant and for Rain Gage No. 2 at Walker Branch Watershed . . . . . . . . . . 3-26

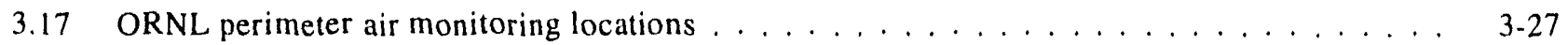

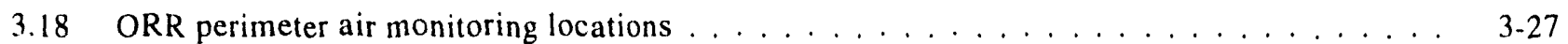

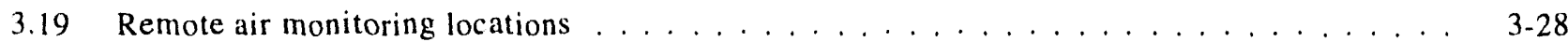

3.20 Location of the K-25 Site ambient air monitors and meteorological tower . . . . . . . . . . 3-31

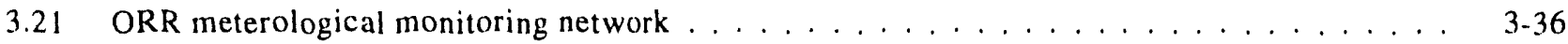

3.221992 wind rose for Y-12 Plant tower MT5 (east) (100-m level), with $99.4 \%$ of

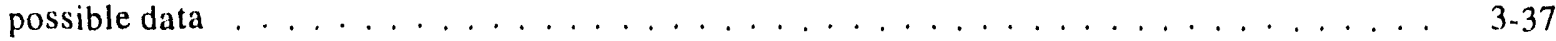

3.23 ORR external gamma measurement locations $\ldots \ldots \ldots \ldots \ldots \ldots \ldots \ldots \ldots \ldots$

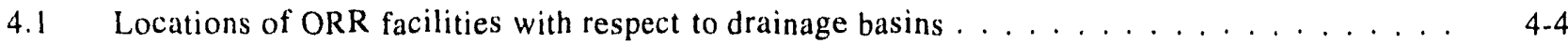

4.2 Surface water sampling locations on the ORR $\ldots \ldots \ldots \ldots \ldots \ldots$

$4.3 \quad \mathrm{Y}-12$ Plant non-NPDES routine surface water monitoring sites $\ldots \ldots \ldots \ldots$

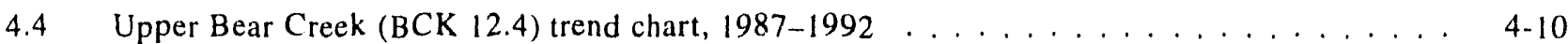

$4.5 \quad$ Y-12 Plant NPDES radiological monitoring plan locations $\ldots \ldots \ldots \ldots \ldots$

4.6 Y-12 Plant NPDES noncompliance status comparison and sources of noncompliances _. . . 4-17

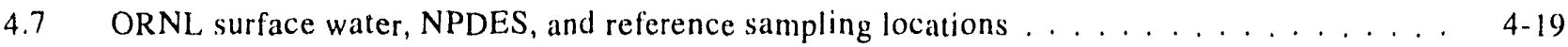

4.8 Surface water sampling locations for mercury monitoring in the ORNL main plant area $\ldots . \quad 4-22$

4.9 Location map of Gallaher and Kingston sampling points $\ldots \ldots \ldots \ldots \ldots \ldots \ldots$

4.10 ORNL NPDES noncompliance status comparison and sources of noncompliances . . . . . . 4-26

4.11 K-25 Site surface water monitoring locations (January I through September 30, 1992) _ . . . 4-29

4.12 K-25 Site surface water monitoring locations for the site monitoring program (October 1 to December 31, 1992) . . . . . . . . . . . . . . . . . . . . . . 4-30

4.13 K-25 Site NPDES major outfalls (October 1 io December 31,1992$) \ldots \ldots \ldots \ldots$. . . . . . . 


\section{Environmental Report Vol. 1, Oak Ridge}

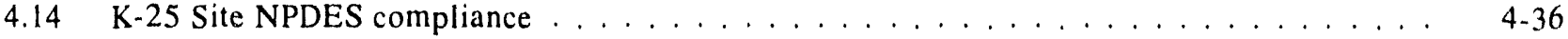

5.1 Schematic vertical relationships of flow zones of the ORR, estimated

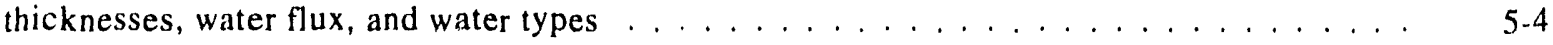

5.2 Map showing the Knox Aquifer and the aquitards on the Oak Ridge Reservation . . . . . $5-5$

5.3 Cross section showing the water table $\ldots \ldots \ldots \ldots \ldots \ldots \ldots$

5.4 Relationship between interim status monitoring and pernit monitoring programs . . . . . . $5-9$

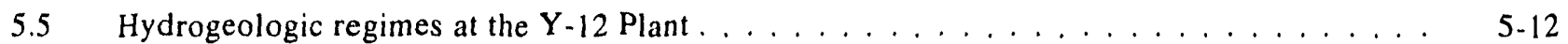

5.6 Locations of exit pathway monitoring pickets in Bear Creek Valley . . . . . . . . . . $5-13$

5.7 Location map for Westbay wells at the $\mathrm{Y}-12$ Plant $\ldots \ldots \ldots \ldots \ldots \ldots$

$5.8 \quad \mathrm{Y}-12$ Plant operable units $\ldots \ldots \ldots \ldots \ldots \ldots \ldots \ldots \ldots \ldots$

5.9 East Fork regime waste-management sites and underground storage tanks $\ldots \ldots \ldots$. . . . $5-21$

5.10 Volatile organic compounds in groundwater in selected wells in the East Fork regime . . . . 5-25

5.11 Nitrate (as $\mathrm{N}$ ) observed in groundwater at the $\mathrm{Y}-12$ Plant $\ldots \ldots \ldots \ldots \ldots \ldots$

5.12 Summed volatile organic compounds in groundwater at the $\mathrm{Y}-12$ Plant $\ldots \ldots \ldots$. $\ldots \ldots$

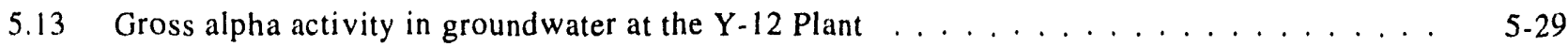

5.14 Gross beta activity in groundwater at the $\mathrm{Y}-12 \mathrm{Plant} \ldots \ldots \ldots \ldots \ldots$

5.15 Exit-pathway monitoring wells at Picket $\mathrm{J} \ldots \ldots \ldots \ldots \ldots \ldots \ldots \ldots$

5.16 Bear Creek Valley Hydrogeologic regime, showing the waste-management sites $\ldots \ldots \ldots$. . . 53

5.17 Concentrations of selected contaminants in monitoring wells GW-243 and GW-225

in the Bear Creek regime . . . . . . . . . . . . . . . . . . . 5-37

5.18 Exit-pathway monitoring wells at Picket $\mathrm{C} \ldots \ldots \ldots \ldots \ldots \ldots \ldots$

5.19 Exit-pathway monitoring wells at Picket $\mathrm{W} \ldots \ldots \ldots \ldots \ldots \ldots \ldots$

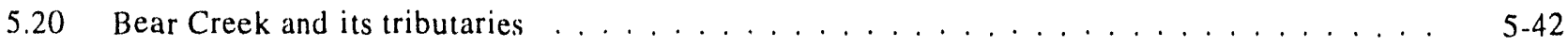

5.21 Waste management sites in the Chestnut Ridge Hydrogeologic regime . . . . . . . . . 5-43

5.22 Concentrations of volatile organic compounds in monitoring wells at the Chestnut Ridge Security Pits . . . . . . . . . . . . . . . . . . . . 5-47 


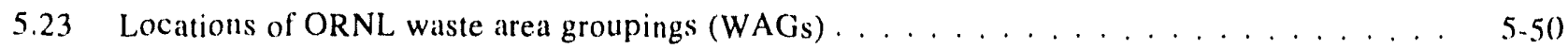

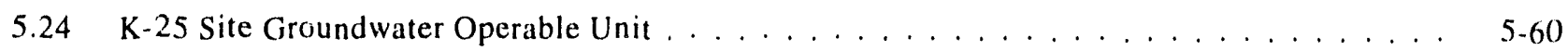

5.25 Proposed exit pathway groundwater surveillance well locations at the K-25 Site . . . . . . 5-63

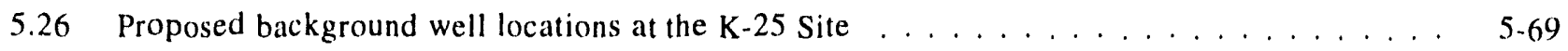

6.1 Map showing milk sampling stations $\ldots \ldots \ldots \ldots \ldots \ldots \ldots \ldots \ldots$

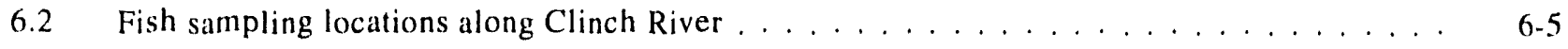

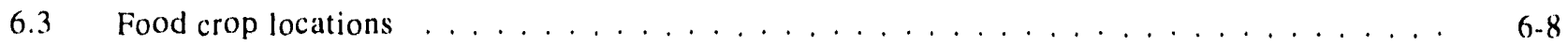

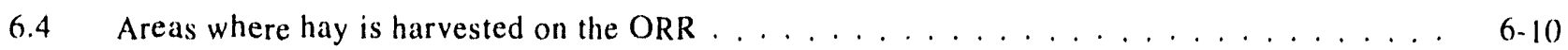

6.5 Locations of channel catfish and redbreast sunfish collection sites for

BMAP bioaccumulation studies $\ldots \ldots \ldots \ldots \ldots \ldots \ldots \ldots \ldots \ldots \ldots$

6.6 Average concentrations of mercury in redbreast sunfish $(n=8)$ collected

at sites in East Fork Poplar Creek, 1984-1992 . . . . . . . . . . . . . . . . . . . . 6-12

6.7 Average concentrations of PCBs in redbreast sunfish $(n=8)$ collected

semiannually at sites in East Fork Poplar Creek, 1985-1992 . . . . . . . . . . . . . . . .

6.8 Average concentrations ( $\pm 1 \mathrm{SE}$ ) of mercury $(\mu \mathrm{g} / \mathrm{g}$, wet weight)

in sunfish collected in fall 1990 at sites on the ORR . . . . . . . . . . . . . . . . $6-14$

6.9 Average concentrations ( $\pm 1 \mathrm{SE})$ of PCB $(\mu \mathrm{g} / \mathrm{g}$, wet weight)

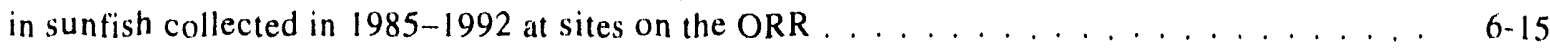

6.10 Fish community density at East Fork Poplar Creek site EFK 23.K, Bear Creek site

BCK 12.4, and White Oak Creek site WCK 3.9, spring 1985 to fall $1992 \ldots \ldots \ldots$. . . . . . . .

6.11 In situ growth of fingernail clams (Sphaerium fabale) during five separate 3-week

exposures at three sites on East Fork Poplar Creek and a reference site (Beaver Creek) . . . . . 6-18

6.12 Cesiuni-137 in fillets from largemouth bass collected in White Oak Lake . . . . . . . . 6-19

7.1 Soil sampling locations around the $\mathrm{K}-25$ Site $\ldots \ldots \ldots \ldots \ldots \ldots$. . . . . . . . . .

7.2 Sediment sampling locations for mercury monitoring in the immediate ORNL area $\ldots \ldots$ 7-7

7.3 Sampling locations for PCB monitoring in the immediate ORNL area . . . . . . . . 7.9

7.4 Sampling locations for PCB monitoring in the greater ORNL area . . . . . . . . 7.9

7.5 Sediment sampling locations in the vicinity of the K-25 Site $\ldots \ldots \ldots \ldots \ldots$.11 
8.1 ORNL spill summary, $1986-1992 \ldots \ldots \ldots \ldots$

8.2 ORNL spill summary, material frequency ..................... . . . . . . . . .

8.3 ORNL spill summary, volume frequency . . . . . . . . . . . . . . . . 8 .13

9.1 Hazardous and mixed waste categories developed for the HAZWDDD Plan . . . . . . . . 9.9

9.2 Categories of solid waste sources and flow of mixed wastes . . . . . . . . . . . 9.12 


\section{List of Tables}

Table

Page

1 Oak Ridge Reservation exposure pathways and effective dose equivalents for a maximally exposed individual $(\mathrm{m}=\mathrm{em}) \ldots \ldots \ldots \ldots \ldots \ldots \ldots \ldots \ldots$

2 Summary of 1992 ORNL compliance activities relevant to DOE Order $5820.2 \mathrm{~A} \ldots \ldots$ lix

2.1 Release point parameters and receptor locations used in the dose calculations . . . . . . . $2-5$

2.2 Calculated radiation doses to maximally exposed off-site individuals from airborne releases during $1992 \ldots \ldots \ldots \ldots \ldots \ldots \ldots \ldots$. . . . . . . . . . . . . . . . . . . . . .

2.3 Calculated collective effective dose equivalents due to airborne releases during $1992 \ldots \ldots$. . .

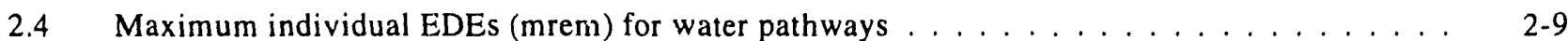

2.5 Summary of estimated radiation dose equivalents to an adult during 1992 at locations of maximum exposure . . . . . . . . . . . . . . . . . . . . . . 2-12

2.6 Five-year trends in committed effective dose equivalent for selected pathways . . . . . . 2-13

2.7 Acceptable daily intakes for chemicals found above detection limits at ORR facilities _. . . 2-15

2.8 Chemical dose/acceptable daily intake comparisons for surface waters at ORR reference

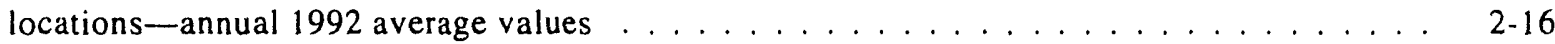

2.9 Chemical dose/acceptable daily intake comparisons for surface waters at Y-12 Plant locations-annual 1992 average values $\ldots \ldots \ldots \ldots \ldots \ldots$

2.10 Chemical dose/acceptable daily intake comparisons for surface waters at ORNL

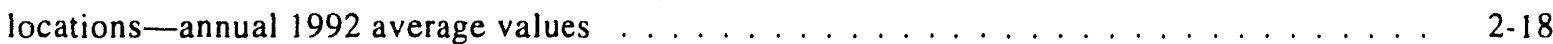

2.11 Chemical dose/acceptable daily intake comparisons for surface waters at K-25 Site perimeter monitoring locations-annual 1992 average values . . . . . . . . . . . . . . . .

2.12 Chemical dose/acceptable daily intake comparisons for fish intake-annual upper $95 \%$ confidence interval values 


\section{Environmental Report Vol. 1, Oak Ridge}

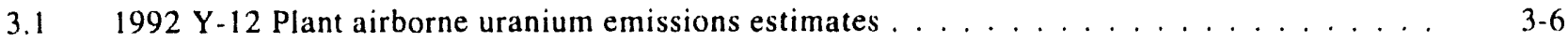

3.2 Data sources for airborne radioactive emissions from ORNL, $1992 \ldots \ldots \ldots$ 3-10

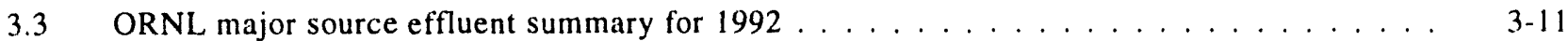

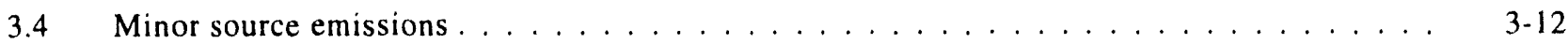

3.5 Total radionuclide emissions during normal operations from the K-25 Site TSCA

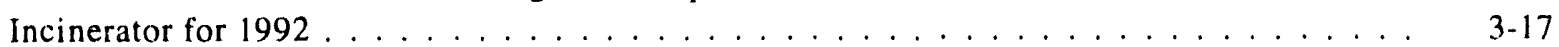

3.61992 radionuclide emissions from minor sources at the $\mathrm{K}-25$ Site $\ldots \ldots \ldots \ldots$. . . . . .

3.7 1992 gross alpha and beta in air at the Y-12 Plant perimeter ambient air

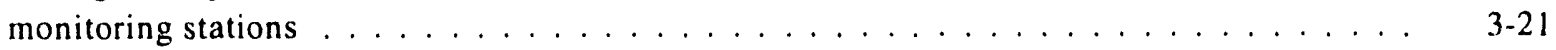

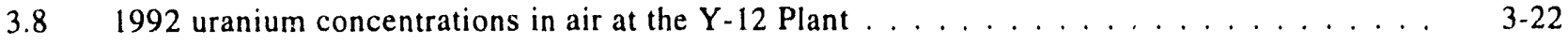

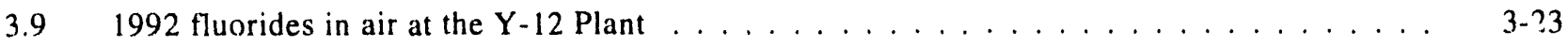

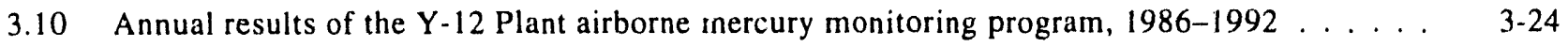

3.111992 total suspended particulates in air at the Y-12 Plant TSP monitoring station . . . . . 3-25

3.121992 PM10 concentrations in air at the Y-12 Plant PM10 monitoring station $\ldots \ldots$ 3-25

3.13 1992 summary of collection and analysis frequencies of ORNL and ORR air monitoring stations $\ldots \ldots \ldots \ldots \ldots \ldots \ldots \ldots \ldots \ldots$

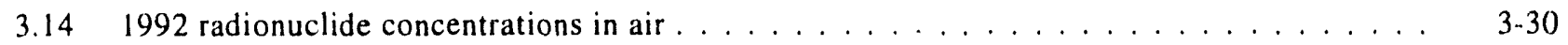

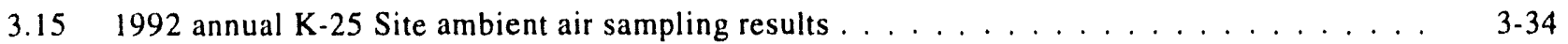

$3.161992 \mathrm{~K}-25$ Site ambient air sampling quarterly lead results $\ldots \ldots \ldots \ldots \ldots \ldots$

3.17 External gamma radiation measurements at ORR perimeter air monitoring stations, $1992 \ldots$ 3-39

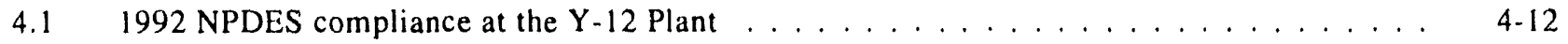

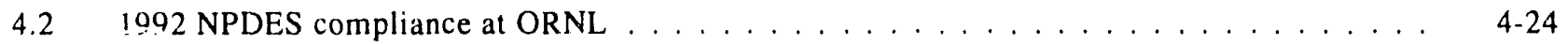

4.31992 NPDES compliance at the K-25 Site $\ldots \ldots \ldots \ldots \ldots \ldots \ldots \ldots \ldots$

5.1 Description of surface-water and spring monitoring stations included in the

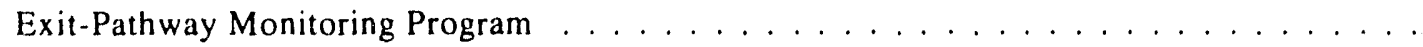

5.2 Summary of the groundwater surveillance program at the Y-12 Plant, $1992 \ldots \ldots$. . . . . 5

$5.3 \quad$ Y-12 Plant monitoring wells installed in $1992 \ldots \ldots \ldots \ldots \ldots \ldots \ldots \ldots$ 
5.4 Summary of ORNL waste area groupings, $1992 \ldots \ldots \ldots \ldots \ldots \ldots \ldots$

5.5 Summary of the groundwater surveiliance program at ORNL, $1992 \ldots \ldots \ldots \ldots$

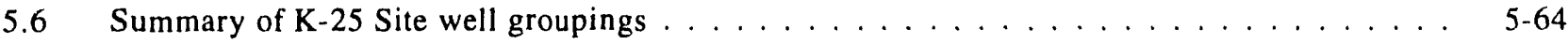

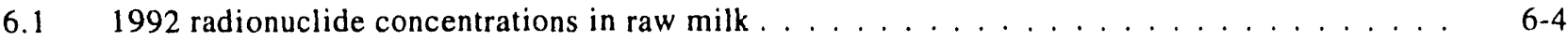

6.2 Metals, pesticides, and PCBs in fish at ORNL sampling locations $\ldots \ldots \ldots \ldots$

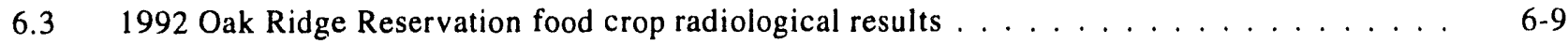

6.41992 Oak Ridge Reservation hay radiological results $\ldots \ldots \ldots \ldots \ldots \ldots \ldots$

6.5 Changes from 1986 to 1992 in average concentrations of PCBs $(\mu \mathrm{g} / \mathrm{g}$, wet wt) and fraction of fish exceeding the Food and Drug Administration (FDA) limit, for channel catfish from White Oak Creek embayment (WCK), the Clinch River (CRK), lower Poplar Creek (PCK), and Melton Hill Reservoir (MHR) . . . . . . . . . . . . . . 6-15

7.1 Summary of collection and analysis frequencies of soil sampling in $1992 \ldots \ldots \ldots \ldots$

7.2 Average radiological results from air station soil samples $\ldots \ldots \ldots \ldots \ldots \ldots$

7.3 1992 summary of concentrations of radionuclides in soil samples taken at the K-25 Site ambient air monitoring stations $\ldots \ldots \ldots \ldots \ldots \ldots \ldots \ldots$

7.4 ORNL 1992 concentrations of mercury in sediment $\ldots \ldots \ldots \ldots \ldots$

7.5 Summary of OKNL PCB concentations detected in sediment in the ORNL area, 1992 . . . . 7-10

7.6 Summary of concentrations of radioisotopes detected in sediment samples taken at the $\mathrm{K}-25$ Site . . . . . . . . . . . . . . . . . . . . $7-10$

7.7 Summary of concentrations of parameters detected in sediment samples taken at the K-25 Site

$9.1 \quad \mathrm{Y}-12$ Plant waste generation summary for $1992 \ldots \ldots \ldots \ldots \ldots$

9.21992 ORNL waste generation summary $\ldots \ldots \ldots \ldots \ldots \ldots \ldots \ldots \ldots \ldots$

9.31992 ORNL radioactive waste data $\ldots \ldots \ldots \ldots \ldots \ldots \ldots \ldots \ldots \ldots \ldots$

$9.4 \quad$ K-25 Plant waste generation summary for $1992 \ldots \ldots \ldots \ldots \ldots \ldots \ldots$

A.1 Y-12 Plant chemical release information, $\mathrm{CY} 1992 \ldots \ldots \ldots \ldots \ldots \ldots$

A.2 ORNL Plant chemical release information, $1992 \ldots \ldots \ldots \ldots \ldots \ldots$

A.3 K-25 Site chemical release information, $1992 \ldots \ldots \ldots \ldots \ldots \ldots \ldots \ldots$ A-7 


\section{Environmental Report Vol. 1, Oak Ridge}

C.1 Commonly used population paramelers and sample statistics $\ldots \ldots \ldots \ldots$ C-2

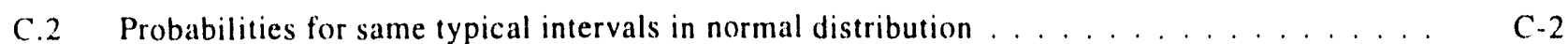




\section{Acronyms and Abbreviations}

\begin{tabular}{|c|c|}
\hline $\mathrm{AA}$ & atomic absorption \\
\hline $\mathrm{ACD}$ & Analytical Chemistry Division \\
\hline $\mathrm{ACL}$ & alternate concentration limit \\
\hline $\mathrm{ACN}$ & acetonitrile \\
\hline ADB & Ash Disposal Basin \\
\hline ADI & acceptable daily intake \\
\hline AEA & Atomic Energy Act \\
\hline $\mathrm{AEC}$ & Atomic Energy Commission \\
\hline AESG & Analytical Environmental Support Group \\
\hline $\mathrm{AGL}$ & above ground level \\
\hline AGM & average geometric mean \\
\hline AGS & Above Grade Storage Facility \\
\hline AIHA & American Industrial Hygiene Association \\
\hline ALARA & as low as reasonably achievable \\
\hline AMAD & activity median aerodynamic diameter \\
\hline ANAP & Abandoned Nitric Acid Pipeline \\
\hline ANSI & American National Standards Institute, Inc. \\
\hline ARAR & applicable or relevant and appropriate requirement \\
\hline ARSS & Aerial Remote Sensing Surveys \\
\hline ASTM & American Society for Testing and Materials \\
\hline ATDL & Atmospheric Turbulence and Diffusion Laboratory \\
\hline ATLC & Atomic Trades and Labor Council \\
\hline AVLIS & atomic vapor laser isotopic separation \\
\hline BAT & best available technology \\
\hline $\mathrm{BC}$ & Beaver Creek \\
\hline $\mathrm{BCBG}$ & Bear Creek Burial Grounds \\
\hline BCHR & Beaver Creek Hydrogeologic Regime \\
\hline $\mathrm{BCK}$ & Bear Creek kilometer \\
\hline $\mathrm{BCV}$ & Bear Creek Valley \\
\hline BCVWDA & Bear Creek Valley Waste Disposal Area \\
\hline $\mathrm{BF}$ & Brushy Fork \\
\hline BMAP & Biological Monitoring and Abatement Programs \\
\hline BMP & best management practices \\
\hline BOD & biochemical oxygen demand \\
\hline $\mathrm{BRC}$ & below regulatory concern \\
\hline BSCP & Background Soil Characterization Project \\
\hline BTM & breakthrough monitors \\
\hline CAA & Clean Air Act \\
\hline CAP & Correction Action Plan \\
\hline CAPCA & Closure and Post Closure Activities \\
\hline
\end{tabular}




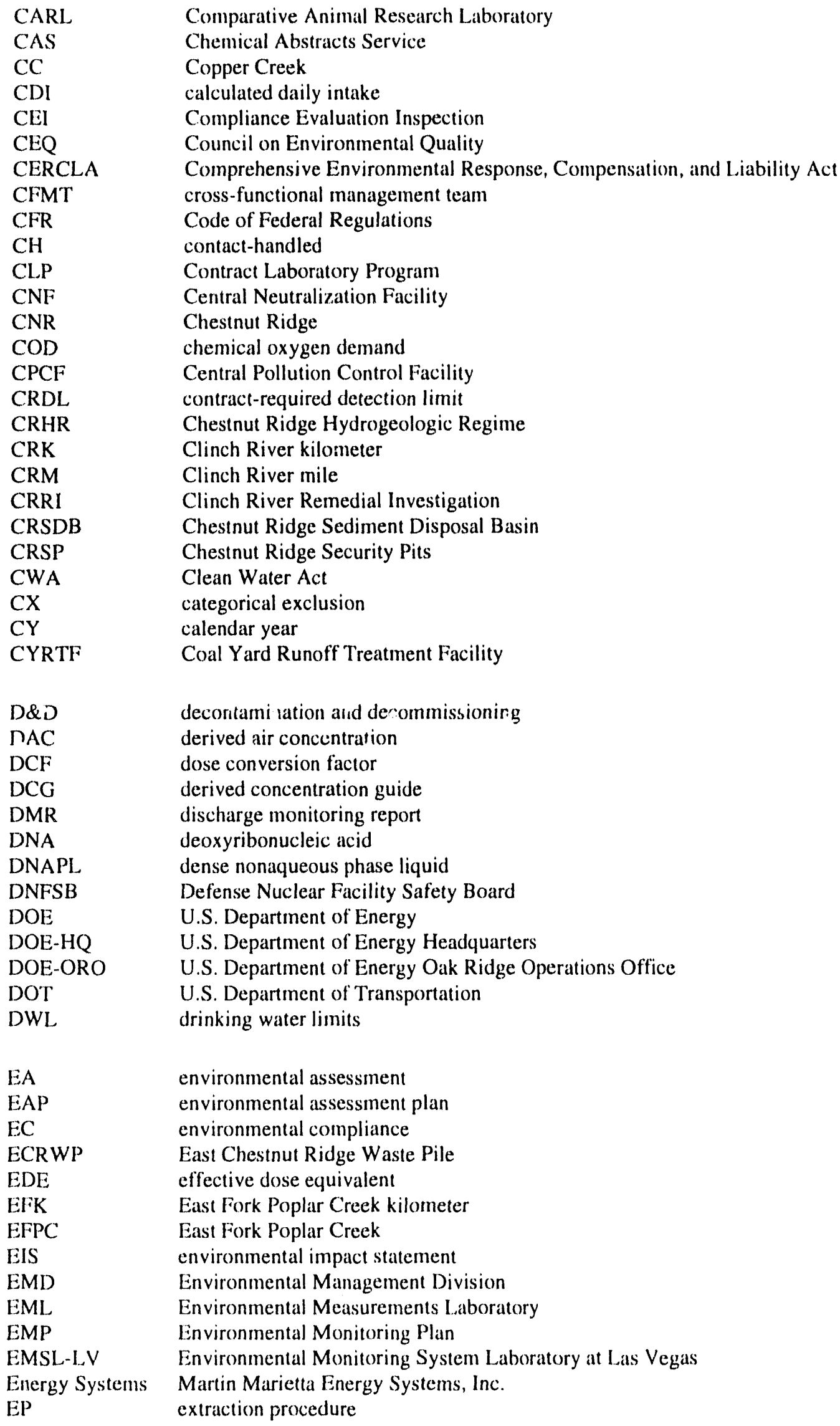




\begin{tabular}{|c|c|}
\hline EPA & U.S. Environmental Protection Agency \\
\hline EPCRA & Emergency Planning and Community Right-To-Y now Act \\
\hline EPIP & Environmental Protection Implementation Plan \\
\hline ERD & Environmental Restoration Division \\
\hline ERDS & Environmental Review and Documentation Section \\
\hline ERP & Environmental Restoration Program \\
\hline E\&SA & Environmental and Safety Activities \\
\hline ESAMS & Energy Systems Action Management System \\
\hline ESD & Environmental Sciences Division \\
\hline ESP & Environmental Surveillance and Protection \\
\hline ET\&I & Equipment Testing and Inspection Division \\
\hline FAC & free available chlorine \\
\hline FDA & Food and Drug Administration \\
\hline FFA & Federal Facility Agreement \\
\hline FFCA & Federal Facility Compliance Agreement \\
\hline FIFRA & Federal Insecticide, Fungicide, and Rodenticide Act \\
\hline FS & feasibility study \\
\hline FTIR & Fourier Transform infrared \\
\hline FWPCA & Federal Water Pollution Control Act \\
\hline FY & fiscal year \\
\hline GQM & groundwater quality monitoring \\
\hline GUT & garage underground tank \\
\hline GW & groundwater \\
\hline GWPP & Groundwater Protection Program \\
\hline GWPS & Groundwater Protection Standard \\
\hline GWQAP & groundwater quality assessment plan \\
\hline GWQAR & groundwater quality assessment report \\
\hline HAP & hazardous air pollutant \\
\hline HAZWDDD & Hazardous Waste Development, Demonstration, and Disposal \\
\hline HAZWRAP & Hazardous Waste Remedial Actions Program \\
\hline $\mathrm{HCK}$ & Hinds Creek kilometer \\
\hline HEPA & high-efficiency particulate air \\
\hline HFIR & High Flux Isotope Reactor \\
\hline HRE & Homogenous Reactor Experiment \\
\hline HSWA & Hazardous and Solid Waste Amendments \\
\hline HWDU & hazardous waste disposal unit \\
\hline IAG & interagency agreement \\
\hline IBI & Index of Biotic Integrity \\
\hline ICP & inductively coupled plasma \\
\hline ICRP & International Commission on Radiological Protection \\
\hline IRIS & Integrated Risk Information System \\
\hline IROD & interim record of decision \\
\hline ISV & in situ vitrification \\
\hline IWC & in-stream waste concentration \\
\hline IWMF & Interim Waste Management Facility \\
\hline $\begin{array}{l}\text { K-25 Site } \\
\text { KHQ }\end{array}$ & $\begin{array}{l}\text { Oak Ridge K-25 Site } \\
\text { Kerr Hollow Quarry }\end{array}$ \\
\hline
\end{tabular}




\begin{tabular}{|c|c|}
\hline LC 50 & lethal concentration for $50 \%$ of organisms \\
\hline LCR & lowest concentration reported \\
\hline LDR & land disposal restrictions \\
\hline LLLW & liquid low-level waste \\
\hline LLW & low-level waste \\
\hline LLWDDD & low-level waste disposal development and demonstration \\
\hline LLWDF & Low-Level Waste Disposal Facilities \\
\hline LLLWEF & Liquid Low-Level Waste Evaporation Facility \\
\hline LSF & Liquid Storage Facility \\
\hline MAA & material access area \\
\hline MACT & Maximum Achievable Control Technology \\
\hline MB & Melton Branch \\
\hline $\mathrm{MCL}$ & maximum contaminant level \\
\hline MDA & minimum detectable activity \\
\hline MDL & method detection limits \\
\hline MHD & Melton Hill Dam \\
\hline MSDS & material safety data sheet \\
\hline MSRE & Molten Salt Reactor Experiment \\
\hline MT & meteorological tower \\
\hline MVLLWIF & Melton Valley Low-Level Waste Inmobilization Facility \\
\hline NAS & National Academy of Sciences \\
\hline NCP & National Contingency Plan \\
\hline NEPA & National Environmental Policy Act \\
\hline ND & not detected \\
\hline NDB & Numeric Data Base \\
\hline NESHAP & National Emission Standards for Hazardous Air Pollutants \\
\hline NFA & no further action \\
\hline NHP & New Hope Pond \\
\hline NIOSH & National Institute for Occupational Safety and Health \\
\hline NIST & National Institute of Standards and Technology \\
\hline NOAA & National Oceanic and Atmospheric Administration \\
\hline NOEC. & no-observed-effect concentration \\
\hline NOEL & no-observed-effect limit \\
\hline NOV & Notice of Violation \\
\hline NPDES & National Pollutant Discharge Elimination System \\
\hline NPL & National Priorities List \\
\hline NRC & U.S. Nuclear Regulatory Commission \\
\hline NRWTF & Nonradiological Wastewater Treatment Facility \\
\hline NWT & Northwest Tributary \\
\hline O\&G & oil and grease \\
\hline OECD & Office of Environmental Compliance and Documentation \\
\hline OLF & Oil Landfarm Area \\
\hline ORAU & Oak Ridge Associated Universities \\
\hline ORGDP & Oak Ridge Gaseous Diffusion Plant \\
\hline ORIGEN & Oak Ridge Isotopic Generation and Depletion Code \\
\hline ORISE & Oak Ridge Institute for Science and Education \\
\hline ORNL & Oak Ridge National Laboratory \\
\hline ORR & Oak Ridge Reservation \\
\hline ORS & Occurrence Reporting System \\
\hline OSHA & Occupational Safety and Health Administration \\
\hline
\end{tabular}




\begin{tabular}{|c|c|}
\hline PA & preliminary assessment \\
\hline PA/SI & preliminary assessment/site investigation \\
\hline PAM & perimeter air monitoring \\
\hline PAT & proficiency analytical testing \\
\hline PC & Pond Closure \\
\hline PCB & polychlorinated biphenyl \\
\hline PCK & Poplar Creek kilometer \\
\hline PCP & pentachlorophenol \\
\hline $\mathrm{PE}$ & performance evaluation \\
\hline PET & Proficiency Environmental Testing \\
\hline PGDP & Paducah Gaseous Diffusion Plant \\
\hline PIDAS & Perimeter Intrusion Detection and Alarm System \\
\hline PIP & Perfcrmance Improvement Process \\
\hline PM10 & particulate matter less than 10 microns in diameter \\
\hline PRTF & Plating Rinsewater Treatment Facility \\
\hline PUFF & polyurethane foam filter \\
\hline PVC & polyvinyl chloride \\
\hline PWA & Proces; Waste Assessment \\
\hline PWMP & Pond Waste Management Project \\
\hline PWTF & Process Waste Treatment Facility \\
\hline PWTP & Process Waste Treatment Plant \\
\hline QA & quality assurance \\
\hline QC & quality control \\
\hline RAM & remote air monitoring \\
\hline RAP & Remedial Action Program \\
\hline RCRA & Resource Conservation and Recovery Act \\
\hline $\mathrm{RCW}$ & recirculating cooling water \\
\hline$R \& D$ & research and development \\
\hline REDC & Radiochemical Engineering Development Center \\
\hline RFA & RCRA Facility Assessment \\
\hline $\mathrm{RfD}$ & reference dose \\
\hline RFI & RCRA facility investigation \\
\hline RH & remote-handled \\
\hline RI/FS & remedial investigation /feasibility study \\
\hline RMA & Rocky Mountain Arsenal \\
\hline RMP & radiological monitoring plan \\
\hline RMPE & Reduction of Mercury in Plant Effluent \\
\hline ROD & Record of Decision \\
\hline RQ & reportable quantity \\
\hline$S-3$ & S-3 Site \\
\hline S\&A & sampling and analysis \\
\hline SARA & Superfund Amendments and Reauthorization Act \\
\hline SDWA & Safe Drinking Water Act \\
\hline SE & standard error of the mean \\
\hline $\begin{array}{l}\text { SERAM } \\
\text { SF }\end{array}$ & Stack Emission Reduction and Monitoring Project \\
\hline SIE & $\begin{array}{l}\text { slope factor } \\
\text { specific ion electrode }\end{array}$ \\
\hline SIP & State Implementation Plan \\
\hline SLF & sanitary landfill \\
\hline SMCL & secondary maximum contaminant level \\
\hline SOP & standard operating procedure \\
\hline
\end{tabular}




\section{Environmental Report Vol. 1, Oak Ridge}

\begin{tabular}{|c|c|}
\hline SPAD & Steam Plant Ash Disposal \\
\hline SPCC & Spill Prevention, Control, and Countermeasures \\
\hline SPWTF & Steam Plant Wastewater Treatment Facility \\
\hline SSF & solid storage facility \\
\hline STP & Sewage Treatment Plant \\
\hline SWDF & solid waste disposal facility \\
\hline SWMU & solid waste management unit \\
\hline SWSA & solid waste storage area \\
\hline TCL & Target Compound List \\
\hline TCLP & toxicity characteristic leaching procedure \\
\hline TCMP & toxicity control and monitoring program \\
\hline TDEC & Tennessee Department of Environment and Conservation \\
\hline TDS & total dissolved solids \\
\hline TOC & total organic carbon \\
\hline TOX & total organic halogens \\
\hline TRC & total residual chlorine \\
\hline TRE & Toxicity Reduction Evaluation \\
\hline TRK & Tennessee River kilometer \\
\hline TRM & Tennessee River mile \\
\hline TRU & transuranic \\
\hline TRV & thermal relief valve \\
\hline TSCA & Toxic Substances Control Act \\
\hline TSF & Tower Shielding Facility \\
\hline TSP & total suspended particulates \\
\hline TSS & total suspended solids \\
\hline TSWMA & Tennessee Solid Waste Management Act \\
\hline TURF & Thorium-Uranium Process Facility \\
\hline TVA & Tennessee Valley Authority \\
\hline TWRA & Tennessee Wildlife Resources Agency \\
\hline UE & uranium enrichment \\
\hline UEFPC & Upper East Fork Poplar Creek \\
\hline UEFPCHR & Upper East Fork Poplar Creek Hydrogeologic Regime \\
\hline UF & ùranium hexafluoride \\
\hline UNC & United Nuclear Corporation \\
\hline USGS & United States Geological Survey \\
\hline UST & underground storage tank \\
\hline VC7002 & Vehicle Cleaning Facility \\
\hline VOA & volatile organic aromatics \\
\hline VOC & volatile organic compound \\
\hline WAC & waste acceptance criteria \\
\hline WAG & waste area grouping \\
\hline WCK & White Oak Creek kilometer \\
\hline WCPA & Waste Coolant Processing Area \\
\hline WCPF & Waste Coolant Processing Facility \\
\hline WETF & West End Treatment Facility \\
\hline WIPP & Waste Isolation Pilot Plant \\
\hline WMA & Waste Management Area \\
\hline WMCBF & Waste Machine Coolant Biodegradation Facility \\
\hline WMCO & Waste Management Coordination Office \\
\hline WMP & Waste Management Plan \\
\hline
\end{tabular}


1992 Environmental Report Vol. 1, Oak Ridge

$\begin{array}{ll}\text { WMP } & \text { Work Management Plan } \\ \text { WOC } & \text { White Oak Creek } \\ \text { WOCE } & \text { White Oak Creek Embayment } \\ \text { WOD } & \text { White Oak Dam } \\ \text { WOL } & \text { White Oak Lake } \\ \text { WOM } & \text { White Oak Mountain } \\ \text { WTF } & \text { Waste Treatment Facility } \\ & \\ \text { Y-12 Plant } & \text { Oak Ridge Y-12 Plant }\end{array}$




\section{Units}

$\begin{array}{ll}\mu \mathrm{Ci} & \text { microcurie } \\ \mu \mathrm{g} & \text { microgram } \\ \mathrm{Bq} & \text { Becquerel } \\ \mathrm{Btu} & \text { British thermal unit } \\ \mathrm{cfm} & \text { cubic feet per minute } \\ \mathrm{Ci} & \text { curie } \\ \mathrm{cm} & \text { centimeter } \\ \mathrm{cm}^{2} & \text { square centimeter } \\ \mathrm{cm} & \text { cubic centimeter } \\ \mathrm{d} & \text { day } \\ \mathrm{ft} & \text { foot } \\ \mathrm{ft}^{2} & \text { square foot } \\ \mathrm{ft} & \text { cubic foot } \\ \mathrm{g} & \text { gram } \\ \mathrm{gal} & \text { gallon } \\ \mathrm{gpd} & \text { gallons per day } \\ \mathrm{gpm} & \text { gallons per minute } \\ \mathrm{h} & \text { hour } \\ \mathrm{ha} & \text { hectare } \\ \mathrm{in} . & \text { inch } \\ \mathrm{kg} & \text { kilogram } \\ \mathrm{km} & \text { kilometer } \\ \mathrm{km} & \text { square kilometer } \\ \mathrm{L} & \text { liter } \\ \mathrm{lb} & \text { pound } \\ \mathrm{m} & \text { meter } \\ & \end{array}$

\begin{tabular}{ll}
$\mathrm{M}^{2}$ & million \\
$\mathrm{m}^{2}$ & square meter \\
$\mathrm{m}^{3}$ & cubic meter \\
$\mathrm{mCi}$ & millicurie \\
$\mathrm{mg}$ & milligrarn \\
$\mathrm{Mgd}$ & million gallons per day \\
$\mathrm{mil}$ & l/loo0 in. \\
$\mathrm{mile}$ & square mile \\
$\mathrm{min}$ & minute \\
$\mathrm{mL}$ & milliliter \\
$\mathrm{mm}$ & millimeter \\
$\mathrm{mrad}$ & millirad \\
$\mathrm{mrem}$ & millirem \\
$\mathrm{mSv}$ & millisievert \\
$\mathrm{NTU}$ & nephelometric turbidity unit \\
$\mathrm{pCi}$ & picocurie \\
$\mathrm{ppb}$ & parts per billion \\
$\mathrm{ppm}$ & parts per million \\
$\mathrm{ppt}$ & parts per trillion \\
$\mathrm{psi}$ & pounds per square inch \\
$\mathrm{R}$ & roentgen \\
$\mathrm{s}$ & second \\
$\mathrm{SU}$ & standard unit \\
${ }^{\circ} \mathrm{C}$ & degrees celsius \\
${ }^{\circ} \mathrm{F}$ & degrees Fahrenheit \\
$\mathrm{yd}$ & cubic yard \\
& \\
\hline 3 &
\end{tabular}

\begin{tabular}{|c|c|c|c|c|c|}
\hline \multicolumn{6}{|c|}{ CONVERSION TABLE } \\
\hline Multiply & By & To obtain & Multiply & By & To obtain \\
\hline acre & 0.405 & ha & ha & 2.47 & acres \\
\hline in. & 2.54 & $\mathrm{~cm}$ & $\mathrm{~cm}$ & 0.394 & in. \\
\hline $\mathrm{ft}$ & 0.305 & $\mathrm{~m}$ & $\mathrm{~m}$ & 3.28 & $\mathrm{ft}$ \\
\hline mile & 1.61 & $\mathrm{~km}$ & $\mathrm{~km}$ & 0.621 & mile \\
\hline $\mathrm{lb}$ & 0.4536 & $\mathrm{~kg}$ & $\mathrm{~kg}$ & 2.205 & $\mathrm{lb}$ \\
\hline lig qt-U.S. & 0.946 & $\mathrm{~L}$ & $\mathrm{~L}^{\circ}$ & 1.057 & lig qt-U.S. \\
\hline $\mathrm{ft}^{2}$ & 0.093 & $\mathrm{~m}^{2}$ & $\mathrm{~m}^{2}$ & 10.764 & $\mathrm{ft}^{2}$ \\
\hline mile $^{2}$ & 2.59 & $\mathrm{~km}^{2}$ & $\mathrm{~km}^{2}$ & 0.386 & mile $^{2}$ \\
\hline $\mathrm{ft}^{3}$ & 0.028 & $\mathrm{~m}^{3}$ & $m^{3}$ & 35.31 & $\mathrm{ft}^{3}$ \\
\hline $\mathrm{Bq}$ & 27 & $\mathrm{pCi}$ & $\mathrm{pCi}$ & 0.037 & $\mathrm{~Bq}$ \\
\hline $\mathrm{nCi}$ & $1 \times 10^{3}$ & $\mathrm{pCi}$ & $\mathrm{pCi}$ & $1 \times 10^{-3}$ & $\mathrm{nCi}$ \\
\hline $\mathrm{dpm} / \mathrm{L}$ & $0.45 \times 10^{-9}$ & $\mu \mathrm{Ci} / \mathrm{cm}^{3}$ & $\mu \mathrm{Ci} / \mathrm{cm}^{3}$ & $2.22 \times 10^{9}$ & $\mathrm{dpm} / \mathrm{L}$ \\
\hline $\mathrm{pCi} / \mathrm{L}$ (water) & $10^{-9}$ & $\mu \mathrm{Ci} / \mathrm{mL}$ (water) & $\mu \mathrm{Ci} / \mathrm{mL}$ (water) & $10^{9}$ & $\mathrm{pCi} / \mathrm{L}$ (water) \\
\hline $\mathrm{pCi} / \mathrm{m}^{3}$ (air) & $10^{-12}$ & $\mu \mathrm{Ci} / \mathrm{cm}^{3}$ (air) & $\mu \mathrm{Ci} / \mathrm{cm}^{3}$ & $10^{12}$ & $\mathrm{pCi} / \mathrm{m}^{3}$ (air) \\
\hline $\mathrm{mCi} / \mathrm{km}^{2}$ & 1 & $\mathrm{nCi} / \mathrm{m}^{2}$ & $\mathrm{nCi} / \mathrm{m}^{2}$ & 1 & $\mathrm{mCi} / \mathrm{km}^{2}$ \\
\hline sievert (Sv) & 100 & rem & rem & 0.01 & sievert (Sv) \\
\hline
\end{tabular}




\section{Executive Summary}

\section{The Site}

The Oak Ridge Reservation (ORR) is a U.S. Department of Energy (DOE) complex that occupies approximately 54 square miles in Anderson and Roane Counties in East Tennessee. The mission for the ORR includes energy and materials research and development, fabrication of nuclear weapon components, and technology development of waste management and environmental restoration. Martin Marietta Energy Systems, Inc., has managed the facilities for DOE since 1984.

The ORR is located in the southern mixed hardwood forest zone that is typified by a diverse collection of tree species and well-developed shrub and herbaceous layers. This area also supports a highly diversified animal community. The climate is moderate, with average temperature extremes ranging from $3.3^{\circ} \mathrm{C}\left(38^{\circ} \mathrm{F}\right)$ in January to $25^{\circ} \mathrm{C}\left(77^{\circ} \mathrm{F}\right)$ in July. The average rainfall is $1.37 \mathrm{~m}$ (54 in.), including $0.26 \mathrm{~m}$ (10.4 in.) of snow. Winds are light and primarily follow the valley and ridge topography.

The land within $8 \mathrm{~km}$ (5 miles) of the ORR is predominantly rural except for the city of Oak Ridge (pop. 27,310), which lies northeast of the ORR center. Other communities in the vicinity of the ORR include Oliver Springs, $11 \mathrm{~km}$ to the northwest; Clinton, $16 \mathrm{~km}$ to the northeast; Lenoir City, $11 \mathrm{~km}$ to the southeast; Kingston, $11 \mathrm{~km}$ to the southwest; and Harriman, $13 \mathrm{~km}$ to the west. Knoxville, $40 \mathrm{~km}$ east of Oak Ridge, is the nearest major metropolitan area, having a population of 165,121 (Fig. 1).

\section{The Facilities}

The ORR consists of three main facilities (Fig. 2):

- Y-12 Plant--The primary mission of the Y-12 Plant prior to 1992 was production and fabrication of nuclear weapon components.
Changes in emphasis of the U.S. defense strategy consequent to the end of the Cold War have precipitated a change in mission for this facility. New directions will include weapons dismantlement, nuclear material storage, technology transfer, decontamination and decommissioning of selected facilities, and environmental restoration.

- Oak Ridge National Laboratory (ORNL)-This facility is a large multipurpose research facility with a basic mission to expand knowledge in areas related to energy. Major programs have included basic research in fission and fusion energy, materials research, biological and ecological effects of radiation, fuel cycle and isotopes research, isotope production, and chemical engineering. In addition to the main facility area, ORNL also manages the Oak Ridge National Environmental Research Park.

- K-25 Site-This site was formerly the Oak Ridge Gaseous Diffusion Plant. The gaseous diffusion plant ceased production in 1985; the mission of the site has evolved since that time. Major activities at the K-25 Site during 1992 included operation of the Toxic Substances Control Act (TSCA) Incinerator, low-level radioactive waste management, and environmental restoration. The Environmental Restoration and Waste Management Programs organization was organized to unify the various ongoing programs at the site.

\section{Radiation Dose Received by the Public from ORR Operations in 1992}

Every person is exposed to naturally occurring and man-made sources of ionizing radiation. As shown in Fig. 3, the average person receives 
ORNL.DWG 87M-7844A3

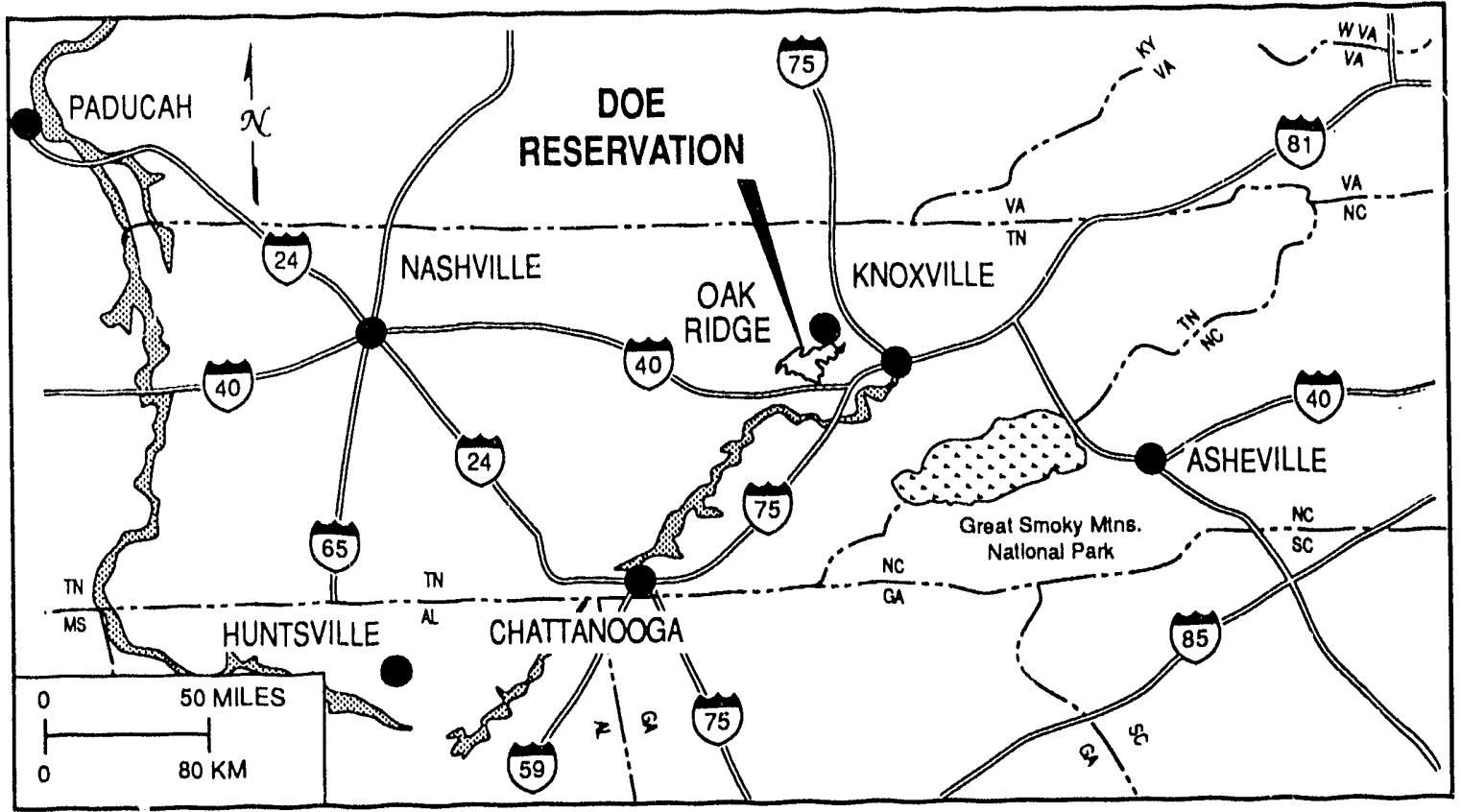

Fig. 1. Map showing location of Oak Ridge and the Oak Ridge Reservation in relation to geographic region.

ORNL-DWG 93M-9616

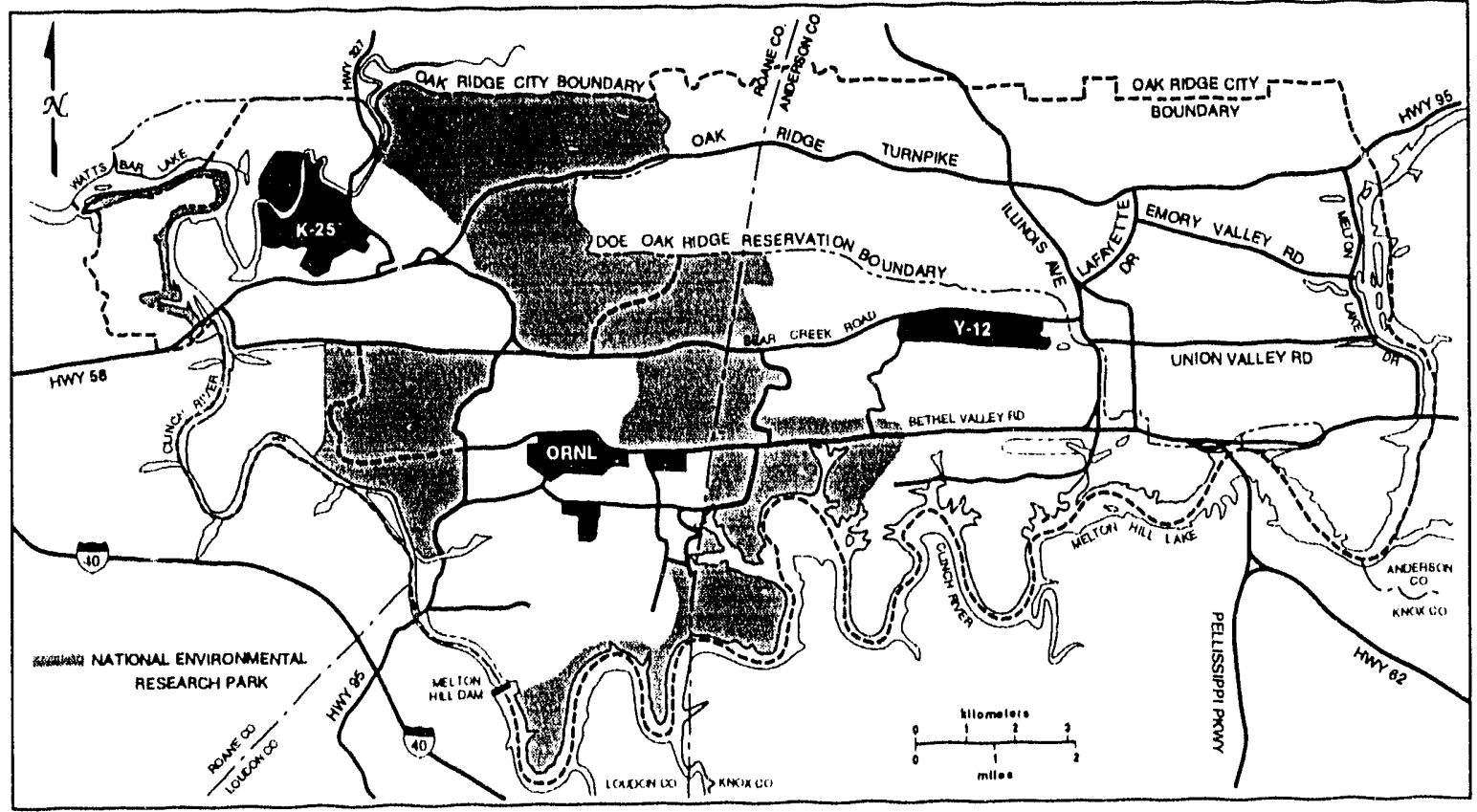

Fig. 2. Map showing the Oak Ridge Reservation and the location of the three major installations. 


\section{Environmental Report Vol. 1, Oak Ridge}

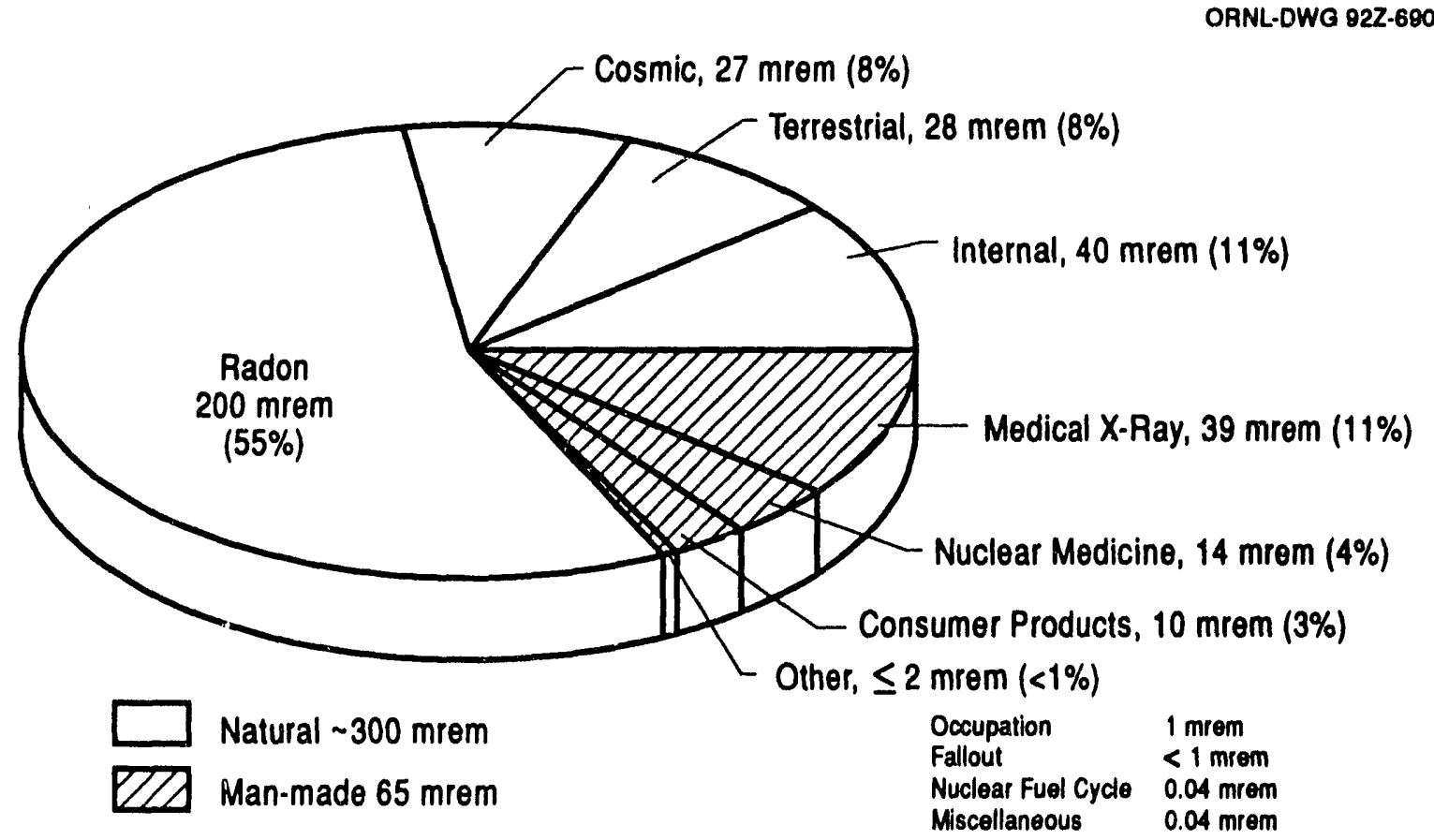

Fig. 3. Typical annual radiation doses from various sources. Source: National Council on Radiation Protection and Measurements, 1987, Ionizing Radiation Exposure of the Population of the United States, NCRP Report No. 93, Bethesda, Md.

approximately $300 \mathrm{mrem} /$ year from natural souries, which include radon gas, terrestrial and cosmic radiations, and naturally occurring radionuclides that are, inhaled and ingested. The average person also receives an additional $65 \mathrm{mrem} /$ year from man-made sources, which include medical X-rays, nuclear medicine, consumer products, and nuclear technology. The actual exposure of any person to the above sources depends upon that person's geographic location and lifestyle.

Radioactive materials released into air and water from operations on the ORR during 1992 could have added to the radiation doses received by nearby residents. A hypothetical maximally exposed individual could have received about $1.4 \mathrm{mrem} /$ year from radionuclides released to the atmosphere and about $0.6 \mathrm{mrem} /$ year from radionuclides discharged to surface waters. A hypothetical person who spent $250 \mathrm{~h} /$ year fishing on a small section of the Clinch River near an experimental plot containing radioactive material could have received about 2 mrem; a similar person fishing Poplar Creek, within the K-25 Site, could have received about 15 mrem. Table 1 provides a summary of exposure pathways and the effective dose equivalents for the maximally exposed individual.

The collective 50-year committed effective dose equivalent to the entire population (approximately 880,000 persons) residing within $80 \mathrm{~km}$ ( 50 miles) of the ORR during 1992 is estimated to be about 43 person-rem from releases of radionuclides from the ORR to the atmosphere. This dose equivalent is about $0.02 \%$ of the collective dose equivalent to the entire population from 1 year of exposure to natural radiation (see Fig. 4). A fatal cancer risk from reception of such doses can be calculated using a risk factor of 0.0005 per person-rem of effective dose equivalent, even though there is no conclusive evidence to support the existence of a risk from reception of such a low dose at such a low dose rate (i.e., the actual risk factor could be 0 ). The calculated fatal cancer risk associated with the 43-person-rem effective dose equivalent is about 0.02 . This means that it would take, on average, about 50 years of such exposures for one fatal cancer to have a chance of developing in the entire population. The chance that an individual who receives the average effective dose equivalent $(0.05 \mathrm{mrem})$ might develop a fatal cancer over a lifetime is about 1 in 40,000,000. 


\section{Environmental Report Vol. 1, Oak Ridge}

Table 1. Oak Ridge Reservation exposure pathways and effective dose equivalents for a maximally exposed individual (mrem)

\begin{tabular}{lcccc}
\hline & $\begin{array}{c}\text { Maximum dose } \\
\text { from ORR }\end{array}$ & $\begin{array}{c}\text { Applicable } \\
\text { standard }\end{array}$ & $\begin{array}{c}\text { Percentage } \\
\text { of standard }\end{array}$ & $\begin{array}{c}\text { Percentage of } \\
\text { natural background }\end{array}$ \\
\hline Airborne effluent & 1.4 & 10 & 14 & 0.47 \\
Drinking water & 0.2 & 4 & 5.0 & 0.067 \\
Fish consumption & 0.4 & & 0.13 \\
Direct radiation $^{a}$ & $2-15$ & 100 & $4-17$ & $0.67-5.0$ \\
All pathways & $4-17$ & 100 & $1.3-5.7$ \\
\hline
\end{tabular}

${ }^{a}$ Based on a person fishing a relatively short stretch of the Clinch River ( 2 mrem) and Poplar Creek ( 15 mrem) for 250 hours per year.

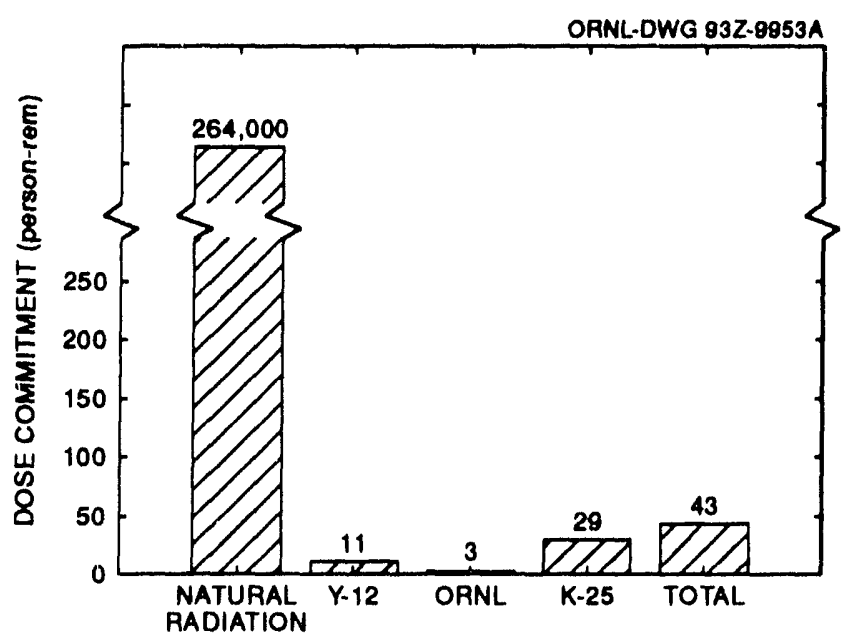

Fig. 4. The collective effective dose equivalent of the entire population within $80 \mathrm{~km}$ (50 miles) of the three installations.

\section{Airborne Discharges, Ambient Air, and Meteorological Measurements}

\section{Permitting Status}

The Tennessee Department of Environment and Conservation (TDEC) has issued 866 permits for emission sources for the three Oak Ridge installations.

\section{Radioactive Discharges to the Atmosphere}

During $1992,5,800 \mathrm{Ci}$ of radionuclides were released to the atmosphere from Oak Ridge installations. Almost all of the activity released was due to tritium and the inert gases xenon and krypton. The total curie discharge of each radionuclide that was quantified is shown in Sect. 3.

Uranium is the primary radioactive element released from the Y-12 Plant. Uranium emissions have shown a gradual decrease in recent years at the plant. The lowest quantity of uranium discharged from the Y-12 Plant in the last 5 years was recorded in 1992. This decrease reflects a reduction in Y-12 Plant process activities, continued improvements in administrative controls of the process activities still operating, and recent improvements in contamination control throughout the $\mathrm{Y}-12$ Plant.

Radioactive airborne emissions from ORNL showed a reduction from about $25,000 \mathrm{Ci}$ to $5,800 \mathrm{Ci}$. This is due largely to the cessation of ${ }^{85} \mathrm{Kr}$ and ${ }^{3} \mathrm{H}$ processing operations. Iodine emissions increased in 1992 concomitant with increased operations at the High Flux Isotope Reactor (HFIR).

At the K-25 Site, the TSCA Incinerator is the only major radionuclide source and is the primary contributor to off-site dose. Based on continuous stack sampling, total radioactive emissions from the incinerator increased from 1991, in part because 1992 was the first full calendar year the incinerator operated. Those emissions resulted in a modeled dose of $0.53 \mathrm{mrem}$ to the maximally exposed off-site individual, which is $87 \%$ of the total $\mathrm{K}-25$ Site dose of $0.61 \mathrm{mrem}$, and well below the National Emission Standards for Hazardous Air Pollutants (NESHAP) regulatory limit of $10 \mathrm{mrem}$.

Discharges, as well as meteorological data, are input into dose models to predict the radiation dose to 
the maximally exposed individual (Fig. 5) and to the population within $80 \mathrm{~km}$ (50 miles) of the DOE Dak Ridge facilities (see Fig. 4).

\section{Radionuclide Concentrations in Air}

Atmospheric radionuclide concentrations occurring in the general environment around the ORR, and the general region are monitored continuously or sampled periodically by an air-monitoring network. The reservation perimeter air monitors assess the impact of the entire ORR on air quality. The remote air monitors provide information about reference concentrations of isotopes and gross parameters for the region.

Measurements were taken for concentrations of 15 radioactivity parameters. Data analyses and summaries are presented in Sect. 3.

Analysis of the ORR perimeter air-sampling data shows that operations on the ORR are very slightly increasing local airborne concentrations of radionuclides. These range from less than $0.01 \%$ to $0.16 \%$ of the derived concentration guides (DCGs) for the network averages. No significant changes in the concentrations of these radionuclides were detected between 1991 and 1992 for the remote stations. Therefore, based on these data, ORR

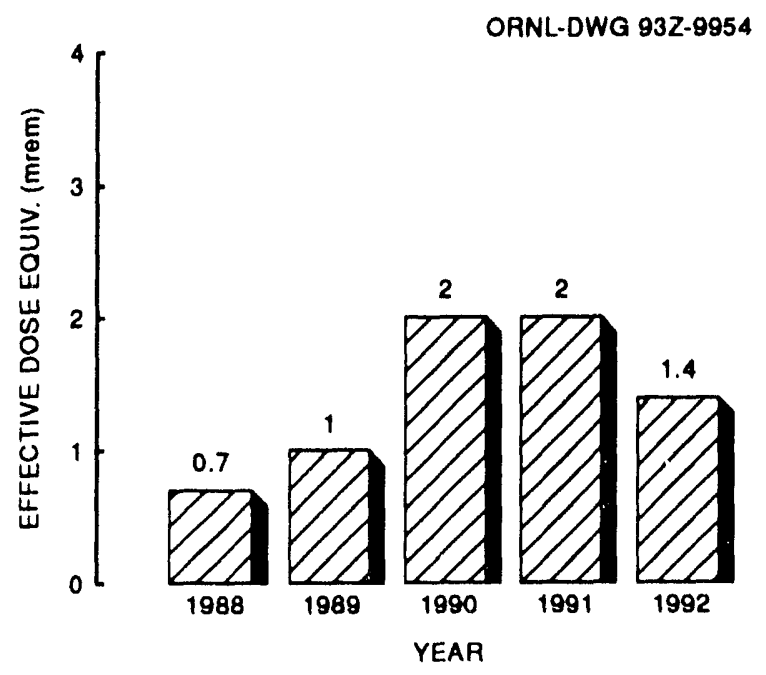

Fig. 5. Estimated maximum effective dose equivalent to the maximally exposed members of the public from airborne emissions from ORR. operations are having a slight impact on local air quality but are not measurably impacting the regional air quality. The local impact is well below the DCG.

\section{Waterborne Discharges and Surface Water Monitoring}

Each of the Oak Ridge installations has a National Pollutant Discharge Elimination System (NPDES) permit. More than 400 NPDES stations were sampled, requiring more than 65,000 water analyses.

In 1992 the Y-12 Plant reduced NPDES noncompliances by more that $50 \%$ from 1991 . The most significant reductions in noncompliances were achieved at Rogers Quarry, with the installation of a subsurface discharge pipe, and at the Y-12 Plant wastewater treatment facilities. The most significant area of NPDES noncompliances was from observations of visible discharges (e.g., foam or oil sheen) at outfalls located directly on the bank of Upper East Fork Poplar Creek.

More than $50 \%$ of the 42 noncompliances in 1992 were due to visible discharges, primarily of foam or oil sheens. Minor discharges of soap from sinks that were tied to the storm sewer resulted in observed foam at the outfall. Most observed oil sheens were the result of parking-lot runoff or minor spills.

During 1992, two Y-12 employees walked the Upper East Fork Poplar Creek bank three times per day looking for visible discharges. Even in the midst of increased surveillance of the creek, NPDES noncompliances due to visible discharges during 1992 decreased by $30 \%$ over 1991 primarily due to the rerouting of sink drains from the storm sewer to the sanitary sewer.

Of the several thousand samples collected for the purposes of self-monitoring to the requirements of the NPDES permit, the $\mathrm{Y}-12$ Plant was in $99.5 \%$ compliance with discharge limits.

ORNL was $99 \%$ in compliance, and the K-25 Site was $99.9 \%$ in compliance.

\section{Radionuclide Discharges to Surface Streams}

The ambient surface water areas monitored by the three installations include the Tennessee and Clinch rivers, White Oak Creek, Bear Creek, East 


\section{Environmental Report Vol. 1, Oak Ridge}

Fork Poplar Creek, and Poplar Creek, all of which could be affected by operations at the DOE installations. Program descriptions and results are presented in Sect. 4.

At the Y-12 Plant, ORNL, and the K-25 Site, radiological effluents were well within limits at all effluent monitoring locations. Radionuclides are discharged to the Clinch River via White Oak Creek for ORNL and Poplar Creek for the Y-12 Plant and $\mathrm{K}-25$ Site. Factors that may be affecting the discharge of radionuclides to the Clinch River are currently under investigation as part of the Environmental Restoration Program. The Gallaher water plant is the closest drinking water source downstream of ORNL.

Figure 6 shows the 5-year trend of maximum calculated 50-year committed effective dose equivalent from drinking water at the Gallaher water plant monitoring station.

\section{Groundwater Monitoring}

A Comprehensive Groundwater-Monitoring Plan for the Y-12 Plant has been developed and implemented to take into account the natural systems that control the rate of contaminant transport, to address regulatory and site-characterization objectives, and to ensure consistent data collection and evaluation techniques. The intent of a comprehensive approach to groundwater monitoring

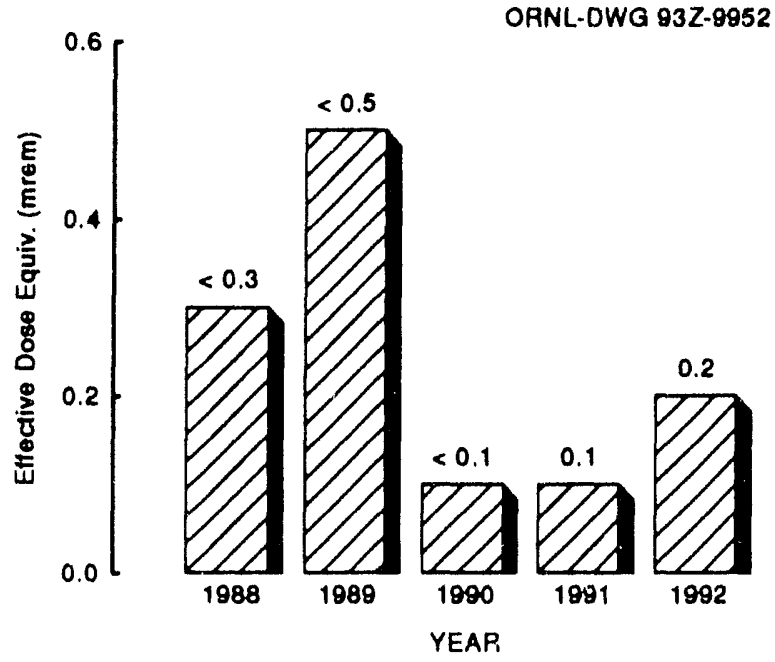

Fig. 6. Maximum calculated 50-year committed effective dose equivalent from drinking water from the Gallaher water plant. is to eliminate redundancy and conflict between different regulating programs whose areas of interest overlap. In the comprehensive plan, the Y-12 Plant is divided into three sections, which are delineated by topography, surface water drainage, and patterns of groundwater flow. These sections include the Bear Creek Hydrogeologic Regime, the Upper East Fork Poplar Creek Hydrogeologic Regime, and the Chestnut Ridge Hydrogeologic Regime.

Principal groundwater contaminants that exceed applicable reference standards at the Y-12 Plant include volatile organics, nitrates, heavy metals, and radioactivity. Although it is too early to quantify the rates and extents of migrations, data indicate the contamination remains relatively close to its source. For instance, at the S-3 Site at the western end of the Y-12 Plant, the highest concentrations are within $150 \mathrm{~m}(500 \mathrm{ft})$ of the site; nitrate, the most widespread groundwater contaminant, has been

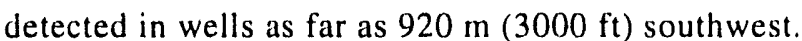
Because nitrate is relatively mobile in groundwater and remains chemically and physically stable during transport, the limit of the nitrate plume may therefore define the maximum horizontal extent of migration.

At ORNL, about 250 known potential waste sites are grouped into 20 waste area groupings (WAGs), of which 11 are being monitored along their boundaries for groundwater quality. Because of the large number of remedial action sites at ORNL located close to one another and because of the proven hydrologic interconnections between many of these units, individual monitoring and assessment was shown to be impractical. Therefore, the concept of WAGs was developed to evaluate potential sources of releases to the environment. A WAG is a group of multiple sites that are geographically contiguous and/or occur within hydrologically defined areas. WAGs allow the establishment of a suitably comprehensive groundwater and surface water monitoring system in a far shorter time than that required to deal with every facility, site, and solid waste management unit (SWMU) individually. Some WAGs share common boundaries, but each WAG represents distinct small drainage areas within which similar contaminants may have been introduced. Monitoring data from each WAG will direct further groundwater studies aimed at addressing individual sites or units within a WAG, as well as contaminant plumes that extend beyond the perimeter of a WAG.

\section{xxxiv Executive Summary}




\section{Environmental Report Vol. 1, Oak Ridge}

The K-25 Site Groundwater Program consisted of 206 groundwater quality monitoring wells in 1992. Groundwater effluent monitoring at the K-25 Site is focused primarily on investigating and characterizing sites for remediation under the Resource Conservation and Recovery Act (RCRA) and Comprehensive Environmental Response, Compensation, and Liability Act (CERCLA). In the past, activities under CERCLA investigations were conducted for individual SWMUs, or groupings of SWMUs. Potentially contaminated units are now grouped into 14 source operable units (OUs) and one groundwater $\mathrm{OU}$. The groundwater $\mathrm{OU}$ was designated as encompassing source OUs and areas that may contain unknown waste sites or groundwater contamination plumes.

Eleven wells at two RCRA sites (K-1407-B and $C$ Ponds) were sampled semiannually as required by a modified interim status detection monitoring program. Wells within eight Well Groupings (former WAGs) underwent annual sampling during 1992. Annual monitoring generally involves sampling for a list of constituents that include field measurements, volatile organics, $\mathrm{pH}$, specific conductivity, gross alpha, gross beta, total uranium, ${ }^{99} \mathrm{Tc}$, and fluoride.

Organics are the most commonly detected contaminants in groundwater at the K-25 Site. Elevated levels of gross alpha and gross beta radioactivity have been detected in a number of wells. Uranium and ${ }^{99} \mathrm{Tc}$, respectively, appear to be primarily responsible for the elevated gross alpha and beta activities. The metals chromium, lead, arsenic, and barium have been detected in a number of wells at levels exceeding drinking water standards. Elevated levels of fluoride have been detected in some wells; polychlorinated biphenyls (PCBs) have also been detected at a few wells.

Information on off-site groundwater monitoring is provided in Sect. 5.7.

\section{Biological Monitoring}

Contaminant concentrations in fish samples during 1992 are comparable to, or are generally lower than, concentrations found in previous years. Samples were collected to measure concentrations of mercury, $\mathrm{PCBs},{ }^{60} \mathrm{Co},{ }^{137} \mathrm{Cs}$, and total radioactive strontium in bluegill from the Clinch River. No guidelines exist for radionuclide concentrations in fish. However, dose calculations were based on concentrations of radionuclides in fish and assumed consumption rates. These calculations are described in Sect. 2.1 of this report. To put doses from waterborne radionuclides into perspective, a person who ate fish caught in Poplar Creek near the Clinch River and drank water from the Kingston water plant could have received a 50-year committed effective dose equivalent of about $0.4 \mathrm{mrem}$, which is about $0.1 \%$ of his or her annual dose from background radiation.

Milk samples were collected from five locations in the $80-\mathrm{km}$ area around the ORR and were analyzed for ${ }^{131} I$ and total radioactive strontium. The estimated effective dose equivalent for drinking this milk averages $0.2 \mathrm{mrem}$. 


\section{Compliance Summary Environmental Compliance Activity U.S. Department of Energy}

\section{Oak Ridge Reservation}

\section{Background and Overview}

The Oak Ridge Reservation (ORR), including the Oak Ridge Y-12 Plant, Oak Ridge National Laboratory (ORNL), Oak Ridge K-25 Site, and the facilities of the Oak Ridge Associated Universities (ORAU), operates in conformance with requirements established by a number of federal and state statutes and regulations, executive orders, U.S. Department of Energy (DOE) orders, and compliance and settlement agreements. Compliance status with regard to major environmental statutes and DOE orders is summarized by site.

DOE Order 5400.1, "General Environmental Protection Program," defines the mandatory environmental standards in effect at DOE operations. These environmental standards fall into three categories: (1) those imposed by federal statutes, regulations, and requirements; (2) those imposed by state and local statutes, regulations, and requirements applicable to DOE; and (3) those imposed by DOE directives. This section summarizes the standards that are significant for environmental compliance with respect to the operations of the ORR.

Several federal, state, and local agencies are responsible for enforcing environmental regulations at the ORR and the component facilities. DOE itself through directives to field of fices and compliance audits, is the initiating organization. Principal among other regulating agencies are the U.S. Environmental
Protection Agency (EPA) Region IV and the Tennessee Department of Environment and Conservation (TDEC). These agencies issue permits, review compliance reports, participate in joint monitoring programs, inspect facilities and operations, and oversee compliance with applicable regulations.

In 1991 TDEC established a DOE Oversight Division located in Oak Ridge to facilitate increased TDEC oversight and involvement in issues at ORR facilities. Under an agreement between TDEC and DOE, the Oversight Division personnel have continuous access to the ORR facility and coordinate regulatory involvement in environmental issues and programs.

EPA develops, promulgates, and enforces environmental protection regulations and technology-based standards as directed by statutes passed by the U.S. Congress. In some instances, EPA has delegated regulatory authority to TDEC when the Tennessee program meets or exceeds EPA's requirements. Where regulatory authority is not delegated, EPA Region IV is responsible for reviewing and evaluating compliance with the EPr regulations as they pertain to the ORR.

Although progress has been made toward achieving full regulatory compliance at the ORR and each of the facilities, much remains to be done. A Federal Facilities Compliance Agreement (FFCA) was signed on June 12,1992, between DOE and EPA 


\section{Environmental Report Vol. 1, Oak Ridge}

that detailed the requirements necessary to achieve compliance with the land-disposal restrictions contained in Chap. 40 of the Code of Federal Regulations (40 CFR 268) for low-level radioactive waste that contains Resource Conservation and Recovery Act (RCRA) hazardous constituents (mixed waste). Ongoing self assessments of compliance status and implementation of corrective actions continue to address environmental issues. These issues are discussed openly with the regulatory agencies to ensure that compliance with all environmental regulations will be attained.

In 1992, the DOE Oak Ridge Operations Office (DOE-ORO) continued to discuss with EPA Region IV the need to negotiate an FFCA for the storage of radioactively contaminated polychlorinated biphenyl (mixed PCB) wastes at facilities on the ORR. An FFCA is needed to allow continued storage w mixed PCB wastes to exceed the 1-year storage limit until treatment and disposal options become available and full compliance with TSCA can be achieved. On June 1, 1992, a formal request to begin negotiation of the FFCA was sent to EPA Region IV.

ORAU manages the Oak Ridge Institute for Science and Education (ORISE). ORISE is classified under RCRA as a Conditionally Exempt Small Quantity Generator. Air emissions through laboratory hoods are beneath permitting limits. The amount of radioactive material used there is below reportable quantities. No liquid radioactive wastes were discharged in 1992.

\section{Current Issues}

\section{The Federal Facilities Compliance Act}

The Federal Facilities Compliance Act was signed on October 6, 1992. The act required (1) that DOE facilities provide inventory, generation, and characterization information about mixed waste to EPA and to states in April 1993 and (2) that the facilities develop site-specific mixed-waste treatment plans by October 1995. The ORR facilities are developing the information for the mixed-waste report and will support the development of ORR site-specific treatment plans.

\section{Comprehensive Environmental Response, Compensation, and Liability Act (CERCLA)}

The ORR was placed on the National Priorities List in December 1989. To satisfy the requirements for an interagency agreement pursuant to Sect. 120 of the Comprehensive Environmental Response, Compensation, and Liability Act (CERCLA), the EPA, DOE, and TDEC signed a Federal Facilities Agreement (FFA) that became effective on January 1, 1992. The FFA is intended to coordinate response and remedial actions under CERCLA and RCRA Hazardous and Solid Waste Amendments (HSWA) permit issued to DOE for the ORR effective on October 25, 1986. The FFA does not replace the RCRA HSWA permit. It coordinates remedial activities necessary to protect human health and the environment but prevents needless duplication of corrective actions or administrative requirements. The FFA also addresses technical standards for new and existing liquid low-level radioactive waste (LLLW) storage tanks.

\section{Radionuclide National Emission Standards for Hazardous Air Pollutants (Rad-NESHAP) Compliance}

An FFCA for the ORR was signed by all parties and has been implemented. All of the milestones in the FFCA have been met, and the ORR is in full compliance with all requirements of Radionuclide National Emissions Standards for Hazardous Air Pollutants (Rad-NESHAP) as set forth in 40 CFR 61, Subpart H. On March 26, 1993, EPA Region IV certified that DOE-ORO had completed all of the actions required by the ORR Rad-NESHAP FFCA and is considered to be in compliance with the Rad-NESHAP regulations (40 CFR 61, Subpart H). The annual off-site dose to the most-exposed member of the public for the ORR was 1.4 mrem in 1992 , which was well below the Rad-NESHAP compliance limit of $10 \mathrm{mrem}$.

\section{Action Filed by Friends of the Earth, Inc.}

On January 17, 1992, Friends of the Earth (FOE), a nonprofit corporation, filed a lawsuit against 


\section{Environmental Report Vol. 1, Oak Ridge}

Admiral Watkins and DOE in the U.S. District Court for the Eastern District of Tennessee, Northern Division. The suit alleges that DOE is violating the terms and conditions of its National Pollution Discharge Elimination System (NPDES) permits for the Y-12 Plant, ORNL, and the K-25 Site.

Specifically, the complaint alleges that discharges of certain quantities of various pollutants into tributaries of the Clinch River, which have their source at the Y-12 Plant, ORNL, and the K-25 Site, have exceeded (and are exceeding) the allowable discharge limits established by the NPDES permits. The FOE injunction seeks to force DOE to comply in all respects with DOE's NPDES permits, declaratory judgments, and the award of various other costs.

FOE made a request for production of documents, and documents were provided. The complaint was amended to add another environmental group and several individuals as plaintiffs to the lawsuit.

In October 1992, FOE filed a motion for summary judgement with the court. In January 1993, DOE and the U.S. Department of Justice filed a cross-motion for denial of summary judgement. An initial hearing is scheduled in Federal District Court in Knoxville, Tennessee, for April 1993.

\section{Tennessee Oversight Agreement}

The state of Tennessee and DOE have entered into a 5-year Monitoring and Oversight Agreement intended to assure Tennessee citizens that their health, safety, and environment are being protected during facility operations, ongoing cleanup activities, and emergency response efforts for the ORR and the surrounding areas.

The agreement was signed on May 13,1991 and reflects the obligations and agreements between DOE and the state regarding technical and financial support provided by DOE to the state for its oversight of these activities. The agreement also ensures that DOE complies with all applicable laws, regulations, and orders. The agreement may be extended beyond 5 years or may be amended as necessary. It may also be modified as appropriate to address community issues that arise.

TDEC is the lead Tennessee state agency for implementation of the agreement. The agreement states that DOE will provide financial support to allow Tennessee to carry out its commitments under the oversight agreement and the FFA regarding cleanup activities.

\section{Moratorium on Off-Site Shipment of Hazardous Waste}

A moratorium on the off-site shipment (to non-DOE sites) of hazardous waste was placed on DOE facilities, including those on the ORR, in May 1991. The moratorium was put in place to prevent waste contaminated with radioactive material from being shipped to a facility which is not licensed to handle nuclear material. The moratorium effectively requires all RCRA hazardous waste generated at the ORR to be managed as mixed waste (hazardous wastes also contaminated with radioactivity) until appropriate procedures are developed and approved to ensure that selected waste streams are free of radioactivity. There is a severe lack of permitted storage, treatment, and disposal capacity for mixed wastes on the ORR and other DOE sites.

The off-site shipment moratorium places severe limitations on the management options for RCRA hazardous waste generated at the ORR facilities. Martin Marietta Energy Systems, Inc., staff are working to develop appropriate procedures for DOE Headquarters approval that will allow resumption of off-site management options for waste generated within the Y-12 Plant that can be demonstrated to contain no additional radioactivity.

\section{The Aerial Remote Sensing Surveys Program}

In 1992 DOE established the Aerial Remote Sensing Surveys (ARSS) Program to plan and coordinate aerial and remote-sensing data-collection activities on the ORR. It was established in support of the Environmental Restoration Program, to provide it with environmental site characterization data, change data, and trend data. Three separate surveys have been conducted during the last year and a half: Phase I, Phase II, and a base map survey. The surveys included a high-resolution radiological (gamma) survey, natural color and color infrared photography surveys at altitudes ranging from 3,000 to $42,000 \mathrm{ft}$ above ground level (AGL), and a multispectral scanning survey at altitudes ranging from 3000 to $9000 \mathrm{ft}$ AGL. 


\section{Environmental Report Vol. 1, Oak Ridge}

The Phase I surveys were conducted from March 30) through April 14, 1992, by EG\&G Energy Measurements, Inc., (Las Vegas and Washington, D.C., Operations) in close cooperation with ORR site personnel. Site personnel were also active in a number of other support activities, including security, subcontractor oversight, and preparation and release of information to site employees and to the public.

Phase II geophysical surveys, conducted by Geonex Aerodat, Inc., included simultaneous magnetic, electromagnetic, and radiological surveys of the ORR by helicopter. These surveys, conducted between November and January 1993, included a testing phase to ensure the viability of the technological and regional reconnaissance survey of the entire ORR. Additional target surveys are planned for the fall of 1993.

A new base-map initiative resulted in the flight of a natural-color and color-infrared photography mission during April 1993, which collected photographs at $7200 \mathrm{ft}$ AGL. This mission utilized the new global positioning system (GPS) equipment interfaced in real time to a GPS base station, recently installed by the National Oceanographic and Atmospheric Administration at McGhee Tyson Airport. New base maps of the ORR will be produced as one of the data products of this initiative.
Results from the aerial radiological surveys will be reported in the EG\&G document An Aerial Radiological Survey of the Oak Ridge Reservation, Oak Ridge, Tennessee (EGG-10617-1229), which is scheduled for release in August 1993. A draft of the report is currently available from the DOE Nevada Operations Office. The results are reported as inferred exposure rates at $1 \mathrm{~m} \mathrm{AGL}$ in the form of radiation contour maps superimposed on high-altitude aerial photographs. Typical background exposure rates were found to vary from 7 to 11 microroentgens per hour. The man-made radionuclides, ${ }^{60} \mathrm{Co}$ and ${ }^{137} \mathrm{Cs}$ and the man-concentrated radionuclides ${ }^{235} \mathrm{U}$ and ${ }^{231} \mathrm{U}$ were detected at several facilities on the ORR.

Preliminary results from the helicopter geophysical surveys are reported in Aerial Remote Sensing Surveys Progress Report: Helicopter Geophysical Survey of the Oak Ridge Reservation, W. E. Doll et al. (ES/ER/TM-62, March 1993).

Data-management activities for the ARSS Program include conversion to digital format for inclusion in site-wide geographic information systems. The data will become part of the Oak Ridge Environmental Information System and will be available electronically (subject to certain restrictions) to all site personnel, regulators, and other users interested in access to the data. 


\section{Compliance Summary Environmental Compliance Activity U.S. Department of Energy}

\section{Oak Ridge Y-12 Plant}

\section{Compliance Status}

\section{Clean Air Act (CAA) and Radionuclide National Emission Standards for Hazardous Air Pollutants (Rad-NESHAP)}

The Oak Ridge Y-12 Plant has about 93 activa air permits covering 400 air emission points. The number of permits and permitted emission points decreased during 1992 because of the reduction of some operations and because some points are exempted from permitting requirements. There are currently about 270 documented exempt minor sources and about 340 exempt minor emission points. Eighty-five radiological stacks are equipped with continuous stack samplers to sample uranium ernissions. A plan for using these samplers to meet the requirements of Title 40 of the Code of Federal Regulations (CFR), Part 61 Subpart H (National Emission Standards for Emissions of Radionuclides other than Radon from Department of Energy Facilities), for sampling significant radionuclides emission points was completed in 1992.

A Federal Facility Compliance Agreement (FFCA) for NESHAP that established methods and schedules for U.S. Department of Energy (DOE) facilities on the Oak Ridge Reservation (ORR) to become fully compliant with these requirements was negotiated betiveen the DOE-Oak Ridge Operations Office (DOE-ORO) and the U.S. Environmental Protection Agency (EPA) in 1991 and signed in 1992.
EPA Region IV certified that the ORR has completed all of the actions required by the Rad-NESHAP FFCA and is considered to be in compliance with Rad-NESHAP Regulation in the Code of Federal Regulations (40 CFR 61, Subpart H). As required by the plan, the Y-12 Plant has implemented a stack-and-vent survey to identify and characterize all radionuclide emission points. A report submitted to EPA in June 1992 identified all major and minor radionuclide emission points. Major radionuclide sources, defined in the regulations as those with the potential to emit greater than $0.1 \mathrm{mrem}$, will be continuously sampled to quantify emissions. Periodic emissions estimates for the minor sources will be made as specified in the compliance plan.

Certification was submitted to the EPA in January 1993 to indicate that all actions required under the FFCA were complete and the ORR facilities were in compliance with NESHAP standards for radionuclides. EPA concurrence was received on March 16, 1993.

Procedures for permitting, compliance inspection, and documentation of compliance are in place. Inspections of all potential air emission sources are conducted on a regular basis. Major sources are appropriately permitted, and documentation of compliance is developed. A number of minor sources (those with no potential to exceed $0.1 \mathrm{mrem}$ ) that are exempt from permitting under state of Tennessee rules are being addressed also. All major emission sources are permitted by the Tennessee Department of Environment and 


\section{Environmental Report Vol. 1, Oak Ridge}

Conservation (TDEC) and are operating in compliance with those permits.

Planning for compliance with anticipated and newly issued requirements of the 1990 Clean Air Act (CAA) Amendments is a major effort. In accordance with the Y-12 Plant CAA Implementation Plan, a Stratospheric Ozone Protection Plan was issued to outline actions necessary to comply with new limitations on the release of ozone-depleting chemicals and with the 1995 production ban on those chemicals. Although EPA personnel have missed many of the milestone dates for issuing new regulations, a number of regulations for stratospheric ozone protection have been issued. The Y-12 Plant Stratospheric Ozone Protection Committee has successfully implemented the work practices required to minimize releases of chlorofluorocarbon refrigerants to the atmosphere. Compliance requirements for motor vehicle air conditioner maintenance and refrigeration system maintenance are being met. Studies are proceeding on finding replacements and performing the necessary modifications to plant refrigeration equipment to accommodate the production ban on ozone-depleting chemicals. Activities are scheduled to be completed by October 1999.

In anticipation of the permitting requirements and implementation of Maximum Achievable Control Technology standards of the 1990 amendments, an effort is under way to improve the stack and vent survey, criteria pollutant emission inventory and hazardous air pollutant emission inventory. These efforts will be required to submit the permit applications required under Title $V$ of the amendments. The applications are expected to be required sometime in 1995.

\section{Clean Water Act (CWA)}

The Y.12 Plant National Pollutant Discharge Elimination System (NPDES) permit encompasses about 220 point-source discharges requiring compliance monitoring that results in about 10,000 annual samples. While noncompliances with the NPDES permit and spills to the environment oceur. progress continues to be made on minimizing these incidents and their effect on receiving streams.

Monitoring of discharges demonstrates the plant has achieved an NPDES permit compliance rate of over $99 \%$. Since the mid-1980s, over 200 untreated discharge sources have been eliminated or treated. Personnel at the Y-12 Plant operate five on-site wastewater treatment plants and numerous wastewater collection facilities Biological monitoring programs conducted on surface streams near the $Y-12$ Plant provide evidence of the ecological recovery of the streams.

An application for renewal of the $Y-12$ Plant NPDES permil was provided to TDEC in November 1989. The NPDES permit expired May 23, 1990. The plant continues to operate under the former permit pending issuance of a new permit by the TDEC as provided in Tennessee Regulations 1200-4-1.05(5)(b).

An NPDES storm water permit application, based on sampling during storm events, was submitted to the TDEC September 30, 1992. In February 1993 the Y-12 Plant also submilted an addendum to the November 1989 NPDES permit application in order 10 update this document with recent sampling/analytical data, changes to discharges, and information on storm water. Discussions with TDEC personnel regarding the permit application and renewal are in progress.

Personnel at the Y-12 Plant operate a sanitary sewer collection system. Sanitary wastewater is discharged to the city of Oak Ridge under an industrial pretreatment permit. A new monitoring station will be built to allow for more accurate monitoring of the sanitary sewage discharges by the Y-12 Plant. No violations to this permit occurred during 1992.

EPA personnel performed a Compliance Sampling Inspection of the Y-12 Plant and the NPDES self-monitoring program on March 31 through April 2, 1992. All inspection results were deemed satisfactory except for a few minor laboratory deficiencies. Site inspections of the sanitary sewer system were conducted by the city of Oak Ridge personnel on March 19 and August 8 , 1992. No deficiencies were found, and continuation of projects relating to the monitoring station and correction of infiltration/inflow were recommended.

\section{Resource Conservation and Recovery Act (RCRA)}

The Y-12 Plant is in compliance with the majority of RCRA requirements. Noncompliance issues have been identified by plant personnet and are being aggressively pursued. Whenever possible, 


\section{Environmental Report Vol. 1, Oak Ridge}

corrective actions are implemented immediately to correct the problem. Other issues require compliance agreements with regulatory agencies to schedule implementation of corrective actions.

- The Y-12 Plant generates hazardous wastes, and personnel operate hazardous waste management units for the treatment and storage of such waste. About 400 areas are operated in the $Y-12$ Plant where hazardous wastes are accumulated. In addition, the $Y-12$ Plant operates about 20 hazardous waste storage and/or treatment units. There are no units at the Y-12 Plant that are actively used for the disposal of hazardous wastes. Closure actions are complete for several previously used hazardous waste disposal units. Closure activities are still under way for several additional disposal units.

- The Y-12 Plant is being operated under interim-status regulations in accordance with a Part A permit application, the most recent version of which was approved in July 1991. An amended Part A permit application was submitted to TDEC in December 1991, but has not yet been acted on. The RCRA Part B permit applications have been submitted for all of the active storage and treatment units listed on the Part A permit application. These Part B applications are still awaiting action by the state staff.

- The Y-12 Plant is operating in compliance with interim status regulations. Planning is under way to construct additional RCRA hazardous waste storage and treatment facilities. The last RCRA hazardous waste compliance inspection conducted by the state staff occurred in April 1992. No notices of violation were issued as a result of this inspection.

On June 12, 1992, negotiation of an FFCA to resolve the compliance issue of storing land ban waste in excess of one year was completed. The FFCA contains a compliance schedule whereby the strategies and plans for removal of the backlog of land ban waste through the use of existing permitted treatment facilities [e.g., K-25 Site Toxic Substances Control Act (TSCA) Incinerator, as well as new facilities] must be accomplished. Resolution of the off-site shipment moratorium will obviously impact the volume of waste that must be addressed by the FFCA and will significantly impact this issue.

\section{Toxic Substances Control Act (TSCA)}

Polychlorinated biphenyls (PCBs) are used at the Y-12 Plant, and PCB wastes are generated. The storage, control, and disposal of these are regulated by TSCA. A compliance issue exists regarding the storage of uranium-contaminated PCB wastes beyond the 1-year limit (see Current Issues, "Uranium-Contaminated PCB Waste Storage" for details).

Several projects have been initiated to reduce and eliminate PCBs and PCB items. These projects include annual audits to inventory regulated PCBs, sampling to ensure that $\mathrm{PCB}$ transformer pads are cleaned and sampled according to regulations, and sampling to ensure regulatory compliance with testing requirements of hydraulic, heat-transfer, and lubricating systems. Per 40 CFR 761, such systems may be utilized if the PCB concentration is less than $50 \mathrm{ppm}$. Those systems found to contain greater than $50 \mathrm{ppm}$ PCB are being decontaminated, and approval is being sought from EPA personnel to reclassify those systems.

The Y-12 Plant generates an annual PCB report for submission to EPA and TDEC. The report provides details of PCBs and PCB items in use, stored for disposal, generated during the year, and disposed of throughout the year.

Significant progress was made during 1992 in addressing historical PCB spills on transformer pads or inside buildings. Cleanup actions for such spills are established at the discretion of EPA. Cleanup inside three buildings at $\mathrm{Y}-12$ was initiated in 1992.

The Y-12 Plant has numerous facilities that contain asbestos materiais. Compliance programs for asbestos management include identification of asbestos materials, monitoring, abatement, and disposal. Procedures that delineate scope, roles, and responsibilities for maintaining compliance with EPA and Occupational Safety and Health Administration (OSHA) regulatory requirements are maintained. No nonconformances with environmental protection standards were identified in 1992. 


\section{Environmental Report Vol. 1, Oak Ridge}

\section{Underground Storage Tanks (USTs)}

The Y-12 Plant UST Program includes 45 USTs. This number incorporates regulated petroleum and hazardous substance USTs, and in the interest of Best Management Practice, tanks that are deferred or exempt. The UST Registration Certificates are effective until March 31, 1994. The following reflects the status of the Y-12 Plant USTs:

- Active/In-Service Petroleum USTs-Seven in total

- Seven existing tank systems were installed since 1986. Compliance with regulatory requirements has been completed on two USTs. The remaining five will be upgraded before the December 22 , 1998, deadline.

- Inactive/Out-of-Service Petroleum USTs-Four in total

- There is one heating oil tank (exempt by definition). This tank is scheduled for permanent closure by removal.

- There are three fuel dispensing holding tanks that have been emply since 1979. These are scheduled for removal in association with the corrective action at the Y-12 Plant East End Fuel Station.

- Closed USTs (Removed or Inert Filled)-Thirty-two in total

- The characterization and over excavation are complete at six tank sites. The final documentation was submitted to TDEC with "no further" action recommended. Written concurrence from TDEC is pending.

- The characterizations are complete for five tank sites (nine tanks in total). Corrective Action Plans have been submitted to the TDEC staff. The TDEC staff approval is required prior to initiating corrective actions.

- There were three heating oil tanks c'osed prior to December 22, 1988; these are exempi because they are excluded from the statutory detinition of USTs or because they were less than $110 \mathrm{gal}$ in size.

- Two emergency power generator tanks were removed in 1974, prior to RCRA, Subtitle I, which excludes these, which held less than liogal.
- Concurrence from TDEC on final tank closures was received on two tank sites.

- The closure reports for four tank sites are in progress.

- Three tank sites (six tanks in total), having a Solid Waste Management Unit (SWMU) designation under the Hazardous and Solid Waste Amendments (HSWA), will be remediated under Comprehensive Environmental Response, Compensation, and Liability Act (CERCLA).

- Hazardous Substance USTs-Two in total

- There are two concrete burial vaults containing solid uranium oxide. These are deferred according to the regulations. Any UST system containing radioactive material that is regulated under the Atomic Energy Act of 1954 is deferred.

\section{Comprehensive Environmental Response, Compensation, and Liability Act (CERCLA)}

The Federal Facilities Agreement (FFA) for the ORR was signed in November 1991, with an effective date of January 1, 1992. In the FFA, the Y-12 Plant has 113 sites listed as No Further Action (NFA), 46 for preliminary assessment/site investigation (PA/SI), and 52 for remedial investigation/feasibility study (RI/FS) phase studies. The Environmental Restoration (ER) staff developed a site management plan, which is the implementing document for the FFA. Both the FFA and the site management plan are due to have the list of sites revised to reflect 103 proposed no further investigation remediation units, $70 \mathrm{PA} / \mathrm{SI}$ phase, $28 \mathrm{RI} / \mathrm{FS}$ phase consolidated into 11 operable units (OUs), and 4 NFA phase for the Y-12 Plant.

The ER Remedial Action Program progress in 1992 included the following:

- Completed construction at the United Nuclear Corporation site. Completed shredding of material and removal of open items at Kerr Hollow Quarry (KHQ), along with the completion of the gas cylinder breaching.

- Completed four of five deep cores/wells in Bear Creek Valley (BCV) to support investigation of contamination of groundwater by dense nonaqueous phase liquids. 
- Completed studies supporting permitting of the Solid Storage Facility (SSF).

- Submitted the Phase II Sampling Plan for Chestnut Ridge (CNR) OU2.

- Initiated work on the RI Work Plan for CNR OU4.

- Produced summary reports of analytical data from Health, Safety, and Environment Organization storm sewer sampling project in support of Upper East Fork Poplar Creek (UEFPC) OUI.

- Completed the planning and implementation documents necessary to start sampling UEFPC. OU2.

- Revised RCRA closure plans for the Diked Tank Storage Facility and Garage UST.

- Initiated work on the Mercury Tank Remediation project.

- Completed piping reroute in Building 9201-2.

- Obtained the final Record of Decision for the Plating Shop.

- Submitted BCV OU2 RI Work Plan.

- Initiated work on BCV OU4 Shallow Groundwater RI Plan.

- Completed Life Cycle Baseline and cost estimates for the Y-12 Plant ER Remedial Action Program.

\section{Emergency Planning and Community Right-To-Know Act (EPCRA)}

The Emergency Planning and Community Right-to-Know Act (EPCRA) contains four major provisions: (1) planning for chemical emergencies, (2) emergency notification of chemical accidents and releases, (3) reporting of hazardous chemical inventories, and (4) toxic chemical release reporting.

The emergency planning section of the law is designed to help the community prepare for and respond to emergencies involving hazardous substances. The emergency notification section of the law requires that a facility immediately notify the community and state of the release of more than a predetermined amount of several hazardous substances; this is also known as release reporting.
Reporting the hazardous chemical inventory provides local communities and agencies with knowledge of potential hazards posed by stored chemicals. The information also aids on-site emergency-preparedness personnel in responding (o an emergency situation. This reporting is done through an annual hazardous chemical inventory, which contains quantities and locations of hazardous chemicals and extremely hazardous substances that have reached the storage threshold as specified within the act (Sect. 312). Also, a list of these chemicals and substances are prepared along with the hazard category (Sect. 311). During CY 1992, the Y.12 Plant reported 39 hazardous chemicals and 7 extremely hazardous substances.

In addition, the toxic chemical release report is prepared to inform communities of releases of some 320 toxic chemicals into the air, water, or soil. If the use of the toxic chemical reaches one of the thresholds specified within the act (Sect. 313) either accidentally or as a result of routine plant operations, then the total amount of the chemical that is releised into the environment must be estimated, and the amount of the chemical transported as waste to another location must be reported. For $\mathrm{CY}$ 1992, the $Y-12$ Plant reported use of six toxic chemicals in processing.

\section{Release Reporting}

Spills and unanticipated releases may trigger one or more of the following statutes: EPCRA lalso known as Title 111 of (the Superfund Amendments and Reauthorization Act) SARA I, CERCLA, RCRA, CWA, CAA, and TSCA. Each spill event is evaluated for reporting requirements. Regulatory agencies as well as federal, state, and local emergency response agencies are notified as appropriate. The $\mathrm{Y}-12$ Plant had two CERCLA reportable events in 1992: a hydrogen fluoride release (see Special Studies, Sect. 8) of approximately $650 \mathrm{lb}$ and a release of $185 \mathrm{gal}$ of untreated waste water at the West End Treatment Facility due to a rupture in a pressurized water line. In addition, three reports of minor ethylene glyeol spills from vehicle radiators were also reported.

Six oil sheens, resulting from the release of small quantities of oil, were reported to the U.S. Coast Guard National Response Center pursuant to requirements of the CWA. There were no reportable 


\section{Environmental Report Vol. 1, Oak Ridge}

releases pursuant to RCRA, CAA, or EPCRA

(Title III, SARA).

To determine whether the Y-12 Plant had any

reportable releases (i.e., those not federally permitted and exceeding the CERCLA reportable quantities), a compliance assessment of all releases or potential release sources was conducted. It was concluded that no releases of reportable quantities are occurring at the Y-12 Plant that qualified for reporting in accordance with 40 CFR 302.8 as continuous releases. For spills of hazardous substances exceeding reportable quantities (RQs), the National Response Center and the Tennessee Emergency Management Agency are notified immediately. For spills of hazardous or extremely hazardous substances that potentially impact the off-site environment, the local emergency planning committees of areas potentially affected by the release would be notified verbally and in writing.

\section{National Environmental Policy Act (NEPA)}

Compliance with NEPA, as administered by the DOE NEPA Implementing procedures (10 CFR 1021) and the Council on Environmental Quality (CEQ) regulations (40 CFR 1500-1508), ensures that consideration is given to environmental values and factors in federal planning and decision making. To strengthen its NEPA review and documentation process, the DOE pronulgated its new NEPA regulations on May 26, 1992. These new regulations expanded the list of Categorical Exclusions (CXs) available for use and refined DOE's NEPA implementing procedures to more closely parallel the CEQ regulations.

The Y-12 Plant NEPA Program maintains compliance with NEPA through the use of its plant and administrative procedures. Operating Organizations such as Maintenance, Development, and Engineering have internal procedures which define additional review and documentation steps that streamline the internal review of projects.

In CY 1992, the Y-! 2 NEPA Program received 60 approved $C X$ determinations from the DOE-ORO. In addition, the Y-12 NEPA Program staff, in utilizing previously approved general Cxs, reviewed and documented more than 575 projects. The DOE Y-12 Site Office and the DOE-ORO NEPA compliance officer approved of this approach and monitored this process through surveillance. The Y-12 NEPA Program presently utilizes 16 general CXs such as Maintenance Support Actions, Minor Building Alterations, and Personnel Safety Enhancements.

In CY 1992, the Y-12 Plant received three approved Environmental Assessments (EAs) for the Plating Shop Replacement, the Environmental Support Facilities project, and the Steam Plant Ash Disposal Facilities project. These EAs were approved by issuance of Findings of No Significant Impacts and did not require Mitigation Action Plans. The approval of the EA for the sale of excess lithium hydroxide was sent out for final state review in April 1993 and will subsequently be submitted to DOE Headquarters (DOE-HQ) for final approval. This EA covers material now stored at the K-25 Site and the Portsmouth Gaseous Diffusion Plant. In addition, new EAs were initiated for the Oak Ridge Reservation Storage Facility project, the Hydrogen Fluoride Supply System for Building 9212, the Alternate Access Road, and the Industrial Waste Compaction Facility. Support work continues on the Alpha 4 Decontamination and Decommissioning (D\&D) EA. A request for direction to initiate an environmental impact statement (EIS) for the Mixed Waste Treatment Facility project was also initiated through the DOE-ORO.

These projects have been evaluated in light of the Programmatic Environmental Impact Statement (PEIS) for the reconfiguration of the DOE Nuclear Weapons Complex (Complex 21) and have been determined to be justified separately and independently of the PEIS, thus allowing the actions to proceed. All EAs initiated through the Y-12 Plant are reviewed against the PEIS to ensure that the project would not prejudice a potential alternative of Complex 21 PEIS.

In conjunction with the NEPA review and documentation process for all new projects, an assessment for compliance with the requirements of numerous sensitive area and cultural resource protection laws is conducted. Examples of these are Endangered Species Act; the National Historic Preservation Act; and Executive Orders 11988, "Floodplain Management," and 11990, "Protection of Wetlands," as administered by the DOE Implementing Regulations on Floodplains and Wetlands and found in 10 CFR 1022. 


\section{Environmental Report Vol. 1, Oak Ridge}

\section{Federal Insecticide, Fungicide, and Rodersticide Act (FIFRA)}

The Y-12 Plant maintains compliance with FIFRA requirements through inspection of controlled pesticide/herbicide storage areas and review of the on-site, restricted-use application program. A new compliance program manual has been developed and will be implemented once quality review is finished. The manual contains requirements and responsibilities for FIFRA compliance.

\section{Safe Drinking Water Act (SDWA)}

The Y-12 Plant is designated as a "Non-transient Non-community" water distribution system by the TDEC Division of Water Supply, and is subject to the Tennessee "Regulations for Public Water Systems and Drinking Water Quality," Chap. 1200-5-1.

Potable Water is received from the DOE-owned water treatment facility located northeast of the Y-12 Plant. In addition to serving the Y-12 Plant, the treatment plant serves the city of Oak Ridge and the Oak Ridge National Laboratory. It is currently managed for DOE by Johnson Controls World Services, Inc.

The treated water is tested for parameters listed under the state and federal drinking water regulations at various points throughout the plant distribution system. In January 1993, the Y-12 Plant completed the first 6-month sampling period, required under the SDWA Lead and Copper Rule, and began the second 6-month sampling period. The Y-12 Plant met the 90 th percentile lead and copper concentration requirements for the first 6-month sample period.

The Y-12 Plant implemented a cross-connect control program in the mid-1980s; during that time a study was conducted by an outside contractor to identify potential and existing cross-connects in the plant. Since that time all known cross-connects have been eliminated and an ongoing program to prevent and eliminate newly identified cross-connects continues. Prevention and elimination of cross-connects is done through an engineering review and permitting system and installation of air-gaps. vacuum breakers, and back-flow prevention devices. As part of the program, an inventory is maintained of installed back-flow prevention devices, and inspection of the devices is conducted in accordance with regulatory requirements.

\section{Environmental Audits}

Nineteen external environmental audits and reviews were conducted at the $\mathrm{Y}-12$ Plant during 1992. Audits conducted by the EPA at the Y-12 Plant included TSCA, NESHAP, and sampling for NPDES monitoring. TDEC conducted reviews covering groundwater, RCRA, Clean Air, and Solid Waste Disposal/Landfill operations. Y-12 Plant environmental programs were found to be very effective at maintaining compliance with regulatory statutes.

In addition to EPA, TDEC, and DOE audits and reviews, the Y-12 Plant organization and the DOE Environmental Protection Division performed numerous assessments and reviews of the environmental programs at the Y-12 Plant. These assessments and reviews focused on the environmental program, record keeping, Quality Assurance programs, health and safety programs, environmental sampling procedures, and storage of toxic and hazardous waste. These assessments led to improved operating procedures and management practices.

\section{DOE Order Assessments}

Compliance assessments of DOE orders were performed as required in accordance with a $\mathrm{Y}-12$ Plant procedure. For the purposes of this self-assessment and as agreed to by DOE-ORO, "compliance" is defined as the existence of written policies, procedures, or instructions that address the requirements of the DOE order. More than 120 detailed compliance assessments were performed in 1992 on individual requirements. Four assessments were completed on DOE orders pertaining to environmental matters. Compliance with the DOE orders was documented or a corrective action plan was created to reach compliance.

During 1992 the following actions were completed on DOE orders pertaining to environmental and waste management activities.

\section{DOE Order 5400.1-General Environmental Protection Program}

During 1992 the Y-12 Plant compliance status moved from partial to full compliance for this order. The Environmental Monitoring Plan for the Oak 


\section{Environmental Report Vol. 1, Oak Ridge}

Ridge Reservation (DOE/OR-1066) was released by DOE in September. The $Y-12$ Site Environmental Protection Implementation Plan (DOE-ORO 1069 Rev. 2) was revised by the DOE-ORO in November 1992. A new procedure to identify compliance issues at the Y-12 Plant was developed and issued. In addition, a revised procedure for conducting environmental appraisals and audits was issued.

\section{DOE Order 5400.5-Radiation Protection of the Public and Environment}

Essential elements of this order have been implemented. During 1992 a Rad-NESHAP FFCA for airborne radionuclides was signed by both $D O E$ and EPA. Personnel from EPA also approved in 1992 the Quality Assurance Project Plan for the NESHAP sampling of radionuclides, and the Y-12 Plant completed necessary upgrades to uranium stack samplers in December 1992 to allow for leak testing. Full compliance with the order will be achieved through the development and approval of an As Low As Reasonably Achievable (ALARA) implementation plan to address radiological releases.

\section{DOE Order 5820.2A-Radioactive Waste Management}

Overall, the $\mathrm{Y}-12$ Plant is in partial compliance with the chapters of this order. As a result of a compliance assessment of this order, as performed by the $\mathrm{Y}-12$ Waste Management Organization in 1992, three noncompliances and one partial compliance were found in Chap. 5, Decommissioning of Radioactive Contaminated Facilities. Five partial compliances were found in Chap. 3, Management of Low Level Waste. Three of these were associated with the Waste Minimization Program while the other two were associated with Waste Management.

The Y-12 Plant Waste Minimization Program complies with the intent of the order; however, documentation of activities associated with minimization of low-level waste is lacking. For that reason, the existing program is being modified and procedures are being developed and implemented with regard to documentation requirements. These improvements will ensure that the waste minimization activities performed to meet the requirements of the order are fully documented.
Aggressive action is under way at the Y-12 Plant to fulfill the needs of the landlord requirements of Chap. 5 of this order. Additional contaminant characterization is needed and as-built drawings are not available for all buildings. A D\&D Program has been established at the Y-12 Plant, and an organizational program structure is in place. The decommissioning of facilities once transitioned into the D\&D Program is under the jurisdiction of the Y-12 D\&D Program. Based on reviews of historical operating records and on the extent of building contamination levels, current building facilities will be transitioned from Defense Programs into the D\&D Program. Currently, Building 9201-4 is the only building at the Y-12 Plant in the D\&D Program. This building has been used for chemical process operations which utilized mercury as a solvent, and is contaminated with mercury, low levels of radioactivity, PCBs, and asbestos. In addition, the D\&D Program organization has recently assumed responsibility for Building 9213 , which is scheduled to transition to DOE's Office of Facility Transition in FY 1994. This building was used by ORNL for critical experiments and contaminants of concern are radioactive isotopes. A readiness review for placing this facility in safe shutdown is in progress with the formal criteria for shutdown, which is scheduled to be established by September 1993.

The Y-12 D\&D Program is heavily involved in the project planning phase of Building 9201-4. Y-12 $D \& D$ is responsible for all Surveillance and Maintenance (S\&M) activities associated with Building 9201-4. An S\&M Plan has been developed and approved for these activities. A baseline design report, the framework for the D\&D Plan, has been submitted to and approved by DOE. Funding for the project has also been formally planned for and obtained. A life cycle baseline has been developed and is currently being modified in association with prioritization of funding.

\section{Other Requirements of DOE Orders}

The Y-12 Plant has inspection and permitting programs for all environmental regulations as required by DOE Order 5480.4, Environmental Protection, Safety, and Health Protection Standards. Inspections to constantly verify and maintain compliance are routinely performed. The $\mathrm{Y}-12$ Plant also has an advanced compliance issue notification 
and tracking system in accordance with DOE Order 5400.2A, Environmental Compliance Issue Coordination. Compliance issues from audits or daily inspection activities are promptly reported as per established guidelines. These issues are then tracked to closure using a computerized data base, which is in the process of being migrated to the Energy Systems Action Management System (ESAMS) electronic tracking system.

\section{Current Issues}

\section{NPDES Storm Water Permitting}

The Y-12 Plant established a monitoring plan in June 1991 to collect the necessary quantitative information concerning storm water runoff from various drainage areas at the Y-12 Plant site. All outfalls containing storm water were grouped into one of two categories: Category I, discharges consisting of precipitation runoff and/or groundwater only; and Category II, discharges consisting of storm water, groundwater, and/or process wastewaters. An individual permit was requested for the Category II outfalls, and for the Category I outfalls a notice of intent was filed for a baseline general permit to discharge storm water associated with industrial activity. Submission of these applications were made to the TDEC on September 30, 1992. The applications were based on extensive sampling and analytical work, mapping, and the assimilation of information on disposal areas, outdoor storage facilities, structural controls, and other features affecting the water quality of surface streams.

\section{Surface Water Corrective Activities}

Activities are under way to reduce discharges of priority pollutants, high temperature, and toxic agents such as chlorine to East Fork Poplar Creek (EFPC). Projects that address the reduction of chlorine from recirculatory cooling water system blowdown, temperature and chlorine reduction in once-through cnoling water discharge, rerouting miscellaneous sources from storm drains, and enhancement of on-site treatment facility capabilities are progressing. Additional efforts relating to reducing non-point-source pollutants to surface streams and mercury pollution are being planned. To support this effort two reports have been prepared and issued:
Feasibility Study of Best Management Practices for Non-Point Source Pollution Control of Parking Lots at the Oak Ridge Y-12 Plant, 1992, and Feasibility Study of Best Management Practices for Non-Point Source Pollution Control at the Oak Ridge Y-12 Plant, February 1993.

\section{Fish Kill Summary}

A chronic fish kill, primarily attributable to elevated concentrations of chlorine in EFPC, has continued throughout 1992. A total of 1669 dead fish was collected from the stretch of EFPC within the Y-12 Plant boundary in 1992. Two treatment systems that provide dechlorination for three major chlorine contributing outfalls were constructed and became operational during the final months of 1992. Since the initiation of the two dechlorination systems the number of fish killed in EFPC as a result of elevated chlorine levels has drastically decreased. Plans are under way for the construction of a third dechlorination system, which will bring the total of EFPC discharge undergoing dechlorination to about $90 \%$.

\section{Oil Sheen Summary}

Five reportable oil sheens were observed on EFPC during 1992, which has been reduced from eight in 1991. Efforts have continued to improve spill prevention measures and spill response time throughout the $\mathrm{Y}-12$ Plant. The number of observations of the recurring sheen at the north/south pipes were also significantly reduced in 1992 as a result of continued efforts to plug floor drains and to eliminate sources which are inappropriately tied to the storm sewer system.

\section{Sanitary Sewer}

A sanitary sewer inflow/infiltration study has been initiated at the request of personnel from the city of Oak Ridge and DOE. Inflow may result from storm water runoff from rain spouts and manholes while groundwater may infiltrate through cracks and crevices in the sewer. In addition, clean water systems such as steam condensate and once-through cooling water may contribute to inflow from the Y-12 Plant. On January 16, 1993, installation of flow meters at the designated monitoring sites throughout 


\section{Environmental Report Vol. 1, Oak Ridge}

the Y-12 Plant sanitary sewer system was completed. There are a total of 12 flow meters set up along the east and west sewer lines, and the operation time of the west line lift pumps is also being recorded. Data from these locations will be collected through August; a report of the results will be completed by August 31,1993 . The locations chosen will enable a determination of the areas of the Y-12 Plant that have major inflow/infiltration problems. The results of the flow monitoring during this project will help in determining which areas of the plant should be investigated further to isolate the correct sources of inflow/infiltration.

Field investigations of specific inflow sources and suspected points of cross-connection with the plant storm drain systems are ongoing. Correction of inflow sources is being addressed as part of the surface water corrective action program.

\section{Land Disposal Restrictions (LDR) Waste}

RCRA mixed, radioactive land ban waste has been stored in some areas at the Y-12 Plant in nonconformance with land disposal restrictions (LDR) storage restrictions. These wastes are currently subject to the land ban storage restrictions that permit storage only for accumulation of sufficient quantities to facilitate proper treatment, recycle, or disposal. These wastes are being stored at the Y-12 Plant because of the nationwide shortage of treatmen! and disposal facilities for these types of waste. Storage of waste for this purpose does not comply with LDR storage restrictions. In 1992 DOE-ORO completed negotiations of an FFCA with EPA Region IV that details the steps needed to attain compliance with LDR requirements.

\section{Uranium-Contaminated PCB Waste Storage}

Uranium-contaminated $\mathrm{PCB}$ wastes are being stored in excess of the one-year limit imposed by TSCA because of the lack of treatment and disposal capabilities. A compliance agreement with EPA Region IV is being pursued.

\section{DOE Environmental Assessment (Tiger Team)}

In September and October 1989. a team of DOE environmental specialists conducted a comprehensive assessment of environmental practices at the $\mathrm{Y}-12$ Plant. The assessment covered the CWA, the CAA, the RCRA, the TSCA, remedial programs, radioactive emissions, NEPA, USTs, and environmental monitoring and surveillance. The assessment expressed concern over 24 compliance issues. Other practices relating to Best Management Practices were also examined. Corrective action plans have been developed and are being implemented for the issues. Of the 62 environmental findings identified by the Tiger Team, 16 remain open and 46 have been completed.

The DOE-HQ Environmental, Safety, and Health (ES\&H) Progress Assessment team completed a 2-week review of the Y-12 Plant on February 1992. The team identified no major concerns and concluded that substantial progress had been made since the 1989 Tiger Team Compliance Audit; however, substantial management effort will still be required to achieve ES\&H excellence. The assessment identified a total of 13 concerns, 5 improvements, and 4 strengths.

\section{Waste Minimization Program}

Process Waste Assessments (PWAs) have been conducted as part of the ongoing programs to identify, screen, and analyze options to reduce the generation of waste. A PWA determines the amount of material for a workplace that is disposed as waste during work operations. It provides a summary of hazardous materials usage and waste production and identifies those processes and operations that need to be improved or replaced to promote waste minimization. The assessment provides a basis for ranking the specific modifications to site processes or other waste minimization options developed during the assessment.

Several project teams throughout the site have achieved considerable success in waste reduction and minimization activities. In addition, a LDR Waste Evaluation Task Team was named in 1992 and chartered to identify streams for reduction, substitution, and/or elimination and to advise generators in ways to do so. Several projects from 
PWAs and the LDR task team were initiated in 1992. Though the projects are at various stages of implementation, further reductions in waste generation as a result of these projects are expected to be realized in 1993 and beyond through continual improvement.

The Y-12 Plant has a formalized Pollution Prevention Awareness Program, which has been in place since 1990. A team of plant employees meet monthly to produce a pollution prevention awareness newsletter and to plan activities that promote awareness among employees. These efforts have resulted in increased pollution prevention awareness among plant employees.

\section{Groundwater Protection Program}

Since initiation of groundwater monitoring activities at KHQ and Chestnut Ridge Sediment Disposal Basin (CRSDB) sporadic, statistically significant analytical results for contaminant indicator parameters have occurred. These units are in RCRA detection monitoring under RCRA interim status, pending resolution of RCRA/CERCLA integration and the requirements for a RCRA post-closure permit. Analysis of data during 1987 indicated that these occurrences were due to seasonal fluctuation and possible grout contamination in the base year sample, not releases from the units. The suspected grout (cement) contamination occurred during the installation of the monitoring well when setting the well casing in cement. At the time, representatives of the state of Tennessee were briefed on the results and the interpretations of the data by DOE and Martin Marietta Energy Systems, Inc., (Energy Systems).

A consensus was reached that the interpretations were valid and that no release of hazardous waste or hazardous waste constituents had occurred. Because of this, it was understood that the units should remain in detection monitoring and that a groundwater quality assessment plan would not be prepared. Subsequent years' data have been consistent with the initial interpretations; however, during CY 1991, the Y-12 Plant received two Notices of Violations (NOVs) from TDEC for failure to prepare site-specific groundwater quality assessment plans for KHQ and CRSDB and for failure to properly report the statistically significant analytical results from CY 1990.
The Y-12 Plant responded to the NOVs but was subsequently issued a civil penalty of $\$ 8,000$. The civil penalty was appealed by Energy Systems. To date a groundwater quality false-positive assessment for the units has been submitted to and approved by the TDEC, and no response from TDEC has been received on the appeal of the civil penalty.

\section{RCRA/CERCLA Integration}

The integration of RCRA and CERCLA has been the subject of debate since May 1991. Final agreement on this issue has not yet been obtained. The RCRA Post-Closure Permit for the S-3 Ponds and other Closure and Post-Closure Activities sites initially sparked the debate. The FFA addresses the coordination of RCRA and CERCLA in Section IV.

The current philosophy of DOE-Environmental Restoration is for the CERCLA process, which is the vehicle described in the FFA for addressing remediation, to address waste units that have been closed and left in place under RCRA and the contamination of groundwater. The administrative requirements of RCRA must still be met. The current position, adopted by DOE-Environmental Restoration and agreed to by TDEC on April 6,1993, is that RCRA post-closure permits will be issued for interim status sites that have been closed, with the sections addressing corrective actions deferred to the CERCLA process.

For interim status facilities that have not completed closure, two different approaches have been utilized. The KHQ and Walk-In Pits are scheduled to be completed as RCRA closure, and any remaining waste or contamination will be addressed under CERCLA consistent with the previously closed sites. The closure plans for three smaller sites within the Y-12 Plant have been modified to reflect closure activities under RCRA and remediation under CERCLA for all activities, if remediation is required.

\section{Summary of Permits}

\section{Air Permits}

Y-12 currently has 89 active operating air permits and 4 active construction permits for a total of 93 active air permits. A total of 10 air permits (nine operating and one construction) are pending TDEC approval. 


\section{Environmental Report Vol. 1, Oak Ridge}

\section{RCRA Permits}

RCRA permilting activities for CY 1992 included one revision of the Fart A permit application: to include additional waste management units and to increase storage capacities for existing units. Activities also included submittal of the remaining RCRA Part B permit application packages for 18 RCRA units. The industrial wastewater treatment units received permit-by-rule status.

\section{NPDES Permits}

$Y-12$ is currently operating under an expired INPDES permit issued by TDEC and EPA Region IV in May 1985 pending permit renewal. TDEC regulations allow for an expired permit to legally remain in effect until the new permit is issued, provided that a permit renewal application is submitted at least 180 days prior to expiration of this old permit |TDEC Rule 1200-4-1-.05(5)(b)|. An application for renewal was submitted to TDEC in November 1989, and an addendum was submitted in February 1993. Additional permits issued pursuant to authority of CWA or the Tennessee Water Quality Control Act for activities that may impact local surface streams include ten aquatic resource alteration permits. 


\section{Compliance Summary Environmental Compliance Activity U.S. Department of Energy}

\section{Oak Ridge National Laboratory}

\section{Compliance Status}

\section{Clean Air Act (CAA) and Radionuclide National Emission Standards for Hazardous Air Pollutants (Rad-NESHAP)}

Authority for enforcement of the Clean Air Act (CAA) is shared between the Tennessee Department of Environment and Conservation (TDEC) for nonradioactive emission sources and the U.S. Environmental Protection Agency (EPA) for radioactive emission sources.

The number of air permits listed in the 1991 Annual Surveillance Report was 59. Activities during 1992, including those initiated in late 1991, have resulted in the cancellation at the U.S. Department of Energy's (DOE's) request of four existing air permits. One additional permit was allowed to expire. All cancellations were for sources determined to be exempt under existing TDEC Air Pollution Control regulations (TDEC Air Pollution Control Rule 1200-3-9-.04) while the expiration was for a source closed pending health and safety upgrades. One new operating permit for fluorescent lamp disposers was issued by TDEC during 1992. Three requests for modifications to existing permits have been submitted to TDEC; all remain outstanding. Thus, as of March 18, 1993, Oak Ridge National Laboratory (ORNL) has 55 permitted sources.

Regulation of radiological emissions is determined by EPA according to requirements of
National Emission Standards for Hazardous Air Pollutants (NESHAP) under the authority of the CAA. ORNL, was not in full compliance with all requirements of the new NESHAP criteria, which the EPA issued on December 15, 1989. A federal facilities compliance agreement (FFCA) that established methods and schedules for all DOE facilities on the Oak Ridge Reservation (ORR) to become fully compliant with requirements of the Code of Federal Regulations (40 CFR 6I, Subpart H), was negotiated between the DOE Oak Ridge Operations Office (DOE-ORO) and EPA Region IV. Final approval was received in May 1992. This FFCA required full compliance by December 15, 1992. All milestones for NESHAP compliance were successfully completed on or before the scheduled completion date, including several continuous emission-monitoring upgrades, which were completed in 1992 to meet the regulatory requirements of $40 \mathrm{CFR}$ 61.93. ORNL is in full compliance with all radiological NESHAP requirements of 40 CFR 61 , Subpart $H$, as explained in a letter from EPA Region IV, dated March 26, 1993. Details of compliance will be provided in the Annual Radiological NESHAP Report. Total effective dose equivalents (EDEs) for 1992 have been determined for the ORR (including ORNL).

Calculated EDEs are well below the 10-mrem NESHAP limit.

TDEC inspected selected ORNL facilities on August 12 and 13, 1992, and no violations were noted. 


\section{Environmental Report Vol. 1, Oak Ridge}

\section{Clean Water Act (CWA)}

The ORNL National Pollution Discharge Elimination System (NPDES) permit, renewed in 1986, lists more than 170 point-source discharges that require compliance monitoring. Many of these are storm drains, roof drains, parking lot drains, and storage area drains. Three major wastewater treatment facilities have been constructed since 1985: the Sewage Treatment Facility, the Coal Yard Runoff Treatment Facility, and the Nonradiological Wastewater Treatment Facility (NRWTF). Occasional spills, upsets, and precipitation runoff from storm and parki.,g lot drains have resulted in NPDES permit effluent limits being exceeded; however, most of these exceedences are associated with precipitation runoff. Progress continues toward minimizing or eliminating these occurrences. The sample compliance rate across all discharge points for 1992 was $98.7 \%$ (99\%). The NRWTF, which went on line April 1, 1990, has continued to operate without a single effluent discharge limit violation.

An application for renewal of the NPDES permit was submitted to TDEC on September 28, 1990, in accordance with the 5-year permitting cycle. The 1986 permit expired on March 31, 1991; TDEC regulations allow wo an expired permit to legally remain in effect until the new permit is issued, provicied that a permit renewal application is submitted at least 180 days prior to expiration of this old permit ['TDEC Rule 1200-4-1-.05(5)(b)].

In October 1992, to comply with state and federal regulations, ORNL submitted a separate, individual NPDES stormwater application. It is anticipated that stormwater discharges will continue to be a part of the ORNL Facility's NPDES Permit. ORNL has applied for and has received ten approvals for several such projects from the U.S. Army Corps of Engineers. TDEC has issued five aquatic resource alteration permits to ORNL.

EPA Region IV conducted a compliance evaluation inspection in 1992. The EPA inspection report was positive in that ORNL received the highest available mark in eight of the nine areas that were evaluated.

\section{Resource Conservation and Recovery Act (RCRA)}

ORNL strives to be fully compliant with RCRA regulations; however, some internal assessments and/or DOE audits have identified some potential issues. Wherever possible, these potential noncompliances have been corrected. Those that cannot be corrected readily (such as compliance with the land disposal restrictions) are resolved with regulators by negotiated agreements or orders. ORNL generates both RCRA hazardous waste and RCRA hazardous waste mixed with radionuclides (i.e., mixed waste). The hazardous and/or mixed wastes are accumulated by individual generators at several satellite accumulation areas or 90-day areas, where it is picked up by waste management personnel. The number of generator accumulation areas at ORNL has increased to 370 and continues to grow as new wastes are identified. Waste management personnel receive the waste from the individual generators and place it in on-site permitted or interim-status storage facilities until it can be shipped off site for treatment, storage, and/or disposal at a RCRA-permitted facility.

ORNL operates several hazardous/mixed waste facilities. ORNL's most recent RCRA Part A revision was submitted on August 19, 1992; another revision incorporating minor changes is planned for fall 1993. Two facilities currently have RCRA Part B permits (Building 7652, Hazardous Waste Storage Facility, and Tank 7830A, Hazardous Waste Storage Tank). A Part B Permit application was submitted in 1989 for the Chemical Detonation Facility, Building 7667. TDEC is expected to take action on the chemical detonation permit application during CY 1993. In accordance with a 1991 consent order with TDEC, ORNL consolidated Part B Permit applications. Five general categories (container storage, transuranic container storage, tank storage, chemical detonation treatment, and transuranic treatment) have been identified.

ORNL received the Part B Permit for Tank $7830 \mathrm{~A}$ on October 15, 1992, and submitted two additional applications in early 1992 for container storage facilities. One application modified the existing Part B permit for Building 7652 to include eight additional storage facilities. Some of those facilities are slated for construction in CY 1993 and beyond. The fourth permit application covers ORNL's transuranic waste storage facilities. That 
application essentially expanded what had been an existing permit for Building 7855 and added eight additional units to that permit. In late 1992, ORNL received a 90 -day emergency permit to store mixed wastes in Building 3038 to allow for reexamination and repackaging of a transuranic (TRU) waste drum. This was prompted by a DOE request to evaluate a personnel contamination incident. The fifth permit will cover a TRU waste treatment facility; it will be submitted in the late 1990s.

Four closure plans were submitted to TDEC in CY 1992. They were Building 7555, Former Hazardous Mixed Waste Storage; Building 7659B, Reactive Chemicals Facility; Building 7860, New Hydrofracture Surface Facilities; and Tank 7075, Used Oil Storage Tank. TDEC approved the closure plans for Buildings 7826 and 7834, TRU Retrievable Drum Storage Facilities, in late 1992. Closure of these units was initiated in early November 1992 and will continue through mid-1994.

Units awaiting issuance of either a Part B operating permit or awaiting TDEC approval of the completed closure activities continue to operate under interim status.

ORNL's RCRA treatment, storage, and disposal facilities and ORNL's satellite and 90-day accumulation areas were inspected by TDEC on April 27 to 29,1992 . No deficiencies or violations were noted by this inspection.

\section{Toxic Substances Control Act (TSCA)}

ORNL manages all nonradioactively contaminated polychlorinated biphenyls (PCBs) in compliance with federal regulations. The facility operates research equipment that contains $\mathrm{PCB}$ capacitors. It also operates miscellaneous equipment, transformers, pumps, and electric equipment that contain PCB-contaminated oil. Both radioactive and nonradioactive $\mathrm{PCB}$ wastes are stored on site in compliant storage units. The nonradioactive $\mathrm{PCBs}$ are transported off site to EPA-approved facilities for disposal in accordance with regulatory requirements. The drums of radioactively contaminated PCB waste are currently stored on site awaiting disposal.

Continued storage of the radioactively contaminated PCB waste beyond I year is not in compliance with TSCA requirements, as further discussed in the Oak Ridge Reservation Compliance Summary current issue entitled "Moratorium on Off-Site Shipment of Hazardous Waste."

ORNL has numerous facilities that contain asbestos materials. Programs for compliant asbestos management include identification of asbestos materials, monitoring, abatement, and disposal. Procedures that delineate scope, roles, and responsibilities for maintaining compliance with EPA and Occupational Safety and Health Administration (OSHA) regulatory requirements are maintained. No nonconformances with environmental protection standards were identified in 1992.

\section{Underground Storage Tanks (USTs)}

ORNL's UST management program incorporates tanks containing regulated petroleum products and hazardous substances as well as those that are exempt or deferred. Program management includes implementation of leak detection, corrosion protection, spill and overflow protection, annual tightness testing, operational controls, record keeping, reporting, and replacement of UST systems that cannot be upgraded by 1998 . The program also addresses the immediate removal from service and remediation of sites with tanks found to be leaking, and it implements any required closures, corrective actions, and any upgrading and/or replacement of affected UST's in accordance with the regulatory requirements. Activities in 1992 included the excavation of three tanks, initiation of and/or continuation of eight environmental investigations and completions of final closure of three USTs. Status of the tanks managed under the UST Program through $\mathrm{i} 992$ is as follows.

- Thirty-one tanks have been excavated or permanently taken out of service (23 approved by TDEC as closed while 8 require additional investigation and/or corrective action before final closure approval).

- Twenty USTS are active but are deferred from 40 CFR 280 Technical Standards and Corrective Action Requirements for Owners and Operators of Underground Storage Tanks (USTs) regulations. These will be taken out of service or upgraded by December 1998. 


\section{Environmental Report Vol. 1, Oak Ridge}

- Two USTs were upgraded in 1990 to meet the current leak detection requirements and are fully regulated.

- One active UST contains heating oil and is excluded from regulation under 40 CFR 280. (A second heating oil UST was taken out of service in 1992).

- Five USTs contain waste oil contaminated with radionuclides and are excluded under $40 \mathrm{CFR}$ 280.

- A schedule for upgrading and/or replacing USTs to meet the regulatory requirements by the 1998 deadline has been established by the UST Management Program. Currently ORNL is ahead of the projected schedule for completion.

\section{Comprehensive Environmental Response, Compensation, and Liability Act (CERCLA)}

ORNL occupies several areas and covers about 3560 acres in Melton Valley and Bethel Valley, 10 miles southwest of downtown Oak Ridge, Tennessee. ORNL's remediation sites are organized into waste area groupings (WAGs) based on drainage area and similar waste characteristics. There are currently seven WAGs and the inactive tanks on the ORNL site that are being investigated and/or remediated under CERCLA. Of these, five WAGs are being investigated in the CERCLA Remedial Investigation/Feasibility Study process. These include

- WAG 1-ORNL Main Plant Area;

- WAG 2-White Oak Creek, White Oak Lake, and its tributaries;

- WAG 5-88-acre site including Solid Waste Storage Area (SWSA) 5, Hydrofracture surface facilities, sludge basin, old hydrofracture waste storage tanks, and TRU waste storage area;

- WAG 6-68-acre site including SWSA 6, the Emergency Waste Basin, and the Explosives Detonation Trench; and

- WAG 10-Subsurface Hydrofracture Facilities, injection wells, observation/monitoring wells, and grout sheets.
Four sites are in the CERCLA Remedial Design/Remedial Action Process:

- WAG 6-68-acre site including SWSA 6, the Emergency Waste Basin, and the Explosives Detonation Trench;

- WAG 11-The White Wing Scrap Yard;

- WAG 13-Cesium-137 Contaminated Field and Erosion/Runoff Study Area; and

- Inactive Liquid Low-Level Radioactive Waste Tanks.

\section{Emergency Planning and Community Right-To-Know Act (EPCRA)}

ORNL submits three reports annually to comply with the reporting requirements of Superfund Amendments and Reauthorization Act (SARA). These provide local communities and emergency response agencies with knowledge of potential hazards posed by stored chemicals and their releases from ORNL facilities. The three annual reporting requirements of SARA Title III are as follows:

- an annual inventory of hazardous chemicals and extremely hazardous substances, including storage totals and locations (Sect. 312);

- Material Safety Data Sheets (MSDS) or a list of hazardous chemicals identified by hazard category (Sect. 311); and

- an annual inventory of toxic chemical releases into the environment (Sect. 313).

ORNL reported 20 hazardous chemicals and extremely hazardous substances for 1992 under Sects. 311 and 312 . Three toxic chemicals are currently reported under Sect. 313.

\section{National Environmental Policy Act (NEPA)}

ORNL is in compliance with NEPA review requirements in accordance with DOE implementing procedures. This compliance is achieved and maintained through the efforts of the Environmental Review and Documentation Section (ERDS) of the Office of Environmental Compliance and 


\section{Environmental Report Vol. 1, Oak Ridge}

Documentation. In 1992, ERDS submitted 32 requests for Categorical Exclusions (CXs) for actions at ORNL, and $15 \mathrm{CX}$ approvals were received. In the same period, six draft Environmental Assessments (EAs) were submitted, and 2 EA approvals were received.

In conjunction with the NEPA review for all new projects by ERDS, an assessment is conducted for compliance with the requirements of the Endangered Species Act, the National Historic Preservation Act, and Executive Orders 11988, Floodplains Management, and 11990, Protection of Wetlands, administered through the DOE Implementing Regulations on Floodplains and Wetlands (10 CFR 1022). Potential impact or involvement of the project in these areas is assessed even if there is a determination of no significant environmental impact under NEPA.

\section{Federal Insecticide, Fungicide, and Rodenticide Act (FIFRA)}

ORNL maintains compliance with FIFRA requirements through inspection of controlled pesticide/herbicide storage areas and review of the on-site, restricted-use application program. A FIFRA compliance manual has been developed that sets forth the requirements for ORNL compliance with FIFRA, documents inspections of FIFRA storage areas, and serves as the basis for development of a gencral ORNL procedure that will be included in the revised Environmental Protection Manual. No unusual occurrences were reported for CY 1992.

\section{Safe Drinking Water Act (SDWA)}

Potable water is obtained from the treatment plant operated by Johnson Controls World Services, Inc., located near the Y-12 Plant. The treated water is tested for parameters listed under the state and federal drinking water regulations. In 1992 the water continued to meet all health standards.

\section{Release Reporting}

Spills and unanticipated releases may trigger chemical-release reporting requirements under provisions of one or more of the following statutes: EPCRA (also known as Title III of SARA), CERCLA, RCRA, CWA, CAA, and TSCA. Each spill event is evaluated for reporting requirements, and regulatory agencies are notified as appropriate. ORNL had six oil sheens in 1992, which were reported to the U.S. Coast Guard National Response Center as required under the CWA. ORNL also had two reportable releases of ethylene glycol, which were reported to the National Response Center as required by the CERCLA 1-lb statutory reporting requirement. No reportable continuous releases as defined in 40 CFR 302.8, have been identified. There were no reportable releases pursuant to RCRA, TSCA, CAA, or EPCRA (Title III, SARA).

\section{DOE Order Compliance}

\section{DOE Order 5400.1, General Environmental Protection Program}

DOE Order 5400.1 serves to "establish environmental protection program requirements, authorities, and responsibilities for DOE operations for assuring compliance with applicable Federal, State, and Local environmental protection laws and regulations, Executive orders, and internal Department policies." '1l. ... r rpecifically defines the mandatory environmental protection standards including those imposed by federal and state statutes, establishes repoiting of environmental occurrences and "periodic routine significant environmental protection information," and provides "requirements and guidance for environmental monitoring programs." Implementation of the order is provided by specific program plans as detailed in Chap. III of the order.

A long-range environmental protection implementation plan (EPIP) is prepared and updated annually as is the Environmental Monitoring Plan (EMP). The EPIP defines specific environmental objectives, including the means and schedules for accomplishment. The EMP defines a comprehensive system for conducting effluent monitoring/sampling and environmental surveillance at ORNL and on the ORR outside of the K-25 Site and the Y-12 Plant. It is designed to meet federal and state regulatory requirements as well as those internal to ORNL and DOE.

Effluent Monitoring requirements are met for the CAA by TDEC Air Emissions Permits for individual discharge sources. Airborne radionuclide emissions 


\section{Environmental Report Vol. 1, Oak Ridge}

are monitored under the NESHAP program. Liquid effluents and ambient stream sites are monitored and reported under several programs. The NPDES program addresses nonradiological pollutants. Radiological effluents are monitored under the ORNL Radiological Monitoring Plan, which is required by the NPDES Permit, and the ORNL Surface Water Monitoring Program. Solid effluents, hazardous and nonhazardous, are managed according to federal and state solid waste disposal regulations, DOE orders, and Martin Marietta Energy Systems, Inc.. (Energy Systems) policy and procedures.

The ORNL environmental surveillance system includes a number of local and perimeter air monitoring stations that monitor climate and air quality around the site. Data from the stations are maintained to facilitate various modeling, dose assessment, tracking, and trending activities.

Environmental surveillance is also conducted under the ORNL Biological Monitoring and Abatement Program, which is an ongoing research effort consisting of a number of subtasks, designed to assess the health of on-site and off-site surface water bodies. The ORNL Groundwater Monitoring Program includes ongoing data collections at numerous water-quality wells on the ORR, as well as a number of off-site drinking-water wells.

Quality assurance and data evaluation are primary considerations for ORNL monitoring, surveillance, and sampling activities. Independent data verification is conducted. Audits of monitoring and sampling activities by state and federal regulatory agencies have been positive; no significant findings have been issued.

\section{DOE Order 5400.5, Radiation Protection of the Public and the Environment}

DOE Order 5400.5 provides guidance and establishes radiation-protection standards and central practices designed to protect the public and the environment against undue risk from DOE operations. The order requires that off-site radiation doses not exceed $100 \mathrm{mrem} / y e a r$ for all pathways. Typically, the maximum potential of $f$-site dose is about $2 \mathrm{mrem} / \mathrm{year}$, including airborne emissions $\sim 0.1 \mathrm{mrem}$, fish consumption $\sim 0.2 \mathrm{mrem}$, drinking water $\sim 0.1 \mathrm{mrem}$, and $\sim 2 \mathrm{mrem}$ from exposure to radiation emanating from an experimental plot near the Clinch River. ORNL doses are well below applicable standards for various areas, including airborne emissions, and drinking water. ORNL conducts various modeling and dose-calculation activities to address the potential for multiple-pathway exposures of workers and the public.

ORNL liquid process wastewater discharges are all below the derived concentration guides (DCGs) for specific radionuclides listed in the order. Some ORNL stormwater and groundwater discharges from areas with legacy contamination may at times exceed the DCG levels. These areas are targeted for remediation under the Environmental Restoration Program, which is ongoing. The ORNL off-site discharge point at White Oak Dam typically shows sum-of-fractions calculations for DCG compliance to be around $60 \%$ of the total allowed. The order disallows disposal of radioactive wastewaters onto soil columns for the purpose of removal via soil adsorption. Areas of ORNL such as White Oak Lake, where ongoing legacy releases may result in soil column deposition, are again the subject of the Environmental Restoration Program.

\section{DOE Order 5820.2A, Radioactive Waste Management}

DOE Order $5820.2 \mathrm{~A}$ became effective September 26, 1988. Its purpose is to establish policies, guidelines, and minimum requirements for which the DOE manages its radioactive waste and contaminated facilities. DOE Order 5820.2A, Chap. VI, contains the requirements that serve as the compliance-assessment mechanism. This includes instructions for setting up an implementation schedule to achieve compliance and a means of reporting continued compliance. In April 1989, an implementation plan was established in accordance with the order. This document established completion dates to achieve compliance for a given requirement of the order. Thereafter, the status is reported annually in the Waste Management Plan (WMP). The WMP is submitted to DOE-ORO and DOE Headquarters (DOE-HQ). The 1992 WMP (ORNL/TM-11433/R2), prepared by the Waste Management and Remedial Action Division, was published in December 1992.

The compliance requirements established in Chap. II, Management of Transuranic (TRU) Waste; 
Table 2. Summary of 1992 ORNL compllance activities relevant to DOE Order 5820.2A

DOE Order 5820.2A Chapters

1992 planned, implemented, or completed compliance activities

Chapter II, Management of Transuranic (TRU) Waste

Waste classification

Waste generation and treatment

Waste certification

Temporary storage at generating sites

Quality assurance

Performance assessment (PA)

Waste acceptance criteria (WAC)

Shipment

Long-term storage

Disposal

Disposal site closure/postclosure

Records and reports
- A new master algorithm for estimating contact-handled transuranic (CH-TRU) drummed radionuclide concentrations was completed.

- Real-time radiography (RTR) is being installed for CH-TRU boxes

- Expanding TRU waste minimization focus

- Revising CH-TRU certification documents to include stored waste and certification plans for transportation

- Resolving the remaining 1991 Waste Isolation Pilot Plant (WIPP)

Waste Acceptance Criteria Certification Committec (WACCC) audit findings

- ORNL will develop Resource Conservation and Recovery Acl (RCRA) contingency plans for planned facilities

- Continuing to bring all TRU waste activities into compliance. New facilitics will be brought on line with NQA-I programs in place

Chapter III, Management of Low-Level Waste (LLW)

- A draft PA was completed for Solid Waste Storage Area (SWSA) 6; final PA to be completed in FY 1993

- WAC has been established for existing LLW treatment, storage, and disposal (TSD) facilities. Draft WAC has been developed for Interim Waste Management Facility (IWMF)

- Phasing in radionuclide concentration WAC with operation of IWMF

- ORNL meets all applicable U.S. Department of Transportation (DOT) and DOE regulations for shipping LLW on site to SWSA 5 and 6

- Safety documentation is in place for existing storage facilities

- LLW classification limits will be established for all LLW disposal facilities

- The IWMF construction and operations are in compliance with this requirement

- LLW is no longer being disposed of in excavations. Operation procedures and training programs have been and will continue to be upgraded

- Residual radioactivity requirements will be incoporated into the development of closure plans

- ORNL is upgrading recordkeeping data system to increase reliability and retrievability of data
Chap. III, Management of Low Level Waste (LLW); and Chap. V, Decommissioning of Radioactively Contaminated Facilities, are directly applicable to ORNL activities. Table 2 summarizes ORNL's 1992 planned or completed activities implemented to meet DOE 5820.2A compliance requirements for TRU and LLW. Refer to the 1992 ORNL WMP for an in-depth description of the DOE $5820.2 \mathrm{~A}$ compliance requirements and compliance status.

\section{DOE Order 5480.4, Environmental Protection, Safety, and Health Protection Standards}

This order specifies and provides requirements for the mandatory and reference environmental, safety, and health (ES\&H) standards, including the identification of the source of such standards.

Mandatory environmental protection standards that 


\section{Environmental Report Vol. 1, Oak Ridge}

are derived from statutory requirements, including those discussed under major environmental statute headings, are implemented by ORNL line organizations and overseen by the Office of Environmental Compliance and Documentation (OECD). ORNL is in compliance with these mandatory environmental protection standards (those derived from statutory as well as policy requirements). A system is maintained for identifying and reporting compliance issues.

\section{Current Issues}

A number of specific compliance issues have been identified. Some of the most significant issues are discussed below.

\section{Clean Air Act Amendments of 1990}

The Clean Air Act amendments of 1990 will result in increased compliance requirements for the operations at ORNL. It is anticipated that Title III (Hazardous Air Pollutants), Title V (Permits), and Title VI (Stratospheric Ozone Protection) will result in the most significant impact.

In order to prepare for additional regulations regarding the emissions of hazardous air pollutants under Title III, and additional permitting requirements under Title $\mathrm{V}$, an existing survey of all emission points is being updated. This survey will locate all emission points and will quantify emissions. Survey results will be useful in the preparation of a Title $\mathrm{V}$ permit application, and will provide information regarding the use and emission of hazardous air pollutants from small sources that are currently exempt from air permit requirements.

Actions to comply with the prohibition to release ozone-depleting substances under Title VI have been implemented. Also, service requirements for motor vehicle air conditioners and labeling requirements have been implemented. ORNL is initiating actions to phase out the use of Class I ozone-depleting substances. The most significant challenge is the replacement or retrofitting of large chiller systems that require Class I refrigerants.

\section{Contaminants Resulting from Storm Runoff}

Precipitation runoff has resulted in total suspended solids (TSS) and oil and grease values that exceed NPDES effluent limits at storm drain and parking lot drain outfalls. Studies were conducted in 1992 to identify potential corrective measures along with their feasibility of implementation. Strategies to reduce or eliminate these precipitation-related exceedences include installing sedimentation basins, source reduction, and administrative actions.

Treatment strategies identified include installation of retention basins and filtration units at individual problem outfalls. An extension of this strategy is to determine the feasibility of combining the flow of several outfalls and rerouting it to a common treatment unit. Source-reduction efforts such as more frequent cleaning of streets and parking lots and increased upgrade and/or maintenance of individual outfalls have been implemented. A detailed cost-benefit analysis for each option has not been completed. A request for a modification to ORNL's NPDES permit has been submitted to TDEC, based on evidence that the NPDES exceedences of TSS and oil and grease limits experienced in the past have not demonstrated a significant impact on the water quality of the White Oak Creek watershed. The proposal was also included in ORNL's NPDES permit-renewal application submitted to TDEC on September 28, 1990. The ORNL proposal's approach is consistent with that of EPA and TDEC storm water regulations that were published in 1990 and 1991. Additional studies were begun in 1992, to quantify more specifically the impact of storm events on aquatic environs.

\section{Ethylene Glycol Spills}

Slow releases of ethylene glycol to the environment have occurred by leakage from old piping serving the Central Chilled Water Facility in the main plant complex at ORNL. Occasional ethylene glycol spills also occur. Although ethylene glycol is not directly toxic to aquatic life, it exhibits a secondary toxic effect via oxygen consumption in water. It has been designated as a toxic air pollutant under the CAA amendments of 1990 . Releases into any environmental media, including surface water, of quantities that exceed the statutory reporting

\section{Ix Compliance Summary}


requirement of $1 \mathrm{lb}$ must be reported according to the requirements of CERCLA. ORNL implemented an action plan for replacing ethylene glycol with water coolant. ORNL replenished the system with water, rather than using water-ethylene glycol solutions as in the past. The ethylene glycol wastewater was transported to the Y-12 Plant for use as a carbon source in its wastewater treatment facility (Biodenitrification Facility).

In instances where major ethylene glycol spills occur, containment is provided as soon as is practical to minimize releases to surface waters. Approval was granted by TDEC to allow treatment of these contained wastes through on-site conventional wastewater treatment facilities and subsequent discharge through NPDES-permitted outfalls. This operation was conducted successfully at ORNL, and the chilled water system's concentration of ethylene glycol has been reduced to $1 \mathrm{ppm}$ or less.

\section{Releases from Burial Grounds and Waste Disposal Areas}

Radionuclides and chemical constituents released from inactive burial grounds and other waste disposal areas have been found in some groundwater and surface water samples from the Bethel Valley and Melton Valley areas of ORNL. Major known releases include ${ }^{90} \mathrm{Sr},{ }^{137} \mathrm{Cs},{ }^{60} \mathrm{Co}$, and ${ }^{3} \mathrm{H}$, as well as hazardous, organic, and inorganic constituents. ORNL provides through the Environmental Restoration Program a comprehensive surveillance and maintenance program of those areas where past research, development, and waste management activities have been conducted and have resulted in residual contamination of facilities or releases to the environment. The federal facilities agreement (FFA) among DOE, EPA, and TDEC addresses selections of interim and final corrective measures and schedules for implementation.

\section{Tiger Team Assessment}

From October 22, 1990, to November 30, 1990, a group of about 80 specialists representing DOE-HQ conducted a Tiger Team assessment of ORNL's Environment, Safety, and Health Program. The environmental subteam reviewed compliance with ORNL procedures, Energy Systems procedures, DOE orders, and federal and state regulations pertaining to environmental protection. Seventy deficiencies were identified; 43 represented nonconformance with procedural and/or regulatory requirements; and 27 involved best management practices.

An action plan that addressed corrective measures for each of the Tiger Team findings was prepared, and, after a number of revisions, it was approved by DOE Secretary James D. Watkins on October 19, 1991. In the time since the Tiger Team review, ORNL has been actively completing those corrective actions that have adequate funding. In cases where funding is not available, it has been requested. As of April 1, 1993, 31 of the findings have been verified by DOE as closed. Sixteen additional findings have been listed as closed by ORNL, but they have not been verified by DOE.

During December 7 through 11, 1992, DOE conducted a performance review of ORNL's Tiger Team Corrective Action Plan. The Environmental Subteam reviewed 144 of the 227 corrective actions. Few problems were noted; the subteam observed "this exercise has considered abundant evidencedocumentary and behavioral-on the part of DOE Oak Ridge (OR) and Martin Marietta Energy Systems (Energy Systems) personnel of a positive, active sensitivity to protection of human health, safety, and the environment."

\section{DOE Oak Ridge Operations Office Appraisal}

At the request of the DOE-ORO ORNL Site Office, DOE-ORO conducted a functional appraisal of selected Environment, Safety, Health, and Quality Assurance programs at ORNL from July 13 to July 24, 1992. Program elements in 17 functional areas were evaluated; 7 areas were reviewed by the Environmental Protection Subteam. The environmental protection areas reviewed included NEPA, UST, RCRA, TSCA, CWA, nonradioactive $\mathrm{CAA}$, and asbestos management.

Although several deficiencies were identified, the Environmental Protection Subteam concluded that the overall Environmental Protection Program at ORNL is in good shape with significant improvements since the previous assessment conducted in 1990. Of the 36 deficiencies noted, the most significant involved management of hazardous waste at the point of generation, lack of documented roles/responsibilities in the Asbestos Management Program, secondary 


\section{Environmental Report Vol. 1, Oak Ridge}

containment for storage tanks and drums not consistent with requirements of the Environmental Protection Manual Procedures and the Spill Prevention, Control and Countermeasures Plan, and inconsistent review of all activities for requirements of the National Historic Preservation Act.

Several proficiencies were also cited. These include management of the TSCA/PCB compliance program, waste reduction and waste minimization activities, availability and use of spill kits, and the Clean Air Compliance and Stack Monitoring programs.

A corrective action plan that addresses all of the deficiencies has been prepared and submitted to DOE-ORO for approval. Comments were received from DOE-ORO on March 25, 1993. A final corrective action plan that incorporates these comments will be issued for final approval by April 30, 1993.

\section{Summary of Permits: RCRA, CWA, and CAA Permit Status}

\section{Clean Air Act}

Air permitting activities for CY 1992 included a review of all existing permitted sources. As of March 18, 1993, ORNL has 55 permitted sources, including a new permit for fluorescent lamp disposer received in October of 1992.

\section{Resource Conservation and Recovery Act}

RCRA permitting activities for CY 1992 included the revision of the Part A application to include additional waste management units and the submittal of consolidated Part B applications. ORNL submitted to the TDEC Part 13 applications for the nine TRU storage units (March 1992), and the nine low-level radioactive mixed and hazardous waste storage units (May 1992). Preparation of the TRU waste treatment unit has not been initiated; it will be submitted in the late 1990s. TDEC issued the Part B Permit for Tank 7830A, October 15, 1992. ORNL now has two units operating under Part B Permits: Tank 7830A and Building 7652.

\section{Clean Water Act}

ORNL is currently operating under an expired NPDES permit issued by TDEC and EPA Region IV on April 1, 1986. TDEC regulations allow for an expired permit to legally remain in effect until the new permit is issued, provided that a permit renewal application is submitted at least 180 days prior to expiration of this old permit [TDEC Rule 1200-4-1-.05(5)(b)]. An application for renewal was submitted to the TDEC on September 28, 1990.

ORNL, anticipates NPDES permit renewal in Calendar Year 1993.

As required by state and federal regulations, ORNL submitted a separate NPDES permit application for stormwater outfalls in October 1992. Additional permits issued pursuant to the authority of the CWA or the Tennessee Water Quality Control Act for activities which may impact local surface streams include ten from the U.S. Army Corps of Engineers and five from the TDEC. 


\section{Compliance Summary Environmental Compliance Activity U.S. Department of Energy}

\section{Oak Ridge K-25 Site}

\section{Compliance Status}

\section{Clean Air Act (CAA), Clean Air Act Amendments, and National Emission Standards for Hazardous Air Pollutants (NESHAP)}

CAA compliance is an integral part of the Tennessee Department of Environment and Conservation (TDEC) air permit program, which requires K-25 Site compliance with all federal air regulations in addition to compliance with the stated air permit conditions. An air program audit performed by TDEC on July 7, 8, and 9, 1992, resulted in no violations, deficiencies, or findings.

The Environmental Monitoring and Permitting Department participates routinely in both walkdowns and internal audits to identify areas for improvement in the operation of air sources. In addition, an Air Source Operator Training Module initiated in 1992 includes instruction on recordkeeping techniques for use in demonstrating compliance.

An increasing number of the new CAA amendment rules have application at the K-25 Site, and a significant effort was made in 1992 to comply with new regulatory requirements under Title VI, Stratospheric Ozone Protection. Planning efforts for Title III, Hazardous Air Pollutants, and Title V, the Federal Air Permit Program, were begun.

The radionuclide NESHAP Rad-NESHAP compliance status was documented each month, as required by the Oak Ridge Reservation (ORR)
Federal Facility Compliance Agreement (FFCA). In March 1993, the U.S. Environmental Protection Agency (EPA) Region IV certified that all K-25 Site requirements of the ORR Rad-NESHAP FFCA were satisfied. Significant among the 1992 activities was the completion of an inventory of K-25 Site major and minor radionuclide emission sources.

Compliance with the Rad-NESHAP dose limit of $10 \mathrm{mrem} / \mathrm{year}$ to the maximum exposed individual of the public was demonstrated by modeling emissions from major and minor point sources during periods of operation. The total dose to the maximally exposed individual from the K-25 Site was 0.61 mrem for 1992. This information is presented annually in the ORR Rad-NESHAP report to the EPA. Source term information was determined using NESHAP Compliance Plan procedures developed in coordination with the EPA. Continuous emissions monitoring is performed at the stack of the Toxic Substances Control Act (TSCA) incinerator, while grab samples and other approved estimation techniques are used on the remaining point and grouped area sources. Supplemental samples were taken, and numerous evaluations were carried out for routine operations as well as for current and planned activities of the Environmental Restoration (ER) and Decontamination and Decommissioning (D\&D) programs.

\section{Clean Water Act (CWA)}

The K-25 Site was issued a renewed National Pollution Discharge Elimination System (NPDES) 
permit on October 1, 1992. This renewed permit covers 7 major outfalls and 139 storm drain outfalls. Of the 7 major outfalls, two are used only for emergency discharges, and one is not scheduled for discharge until April 1996. Prior to issuance of the renewed permit in October 1992, the site operated under an expired permit that covered eight discharge locations. About 22,000 analyses were performed annually as required by the expired NPDES permit. Even though a $99 \%$-plus compliance rate was experienced, occasional excursions occurred outside the NPDES permit discharge limits. Each excursion was reported under the Occurrence Reporting System (ORS). An ORS report identifies causes and corrective actions to prevent future occurrences. More than half of the excursions experienced were for aluminum at the Mitchell Branch sampling station; chemical oxygen demand (COD) and low dissolved oxygen at the K-1007-B Pond outfall; and low dissolved oxygen and elevated suspended solids at the K-901-A Holding Pond. These excursions were the result of natural occurrences during periods of heavy rainfall and thus were not process related. The renewed NPDES permit requires monitoring of the storm drain pipes discharging into settling ponds around the perimeter of the site rather than monitoring of the pond outlets. This will enable the site to better identify sources of discharges into the pond. In addition, the renewed NPDES permit requires development and implementation of a Stormwater Pollution Prevention Plan by October 1993. This plan will identify areas with the potential to discharge pollutants to the receiving waters and will include a pollutant control strategy to identify actions to minimize discharges of pollutants.

Under the renewed NPDES permit, about 1500 analyses are performed monthly. The site has continued to maintain a $99 \%$-plus compliance rate and continues to report and investigate each excursion under the ORS system.

Corrective actions relating to the NPDES Program include identifying projects to treat and/or remove non-point sources of pollution. These projects include the rehabilitation of sanitary sewer lines to prevent infiltration, the removal and/or treatment of effluents to storm drains to remove residual chlorine, and the remediation of sites that may be contributing to surface water contamination.
A problem with infiltration into the sewage collection system causes excursions at the K-1203 Sewage Treatment Plant during heavy rainfall. A portion of the system has been rehabilitated. To repair the balance of the system, a line-item project is scheduled for completion by September 30, 1995. There are plans to convert the sewage treatment plant from chlorine disinfection to ultraviolet units for fecal coliform control. This will eliminate NPDES excursions for chlorine.

EPA Region IV performed an audit of the K-25 Site NPDES Program in May 1992. No violations, deficiencies, or findings were identified during the closeout.

\section{Resource Conservation and Recovery Act (RCRA)}

In accordance with a consent order with TDEC to update and combine Part B applications, the K-25 Site submitted RCRA Part B Permit Applications to TDEC by May 31, 1992. TDEC issued three RCRA permits for the K-25 Site in September 1992. These permits, which are currently under appeal, consist of (1) the K-1435 and K-1425 TSCA Incinerator storage and treatment units, (2) tank storage and treatment units, and (3) all other units at the site (primarily container storage).

The permits were appealed to the Solid Waste Disposal Control Board because the permit requires waste received from off site to originate from state-approved facilities. In the permit, "on site" is defined as the K-25 Site. The primary state-approved off-site facilities identified are the Paducah and Portsmouth gaseous diffusion plants, the Y-12 Plant, the RMI Company, ORNL, and the Feed Materials Production Center. DOE believes that approval should not be required for receipt of hazardous waste from other DOE installations. The TSCA Incinerator is currently operated under a RCRA Part B permit that was issued in 1987. A final permit for the TSCA Incinerator is expected to be issued in the near future.

The K-25 Site RCRA Part A application was revised and submitted to TDEC in 1992 to be consistent with the updated Part B applications. Closure plans for seven units, including an amended closure plan for the K-1407-B and -C Ponds, were submitted to the TDEC in 1992. A closure plan for the K-1417 Drum Storage Yard and the K-1419

\section{Ixiv Compliance Summary}


Sludge Treatment Facility is currently being prepared for submittal to TDEC.

K-1417 Drum Storage Yard activities in 1992 included the completion of stabilized sludge processing and removal of stabilized sludge to indoor RCRA waste management units and the initiation of raw sludge processing.

The K-25 Site received and responded to a Notice of Violation (NOV) that was issued by the TDEC in December 1992 for an overfeed of aqueous waste that occurred at the TSCA Incinerator. The $\mathrm{K}-25$ Site had notified the TDEC concerning the incident in September 1992. The aqueous waste feed exceeded the TSCA Incinerator permit limit for 8 hours (September 17-18, 1992). No adverse impact to human health or the environment resulted from the overfeed. Several corrective actions were required, including the installation of new flowmeters at the incinerator.

TDEC performed the annual RCRA hazardous waste inspection in April 1992. No deficiencies were noted in the closeout. TDEC also performed an inspection of the TSCA Incinerator in July 1992 with no deficiencies noted in the closeout.

\section{Toxic Substances Control Act (TSCA)}

The Uranium Enrichment Federal Facilities Compliance Agreement (UE-FFCA) between the EPA and DOE was signed on February 1992. Under this agreement action plans have been developed and implemented for removal and disposal of large volumes of PCB material at the site. Quarterly meetings between DOE and EPA representatives have facilitated implementation of the agreement.

The number of PCB transformers at the K-25 Site was reduced from 133 to 15 in 1992. This was accomplished through draining and reclassification efforts of the past 2 years. Decontamination and decommissioning efforts are under way to remove the drained transformers and PCB capacitors from the site.

In excess of 1.25 million Ib of PCB wastes were disposed of at the TSCA Incinerator located at the K-25 Site in 1992.

Two large heat-transfer systems contaminated with PCBs were identified through self-assessment. A proposal for draining and flushing these systems to below regulatory limits is being presented to the EPA under the UE-FFCA.

Major near-term plans include

- pursuing EPA approval of a PCB Drum Wash Station to decontaminate PCB containers,

- renewal of EPA approval for disposal of PCBs at the K-1435 TSCA Incinerator,

- completion of the 1992 Annual PCB Document, and

- negotiation of the ORR PCB Federal Facilities Compliance Agreement (ORR-FFCA).

The current UE-FFCA covers the Portsmouth and Paducah gaseous diffusion plants and the K-25 Site. All K-25 Site UE-FFCA milestones either have been completed or are proceeding on schedule.

Gasket-removal activity and potentially other removal activities have been placed on hold pending renegotiation of the removal schedule by DOE and EPA.

An effort to negotiate an additional agreement to include the two other Oak Ridge facilities (the Y-12 Plant and ORNL) has been under way for some time. Since then, Congress has acted to create a new Uranium Enrichment Corporation, which will incorporate the Portsmouth and Paducah plants. Quarterly UE-FFCA meetings with EPA Headquarters have resulted in an agreement to continue coverage under the UE-FFCA for the Uranium Enrichment Corporation and independently for the K-25 Site until negotiation of a new ORR-FFCA. The ORR-FFCA will consolidate K-25 Site coverage under the UE-FFCA into a more comprehensive agreement to include the other Oak Ridge DOE facilities. Negotiation and administration of the ORR-FFCA have been delegated by EPA Headquarters to EPA Region IV.

\section{Underground Storage Tanks (USTs)}

There are seven active petroleum USTs at the K-25 Site. Three of the seven USTs provide fuel to power emergency generators. The K-1402 diesel UST was removed as part of a site check to investigate if a suspected release occurred. Results of soil samples collected from the K-1402 UST pit did not detect contamination beyond the tank backfill. The K-25 Site has received approval from TDEC to treat the 


\section{Environmental Report Vol. 1, Oak Ridge}

K-1402 UST soils on site. In addition to the seven active USTs, two former UST sites are presently being addressed under the ER Program: K-1414 Diesel and K-1220-NE. The K-25 Site ER Program is currently working with the TDEC/DOE-Oversight on negotiating 30-day time extensions for the K-1414 and $\mathrm{K}-1220$ NE USTs until all regulatory requirements are satisfied.

\section{Comprehensive Environmental Response, Compensation, and Liability Act (CERCLA)}

The following eight sites were under investigation by the K-25 Site ER Program during 1992:

- K-1420 Operable Unit (OU),

- K-1070 OU, (C/D Classified Burial Ground),

- $\mathrm{r}$-901 OU,

- K-770 OU,

- K-1407 B Holding Pond,

- K-1407 C Retention Basin,

- K-1070 SW31 Perennial Spring, and

- K-1417 Storage Yard.

The K-1420 OU consists of four components: wastewater process lines, an oil-storage yard, an incinerator, and a mercury recovery room. A Phase I Remedial Investigation (RI) document was issued in 1992. Work began on activities such as data validation and project planning of a process line camera survey. The $\mathrm{K}-1070 \mathrm{OU}$ is located on the eastern edge of the K-25 Site and is composed of a 22 -acre burial ground and three storage dikes. The Phase II Work Plan for this OU was submitted to TDEC and the EPA in early 1992. An electromagnetic and radiological survey was conducted in September 1992. The purpose of this survey was to provide a detailed conductivity map to determine burial waste boundaries.

K-901 OU consists of a contaminated burial ground, landfarm, holding pond, and two construction waste disposal areas. The K-770 OU includes a contaminated scrap metal yard and contaminated debris, two buildings, and a sewage treatment plant. RI field activities for both of these OUs are scheduled to begin in 1993.
The K-1407-B Holding Pond and K-1407-C Retention Basin are RCRA Interim Status units, and are awaiting clean closure under TDEC regulations. At that time they will become CERCLA units. An interim record of decision (IROD) is scheduled for submittal in early 1993.

The K-1070 SW31 Perennial Spring is located within the K-1070 OU. In 1992, the site was in the CERCLA Remedial Design/Remedial Action process, with field activities scheduled to begin in August 1993.

The K-1417 Storage Yard, also known as the Pond Waste Management Project, is managed under the CERCLA process (Please see the "Current Issues" section, page $\mathrm{lxx}$ ).

\section{Emergency Planning and Community Right-To-Know Act (EPCRA)}

EPCRA was enacted as a stand-alone portion (Title III) of the Superfund Amendments and Reauthorization Act of 1986 (SARA). Under the provisions of Title III, states developed emergency planning districts and identified local emergency response organizations that could respond in the event of a hazardous release from a local facility. Facilities must notify these districts of materials maintained and of releases occurring from their sites.

The K-25 Site submits three reports annually to comply with the hazardous material reporting requirements of SARA. These reports provide to the communities and emergency response agencies lists of potential hazards posed by stored chemicals and their releases from the K-25 facilities. The three annual reporting requirements of SARA Title III are

- annual hazardous chemical inventory reporting, including storage locations and total quantities stored (Sect. 312);

- facilities to furnish material safety data sheet (MSDS) or a list of hazardous chemicals identified by hazard category (Sect. 311); and

- facilities to provide an annual inventory of toxic chemical releases into the environment as defined by SARA Title III, Sect. 313). 


\section{Environmental Report Vol. 1, Oak Ridge}

The K-25 Site currently reports 16 hazardous and 5 extremely hazardous materials under Sects. 312/311 and 3 toxic chemicals under Sect. 313.

\section{National Environmental Policy Act (NEPA) Program}

The NEPA Program at the K-25 Site is focusing on establishing effective and responsive communications with program managers and project engineers with the goal of establishing NEPA as a key consideration in the formative stages of project planning. This is being accomplished through NEPA implementation training programs, tailoring NEPA status reports to be responsive to customer needs, and a concerted effort to work one-on-one with program and project personnel. Complementary to our effort to work with program and project personnel is increased efforts at establishing clear communication channels within the Environmental Management Division (EMD) to ensure that all EMD personnel are aware of new projects up front and have the opportunity to review and provide input on their areas of environmental concern. This is being accomplished by use of a trial EMD form that is issued by the NEPA Group within EMD.

An Environmental Assessment, with supporting Floodplain Assessment, Statement of Findings and Finding of No Significant Impact for the K-1515 Sanitary Plant modification, are currently under review. In addition, categorical exclusions (CXs) for a Drum Wash Station, Recycling of Contaminated Radioactive Scrap Metal, and Satellite and 90-Day Accumulation Areas, are also under review. DOE CX determinations were made for the K-25 Site Electrical Utilities Upgrade, the K-25 Site Sanitary Sewage Collection System Rehabilitation Project, and the K-25 Site decontamination and decommissioning (D\&D) Pilot Project involving one cell of the K-27 Building.

In conjunction with the NEPA process, new projects at the K-25 Site continued to be reviewed for compliance with the following statutes: Endangered Species Act; National Environmental Policy Act; National Historic Preservation Act; Executive Order 11988, Floodplain Management; and Executive Order 11990, Protection of Wetlands. Increased emphasis is being placed on early identification of impacts on proposed projects precipitated by compliance with these statutes. If determined necessary, surveys are requested and performed for verification and documentation of compliance.

\section{Threatened and Endangered Species, Wetlands, and Floodplains}

As part of the NEPA process, ORNL Environmental Sciences is consulted to minimize potential effects to threatened and endangered species, wetlands, or floodplains. Surveys are performed and mitigating measures are designed as needed. Martin Marietta Energy Systems, Inc., (Energy Systems) and the DOE Oak Ridge Operations Office (DOE-ORO) are currently initiating formal consultation on threatened and endangered species with the U.S. Fish and Wildlife Service. The Army Corps of Engineers is contracted to perform surveys for historical/cultural, wetlands, floodplains, and threatened and endangered species for the ORR to facilitace compliance with these issues.

\section{National Historic Preservation Act of 1966}

Energy Systems and the K-25 Site presently have the necessary procedures to ensure compliance with the National Historic Preservation Act.

Archaeological, historical, and cultural resource reviews are conducted on a case-by-case basis, and consultations with the Tennessee state historic preservation officer are made through DOE-ORO as required by Section 106 of the Act. Energy Systems Procedure ESP-EP- 163 (5/27/92) and Energy Systems Standard ESS-EP-101 (2/25/92) are in place to ensure that these resources are considered. When the Energy Systems Resource Management Organization was established in 1982, archaeological/historical/cultural resources were identified along with 14 other sensitive resource categories to be considered.

A programmatic agreement between DOE-ORO and the Advisory Council will be in effect about July 15,1993 . This agreement will identify certain routine actions as "categorical exclusions" not requiring further state historic preservation officer or council review. It will also require that DOE produce a draft Historic Resource Management Plan for the ORR within 18 months of the approval of the programmatic agreement. An ad hoc committee of Energy Systems site historical resource coordinators are currently scoping the logistical responsibilities, 


\section{Environmental Report Vol. 1, Oak Ridge}

data needs, and funding for the Historic Resource Management Plan.

A session about National Historic Preservation Act Sect. 106 responsibilities is being added to the NEPA training module. Section 106 briefings have been given at staff meetings for divisions and departments at K-25 Site and to the NEPA Task Team, which addresses all five sites.

Current case-by-case actions include the following. The Tennessee State Historic Preservation Officer has been notified of "no historic properties found" for the K-25 Sewer Line Upgrade, K-1423 Drum Compaction and Waste Storage and Processing facilities, K-1202 and K-1420-A Transfer Station and Enclosures, K-1404 Drum Wash Station, and K-1515 Lagoon Project. Consultation with the state historic preservation officer has determined "no adverse effect" by the K-27 building Decontamination and Decommissioning Pilot Demonstration Project. Memoranda of agreement addressing "adverse effect" have been sent to the state historic preservation officer for Advisory Council comment on K-1(128-40/69 Guard Stations Demolition and K-25 Cooling Tower (eight towers) Demolition projects. A memorandum of agreement is in progress addressing "adverse effect" for the K-25 Site Power Plant Demolition Project (18 buildings).

\section{Federal Insecticide, Fungicide, and Rodenticide Act (FIFRA)}

The K-25 Site maintains compliance with FIFRA requirements through inspection of controlled pesticide/herbicide storage areas and review of the on-site, restricted-use application program. A standard operating procedure has been developed for pesticide/herbicide storage, handling, and application activities by maintenance and grounds-keeping personnel. A site standard practice procedure has been developed for storage and inspection of hazardous materials with specific requirements for FIFRA materials. The K-25 Site has met the suggested guidelines for the storage and application of pesticides, as presented in 40 CFR 150-189, that are applicable to current operations.

\section{Safe Drinking Water Act (SDWA)}

The K-25 Site operates a water treatment system to provide potable water. This system consists of a raw water pumping station on the Clinch River, a filtration and treatment plant, finished water storage tanks, and a distribution system. The facility operators have a Class IV Water Operator Certification from the state.

The K-1515 Water Treatment fiacility, which is located south of the site, is in compliance with drinking water quality standards. The water is tested monthly and quarterly for various constituents, and the results are reported to TDEC. The plant was inspected by TDEC on October 23, 1991, and received a numerical rating of 96 , placing it among the state's approved water systems. Several small maintenance items and painting of the building and storage tanks have been completed. The supply of water is obtained from the Clinch River. The facility will require a new back wash treatment system io remove chlorine and suspended solids to eomply with NPDES discharge requirements. This project is scheduled for FY 1994.

\section{Release Reporting}

Spills and unanticipated releases may trigger release reporting requirements under provisions of one or more of the following statutes: (1) EPCRA (also known as Title III of SARA), (2) CERCLA, (3) RCRA, (4) CWA, (5) CAA, (6) TSCA. Each spill event is evaluated for reporting requirements and regulatory agencies including federal, state, and local emergency response agencies are notified as appropriate. The K-25 Site had three reportable releases (i.e., those not federally permitted and exceeding the CERCLA reportable quantity) during 1992. All were ethylene glycol releases $(3.76 \mathrm{lb}$, $2.33 \mathrm{lb}$, and $1.86 \mathrm{lb}$ ). Only one of the spills resulted in an off-site release and therefore became an EPCRA event $(3.76 \mathrm{lb})$. The other two releases were to pavement on the K-25 Site and were completely contained.

To determine whether the K-25 Site had any reportable releases (i.e., those not federally permitted and exceeding the CERCLA reportable quantities), a compliance assessment of all releases or potential releases is conducted annually. Additionally, 10 determine whether the K-25 Site had any reportable continuous releases, a compliance assessment was performed; no reportable continuous releases were identified. 


\section{DOE Order Assessment}

The K-25 Site Monitoring Program has been established to direct K-25 Site organizations in matters related to DOE order compliance. The responsibilities of the program include the following:

- protection of the public health and the environment;

- identification of potential environmental problems;

- evaluation of existing environmental contamination and determining the need for remedial actions and mitigative measures;

- monitoring the progress of ongoing remedial actions and cleanup measures;

- informing the public of environmental issues related to DOE operations;

- ensuring compliance with all federal, state, and local regulations and DOE requirements; and

- identifying and assessing unusual environmental occurrences.

\section{DOE Order 5400.1}

The annual environmental report for the K-25 Site is prepared as a subpart of the composite report that provides a comprehensive summary of ORR environmental activities as required by DOE Order 5400.1. This order also requires that Long Range Environmental Plans be developed for each facility. The K-25 Site was covered under the Oak Ridge Gaseous Diffusion Plant (ORGDP) Long-Range Environmental and Waste Management Plan, issued September 1989, until the Oak Ridge K-25 Site Long-Range Environmental Protection Plan was issued in June 1992. The plan defines specific environmental objectives and the means and schedules for attaining these objectives and completing programs and projects.

The ORR Site Environmental Monitoring Plan (EMP) describes each element of the Environmental Monitoring Program that is conducted at the K-25 Site and other sites on the ORR, including both effluent monitoring and environmental surveillances. Environmental surveillance monitoring includes sampling and analysis of surface water, soil and sediment, ambient air, and groundwater for chemicals and radionuclides.
The first Groundwater Management Plan was issued in April 1989, and has been written to serve as a living document which is annually reviewed and reissued every 3 years. The plan was reviewed in May 1992 and is currently scheduled to be revised and reissued in May 1993.

In December 1991, the required Waste Minimization Program was incorporated into the K-25 Site Pollution Prevention Program, and they are now reported as a combined program. The Pollution Prevention Program is designed to eliminate or minimize pollutant releases from operations to all environmental media to protect public health and the environment. The K-25 Site Waste Minimization Council, composed of representatives from each division, plays a major role in providing awareness and a mechanism for communication of waste minimization activities. The following is a summary of waste minimization activities:

- A Performance Improvement Project team has been formed to study and make recommendations on photographic waste reduction by recovery of silver from solution.

- Acid digestion and other analytical procedures by the laboratory have been modified to reduce stack emissions and acid waste generation.

- Color printers have been purchased to reduce the need for the photographic process.

- Most aerosol cans have been banned.

- A chemical evaporator has been purchased to reduce the volume of photographic waste.

- Extensive radioactivity monitoring has led to the segregation of various wastes for their on-site recycling, disposal, or sale.

\section{DOE Order $\mathbf{5 4 0 0 . 5}$}

An action to review and revise the existing K-25 Site as low as reasonably achievable (ALARA) Charter and Standard Practice Procedure is currently scheduled, which will fully implement an environmental ALARA program. Other scheduled actions include the development of a standard operating procedure for conducting environmental ALARA reviews of new and existing processes.

In August 1992, specific guidance from DOE concerning soil column discharge was requested in order to address a 1991 Tiger Team Assessment 


\section{Environmental Report Vol. 1, Oak Ridge}

finding. The guidance provided by DOE is being incorporated into an effort in the identification of all potential soil column discharge areas at the K-25 Site.

Surface water discharges at the K-25 Site were sampled and analyzed for radioisotopes in 1992, and it was found that annual average concentrations for individual radionuclides did not exceed the applicable derived concentration guides (DCGs) listed in DOE Order 5400.5. A pathway analysis will be conducted to define K-25 environmental surveillance requirements. This analysis will include background concentrations and bioaccumulation data to be evaluated for both radiological and nonradiological parameters.

Reporting requirements under this order are demonstrated through the Energy Systems procedure ESS-OP-301, "Occurrence Reporting System" and the annual publication of the environmental report.

\section{DOE Order 582u.2A}

A K-25 Site Waste Management Program has been established to ensure that (1) the generation of all waste is minimized to the extent reasonably achievable and (2) the treatment, storage. transportation, and disposal of wastes are conducted in a manner that protects the health and safety of on-site personnel, the general public, and the environment. These objectives are met to comply with all applicable laws, federal and state agreements, and DOE orders, including DOE $5820.2 \mathrm{~A}$. The K-25 Site Waste Management Plan, revised in December 1992, details Waste Management Program objectives and current methods of accomplishment in a site-wide comprehensive and integrated manner. The plan, which is updated and reissued on an annual basis, also contains a radioactive waste implementation summary update that satisfies compliance protocols specified by DOE $5820.2 \mathrm{~A}$.

K-25 radioactive waste management activities conducted under DOE $5820.2 \mathrm{~A}$ are primarily related to low-level waste (LLW) because the site does not store or generate high-level radioactive waste. Although transuranic (TRU)-contaminated material exists on site, the concentration limits are less than that for TRU waste. LLW management operations concentrate on solid waste management operations, although gaseous LLW streams also exist.

\section{Other DOE Orders}

The K-25 Site administers assessment and permitting programs for all environmental regulations. Routine assessments are performed to maintain and verify compliance. Compliance issues resulting from audits or routine assessment activities are documented and reported to appropriate levels of management. Follow-up actions are taken to verify implementation of these corrective actions. The K-25 Site has issued a standard practice procedure in accordance with DOE Order 5000.3. All 10-day and final occurrence reports are prepared and submitted to the K-25 Site Occurrence Reporting Support Center. From there, the reports are entered into the DOE nationwide data base.

\section{Current Issues}

A number of specific compliance issues have been identified as a result of recent intensive efforts to attain full compliance. The significant issues are discussed below.

\section{Discharges of Toxic Pollutants to Surface Waters}

The K-25 Site has been listed by EPA and TDEC as a point-source discharger of toxic priority pollutants under CWA Sect. 304(1). Chlorine discharged to Mitchell Branch in once-through cooling water has been identified as a primary source of toxicity to the stream. Dechlorination units have been placed at selected storm drains to treat these discharges, and they have eliminated the toxic impact of chlorine on Mitchell Branch. Efforts to identify and eliminate minor toxic contributors are continuing.

\section{Toxic Substances Control Act (TSCA)}

The focus of the TSCA Compliance Program at the $\mathrm{K}-25$ Site is on compliance with the PCB regulations. Currently there are no outstanding notices of violation or noncompliance. The program is presently concentrated on three major functions: (1) developing the K-25 Site PCB Management Program and plan, (2) producing compliance documents and reports, and (3) providing guidance to various organizations on issues that arise. 


\section{Environmental Report Vol. 1, Oak Ridge}

PCB Program inaragement development is organized around corrective actions resulting from the 1991-1992 Tiger Team Assessment. In 1992, the program development efforts resulted in

- the hiring of the equivalent of two full-time employees for PCB management support;

- issuance of the K-25 Site PCB Management Program policy statement;

- issuance of PCB storage area guidance and formalization of a PCB storage area registration system;

- finalization of SPP-41(12, "Cleanup of Spills Involving PCBs";

- issuance of a position statement on spare electrical equipment containing PCBs; and

- a development of a $\mathrm{PCB}$ incident-reporting requirements table.

Thus far in CY 1993, a PCB cross-functional management team (CFMT) has been established to aid in program communication and integration. Also planned for 1993 is the completion of a comprehensive PCB Management Program Plan and development of additional PCB management procedures. Procedure development and training program development are planned through 1996. An assessment program will be implemented to monitor the execution of the PCB Management Program Plan, procedures, and training throughout the K-25 Site. Major near-term items requiring attention include the application for EPA approval of the PCB Drum Wash Station, Renewal of EPA approval for disposal of PCBs at the K-1435 TSCA Incinerator, completion of the 1992 Annual PCB Document, and support for the negotiation of the ORR-FFCA.

The current UE-FFCA covers the Portsmouth and Paducah gaseous diffusion plants and the K-25 Site.

All K-25 Site UE-FFCA milestones either have been completed or are proceeding on schedule.

Gasket-removal activity and potentially other removal activities have been placed on hold pending renegotiation of the removal schedule by DOE and EPA.

An effort to negotiate an additional agreement to include the $(w)$ other Oak Ridge facilities (the $\mathrm{Y}-12$ Plant and ORNL) has been under way for some time. Since then, Congress has acted to create a new Uranium Enrichment Corporation, which will incorporate the Portsmouth and Paducah plants. Quarterly UE-FFCA meetings with EPA Headquarters have resulted in an agreement to continue coverage under the UE-FFCA for the Uranium Enrichment Corporation and independently for the K-25 Site until negotiation of a new ORR-FFCA. The ORR-FFCA will consolidate K-25 Site coverage under the UE-FFCA into a more comprehensive agreement to include the other Oak Ridge DOE facilities. Negotiation and administration of the ORR.FFCA have been delegated by EPA Headquarters to EPA Region IV.

Among the proposals made for consideration in the agreement, is an extension of the allowance under the UE-FFCA to store radioactive PCB wastes for periods in excess of 1 year to the entire ORR. The PCB regulations require disposal of $\mathrm{PCB}$ items within I year of removal from service. This proposal would allow PCB waste to be stored until adequate disposal capacity becomes available, either at the TSCA Incinerator or at off-site facilities, or until DOE can certify that the PCB wastes are nonradioactive, thereby enabling disposal at a conventional off-site disposal facility.

\section{K-1417 Storage Yard}

Sludges contaminated with low-level radioactivity were generated by settling and scrubbing operations and were stored in K-1407-B and $\mathrm{K}-1407-\mathrm{C}$ ponds in the past. Sludges had been removed from these ponds, and portions were fixed in concrete at K-1419 and stored above ground at K-1417 Drum Storage Yard.

In 1989, during routine inspections of the drums of stabilized K-1407 pond sludge at the K-1417 Storage Facility, it was discovered that many of the drums had begun to corrode. Certain constituents contained in the sludge proved to be incompatible with the container material.

In September 1991, TDEC issued a Commissioner's Order against Energy Systems and DOE for RCRA violations regarding storage of drums at the K-25 Site. The order assessed a \$96,004 penalty against Energy Systems and also sought implementation of the corrective action plan previously submitted to TDEC by DOE and Energy Systems. This action was appealed in October 1991.

An action plan has been implemented to decant and/or dewater the mixed waste contained in the 
drums. Implementation of the Pond Waste Management Project (PWMP) action plan, coordinated with state and federal regulators, began in October 1991, and is continuing. About 45,600 drums of stabilized sludge have been processed and placed in compliant storage, with completion of this phase occurring in October 1992. Of the 45,600 drums, roughly 8,300 stabilized drums were removed from the K-25 vaults and processed by Energy Systems labor forces, and about 37,300 drums were processed by a subcontractor. These drums have been stored in existing facilities in Buildings $\mathrm{K}-31$ and $\mathrm{K}-33$, and in new storage facilities constructed in the K-1065 area.

Dewatering of about 32,000 drums of raw sludge began in September 1992. The processing rate of the dewatering subcontractor was not adequate to meet regulatory milestones, and in early November the subcontractor proposed modifications to his precess equipment to improve its performance. On November 14, 1992, a fatal accident occurred during the installation of the equipment modifications. The subcontractor was put on stand-down pending the results of a DOE Type $A$ investigation. Discussions were held with the state and federal regulators to keep them informed of the project status, including plans for restart of the project. As of April 1, 1993, an evaluation of alternatives for restart of the project is in progress.

\section{National Pollutant Discharge Elimination System (NPDES) Permit}

The NPDES permit for the K-25 Site expired on September 27, 1989. An application for a new permit wits submitted before the expiration of the existing permit, as required by TDEC and approval to operate under the conditions of the expired permit was issued by TDEC. A renewed NPDES permit was issued for the site on October 1, 1992.

Several NPDES permit exceedences attributed to natural causes occurred repeatedly under the expired permit. The new NPDES permit will eliminate many of these exceedences that are attributed to natural causes because it will require monitoring of storm drain discharges into settling ponds and streams. The previous permit required monitoring at the outlets of these streams and ponds after natural phenomena had occurred that were not related to discharges from the site.
The Mitchell Branch dechlorinators began operating in June 1991, reciucing total residual chlorine output from three storm drain systems. An engineering project to eliminate chlorinated discharges to Mitchell Branch was completed in October 1992, and the dechlorination units were deactivated.

On January 17, 1992, Friends of the Earth filed a lawsuit under the CWA for DOE Oak Ridge Sites NPDES violations in the U.S. District Court for the Eastern District of Tennessee, Northern Division. Many of the noncompliances alleged in the lawsuit could not occur with the new permit.

\section{Pollution Prevention}

The K-25 Site participated in the EPA 33/50 Toxic Chemical Emission Reduction Program (33\% by 1992 and $50 \%$ by 1995), as requested by the Martin Marietta Corporation, and met over 50\% reduction goals by 1992. The Analytical Services Division reduced the volume of trash designated as RCRA mixed waste by one-third through on-the-job training and performance management team efforts. The K-25 Site has a pollution-prevention council made up of representatives from each division to provide awareness and communication to the $\mathrm{K}-25$ Site. Pollution Prevention training is provided by the Waste Management Division to all employees. The $\mathrm{K}-25$ Site issues a quarterly waste minimization newsletter.

\section{Uranium Hexafluoride (UF6) Cylinder Program}

The Uranium Hexafluoride $\left(\mathrm{UF}_{6}\right)$ Cylinder Program is directed toward improving the safety and reliability of long-term storage for 7000 cylinders at the K-25 Site. In storage at this site are approximately 5000 10- and 14-ton cylinders of depleted $U_{6}, 1000$ cylinders of normal-assay feed $\mathrm{UF}_{6}, 400$ heel-quantity cylinders (those containing more than $50 \mathrm{lb}$ of "enriched" material), and 600 miscellaneous empty cylinders. Both depleted and enriched $U_{6}$ are regulated by DOE through the provisions of the Atomic Energy Act.

The K-25 Site $\mathrm{UF}_{6}$ Cylinder Program is being designed to develop a clear understanding of the current conditions of the cylinders and define any near-and long-term actions for safe storage of the 
cylinders pending decisions on ultimate disposition of the $\mathrm{UF}_{6}$ material. Some of the initial actions in the program are a baseline inspection, a corrosion coupon program, and an ultrasonic thickness measurement program. The baseline inspection identified a variety of cylinder defects which will require special attention and also identified four breached cylinders. Immediate corrective actions have been taken to handle the breached cylinders and a schedule of activities has been developed for moving and repairing the cylinders.

Shipment of the feed cylinders to the Paducah Gaseous Diffusion Plant has been suspended temporarily. The shipment is planned to resume April 17, 1993. The current DOE direction for the 5000 depleted cylinders is to store them until at least the year 2020, at which time conversion to oxide will be performed if no other uses have been determined. A plan for cleaning the heel cylinders and empties has not yet been approved (this may be performed at the K-25 Site or at one of the operating gaseous diffusion plants).

\section{Summary of Permits}

\section{RCRA, CWA, and CAA Permit Status}

\section{RCRA}

TDEC issued three RCRA permits for the K-25 Site in September 1992. These permits which are currently under appeal, consist of (1) the K-1435 and $\mathrm{K}-1425 \mathrm{TSCA}$ Incinerator storage and treatment units, (2) tank storage and treatment units, and (3) all other units at the site (primarily containing storage). The TSCA Incinerator at the site is currently being operated under a RCRA Part B permit that was issued in 1987. A modification to the permit for the TSCA Incinerator is expected to be issued in the near future.

The K-25 Site RCRA Part A application was revised and submitted to TDEC in 1992 to be consistent with the updated Part B applications. Closure plans for seven units, including an amended closure plan for the K-1407-B and -C Ponds, were submitted to the TDEC in 1992. A closure plan for the K-1417 Drum Storage Yard and the K-1419 Sludge Treatment Facility is currently being prepared for submittal to TDEC.

\section{CWA}

Until October 1, 1992, the K-25 Site operated under an expired NPDES permit that was issued by TDEC.The NPDES permit for the K-25 Site expired on September 27, 1989. A renewed NPDES permit was issued to the site by TDEC on October I, 1992.

\section{CAA}

Air sources at the K-25 Site currently total 201 , of which 42 are exempt from permitting requirements; 159 are covered by 85 permits issued by TDEC. A site permitting procedure was completed in 1992, and a site training program was implemented for air source operators. These efforts have led to an increased awareness among operators of current and planned air sources to have valid operating permits and to renew them in a timely manner. Continuing dialogue with the source operators and with the building managers provides a basis for the withdrawal of permits on sources that are no longer operating. Numerous renewals and possible withdrawals are pending for 1993.

A current listing of permitted and exempt air sources is contained in Vol. 2. 


\section{RESERVATION DESCRIPTION AND SETTING}

1.1 Operations on the Oak Ridge Reservation ..... 1-3

$1.1 .1 \quad$ Y-12 Plant . . . . . . . . . . . 1-5

1.1.2 Oak Ridge National Laboratory ..... 1-6

$1.1 .3 \quad$ K-25 Site ................ 1-6

1.1.4 Oak Ridge Institute for Science and

Education ............... 1-8

1.2 Regional Demography . . . . . . . . . . . 1-8

1.3 Climatic and Atmospheric Processes ...... 1-8

1.3.1 Temperature . . . . . . . . . . 1-9

1.3.2 Winds .................. 1.9

1.3.3 Precipitation . . . . . . . . . . . . . 1-9

1.3.4 Evapotranspiration ........... 1-11

1.4 Geology . . . . . . . . . . . . . . . 1-12

1.4.1 Stratigraphy .............. 1-12

1.4.2 Structural Framework .......... 1-12

1.5 Groundwater ................... 1-14

1.5.1 Groundwater Occurrence . . . . . . . . . 1-14

1.5.2 Groundwater Use . . . . . . . . . . . . 1-15

1.6 Surface Water ................. 1-15

1.6.1 Stream Classification . . . . . . . . . . 1-16

1.6.2 Surface Water Hydrology . . . . . . . . . 1-16

1.6.3 Watershed Characteristics ... . . . . 1.17

1.6 .4 Water Use .............. 1-17

1.7 Environmental Monitoring $\ldots \ldots \ldots \ldots \ldots$ 1-17

1.8 References .................. 1-18 


\section{Environmental Report Vol. 1, Oak Ridge}

\section{Reservation Description and Setting}

This report provides information regarding the impacts of the U.S. Department of Energy's (DOE's) Oak Ridge Reservation (ORR) facilities on the public and the environment. It describes the environmental surveillance and effluent monitoring activities conducted at and around facilities operated by Martin Marietta Energy Systems, Inc., (Energy Systems) for DOE. Preparation and publication of this report is in accordance with DOE Order 5400.1. The order specifies the report's content and a publication deadline of June for data from the previous calendar year.

The primary objective of this report is to summarize all information collected for the previous calendar year regarding effluent monitoring, environmental surveillance, and estimates of radiation and chemical dose to the surrounding population. When multiple years of information are available for a program, trends are also evaluated. The first seven sections of Vol. 1 of this report address this objective. The last three sections of Vol. 1 provide information on special environmental studies, solid waste management, and quality assurance programs. Chemicals covered by the Superfund Amendments and Reauthorization Act (SARA) Title III, Sect. 313, report on gaseous emissions are included in Appendix A. Corrections and amendments to the 1991 report are discussed in Appendix B. Volume 2 is a compilation of the data that are summarized in Vol. ; and includes some relevant descriptive reference material that does not change from year to year. Volume 2 is not intended to be a stand-alone report. Volume 1 is published for general distribution. Volume 2 is available on request for those members of the audience who require more detailed information. Requests for Vol. 2 should be made to Oak Ridge National Laboratory (ORNL)
Laboratory Records, P.O. Box 2008, Oak Ridge, TN 37831-6285.

Although located within the corporate limits of the city of Oak Ridge in eastern Tennessee, the ORR site is predominantly to the west and south of the population center of Oak Ridge. The reservation consists of about 14,029 ha $(34,667$ acres $)$ of federally owned lands. The city and the reservation are shown on the map of Tennessee in Fig. 1.1.

Oak Ridge lies in a valley between the Cumberland and southern Appalachian mountain ranges and is bordered on two sides by the Clinch River. The Cumberland Mountains are about $16 \mathrm{~km}$ (10 miles) to the northwest; the Great Smoky Mountains are about $113 \mathrm{~km}$ (70 miles) to the southeast as shown in Fig. 1.1.

\subsection{Operations on the Oak Ridge Reservation}

The ORR contains three major operating facilities: the Oak Ridge Y-12 Plant (Y-12 Plant), ORNL, and the Oak Ridge K-25 Site (K-25 Site). The locations of these three facilities are shown in Fig. 1.2. The on-reservation DOE buildings and structures outside the major plant sites consist of the Scarboro Facility, Clark Center Recreational Park, Central Training Facility, and the Transportation Safeguards Laboratory maintenance facility. The off-reservation DOE buildings and structures consist of the Federal Office Building, Office of Scientific and Technical Information, Oak Ridge Institute for Science and Education (ORISE), Atmospheric Turbulence and Diffusion Division - National Oceanographic and Atmospheric Administration, the American Museum of Science and Energy, Energy Systems administrative support office buildings, and the former museum building. The administrative units 
ORNL.DWG $87 \mathrm{M} \cdot 7844 \mathrm{R} 3$

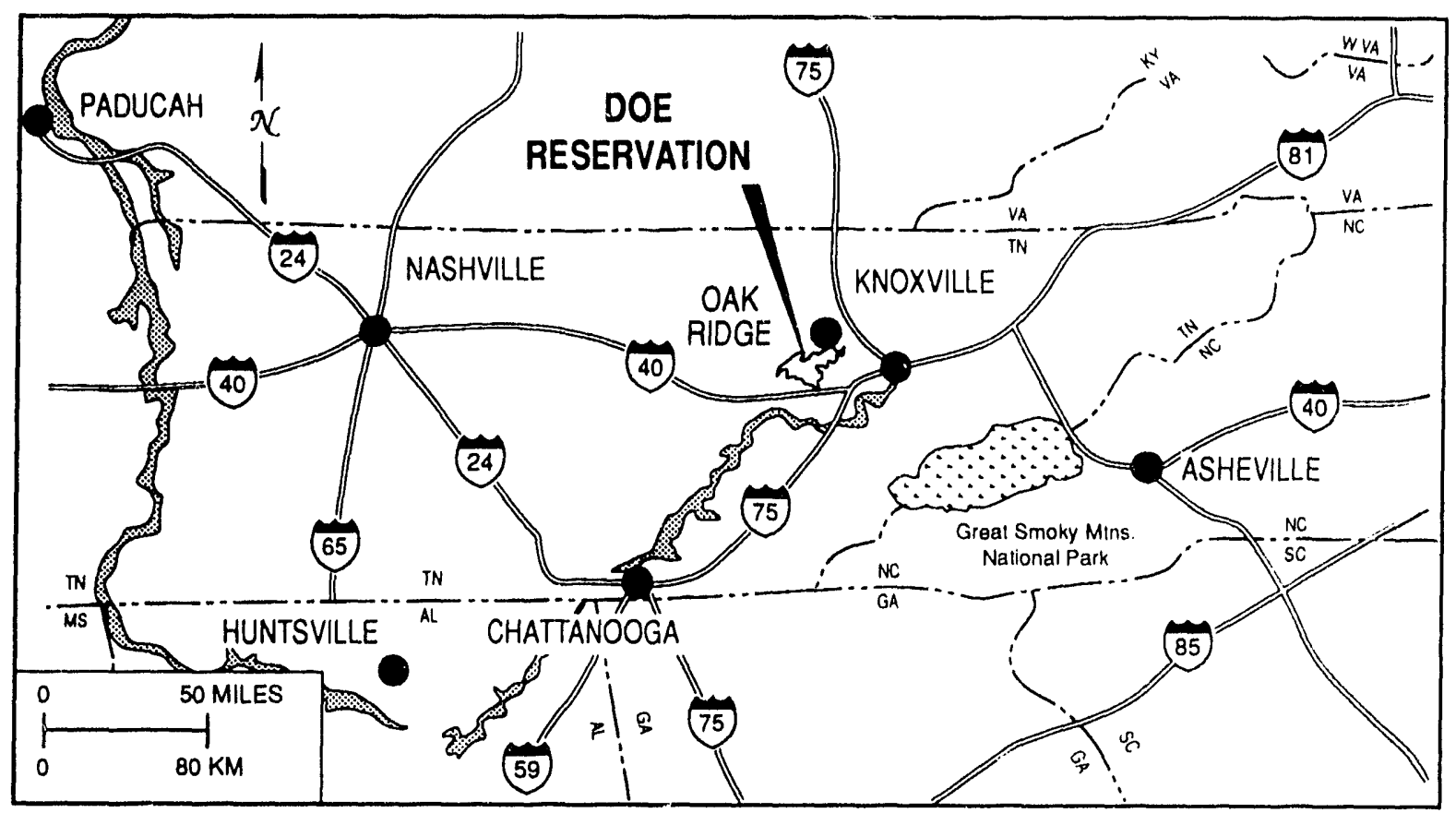

Fig. 1.1. Map showing location of Oak Ridge and the Oak Ridge Reservation in relation to geographic region.

ORNL-DWG 93M-9618

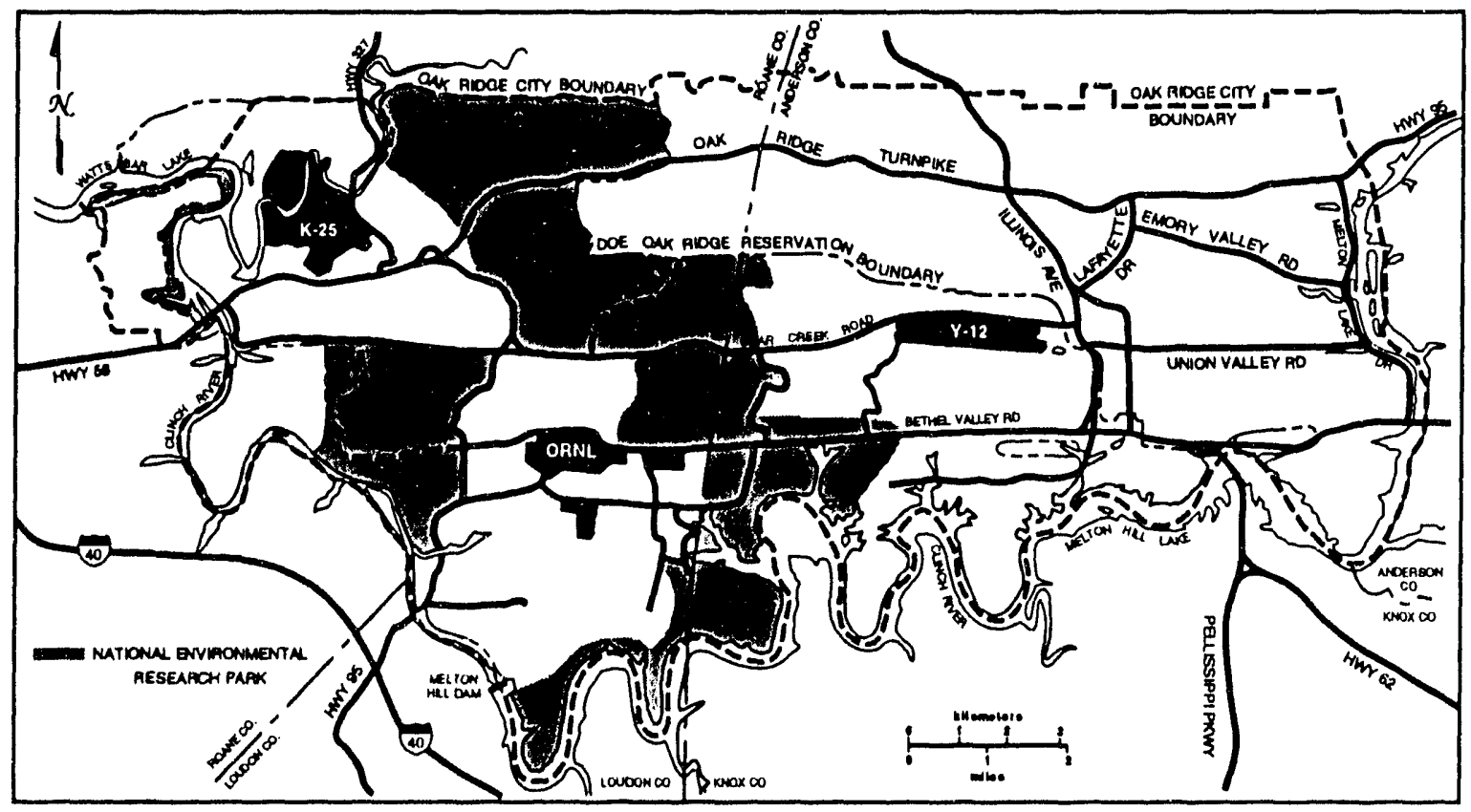

Fig. 1.2. Map showing the Oak Ridge Reservation and the location of the three major installations. 
(units managed by a major installation or by central Energy Systems) on the ORR are listed in Table 1.1. of Vol. 2.

\subsubsection{Y-12 Plant}

Until 1992 the primary mission of the Y-12 Plant (Fig. 1.3) was the production and fabrication of nuclear weapon components. Activities associated with these functions included production of lithium compounds, recovery of enriched uranium from scrap material, and fabrication of uranium and other materials into finished parts. Fabrication operations included vacuum casting, arc melting, powder compaction, rolling, forming, heat treating, machining, inspection, and testing.

Currently the Y-12 Plant is in the midst of refocusing its technical capabilities and expertise to serve the DOE and customers who are approved by the DOE. The Y-12 Plant continues to serve as a key manufacturing technology center for the development and demonstration of unique materials, components, and services of importance to the DOE and the nation. Specific focus areas for the Y-12 Plant in coming years include

- weapons dismantlement and storage;

- enriched uranium material warehousing and management;

- nuclear weapons process technology and development support;

- Y-12 Plant management/landlord activities, including taking standby or shutdown facilities into a safe, legally compliant condition;

- identifying and managing the decontamination and decommissioning of facilities;

- providing unique capabilities and technologies not found in the private sector on DOE-approved tasks;

ORNL-PHOTO 9287-89

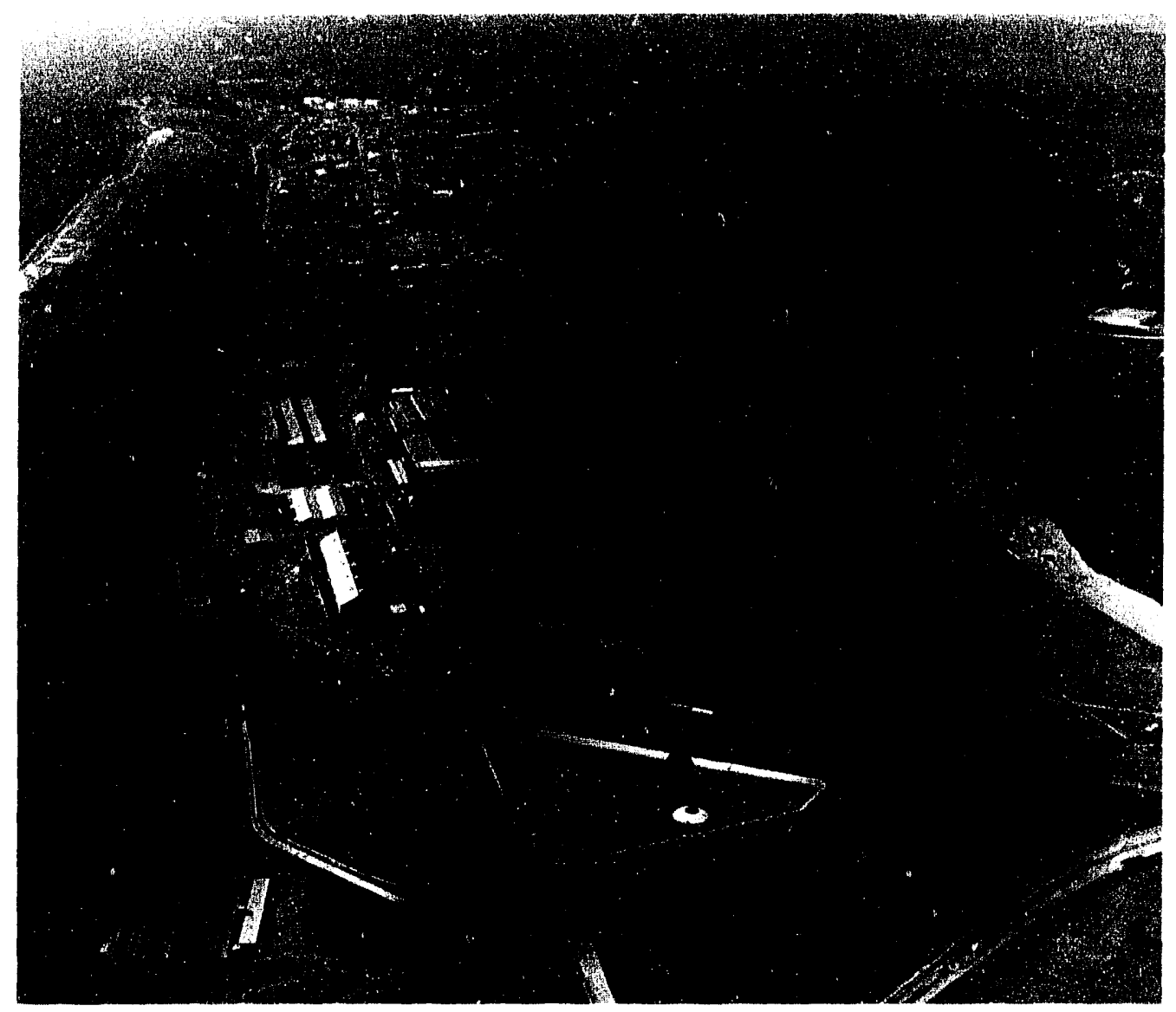

Fig. 1.3. Oak Ridge Y-12 Plant (view looking northwest). 
- transferring technology developed at DOE facilities to enhance our industrial competitive edge in worldwide markets; and

- maintaining and supporting the National Security Program Office for DOE.

\subsubsection{Oak Ridge National Laboratory}

ORNL (Fig. 1.4), located toward the west end of Melton and Bethel valleys, is a large, multipurpose research laboratory whose basic mission is to expand knowledge, both basic and applied, in areas related to energy. ORNL's facilities include a high-flux nuclear research reactor, chemical pilot plants, research laboratories, radioisotope production laboratories, accelerators, fusion test devices, and support facilities. In addition to the main ORNL complex, the Oak Ridge National Environmental Research Park is managed by ORNL, and the ORNL Biology and Fusion Energy divisions and staff from other ORNL divisions are located at the Y-12 Plant. Staff from the
Engineering Technology Division are located at the K-25 Site.

\subsubsection{K-25 Site}

Until the summer of 1985 , the primary mission of the K-25 Site (Fig. 1.5) was enrichment of uranium hexafluoride $\left(\mathrm{UF}_{6}\right)$ in the ${ }^{235} \mathrm{U}$ isotope for use as a fuel in nuclear reactors. The gaseous diffusion process was utilized to produce the enrichment services. In August 1985, the gaseous diffusion process at the K-25 Site was placed in a "ready standby" mode because of declining demands for enriched uranium. The decision to shut down the gaseous diffusion cascade permanently was made in December 1987.

In addition to operating the gaseous diffusion process, $\mathrm{K}-25$ Site personnel were involved in developing and demonstrating more energy-efficient and cost-effective methods for uranium enrichment. Two such methods under development at the $\mathrm{K}-25$ Site were the gas centrifuge process and the

ORNL.PHOTO 9282.89

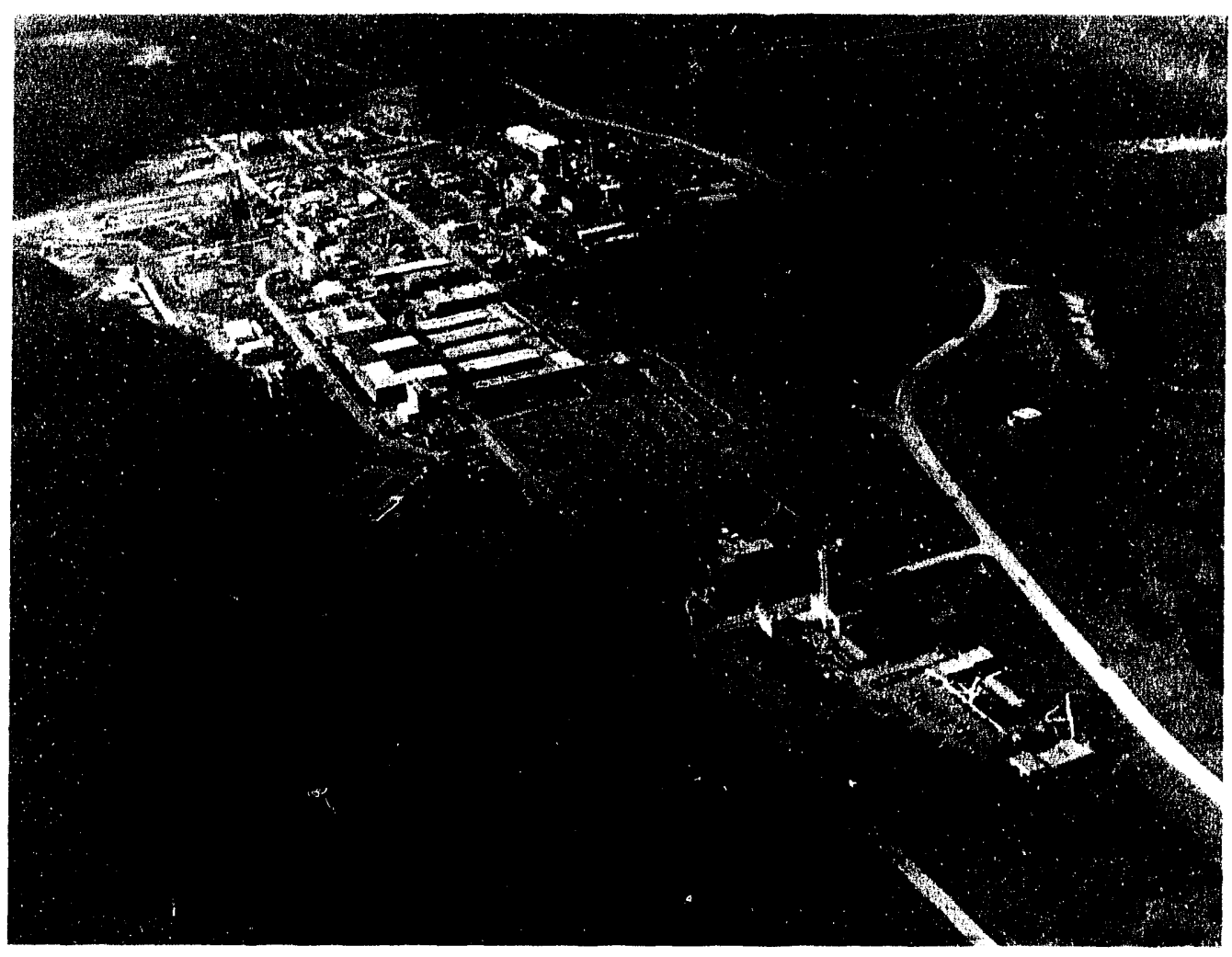

Fig. 1.4. Oak Ridge National Laboratory (view looking west). 


\section{Environmental Report Vol. 1, Oak Ridge}

ORNL-PHOTO 9284.89

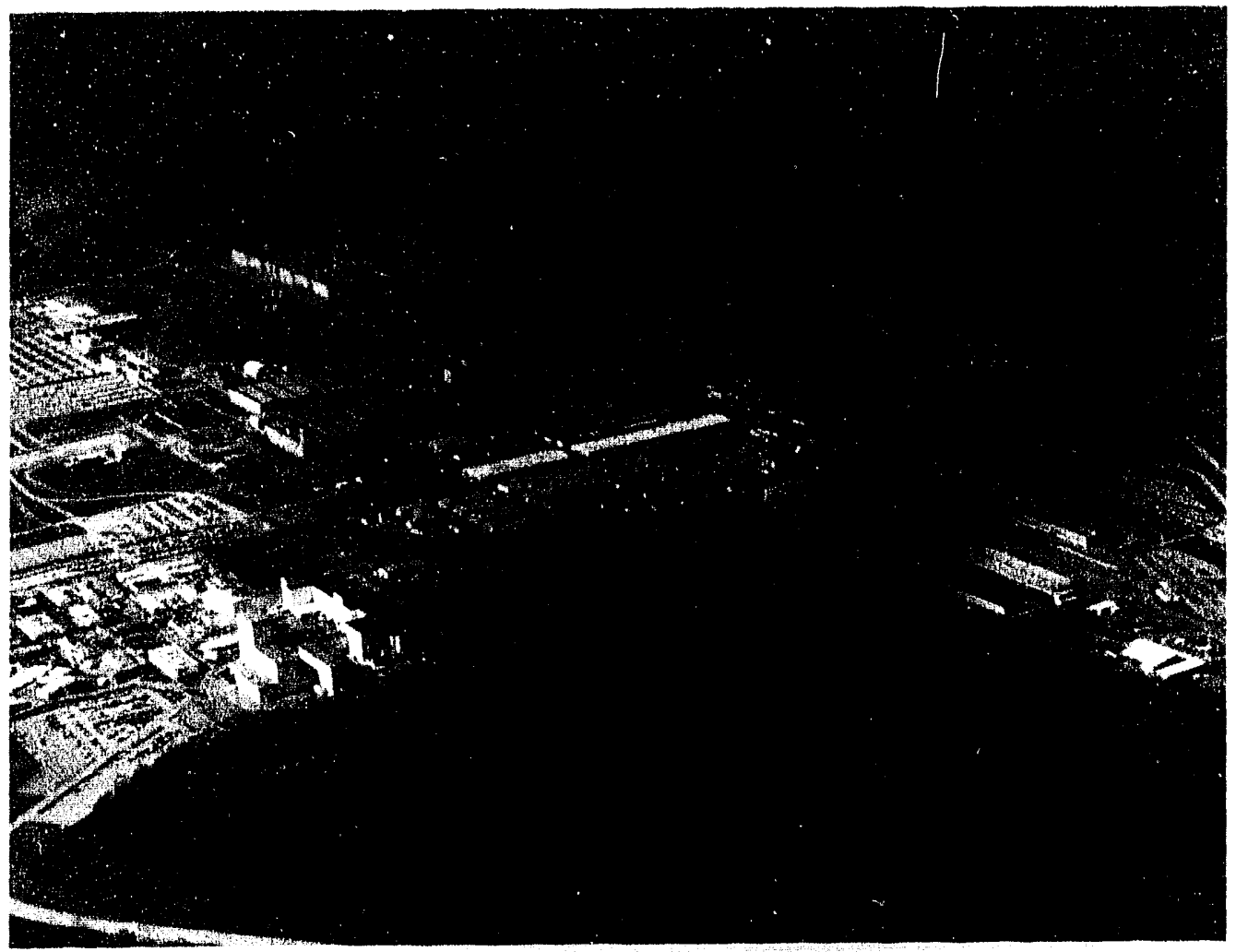

Fig. 1.5. Oak Ridge K-25 Site (view looking northwest).

atomic vapor laser isotopic separation (AVLIS) system. In 1985 the gas centrifuge process was shut down. In 1986 the AVLIS work at the K-25 Site was significantly reduced, and in 1992 AVLIS work was put on hold.

Major changes in the role of the K-25 Site began evolving during 1986 and 1987. A significant increase in work for agencies other than DOE is projected in the future. The unique technologies, expertise, and facilities at the K-25 Site constitute a national resource that can be used effectively to solve problems of national importance in areas that complement the ongoing DOE missions. Although enrichment operations at the K-25 Site are shut down, some waste streams are being generated, and wastes now in storage will require disposal in the future.

Waste management activities at the K-25 Site are increasing. Low-level radioactive wastes from other DOE-Oak Ridge Operations Office (DOE-ORO) sites are being placed in K-25 building vaults until a final disposition strategy is identified. Also, polychlorinated biphenyl (PCB) wastes and Resource Conservation and Recovery Act (RCRA) wastes contaminated with uranium began arriving from other DOE-ORO sites in 1987 for incineration in the K-1435 Toxic Substances Control Act (TSCA) Incinerator.

In September 1989 Energy Systems formed the Applied Technology Organization, which has overall management responsibility for the K-25 Site. Its responsibilities include maintenance of shut-down uranium enrichment facilities; support services for the Energy Systems central engineering, central computing, and central finance organizations; waste management programs, including the TSCA Incinerator and the Central Waste Management programs; and management of programs that include the AVLIS Program, International Technology Programs, the Hazardous Waste Remedial Actions Program, Data Systems Research and Development Program, Space and Defense Technology Program, and the Work For Others Program (which included 
work at ORNL and the Y-12 Plant as well as at the K-25 Site.)

In February 1992 Energy Systems formed the Environmental Restoration and Waste Management Programs organization to unify the K-25 Site Landlord Program, the Environmental Restoration Program, Central Waste Management Program, Decontamination and Deccmmissioning Program, Hazardous Waste Remedial Actions Program, International Technology Programs, and the Mission Success Program. The new management structure will foster a more integrated environment, safety, and health function throughout the Environmental Restoration and Waste Management Programs organization and will ensure greater efficiency and responsiveness to DOE.

\subsubsection{Oak Ridge Institute for Science and Education}

Oak Ridge Associated Universities (ORAU), a not-for-profit consortium of 65 colleges and universities, manages and operates ORISE for DOE. Among its diverse activities, ORISE has stewardship responsibility for two tracts on the southeastern border of the ORR that from the late 1940s to the mid-1980s were part of an agricultural experiment station owned by the federal government and, until 1981, were operated by the University of Tennessee.

The first tract, the South Campus, occupies about 36 ha (90 acres) and lies immediately southeast of the intersection of Bethel Valley Road and Pumphouse Road. II houses one of ORISE's four operating divisions and is being developed for other programmatic uses. Air emissions through laboratory hoods are beneath permitting limits. The amount of radioactive material used there is below reportable quantities, and no liquid radioactive wastes were discharged in 1992. ORISE is classified under RCRA as a Conditionally Exempt Small Quantity Generator, and its site accumulation area is located in the Chemical Safety Building on the South Campus.

The Freels Bend tract consists of about 101 ha (250 acres) on the northeastern edge of Freels Bend abutting Melton Hill Lake. Although no programmatic activities are conducted at this site, ORISE does provide maintenance and security, including security for the decommissioned system of ${ }^{611}$ Co sources at the Variable Dose Rate Irradiation Facility.

\subsection{Regional Demography}

Except for the city of Oak Ridge (pop. 27,000) the land within $8 \mathrm{~km}$ ( 5 miles) of the ORR is predominantly rural and is used largely for residences, small farms, and cattle pasture. Fisining, boating, water skiing, and swimming are favorice recreational activities in the area. The approximate location and population of the towns nearest the ORR are Oliver Springs (pop. 3400$), 11 \mathrm{~km}$ (6.8 miles) to the northwest; Clinton (pop. 9000), $16 \mathrm{~km}$ (10 miles) to the northeast; Lenoir City (pop. 6100), $11 \mathrm{~km}$ (6.8 miles) to the southeast; Kingston (pop. 4600), $11 \mathrm{~km}$ (6.8 miles) to the southwest; and Harriman (pop. 7100$), 13 \mathrm{~km}$ (8 miles) to the west. Pcpulation levels are based on 1990 U.S. census data (U.S. Department of Commerce 1991). Figure 1.6 shows the locations of these towns. Knoxville, the major metropolitan area nearest Oak Ridge, is located about $40 \mathrm{~km}$ ( 25 miles) to the east and has a population of about 165,000 . Table 1.2 of Vol. 2 lists cities and population centers within a 16 - and $80-\mathrm{km}$ (50-mile) radius of the ORR. Directional $80-\mathrm{km}$-radius population density maps are shown in Figs. 1.7 and 1.8. Figures 1.1 and 1.2 of Vol. 2 show populaticn levels within 16 and $80 \mathrm{~km}$ of the ORR by sector. The center of these figures is the center of the ORR, and most of the area within an $8-\mathrm{km}$ (5-mile) radius is part of the ORR. Fewer than 13,000 people live within $8 \mathrm{~km}$ of the ORR center. The Tennessee Valley Authority (TVA) Melton Hill and Watts Bar reservoirs on the Clinch and Tennessee rivers form the eastern, southern, and western boundaries of the ORR, and the residential sector of Oak Ridge forms the northern boundary.

\subsection{Climatic and Atmospheric Processes}

The nearby Cumberland and Great Smoky mountains have a moderating influence on the climate of the ORR. The mountains frequently divert from this region hot, southeasterly winds that develop along the southern Atlantic coast. In general, this results in warm, humid summers and cool winters, with no noticeable extremes in precipitation, temperature, or winds. Spring and fall are typically long, and the weather is normally sunny with mild 


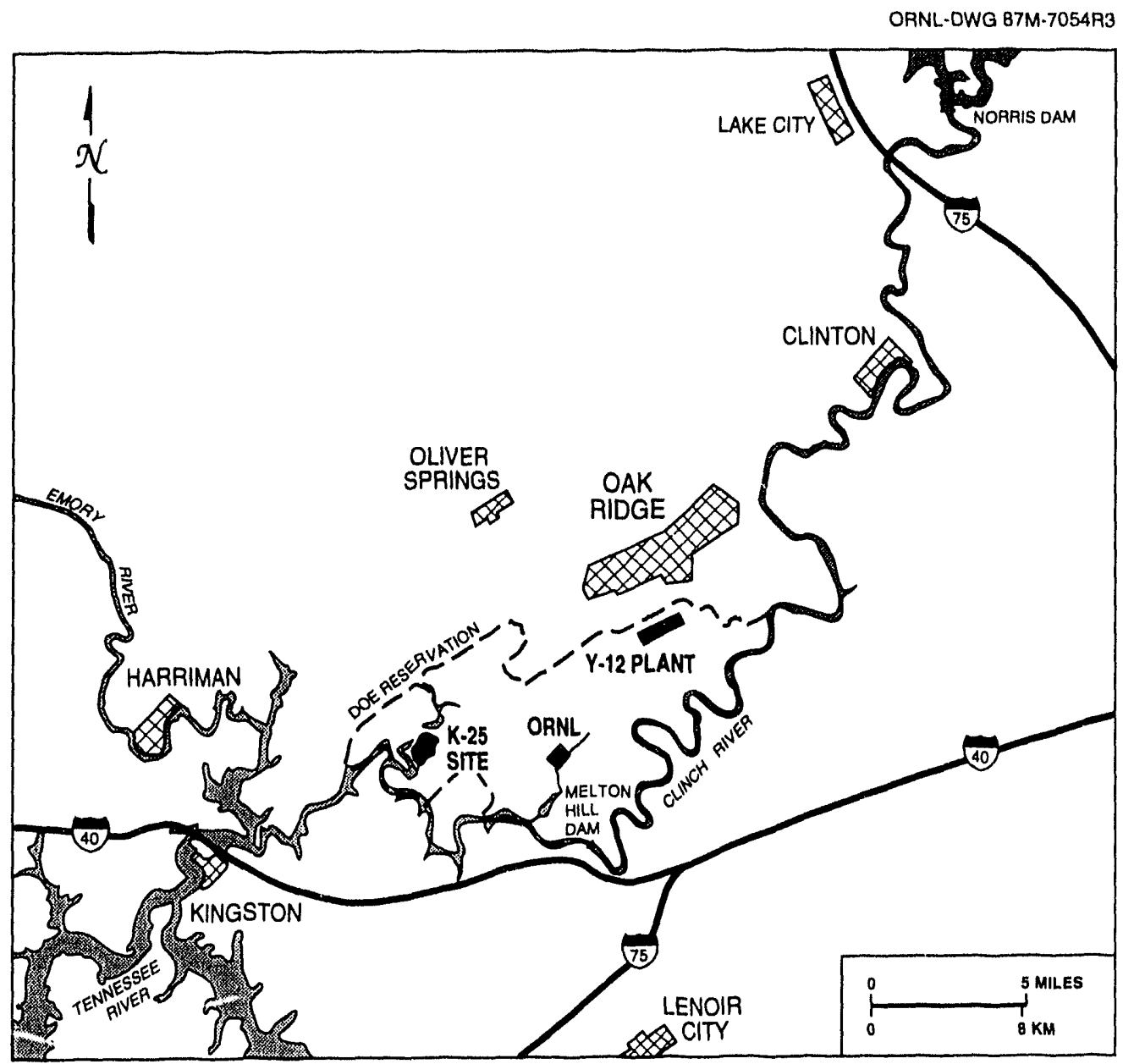

Fig. 1.6. Location map of towns nearest the Oak Ridge Reservation.

temperatures. Severe storms such as tornadoes or high-velocity winds are rare.

\subsubsection{Temperature}

The mean annual temperature for the Oak Ridge area is $14.4^{\circ} \mathrm{C}\left(58^{\circ} \mathrm{F}\right)$ (Webster and Bradley 1988 ). The coldest month is usually January, with temperatures averaging about $3.3^{\circ} \mathrm{C}\left(38^{\circ} \mathrm{F}\right)$ but occasionally dipping as low as $-17^{\circ} \mathrm{C}\left(0^{\circ} \mathrm{F}\right)$. Temperature differences between December through February are minor, however. July is typically the hottest month of the year, with temperatures averaging $77^{\circ} \mathrm{F}$ but occasionally peaking at over $37.8^{\circ} \mathrm{C}\left(100^{\circ} \mathrm{F}\right)$. Average daily temperatures fluctuate $12^{\circ} \mathrm{C}\left(53.6^{\circ} \mathrm{F}\right)$ over the course of the year (Davis et al. 1984).

\subsubsection{Winds}

Winds in the Oak Ridge area are controlled in large part by the valley and ridge topography. Prevailing winds are either up-valley (northeasterly) daytime winds or down-valley (southwesterly) nightime winds. Tornadoes and high-velocity winds are rare; wind speeds are less than $11.9 \mathrm{~km} / \mathrm{h}$ (7.4 mph) $75 \%$ of the time, and wind speeds exceeding $30 \mathrm{~km} / \mathrm{h}(18.5 \mathrm{mph})$ are rare.

\subsubsection{Precipitation}

Precipitation varies both within and between years, as shown in Fig. 1.9. The 40-year annual average precipitation (water equivalent) is $1.37 \mathrm{~m}$ (53.75 in.), including about $0.26 \mathrm{~m}$ (10.4 in.) of snowfall, with monthly precipitation peaking in 

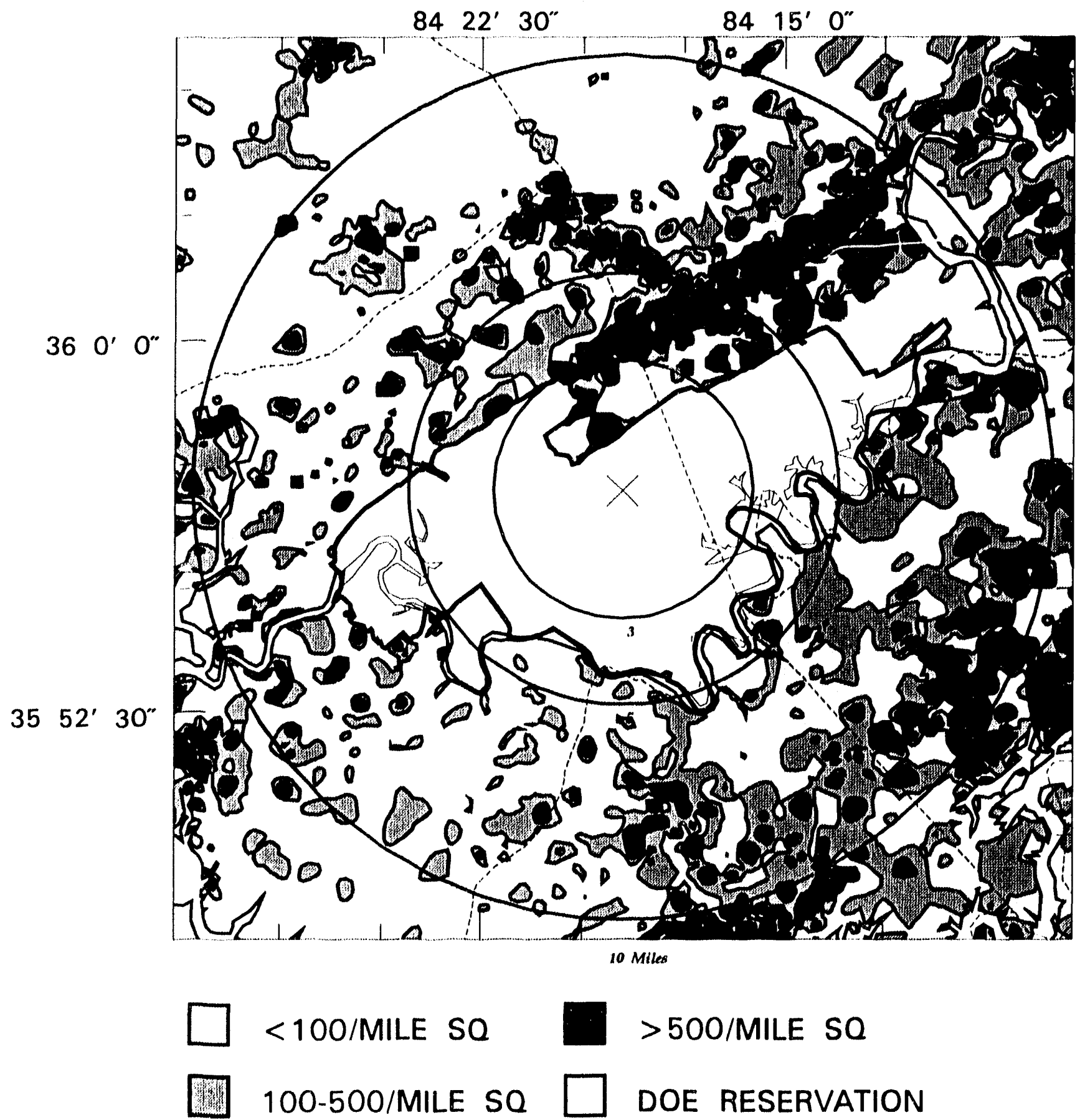

Fig. 1.7. Projected 1992 population densities within $16 \mathrm{~km}$ (10 miles) of the center of the Oak Ridge Reservation, based on 1990 census data (U.S. Department of Commerce 1991). Dashed lines indicate county boundaries.

January and ficbruary. Precipitation in 1992 was 44.2 in., about $9.5 \mathrm{in}$. below the annual average.

Winter storms are generally of low intensity and long duration. Another peak in rainfall occurs in July when shorl, heavy rains associated wilh thunderstorms are common. Typically in October, slow-moving high-pressure cells suppress rain and, whife remaining nearly stationary for many days, 
ORNL-DWG 93-10160

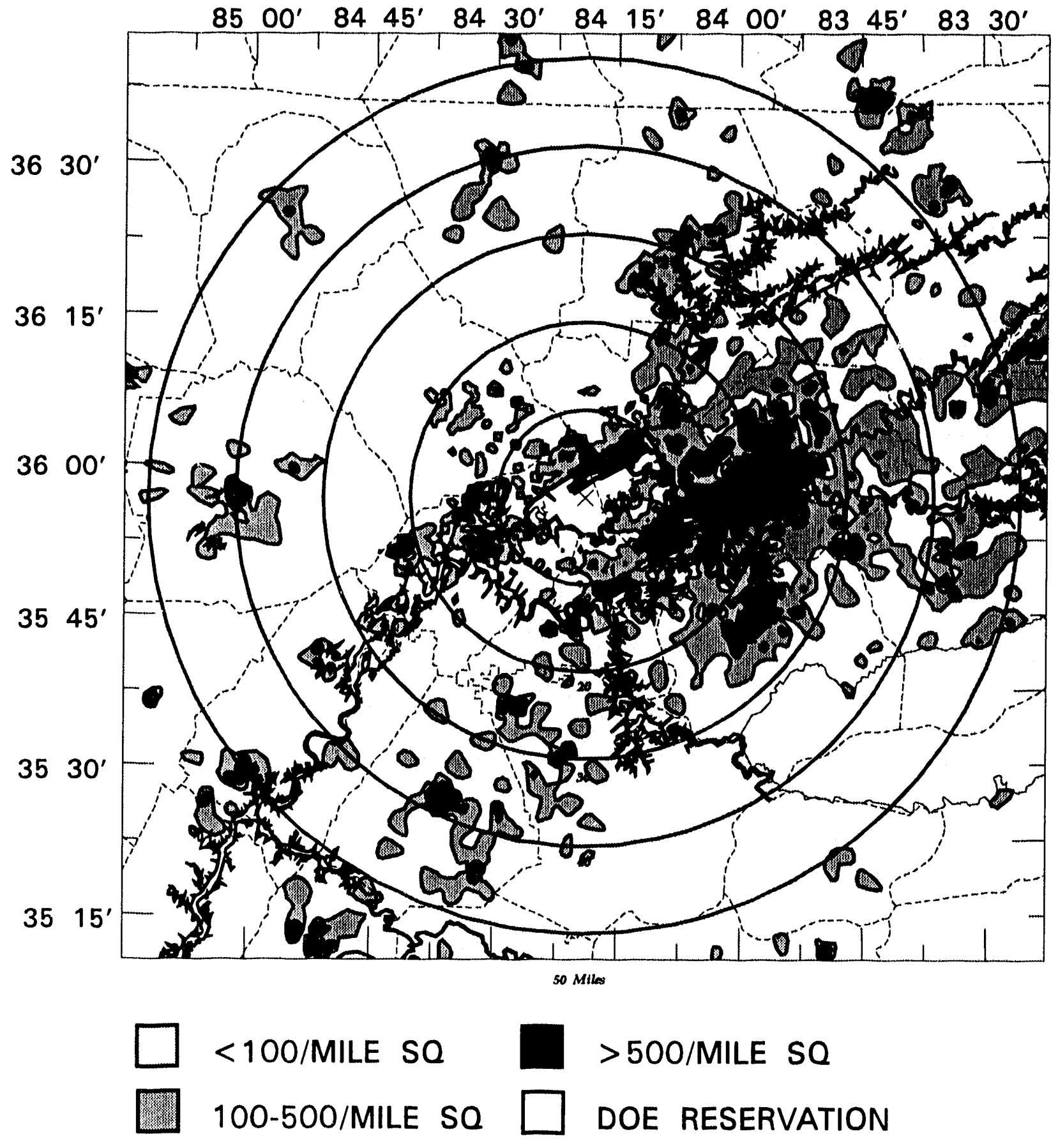

Fig. 1.8. Projected 1992 population densities within $80 \mathrm{~km}$ (50 miles) of the Oak Ridge Reservation, based on 1990 census data (U.S. Department of Commerce 1991). Dashed lines indicate county boundaries.

provide mild, clear, dry weather. Poor air dilution (and thus the primary air pollution episodes) occurs with the greatest frequency and severity during this period.

\subsubsection{Evapotranspiration}

Regionally, annual evapotranspiration has been estimated to range from 81 to $89 \mathrm{~cm}$ (32 to $35 \mathrm{ill}$.), or 


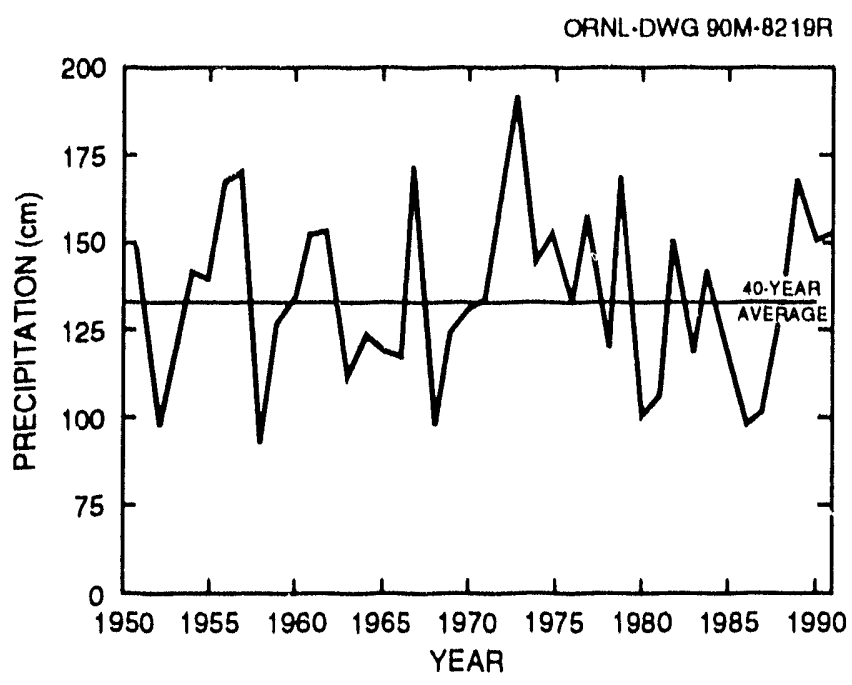

Fig. 1.9. Annual precipitation history of the Oak Ridge area.

60 to $65 \%$ of rainfall (Farnsworth et al. 1982). Evapotranspiration in the Oak Ridge area is 74 to $76 \mathrm{~cm}$ (29 to $30 \mathrm{in}$.), or 55 to $56 \%$ of annual precipitation (TVA 1972; Moore 1988; and Hatcher et al. 1989). Evapotranspiration is variable within any given year and is greatest in association with the growing season, which in the vicinity of the ORR averages 220 days, from April through September. During this period, evapotranspiration often exceeds the rate of precipitation, resulting in soil moisture deficits.

\subsection{Geology}

The ORR is located in the Tennessee section of the Valley and Ridge Province, which is part of the southern Appalachian fold and thrust belt (Fig. 1.10; see also Fig. 1.3 of Vol. 2). The area is characterized by a succession of northeast-trending thrust faults that structurally stack and replicate the Paleozoic rocks of this area (Fig. 1.11 and Fig. 1.12; see also Fig. 1.4 of Vol. 2). As a result of thrusting and subsequent differential erosion, a series of valleys and ridges have formed that parallel the thrust faults. In general, the more-resistant siltstone, sandstone, and dolomite units form the region's ridges; the less-resistant shales and shale-rich carbonates underlie its valleys.

\subsubsection{Stratigraphy}

Throughout the ORR, differential erosion and weathering has resulted in an overall geologic sequence where competent bedrock is overlain by a mantle of regolith (characterized by weathered. unconsolidated materials formed in-place through chemical and physical weathering of the underlying parent bedrock), which is overlain by a veneer of soils or alluvial sediments. In many of the operational areas on the ORR, the natural soil and regolith have been disturbed, removed, reworked, or replaced by fill materials.

The bedrock stratigraphy of the ORR, in ascending order, includes the Lower Cambrian Rome Formation, the Cambrian Conasauga Group, the Cambron-Ordovician Knox Group, and the Middle Ordovician Chickamauga Group. Younger Upper Ordovician to Mississipian rocks are exposed locally in the cores of two synclines north of the White Oak Mountain Thrust Fault (Fig. 1.11). Although minor carbonate beds are found through the Conasauga Group bedrock, the principal carbonate formations on the ORR are the upper Conasauga Group Maynardville Limestone, Chickamauga Group limestones, and the Knox Group. Other formations on the ORR are characterized by silty sandstones, siltstones, limey siltstones, and shales.

\subsubsection{Structural Framework}

The ORR is located in a foreland fold and thrust belt. As a result, its geology is strongly influenced by structural features at all scales, including regional thrust faults, local thrust, normal and tear faults, local folding of relatively weak bedrock units, and widespread fracture development. The large-scale fault features were formed during the PermianPennsylvanian age Alleghenian Orogeny and are not active structures.

Although fracture formation has occurred at various times ranging from the Ordovician period (from initial deposition and burial) to the present (as a result of unloading associated with erosion and unroofing processes), the Alleghenian Orogeny was probably the strongest influence on fracture development. 
ORNL.DWG 87M-18655R3

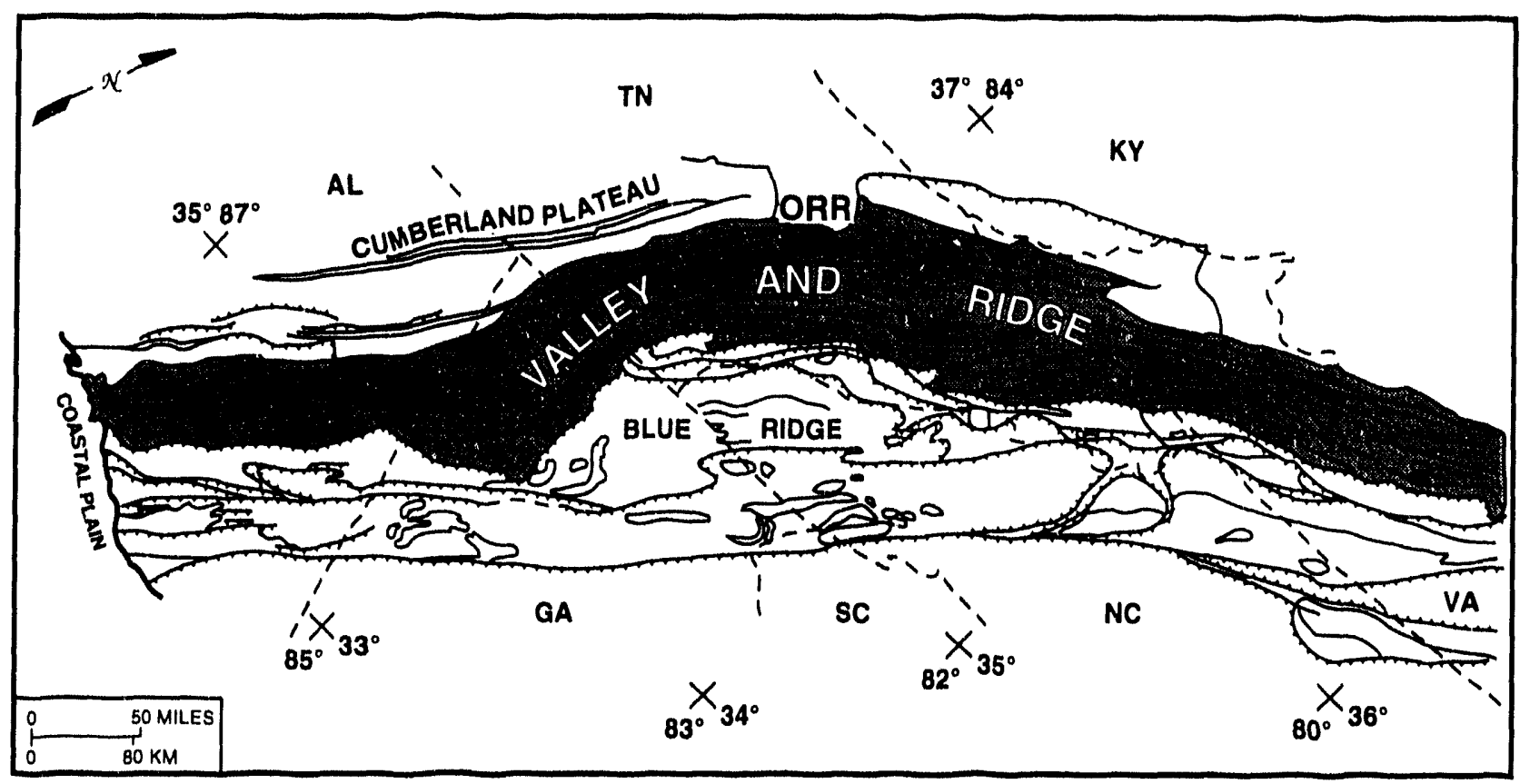

Fig. 1.10. Geology of the southern Appalachians.

ORNL.DWG 91M-8346BN

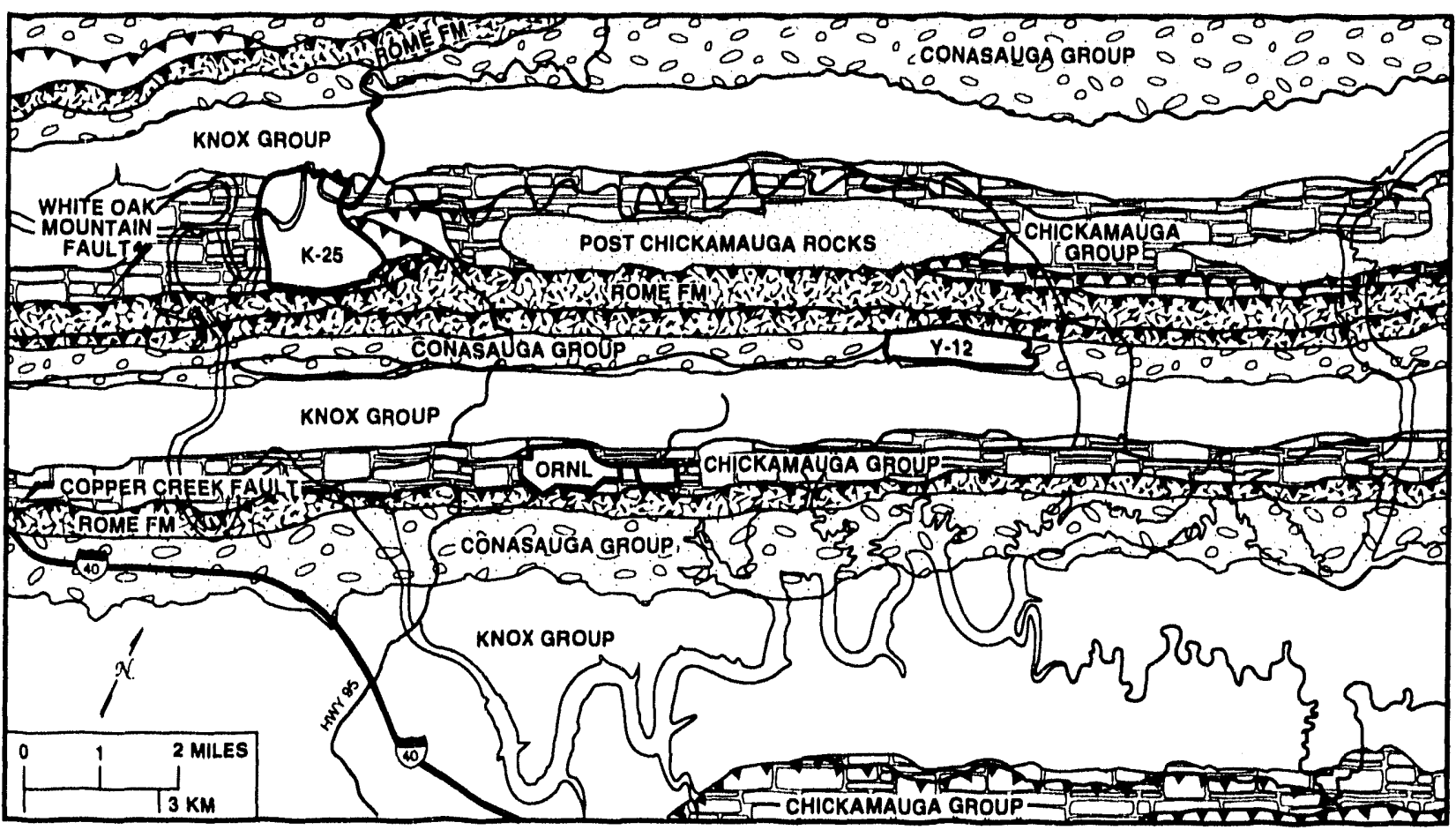

Fig. 1.11. Geologic map of the Oak Ridge Reservation. 
ORNL-DWG 85M-10908R

NW

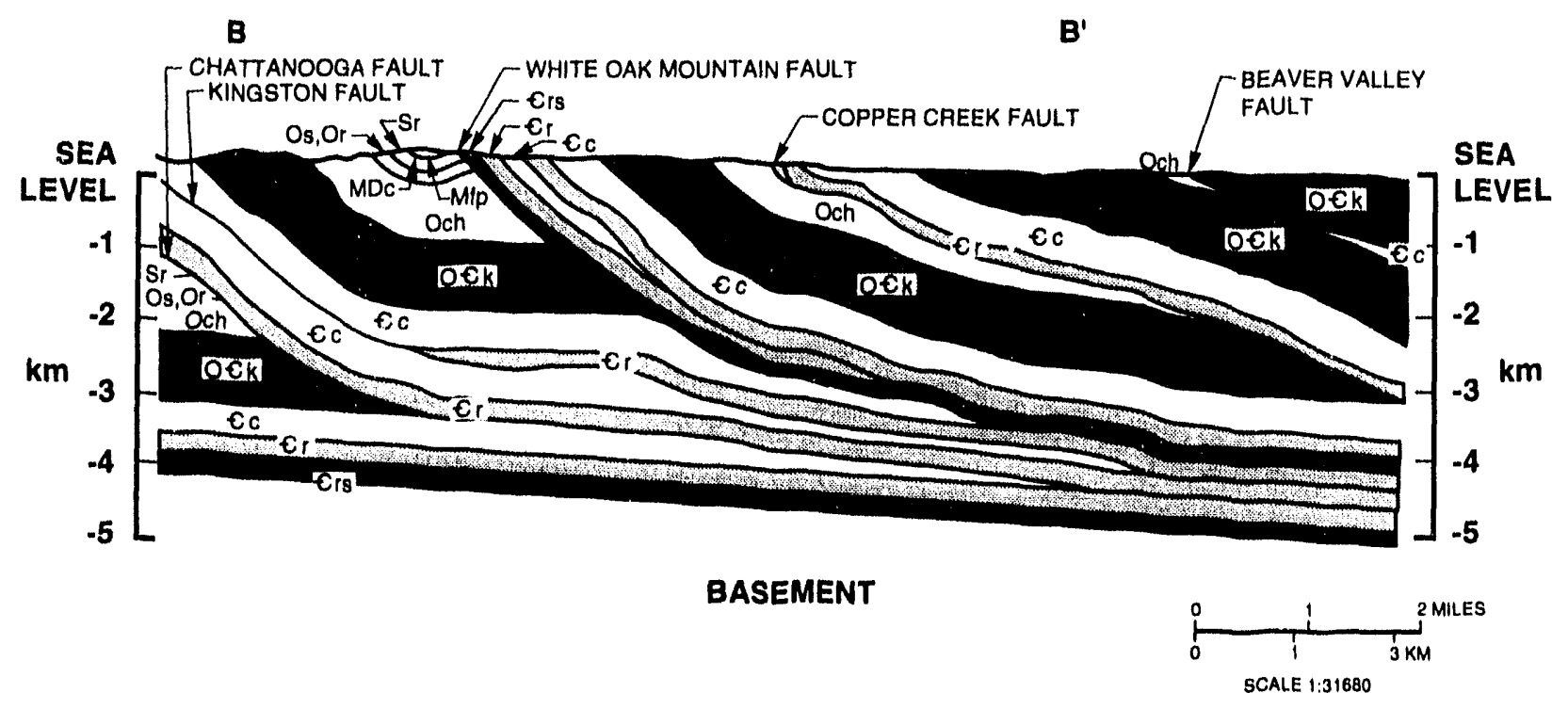

Fig. 1.12. Geologic cross section of the Oak Ridge Reservation.

Three principal fracture orientations are noted on the ORR based upon bedrock outcrop mapping (Fig. 1.13). One fracture set is parallel to strike of the bedrock, dipping parallel to bedding. The second fracture set is also parallel to formation strike, but perpendicular to bedding dip. The dip of this set also varies with bedding plane dip and thus is a function of depth, inclined near the surface where bedding planes dip more steeply and vertical at depths where the bedding plane dip flattens. A third fracture set is perpendicular to formation strike. At least these three, but as many as five distinct fracture orientations can be observed in a given borehole location. Furthermore, although weathered, these fractures are either maintained or in some cases enhanced in the regolith.

\subsection{Groundwater}

Groundwater is a potential source of potable water as well as water for irrigation, industrial, and domestic uses. Ground water also may provide a pathway for transport of contaminants and is therefore a necessary element in monitoring programs at the ORR. This section provides an overview of groundwater hydrology on the ORR and a discussion of groundwater use. Further details are presented in Sect. 5.

\subsubsection{Groundwater Occurrence}

Groundwater on the ORR occurs as localized perched water; as transient, shallow, subsurface stormflow in the unsaturated zone; and as an uncontined water table aquifer in the saturated zone. The water table marks the top of the saturated zone and generally occurs at shallower depths along low-lying areas and surface water features and at greater depths in higher topographic positions. No major confining layers have been identified in which groundwater occurs as a continuum from the water table surface to depths in bedrock. Groundwater flow is controlled by fracture and/or solution cavity distribution and orientation. However, because of topographic relief and a decrease in fracture density with depth, groundwater flow is restricted primarily to shallow depths, and groundwater discharges primarily to nearby surface water features within the ORR. At greater depths, the groundwater on the ORR 


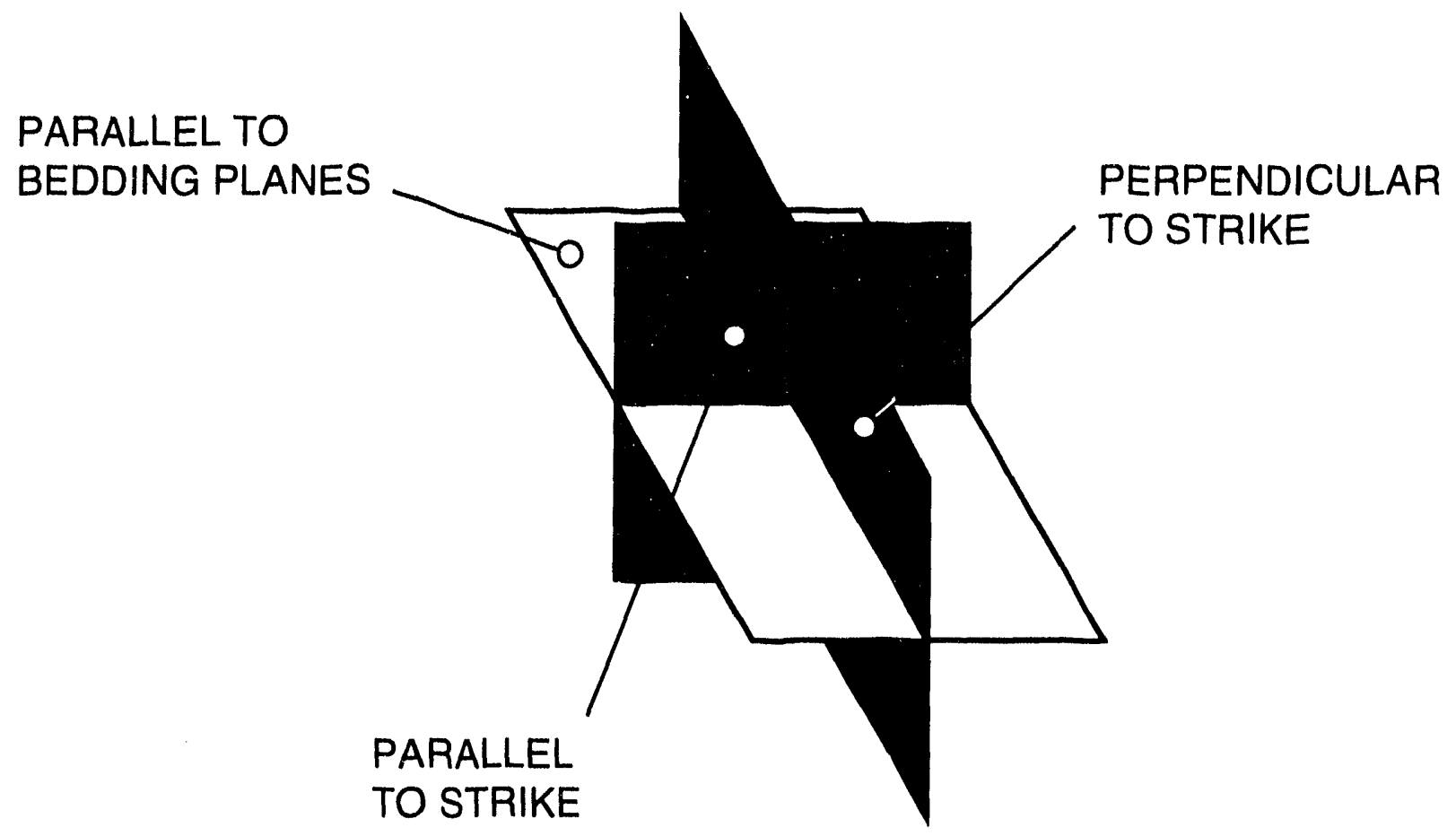

Fig. 1.13. Three sets of fracture orientations.

transitions from fresh water to a nonpotable, highly saline brine.

\subsubsection{Groundwater Use}

Groundwater in the Tennessee Valley region provides water to many rural residences, industries, and public water supply systems, and it sustains baseflow in streams and rivers. Most farm use is for livestock watering and washing. More than 50\% of the population of Tennessee relies on groundwater for drinking water supplies (Henry et al. 1986).

Twenty-one percent of the water used in the state (exclusive of hydroelectric use) is groundwater. Of this amount, about $55 \%$ is withdrawn for public and domestic supplies, $42 \%$ for self-supplied industrial use, and $1 \%$ for irrigation (Bradley and Hollyday 1985; Henry et al. 1986).

The major portion of the industrial and drinking water supply in the Oak Ridge area is provided from surface water sources. However, single-family wells are common in adjacent rural areas not serviced by public water supply systems. A comparison of census data showing the number of households $(175,701)$ versus the number of households with public utility connections $(165,145)$ in the five counties surrounding the ORR (Anderson, Knox, Loudon, Morgan, and Roane counties) shows that $94 \%$ of the population relies on public utility sources for the potable water supply (Wellcourt 1986; Smith 1986). However, a total of 20,624 drilled, dug, or other residential wells (representing about $11 \%$ of the total households) are documented within the five-county area, suggesting groundwater is used for other than potable water supplies in the area. Other than those adjacent to the city of Oak Ridge, most of the residential wells in the immediate area are located south of the Clinch River. Groundwater is not used as a source of potable water on the ORR. Well yields are typically low (less than $2 \mathrm{gpm}$ ) on the ORR and are generally insufficient to serve as a reliable potable water supply. Exceptions to this are wells in the principal carbonate aquifer units, in which well yields may exceed $1000 \mathrm{gpm}$.

\subsection{Surface Water}

Potable water for most nonrural areas comes from surface water. This section includes discussions 


\section{Environmental Report Vol. 1, Oak Ridge}

of stream classification, surface water hydrology, watershed characteristics, and water use.

\subsubsection{Stream Classification}

The Clinch River is the major surface water body that receives discharges from the Oak Ridge installations. Four TVA reservoirs influence the flow and/or water levels of the lower Clinch: Norris and Meıton Hill on the Clinch River and Watts Bar and Fort Loudon on the Tennessee River.

The area on and around the ORR has no streams classified as wild and scenic rivers. Most of the streams on the ORR are classified for fish and aquatic life, irrigation, and livestock watering and wildlife. Table 1.3 in Vol. 2 gives the state of Tennessee stream use classifications for the Clinch River and its tributaries on or near the ORR. Classifications are based on water quality, designated uses, and resident aquatic biota. For each designated water-use classification, specific water quality criteria are applied. These criteria form the basis for each facility's National Pollution Discharge Elimination System (NPDES) permit as mardated by the Clean Water Act.

\subsubsection{Surface Water Hydrology}

Figure 1.14 shows the locations of surface water bodies in the vicinity of the ORR. The ORR is bounded on the south and west by a $63-\mathrm{km}$ stretch of the Jlinch River. Melton Hill Dam is located at Clinch River kilometer (CRK) 37.2 (river mile 23), forming the Melton Hill Reservoir. Several major embayments bound the ORR; the largest is the Bearden Creek embayment, which has a surface area of about 48 ha (120 acres). Other embayments include Walker Branch, McCoy Branch, and Scarboro Creek.

Both groundwater and surface water are drained from the ORR by a network of small tributaries of the Clinch River, as shown in Fig. 1.14. At Kingston, the Clinch River flows into the Tennessee River, which is the seventh largest river in the United States.

Water levels of the Clinch River in the vicinity of the ORR are regulated by TVA.

Each of the three DOE facilities is located in a different subbasin of the Clinch River. Drainage from the Y-12 Plant enters both Bear Creek and East Fork Poplar Creek; ORNL drains into White Oak Creek and several tributaries of the Clinch River; and the K-25 Site drains predominantly into Poplar Creek and Mitchell Branch.

ORNL-DWG 87M-8246AR2

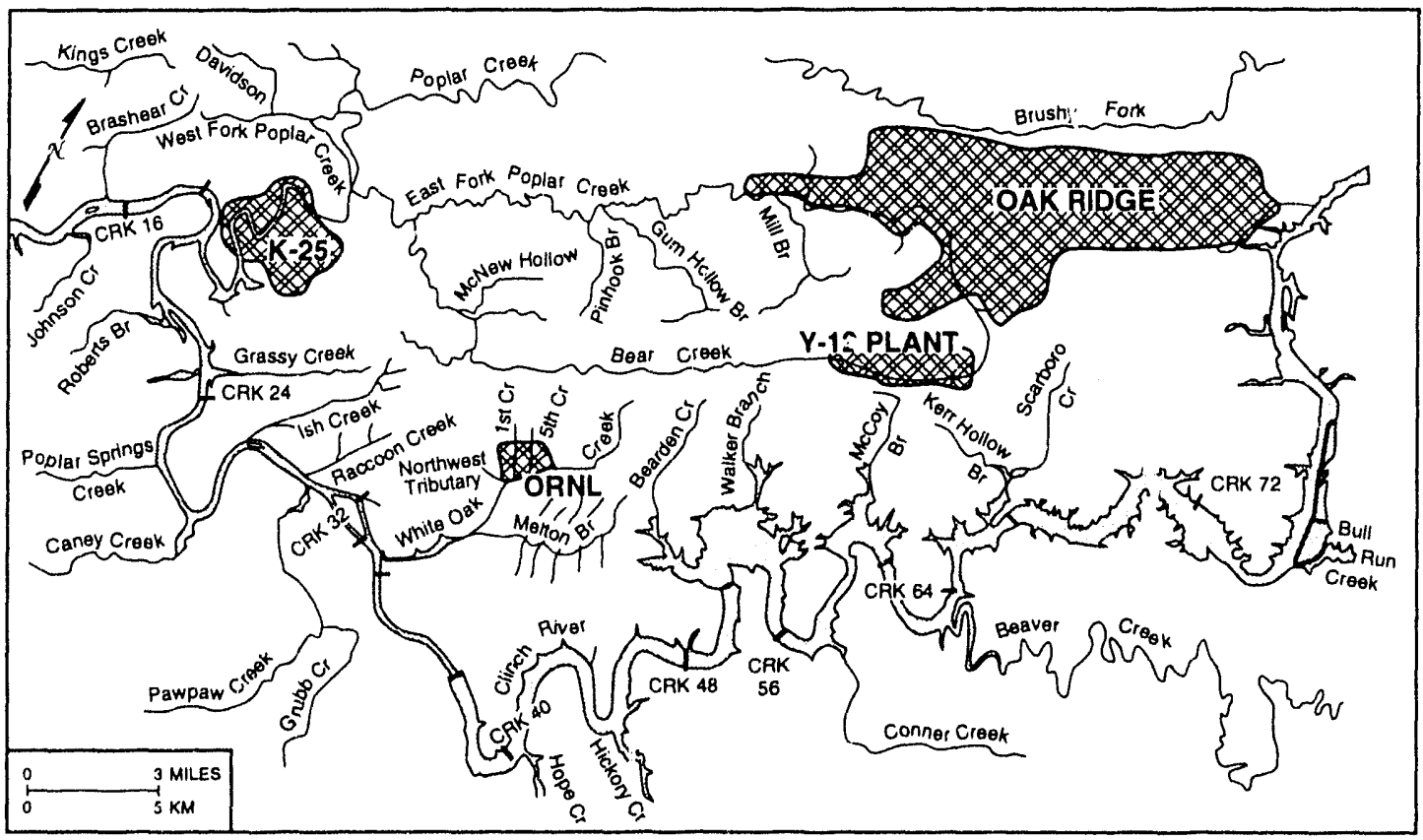

Fig. 1.14. Location map of Oak Ridge Reservation tributaries.

\section{1-16 Reservation Description and Setting}




\section{Environmental Report Vol. 1, Oak Ridge}

\subsubsection{Watershed Characteristics}

The Clinch River has its headwaters near Tazewell, Virginia, and empties into the Tennessee River near Kingston, at Tennessee River kilometer (TRK) 914 (river mile 568). The Clinch watershed comprises about $11 \%$ of the Tennessee River watershed. Four dams operated by TVA control the flow and levels of the Clinch River. Norris Dam, constructed in 1936, is about $50 \mathrm{~km}$ ( 31 miles) upstream from the ORR. Melton Hill Dam, completed in 1963, controls the flow of the river near the ORR. Its primary function is power generation (Boyle et al. 1982). Fort Loudon Dam, on the Tennessee River upstream of the confluence with the Clinch River, controls water flow into Watts Bar Lake, which is formed by Watts Bar Dam. Watts Bar Dam is located on the Tennessee River downstream of the Clinch.

\subsubsection{Water Use}

Five public water supplies are located downstream within $80 \mathrm{~km}$ ( 50 miles) of the ORR. The $\mathrm{K}-25$ Site water treatment plant is located $4 \mathrm{~km}$ (2.5 miles) above the mouth of Poplar Creek and supplies drinking water to about 4000 employees. The Kingston ater treatment plant serves about 6841 persons, and its intake is located at TRK 914.7 (river mile 568.4 ), about $0.6 \mathrm{~km}$ ( 0.37 miles) above the confluence of the Clinch and Tennessee rivers and $34.1 \mathrm{~km}$ ( 21.1 miles) below the mouth of Poplar Creek. The Rockwood treatment plant serves about 7387 persons and is located downstream of Kingston on the King Creek embayment near Thief Neck Island. The remaining water plants are on Chickamauga Reservoir. The Dayton plant serves 9605 persons and is located at TRK 810.6 (river mile 503.7). The Soddy-Daisy/Falling Water Utility District plant draws water from the Soddy Creek embayment of Chickamauga Reservoir, about $8 \mathrm{~km}$ $(5$ miles) from the reservoir proper.

\subsection{Environmental Monitoring}

Published environmental summary reports for the ORR have been issued for each year since 1971. The current environmental program is designed primarily to meet various regulatory requirements and DOE directives and to rovide a continuity of data on environ iental media at unregulated locations. The federal legislative framework that establishes standards and regulates environmental releases consists mainly of the following: Clean Air Act (CAA); The Clean Water Act (CWA); Safe Drinking Water Act (SDWA); Comprehensive Environmental Response, Compensation, and Liability Act (CERCLA), also known as "Superfund"; RCRA; TSCA; SARA; the Atomic Energy Act; and Federal Insecticide, Fungicide, and Rodenticide Act (FIFRA). Administrative bodies principally concerned with implementation and enforcement on the federal level are the U.S. Environmental Protection Agency (EPA) and DOE and, on the state level, the Tennessee Department of Environment and Conservation (TDEC).

Environmental monitoring consists of two major activities: effluent monitoring and environmental surveillance. Effluent monitoring is the collection and analysis of samples, or measurements, of liquid and gaseous effluents. Environmental surveillance is the collection and analysis of samples or direct measurements, of air, water, soil, foodstuff, biota, and other media from DOE sites and their environs. Environmental monitoring is performed by each site to characterize and quantify contaminants, assess radiation exposures of members of the public, demonstrate compliance with applicable standards and permit requirements, and assess the effects (if any) on the local environment.

The samples are analyzed for various radioactive, physical, and chemical parameters. In some cases, such as liquid effluent outfalls, the discharge permit may require the analysis of more than 60 different parameters.

Annual summaries are presented in the following sections for each of the media sampled. The summary tables generally give the number of samples collected and the maximum, minimum, average, and standard error of the mean values of parameters for which determinations were made. This value is based on multiple samples collected throughout the year. It includes the random uncertainty over time and space associated with sampling, analysis, and the intrinsic variability of meria. The random unsertainty is a statement of precision (or imprecision). a measure of the reproducibility or scatter in a sc: of successive measurements, and an indication of the stability of the average value for a parameter. When differences in the magnitudes of the observations are small, the 


\section{Environmental Report Vol. 1, Oak Ridge}

standard error is small, and the precision is said to be high; when the differences are large, the standard error is large, and the precision is low. Random uncertainties are assessed and propagated by statistical methods (see Appendix $C$ for calculations). Average values have been compared where possible with applicable guidelines, criteria, or standards as a means of evaluating the impact of effluent releases or environmental concentrations.

In some of the tables, radionuclide cui. :entrations are compared with derived concentration guides (DCGs) as published in DOE Order 5400.5. DOE Order 5400.5 defines a DCG as the concentration of a radionuclide in air or water from which, under conditions of continuous exposure by one exposure pathway (i.e., drinking water, inhaling air, or submersion) for 1 year, a "reference person" would receive an effective dose equivalent of $100 \mathrm{mrem}$. A reference person is a hypothetical human who is assumed to inhale $8400 \mathrm{~m}^{3}(296,700$ $\mathrm{ft}^{3}$ ) of air in a year and to drink $730 \mathrm{~L}$ (190 gal) of water in a year. When there are multiple DCGs for a given isotope, the most restrictive value is used. When total radioactive strontium is measured, it is compared to the DCG for ${ }^{90} \mathrm{Sr}$, which is the most restrictive value. When the percentage of the $D C G$ is less than 0.010 , the percent is reported as less than 0.01 .

The current convention for radioactivity data at the instrument detection limit is to treat it in the same manner as instrument responses above the detection limit. The instrument background is subtracted from the actual instrument signal, and the result is reported. Because of the intrinsic uncertainties associated with making radiation measurements, it is possible to subtract a background value from a sample result and get a negative number. The advantage to this approach is that no bias is introduced in calculating statistical summaries of the data.

On September 16, 1992, a new document entitled Environmental Monitoring Plan for the Oak Ridge Reservation (EMP) was approved by the manager, DOE-ORO. This plan was prepared to document the rationale and design criteria for the effluent monitoring and environmental surveillance programs that are conducted to meet established standards, environmental laws, and DOE orders. Authorization and requirement for the EMP are contained in DOE Order 5400.1 entitled "General Environmental Protection Program." The EMP outlines the goals of environmental monitoring for the ORR and its facilities and includes some activities that are not presently conducted. In general, the programs described in the EMP represent an increase in surveillance activities over past practices. The TDEC Department of Energy Oversight Division reviewed a draft of the EMP. Its comments were considered, and most were incorporated into the final EMP. Work is now under way to modify the present environmental monitoring program to reflect the changes described in the EMP. Many of these changes will be depicted in the annual site environmental report in CY 1993.

\subsection{References}

Boyle, J. W., et al. 1982. Environmental Analysis of the Operation of the Oak Ridge National Laboratory ( $X$-10 Site), ORNL 5870, Oak Ridge, Tenn., pp. 52-54.

Bradley, M. W., and E. F. Hollyday. 1985.

"Tennessee Groundwater Resources," in National

Water Summary-Ground-Water Resources, USGS Water-Supply Pap. 2275, Washington, D.C.

Davis, E. C., et al. 1984. Site Characterization Techniques Used at a Low-Levei Waste Shallow Land Burial Field Demonstration Facility, ORNL/TM-9146, Oak Ridge, Tenn.

Farnsworth, R. K., E. S. Thompson, and E. L. Peck. 1982. Evaporation Atlas for the Continguous 48 United States. NOAA Technical Report NWS 33, National Weather Service, Office of Hydrology, Washington, D.C.

Hatcher, R. D., et al. 1989. Field Guide and Perspective on the Geology' and Hydrology of the Oak Ridge Reservation, Oak Ridge National Laboratory/Univ. of Tennessee. Oak Ridge, Tenn. Henry, C. D., et al. 1986. Factors Influencing the Development of a Groundwater Protection Strategy by the State of Tennessee. ORNL/Sub/85-97368/1, Oak Ridge, Tenn. Moore, G. K. 1988. Concepts of Groundwater Occurrence and Flow Near Oak Ridge National Laboratory, Tennessee. ORNL/TM-1368, Oak Ridge, Tenn. 


\section{Environmental Report Vol. 1, Oak Ridge}

Smith, O., Tennessee Water Well Association, Nashville, Tenn., letter to T. Cothron, Tennessee Department of Health and Environment, Division of Groundwater Protection, Nashville, Tenn., July 1986.

Tennessee Valley Authority (TVA). 1972. Upper Bear Creek Experimental Project: A Continuous Daily-Streamflow Model, Research Paper No. 8, Division of Water Control Planning, Knoxville, Tenn.

U.S. Department of Commerce, Bureau of the Census. April 1991.1990 Census of Population and Housing Public Law 94-17I Data, Washington, D.C.

Webster, D. A., and M. W. Bradley. 1988. Hydrology of the Melton Valley Radioactive Waste Burial Grounds at Oak Ridge National Laboratory, U.S. Geological Survey Open File Report 87-686, Knoxville, Tenn.

Wellcourt Data Base, National Groundwater Information Center, Groundwater Publishing Company, Dublin, Ohio, January 1986. 


\section{POTENTIAL RADIATION AND CHEMICAL DOSE TO THE PUBLIC}

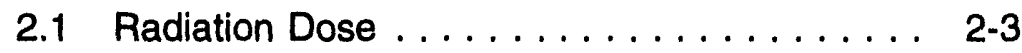

2.1.1 Terminology . . . . . . . . . . 2-3

2.1.2 Methods of Evaluation .......... 2-4

2.1.3 Doses to Aquatic Biota . . . . . . . . . 2-11

2.1.4 Current-Year Summary . . . . . . . 2 2-12

2.1.5 Five-Year Trends ........... 2-13

2.1.6 PC intial Contributions from Off-Site Sources .............. 2-13

2.1.7 Findings ........... 2-13

2.2 Chemical Dose . . . . . . . . . . . . . . 2-14

2.2.1 Terminology . . . . . . . . . . 2-14

2.2.2 Methods of Evaluation . . . . . . . . 2-14

2.2.3 Current-Year Summary . . . . . . . . 2-21

2.3 References . . . . . . . . . . . . . . . . . . . . 2-21 


\section{Potential Radiation and Chemical Dose to the Public}

\subsection{Radiation Dose}

Small quantities of radionuclides were released to the environment from operations at the ORR facilities during 1992. Those releases are quantified and characterized in Sects. 3-7. This section presents estimates of the potential consequences of the releases and describes the methods used to make the estimates.

\subsubsection{Terminology}

Most consequences to humans associated with radionuclide releases to the environment are caused by interactions between radiations emitted by the radionuclides and human tissue. These interactions involve the transfer of energy from the radiations to tissue, a process that may Jamage the tissue. The radiations may come from radionuclides located outside the body (in or on environmental media or objects) or from radionuclides deposited inside the body (via inhalation, ingestion, and, in a few cases, absorption through the skin). Exposures to radiations from nuclides located outside the body are called external exposures; exposures to radiations from nuclides deposited inside the body are called internal exposures. This distinction is important because external exposures occur only when a person is near or in a radionuclide-containing medium; internal exposures continue as long as the radionuclides remain inside the person. Also, external exposures may result in uniform irradiation of the entire body and all its components; internal exposures usually result in nonuniform irradiation of the body. (Whe: taken into the body, most radionuclides deposit preferentially in specific organs or tissue and thus do not irradiate the body uniformly.)

A number of specialized units have been defined for characterizing exposures to ionizing radiation. Because the damage associated with such exposures results primarily from the deposition of radiant energy in tissue, the units are defined in terms of the amount of incident radiant energy absorbed by tissue and the biological consequences of the absorbed energy. Some of these units are defined as follows.

Absorbed dose. A physical quantity that defines the amount of incident radiant energy absorbed per unit mass of an irradiated material; its unit of measure is the rad. The absorbed dose depends on the type and energy of the incident radiation and on the atomic number of the absorbing material.

Dose equivalent. A quantity that expresses the biological effectiveness of an absorbed dose in a specified human organ or tissue; its unit of measure is the rem. The dose equivalent is numerically equal to the absorbed dose multiplied by modifying factors that relate the absorbed dose to biological effects. In this report, as in many others, the term "dose equivalent" often is shortened to "dose."

Effective dose equivalent (EDE). A riskequivalent dose equivalent that can be used to estimate health-effects risks to exposed persons. It is a weighted sum of dose equivalents to specified organs. The weighting factors and specific organs are described in Publications 26 and 30 of the International Commission on Radiological Protection (1977 and 1978).

Committed (effective) dose equivalent. The total (effective) dose equivalent that will be received over a specified time ( 50 years in this document) because 
of exposures to, and intakes of, radionuclides during the year of interest.

Collective effective dose equivalent. The sum of effective dose equivalents to all individuals in an e:posed population.

Dose conversion factor ( $D C F)$. The dose equivalent received from exposure to a unit quantity of a radionuclide via specific exposure pathway. Two types of DCFs exist. One type gives the committed dose equivalent (rem) resulting from intake (via inhalation and ingestion) of a unit activity $(1.0 \mu \mathrm{Ci})$ of a radionuclide. The second gives the dose equivalent rate (mrem/year) per unit activity $(1.0 \mu \mathrm{Ci})$ of a radionuclide in a unit $\left(\mathrm{cm}^{3}\right.$ or $\left.\mathrm{cm}^{2}\right)$ of an environmental compartment (air volume or ground surface). All DCFs used in this report were approved by DOE or by EPA (DOE 1988a; DOE 1988b; Beres 1990; EPA 1988).

\subsubsection{Methods of Evaluation}

\subsubsection{Airborne Radionuclides}

Characterization of the radiological
consequences of radionuclides released to the
atmosphere from ORR operations during 1992 was
accomplished by calculating, for each plant and for
the entire ORR, EDEs to the maximally exposed
off-site individual and to the entire population
residing within $80 \mathrm{~km}$ ( 50 miles) of the plants. The
dose calculations were made using the CAP-88
package of computer codes (Beres 1990), which was
developed under sponsorship of the EPA for use in
demonstrating compliance with the National
Fmission Standards for Hazardous Air Pollutants
(NESHAP)-Radionuclides, 40 CFR 61 , Subpart H.
This package contains the most recent, approved
version of the AIRDOS-EPA and DARTAB computer
codes and the ALLRAD88 radionuclide data file. The
AIRDOS-EPA computer code implements a
steady-state, Gaussian plume, atmospheric dispersion
model to calculate concentrations of radionuclides in
the air and on the ground. It also uses Regulatory
Guide 1.109 (NRC 1977) food chain models to
calculate radionuclide concentrations in foodstuffs
(vegetables, meat, and milk) and subsequent intakes
by humans. The concentrations and human intakes
are used by the EPA's latest version of the DARTAB
computer code to calculate EDEs from radionuclides

Characterization of the radiological consequences of radionuclides released to the atmosphere from ORR operations during 1992 was accomplished by calculating, for each plant and for the entire ORR, EDEs to the maximally exposed off-site individual and to the entire population residing within $80 \mathrm{~km}$ ( 50 miles) of the plants. The dose calculations were made using the CAP- 88 package of computer codes (Beres 1990), which was demonstrating compliance with the National Fmission Standards for Hazardous Air Pollutants (NESHAP)-Radionuclides, 40 CFR 61, Subpart $\mathrm{H}$. This package contains the most recent, approved version of the AIRDOS-EPA and DARTAB computer codes and the ALLRAD88 radionuclide data file. The AIRDOS-EPA computer code implements a steady-state, Gaussian plume, atmospheric dispersion model to calculate concentrations of radionuclides in the air and on the ground. It also uses Regulatory Guide 1.109 (NRC 1977) food chain models to calculate radionuclide concentrations in foodstuffs (vegetables, meat, and milk) and subsequent intakes by humans. The concentrations and human intakes computer code to calculate EDEs from radionuclides released to the atmosphere. The dose calculations use the DCFs contained in the ALLRAD88 data file (Beres 1990).

Three types of radionuclide releases were reported in the ORR NESHAP report for 1992: monitored, sampled, and calculated. Monitored releases are quantified using data from continuous sampling systems. Monitored sources during 1992 included the combined monitored stacks at the Y-12 Plant; stacks associated with Buildings 2026, $3020,3039,7830,7877$, and 7911 at ORNL; and the TSCA incinerator (K-1435) stack at the K-25 Site. Sampled releases are calculated using measured radionuclide contents of various media (e.g., grab samples of room air concentrations and sections of filters) and measured flow rates through the sampled media. Sampled sources during 1992 include room exhausts at the Y-12 Plant; stacks associated with Buildings 2000, 3018, 3074, 3544, 7025, and 7512 at ORNL; and discharge points associated with the $\mathrm{K}-1015$ laundry, the $\mathrm{K}-1417$ pond waste management facility, and the K-1420 valve disassembly shop at the K-25 Site. Calculated releases are determined from source (e.g., hot cell, hood, and storage area) inventories using EPA approved emission factors. Calculated releases are largely hypothetical releases. Their purpose is to determine whether source monitoring or sampling should be used; however, we have been instructed to reflect in this report all doses reported in the NESHAP report. Therefore, radiation doses associated with the hypothetical calculated releases are added to the doses associated with the monitored al d sampled releases.

Radionuclide releases were modeled for 12 monitored and sampled release points at ORNL, for 4 release points at the K-25 Site, and for one combined release point at the $\mathrm{Y}-12$ Plant. Table 2.1 lists the source parameter values used in the calculations. The radionuclide release inventory for the monitored and sampled sources is detailed in Sect. 3 and summarized in Tables 2.1, 2.2, and 2.3 of Vol. 2, which are lists of the nuclides released, the quantity (Ci) released from each release point, and the particle size, expressed as activity median aerodynamic diameter (AMAD), and solubility classes used in the calculations.

Meteorological data used in the calculations consisted of joint frequency (STAR) distributions of wind direction, wind speed class, and atmospheric

\section{2-4 Potential Radiation and Chemical Dose to the Public}




\section{Environmental Report Vol. 1, Oak Ridge}

Table 2.1. Release point parameters and receptor locations used in the dose calculations

\begin{tabular}{|c|c|c|c|c|c|c|c|}
\hline \multirow{2}{*}{$\begin{array}{l}\text { Source } \\
\text { name }\end{array}$} & \multirow[t]{2}{*}{ Type } & \multirow{2}{*}{$\begin{array}{c}\text { Release } \\
\text { height } \\
(\mathrm{m})\end{array}$} & \multirow{2}{*}{$\begin{array}{c}\text { Inner } \\
\text { diameter } \\
\text { (m) }\end{array}$} & \multirow{2}{*}{$\begin{array}{c}\text { Gas exit } \\
\text { velocity } \\
(\mathrm{m} / \mathrm{s})\end{array}$} & \multirow{2}{*}{$\begin{array}{c}\text { Gas exit } \\
\text { temperature } \\
\left({ }^{\circ} \mathrm{C}\right)\end{array}$} & \multicolumn{2}{|c|}{$\begin{array}{l}\text { Distance }(\mathrm{m}) \text { and direction to } \\
\text { maximally exposed individual }\end{array}$} \\
\hline & & & & & & Plant & ORR \\
\hline \multicolumn{8}{|c|}{$Y \cdot 12$ Plant } \\
\hline All & Point & 20 & 0 & 0 & Ambient & 1080 NNE & $1080 \mathrm{NNE}$ \\
\hline \multicolumn{8}{|c|}{ ORNL } \\
\hline 2026 & Point & 22.9 & 1.07 & 11.1 & Ambient & 4970 SW & $9300 \mathrm{NE}$ \\
\hline 3020 & Point & 61.0 & 1.52 & 9.6 & Ambient & 4970 SW & $9300 \mathrm{NE}$ \\
\hline 3039 & Point & 76.2 & 2.44 & 11.4 & Ambient & $4970 \mathrm{SW}$ & $9300 \mathrm{NE}$ \\
\hline 7025 & Point & 4.0 & 0.31 & 12.9 & Ambient & $6910 \mathrm{SW}$ & $7550 \mathrm{NNE}$ \\
\hline 7512 & Point & 30.5 & 0.91 & 8.2 & Ambient & 5160 WSW & 9640 NNE \\
\hline 7911 & Point & 76.2 & 1.52 & 12.2 & Ambient & 5160 WSW & 9640 NNE \\
\hline 7830 & Point & 4.6 & 0.22 & 8.3 & Ambient & 3860 WSW & 10990 NNE \\
\hline 7877 & Point & 13.9 & 0.51 & 9.3 & Ambient & 3860 WSW & $10990 \mathrm{NNE}$ \\
\hline 2000 & Point & 15.2 & 0.66 & 9.5 & Ambient & $4970 \mathrm{SW}$ & $9300 \mathrm{NE}$ \\
\hline 3018 & Point & 61.0 & 4.11 & 0.2 & Ambient & 4970 SW & $9300 \mathrm{NE}$ \\
\hline 3074 & Point & 4.0 & 0.26 & 10.2 & Ambient & 4970 SW & $9300 \mathrm{NE}$ \\
\hline 3544 & Point & 9.5 & 0.27 & 18.5 & Ambient & 4970 SW & $9300 \mathrm{NE}$ \\
\hline \multicolumn{8}{|c|}{ K-25 Site } \\
\hline K- 1435 & Point & 30.5 & 1.37 & 5.8 & 79.6 & 5180 WSW & 13000 ENE \\
\hline$K-1420$ & Point & 18.3 & 0.60 & 50.7 & Ambient & 4820 WSW & 13250 ENE \\
\hline $\mathrm{K}-1015$ & Point & 3.7 & 0 & 0 & Ambient & $4580 \mathrm{~W}$ & 14000 ENE \\
\hline K- 1417 & Point & 10.7 & 1.83 & 22.7 & Ambient & 5060 WSW & 13200 ENE \\
\hline
\end{tabular}

stability category. These were derived from data collected during 1992 at the $100-\mathrm{m}$ height on meteorological tower 2 (MT2) for stacks 2000, 2026, $3018,3020,3039,3074,3544$, and 7025 , and the 30-m height on MT4 for stacks 7512, 7830, 7877, and 7911 at ORNL; at the $60-\mathrm{m}$ height on MT1 for the K-25 Site; and at the 60-m height on MT6 for the Y-12 Plant. (See Fig. 2.1.) Rainfall on the Oak Ridge Reservation during 1992 was $112 \mathrm{~cm}$, the average air temperature was $20^{\circ} \mathrm{C}$, and the average mixing layer height was $1000 \mathrm{~m}$.

The dose calculations assumed that each person remained at home (actually outside the house) and unprotected during the entire year and obtained food according to the rural pattern defined in the NESHAP background documents (EPA 1989). This pattern specifies that $70 \%$ of the vegetables and produce, $44.2 \%$ of the meat, and $39.9 \%$ of the milk consumed by each person are produced in the local area (e.g., a home garden). The remaining portion of each food is assumed to be produced within $80 \mathrm{~km}$ (50 miles) of the ORR. For collective EDE estimates, production of beef, milk, and crops within $80 \mathrm{~km}$ of the ORR was calculated using the state-specific production rates provided with CAP- 88 .

Calculated EDEs due to radionuclides emitted to the atmosphere from the ORR are listed in Tables 2.2 (maximum individual) and 2.3 (collective). The EDE received by the hypothetical, maximally exposed individual for the ORR was calculated to be approximately $1.4 \mathrm{mrem}(0.014 \mathrm{mSv})$, which is below the 10-mrem $(0.10-\mathrm{mSv})$ NESHAP standard and well below the approximately $300 \mathrm{mrem}(3 \mathrm{mSv})$ that the average individual receives from natural sources of radiation. About $0.2 \mathrm{mrem}$ of the $1.4 \mathrm{mrem}$ is due to calculated emissions. This individual is located approximately $9300 \mathrm{~m}$ (5.8 miles) NE of the 3039 stack at ORNL, approximately $13,000 \mathrm{~m}$ ( 8.1 miles) ENE of the K-1435 (TSCA Incinerator) stack at the K-25 Site, and approximately $1080 \mathrm{~m}$ ( 0.7 miles) NNE of the Y-12 Plant release point. The calculated collective EDE to the entire population within 


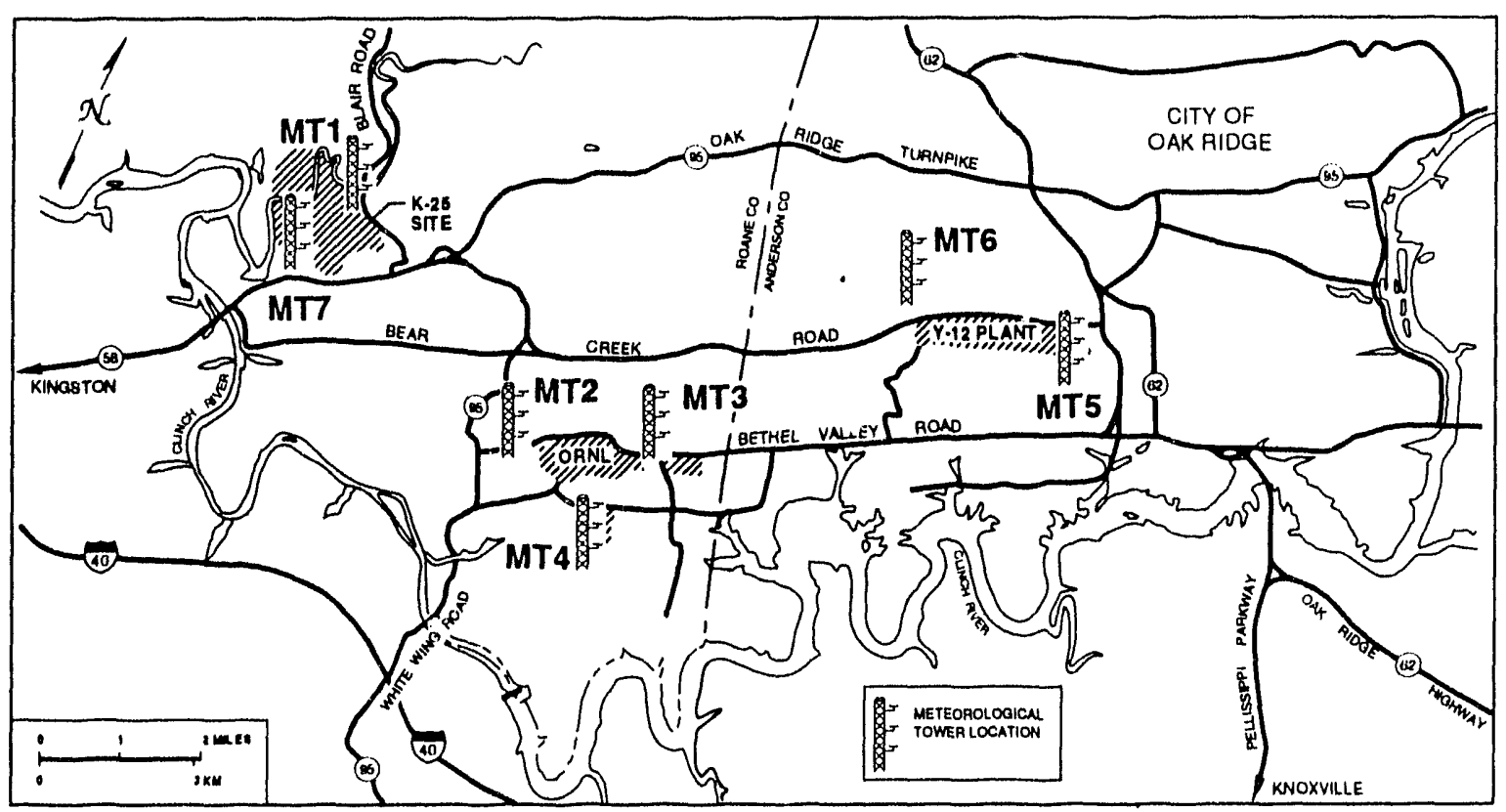

Fig. 2.1. ORR meteorological monitoring network.

$80 \mathrm{~km}$ (50 miles) of the URR (approximately 879,546 persons) was approximately 43 person-rem ( 0.43 person-Sv), which is $0.02 \%$ of the 264,000 person-rem that this population could have received from natural sources of radiation. About 5 of the 43 person rem are due to calculated emissions.

The EDE received by the hypothetical, maximally exposed individual for the $\mathrm{Y}-12$ Plant was calculated to be $1.2 \mathrm{mrem}(0.012 \mathrm{mSv})$. This individual is located approximately $1080 \mathrm{~m}$ (0.7 miles) NNE of the Y-12 Plant release point. Essentially, all (98\%) of this dose is due to ingestion and inhalation of uranium, primarily ${ }^{234} \mathrm{U},{ }^{235} \mathrm{U}$, and ${ }^{238} \mathrm{U}$. The contribution of $Y-12$ Plant emissions to the 50-year committed collective EDE to the population residing within $80 \mathrm{~km}$ of the ORR was calculated to be approximately 11 person-rem ( 0.11 person-Sv), which is $25 \%$ of the collective EDE for the ORR.

The EDE received by the hypothetical, maximally exposed individual for ORNL was calculated to be $0.1 \mathrm{mrem}(0.001 \mathrm{mSv})$. This individual is located $4970 \mathrm{~m}$ ( $3.1 \mathrm{miles}) \mathrm{SW}$ of the 3039 stack and $5160 \mathrm{~m}$ ( 3.2 miles) WSW of the 7911 stack. Approximately $28 \%$ of this dose is due to ingestion and inhalation of ${ }^{3} \mathrm{H}$; about $32 \%$ is due to immersion in noble gases. The contribution of ORNL emissions to the collective EDE to the population residing within $80 \mathrm{~km}$ of the ORR was calculated to be 3 person-rem ( 0.03 person-Sv), which is $7 \%$ of the collective EDE for the ORR.

The EDE received by the hypothetical, maximally exposed individual for the K-25 Site was calculated to be $0.6 \mathrm{mrem}(0.006 \mathrm{mSv}$;. This individual is located approximately $5180 \mathrm{~m}$ (3.2 miles) WSW of the K-1435 (TSCA Incinerator) stack. Approximately $89 \%$ of this dose is due to ingestion and inhalation of uranium, approximately $7 \%$ is due to thorium, and approximately $3 \%$ is due to plutonium. The contribution of K-25 Site emissions to the collective EDE to the population residing within $80 \mathrm{~km}$ of the ORR was calculated to be 29 person-rem $(0.29$ person-Sv), which is $67 \%$ of the collective EDE for the ORR.

The apparent contradiction between maximum individual doses (higher for the Y-12 Plant and lower for the K-25 Site) and collective EDEs (lower for the $\mathrm{Y}-12$ Plant and higher for the $\mathrm{K}-25$ Site) is due to the locations of the maximally exposed individuals. At the Y-12 Plant, the individual is $1080 \mathrm{~m}$ from the stack. At the K-25 Site, the individual is $5180 \mathrm{~m}$ from the major stack. If the individual at the K-25 Site were located $1080 \mathrm{~m}$ from the stack, that individual's

\section{2-6 Potential Radiation and Chemical Dose to the Public}


Table 2.2. Calculated radiation doses to maximally exposed off-site individuals from airborne releases during 1992

\begin{tabular}{lcc}
\hline \multirow{2}{*}{ Plant } & \multicolumn{2}{c}{ Total effective dose equivalents (mrem) } \\
\cline { 2 - 3 } & Plant max & ORR max \\
\hline ORNL $^{a}$ & 0.1 & 0.05 \\
K-25 Site $^{b}$ & 0.6 & 0.2 \\
Y-12 Plant $^{c}$ & 1.2 & 1.2 \\
Entire ORR $^{d}$ & NA & 1.4 \\
\hline
\end{tabular}

${ }^{a}$ The maximally exposed individual is located $4970 \mathrm{~m}$ ( 3.1 miles) SW of the 3039 stack and $5160 \mathrm{~m}$ (3.2 miles) WSW of the 7911 stack.

${ }^{b}$ The maximally exposed individual is located $5180 \mathrm{~m}$ (3.2 miles) WSW of the K-1435 stack.

'The maximally exposed individual is located $1080 \mathrm{~m}(0.7 \mathrm{miles}) \mathrm{NNE}$ of the $\mathrm{Y}-12$ Plant release point.

${ }^{d}$ The maximally exposed individual for the entire ORR is the Y-12 Plant maximally exposed individual.

Table 2.3. Calculated collective effective dose equivalents due to airborne releases during 1992

\begin{tabular}{lc}
\hline Plant & $\begin{array}{c}\text { Effective } \\
\text { dose equivalents } \\
\text { (person-rem) }\end{array}$ \\
\hline ORNL & 3 \\
K-25 Site & 29 \\
Y-12 Plant & 11 \\
ORR & 43 \\
\hline
\end{tabular}

${ }^{a}$ The collective effective dose equivalents to the 879,546 persons residing within $80 \mathrm{~km}$ (50 miles) of the ORR.

EDE would be higher than that of the EDE for the individual at the $\mathrm{Y}-12$ Plant.

The reasonableness of the calculated radiation doses can be inferred by examining the radiation doses that could be received from measured air concentrations of radionuclides at the ORR perimeter air monitoring stations (PAMs) and the remote air monitoring stations (RAMs). (Station locations are given in Figs. 3.18 and 3.19; measured air concentrations are given in Table 3.12 of Vol. 2.) Individuals assumed to reside at the PAMs could receive EDEs between 0.1 and $0.4 \mathrm{mrem} / \mathrm{year}$; these doses include contributions from naturally occurring (background) radionuclides, from radionuclides released from the ORR, and radionuclides released from any other sources. An indication of doses due to sources not on the ORR can be obtained from the EDEs calculated at the two RAMs, which were about $0.1 \mathrm{mrem} /$ year.
Of particular interest is a comparison of doses calculated using measured air concentrations at PAMs located near the maximally exposed individuals for each plant and doses calculated to those individuals using CAP- 88 and measured emissions. PAM 46 is located near the maximally exposed individual for the Y-12 Plant and the entire ORR. The EDE calculated at PAM 46 was $0.4 \mathrm{mrem} / \mathrm{year}$, which is smaller than the $1.4 \mathrm{mrem} /$ year to the maximally exposed individual modeled by the CAP- 88 code. PAM 39 is located near the maximally exposed individual for ORNL. The EDE calculated at PAM 39 was $0.1 \mathrm{mrem} / \mathrm{year}$, which is about the same as that to the maximally exposed individual based on CAP- 88 code modeling. PAM 35 is located near the maximally exposed individual for the K-25 Site. The EDE calculated at PAM 35 was $0.3 \mathrm{mrem} / \mathrm{year}$, which is smaller than 


\section{Environmental Report Vol. 1, Oak Ridge}

the $0.6 \mathrm{mrem} / \mathrm{year}$ modeled value to the maximally exposed individual.

\subsubsection{Waterborne Radionuclides}

Radionuclides discharged to surface waters from the ORR enter the Tennessee River system via the Clinch River and various feeder streams. Discharges from the Y-12 Plant enter the Clinch River via Bear Creek and East Fork Poplar Creek, both of which enter Poplar Creek prior to entering the Clinch River. Discharges from ORNL enter the Clinch River via White Oak Creek and White Oak Lake. Discharges from the K-25 Site enter the Clinch River via Poplar Creek. These discharges are characterized in Sect. 4. This section discusses the potential radiological impacts of these discharges to persons who drink water, eat fish, swim, boat, and use the shoreline at various locations along the Clinch and Tennessee rivers.

Two methods were used to determine potential EDEs due to radionuclides in water and fish. Method I used measured, annual-average, nuclide concentrations in water samples taken at the K-25 Site (Gallaher) water plant and at the Kingston municipal water plant (Table 4.58, Vol. 2) to calculate a maximum individual EDE from drinking water; it also used fish samples from CRK 84, 80, 32, and 16 and from PCK 2.2 (Tables 6.2-6.7, Vol. 2) to calculate EDEs from eating fish. The measured concentrations may include both naturally occurring radionuclides (background) and radionuclides emitted from the sites.

Method 2 used measured stream flows and measured radionuclide discharges from the plants (Tables 2.4-2.6, Vol. 2) to calculate annual-average nuclide concentrations in water. Concentrations in fish were calculated using the LADTAP XL methodology (Hamby 1991), which employs fish to water bioaccumulation factors to calculate radionuclide concentrations in fish from concentrations in water. Results of the maximally exposed individual EDE calculations are summarized in Table 2.4.

The concentrations of radionuclides in drinking water that produced the highest calculated individual EDE occurred at the Gallaher water plant. A person who drank $730 \mathrm{~L}$ of this water during 1992 could have received an EDE of approximately $0.2 \mathrm{mrem}$
(0.002 $\mathrm{mSv})$, using Method 1 calculations, or approximately $0.1 \mathrm{mrem}(0.001 \mathrm{mSv})$ using Method 2.

The concentrations of radionuclides in fish that produced the highest calculated individual EDE occurred in Poplar Creek, near the K-25 Site. A person who ate $21 \mathrm{~kg}$ of fish (a full year's supply) from this location during 1992 could have received an EDE of approximately $0.2 \mathrm{mrem}(0.002 \mathrm{mSv})$ using Method 1, or approximately $0.4 \mathrm{mrem}$ $(0.004 \mathrm{mSv})$ using Method 2. The major difference between the two estimates is that Method 2 predicts concenirations of radium, thorium, ${ }^{237} \mathrm{~Np}$, and plutonium based on measured values of these radionuclides in effluents at the discharge points. These radionuclides were not reported in the measured samples.

Maximum individual EDEs due to swimming and boating during 1992 were low, less than $0.0012 \mathrm{mrem}$ $(0.000012 \mathrm{mSv})$ and $0.0006 \mathrm{mrem}(0.000006 \mathrm{mSv})$, respectively, in Poplar Creek. The maximum EDE due to shoreline activities also was low. Method 2 calculations give a maximum individual EDE of 0.02 mrem $(0.0002 \mathrm{mSv})$ along the Clinch River shoreline.

When all pathways are considered, the maximally exposed individual to waterborne radionuclide discharges could have received an EDE of approximately $0.4 \mathrm{mrem}(0.004 \mathrm{mSv})$ by Method 2 or 0.3 mrem by Method 1. The collective EDE to the 50-mile population was calculated to be approximately 1 person-rem $(0.01$ person-Sv). These are small percentages of individual and collective doses attributable to natural background radiation, $1 \%$ and $0.0004 \%$, respectively.

\subsubsection{Radionuclides in Other Environmental Media}

\subsection{Milk}

The CAP- 88 computer codes calculate radiation doses due to ingestion of meat, milk, and vegetables that contain radionuclides released to the atmosphere. The doses are included in the dose calculations for airborne radionuclides (Sect. 2.1.2).

One environmental pathway for ingestion, drinking milk, also was evaluated using radionuclide concentrations measured in milk collected from

\section{2-8 Potential Radiation and Chemical Dose to the Public}


Table 2.4. Maximum individual EDEs (mrem) for water pathways

\begin{tabular}{|c|c|c|c|c|c|}
\hline Location & $\begin{array}{l}\text { Upper CR } \\
(\text { Gallaher } \\
\left({ }^{a}\right)\end{array}$ & $\begin{array}{l}\text { Poplar } \\
\text { Creek }\end{array}$ & $\begin{array}{l}\text { Kingston area } \\
\left(\text { Kingston }^{c}\right)\end{array}$ & $\begin{array}{l}\text { Watts Bar } \\
\left(\text { Rockwood }^{d}\right)\end{array}$ & $\begin{array}{l}\text { Chickamauga } \\
\text { (Daytone, } \\
\text { Soddy-Daisy/ } \\
\text { Falling Waterf) }\end{array}$ \\
\hline \multicolumn{6}{|c|}{ Method I (using measured concentrations) } \\
\hline $\begin{array}{l}\text { Drinking waterg } \\
\text { Eating fish }\end{array}$ & $\begin{array}{l}0.22 \\
0.042\end{array}$ & $\begin{array}{c}h \\
0.21\end{array}$ & $\begin{array}{c}0.054 \\
h\end{array}$ & $\begin{array}{l}h \\
h\end{array}$ & $\begin{array}{l}h \\
h\end{array}$ \\
\hline \multicolumn{6}{|c|}{ Method 2 (using discharge and river flow data) } \\
\hline Drinking waterg & 0.11 & $0^{j}$ & 0.022 & 0.020 & 0.015 \\
\hline Eating fish ${ }^{i}$ & 0.24 & 0.41 & 0.038 & 0.035 & 0.027 \\
\hline Swimmingk & 0.00011 & 0.0012 & 0.000017 & 0.000016 & 0.000012 \\
\hline Boatingl & 0.000036 & 0.00058 & 0.0000058 & 0.0000053 & 0.0000041 \\
\hline Shoreline $^{m}$ & 0.016 & 0.0028 & 0.0025 & 0.0023 & 0.0017 \\
\hline Total & 0.37 & 0.42 & 0.063 & 0.057 & 0.044 \\
\hline
\end{tabular}

${ }^{a} \mathrm{CR}=$ Clinch River.

${ }^{b}$ DOE drinking water plant serving 4000 persons.

'Public water supply serving 6841 persons.

¿Public water supply serving 7387 persons.

ePublic water supply serving 9605 persons.

fPublic water supply serving 9742 persons.

8 Drinks 730 L/year of water.

${ }^{h}$ No samples taken.

${ }^{i}$ Eats $21 \mathrm{~kg} /$ year of fish from location.

jPoplar Creek is not a source of drinking water.

${ }^{k}$ Swims $27 \mathrm{~h} /$ year.

'Boats $63 \mathrm{~h}$ /year.

mUses shoreline $67 \mathrm{~h} /$ year.

nearby farms. An individual was assumed to drink $310 \mathrm{~L}$ of milk containing the highest measured quantity of total strontium (taken to be ${ }^{90} \mathrm{Sr}$ ) (see Sect. 6.1 and Table 6.1 in Vol, 2). Such an individual could have received an EDE of about $0.2 \mathrm{mrem}$ $(0.002 \mathrm{mSv})$. No ${ }^{131} \mathrm{I}$ was detected in milk samples during 1992.

\subsection{Crops}

Another environmental pathway for ingestion that was evaluated separately is eating vegetables. In 1992, vegetables were sampled from three off-site gardens. Hay grown on the ORR also was sampled.

Three types of vegetables were sampled: tomatoes, greens, and turnips. These vegetable types were chosen as representative of fruit-bearing, leafy, and root vegetables. Tables 6.3 and 6.4 , Vol. 1, list the radionuclides concentrations found in the vegetable and hay samples. Most of the radioactivity in these samples is due to ${ }^{40} \mathrm{~K}$, a naturally occurring radionuclide that is not emitted from operations on the ORR. About $97 \%$ of activity in vegetables from near the K-25 Site, 99\% from near ORNL, and 99\% from near the Y-12 Plant was due to ${ }^{40} \mathrm{~K}$.

To calculate potential EDEs from eating the sampled vejetables, it was assumed that a person ate $13 \mathrm{~kg}$ of leafy vegetables and $55 \mathrm{~kg}$ of the other vegetable types during the year. These ingestion rates represent about $70 \%$ of an individual's total annual consumption of vegetables (Beres 1990; NRC 1977). Based on these assumptions, the maximum individual's EDE from eating all three vegetable types could have been approximately 9 mrem (about 3 mrem from fruit-bearing vegetables, about $2 \mathrm{mrem}$ from leafy vegetables, and about 5 mrem from root vegetables). If the ${ }^{40} \mathrm{~K}$ contribution to this dose, about $79 \%$ or $7 \mathrm{mrem}$, is excluded, the maximum individual EDE could have been about $2 \mathrm{mrem}$. This $2 \mathrm{mrem}$ 


\section{Environmental Report Vol. 1, Oak Ridge}

was due to the other radionuclides detected in the vegetables, ${ }^{228} \mathrm{Th},{ }^{23(1)} \mathrm{Th},{ }^{214} \mathrm{U},{ }^{235} \mathrm{U},{ }^{238} \mathrm{U}$, and total strontium. Although these nuclides are measured in emissions from the ORR, they occur naturally in soil and fertilizers that are spread on gardens. Thus, it is believed that most of the radioactivity found in the vegetables, and the associated radiation doses, are not attributable to ORR operations.

A sample of hay grown on the ORR contained ${ }^{7} \mathrm{Be}$ and ${ }^{40} \mathrm{~K}$ (see Table 6.4, Vol. 1). Essentially all of the dose to man, from eating beef and drinking milk from cattle that eat hay, was due to the naturally occurring ${ }^{41} \mathrm{~K}$. The EDE from drinking milk and eating beef containing ${ }^{7} \mathrm{Be}$ (also naturally occurring) was 0.0004 mrem.

\subsection{Deer}

As described in Sect. 6.3, several deer hunts were held on the ORR during 1992. A total of 520 deer were killed, of which 12 were confiscated because their radionuclide content exceeded the release standard. The remaining 508 deer had an average field-dressed weight of about $36 \mathrm{~kg}$ (79 lb). Assuming $55 \%$ of the dressed weight is edible, the average deer would yield about $20 \mathrm{~kg}$ (44 lb) of meat. Therefore, based on the average weight, the total harvest of edible meat was about $10,012 \mathrm{~kg}$ $(22,073 \mathrm{lb})$.

All deer were surveyed at the Tennessee Wildlife Resources Agency inspection station to determine the ${ }^{137} \mathrm{C}$ s content in tissue and total strontium in bone. Tissue samples from randomly selected deer were collected for laboratory analysis for ${ }^{60} \mathrm{Co}$ and total strontium. However, the analytical results for ${ }^{60} \mathrm{Co}$ and strontium were not analyzed in time for inclusion in this report. Therefore, 1991 results are used to estimate radiation doses due to ${ }^{60} \mathrm{Co}$ and strontium. The average ${ }^{137} \mathrm{Cs}$ concentration in the 508 released deer was $0.13 \mathrm{pCi} / \mathrm{g}$. Based on 1991 random sampling results, the average ${ }^{60} \mathrm{Co}$ concentration was 0.004 $\mathrm{pCi} / \mathrm{g}$, and the average total strontium concentration (assumed to be ${ }^{90} \mathrm{Sr}$ ) was $0.092 \mathrm{pCi} / \mathrm{g}$.

The collective EDE from eating all the harvested deer meat could have been about 0.2 person-renı (0.002 person-Sv). The EDE for an individual consuming one deer with average concentrations of ${ }^{137} \mathrm{Cs}$, ${ }^{61} \mathrm{Co}$, and total strontium $\left({ }^{91} \mathrm{Sr}\right)$ was estimated to be $0.4 \mathrm{mrem}$. To estimate the EDE to the maximumly exposed individual, it was assumed that this person consumed two deer that due to their radionuclide content and weight could give the highest individual EDE. The two deer that gave the highest dose estimates each contained approximately $1.4 \mathrm{pCi} / \mathrm{g}$ of ${ }^{137} \mathrm{Cs}$ and were assumed to contain the highest measured (1991) concentrations of ${ }^{60} \mathrm{Co}$ and ${ }^{90} \mathrm{Sr}$ in the random samples, namely $0.12 \mathrm{pCi} / \mathrm{g}$ of ${ }^{61} \mathrm{Co}$ and $0.25 \mathrm{pCi} / \mathrm{g}$ of ${ }^{91} \mathrm{Sr}$. In this unlikely event that one person consumed both of the highest-dose deer, that person could have received an EDE of about 4.5 mrem $(0.045 \mathrm{mSv})$. No information is available concerning background concentrations of radionuclides in the deer. At least some of the ${ }^{137} \mathrm{Cs}$ is due to deposition from past weapons tests.

\subsection{Waterfowl}

Waterfowl are known to use waters on the ORR, even though such use is actively discouraged in contaminated areas. Two species of waterfowl that are resident on or near the ORR are giant Canada geese and wood ducks. Some data have been collected on radionuclide concentrations in these fowl; however, the degree to which the collected data give a representative picture of such concentrations is unknown.

Fifteen geese were sampled for ${ }^{137} \mathrm{Cs}$. Of the 15 geese collected, only 4 had detectable levels of ${ }^{137} \mathrm{Cs}(<1 \mathrm{pCi} / \mathrm{g}$ fresh weight) in tissue. Two of the geese were from the K 25 Site, and two were from ORNL. In addition, two geese were collected from ORNL Pond 3524. One goose had a ${ }^{137} \mathrm{Cs}$ concentration of $0.97 \mathrm{pCi} / \mathrm{g}(-36 \mathrm{~Bq} / \mathrm{kg})$ in breast tissue; the other had $4.4 \mathrm{pCi} / \mathrm{g}(-163 \mathrm{~Bq} / \mathrm{kg})$.

The average male giant Canada goose weighs about $5.7 \mathrm{~kg}$ ( $1.25 \mathrm{lb})$, half of which is assumed to be edible. Thus a person eating the most contaminated goose could have received an EDE of about $0.6 \mathrm{mrem}$ $(0.006 \mathrm{mSv})$. A person eating the average goose could have received an EDE of about $0.06 \mathrm{mrem}$ $(0.0006 \mathrm{mSv})$. The collective EDE from eating 412 geese harvested in the middle Tennessee unit, which includes the ORR, during the 1991-1992 hunting season, assuming all were contaminated at the average level, could have been approximately 0.02 person-rem $(0.0002$ person-Sv). The goose hunting season lasted about 56 days. The daily bag limit is two geese.

\section{2-10 Potential Radiation and Chemical Dose to the Public}




\section{Environmental Report Vol. 1, Oak Ridge}

using factors such as a geometry roughness factor, sediment deposition transfer factor, and nuclide-specific ground-surface irradiation dose factors.

Table 2.7 in Vol. 2 is a list of average and maximum total doses rates to aquatic organisms from waterways at ORNL. These aquatic doses are based on water concentrations associated with nine different sampling locations: Melton Branch (Outfall X-13 and 2), White Oak Creek (Outfall X-14), White Oak Dam (Outfall X-15), First Creek, Fifth Creek, Raccoon Creek, Northwest Tributary, and at the 7500 Bridge. The results from these calculations indicate that absorbed dose rates to aquatic biota should not exceed $1 \mathrm{rad} /$ day. The highest doses rates, which were associated with maximum water concentrations of radionuclides in water, occurred at First Creek with 2.7E-3 rad/day (the same dose was estimated at White Oak Dam) to fish, 1.0E-3 rad/day to crustacea, and $7.2 \mathrm{E}-3 \mathrm{rad} /$ day to muskrats. Even with maximum radionuclide concentrations at these locations, the absorbed doses were significantly less than the limit of $1 \mathrm{rad} /$ day.

Table 2.8 in Vol. 2 is a list of average dose rates to aquatic organisms from waterways at the Y-12 Plant and K-25 Site. At Y-12, aquatic organism doses were estimated using radionuclide water concentrations obtained at Bear Creek (Outfall 304), East Fork Poplar Creek (Station 17), and Rogers Quarry (Outfall 302). The highest estimated average dose to fish was at East Fork Poplar Creek, 1.3E-3 rad/day. The highest average dose estimated for crustacea was $6.5 \mathrm{E}-4 \mathrm{rad} / \mathrm{day}$ at Bear Creek (Outfall 304). Doses to muskrats were not calculated because plant bioaccumulation factors for all radionuclides were not available. Similar analyses were conducted at $\mathrm{K}-25$. The waterways evaluated were Poplar Creek (at Outfalls 010 and 057) and in the holding pond that discharges into the Clinch River (Outfall 034). The highest estimated absorbed dose to fish was 5.1E-6 rad/day at Poplar Creek (Outfall 057). The highest dose rate for crustacea was at Poplar Creek (Outfall 010), 1.3E-4 rad/day (approximately the same dose was estimated at Outfall 057). The highest dose rate to muskrats was at Poplar Creek (Outfall 010), 1.0E-5 rad/day. Data were not available to estimate maximum doses to aquatic organisms. However, absorbed doses estimated from maximum radionuclide water concentrations determined at ORNL still resulted in doses far less than the $1 \mathrm{rad} /$ day limit. Based on these analyses at both the Y-12 Plant and the K-25 Site, absorbed doses to aquatic organisms should be much less than the DOE Order 5400.5 limit of $1 \mathrm{rad} / \mathrm{day}$.

\subsubsection{Current-Year Summary}

A summary of the maximum EDEs to individuals via several pathways of exposure is given in Table 2.5. It is unlikely (if not impossible) that any real person could have been irradiated by all of these sources and pathways for a period of one year. However, if the resident who received the highest EDE (1.4 mrem) from gaseous effluents, also drank

Table 2.5. Summary of estimated radiation dose squivalents to an adult during 1992 at locations of maximum exposure

\begin{tabular}{clc}
\hline Pathway & \multicolumn{1}{c}{ Location } & $\begin{array}{c}\text { Effective } \\
\text { (mrem) }\end{array}$ \\
\hline $\begin{array}{c}\text { Gaseous effluents } \\
\text { Inhalation plus direct } \\
\text { radiation from air, ground, }\end{array}$ & $\begin{array}{c}\text { Nearest resident to } \\
\text { Y-12 Plant }\end{array}$ & 1.2 \\
and food chains & ORNL & 0.1 \\
& K-25 Site & 0.6 \\
ORR & & 1.4 \\
Liquid effluents & Gallaher & 0.2 \\
Drinking water & Poplar Creek & 0.4 \\
Eating fish & Poplar Creek & 0.02 \\
Other activities & Clinch River shoreline & 2 \\
Direct radiation & Poplar Creek (K-25 Site) & 15 \\
\hline
\end{tabular}

\section{2-12 Potential Radiation and Chemical Dose to the Public}


water from the Gallaher plant $(0.2 \mathrm{mrem})$, ate fish from Poplar Creek ( $0.4 \mathrm{mrem})$, and fished the Clinch River near the cesium field ( $2 \mathrm{mrem})$, he or she could have received a total EDE of about $4 \mathrm{mrem}$ $(0.04 \mathrm{mSv})$, or about $1 \%$ of the annual dose (300 mrem) from background radiation. If the individual fished Poplar Creek (15 mrem), the maximum individual dose could have been about $17 \mathrm{mrem}(0.17 \mathrm{mSv}), 6 \%$ of the natural background dose.

DOE Order 5400.5 limits to no more than $100 \mathrm{mrem}(1 \mathrm{mSv})$ the effective dose equivalent that an individual may receive from all exposure pathways from all radionuclides released from the ORR during one year. As described above, the 1992 maximum EDE could have been 4 or $17 \mathrm{mrem}$ $(0.04$ or $0.17 \mathrm{mSv})$, or less than $17 \%$ of the DOE Order 5400.5 limit.

\subsubsection{Five-Year Trends}

Dose equivalents associated with selected exposure pathways for the years 1988-1992 are given in Table 2.6. The small variations in values over this 5 -year period likely are not statistically significant. The dose estimates for direct irradiation along the Clinch River have been corrected for background.

\subsubsection{Potential Contributions from Off-Site Sources}

Three off-site facilities were identified as potential contributors to radiation exposure of the public around the ORR. Airborne emissions from these facilities (based on information supplied by the facilities), when combined with emissions from the ORR, are not expected to cause any individual to receive an EDE in excess of EPA or DOE limits. No information was obtained about waterborne releases, if any, from these facilities.

A waste processing facility located on Bear Creek Road reported a maximum individual dose of 0.03 mrem due to airborne emissions. A depleted uranium processing facility located on Illinois Avenue reported a maximum emission of $0.050 \mathrm{~kg}$ $(0.11 \mathrm{lb})$ of depleted uranium. A dose estimate was not reported, but comparison with Y-12 Plant emissions of enriched and depleted uranium $(17.8 \mathrm{~kg})$ indicates that the dose should be at least 300 times lower than the 1 mrem maximum attributable to the Y-12 Plant. A decontamination facility located on Flint Road in Oak Ridge reported a maximum individual EDE of about $7.4 \mathrm{mrem}$ at their nearest house. The EDE at the ORR maximum location was calculated to be about $0.02 \mathrm{mrem}$.

\subsubsection{Findings}

The maximally exposed off-site individual could have received a 50-year committed EDE of approximately $1.4 \mathrm{mrem}$ due to airborne effluents from the ORR. This dose is within the limit specified in the Clean Air Act for DOE facilities. The estimated collective committed EDE to the approximately $8.8 \times 10^{5}$ persons living within $80 \mathrm{~km}$ (50 miles) of the ORR was approximately 43 person-rem for 1992 airborne emissions. This represents about $0.02 \%$ of the $2.6 \times 10^{5}$ person-rem that the surrounding population would receive from all sources of natural radiation.

Table 2.6. Five-year trends in committed effective dose equivalent for selected pathways

\begin{tabular}{|c|c|c|c|c|c|}
\hline \multirow{2}{*}{ Pathway } & \multicolumn{5}{|c|}{ Effective dose equivalent (mrem) } \\
\hline & 1988 & 1989 & 1990 & 1991 & 1992 \\
\hline All air & 0.7 & 1 & 2 & 2 & 1.4 \\
\hline Fish consumption & 0.2 & 0.2 & 0.3 & 0.3 & 0.4 \\
\hline Drinking water (Kingston) & 0.1 & $<0.3$ & 0.04 & 0.1 & 0.05 \\
\hline Direct radiation (Clinch River) & $2^{a}$ & $2^{a}$ & $2^{a}$ & $2^{a}$ & $2^{a}$ \\
\hline Direct radiation (Poplar Creek) & & & & $15^{a}$ & $15^{a}$ \\
\hline
\end{tabular}

"These values have been corrected by removing the contribution of natural background radiation. 


\section{Environmental Report Vol. 1, Oak Ridge}

\subsection{Chemical Dose}

Varying amounts of chemicals were released to the environment from operations at ORR facilities during 1992. These releases are characterized and quantified in Sect. 4. This section estimates potential human exposure to these chemicals, and the exposures are compared to acceptable levels of exposure as defined by federal standards and regulations.

Chemicals enter the body by several pathways, including inhalation of air and dust, ingestion of food and water, and absorption through the skin. Engineering calculations indicate that no sources on the ORR require monitoring to demonstrate compliance with NESHAP regulations; thus, monitoring and analysis are not required. Potential exposure through dermal contact is considered to be unlikely for members of the general public because the sites are restricted areas.

The environmental monitoring data on surface water and fish allow an analysis of the ingestion pathway via drinking water and consumption of fish.

\subsubsection{Terminology}

The following terms are pertinent to the understanding of exposure.

Acceptable Daily Intake (ADI). Intake of a chemical, measured in $\mathrm{mg} /$ day, that is not anticipated to result in an adverse health effect over a lifetime of exposure. ADIs are calculated from several different federal standards and regulations.

Calculated Daily Intake (CDI). Intake of a chemical, expressed in $\mathrm{mg} /$ day. Adults are assumed to drink $2 \mathrm{~L}$ of water per day.

Slope Factor (SF). An estimate based on a lifetime probability that a chemical will cause cancer at a dose of $1 \mathrm{mg} / \mathrm{kg} /$ day.

Maximum Contaminant Level (MCL). EPA National Interim Primary and National Primary Drinking Water regulations that apply to all community or public water systems.

Reference Dose ( $R f D)$. An estimate of the daily exposure to the human population, including sensitive individuals, that is likely to be without an appreciable risk of deleterious effects during a lifetime.

Secondary Maximum Contaminant Level (SMCL). EPA National Secondary Drinking Water regulations that apply to public water systems. The EPA SMCLs are unenforceable criteria that apply to taste and odor; however, Tennessee SMCLs, which are the same as the federal SMCLs, are enforceable.

\subsubsection{Methods of Evaluation}

\subsubsection{Airborne Chemicals}

The release of chemicals into the air at ORR facilities is discussed in Sect. 3. Air permits issued by TDEC allow release of permitted quantities of chemicals. Sampling or monitoring is required only at the ORNL steam plant. No air-monitoring data amenable to human exposure analysis were available.

\subsubsection{Waterborne Chemicals}

EPA has set acceptable daily intake (ADI) standards for chemicals in the form of oral reference doses (RfDs) and slope factors (SFs). These values are available from EPA's Integrated Risk Information System (1993). For noncarcinogenic chemicals, daily exposure to the $\mathrm{RfD}$, in $\mathrm{mg} / \mathrm{kg} /$ day, should result in no adverse effect over a lifetime. ADIs in $\mathrm{mg} /$ day were calculated from RfDs by multiplying by $70 \mathrm{~kg}$, the average human body weight.

For carcinogens, ADIs were calculated from SFs using the formula:

$$
A D I=\frac{1 \times 10^{-5} \times B W}{S F}
$$

where

$$
\begin{aligned}
B W= & 70 \mathrm{~kg} \text { and } \\
S F= & \text { a slope factor of risk per unit dose } \\
& \text { (risk per } \mathrm{mg} / \mathrm{kg} / \mathrm{day} \text { ). }
\end{aligned}
$$

A 1 in $100,000\left(10^{-5}\right)$ lifetime risk of developing cancer was used in calculating the ADI.

For chemicals for which RfDs and SFs were not available, national primary and secondary drinking water regulations were used to calculate ADIs. The regulation concentrations, expressed in $\mathrm{mg} / \mathrm{L}$, were converted to ADI values by multiplying by $2 \mathrm{~L}$ (the average daily adult water intake).

\section{2-14 Potential Radiation and Chemical Dose to the Public}


Acceptable daily intakes for chemicals found in surface water at concentrations above detection limits are listed in Table 2.7. For RfDs and SFs, it is assumed that ingestion is the pathway of exposure.

Calculated daily intakes (CDIs) based on concentrations of chemicals found above detection limits at reference sites and at the three ORR sites are listed in Tables 2.8-2.12. Average values of the sampling data (in $\mathrm{mg} / \mathrm{L}$ ) were multiplied by two to estimate daily intake levels based on consumption of $2 \mathrm{~L}$ of water per person. The listed CDIs are hypothetical because the sampled waters are not sources of drinking water. Much of the sampling data for individual chemicals were reported as "less than" $(<)$ values, indicating that concentrations were below the limit of detection of the instruments used. These data were used in the analysis only if one or more samples had values above the detection limit. The CDIs were compared with the ADIs to establish whether the ingestion of $2 \mathrm{~L}$ of water would result in an exposure above the ADI. CDI/ADI ratios less than one indicate an acceptable level of risk, while CDI/ADI ratios greater than one indicate an unacceptable risk, or the need for further study. Where CDIs are expressed as < values, CDI/ADI ratios are also expressed as $<$ values, and the exposure cannot be fully quantified.

Sampling data for only inorganic chemicals, metals, and anions were available for the two reference sites, Melton Hill Dam and White Oak Creek headwaters (Table 2.8). These sampling locations represent background concentrations before the influence of the ORNL site and are useful for identifying the nonsite-related levels of chemicals.

Table 2.7. Acceptable daily intakes for chemicals found above detection limits at ORR facilities

\begin{tabular}{|c|c|c|}
\hline Chemical & $\begin{array}{c}\text { ADI } \\
\text { (mg/day) }\end{array}$ & Reference \\
\hline Aluminum & 0.1 & $\mathrm{SMCL}^{a}$ \\
\hline Antimony & 0.028 & RID \\
\hline Arsenic & 0.021 & RfD \\
\hline Barium & 4.9 & RfD \\
\hline Beryllium & 0.35 & RfD \\
\hline Boron & 6.3 & RfD \\
\hline Cadmium & 0.035 & RfD \\
\hline Chloride & 500 & SMCL \\
\hline Chromium VI & 0.35 & RfD \\
\hline Copper & 2.6 & SMCL \\
\hline Cyanide & 1.4 & RID \\
\hline Fluoride & 4.2 & RfD \\
\hline Iron & 0.6 & $\mathrm{MCL}$ \\
\hline Lead & 0.03 & $\mathrm{MCL}^{b}$ \\
\hline Manganese & 0.35 & $\mathrm{RfD}$ \\
\hline Mercury & 0.021 & RfD \\
\hline Methylene chloride & 0.09 & SF \\
\hline Molybdenum & 0.35 & $\mathrm{RfD}$ \\
\hline Nickel & 1.4 & RfD \\
\hline Nitrate & 112 & $\mathrm{RfD}$ \\
\hline PCBs & 0.00009 & $\mathrm{SF}$ \\
\hline Selenium & 0.35 & $\mathrm{RfD}$ \\
\hline Silver & 0.35 & RfD \\
\hline Strontium & 42 & RID \\
\hline Sulfate & 800 & $\mathrm{MCL}$ \\
\hline Thallium & 0.0049 & $\mathrm{RfD}$ \\
\hline Trichloroethane & 0.012 & SF \\
\hline Uranium (natural) & 0.21 & $\mathrm{RfD}$ \\
\hline Zinc & 21 & RfD \\
\hline
\end{tabular}

${ }^{a}$ SMCLs apply to all public water systems.

${ }^{b}$ MCLs apply to all public water systems or to community water systems (lead). 


\section{Environmental Report Vol. 1, Oak Ridge}

Table 2.8. Chemical dose/acceptable daily intake comparisons for surface waters at ORR reference locations-annual 1992 average values

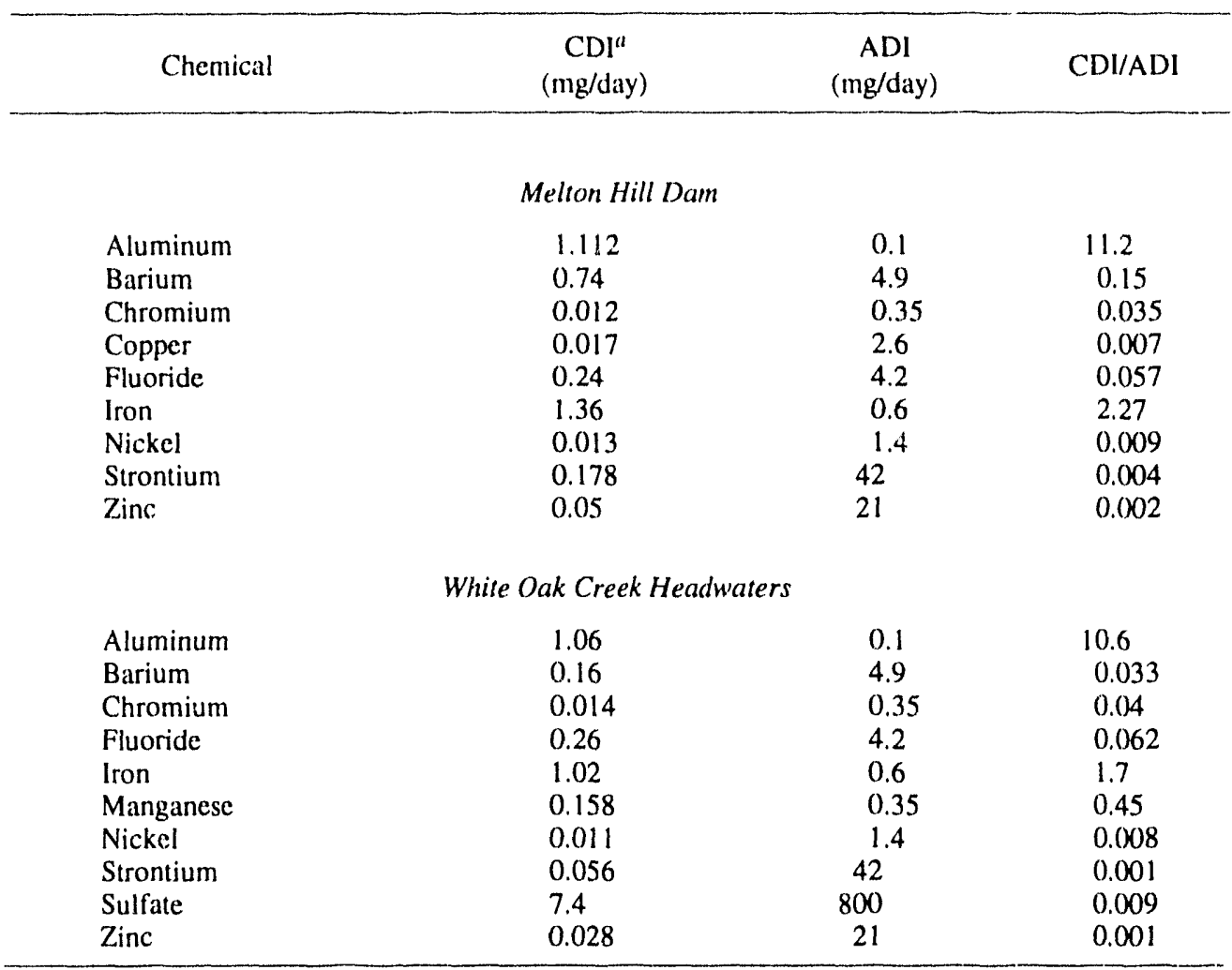

${ }^{a}$ Values based on 1992 annual average sampling concentrations.

With the exceptions of aluminum and iron, CDI/ADI ratios were less than one. The high concentrations of aluminum and iron in both the reference and monitoring samples may be a reflection of the turbidity and high suspended solids in some of the samples. Furthermore, the SMCLs that apply to aluminum and iron are not health values but are aesthetic, unenforceable criteria.

Twenty-six inorganic chemicals for which ADI values are available were present at concentrations above the limits of detection at the two Y-12 Plant surface water sampling stations (Table 2.9).

Aluminum, manganese, nitrate, and uranium (total) had CDI/ADI ratios greater than one in upper Bear Creek. The CDI/ADI ratio for uranium is based on an average concentration that includes samples that had concentrations below detection limits. Therefore, this average concentration and the resulting CDI/ADI ratio may be overestimates. Also, Upper Bear Creek is located on site; it is not an off-site discharge point from the Y-12 Plant. At Station 17 on East Fork
Poplar Creek, no CDI/ADI ratios were greater than 1.0 for the chemicals detected.

Fourteen inorganic chemicals and one organic chemical at the White Oak Dam sampling location were present at concentrations above the limits of detection (Table 2.10). To estimate the contribution of ORNL chemical effluents to the Clinch River, the amount of contaminants released per year was divided by the annual volume of the Clinch River. It was assumed that these contaminants were uniformly mixed in Clinch River water. It was also assumed that there were no other sources of contamination. No CDI/ADI ratios were greater than one. The CDI/ADI ratios taking into account only ORNL effluent concentrations (no contribution from the Clinch River) were less than one, with the exception of aluminum and iron, which were similar to ratios observed at other surface water locations. Therefore, the chemical contribution from ORNL was found to be negligible compared with existing chemical concentrations found upstream in the Clinch River. 


\section{Table 2.9. Chemical dose/acceptable daily intake comparisons for surface waters at Y-12 Plant locations-annual 1992 average values}

\begin{tabular}{|c|c|c|c|}
\hline Chemical & $\begin{array}{c}\mathrm{CDI}^{\mu} \\
\text { (mg/day) }\end{array}$ & $\begin{array}{c}\text { ADI } \\
\text { (mg/day) }\end{array}$ & CDI/ADI \\
\hline \multicolumn{4}{|c|}{ Upper Bear Creek (km 11.97) } \\
\hline Aluminum & 0.34 & 0.1 & 3.4 \\
\hline Barium & $<0.834$ & 4.9 & $<0.17$ \\
\hline Boron & 0.13 & 6.3 & 0.02 \\
\hline Cadmium & $<0.016$ & 0.035 & $<0.457$ \\
\hline Chromium & $<0.004$ & 0.35 & $<0.011$ \\
\hline Copper & $<0.012$ & 2.6 & $<0.006$ \\
\hline Cyanide & $<0.004$ & 1.4 & $<0.003$ \\
\hline Iron & $<0.26$ & 0.6 & $<0.433$ \\
\hline Lead & $<0.006$ & 0.03 & $<0.193$ \\
\hline Manganese & 2.22 & 0.35 & 6.3 \\
\hline Mercury & $<0.0004$ & 0.021 & $<0.019$ \\
\hline Nickel & $<0.058$ & 1.4 & $<0.041$ \\
\hline Nitrate & 244 & 112 & 2.18 \\
\hline Phenols & $<0.004$ & 42 & $<9.5 \mathrm{E}-5$ \\
\hline Selenium & $<0.004$ & 0.35 & $<0.0114$ \\
\hline Strontium & 1.28 & 42 & 0.03 \\
\hline Uranium & $<0.44$ & 0.21 & $<2.1$ \\
\hline Zinc & $<0.02$ & 21 & $<0.001$ \\
\hline \multicolumn{4}{|c|}{ East Fork Poplar Creek Station 17} \\
\hline Chromium & $<0.012$ & 0.35 & $<0.034$ \\
\hline Copper & $<0.014$ & 2.6 & $<0.005$ \\
\hline Chloride & 38 & 500 & 0.076 \\
\hline Fluoride & 2 & 4.2 & 0.476 \\
\hline Lead & $<0.004$ & 0.03 & $<0.133$ \\
\hline Mercury & 0.0028 & 0.021 & 0.133 \\
\hline Molybdenum & $<0.014$ & 0.35 & $<0.04$ \\
\hline Nitrate & 11.22 & 112 & 0.10 \\
\hline Sulfate & 136 & 800 & 0.17 \\
\hline Uranium & 0.062 & 0.21 & 0.295 \\
\hline Zinc & 0.088 & 21 & 0.004 \\
\hline
\end{tabular}

${ }^{a}$ Values based on 1992 annual average sampling concentrations.

Surface water samples at four perimeter monitoring locations at the K-25 Site were analyzed for inorganic and organic chemicals. Fourteen elements and 2 organics for which ADI values are available were detectable (Table 2.11). None of these chemicals had a CDI/ADI ratio greater than one.

Chemicals in water can be accumulated by aquatic organisms that may be eaten by humans. Bluegill (sunfish) from the Clinch River and Poplar Creek were analyzed for a number of metals, pesticides, and PCBs (see Tables 6.2-6.7 of Vol. 2). Table 2.12 summarizes the CDIs and the CDI/ADI ratios for chemical concentrations (upper $95 \%$ confidence interval). For locations where at least one sample was greater than the detection limit, a one-tail upper bound of the $95 \%$ confidence interval was used to calculate the analyte concentration. Chemicais with C.DI/ADI ratios greater than one were arsenic, mercury, heptachlor, 4, $4^{\prime}$-DDT, and PCBs (Aroclor-1242, Aroclor-1254, and Aroclor-1260). Similar CDI/ADI ratios were observed for these chemicals (with the exception of mercury) both upstream and downstream of ORR facilities. Arsenic $\mathrm{CDI} / \mathrm{ADI}$ ratios were greater than 1.0 at locations upstream of ORNL (CRK 84, 80, and 66), but decreased to less than 1.0 below Melton Hill Dam. This indicates that these chemicals and their 
Table 2.10. Chemical dose/acceptable daily intake comparisons for surface waters at ORNL locations-annual 1992 average values

\begin{tabular}{|c|c|c|c|}
\hline Chemical & $\begin{array}{c}\mathrm{CDI}^{a} \\
\text { (mg/day) }\end{array}$ & $\begin{array}{c}\text { ADI } \\
\text { (mg/day) }\end{array}$ & CDI/ADI \\
\hline \multicolumn{4}{|c|}{ Discharge Point X15 White Oak Dam (effluent concentrations) } \\
\hline Aluminum & 1.74 & 0.1 & 17.4 \\
\hline Cadmium & 0.0046 & 0.035 & 0.131 \\
\hline Chromium & 0.034 & 0.35 & 0.097 \\
\hline Copper & 0.022 & 2.6 & 0.008 \\
\hline Fluoride & 1.44 & 4.2 & 0.342 \\
\hline Iron & 1.86 & 0.6 & 3.1 \\
\hline Lead & 0.0082 & 0.03 & 0.273 \\
\hline Manganese & 0.32 & 0.35 & 0.91 \\
\hline Mercury & 0.00017 & 0.021 & 0.0082 \\
\hline Nickel & 0.026 & 1.4 & 0.0186 \\
\hline Nitrate & 1.46 & 112 & 0.013 \\
\hline PCB & 0.0036 & 0.00009 & 40 \\
\hline Sulfate & 92 & 800 & 0.115 \\
\hline Silver & 0.001 & 0.35 & 0.029 \\
\hline Zinc & 0.046 & 21 & 0.002 \\
\hline \multicolumn{4}{|c|}{ Discharge Point X15 (White Oak Dam; mixed with Clinch River) } \\
\hline Aluminum & $1.9 \mathrm{E}-4$ & 0.1 & $1.9 \mathrm{E}-4$ \\
\hline Cadmium & $5.08 \mathrm{E}-7$ & 0.035 & $1.45 \mathrm{E}-4$ \\
\hline Chromium & $3.76 \mathrm{E}-6$ & 0.35 & $1.07 \mathrm{E}-5$ \\
\hline Copper & $2.43 E-6$ & 2.6 & $9.36 \mathrm{E}-7$ \\
\hline Fluoride & $1.59 \mathrm{E}-4$ & 4.2 & $3.79 \mathrm{E}-5$ \\
\hline Iron & $2.04 \mathrm{E}-4$ & 0.6 & $3.4 \mathrm{E}-4$ \\
\hline Lead & $9.06 \mathrm{E}-7$ & 0.03 & $3.02 \mathrm{E}-5$ \\
\hline Manganese & $3.5 \mathrm{E}-5$ & 0.35 & $1.0 \mathrm{E}-4$ \\
\hline Mercury & $1.9 \mathrm{E}-8$ & 0.021 & $9.06 \mathrm{E}-7$ \\
\hline Nickel & $2.88 \mathrm{E}-6$ & 1.4 & $2.06 \mathrm{E}-6$ \\
\hline Nitrate & $1.6 \mathrm{E}-4$ & 112 & $1.44 \mathrm{E}-6$ \\
\hline PCB & $3.98 \mathrm{E}-7$ & $9 \mathrm{E}-5$ & $4.4 \mathrm{E}-3$ \\
\hline Sulfate & $1.0 \mathrm{E}-2$ & 800 & $1.3 \mathrm{E}-5$ \\
\hline Zinc & $5.08 \mathrm{E}-6$ & 21 & $2.42 \mathrm{E}-7$ \\
\hline
\end{tabular}

${ }^{a}$ Values based on 1992 annual average sampling concentrations.

associated concentrations were not generated from ORNL sources.

The highest concentration (upper $95 \%$ confidence interval) of mercury in bluegill, $0.41 \mathrm{mg} / \mathrm{kg}$ wet weight, was found at CRK 16. Assuming that the average person eats $21 \mathrm{~kg}$ of fish per year $(0.058 \mathrm{~kg} / \mathrm{day})$, the average daily intake of mercury would be $0.024 \mathrm{mg} /$ day. This results in a CDI/ADI $(0.024 / 0.021)$ ratio of 1.1 . The calculated average intake for ingestion of both fish and water results in a CD! of $0.027 \mathrm{mg} /$ day $(0.024 \mathrm{mg} /$ day from fish plus $0.0028 \mathrm{mg} /$ day from water at monitoring station 17 ) and a CDI/ADI ratio of 1.3 . The primary source of the CDI was from ingestion of fish. (No one actually drinks water from CRK 16.) The estimated mercury concentration in fish from this location is based on the upper $95 \%$ confidence interval. This means that there is $95 \%$ confidence that the mercury concentration will be less than or equal to $0.41 \mathrm{mg} / \mathrm{kg}$ wet weight. Therefore, the average amount of contaminant ingested would result with $95 \%$ confidence in a CDI of less than or equal to $0.024 \mathrm{mg} / \mathrm{day}$.

PCB concentrations in bluegill were taken at five locations on Clinch River and at one location on Poplar Creek. The CDIs and the CDI/ADI ratios 
1992 Environmental Report Vol. 1, Oak Ridge

Table 2.11. Chemical dose/acceptable daily intake comparisons for surface waters at K-25 Site perimeter monitoring locations-annual 1992 average values

\begin{tabular}{|c|c|c|c|}
\hline Chemical & $\begin{array}{c}\mathrm{CDI}^{a} \\
\text { (mg/day) }\end{array}$ & $\begin{array}{c}\mathrm{ADl} \\
\text { (mg/day) }\end{array}$ & CDI/ADI \\
\hline \multicolumn{4}{|c|}{ West Fork Poplar Creek (background stream) } \\
\hline Chloride & 10 & 500 & 0.02 \\
\hline Copper & $<0.012$ & 2.6 & $<0.005$ \\
\hline Fluoride & 0.3 & 4.2 & 0.071 \\
\hline Iron & 0.54 & 0.6 & 0.9 \\
\hline Manganese & 0.278 & 0.35 & 0.79 \\
\hline Methylene chloride & 0.004 & 0.09 & 0.044 \\
\hline Nitrate & 0.94 & 112 & 0.008 \\
\hline Sulfate & 74 & 800 & 0.09 \\
\hline Zinc & 0.0144 & 21 & 0.0007 \\
\hline \multicolumn{4}{|c|}{ Poplar Creek (Monitoring Station K-716) } \\
\hline Arsenic & 0.0078 & 0.021 & 0.37 \\
\hline Copper & $<0.015$ & 2.6 & 0.006 \\
\hline Fluoride & 0.343 & 4.2 & 0.0816 \\
\hline Lead & 0.0162 & 0.03 & 0.541 \\
\hline Manganese & 0.356 & 0.35 & 1.0 \\
\hline Mercury & 0.0012 & 0.021 & 0.058 \\
\hline Methylene chloride & 0.006 & 0.09 & 0.067 \\
\hline Nitrate & 2.03 & 112 & 0.018 \\
\hline Sulfate & 53.2 & 800 & 0.067 \\
\hline Trichloroethane & $<0.002$ & 0.012 & 0.167 \\
\hline Uranium & 0.0047 & 0.21 & 0.023 \\
\hline Zinc & 0.043 & 21 & 0.002 \\
\hline \multicolumn{4}{|c|}{ Clinch River (Monitoring Station K-1513) } \\
\hline Copper & 0.008 & 2.6 & 0.003 \\
\hline Fluoride & 0.3 & 4.2 & 0.071 \\
\hline Manganese & 0.074 & 0.35 & 0.21 \\
\hline Methylene chloride & 0.013 & 0.09 & 0.144 \\
\hline Nitrate & 1.08 & 112 & 0.0096 \\
\hline Sulfate & 41.6 & 800 & 0.05 \\
\hline Zinc & 0.0094 & 21 & 0.0004 \\
\hline \multicolumn{4}{|c|}{ Clinch River (Brashear Island) } \\
\hline Arsenic & 0.008 & 0.021 & 0.038 \\
\hline Cadmium & 0.0024 & 0.035 & 0.0686 \\
\hline Copper & 0.0098 & 2.6 & 0.004 \\
\hline Fluoride & 0.267 & 4.2 & 0.063 \\
\hline Lead & 0.007 & 0.03 & 0.22 \\
\hline Manganese & 0.139 & 0.35 & 0.40 \\
\hline Mercury & 0.0004 & 0.021 & 0.019 \\
\hline Nickel & 0.047 & 1.4 & 0.033 \\
\hline Nitrate & 0.92 & 112 & 0.008 \\
\hline Sulfate & 42 & 800 & 0.05 \\
\hline Zinc & 0.013 & 21 & 0.0006 \\
\hline
\end{tabular}

"Values based on 1992 annual average sampling concentrations. 
1992 Environmental Report Vol. 1, Oak Ridge

Table 2.12. Chemical dose/acceptable daily intake comparisons for fish intake - annual upper $95 \%$ confidence interval values

\begin{tabular}{lccc}
\hline Chemical & $\begin{array}{c}\text { CDI } \\
(\mathrm{mg} / \text { day })\end{array}$ & $\begin{array}{c}\text { ADI } \\
(\mathrm{mg} / \text { day })\end{array}$ & CDI/ADI \\
\hline
\end{tabular}

CRK 84 (above ORNL)

Arsenic
Mercury
Selenium
Zinc
Heptachlor
Aroclor- 1242
Aroclor- 1254

0.055

0.083

0.050

0.64

0.00044

0.027

0.024

$\begin{array}{cc}0.021 & 2.6 \\ 0.021 & 0.23 \\ 0.35 & 0.14 \\ 21 & 0.030 \\ 0.00016 & 2.8 \\ 9.09 \mathrm{E}-5 & 300 \\ 9.09 \mathrm{E}-5 & 270\end{array}$

CRK 80 (above ORNL)

Arsenic

Mercury

Selenium

Zinc

Heptachlor

Aroclor-1254

0.057
0.003
0.058
0.064
0.00026
0.048

0.021

0.021

0.35

21

0.0001

9.09E-5

270

CRK 66 (above ORNL)

Arsenic

Mercury

Selenium

Zinc

Heptachlor

Aroclor-1254

0.058
0.0035
0.043
0.042
0.00026
0.04

\subsection{1}

0.021

0.35

21

0.00016

9.09E-5

$$
2.7
$$

0.171

0.151

0.030

1.641

CRK 32 (below ORNL)

Arsenic
Copper
Lead
Mercury
Selenium
Zinc
$4,4^{\prime}$-DDT
Heptachlor
Aroclor- 1260

0.015

0.028

0.012

0.0041

0.032

0.87

0.00081

0.0027

0.053

$\begin{array}{ll}0.021 & 0.71 \\ 2.0 & 0.01 \\ 0.03 & 0.41 \\ 0.021 & 0.20 \\ 0.35 & 0.091 \\ 21 & 0.041 \\ 0.002 & 0.39 \\ 0.00016 & 17 \\ 9.09 \mathrm{E}-5 & 580\end{array}$

CRK 16 (below ORNLY-12/K-25)

Arsenic
Lead
Mercury
Selenium
Zinc
$4,4^{\prime}$-DDT
Heptachlor
Aroclor-1260

\subsection{9}

0.0013

0.024

0.03

0.64

0.0038

0.0026

0.043

0.021
0.03
0.021
0.35
21
0.002
0.00016
$9.09 \mathrm{E}-5$

1.1

0.085

0.030

1.9

16

470

PCK 2.2 (below $Y \cdot 12 / K-25$ )

Arseníc
Lead
Mercury
Selenium
7.inc
$4,4^{\prime}$-DDT
Heptachlor
Aroclor- 1242
Aroclor- 1260

0.005

0.0041

0.013

0.038

0.81

0.0036

0.0026

0.026

0.044

0.021
0.03
0.021
0.35
21
0.002
0.00016
$9.09 \mathrm{E}-5$
$9.09 \mathrm{E}-5$

0.24
0.14
0.64
0.11
0.039
1.7
16
280
480

\section{2-20 Potential Radiation and Chemical Dose to the Public}


varied somewhat between locations; however, the CDIs above and downstream of the ORR facilities were comparable.

Surface water monitoring stations are generally located within areas of DOE facilities that are not readily accessible to the general public. Therefore, consumption of water from these points is unlikely. Furthermore, as a pollutant moves downstream and the volume of water increases, the concentration of pollutant decreases.

\subsubsection{Chemicals in Other Environmental Media}

An important pathway of concern for human exposure to chemicals is through atmospheric deposition onto vegetation and subsequent transfer into beef and milk. Direct measurements for concentrations of chemicals in vegetation, beef, or milk in the vicinity of ORR facilities have not been made. As noted above, engineering estimates indicate that no sources on the ORR release reportable quantities of chemicals.

\subsubsection{Direct Exposure}

Direct exposure to chemicals does not represent a likely pathway of exposure at the ORR facilities. For airborne releases, concentrations off-site are too small to be a concern through the dermal exposure pathway. For aquatic releases, outfalls are generally located within areas of DOE facilities that are not readily accessible to the general public. Although exposures for the consumption of drinking water at the monitoring stations were calculated, public consumption of water from the outfalls or at the monitoring stations is highly unlikely.

\subsubsection{Current-Year Summary}

Analyses of exposure to waterborne inorganic chemicals show that the majority of CDI/ADI ratios for on-site waters are less than one, indicating that intake of most chemicals would be below acceptable daily intake levels from drinking on-site waters. Off-site exposures would be 10 to 100 times lower because of dilution in the Clinch River. Two inorganic chemicals, aluminum and iron, which were above ADI, were also high in the reference samples, indicating that they were not contaminants from the
ORR. Most organic chemicals were below the limit of analytical detection and should pose no risk to the public.

\subsection{References}

Baker, D. A., and Soldat, J. K. 1993. Methods for Estimating Doses to Organisms from Radioactive Materials Released into the Aquatic Environment, PNL-8150, Pacific Northwest Laboratories, Richland, Wash.

Beres, D. A. 1990. The Clean Air Act Assessment Package-1988 (CAP-88): A Dose and Risk Assessment Methodology for Radionuclide Emissions to Air, Vols. 1-3, SC\&A, Inc., McLean, Va.

Hamby, D. M. 1991. LADTAP XL: An Improved Electronic Spreadsheet Version of LADTAP II, WSRC-RP-91-975, Westinghouse Savannah River Company, Aiken, S.C.

International Commission on Radiological Protection (ICRP). 1977. Recommendations of the International Commission on Radiological Protection, Publication 26, Pergamon Press, Oxford.

International Commission on Radiological Protection (ICRP). 1978. Recommendations of the International Commission on Radiological Protection, Publication 30, Pergamon Press, Oxford.

Myrick, T. E., B. A. Bervin, and F. F. Haywood. 1981. State Background Radiation Levels, ORNL/TM-7343, Oak Ridge, Tenn.

McCormick, J., Manager, Chattanooga Field Office, Division of Water Supply, Tennessee Department of Environment and Conservation, Chattanooga, Tenn., personal communication with P. A. Scofield, Office of Environmental Compliance and Documentation, Oak Ridge National Laboratory, Oak Ridge, Tenn., January 1992.

Roberts, S., Manager, Knoxville Field Office, Division of Water Supply, Tennessee Department of Environment and Conservation, Knoxville, Tenn., personal communication with P. A. Scofield, Office of Environmental Compliance and Documentation, Oak Ridge National Laboratory, Oak Ridge, Tenn., January 1992.

Scofield, P. A. January 1992. Personal communications from $S$. Roberts, Knoxville 


\section{Environmental Report Vol. 1, Oak Ridge}

Field Office, and J. McCormick, Chattanooga

Field Office, Division of Water Supply,

Tennessee Department of Environment and

Conservation.

U.S. Department of Energy (DOE). 1988a. External Dose-Rate Conversion Factors for Calculation of Dose to the Public, DOE/EH-0070.

U.S. Department of Energy (DOE). 1988b. Internal Dose Conversion Factors for Calculation of Dose io the Public, DOE/EH-0071.

U.S. Environmental Protection Agency (EPA). 1988. Limiting Values of Radionuclide Intake and Air Concentration and Dose Conversion Factors for Inhalation, Submersion, and Ingestion, Federal Guidance Report No. 11, EPA-520/1-88-020.
U.S. Environmental Protection Agency (EPA). 1989. Risk Assessments Methodology, Environmental Impact Statement, NESHAPS for Radionuclides, Background Information, Vol. 1, EPA/520/1-89-005.

U.S. Environmental Protection Agency (EPA). 1991. Integrated Risk Information System (IRIS), Washington, D.C.

U.S. Nuclear Regulatory Commission (NRC). 1977. Calculation of Annual Doses to Man from Routine Releases of Reactor Effluents for the Purpose of Evaluating Compliance with 10 CFR 50, Regulatory Guide 1.109, Appendix I, Revision 1, NRC Office of Standards Development, Washington, D.C. 


\section{AIRBORNE DISCHARGES, AMBIENT AIR MONITORING, METEOROLOGICAL MONITORING, AND EXTERNAL GAMMA RADIATION}

3.1 Regulatory Requirements .......... 3-3

3.2 Airborne Discharges . . . . . . . . . . . . 3-3

3.2.1 Y-12 Plant . . . . . . . . . . . . . . 3-4

3.2.2 Oak Ridge National Laboratory . . . . . 3- 3-7

3.2.3 K-25 Site . . . . . . . . . . . . . . 3-14

3.3 Ambient Air Monitoring . . . . . . . . . . 3-17

3.3.1 Y-12 Plant . . . . . . . . . . . 3-17

3.3.2 Oak Ridge National Laboratory . . . . 3-23

3.3.3 K-25 Site . . . . . . . . . . . . . 3-29

3.4 Meteorological Monitoring . . . . . . . . . 3-35

3.4.1 Description ............. . . 3-35

3.4 .2 Summary $\ldots \ldots \ldots \ldots \ldots \ldots . \ldots . . . . .36$

3.5 External Gamma Radiation . . . . . . . . 3-37

\subsubsection{Sample Collection and Analytical}

Procedures ............ . . 3-37

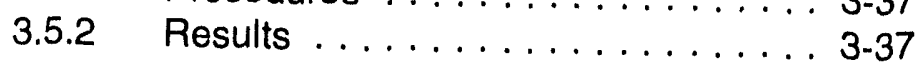

3.6 References . . . . . . . . . . . . . . 3-38 
1992 Environmental Report Vol. 1, Oak Ridge

\section{Airborne Discharges, Ambient Air Monitoring, Meteorological Monitoring, and External Gamma Radiation}

\subsection{Regulatory Requirements}

Airborne discharges from the U.S. Department of Energy (DOE) Oak Ridge facilities, both radioactive and nonradioactive, are subject to regulations issued by the U.S. Environmental Protection Agency (EPA) and the Tennessee Department of Environment and Conservation (TDEC) Air Pollution Control Board as well as DOE orders. Radioactive emissions are regulated by EPA Region IV under the Clean Air Act's (CAA) National Emission Standards for Hazardous Air Pollutants (NESHAP) 40 CFR 61, subpart $\mathrm{H}$. The nonradioactive emissions are reguiated inder the rules of the TDEC Division of Air Pollution Control.

The TDEC air pollution control rules regulate pollution sources to protect the public health and welfare and the environment. These rules include regulations for maximum allowable ambient air concentrations of certain pollutants, open burning, pollution sources such as coal-fired boilers and processes, fugitive emission sources, performance standards for new sources, and hazardous air pollutants. State-issued permits are required for air pollution sources with the exception of certain very small emission sources that are specifically exempt from permit requirements.

The NESHAP regulations limit the amount of annual radioactive exposure or dose to the nearest or most affected member of the public. In December 1989, the NESHAP regulations were reissued.

Negotiations between EPA and DOE were initiated to bring the Oak Ridge Reservation (ORR) into full compliance with the new regulations. As a result of those negotiations, a federal facilities compliance agreement (FFCA) was signed in May 1992 by the DOE field office manager and was implemented at the ORR facilities. The ORR fulfilled all of its FFCA commitments and came into compliance with the regulations by December 1992. On March 26, 1993, EPA-IV certified that the DOE Oak Ridge Operations Office (DOE-ORO) had completed all actions required by the FFCA and is considered in compliance with the Radionuclide NESHAP regulations, 40 CFR 61, Subpart $\mathrm{H}$.

DOE regulations governing airborne emissions are established in DOE orders 5400.1 and 5400.5, and DOE/EH-0173T. The criteria in NESHAP regulations and DOE orders define major effluent sources as emission points with the potential to discharge radionuclides in quantities that could cause an effective dose equivalent of $0.1 \mathrm{mrem} / \mathrm{year}$ or greater to a member of the public. Potential emissions are calculated for a source by assuming the loss of pollution control equipment while the source is otherwise operating normally.

\subsection{Airborne Discharges}

Each ORR facility has a comprehensive air pollution control and monitoring program to ensure that airborne discharges meet regulatory requirements and do not adversely affect ambient air quality. Air pollution controls at the three Oak Ridge facilities include exhaust gas scrubbers, baghouses, and exhaust filtration systems designed to remove airborne pollution from the exhaust gases before their release to the atmosphere. Process modifications and material substitutions are also made in an effort to minimize air emissions. In addition, administrative 


\section{Environmental Report Vol. 1, Oak Ridge}

controls play a role in regulating emissions. Each installation has developed an emissions inventory program that includes stack sampling to determine the amounts of pollutants that are not removed by the air pollution control equipment. Ambient air monitoring is also conducted around the facilities and at several locations within surrounding East Tennessee communities to assess the impacts of ORR operations on the ambient air quality of the region.

The remainder of Sect. 3 describes airborne pollutants emitted from the Oak Ridge facilities during 1992. The subsections also describe the emissions sampling and monitoring performed at each facility and present data on measured pollutant concentrations within the surrounding communities. A brief section is also included on meteorological measurements conducted during 1992 at each facility. A discussion of atmospheric dispersion modeling and atmospheric radiological dose modeling is included in Sect. 2.

\subsubsection{Y-12 Plant}

\subsubsection{Description}

The release of contaminants into the atmosphere at the Y-12 Plant occurs almost exclusively as a result of plant production, maintenance and waste management operations, and steam generation. Most process operations are served by process ventilation systems that remove air contaminants from the workplace. More than 400 of these are permitted by TDEC (Table 3.1, Vol. 2). The allowable level of pollutant emissions from permitted sources (as opposed to actual emissions, which are lower than the allowables) was 9605 tons/year of regulated pollutants. Most of these pollutants are attributed to the operation of the Y-12 Steam Plant.

The two Y-12 Steam Fiant exhaust stacks are each equipped with Lear Siegler RM41 opacity monitoring systems. The opacity monitoring systems are required, under the current operating air permit, to be fully operational $95 \%$ of the operational time of the monitored units every month. The east and west stack opacity monitors were each operational more than $99 \%$ of the time. Both opacity monitoring systems were taken out of service for calibration/certification (performed annually) and for maintenance activities to repair stuck shutters that occurred as a result of a power failure and self-check. There were two periods of excess opacity in 1992. On March 30, excess opacity emissions from the west stack were limited to two 6-min periods and were the result of the operator error in valving out instrument air, causing the baghouse bypass to open. On May 27, excess opacity emissions from the east stack were limited to one 6-min period and resulted from a power failure that caused the baghouse bypass to open. Quarterly reports of the operational status of the Y-12 Steam Plant are submitted to the TDEC Department of Air Pollution Control. Annual opacity calibration error test reports were submitted in July 1992.

About 81 of the permitted exhaust systems serve areas where depleted or enriched uranium is processed; they are monitored continuously for radioactive emissions. Twenty-eight of these samplers are equipped with alarm systems (breakthrough monitors) able to detect significant increases in the rate of emissions. Breakthrough monitors are located where a potential for excessive emissions exists in the event of a filter failure or process upset. Additionally, there are several hundred room air ventilation systems in plant buildings. These systems are typically not significant emission points for air pollutants because room air pollution concentrations are kept very low for the protection of workers.

Atmospheric discharges from Y-12 Plant production operations are minimized through the extensive use of air pollution control equipment. High-efficiency particulate air (HEPA) filters are used to essentially eliminate particulate emissions (including uranium) from numerous production shops. HEPA filters remove more than $99 \%$ of the particulates from the exhaust gases. Exhaust gas scrubbers, baghouses, and other emission control equipment are used to reduce airborne discharges of other pollutants. Improvements continue to be made to the plant's exhaust ventilation systems to further reduce emissions. While many of these improvements involve the installation of new air pollution control equipment, material substitution and process modification projects are also being examined and implemented to reduce plant emissions and to comply with waste minimization strategies currently being pursued by plant operations.

\section{3-4 Airborne, Ambient Air, Meteorological, and External Gamma}


A stack and vent survey has been initiated through the Engineering Division to identify and assign unique numbers to all emission points at the Y-12 Plant. Each stack and vent will be assessed as to its potential to emit hazardous materials considering both routine and accidental emissions. Those without any emission potential, such as steam vents, will not require further documentation. Emission estimates will be generated for the vents potentially emitting hazardous materials.

The focus of the initial stack and vent survey was the radionuclide area. All areas of the $\mathrm{Y}-12$ Plant that handle radioactive materials were reviewed for unmonitored exhausts. Estimates of emissions were generated for unmonitored stacks and vents as they were identified.

The 1989 NESHAP regulation for radionuclides defines emissions sampling and reporting requirements for demonstrating compliance with the 10-mrem effective-dose-equivalent standard.

Continuous emission sampling, using methods that comply with ANSI N 13.1 (1969, R-1982) standards, is required for any emission point with the potential to cause a public dose exceeding 0.1 mrem. During 1992,65 of the Y-12 Plant's 81 continuously monitored stacks were judged to have the potential to emit radioactive effluents that contribute greater than $0.1 \mathrm{mrem} / y e a r$ effective dose equivalent to an off-site individual. Two other sources with this potential has been identified in the stack and vent survey. Stacks 112 and 115 were also potential major emission points through January 1992, when both stacks were taken out of service. Stacks 112 and 115 are on Buildings 9212 and 9206, respectively. Plans are under way to equip stack 112 with the appropriate monitoring equipment prior to restart of operation. Operations for Stack 115 will not be restarted.

During 1992 four of the active monitored stacks at the $\mathrm{Y}-12$ Plant were permanently taken out of service. All four stacks $(53,54,56$, and 57$)$ served the A-wing machine shop at Building 9212, which was shut down. Stack 57 had been classified as a major source. There were 77 active monitored stacks at the end of 1992 .

Although the $\mathrm{Y}-12$ Plant airborne discharges were well within regulatory guidelines, the sampling methods and emission methods did not fully meet EPA requirements until the fourth quarter of 1992.
During the fourth quarter of 1992 two projects were completed that fulfilled an FFC.A that had been negotiated with the EPA Region IV staff. The first project was the modification of all the active continuous samplers to allow for leak testing of fittings. The modifications involved the installation of valves onto the probe and sampling assemblies. These modifications were completed in the fourth quarter of 1992, and all the active stacks were leak-tested as part of the quarterly calibration operations.

The second significant project in 1992 was a negotiated settlement with the EPA Region IV staff on estimating emissions for stacks that have a large amount of flow variability between quarterly measurements. The EPA Region IV staff was concerned that the large variability in the measured stack velocities in some of the Y-12 Plant stacks would prevent the continuous samplers from operating at acceptable isokinetic conditions. For stacks that exhibit significant flow variation between quarterly measurements, a conservative method of calculating emissions was agreed to in exchange for not having to install expensive continuous stack flow monitors.

\subsubsection{Summary}

Y-12 Plant radiological uranium emission estimates are broken down in Table 3.1. Y-12 Plant monitored process emission totals were made using stack sampling data obtained from sampling equipment installed in March 1987 under the Stack Radiological Monitoring Project. Uranium stack losses were continuously measured on 81 process exhaust stacks by extracting a representative sample of stack gas through a multipoint sampling probe. Particulate matter (including uranium) is removed from the stack sample through filtration by a 47-mm-diam paper filter. Sample filters at each location are changed routinely, on an average of three times per week, and analyzed for total uranium by the fluorometric method in the Y-12 Plant Laboratory.

In addition, the sampling probes and tubing are removed quarterly, washed with nitric acid, and the wash collected and analyzed for total uranium. At the end of the year, the probe wash data are included in the final calculations in determining total uranium emissions from each stack. 


\section{Environmental Report Vol. 1, Oak Ridge}

\section{Table 3.1. 1992 Y-12 Plant airborne uranium emissions estimates ${ }^{a}$}

\begin{tabular}{lccc}
\hline \multicolumn{1}{c}{ Source of emissions } & \multicolumn{2}{c}{ Quantity emitted } \\
\cline { 2 - 3 } & $(\mathrm{kg})$ & $(\mathrm{Ci})$ \\
\hline Enriched uranium process exhaust (monitored) & 0.5 & 0.036 \\
Depleted uranium process exhaust (monitored) & 6.8 & 0.004 \\
Enriched uranium process and laboratory exhaust (unmonitored) & 0.1 & 0.004 \\
Depleted uranium process and laboratory exhaust (unmonitored) & 4.6 & 0.002 \\
Enriched uranium room exhaust (unmonitored) & 0.2 & 0.011 \\
Depleted uranium room exhaust (unmonitored) & 5.6 & 0.003 \\
\cline { 2 - 3 } & & 17.8 & 0.060 \\
\hline
\end{tabular}

aSee Table 2.2 for off-site committed dose equivalents resulting from Y-12 Plant uranium emissions.

Emissions from the unmonitored process and laboratory exhausts were from 73 emission points. Two of the sources, Stack 112 and Stack 115, were sampled by impinger-type samplers because of the corrosive conditions in the stacks until the processes were shut down in January 1992. The 71 additional unmonitored process and laboratory exhausts are all categorized as minor emission sources, and estimates were generated according to EPA-approved calculation methods.

Emissions from room ventilation systems are estimated from health physics data on airborne radioactivity concentrations in the work areas. Any monthly concentration averages that exceeded $10 \%$ of the derived air concentration (DAC) were included in the annual emission estimate. The DAC is a radionuclide concentration level established by DOE orders. It is designed to protect the health of workers in radiation areas. The annual average concentrations are used with the design ventilation rates to arrive at the annual emission estimate. There were 12 ventilation areas from the enriched buildings and 15 ventilation areas from the depleted buildings where the average concentration exceeded $10 \%$ of the DAC in 1992.

Radionuclides other than uranium are handled in millicurie quantities as a part of Oak Ridge National Laboratory (ORNL) and Y-12 laboratory activities at facilities in the Y-12 Plant. The releases from these activities are minimal and have a negligible impact on the total Y-12 Plant dose; therefore, only Y-12 Plant uranium discharges are shown in Table 3.1.

\subsubsection{Discussion}

An estimated $0.060 \mathrm{Ci}(17.8 \mathrm{~kg})$ of uranium was released into the atmosphere in 1992 as a result of Y-12 Plant processing operations (Figs. 3.1 and 3.2). Because the specific activity of enriched uranium is much greater than that of depleted uranium, about $85 \%$ of the curie release was from emissions of enriched uranium particulate, whereas only $5 \%$ of the total mass of uranium released was from enriched uranium losses.

As illustrated in Fig. 3.1, 1992 Y-12 Plant uranium emissions estimates in total curies were essentially the same as in 1991. This decrease reflects a reduction in $\mathrm{Y}-12$ Plant process activities, continued improvements in administrative controls of the process activities still operating, and improvements in contamination control throughout the Y-12 Plant (notable in the room exhaust estimates from health physics data). Only five buildings contained areas where uranium concentrations exceeded $10 \%$ of the DAC in 1992.

Twenty-eight stacks with the greatest potential to emit significant amounts of uranium are equipped with breakthrough monitors, which alert operations personnel to process-upset conditions or to a decline in filtration system efficiencies. The breakthrough monitors have been instrumental in helping to reduce excessive emissions from several enriched process areas over the past few years. When an alarm is received, operations personnel take prompt action to reduce or stop the emission, such as shutting down a

\section{3-6 Airborne, Ambient Air, Meteorological, and External Gamma}




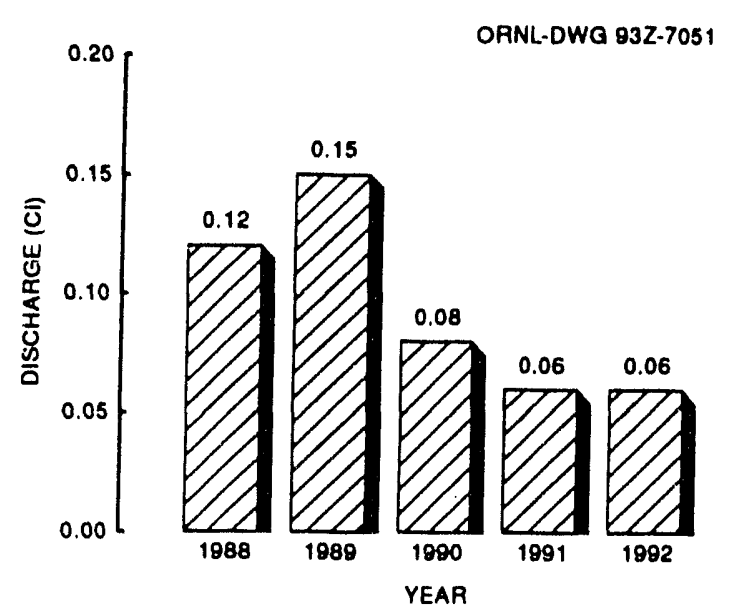

Fig. 3.1. Total curie discharges of uranium from the Y-12 Plant to the atmosphere, 1988-1992.

process, until the cause of the excessive emission can be identified and corrected.

\subsubsection{Chemical Emissions}

Emission estimates have been made for a number of major pollutant categories. These are itemized in Appendix A (see Table A.1), which addresses chemical releases and SARA Title III, Sect. 313.

\subsubsection{Oak Ridge National Laboratory}

\subsubsection{Description}

Airborne discharges at ORNL consist primarily of ventilation air from radioactively contaminated or potentially contaminated areas, vents from tanks and processes, and ventilation for reactor facilities. Many of the sources, mostly nonradioactive, are permitted by the TDEC Air Pollution Control Board. A list of current air permits for emission sources at ORNL is presented in Table 3.2 of Vol. 2. The allowable levels of pollutant emissions from permitted sources are based on 9748 tons/year of regulated pollutants. Most airborne emissions are treated and filtered before discharge to the atmosphere. Typically, radioactively contaminated and potentially contaminated airborne emissions are treated, then filtered with HEPA and/or

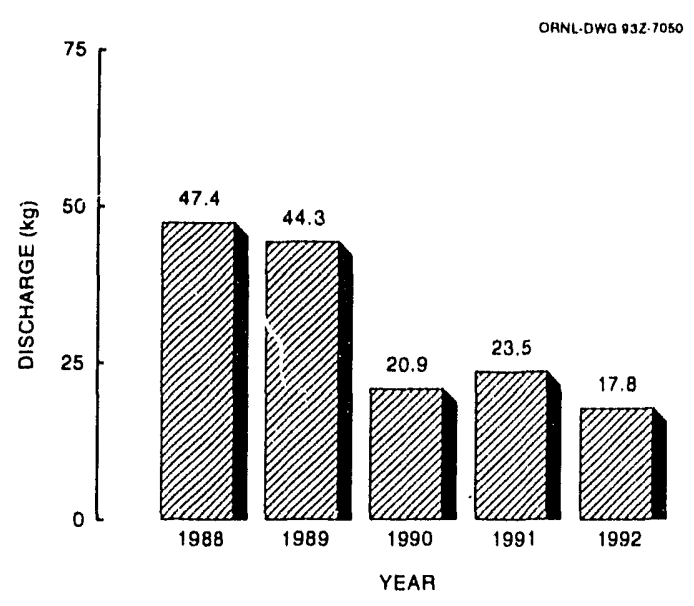

Fig. 3.2. Total kilograms of uranium discharged from the $Y-12$ Plant to the atmosphere, 1988-1992.

charcoal filters before discharge to ensure that any radioactivity released is as low as possible.

Discharges from each stack are unique because of the wide variety of research activities performed at ORNL. Radiological gaseous emissions from ORNL typically consist of solid particulates, adsorbable gases (e.g., iodine), tritium, and nonadsorbable gases.

The major radiological emission point sources for ORNL consist of the following four stacks located in the Bethel and Melton valleys:

\begin{tabular}{|c|c|}
\hline Building & Description \\
\hline 2026 & High Radiation Level Analytical Laboratory \\
\hline 3020 & Radiochemical Processing Plant \\
\hline \multirow[t]{4}{*}{3039} & 3500 and 4500 areas cell ventilation system \\
\hline & Central off-gas and scrubber system \\
\hline & Isotope solid state ventilation system \\
\hline & 3025 and 3026 areas cell ventilation system \\
\hline \multirow[t]{3}{*}{7911} & Melton Valley complex (High Flux Isotope \\
\hline & Reactor, Radiochemical Engineering \\
\hline & Development Center) \\
\hline
\end{tabular}

Figure 3.3 shows the locations of the four main stacks whose emissions are routinely quantified.

A stack and vent survey has been initiated to identify and assign unique numbers to all emission points at ORNL. Each stack and vent will be assessed for its potential to discharge regulated air pollutant emissions. Those with no potential for regulated air pollutant emissions, such as steam vents, will not 
ORNL-DWG 88M-7048R5

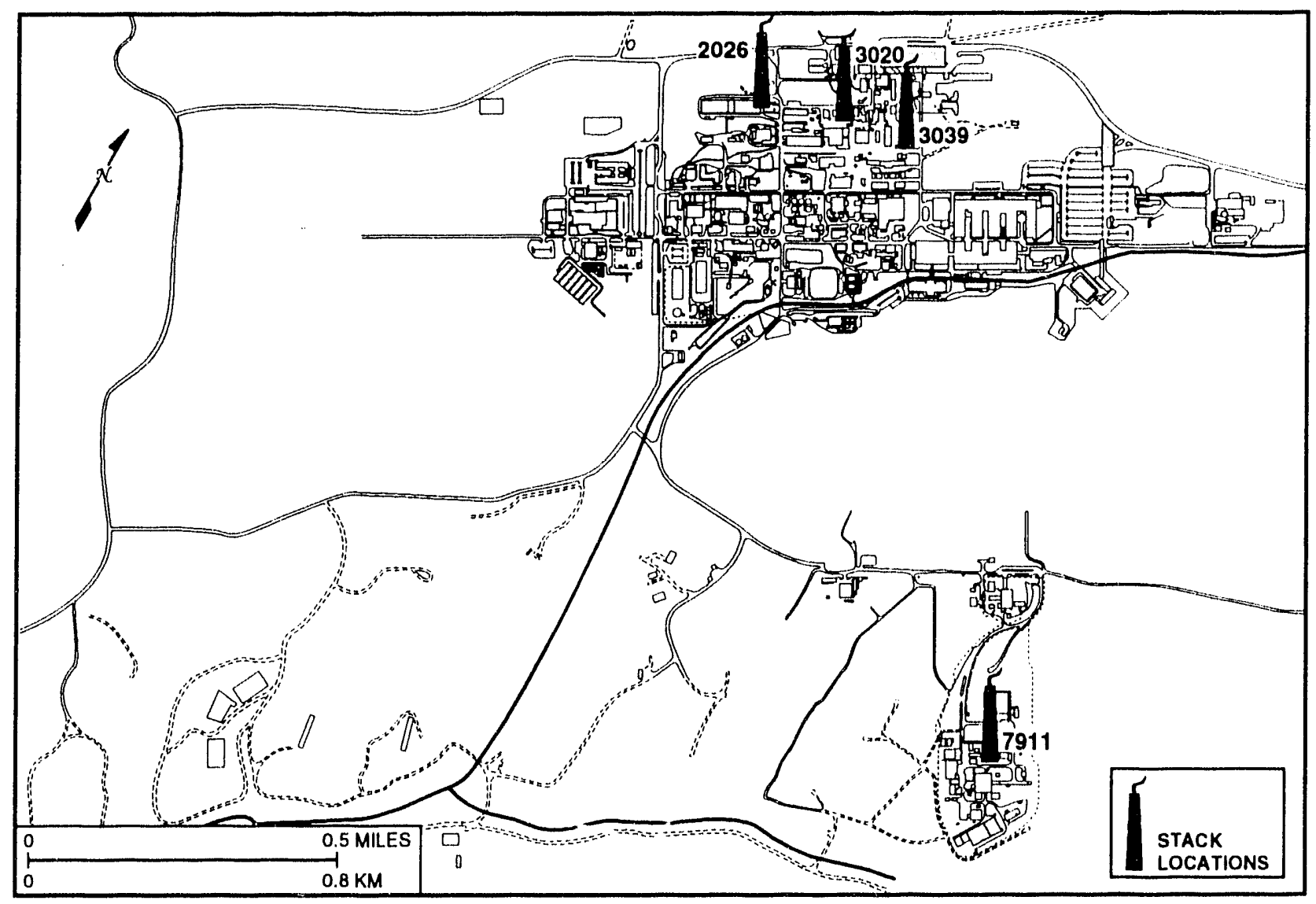

Fig. 3.3. Locations of major stacks (emission points) at ORNL.

require any further documentation. The first phase of the stack and vent survey focused primarily on radioactive emission sources. The results of the survey identified 17 minor point sources or group sources. Emissions estimates were made for each of these point or group sources in 1992.

\subsubsection{Airborne Emissions Sampling}

Each of the four major point sources is equipped with a variety of surveillance instrumentation, including radiation alarms, near-real-time monitors, and continuous sample collectors. Only data resulting from analysis of the continuous samples are used in this report because the other equipment does not provide data of sufficient accuracy and precision to support the quantitation of emission source terms.

The single exception is for noble gases, which cannot be quantitatively captured on a sampling medium and must be evaluated by means of an on-line detector.

In addition to the major sources, ORNL has a number of minor sources that have the potential to emit radionuclides to the atmosphere. Minor sources are composed of any ventilation systems or components such as vents, lab hoods, room exhausts, and stacks that do not meet the criteria for a major source but are located in or vent from a radiological control area.

During 1992, the sampling systems at all of ORNL's major sources were upgraded to correct deficiencies in the sampling layout and/or instrumentation as required by the NESHAP regulation. The regulation requires continuous emission sampling, using methods that comply with ANSI N 13.1 (1969, R-1982) standards, for any emission point with the potential to cause an annual 


\section{Environmental Report Vol. 1, Oak Ridge}

public dose exceeding 0.1 mrem. An upgrade program was initiated to modify each source to meet compliance criteria. The upgrade program was completed in the fall of 1992 fulfilling the commitments in the FFCA between DOE and EPA Region IV. The modifications included relocating the sampling location at 2026,3039, and 7911; installing a new probe in each stack; and adding a tritium collection system to 2026 . The present sampling systems generally consist of multipoint in-stack sampling probes, sample transport lines, a particulate filter, an activated charcoal canister, a silica-gel tritium trap, flow measurement and totalizing instruments, a sampling pump, and a return line to the stack. The sampling system at stack 3020 does not have a tritium trap.

In addition to the new instrumentation, a number of new programs have been implemented to ensure compliance with the regulations. A velocity profile program was initiated in 1992, whereby a quarterly velocity profile at each major stack is completed following the criteria in EPA Method 2. This ensures that the continuous samplers are sampling at acceptable isokinetic conditions and obtains accurate stack flow data for subsequent emission rate calculations. An annual leak check program was implemented to verify the integrity of the sample transport system, including the sample components. Also, a probe cleaning program was begun to ensure that all radioactive particulate matter emitted from a major source is collected and analyzed. This program requires the annual removal, cleaning, and collection of the rinsate from the sample probes at the major stacks.

In addition to major sources, minor sources were also evaluated during 1992 in accordance with the new NESHAP requirement. A variety of methods were used to determine the emissions from the various minor sources. All methods used for minor source emission calculations complied with the criteria agreed upon by EPA in The NESHAP Compliance Plan for the ORR. These minor sources will be evaluated on a 1-to 3 -year basis depending upon the source type.

All emissions, both major and minor, are compiled annually to determine the overall ORNL source term and associated dose. This is discussed in more detail in Sect. 2.

Data sources for the various isotopes identified in the 1992 airborne emission source term for major sources are shown in Table 3.2 and are further discussed in the summary. Double entries in the table indicate isotopes that were captured by more than one sampling medium.

\subsection{Summary}

The 1992 radioactive airborne emissions data for major sources included 41 isotopes. Table 3.2 provides a listing of the isotopes from each of the four stacks and the respective sampling media on which they were captured.

The charcoal canisters, particulate filters, and silica gel traps were collected weekly. The weekly tritium samples were composited for analysis every 2 weeks for about the first two quarters of 1992. For better quantification, the samples were then submitted weekly for the remainder of the year.

Charcoal canisters are a standard method for capturing and quantifying radioactive iodines in airborne emissions. Gamma spectrometric analysis of the charcoal samples quantifies the adsorbable gases.

Particulate filters were held for $8 \mathrm{~d}$ prior to a gross alpha and gross beta analysis to minimize the contribution from short-lived isotopes such as ${ }^{220} \mathrm{Rn}$ and its daughter products. For the 7911 filter, a weekly gamma scan was initiated in the latter part of the year to better detect short-lived gamma isotopes from the reactor. The weekly filters are then composited quarterly and analyzed for alpha-, beta-, and gamma-emitting isotopes. Compositing provides a better opportunity for quantification of these low-concentration isotopes. In addition to the particulate filters, the sample probe is removed from the stack at the end of the year for an annual cleaning and sampling. The probe is carefully rinsed and the rinsate is collected and submitted to the laboratory for isotopic analysis identical to that of the particulate filter. The data from the charcoal cartridges, silica gel, probe wash, and the quarterly filter composites are compiled to give the annual emissions for each major source.

Noble gas emissions from Stack 7911 were derived from real-time monitoring data. Noble gases are chemically inert and, consequently, cannot be trapped on a collecting medium for analysis. Instead, after the monitoring system gas stream has passed through the particulate filter and the charcoal filter, a part of the stream is pumped through a lead-shielded chamber that is equipped with a beta detector. The 


\section{Environmental Report Vol. 1, Oak Ridge}

Table 3.2. Data sources for airborne radioactive emissions from ORNL, 1992

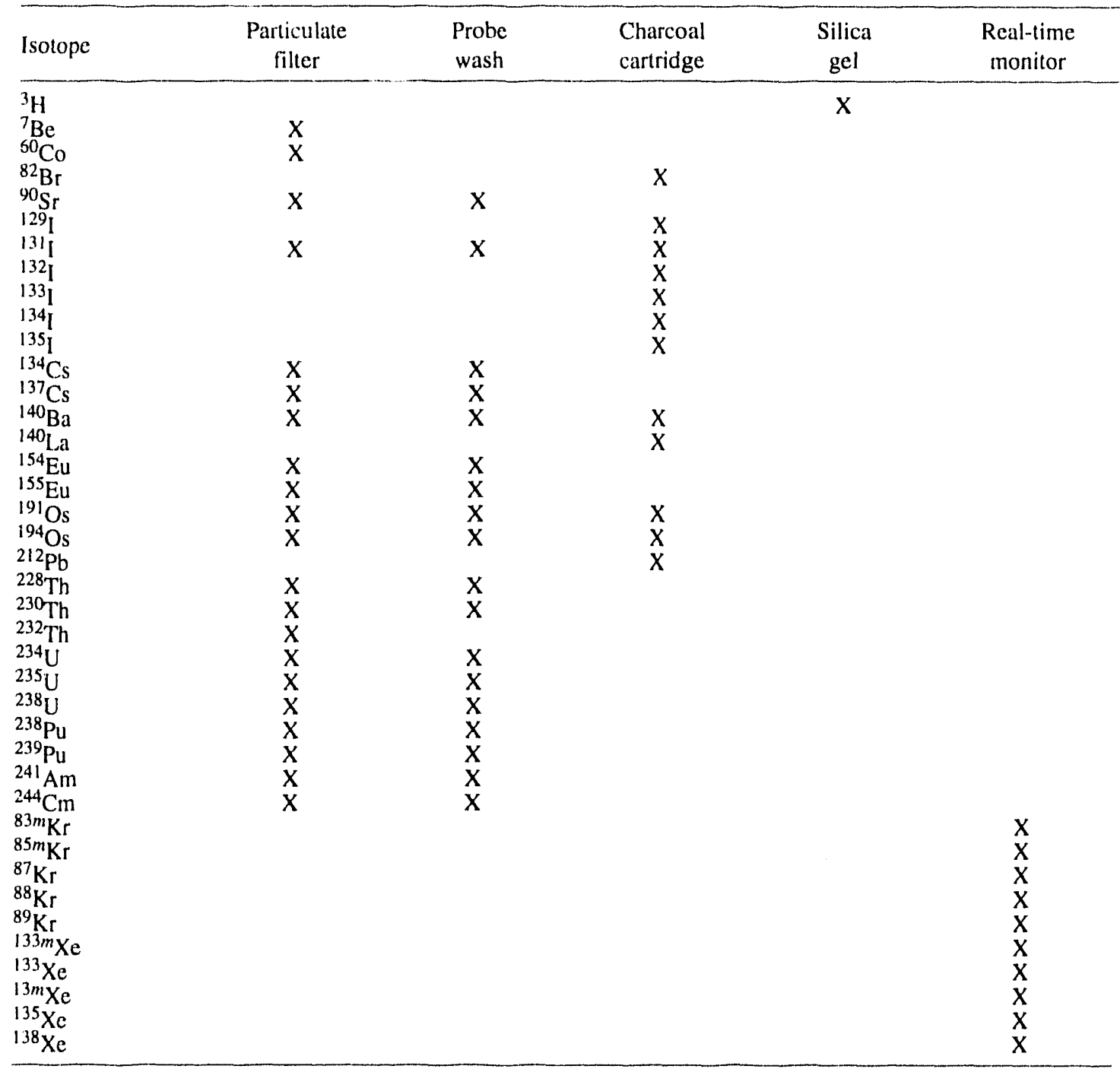

implicit assumption is that the upstream collecting media have removed all but the noble gases. The noble gas monitoring data are accrued as total counts; because the elapsed time is known, these data can be converted to a count rate. The chamber has been calibrated with ${ }^{85} \mathrm{Kr}$ at two concentrations. The calibration results can be used to convert counts per minute into noble gas activity as ${ }^{85} \mathrm{Kr}$. The 1992 noble gas emissions are based on the average counts-per-minute value for January-December 1992 and converted (using the calibration data) to an annual noble gas emission as ${ }^{85} \mathrm{Kr}$ equivalent.

\subsection{Radioactive Emissions}

The annual isotopic radioactive airborne emissions for major sources are presented in Table 3.3, and the minor source emissions are presented in Table 3.4. All data included in the table were determined to be significantly different from zero at the $95 \%$ confidence level. Any number that was not significantly different from zero was not included in the emission calculation.

Trends in historically analyzed emission parameters, tritium, ${ }^{131} \mathrm{I},{ }^{85} \mathrm{Kr}$, and ${ }^{133} \mathrm{Xe}$ are presented in Figs. 3.4-3.7. The tritium emissions, as shown in Fig. 3.4, are down an order of magnitude from the 
1992 Environmental Report Vol. 1, Oak Ridge

Table 3.3. ORNL major source emissions summary for 1992 (total curies)

\begin{tabular}{|c|c|c|c|c|c|}
\hline & Isotope & 7911 & 3020 & 2026 & 3039 \\
\hline${ }^{3} \mathrm{H}$ & & $5.44 \mathrm{E}+01$ & & $7.14 \mathrm{E}-0) 3$ & $1.95 \mathrm{E}+03$ \\
\hline${ }^{7} \mathrm{Be}$ & & & & & $8.74 \mathrm{E}-06$ \\
\hline${ }^{60} \mathrm{Co}$ & & $1.88 \mathrm{E}-08$ & & $3.83 \mathrm{E}-07$ & $1.99 \mathrm{E}-(-5)$ \\
\hline${ }^{82} \mathrm{Br}$ & & & & $1.02 \mathrm{E}-05$ & \\
\hline${ }^{90} \mathrm{Sr}$ & & $9.56 \mathrm{E}-06$ & $3.11 \mathrm{E}-06$ & $3.86 \mathrm{E}-05$ & $5.97 \mathrm{E}-0.5$ \\
\hline 1291 & & $1.89 \mathrm{E}-04$ & & & \\
\hline $131_{1}$ & & $1.25 \mathrm{E}-01$ & $1.60 \mathrm{E}-07$ & $3.81 \mathrm{E}-04$ & $3.22 \mathrm{E}-05$ \\
\hline $132 !$ & & $1.36 \mathrm{E}+00$ & & & \\
\hline${ }^{133} \mathrm{I}$ & & $6.48 \mathrm{E}-01$ & $1.58 \mathrm{E}-0.5$ & $9.32 \mathrm{E}-0.5$ & $8.72 \mathrm{E}-0.5$ \\
\hline 134 & & $2.05 \mathrm{E}-02$ & & $5.55 \mathrm{E}-07$ & \\
\hline 1351 & & $1.22 \mathrm{E}+00$ & $2.76 \mathrm{E}-04$ & $3.69 \mathrm{E}-0.5$ & $7.62 \mathrm{E}-04$ \\
\hline${ }^{134} \mathrm{Cs}$ & & & & $5.55 \mathrm{E}-07$ & \\
\hline${ }^{137} \mathrm{Cs}$ & & $2.92 \mathrm{E}-06$ & $3.73 \mathrm{E}-06$ & $2.80 \mathrm{E}-04$ & $9.72 \mathrm{E}-(1) 5$ \\
\hline${ }^{137} \mathrm{Ba}$ & & $2.92 \mathrm{E}-6$ & $3.73 \mathrm{E}-6$ & $2.80 \mathrm{E}-4$ & $9.72 \mathrm{E}-5$ \\
\hline${ }^{140} \mathrm{Ba}$ & & $1.00 \mathrm{E}-04$ & & & \\
\hline${ }^{140} \mathrm{La}$ & & $1.39 \mathrm{E}-06$ & & & \\
\hline${ }^{154} \mathrm{Eu}$ & & & & $1.66 \mathrm{E}-06$ & $4.21 \mathrm{E}-(06$ \\
\hline${ }^{155} \mathrm{Eu}$ & & & & $3.01 \mathrm{E}-06$ & \\
\hline${ }^{191} \mathrm{Os}$ & & & & $9.59 \mathrm{E}-03$ & $1.31 \mathrm{E}-(02$ \\
\hline${ }^{194} \mathrm{Os}$ & & & & & $1.68 \mathrm{E}-(12$ \\
\hline $212 \mathrm{~Pb}$ & & $1.84 \mathrm{E}-01$ & $2.26 \mathrm{E}-01$ & $1.81 \mathrm{E}-01$ & $9.58 \mathrm{E}-01$ \\
\hline${ }^{228} \mathrm{Th}$ & & $6.70 \mathrm{E}-09$ & $1.90 \mathrm{E}-08$ & $8.99 \mathrm{E}-06$ & $5.04 \mathrm{E}-107$ \\
\hline${ }^{230} \mathrm{Th}$ & & $2.32 \mathrm{E}-08$ & $1.14 \mathrm{E}-07$ & $1.92 \mathrm{E}-07$ & $3.18 \mathrm{E}-07$ \\
\hline${ }^{232} \mathrm{Th}$ & & $2.39 \mathrm{E}-09$ & $4.36 \mathrm{E}-09$ & $3.99 \mathrm{E}-09$ & $7.87 \mathrm{E}-09$ \\
\hline${ }^{234} \mathrm{U}$ & & $1.20 \mathrm{E}-07$ & $2.37 \mathrm{E}-07$ & $2.09 \mathrm{E}-05$ & $8.65 \mathrm{E}-07$ \\
\hline${ }^{235} \mathrm{U}$ & & $1.31 \mathrm{E}-08$ & $2.02 \mathrm{E}-08$ & $3.80 \mathrm{E}-07$ & $6.33 \mathrm{E}-08$ \\
\hline${ }^{238} \mathrm{U}$ & & $2.84 \mathrm{E}-08$ & $3.07 \mathrm{E}-08$ & $3.55 \mathrm{E}-07$ & $8.05 \mathrm{E}-08$ \\
\hline${ }^{238} \mathrm{Pu}$ & & $2.04 \mathrm{E}-08$ & $2.68 \mathrm{E}-07$ & $6.79 \mathrm{E}-06$ & $3.11 \mathrm{E}-(1) 7$ \\
\hline${ }^{239} \mathrm{Pu}$ & & $6.83 \mathrm{E}-08$ & $1.90 \mathrm{E}-07$ & $1.88 \mathrm{E}-05$ & $1.50 \mathrm{E}-106$ \\
\hline $24 ! \mathrm{Am}$ & & $3.08 \mathrm{E}-08$ & $3.54 \mathrm{E}-07$ & $1.26 \mathrm{E}-05$ & $5.42 \mathrm{E}-07$ \\
\hline${ }^{2+4} \mathrm{Cm}$ & & $5.33 \mathrm{E}-07$ & $1.01 \mathrm{E}-06$ & $1.97 \mathrm{E}-04$ & $4.23 \mathrm{E}-06$ \\
\hline${ }^{83 m} \mathrm{Kr}$ & & $7.32 \mathrm{E}+01$ & & & \\
\hline${ }^{85 m} \mathrm{Kr}$ & & $1.73 \mathrm{E}+02$ & & & \\
\hline${ }^{87} \mathrm{Kr}$ & & $3.50 \mathrm{E}+02$ & & & \\
\hline${ }^{88} \mathrm{Kr}$ & & $4.94 \mathrm{E}+02$ & & & \\
\hline${ }^{89} \mathrm{Kr}$ & & $6.27 \mathrm{E}+02$ & & & \\
\hline $133 m \times \mathrm{Xe}$ & & $2.74 E+01$ & & & \\
\hline${ }^{133} \mathrm{Xe}$ & & $8.81 E+02$ & & & \\
\hline${ }^{135 m} \mathrm{Xe}$ & & $1.55 E+02$ & & & \\
\hline $\begin{array}{l}{ }^{135} \mathrm{Xe} \\
138 \mathrm{Xe}\end{array}$ & & $\begin{array}{l}2.82 \mathrm{E}+01 \\
8.50 \mathrm{E}+02\end{array}$ & & & \\
\hline
\end{tabular}

1991 emissions as a result of reduction in tritium work at ORNL.

The noble gas source term for 7911 contains a variety of noble gases. Historically, the noble-gas composition was assumed to be $83 \%{ }^{133} \mathrm{Xe}$ and $17 \%$ ${ }^{85 m} \mathrm{Kr}$. A better method to determine the noble gas composition has been implemented. The noble gases emitted from the 7911 stack will be assumed to be that determined from the Oak Ridge Isotopic Generation and Depletion (ORIGEN) computer code (Hermann and Westfall 1992) for the core of the High Flux Isotope Reactor (HFIR) after $24 \mathrm{~d}$ of operation. The isotopic percentages (see spot table) were applied to the data derived from the in-line noble-gas

\begin{tabular}{cc}
\hline Isotope & Percentage \\
\hline${ }^{83 m} \mathrm{Kr}$ & 2 \\
$85{ }^{\prime} \mathrm{Kr}$ & 4.73 \\
$87 \mathrm{Kr}$ & 9.56 \\
$88 \mathrm{Kr}$ & 13.51 \\
$89 \mathrm{Kr}$ & 17.14 \\
$133 \mathrm{~m} \times \mathrm{Xe}$ & 0.75 \\
$133 \mathrm{Xe}$ & 24.08 \\
$135 \mathrm{Xe}^{\mathrm{X}}$ & 4.23 \\
$135 \mathrm{Xe}$ & 0.77 \\
$138 \mathrm{Xc}$ & 23.23 \\
\hline
\end{tabular}

monitor to determine the curies of each noble gas listed for 7911 in Table 3.3 .

Use of the newer composition leads to higher dose estimates than were obtained using the historical 


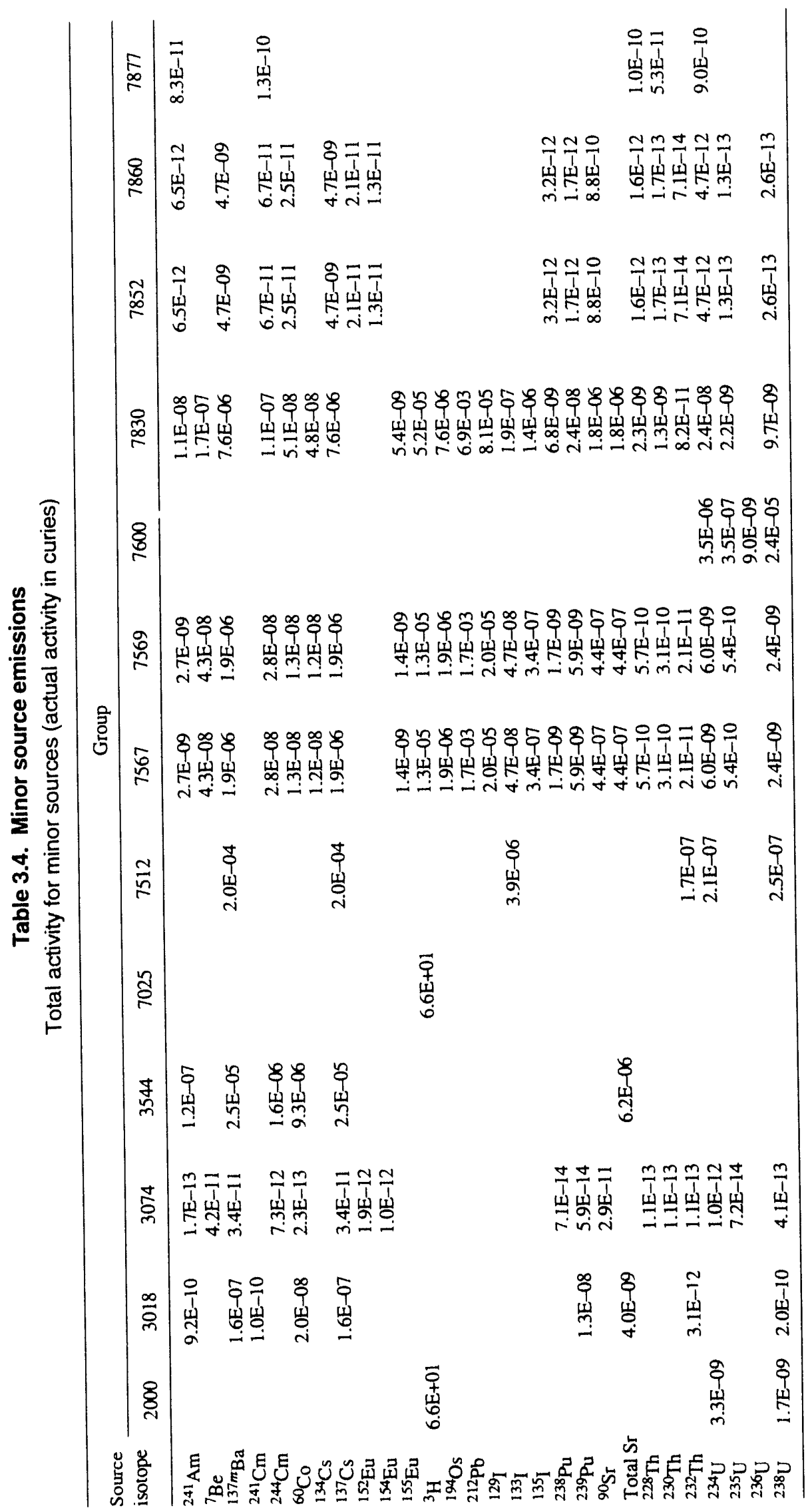




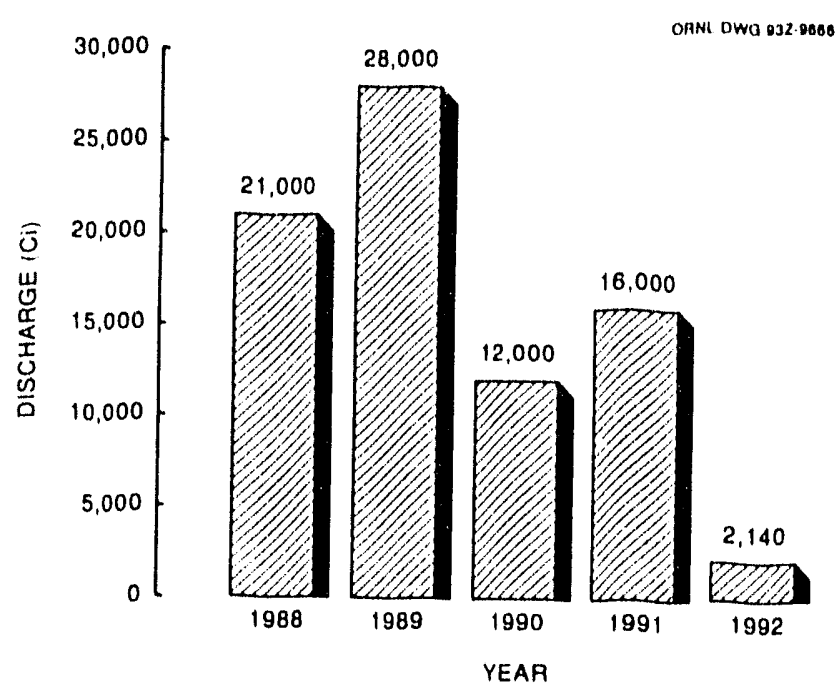

Fig. 3.4. Total discharges of ${ }^{3} \mathrm{H}$ from ORNL to the atmosphere, 1988-1992.

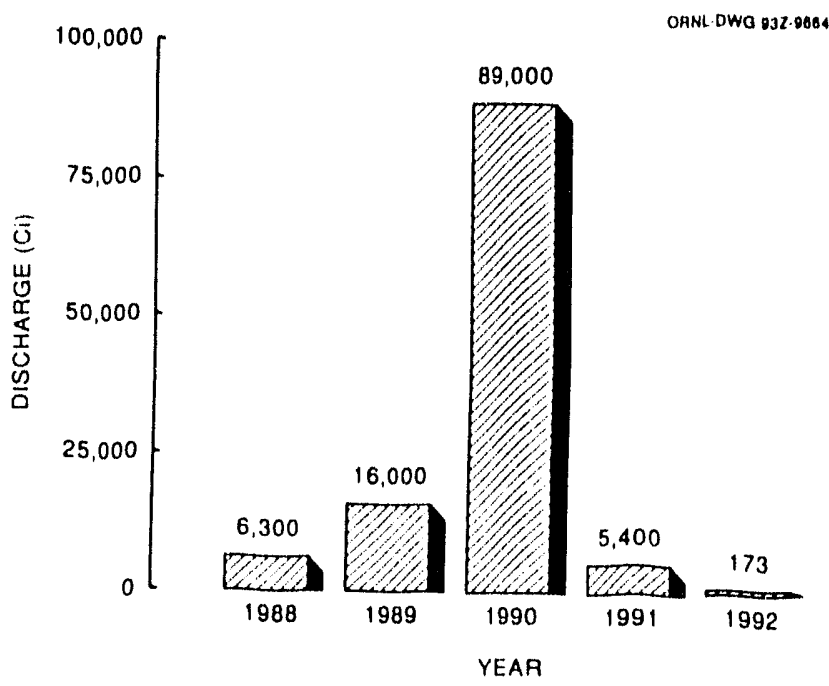

Fig. 3.6. Total discharges of ${ }^{85} \mathrm{Kr}$ from ORNL to the atmosphere, 1988-1992.

composition. An assessment of the potential impacts of the emission source term to the public is presented in Sert. 2.

since the packaging of ${ }^{85} \mathrm{Kr}$ has been moved 10 the Idaho National Engineering Laboratory and the 1991 emissions of ${ }^{85} \mathrm{Kr}$ were very low in $1991,{ }^{85} \mathrm{Kr}$ is no longer being monitored at Stack 3039.

\subsection{Chemical Emissions}

Total particulate and chemical emissions from any one emission point at ORNL, are very low, except

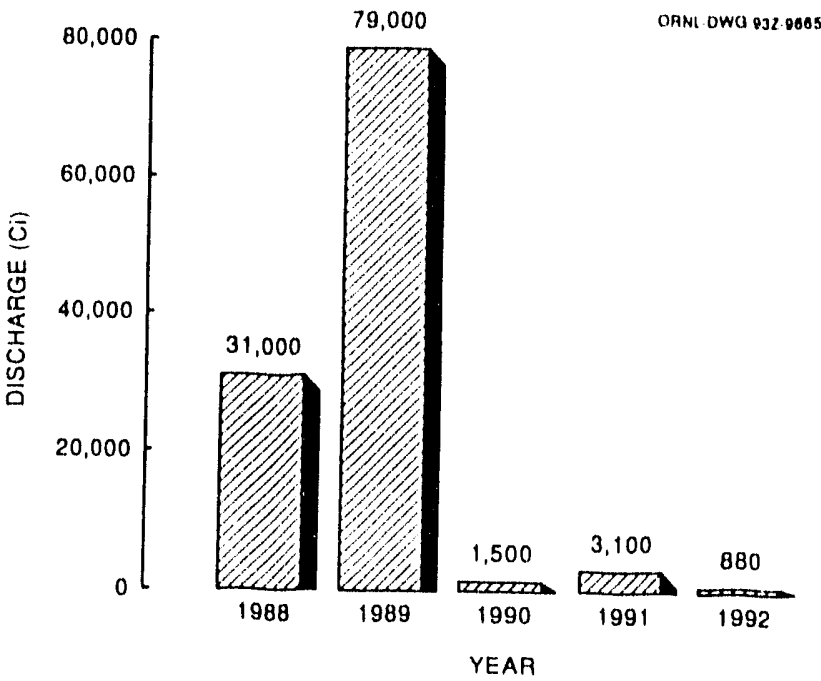

Fig. 3.5. Total discharges of ${ }^{133} \mathrm{Xe}$ from ORNL to the atmosphere, 1988-1992.

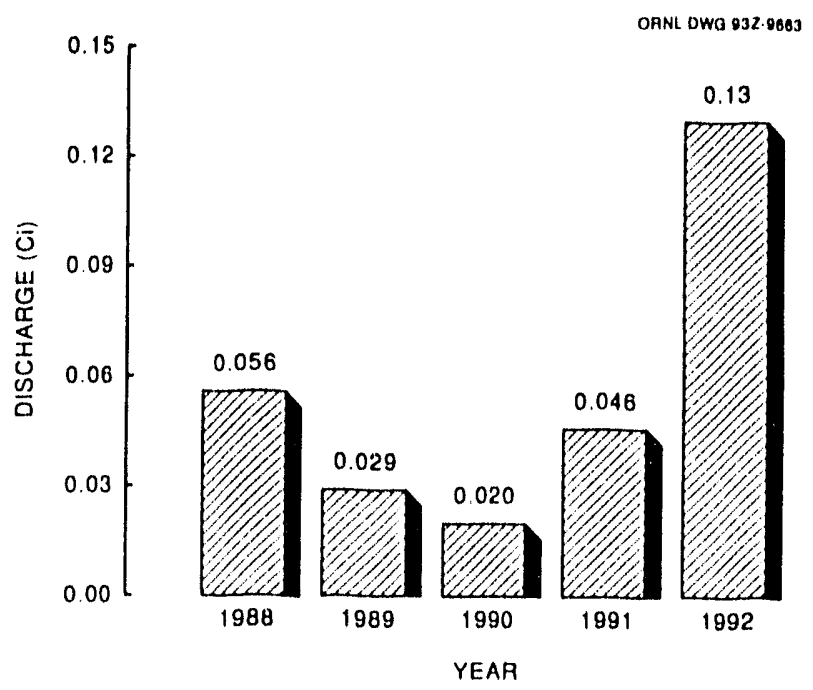

Fig. 3.7. Total discharges of ${ }^{131} \mid$ from ORNL to the atmosphere, 1988-1992.

for the steam plant. Therefore, the air permits issued by the TDEC Air Pollution Control Board do not require sampling or monitoring at any of the permitted emission points except the steam plant: however, sampling is conducted monthly at the Nonradiological Wastewater Treatment Facility to ensure that the volatile organic compound airborne emissions do not exceed the permit limits. Estimates of major chemical emissions are included in Appendix A (Table A.2). 


\subsubsection{K-25 Site}

\subsubsection{Description}

The K-25 Site airborne discharges result from residual contamination, waste storage and disposal, site remediation, and site operational support activities (Table A.3). Since the shutdown of the gaseous diffusion process sources, the primary source of radiological emissions is the Toxic Substances Control Act (TSCA) Incinerator. It operates in full regulatory compliance using extensive exhaust gas treatment and control equipment and is the only major radionuclide emission source. A schematic of the K-25 Site air emission sources and the relevant air pollution control program are presented in Fig. 3.8 and Fig. 3.9, respectively.

Steam plant emissions have accounted for most of the criteria pollutant emissions, although efforts continued in 1992 to convert to the use of more efficient natural gas boilers, with number 2 fuel oil used as an occasional backup and coal burning phased out completely. Construction has begun on another natural gas/fuel oil boiler with flue gas recirculation to control nitrogen oxide emissions; this boiler, along with a similar one placed in operation in 1991, is more efficient than the older boilers and will provide most of the steam for the K-25 Site.

A primary source of Title XI pollutants at the K-25 Site has been the former gaseous diffusion process buildings, where the refrigerant chlorofluorocarbon (CFC-114) has remained in the process cooling systems. An estimated 2.3 million pounds of the coolant remain in the massive systems, and an estimated 19,000 pounds of $\mathrm{CFC}-114$ vapor, a Class I ozone-depleting substance, were lost through leakage in 1992. Planning and initial activities are under way to transfer the remaining coolant to the operational gaseous diffusion plants at Portsmouth, Ohio, and Paduciah, Kentucky.

The permitted air sources at the K-25 Site are listed in Table 3.3 in Vol. 2. Many of these sources are in standby status since the shutdown of the gaseous diffusion process. As new uses for these sources are identified the permits will be updated to reflect the new process. Based on a potential to emit 1122 tons per year of applicable regulated pollutants from these permilled sources, the annual air emission fee per the K-25 Site was calculated by TDEC as $\$ 5329.50$.

\subsubsection{Radioactive Emissions}

Figure 3.8 describes the general types of air emission sources at the K-25 Site, and Fig. 3.9 is an overview of the air pollution control program. The locations of airborne radioactive effluent release points at the K-25 Site are shown in Fig. 3.I0.

Radioactive emissions data were determined from either sampling results or calculations, as follows:

- Continuous stack sampling was performed during operating periods of the TSCA Incinerator, which is the only major radionuclide emission source at the K-25 Site. The total 1992 radionuclide emissions from the incinerator are shown in Table 3.5. The sum of all minor emissions (other than the K-1435 TSCA incinerator) are shown in Table 3.6.

- The minor point sources that were sampled using grab-sample techniques (e.g., EPA Method 5 techniques) were the K-1015 Laundry and the K-1417 Pond Waste Management Project (PWMP) Dewatering. PWMP Dewatering was initiated to dry K-1417 Pond waste sludge; stack samples taken at startup during the highest production rates were applied to actual operating hours in 1992.

- The K-1420 Disassembly Area emissions were determined by analyzing the exhaust HEPA filter.

- Point sources for which the emissions were calculated using an EPA-approved material balance method were the grouped sources K-1004A,B,C,D and K-1435-A Laboratories (22 emission points), the K-1004L Laboratories (29 emission points), and the K-1006 Laboratories (20 emission points), and three laboratory vents in three separate buildings.

- Sources for which the emissions were calculated using 40 CFR 61, Appendix D, criteria were the $\mathrm{K}-1435$ storage tanks and $\mathrm{K}-1008 \mathrm{-C}$ - respirator cleaning hood.

\section{3-14 Airborne, Ambient Air, Meteorological, and External Gamma}




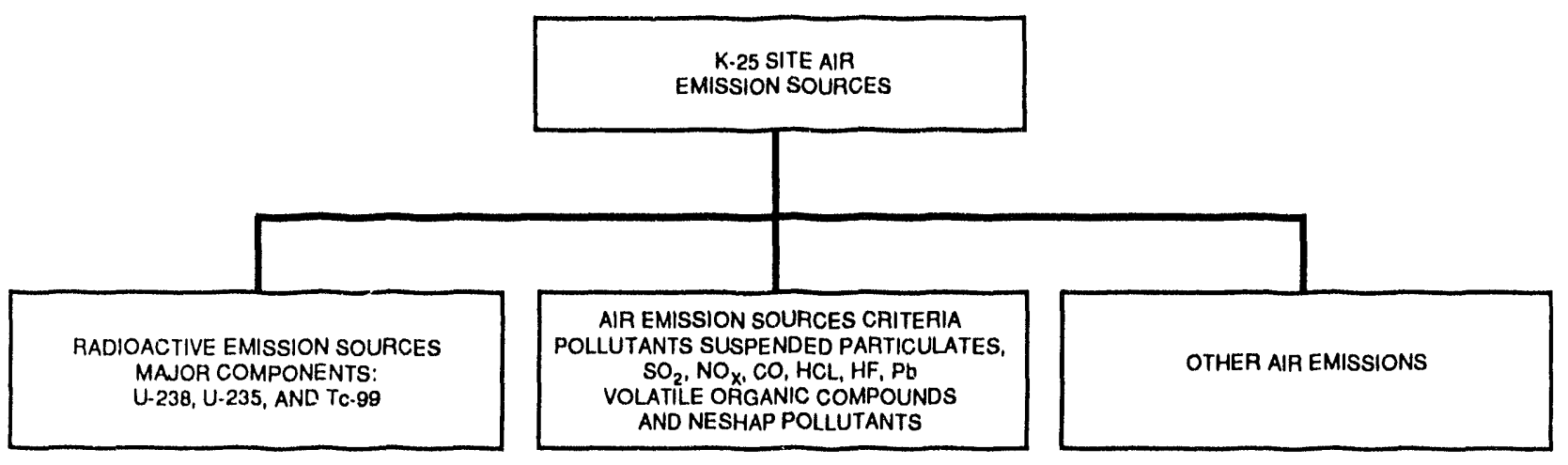

Fig. 3.8. Air emission sources at the K-25 Site.

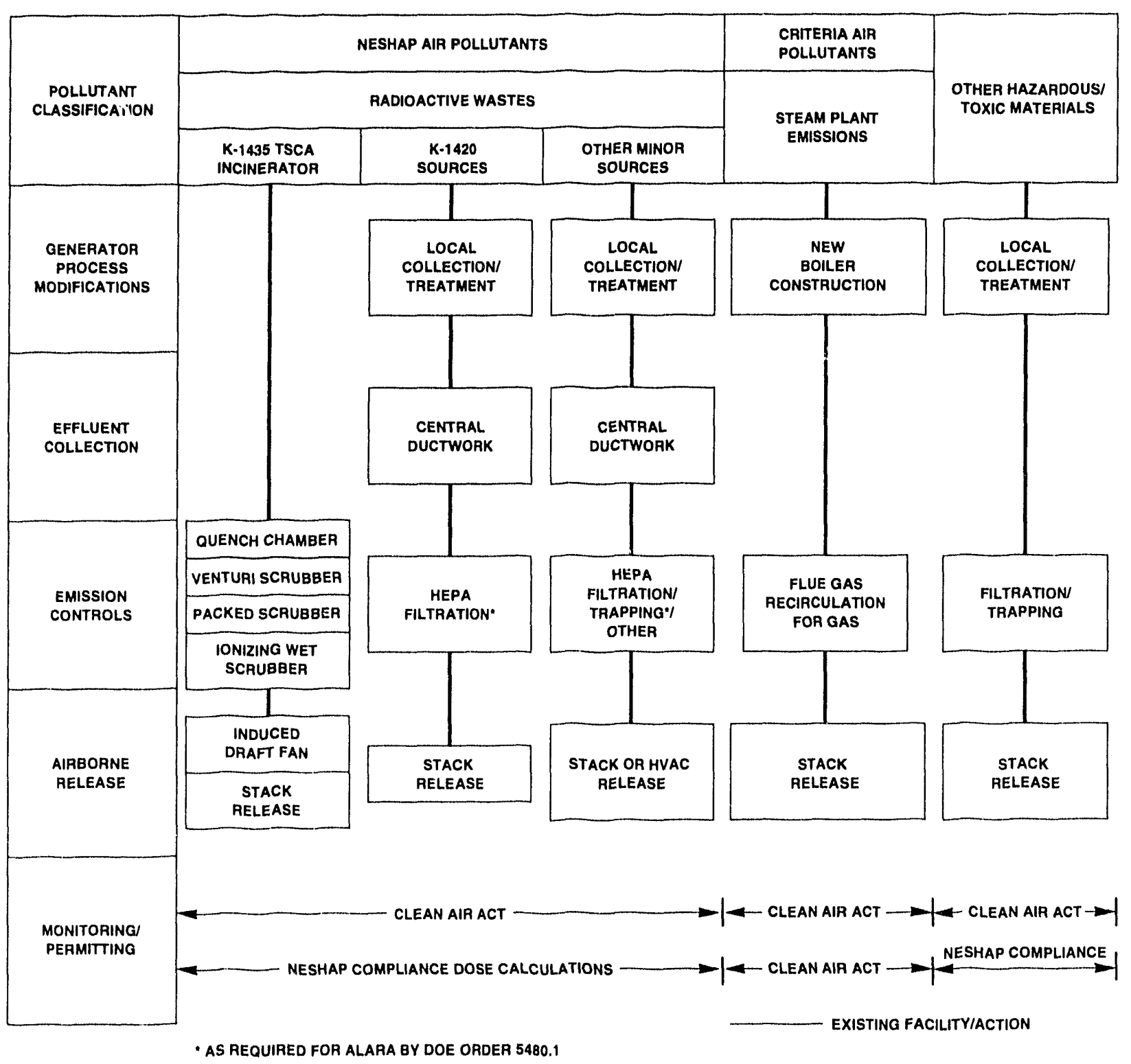

Fig. 3.9. Air pollution control program at the K-25 Site. 
ORNL.DWG 87M-8357135

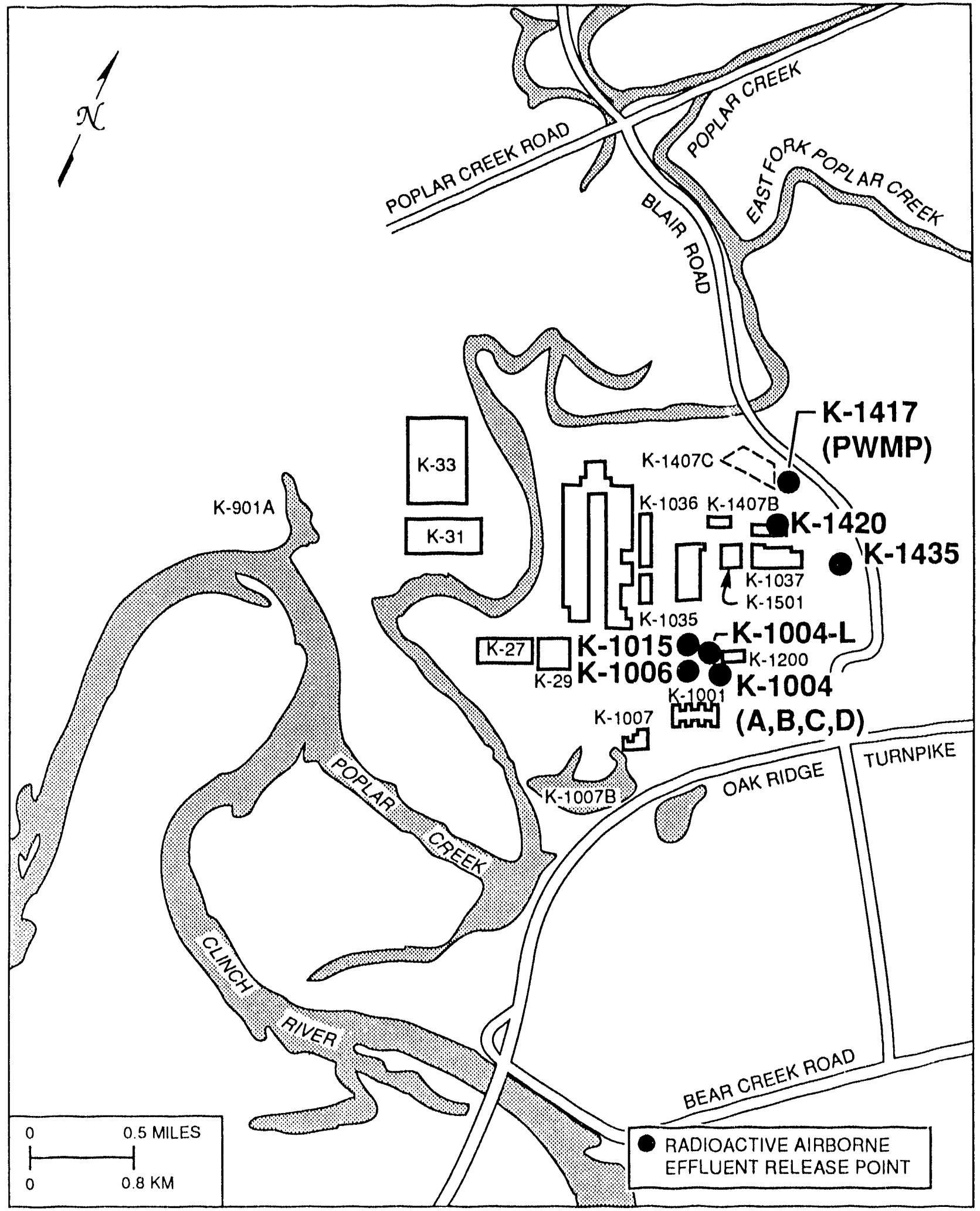

Fig. 3.10. Locations of radioactive airborne effluent release points at the K-25 Site. 


\section{Environmental Report Vol. 1, Oak Ridge}

Table 3.5. Total radionuclide emissions during normal operations from the K-25 Site TSCA Incinerator for 1992

\begin{tabular}{cc}
\hline Radionuclide & $\begin{array}{c}\text { Emissions } \\
(\mathrm{Ci})\end{array}$ \\
\hline${ }^{237} \mathrm{~Np}$ & $1.10 \mathrm{E}-4$ \\
${ }^{238} \mathrm{Pu}$ & $8.54 \mathrm{E}-6$ \\
${ }^{239} \mathrm{Pu}$ & $6.06 \mathrm{E}-6$ \\
${ }^{99} \mathrm{Tc}$ & $-6.59 \mathrm{E}-3$ \\
${ }^{228} \mathrm{Th}$ & $1.54 \mathrm{E}-3$ \\
${ }^{230} \mathrm{Th}$ & $6.84 \mathrm{E}-5$ \\
${ }^{232} \mathrm{Th}$ & $2.96 \mathrm{E}-5$ \\
${ }^{234} \mathrm{Th}$ & $-6.25 \mathrm{E}-2$ \\
${ }^{137} \mathrm{Cs}$ & $-1.74 \mathrm{E}-4$ \\
${ }^{234 m} \mathrm{~Pa}$ & $3.84 \mathrm{E}-1$ \\
${ }^{144} \mathrm{Ce}$ & $1.23 \mathrm{E}-6$ \\
${ }^{40} \mathrm{~K}$ & $1.01 \mathrm{E}-3$ \\
${ }^{106} \mathrm{Ru}$ & $4.36 \mathrm{E}-4$ \\
Total uranium & $5.99 \mathrm{E}-2$ \\
${ }^{234} \mathrm{U}$ & $2.28 \mathrm{E}-2$ \\
${ }^{235} \mathrm{U}$ & $9.19 \mathrm{E}-4$ \\
${ }^{238} \mathrm{U}$ & $3.62 \mathrm{E}-2$ \\
\hline
\end{tabular}

- Stack emissions from the K-1015 Laundry were determined from operational data and representative sampling.

Figures 3.11 and 3.12 compare the K-25 Site's 1992 discharges of uranium with those of previous years. 1992 was the first full year of incinerator operations, and the uranium emissions originated almost entirely from these operations. Also shown are the technetium trends in Figs. 3.13 and 3.14.

\subsection{Ambient Air Monitoring}

In addition to stack monitoring and sampling conducted at the DOE Oak Ridge installations, an ambient air monitoring program has been developed to measure radiological and other selected parameters directly in the ambient air adjacent to the facilities. Ambient air monitoring provides direct measurement of airborne concentrations of radionuclides and other hazardous pollutants in the environment surrounding the facilities, allows facility personnel to determine the relative level of contaminants at the monitoring locations during an emergency, verifies that the contributions of fugitive and diffuse sources are insignificant, and serves as a check on dose-modeling calculations.
Table 3.6. 1992 radionuclide emissions from minor sources at the K-25 Site

\begin{tabular}{lr}
\hline Radionuclide & $\begin{array}{c}\text { Minor source totals } \\
\text { (Ci/year) }\end{array}$ \\
\hline${ }^{237} \mathrm{~Np}$ & $-1.66 \mathrm{E}-04$ \\
${ }^{238} \mathrm{Pu}$ & $5.94 \mathrm{E}-04$ \\
${ }^{239} \mathrm{Pu}$ & $1.06 \mathrm{E}-04$ \\
${ }^{99} \mathrm{Tc}$ & $6.10 \mathrm{E}-02$ \\
${ }^{228} \mathrm{Th}$ & $-5.45 \mathrm{E}-05$ \\
${ }^{230} \mathrm{Th}$ & $6.73 \mathrm{E}-04$ \\
${ }^{232} \mathrm{Th}$ & $-7.71 \mathrm{E}-06$ \\
${ }^{234} \mathrm{Th}$ & $-7.44 \mathrm{E}-03$ \\
${ }^{137} \mathrm{Cs}$ & $8.16 \mathrm{E}-05$ \\
${ }^{137 m} \mathrm{Ba}$ & $8.16 \mathrm{E}-05$ \\
${ }^{234 m} \mathrm{~Pa}$ & $2.34 \mathrm{E}-02$ \\
${ }^{144} \mathrm{Ce}$ & $0.00 \mathrm{E}+00$ \\
${ }^{40} \mathrm{~K}$ & $0.00 \mathrm{E}+00$ \\
${ }^{106} \mathrm{Ru}$ & $0.00 \mathrm{E}+00$ \\
${ }^{234} \mathrm{U}$ & $2.66 \mathrm{E}-03$ \\
${ }^{235} \mathrm{U}$ & $2.02 \mathrm{E}-04$ \\
${ }^{238} \mathrm{U}$ & $1.16 \mathrm{E}-03$ \\
& \\
Total & $8.22 \mathrm{E}-02$ \\
\hline
\end{tabular}

The following sections discuss the ambient air monituring networks for the Energy Systems Oak Ridge instaliations. The ORR network consists of eight ambient air monitors located around the perimeter of the reservation and at two remote locations in the surrounding communities. With the exception of perimeter air monitors around the Y-12 Plant and the K-25 Site and TSCA ambient air monitors near the K.-25 Site, all ambient air monitors were operated by ORNL during 1992. The following discussions include data summary tables in which 1992 ambient air monitoring results for each station are presented. For a more complete presentation of these data, see Vol. 2, Tables 3.4-3.12.

\subsubsection{Y-12 Plant}

\subsubsection{Description}

The Y-12 Plant currently operates a number of monitoring stations to assess ambient air quality within the plant and around the plant perimeter. The following types of ambient monitoring systems are in place at the facility:

- twelve low-volume uranium particulate monitoring stations; 


\section{9פ2 Environmental Report Vol. 1, Oak Ridge}

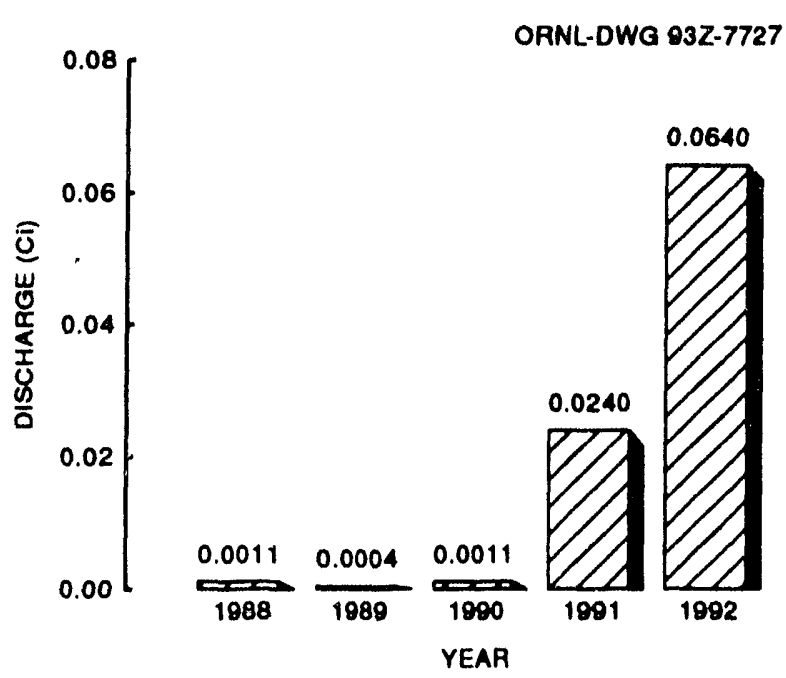

Fig. 3.11. Total curie discharges of uranium from the K-25 Site to the atmosphere, 1988-1992.

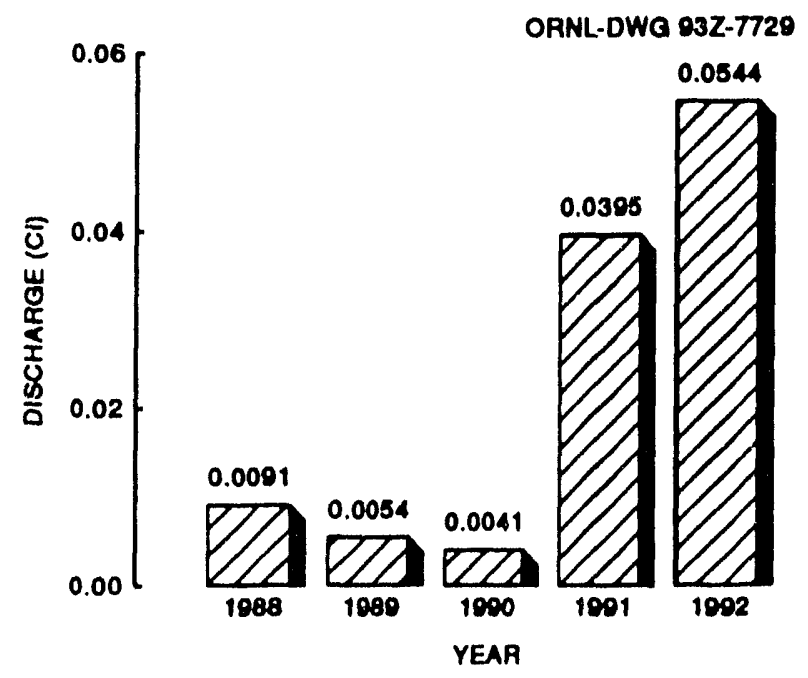

Fig. 3.13. Total curie discharges of technetium from the K-25 Site to the atmosphere, 1988-1992.

- eleven fluoride monitoring stations;

- two TSP/PM10 monitoring stations; and

- four mercury monitoring stations.

In addition to the permanent monitoring stations, two mobile Fourier Transform Infrared Spectroscopy (FTIR) systems have been obtained for the

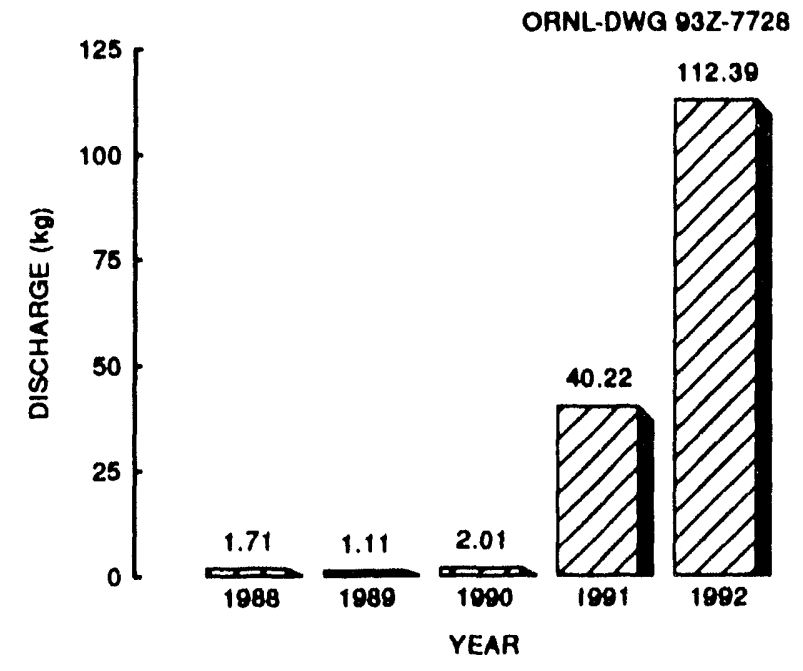

Fig. 3.12. Total kilograms of uranium discharged from the K-25 Site to the atmosphere, 1988-1992.

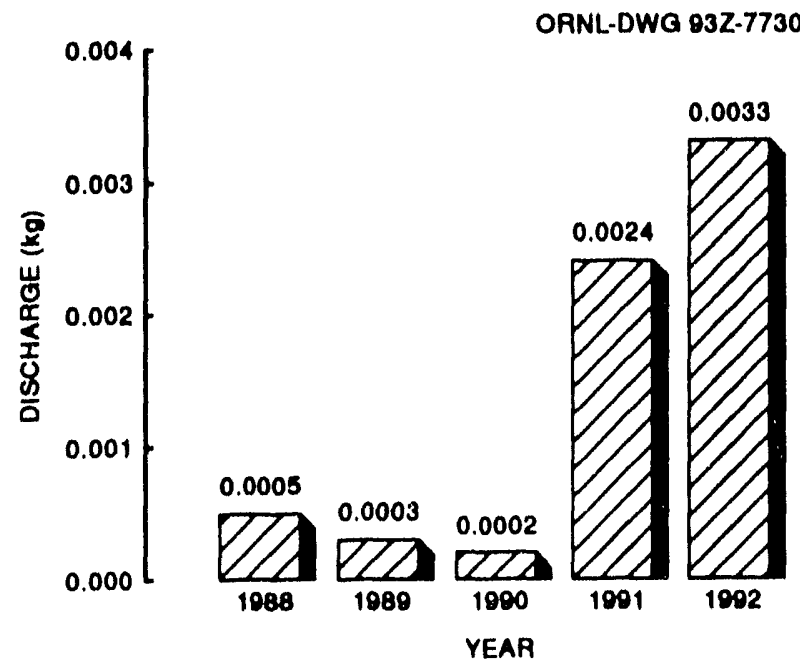

Fig. 3.14. Total kilograms of technetium discharges from the K-25 Site to the atmosphere, 1988-1992.

measurement of gaseous hazardous air pollutants. All ambient air monitoring systems of the Y-12 Plant are operated as a best management practice and are not required for regulatory or DOE order compliance.

The Y-12 Plant operates 12 ambient air monitoring stations located around the plant perimeter for routine measurement of suspended 
ORNL-DWG 86M-9184R3

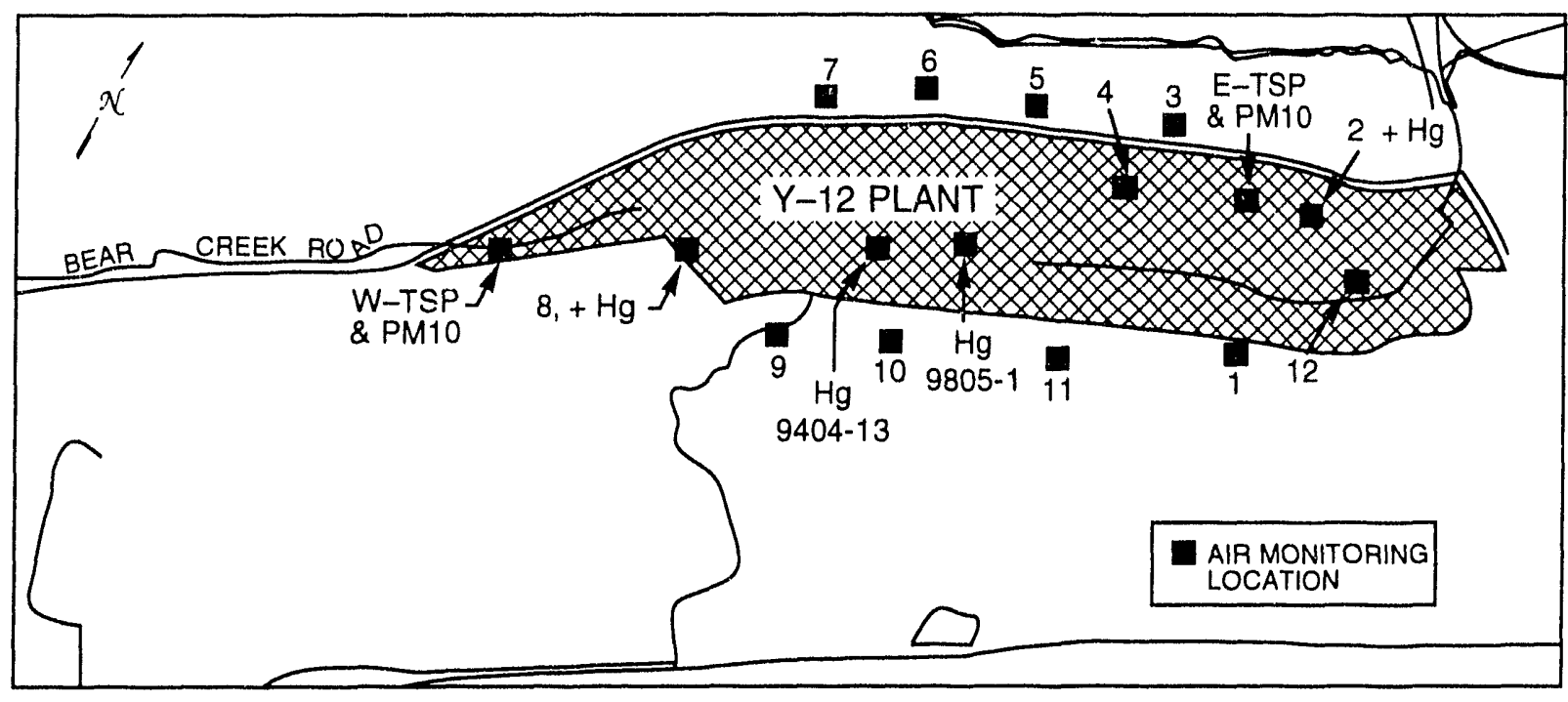

Fig. 3.15. Ambient air monitoring stations at the Y-12 Plant.

uranium particulate matter. Samples are collected by pulling ambient air across a square $14-\mathrm{cm}(5.5$-in.) filter, which is analyzed by the Y-12 Plant Analytical Services Organization for gross alpha and gross beta. In addition, alpha spectroscopy is performed to measure activity of specific uranium radionuclides. The location of the monitoring stations are shown in Fig. 3.15.

Along with uranium particulate matter, atmospheric fluoride samples are collected at 11 of the 12 sites. Atmospheric fluoride in the ambient air is collected on $37-\mathrm{mm}(1.5$-in.) diameter filters that have been pretreated with potassium carbonate. The filters are analyzed by the $\mathrm{Y}-12$ Plant Laboratory using the selective ion electrode method (EPA 340.2). The ambient air fluoride monitoring stations are shown in Fig. 3.15.

Monitors for total suspended particulate (TSP) and respirable particulate (PM10) in the ambient air are located at the east and west ends of the site. Sampling for particulate matter consists of drawing air at a known rate through a preweighed filter for $24 \mathrm{~h}$ every $6 \mathrm{~d}$. A particle concentration can be calculated from the weight differential associated with the particle accumulation on the filter during the sample period. The TSP sampling system uses a glass filter; the PM10 sampling system uses a quartz filter.

Concentration values are compared with the Tennessee primary and secondary ambient air quality standards. Sample results are not submitted to TDEC or EPA but are used as an internal measure of area ambient air quality. If a sample is found to exceed the state standard, Y-12 Plant personnel have the filter scrutinized under a microscope to determine the cause. In all previous cases, the increase in particulate matter did not result from process emissions. Rather, most of the filter was covered with road dust, pollen, insects, and other particles arising from the natural environment.

In 1990 three PM10 samplers designed to collect particles smaller than 10 microns were installed adjacent to the existing TSP samplers; one PM10 at the west site and two PM10s at the east site. The PM10s were brought on line in the fall of 1990 and were operated on the same schedule as the TSPs. Some data from the PM10s were collected in 1991. However, most results indicated a negative net weight. A study was conducted to determine the cause. As a result, changes were made in handling the special quartz filters both in the field and in the lab. In addition, the lab ordered a new scale for weighing the TSP and PM10 filters. The scale was installed in 1992.

In 1986 the Y-12 Plant established an on-site monitoring program to measure mercury vapor concentrations in ambient air. The goals of the program were to establish a historical data base of mercury concentrations in ambient air at the Y-12 Plant, identify spatial and temporal trends in mercury vapor concentrations, and demonstrate 


\section{Environmental Report Vol. 1, Oak Ridge}

protection of the environment and human health from releases of mercury from the $Y-12$ Plant to the atmosphere. Airborne mercury at the Y-12 Plant results primarily from mercury vaporization from contaminated soils, the burning of coal at the Y-12 Steam Plant, and fugitive emissions from Bldg. 9201-4, a former lithium isotope separation facility that is contaminated with mercury.

Four ambient mercury monitoring stations (stations on the east and west ends of the plant and two stations near Building 9201-4) were established on site in 1986, with an additional site added at New Hope Pond in August 1987. In February 1988, a control site was established at Rain Gage No. 2 on Chestrut Ridge in the Walker Branch Watershed. After collecting data for one calendar year to establish background concentrations and a seasonal pattern for the control site, the Rain Gage No. 2 site was discontinued. The New Hope Pond site was abandoned in 1989, several months after the closure of the pond.

Because no established or EPA-approved methods for measuring mercury vapor in ambient air existed when the program was initiated, staff of the ORNL Environmental Sciences Division developed a method to meet the needs of the monitoring program for the Y-12 Plant. At each of the sites, airborne mercury is collected on charcoal by pulling air through a Teflon filter followed by a flow-limiting orifice and a sampling tube packed with iodated charcoal. The charcoal sampling tubes are changed every $7 \mathrm{~d}$. A verage air concentration of mercury vapor for each 7-d sampling period is calculated by dividing the total quantity of mercury collected on the charcoal by the total volume of air (corrected to standard conditions) pulled through the tube.

Beginning in January 1992, mercury collected on the charcoal is analyzed by neutron activation analysis. Prior to 1992, mercury on charcoal was analyzed by cold vapor atomic absorption spectrophotometry after digestion in nitric-perchloric acid.

\subsubsection{Summary}

Ambient air monitoring results for the $\mathrm{Y}-12$ Plant perimeter air monitors are summarized in Tables 3.7-3.12. Table 3.7 shows the maximum, minimum, and average gross alpha and gross beta concentrations measured at each of the 12 stations during 1992. Similarly, the ${ }^{234} \mathrm{U},{ }^{235} \mathrm{U},{ }^{236} \mathrm{U}$, and ${ }^{23 .} \mathrm{U}$ average concentrations are shown in Table 3.8. Table 3.9 shows similar data for ambient fluoride concentrations during 1992 as well as a comparison with the state standard for fluorides.

Table 3.10 and Fig. 3.16 present the mercury monitoring data summarized for the entire period from 1986 through 1992. Table 3.11 shows TSP data for the two Y-12 Plant TSP ambient air monitoring stations during 1992. Table 3.12 shows 1992 PM 10 data. More detailed data are available in Vol. 2 , Tables 3.4-3.8.

\subsubsection{Discussion}

Ambient air concentrations of fluorides measured during 1992 at each of the Y-12 Plant perimeter air monitoring fluoride stations were well below TDEC standards, averaging less than $1 \%$ of the standards with the exception of Station 5, which ran with an unacceptably low flow for several months. This adversely affected the calculated concentrations. The low flow condition has been corrected, and ambient air sampling personnel are working closely with maintenance to ensure that such conditions are corrected in a timely manner.

Ambient uranium isotope concentrations measured at each of the 12 perimeter air monitoring stations around the $\mathrm{Y}-12$ Plant were also very low. Although there is no federal or state standard that applies to ambient uranium or uranium isotope concentrations, measured values are within guidelines set forth in DOE Order 5400.5 .

Table 3.4 in Vol. 2 gives gross alpha and gross beta concentrations in air at the Y-12 Plant for 1992.

TSP and PM10 samples collected at the Y-12 Plant indicated no exceedances of state primary or secondary standards in 1992. Samples were not collected in January through April pending the installation of a new scale in the plant laboratory.

With few exceptions, results of the mercury-monitoring program show significant decreases (Student's t-test at the 1\% level) in annual means for ambient mercury vapor measured at the plant sites during 1989, 1990, 1991, and 1992 when compared with the means for 1986 through 1988. The decrease in ambient mercury recorded at these sites is thought to be related to the reduction in coal burned at the Y-12 steam plant beginning in 1989 and to the 
1992 Environmental Report Vol. 1, Oak Ridge

Table 3.7. 1992 gross alpha and beta in air at the Y-12 Plant perimeter ambient air monitoring stations

\begin{tabular}{|c|c|c|c|c|}
\hline \multirow[t]{2}{*}{ Station } & \multirow{2}{*}{$\begin{array}{l}\text { Number of } \\
\text { analyses }^{a}\end{array}$} & \multicolumn{3}{|c|}{$\begin{array}{c}\text { Concentration } \\
\left(10^{-15} \mu \mathrm{Ci} / \mathrm{cm}^{3}\right)^{b}\end{array}$} \\
\hline & & $\operatorname{Max}$ & Min & Av \\
\hline \multicolumn{5}{|c|}{. } \\
\hline \multicolumn{5}{|c|}{ Gross alpha } \\
\hline 1 & 4 & 0.324 & -0.026 & 0.184 \\
\hline 2 & 4 & 0.513 & -0.289 & 0.126 \\
\hline 3 & 4 & 0.423 & 0.149 & 0.318 \\
\hline 4 & 4 & 0.521 & -0.730 & -0.010 \\
\hline 5 & 4 & 0.756 & 0.053 & 0.521 \\
\hline 6 & 4 & 0.454 & 0.020 & 0.253 \\
\hline 7 & 4 & 0.234 & 0.032 & 0.147 \\
\hline 8 & 4 & 0.481 & -0.114 & 0.188 \\
\hline 9 & 4 & 0.492 & 0.068 & 0.203 \\
\hline 10 & 4 & 0.448 & -0.092 & 0.221 \\
\hline 11 & 4 & 0.234 & 0.125 & 0.181 \\
\hline 12 & 4 & 0.463 & 0.068 & 0.214 \\
\hline \multicolumn{5}{|c|}{ Gross beta } \\
\hline 1 & 4 & 6.280 & 3.357 & 4.727 \\
\hline 2 & 4 & 6.537 & 0.137 & 4.518 \\
\hline 3 & 4 & 6.448 & 5.379 & 6.109 \\
\hline 4 & 4 & 5.328 & 2.241 & 4.101 \\
\hline 5 & 4 & 6.350 & 4.191 & 5.128 \\
\hline 6 & 4 & 7.174 & 2.270 & 4.028 \\
\hline 7 & 4 & 5.994 & 3.566 & 4.766 \\
\hline 8 & 4 & 6.227 & 3.347 & 4.546 \\
\hline 9 & 4 & 7.242 & 4.240 & 5.494 \\
\hline 10 & 4 & 6.581 & 4.250 & 5.482 \\
\hline 11 & 4 & 6.750 & 3.784 & 5.205 \\
\hline 12 & 4 & 6.725 & 4.312 & 5.409 \\
\hline
\end{tabular}

${ }^{a}$ Gross alpha and gross beta radiation analyses are performed quarterly using a composite of sample filter papers changed out weekly throughout the quarter. For average uranium air concentration data, refer to Table 3.5 and Vol. 2, Sect. 3.

${ }^{b}$ To convert from $10^{-15} \mu \mathrm{Ci} / \mathrm{cm}^{3}$ to $10^{-11} \mathrm{Ba} / \mathrm{c}^{3} \mathrm{n}^{3}$, multiply by 3.7 .

completion of several major engineering projects prior to 1989 (e.g., New Hope Pond closure, the Perimeter Intrusion Detection Assessment System, Reduction of Mercury in Plant Effluent, and Utility Systems Restoration) that may have temporarily elevated mercury air concentrations because of disturbances to contaminated soil and sediment. Concentrations of ambient mercury vapor, which showed an increase in 1989 at Ambient Station No. 8 at the west end of the plant, have decreased from 1990 to 1992 to the lowest annual average measured for this site. With the exception of Ambient Station No. 8, the average annual concentration of ambient mercury vapor for each site, though lower in 1992, was not significantly different (Student's t-test at the
$1 \%$ level) from the 1991 average. The seasonal pattern (Fig. 3.16) of higher mercury concentrations recorded during the warmer months of the year continued in 1992.

In summary, although ambient mercury concentrations at the $\mathrm{Y}-12$ Plant are elevated above natural background and occasionally may reach greatly elevated concentrations for short periods in localized areas, results indicate that on-site concentrations of mercury vapor are well below the NESHAP guideline of $1 \mu \mathrm{g} / \mathrm{m}^{3}$ (30-d average) and the American Conference of Governmental Industrial Hygienists' threshold limit value of $50 \mu \mathrm{g} / \mathrm{m}^{3}$ (time-weighted average for 8-h workday and 40-h work week). 
1992 Environmental Report Vol. 1, Oak Ridge

Table 3.8. 1992 uranium concentrations in air at the Y-12 Plant

\begin{tabular}{|c|c|c|c|c|c|}
\hline \multirow[t]{2}{*}{ Station } & \multirow{2}{*}{$\begin{array}{l}\text { Number of } \\
\text { analyses }\end{array}$} & \multicolumn{3}{|c|}{$\begin{array}{l}\text { Concentration } \\
\left(10^{-15} \mu \mathrm{Ci} / \mathrm{cm}^{3}\right)^{b}\end{array}$} & \multirow{2}{*}{$\begin{array}{c}\mathrm{DCG}^{\mathrm{c}} \\
(\%)\end{array}$} \\
\hline & & Max & Min & Av & \\
\hline \multicolumn{6}{|c|}{${ }^{234} U$} \\
\hline 1 & 4 & 0.0748 & 0.0045 & 0.0509 & 0.06 \\
\hline 2 & 4 & 0.1235 & 0.0092 & 0.0614 & 0.07 \\
\hline 3 & 4 & 0.4482 & 0.0212 & 0.2927 & 0.33 \\
\hline 4 & 4 & 0.3203 & 0.0215 & 0.2229 & 0.25 \\
\hline 5 & 4 & 1.6897 & 0.0254 & 0.7409 & 0.82 \\
\hline 6 & 4 & 0.1440 & 0.0100 & 0.1088 & 0.12 \\
\hline 7 & 4 & 0.2160 & 0.0022 & 0.1672 & 0.19 \\
\hline 8 & 4 & 0.4340 & 0.0080 & 0.1904 & 0.21 \\
\hline 9 & 4 & 0.1398 & 0.0070 & 0.0872 & 0.10 \\
\hline 10 & 4 & 0.0730 & 0.0047 & 0.0474 & 0.05 \\
\hline 11 & 4 & 0.1019 & 0.0044 & 0.0545 & 0.06 \\
\hline 12 & 4 & 0.0827 & 0.0053 & 0.0562 & 0.06 \\
\hline \multicolumn{6}{|c|}{${ }^{235} U$} \\
\hline 1 & 4 & 0.0021 & 0.0010 & 0.0017 & $<0.01$ \\
\hline 2 & 3 & 0.0050 & 0.0016 & 0.0040 & $<0.01$ \\
\hline 3 & 4 & 0.0130 & 0.0029 & 0.0100 & 0.01 \\
\hline 4 & 4 & 0.0120 & 0.0030 & 0.0104 & 0.01 \\
\hline 5 & 4 & 0.0464 & 0.0026 & 0.0213 & 0.02 \\
\hline 6 & 4 & 0.0049 & 0.0018 & 0.0044 & $<0.01$ \\
\hline 7 & 4 & 0.0139 & 0.0022 & 0.0085 & 0.01 \\
\hline 8 & 4 & 0.0679 & 0.0014 & 0.0244 & 0.02 \\
\hline 9 & 3 & 0.0037 & 0.0010 & 0.0022 & $<0.01$ \\
\hline 11 & 4 & 0.0030 & 0.0010 & 0.0022 & $<0.01$ \\
\hline 12 & 3 & 0.0033 & 0.0010 & 0.0025 & $<0.01$ \\
\hline \multicolumn{6}{|c|}{${ }^{236} U$} \\
\hline 1 & 3 & 0.0012 & 0.0006 & 0.0009 & $<0.01$ \\
\hline 2 & 3 & 0.0040 & 0.0007 & 0.0024 & $<0.01$ \\
\hline 3 & 3 & 0.0066 & 0.0013 & 0.0043 & $<0.01$ \\
\hline 4 & 3 & 0.0037 & 0.0013 & 0.0037 & $<0.01$ \\
\hline 5 & 4 & 0.0072 & 0.0017 & 0.0055 & $<0.01$ \\
\hline 6 & 4 & 0.0036 & 0.0011 & 0.0025 & $<0.01$ \\
\hline 7 & 4 & 0.0028 & 0.0011 & 0.0024 & $<0.01$ \\
\hline 8 & 4 & 0.0110 & 0.0010 & 0.0051 & $<0.01$ \\
\hline 9 & 3 & 0.0018 & 0.0006 & 0.0007 & $<0.01$ \\
\hline 10 & 3 & 0.0012 & 0.0004 & 0.0003 & $<0.01$ \\
\hline 11 & 3 & 0.0010 & 0.0005 & 0.0006 & $<0.01$ \\
\hline 12 & 4 & 0.0025 & 0.0006 & 0.0015 & $<0.01$ \\
\hline
\end{tabular}


1992 Environmental Report Vol. 1, Oak Ridge

Table 3.8. (continued)

\begin{tabular}{|c|c|c|c|c|c|}
\hline \multirow[t]{2}{*}{ Station } & \multirow{2}{*}{$\begin{array}{l}\text { Number of } \\
\text { analyses }\end{array}$} & \multicolumn{3}{|c|}{$\begin{array}{c}\text { Concentration } \\
\left(10^{-15} \mu \mathrm{Ci} / \mathrm{cm}^{3}\right)^{b}\end{array}$} & \multirow{2}{*}{$\begin{array}{c}\mathrm{DCG}^{\mathrm{C}} \\
(\%)\end{array}$} \\
\hline & & Max & $\operatorname{Min}$ & Av & \\
\hline \multicolumn{6}{|c|}{${ }^{238} U$} \\
\hline 1 & 4 & 0.0095 & 0.0017 & 0.0072 & $<0.01$ \\
\hline 2 & 4 & 0.0170 & 0.0023 & 0.0105 & 0.01 \\
\hline 3 & 4 & 0.0847 & 0.0032 & 0.0433 & 0.04 \\
\hline 4 & 4 & 0.1116 & 0.0036 & 0.0469 & 0.05 \\
\hline 5 & 4 & 0.0221 & 0.0027 & 0.0156 & 0.02 \\
\hline 6 & 4 & 0.0119 & 0.0026 & 0.0100 & 0.01 \\
\hline 7 & 4 & 0.0198 & 0.0032 & 0.0145 & 0.01 \\
\hline 8 & 4 & 0.0456 & 0.0028 & 0.0246 & 0.02 \\
\hline 9 & 4 & 0.0288 & 0.0029 & 0.0180 & 0.02 \\
\hline 10 & 4 & 0.0202 & 0.0023 & 0.0123 & 0.01 \\
\hline 11 & 4 & 0.0129 & 0.0010 & 0.0084 & $<0.01$ \\
\hline 12 & 4 & 0.0158 & 0.0022 & 0.0081 & $<0.01$ \\
\hline
\end{tabular}

"Isotopic uranium determinations are performed quarterly using a composite of samples collected weekly throughout the quarter.

${ }^{b}$ To convert from $10^{-15} \mu \mathrm{Ci} / \mathrm{cm}^{3}$ to $10^{-11} \mathrm{~Bq} / \mathrm{cm}^{3}$, multiply by 3.7

'Percent DCG $=$ average $\times 100 /$ derived concentration guide $(D C G)$. The DCG is specified by isotope in DOE Order $54(00.5 ;$ the most conservative values are used.

Table 3.9. 1992 fluorides in air at the Y-12 Plant

\begin{tabular}{|c|c|c|c|c|c|c|}
\hline \multirow[t]{2}{*}{ Station } & \multirow{2}{*}{$\begin{array}{l}\text { Number of } \\
\text { samples }\end{array}$} & \multicolumn{4}{|c|}{$\begin{array}{l}\text { Concentration } \\
\qquad\left(\mu \mathrm{g} / \mathrm{m}^{3}\right)\end{array}$} & \multirow{2}{*}{$\begin{array}{c}\text { Percentage } \\
\text { of } \\
\text { standard }^{b}\end{array}$} \\
\hline & & Max & $\operatorname{Min}$ & Av & Tenn. std. ${ }^{a}$ & \\
\hline 1 & 51 & 0.0121 & 0.0062 & 0.0080 & 1.6 & 0.50 \\
\hline 2 & 36 & 0.0169 & 0.0016 & 0.0095 & 1.6 & 0.59 \\
\hline 3 & 51 & 0.0181 & 0.0070 & 0.0084 & 1.6 & 0.53 \\
\hline 4 & 51 & 0.0297 & 0.0062 & 0.0093 & 1.6 & 0.58 \\
\hline $5^{c}$ & 44 & 0.2804 & 0.0050 & 0.1278 & 1.6 & 7.99 \\
\hline 6 & 49 & 0.0140 & 0.0062 & 0.0094 & 1.6 & 0.59 \\
\hline 7 & 51 & 0.0156 & 0.0056 & 0.0079 & 1.6 & 0.49 \\
\hline 8 & 51 & 0.0187 & 0.0070 & 0.0084 & 1.6 & 0.53 \\
\hline 9 & 51 & 0.0124 & 0.0063 & 0.0079 & 1.6 & 0.49 \\
\hline 10 & 50 & 0.0140 & 0.0061 & 0.0075 & 1.6 & 0.47 \\
\hline 11 & 51 & 0.0133 & 0.0062 & 0.0077 & 1.6 & 0.48 \\
\hline
\end{tabular}

arennessee standard 7 -d average $=1.6 \mu \mathrm{g} / \mathrm{m}^{3}$.

${ }^{h}$ Percentage of standard calculated using average fluoride concentration.

'Consistent low flow on sampler.

\subsubsection{Oak Ridge National Laboratory}

\subsubsection{Description}

The objectives for the ambient program are (1) to sample at stations that were most likely to show impacts of airborne emissions from the operation of
ORNL, (2) to maintain surveillance of airborne radionuclides at the ORR perimeter, and (3) to collect reference data from remote locations. Figure 3.17 shows the stations that are in the ORNL ambient air program. Figure 3.18 shows the ORR perimeter monitoring locations, and Fig. 3.19 indicates the remote air locations. The specific stations associated with each of these objectives are as follows: 


\section{Environmental Report Vol. 1, Oak Ridge}

Table 3.10. Annual results of the Y-12 Plant airborne mercury monitoring program, 1986-1992

\begin{tabular}{|c|c|c|c|c|c|}
\hline \multirow[t]{2}{*}{ Site } & \multirow[t]{2}{*}{ Year } & \multirow{2}{*}{$\begin{array}{c}\text { Number } \\
\text { of } \\
\text { samples }\end{array}$} & \multicolumn{3}{|c|}{$\begin{array}{l}\text { Mercury vapor concentration } \\
\qquad\left(\mu \mathrm{g} / \mathrm{m}^{3}\right)\end{array}$} \\
\hline & & & $\operatorname{Max}$ & Min & $A v^{\prime \prime}$ \\
\hline $\begin{array}{l}\text { Ambient No. } 2 \\
\text { (east end of } Y-12 \text { ) }\end{array}$ & $\begin{array}{l}1986 \\
1987 \\
1988 \\
1989 \\
1990 \\
1991 \\
1992\end{array}$ & $\begin{array}{l}34 \\
52 \\
52 \\
52 \\
52 \\
51 \\
36\end{array}$ & $\begin{array}{l}0.058 \\
0.033 \\
0.036 \\
0.012 \\
0.018 \\
0.073 \\
0.015\end{array}$ & $\begin{array}{r}0.003 \\
\Upsilon .001 \\
0.003 \\
0.003 \\
<0.001 \\
<0.001 \\
0.002\end{array}$ & $\begin{array}{l}0.011 \\
0.009 \\
0.010 \\
0.006 \\
0.006 \\
0.008 \\
0.005\end{array}$ \\
\hline $\begin{array}{l}\text { Ambient No. } 8 \\
\text { (west end of } Y-12 \text { ) }\end{array}$ & $\begin{array}{l}1986 \\
1987 \\
1988 \\
1989 \\
1990 \\
1991 \\
1992\end{array}$ & $\begin{array}{l}27 \\
52 \\
52 \\
52 \\
51 \\
51 \\
49\end{array}$ & $\begin{array}{l}0.034 \\
0.067 \\
0.407 \\
1.187 \\
0.025 \\
0.067 \\
0.022\end{array}$ & $\begin{array}{r}<0.001 \\
0.007 \\
0.007 \\
0.006 \\
0.002 \\
0.005 \\
0.001\end{array}$ & $\begin{array}{l}0.017 \\
0.032 \\
0.041 \\
0.143 \\
0.011 \\
0.016 \\
0.007\end{array}$ \\
\hline $\begin{array}{l}\text { Bldg. } 9404-13 \\
\text { (SW of Bldg. 9201-4) }\end{array}$ & $\begin{array}{l}1986 \\
1987 \\
1988 \\
1989 \\
1990 \\
1991 \\
1992\end{array}$ & $\begin{array}{l}31 \\
52 \\
51 \\
52 \\
52 \\
51 \\
45\end{array}$ & $\begin{array}{l}0.197 \\
0.465 \\
0.340 \\
0.250 \\
0.277 \\
0.181 \\
0.137\end{array}$ & $\begin{array}{l}0.033 \\
0.044 \\
0.028 \\
0.024 \\
0.001 \\
0.018 \\
0.010\end{array}$ & $\begin{array}{l}0.108 \\
0.174 \\
0.137 \\
0.101 \\
0.067 \\
0.070 \\
0.056\end{array}$ \\
\hline $\begin{array}{l}\text { Bldg. } 9805-1 \\
\text { (SE of Bldg. } 9201-4 \text { ) }\end{array}$ & $\begin{array}{l}1986 \\
1987 \\
1988 \\
1989 \\
1990 \\
1991 \\
1992\end{array}$ & $\begin{array}{l}15 \\
52 \\
52 \\
51 \\
52 \\
48 \\
49\end{array}$ & $\begin{array}{l}0.137 \\
0.226 \\
0.384 \\
0.206 \\
0.162 \\
0.275 \\
0.125\end{array}$ & $\begin{array}{l}0.026 \\
0.036 \\
0.017 \\
0.017 \\
0.018 \\
0.003 \\
0.001\end{array}$ & $\begin{array}{l}0.070 \\
0.109 \\
0.097 \\
0.072 \\
0.070 \\
0.058 \\
0.038\end{array}$ \\
\hline New Hope Pond ${ }^{b}$ & $\begin{array}{l}1987 \\
1988 \\
1989\end{array}$ & $\begin{array}{l}20 \\
52 \\
37\end{array}$ & $\begin{array}{l}0.039 \\
0.412 \\
0.009\end{array}$ & $\begin{array}{l}0.006 \\
0.004 \\
0.002\end{array}$ & $\begin{array}{l}0.016 \\
0.046 \\
0.004\end{array}$ \\
\hline $\begin{array}{l}\text { Rain Gage No. } 2^{\circ} \\
\text { (Chestnut Ridge) }\end{array}$ & $\begin{array}{l}1988 \\
1989\end{array}$ & $\begin{array}{l}47 \\
47\end{array}$ & $\begin{array}{l}0.016 \\
0.015\end{array}$ & $\begin{array}{r}0.002 \\
<0.001\end{array}$ & $\begin{array}{l}0.006 \\
0.005\end{array}$ \\
\hline
\end{tabular}

"NESHAP 30-day average standard $=1 \mu \mathrm{g} / \mathrm{m}^{3}$.

"Site discontinued September 19, 1989.

'Si.: Jiscontinued October 31, 1989.

1. The ORNL perimeter air monitoring (PAM) network includes Stations 1, 2, 3, and 7 (Fig. 3.17).

2. The DOE ORR PAM network includes Stations 35 , 37, 38, 39, 40, 42, 46, and 48 (Fig. 3.18).

3. The remote air monitoring (RAM) network consists of Norris Dam (Station 51) and Loudon Dam (Station 52) (Fig. 3.19).
Sampling is conducted at each ORNL station to quantify levels of absorbable gas (e.g., iodine), gross alpha, gross beta, and gamma-emitting radionuclides. Station 3 was equipped with a sampler for measuring tritium. Sampling is conducted at each ORR station to quantity levels of alpha-, beta-, and gammaemitting isotopes. Tritium was sampled at Station 48 all year. In October 1992, tritium sampling was 


\section{Environmental Report Vol. 1, Oak Ridge}

Table 3.11. 1992 total suspended particulates in air at the Y-12 Plant TSP monitoring station

\begin{tabular}{|c|c|c|c|c|c|c|c|}
\hline \multirow[b]{2}{*}{ Station } & \multirow{2}{*}{$\begin{array}{l}\text { Number of } \\
\text { samples }\end{array}$} & \multicolumn{5}{|c|}{ Concentration $\left(\mu \mathrm{g} / \mathrm{m}^{3}\right)$} & \multirow{2}{*}{$\begin{array}{l}\text { Number of } \\
\text { exceedences }\end{array}$} \\
\hline & & Max & Min & Av & $\begin{array}{l}\text { Tenn. } \\
\text { Sid. }\end{array}$ & $\begin{array}{c}\% \\
\text { Std. }\end{array}$ & \\
\hline East & 38 & 51.73 & 8.83 & 27.64 & 260 & 10.63 & () \\
\hline West & 34 & $73 .(12$ & 3.15 & 24.94 & 260 & 9.59 & () \\
\hline
\end{tabular}

"TSP is no longer regulated; however, these measurements are still compared with the previous primary air quality standard of $260 \mu \mathrm{g} / \mathrm{m}^{3} / 24 \mathrm{~h}$.

Table 3.12. $1992 \mathrm{PM} 10$ concentrations in air at the Y-12 Plant PM10 monitoring station

\begin{tabular}{|c|c|c|c|c|c|c|c|}
\hline \multirow[b]{2}{*}{ Station } & \multirow[b]{2}{*}{$\begin{array}{c}\text { Number of } \\
\text { samples }\end{array}$} & \multicolumn{4}{|c|}{ Concentration $\left(\mu \mathrm{g} / \mathrm{m}^{3}\right)$} & \multirow[b]{2}{*}{$\begin{array}{c}\% \\
\text { Std }\end{array}$} & \multirow[b]{2}{*}{$\begin{array}{l}\text { Number of } \\
\text { exceedences }\end{array}$} \\
\hline & & $\operatorname{Max}$ & Min & Av & $\begin{array}{l}\text { Tenn. } \\
\text { Std. }\end{array}$ & & \\
\hline $\begin{array}{c}\text { West } \\
\text { East } \\
\text { East Co-located }\end{array}$ & $\begin{array}{l}27 \\
29 \\
11\end{array}$ & $\begin{array}{l}29.14 \\
28.69 \\
28.48\end{array}$ & $\begin{array}{l}1.44 \\
1.59 \\
0.17\end{array}$ & $\begin{array}{l}13.23 \\
14.61 \\
12.01\end{array}$ & $\begin{array}{l}260 \\
260 \\
260\end{array}$ & $\begin{array}{l}5.09 \\
5.62 \\
4.62\end{array}$ & $\begin{array}{l}0 \\
0 \\
0\end{array}$ \\
\hline
\end{tabular}

"Tennessee primary air quality standard is $260 \mu \mathrm{g} / \mathrm{m}^{3} / 24 \mathrm{~h}$. Tennessee secondary air quality standard is $150 \mu \mathrm{g} / \mathrm{m}^{3} / \mathrm{h}$.

initiated at the other ORR stations. The sampling and analysis frequencies for each station are given in Table 3.13.

Airborne radioactive particulates are sampled biweekly by pumping a continuous flow of air through a $47-\mathrm{mm}$ (1.88-in.) diam filter. At the ORNL stations the airborne adsorbable gases are collected biweekly using a canister containing activated charcoal that is downstream of the particulate filter. The charcoal canister is analyzed within $24 \mathrm{~h}$ after collection. The initial and final dates, time on and off, and flow rates are recorded when a sample medium is mounted or removed. The total volume of air that flowed through the sampler is obtained from a flow totalizer. The concentration of radionuclides in air is calculated by dividing the total activity per sample by the total volume of air sampled.

During 1992 a biweekly sample for atmospheric tritium was collected from ORNL PAM Station 3 and composited every 4 weeks. Atmospheric tritium in the form of water vapor is removed from the air by silica gel. The silica gel is heated in a distillation flask in the laboratory to remove the moisture, and the distillate is counted in a liquid scintillation counter.
Annual composites of particulate air filters from each station are analyzed for specific radionuclides. Annual compositing of the particulate air filters for analysis of long-lived isotopes has been adopted because the data from previous years showed very low concentrations of these radionuclides.

Data summaries for individual monitoring stations are provided in Tables 3.9-3.12 in Vol. 2.

\subsubsection{Summary}

Annual data summaries are presented in Table 3.14. As discussed previously, the data are divided into three groups. The ORNL PAM stations are designed to collectively assess the specific impact of ORNL upon the local air quality. The reservation PAM stations assess the impact of the entire ORR on air quality. Comparing these two sets of data provides insight into the relative impact of ORNL upon the local air quality as compared with other facilities on the reservation. The RAM stations provide information on reference concentrations of isotopes and gross parameters for the region. Many of the radionuclides in the data summary are naturally occurring isotopes commonly found in soil, water, and fossil fuels. It is highly unlikely that analyte 
ORNL-DWG 91M-7248R
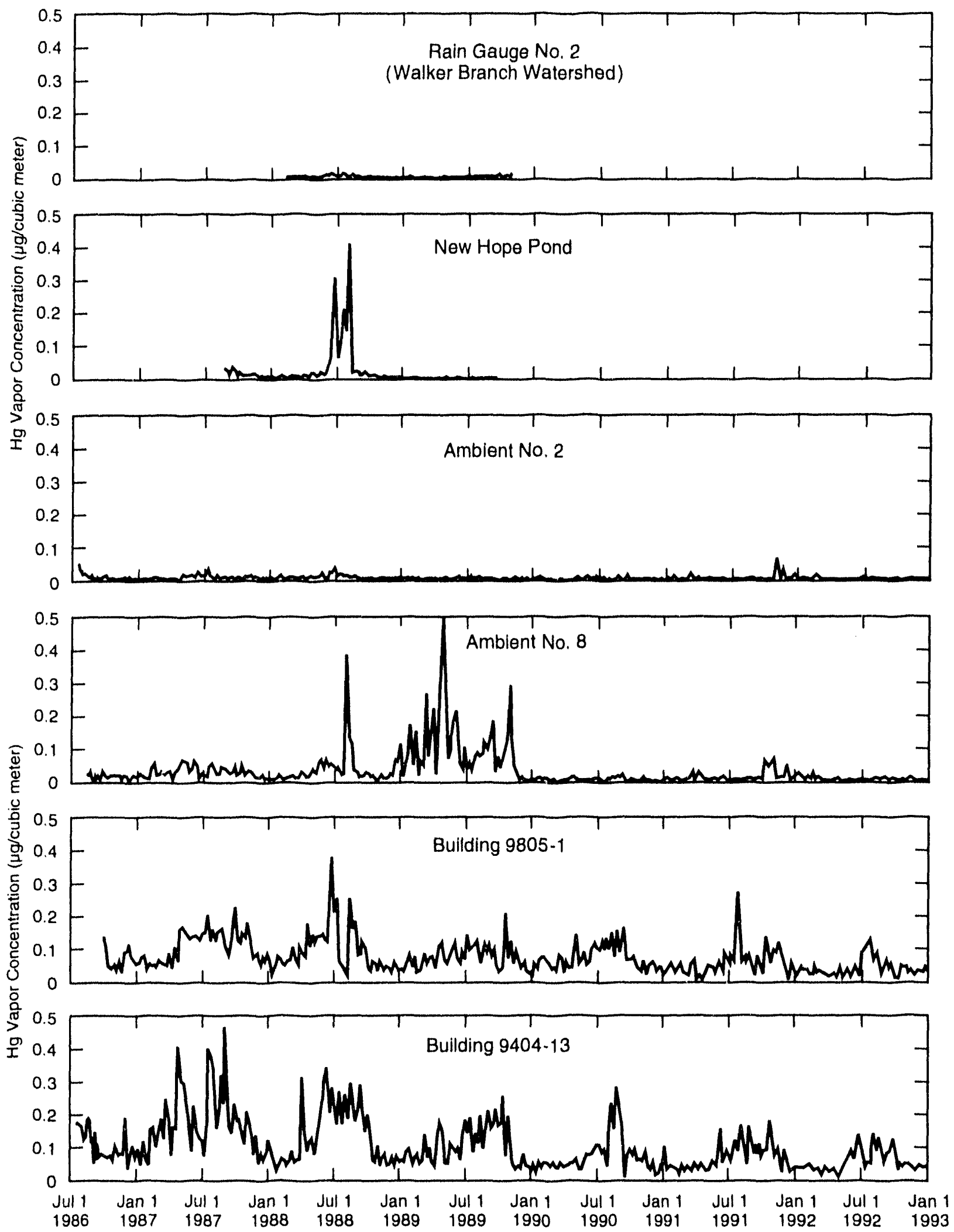

Fig. 3.16. Time trends in mercury vapor concentrations for five monitoring sites at the $\mathrm{Y}-12$ Plant and for Rain Gage No. 2 at Walker Branch Watershed. 


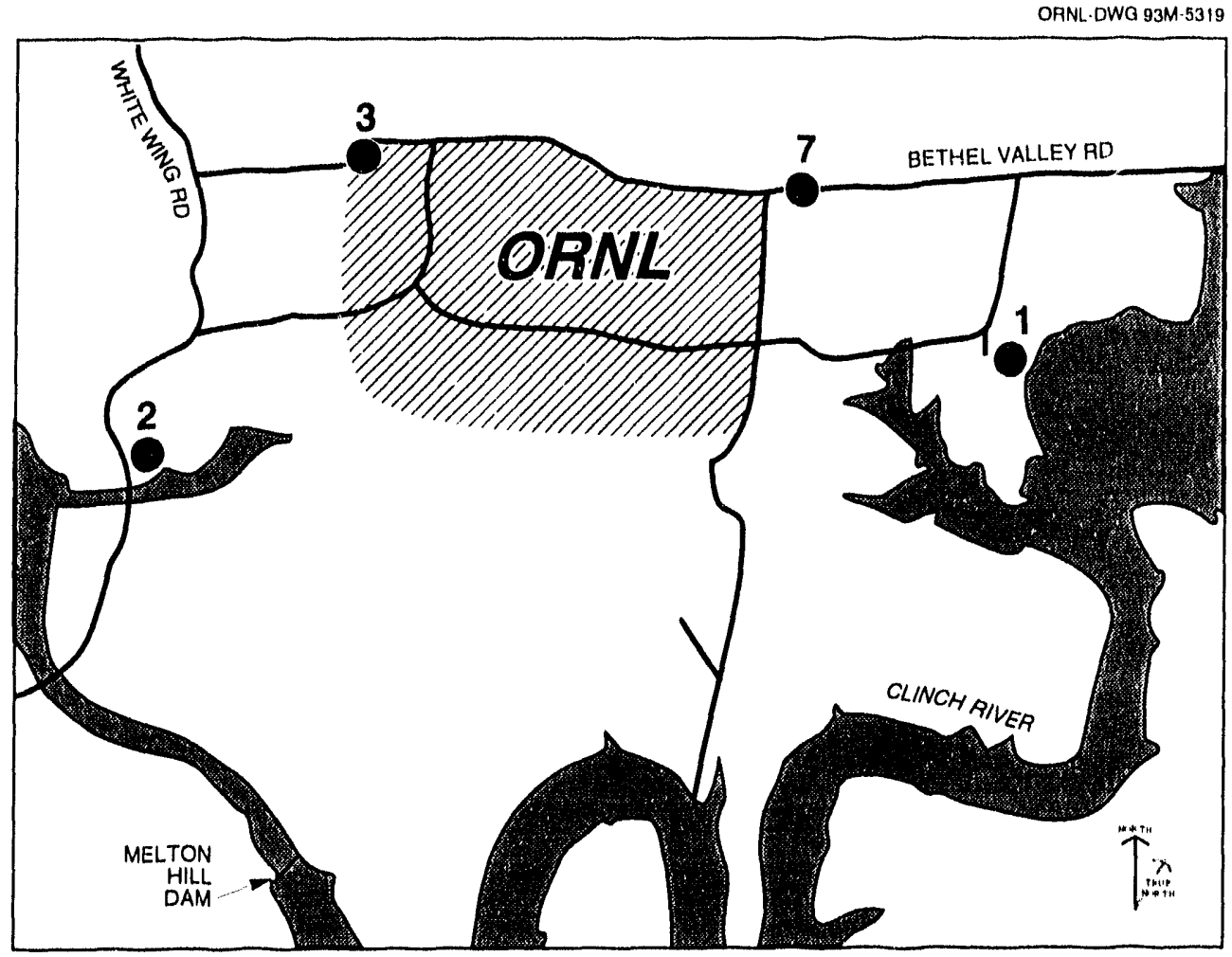

Fig. 3.17. ORNL perimeter air monitoring locations.

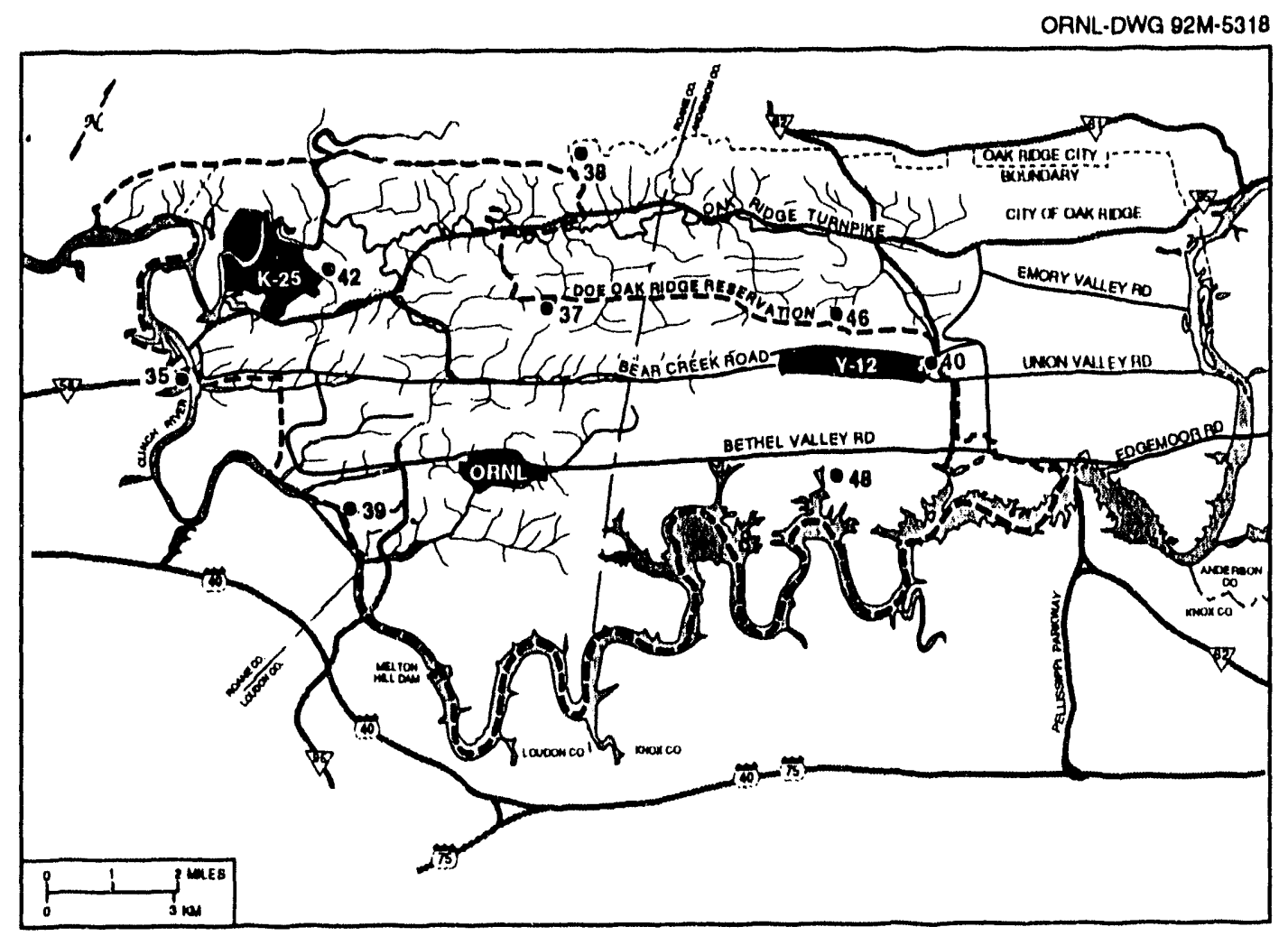

Fig. 3.18. ORR perimeter air monitoring locations. 


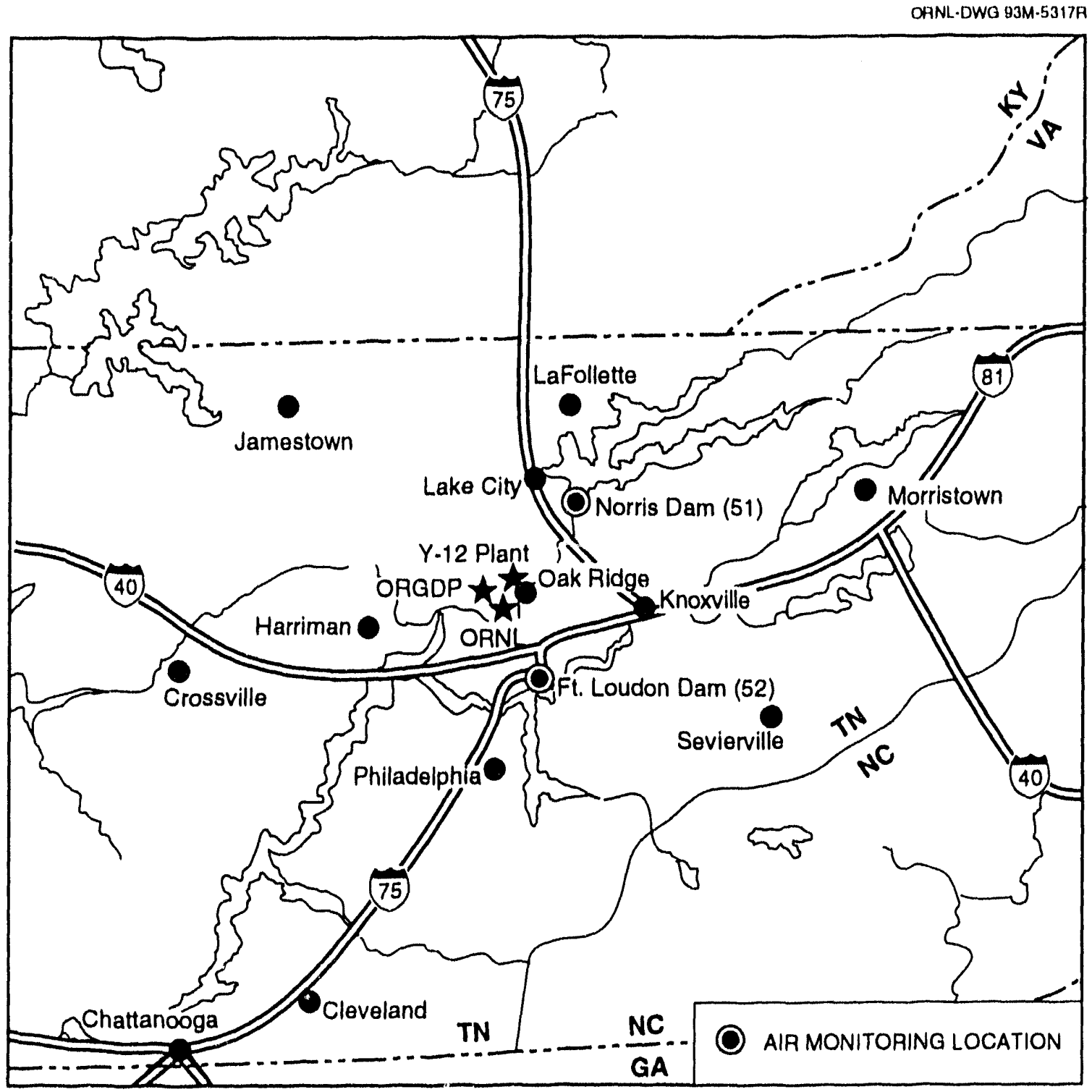

Fig. 3.19. Remote air monitoring locations.

concentrations at the RAM stations are impacted by the operations at ORNL or the ORR. By comparing the ORNL and ORR data with the RAM station data, the net impact of ORNL. and the ORR upon the regional air quality can be assessed.

The data summary consists of the analytical parameters, total samples for the year for each parameter, the range of values, the average, and the standard error. Only numbers that were determined to be significantly different from zero were included in the data calculation.

The average concentration in the tables is the average of the significant values only; this average is divided by the derived concentration guide (DCG) for inhalation of that isotope, multiplied by 100 , and presented in the table as the percent of the DCG unless the percent is less than 0.01. In that case, the percent is reported as less than 0.01. A discussion of data conventions and the use of negative numbers as well as the definition of DCG is given in Sect. 1.

Iodine-131 for ORNL was less than $0.01 \%$ of the DCG. The tritium concentration for Station 3 was $0.019 \%$ of the DCG, a decrease from the 1991 data. This decrease is consistent with the ORNL stack monitoring data. 
Table 3.13. 1992 summary of collection and analysis frequencies of ORNL and ORR air monitoring stations

\begin{tabular}{|c|c|c|c|c|}
\hline Station & Parameter & $\begin{array}{l}\text { Collection } \\
\text { frequency }\end{array}$ & Type & $\begin{array}{l}\text { Analysis } \\
\text { frequency }\end{array}$ \\
\hline $\begin{array}{l}\text { ORNL } \\
(1,2,3,7)\end{array}$ & $\begin{array}{l}\text { U, Pu, Th, Be, Am, Cm } \\
\text { Total rad } \mathrm{Sr} \\
\text { Gamma scan (filter) } \\
\text { Gamma scan (charcoal) }\end{array}$ & $\begin{array}{l}\text { Biweekly } \\
\text { Biweekly } \\
\text { Biweekly } \\
\text { Biweekly }\end{array}$ & $\begin{array}{l}\text { Continuous } \\
\text { Continuous } \\
\text { Continouus } \\
\text { Continuous }\end{array}$ & $\begin{array}{l}\text { Annual } \\
\text { Annual } \\
\text { Annual } \\
\text { Biweekly }\end{array}$ \\
\hline $\begin{array}{l}\text { ORNL } \\
\text { (3) }\end{array}$ & Tritium & Biweekly & Continuous & Every 4 wecks \\
\hline $\begin{array}{l}\text { ORR } \\
\begin{array}{l}(35,37,38,39,40 \\
42,46,48,51,52)\end{array}\end{array}$ & $\begin{array}{l}\text { U, Pu, Th, Be, Am, Cm } \\
\text { Total rad } \mathrm{Sr} \\
\text { Gamma scan (filter) } \\
\text { Tritium }\end{array}$ & $\begin{array}{l}\text { Weekly } \\
\text { Weekly } \\
\text { Weekly } \\
\text { Biweekly }\end{array}$ & $\begin{array}{l}\text { Continuous } \\
\text { Continuous } \\
\text { Continuous } \\
\text { Continuous }\end{array}$ & $\begin{array}{l}\text { Annual } \\
\text { Annual } \\
\text { Annual } \\
\text { Every } 4 \text { weeks }\end{array}$ \\
\hline
\end{tabular}

A comparison of ORNL and ORR perimeter air sampling data with the remote air sampling data, using the percent DCG value (Table 3.14), shows that neither ORNL nor the ORR has a significant impact on the local air quality. No significant changes in the concentrations of radionuclides were detected between the 1991 data and the 1992 data for the remote stations. Therefore, based on these data, ORR operations have had no significant impact on the local or regional air quality.

\subsubsection{K-25 Site}

\subsubsection{Description}

Environmental surveillance is conducted to monitor the effects, if any, of the K-25 Site upon the on-site and off-site environment and natural resources. Environmental surveillance programs and components were determined on a site-specific basis Surveillance programs include monitoring stations, sampling and analysis, record keeping, and fuality assurance. The ambient air quality monitorin? program is designed to accomplish the following:

- establish background concentration levels of pertinent chemical species,

- determine the highest concentrations of the pertinent pollutant species expected to occur in the vicinity of DOE operations,
- determine representative pollutant concentrations in areas where public health and other concerns should be considered, and

- evaluate the effects of emissions on ambient levels of pertinent contaminants.

In 1986 the ambient air monitoring program underwent a major evaluation and modification with respect to changes in K-25 Site operations plus current and proposed monitoring regulations. Items that were considered in redesigning the ambient air program were types of monitors, numbers of monitors, locations of monitors, pollutants to be monitored, and frequency of sampling for these pollutants.

The result of the 1986 effort changed the ambient air monitoring program to a five-station network positioned appropriately for environmental surveillance of the K-25 Site (Fig. 3.20). The current five-station network has not been changed since the 1986 modifications except for the addition of a high-volume sampler for collecting suspended particles, $\leq 10 \mu \mathrm{m}$ diam. The monitor was added in 1987 in anticipation of regulations requiring this system. See the following spot table for an overview of sampling station locations and distances with respect to the TSCA Incinerator and a summary of site designation, sampler type, and location details. Stations $1(\mathrm{~K} 1)$ and $2(\mathrm{~K} 2)$ are positioned to best advantage for monitoring in the prevailing downwind directions. It has been demonstrated that the existing sites are in line with computer modeling results. The 
1992 Environmental Report Vol. 1, Oak Ridge

Table 3.141992 radionuclide concentrations in air

\begin{tabular}{|c|c|c|c|c|c|c|c|}
\hline \multirow{2}{*}{ Arci $^{h}$} & \multirow[b]{2}{*}{ Determination } & \multirow{2}{*}{$\begin{array}{l}\text { Number detected/ } \\
\text { number of } \\
\text { samples }\end{array}$} & \multicolumn{5}{|c|}{ Concentration $\left(10^{-15} \mu \mathrm{Ci} / \mathrm{mL}\right)$ of detected values ${ }^{a}$} \\
\hline & & & $\operatorname{Max}^{\circ}$ & $\operatorname{Min}^{\prime}$ & $A v^{c}$ & $\begin{array}{l}\text { Standard } \\
\text { error }\end{array}$ & $\begin{array}{c}\text { DCG } \\
(\%)\end{array}$ \\
\hline \multirow[t]{15}{*}{ ORNL PAMs } & 13.11 & $1 / 97$ & 5.5 & 5.5 & 5.5 & & \\
\hline & $133 I$ & 9/97 & 25 & 4.7 & 8.3 & 2.1 & $<0.01$ \\
\hline & 1351 & $5 / 97$ & 71 & 28 & 50 & 8.8 & 0.011 \\
\hline & ${ }^{212} \mathrm{~Pb}$ & $3 / 97$ & 150 & 22 & 67 & 44 & \\
\hline & ${ }^{3} \mathrm{H}$ & $13 / 13$ & 64,000 & 4,500 & 19,000 & 4,900 & 0.019 \\
\hline & ${ }^{244} \mathrm{Cm}$ & $2 / 4$ & 0.030 & 0.021 & 0.025 & 0.0048 & 0.064 \\
\hline & ${ }^{137} \mathrm{Cs}$ & $2 / 4$ & 0.090 & 0.029 & 0.060 & 0.030 & $<0.01$ \\
\hline & ${ }^{239} \mathrm{Pu}$ & $1 / 4$ & 0.0028 & 0.0028 & 0.0028 & $d$ & 0.014 \\
\hline & ${ }^{228} \mathrm{Th}$ & $4 / 4$ & 0.041 & 0.011 & 0.030 & 0.0067 & 0.074 \\
\hline & ${ }^{230} \mathrm{Th}$ & $4 / 4$ & 0.053 & 0.036 & 0.042 & 0.0037 & 0.11 \\
\hline & ${ }^{232} \mathrm{Th}$ & $4 / 4$ & 0.043 & 0.019 & 0.027 & 0.0054 & 0.39 \\
\hline & Total $\mathrm{Sr}$ & $1 / 4$ & 0.070 & 0.070 & 0.070 & $d$ & $<0.01$ \\
\hline & ${ }^{234} \mathrm{U}$ & $4 / 4$ & 0.044 & 0.022 & 0.033 & 0.0053 & 0.037 \\
\hline & ${ }^{2.35} \mathrm{U}$ & $2 / 4$ & 0.0060 & 0.0048 & 0.0054 & 0.00062 & $<0.01$ \\
\hline & ${ }^{238} \mathrm{U}$ & $4 / 4$ & 0.021 & 0.015 & 0.018 & 0.0014 & 0.018 \\
\hline \multirow[t]{11}{*}{ ORR PAMs } & ${ }^{3} \mathrm{H}$ & $27 / 31$ & 650,000 & 2,400 & 51,000 & 24,000 & 0.051 \\
\hline & ${ }^{244} \mathrm{Cm}$ & 1/8 & 0.050 & 0.050 & 0.050 & $d$ & 0.13 \\
\hline & ${ }^{60} \mathrm{Co}$ & $4 / 8$ & 0.15 & 0.062 & 0.10 & 0.018 & $<0.01$ \\
\hline & ${ }^{238} \mathrm{Pu}$ & $1 / 8$ & 0.0040 & 0.0040 & 0.0040 & $d$ & 0.013 \\
\hline & ${ }^{228} \mathrm{Th}$ & $7 / 8$ & 0.016 & 0.0050 & 0.0089 & 0.0014 & 0.022 \\
\hline & ${ }^{230} \mathrm{Th}$ & $8 / 8$ & 0.023 & 0.011 & 0.017 & 0.0016 & 0.042 \\
\hline & ${ }^{232} \mathrm{Th}$ & $8 / 8$ & 0.011 & 0.0052 & 0.0072 & 0.00066 & 0.10 \\
\hline & Total Sr & $1 / 8$ & 0.072 & 0.072 & 0.072 & $d$ & $<0.01$ \\
\hline & ${ }^{234} \mathrm{U}$ & $8 / 8$ & 0.21 & 0.0050 & 0.063 & 0.025 & 0.07 \\
\hline & ${ }^{235} \mathrm{U}$ & $5 / 8$ & 0.052 & 0.0047 & 0.016 & 0.0091 & 0.016 \\
\hline & ${ }^{238} \mathrm{U}$ & $8 / 8$ & 0.032 & 0.0094 & 0.017 & 0.0026 & 0.017 \\
\hline \multirow[t]{10}{*}{ RAMs } & ${ }^{3} \mathrm{H}$ & $4 / 6$ & 190,000 & 4,400 & 53,000 & $47,000)$ & 0.053 \\
\hline & ${ }^{137} \mathrm{Cs}$ & $1 / 2$ & 0.048 & 0.048 & 0.048 & $d$ & $<0.01$ \\
\hline & ${ }^{238} \mathrm{Pu}$ & $1 / 2$ & 0.0044 & 0.0044 & 0.0044 & $d$ & 0.015 \\
\hline & ${ }^{228} \mathrm{Th}$ & $1 / 2$ & 0.0084 & 0.0084 & 0.0084 & $d$ & 0.021 \\
\hline & ${ }^{230} \mathrm{Th}$ & $2 / 2$ & 0.021 & 0.010 & 0.015 & 0.0054 & 0.038 \\
\hline & ${ }^{232} \mathrm{Th}$ & $2 / 2$ & 0.0047 & 0.0029 & 0.0038 & 0.00093 & 0.055 \\
\hline & Total Sr & $1 / 2$ & 0.10 & 0.10 & 0.10 & $d$ & $<(0.01$ \\
\hline & ${ }^{234} \mathrm{U}$ & $2 / 2$ & 0.034 & 0.027 & 0.030 & 0.0036 & 0.034 \\
\hline & ${ }^{2.35} \mathrm{U}$ & $2 / 2$ & 0.0050 & 0.0029 & 0.0040 & 0.0011 & $<0.01$ \\
\hline & ${ }^{2.18} \mathrm{U}$ & $2 / 2$ & 0.011 & 0.0074 & 0.0092 & 0.0018 & $<0.01$ \\
\hline
\end{tabular}

"Multiply $\mu \mathrm{Ci} / \mathrm{mL}$ by $37 \times 10^{3}$ to convert $10 \mathrm{~Bq} / \mathrm{mL}$.

"See Figs. 3.17, 3.18, and 3.19 .

"Maximum, minimum, and average are calculated on individual values that were determined to be significantly different from zero at a $95 \%$ confidence level.

“Not applicable.

K-25 Site network is designed to meet DOE requirements and to monitor selected pollutants for the ongoing understanding of the impact of plant operations on the immediate environment.

Ambient air monitoring systems that have demonstrated performance characteristics for sampling particulate matter are filtration systems in which suspended particles are collected on a filter by drawing a known volume of ambient air through the filter. This type of system is appropriate for all airborne particulate pollutants at the K-25 Site (such as hazardous air pollutants, including the metals and metal compounds of lead, chromium, nickel, and uranium). Two filter sampling systems chosen to be used as part of the ambient air monitoring program are the Andersen Instrument, Inc. (formerly General 


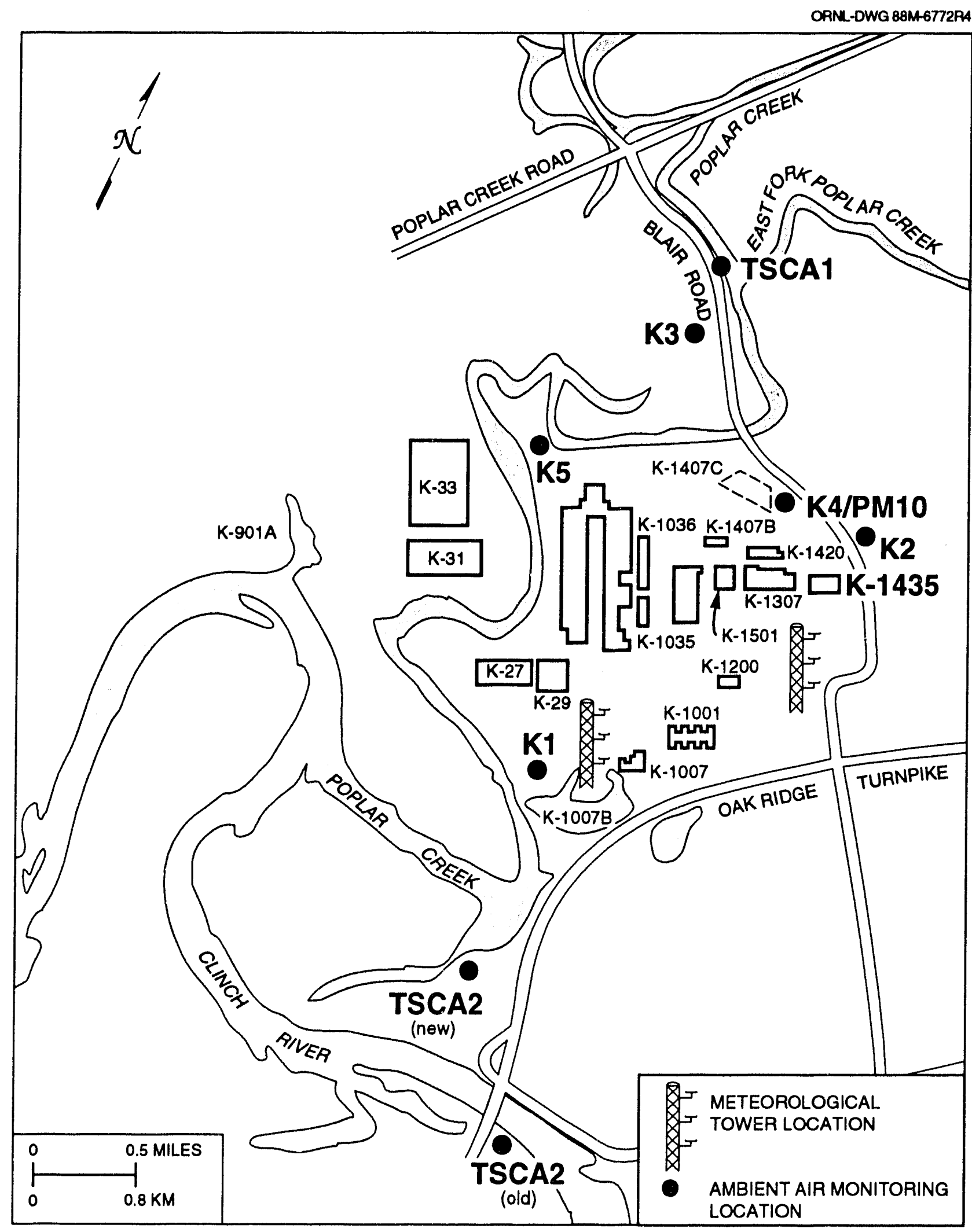

Fig. 3.20. Location of the K-25 Site ambient air monitors and meterological tower. 


\begin{tabular}{|c|c|c|c|}
\hline Station & $\begin{array}{l}\text { Sampler } \\
\text { type(s) }\end{array}$ & $\begin{array}{l}\text { Distance from } \\
\text { TSCA (meters) }\end{array}$ & $\begin{array}{c}\text { Direction } \\
\text { from TSCA }\end{array}$ \\
\hline $\begin{array}{l}\mathrm{K} 1 \\
\mathrm{~K} 2 \\
\mathrm{~K} 3\end{array}$ & $\begin{array}{l}\mathrm{HV} \\
\mathrm{HV} \\
\mathrm{HV}\end{array}$ & $\begin{array}{r}1880 \\
480 \\
1635\end{array}$ & $\begin{array}{l}\text { SW } \\
\text { NE } \\
\text { NNW }\end{array}$ \\
\hline $\mathrm{K} 4$ & $\begin{array}{l}\text { HV and } \\
\text { PM10 }\end{array}$ & 625 & NW \\
\hline K5 & HV & 1805 & NW \\
\hline TSCA1 & $\begin{array}{l}\text { HV and } \\
\text { PUFF (2) }\end{array}$ & 2000 & NNW \\
\hline $\begin{array}{l}\text { TSCA2 } \\
\text { (old) }^{a}\end{array}$ & $\begin{array}{l}\text { HV and } \\
\text { PUFF (2) }\end{array}$ & 3105 & SSW \\
\hline $\begin{array}{l}\text { TSCA2 } \\
(\text { new })^{a}\end{array}$ & $\begin{array}{l}\text { HV and } \\
\text { PUFF (2) }\end{array}$ & 2720 & SW \\
\hline
\end{tabular}

${ }^{a}$ The TSCA2 station was relocated in December 1992.

Metal Works, Inc.), GMWL-2000 high-volume air sampling system (HV) for TSP sampling, and a similar sampling systern (PM10) to collect TSP $\leq 10-\mu \mathrm{m}$ diam. Both systems are appropriate for sampling uranium and other metals that are present in the atmosphere as airborne particulate matter. Additionally, a modified HV system is used to sample for selected semivolatile organics.

The K-25 Site ambient air monitoring network consists of five HV samplers and one PM 10 sampler. The PM10 sampler is collocated with an HV sampler at station 4 (K4). The placement of the PM10 monitor at $\mathrm{K} 4$ was based upon established sitting criteria. The intent is to locate PM10 sampling sites in areas of highest concentrations whether they be mobile or multiple stationary sources. Sites having annual mean TSP matter concentrations among the highest $25 \%$ of the annual mean TSP concentrations for all the sites in the network meet PM10 sitting criteria. K4 data have consistently met these criteria for proper placement of the PM10 monitor.

The sampling schedule for the K-25 Site ambient air monitoring network was established in 1986 as per existing regulations and assumed PM10 sampling requirements. For manual methods (excluding PM10 samplers) at least one 24-h sample is taken every sixth day. For PM10 samplers a 24-h sample must be taken from midnight to midnight (local time) to ensure national consistency. All ambient air monitors currently in use are operating on the midnight-tomidnight schedule. The PM10 monitoring schedule was based on Tennessee's State Implementation Plan (SIP) grouping defined in terms of the estimated probability of not attaining the PM10 National Ambient Air Quality Standards (NAAQS):

- Group I-PM10 sampling everyday;

- Group II-PM10 sampling every other day; and

- Group III-PM10 sampling every sixth day.

The K-25 Site is in an area designated as Group III; PM10 sampling may be required every sixth day. At this time the area including the K-25 Site is classified as an "attainment" area. Because of this classification, PM10 monitoring is not required. However, it has been a K-25 Site best management practice to maximize environmental monitoring capabilities in this area to continue to support area classification criteria designating attainment. The following table lists the parameter analysis matrix for all ambient air monitoring in and around the $\mathrm{K}-25$ Site.

All parameters were chosen with regard to existing and proposed regulations and the level of effort at the K-25 Site. Changes of emissions from the K-25 Site may warrant periodic reevaluation of the parameters being sampled and the monitoring site locations.

In 1988 two additional ambient air monitoring stations were designed, sited, and installed at the K-25 Site. These stations were designed to detect polychlorinated biphenyls (PCBs), furans, dioxins, hexachlorobenzene, and uranium that may be accidentally released because of possible operational upsets of the K-1435 TSCA Incinerator. The station

\section{Summary of the current K-25 Site network measured ambient air pollutants}

\begin{tabular}{|c|c|c|c|c|c|c|c|}
\hline \multirow{2}{*}{ Parameter ${ }^{a}$} & \multicolumn{7}{|c|}{ Station number } \\
\hline & $\mathrm{K} 1$ & $\mathrm{~K} 2$ & K3 & K4 & K5 & TSCA1 & TSCA2 \\
\hline TSP & $\mathrm{x}$ & $\mathrm{X}$ & $x$ & $\mathrm{X}$ & $\mathrm{X}$ & & \\
\hline PM10 & & & & $\mathrm{X}$ & & & \\
\hline Total chromium & $\mathrm{x}$ & $X$ & $\mathrm{X}$ & $\mathrm{X}$ & $X$ & & \\
\hline Lead & $\mathrm{x}$ & $\mathrm{X}$ & $x$ & $\mathrm{X}$ & $x$ & & \\
\hline Nickel & $\mathrm{X}$ & $x$ & $x$ & $\mathrm{X}$ & $x$ & & \\
\hline Total uranium & $\mathrm{x}$ & $x$ & $X$ & $X$ & $\mathrm{X}$ & $x$ & $x$ \\
\hline PCB & & & & & & $X$ & $X$ \\
\hline Furan & & & & & & $X$ & $X$ \\
\hline Hexachlorobenzene & & & & & & $X$ & $x$ \\
\hline Dioxin & & & & & & $X$ & $X$ \\
\hline
\end{tabular}

"All parameters are reported as mass per unit volume of air. 
locations are shown in Fig. 3.20 as TSCAl and TSCA2. (Note: TSCA2 was relocated in December 1992.) Each station is equipped with one HV for uranium and two polyurethane foam filters (PUFFs) systems for selected semivolatile organics sampling. Monitoring protocol requires that the TSCA Incinerator ambient air monitors TSCA 1 and TSCA2 sample $24 \mathrm{~h} / \mathrm{d}, 7 \mathrm{~d} /$ week as long as the TSCA Incinerator is operational (burning waste). Original protocol required that samples be collected every $48 \mathrm{~h}$ and analyzed if certain predetermined abnormal operations occurred during that period. All samples are stored for a minimum of $30 \mathrm{~d}$. During 1992, 128 sets of samples were collected and stored. (One set includes samples from the HV and two PUFF monitors at each TSCA station.) There were no upsets or other potential environmental releases during 1992 that met abnormal operations criteria, and therefore no analyses of the TSCA samples were performed.

During the fourth quarter of 1992 the TSCA Incinerator operations were discontinued for the scheduled replacement of the ionizing wet scrubber system. During this period a study was conducted to evaluate the appropriateness of the current locations of the TSCA1 and TSCA2 monitoring stations with respect to DOE orders. The results of this study indicated that additional industry in the area could influence results of TSCA2 samples and that any contribution of the K-25 Site could not be differentiated. As a result of this finding, the TSCA2 station was relocated to the north side of the Clinch River on the peninsula between Poplar Creek and the river (see Fig. 3.20). The new site meets all sitting criteria to determine the impact of a radiological release upon the most affected resident. The new site was operational before operations of the TSCA Incinerator resumed at the end of December 1992.

\subsubsection{K-25 Site Ambient Air Sampling Summary}

\subsection{Summaries by Parameter}

Ambient air samples are taken once every sixth day at the K-25 Site. The samples are tested to obtain data for six parameters: TSP, PM 10, lead, chromium, nickel, and uranium. These data are analyzed to verify that primary and secondary daily ambient air standards for applicable parameters have not been exceeded. The daily data that accumulate during the calendar year (January 1 to December 31 ) are further analyzed to verify that annual air standards have not been exceeded (Table 3.15). Lead is unique among the ambient air parameters in that its standard requires samples on a quarterly basis.

Annual summaries for each parameter are given in the following sections. A quarterly summary is given for lead.

\section{Total Suspended Solids}

The highest annual TSP average recorded was at station $\mathrm{K} 4$. A result of $25.00 \mu \mathrm{g} / \mathrm{m}^{3}$ was calculated and is only $33.3 \%$ of the primary and $41.4 \%$ of the secondary standard. No annual primary or secondary standards were exceeded.

\section{PM10}

The highest annual PM 10 average recorded is $19.24 \mu \mathrm{g} / \mathrm{m}^{3}$ and is only $38.5 \%$ of the primary and secondary annual standard. The K-25 Site is in a PM 10 "attainment" area, and the data demonstrate meeting the criteria for attainment designation.

\section{Lead}

Quarterly average pollutant levels for lead are summarized in Table 3.16. No standards for lead were exceeded.

\section{Chromium}

There are no annual standards for chromium; however, annual averages were calculated for comparative purposes. The highest annual average recorded was $<0.0064 \mu \mathrm{g} / \mathrm{m}^{3}$ at station $\mathrm{Kl}$.

\section{Nickel}

There are no annual standards for nickel; however, annual averages were calculated for comparative purposes. The highest annual average recorded was $<0.0104 \mu \mathrm{g} / \mathrm{m}^{3}$ at station $\mathrm{K} 4$.

\section{Uranium}

The highest annual uranium average was at station $\mathrm{K} 2$. A result of $<0.00042 \mu \mathrm{g} / \mathrm{m}^{3}$ was 
Table 3.15. 1992 annual K-25 Site ambient air sampling results

\begin{tabular}{|c|c|c|c|c|c|c|c|c|c|}
\hline \multirow{3}{*}{ Monitor } & \multirow{3}{*}{$\begin{array}{l}\text { Number } \\
\text { of samples }\end{array}$} & \multirow{2}{*}{\multicolumn{3}{|c|}{$\begin{array}{l}\text { Concentration } \\
\qquad\left(\mu \mathrm{g} / \mathrm{m}^{3}\right)\end{array}$}} & \multicolumn{5}{|c|}{ Percent of standard } \\
\hline & & & & & \multicolumn{3}{|c|}{ Primary } & \multicolumn{2}{|c|}{ Sccondary } \\
\hline & & $A v^{c}$ & 24-h Min & 24-h Max & 24-h & Qtr & Year & 24-h & Year \\
\hline
\end{tabular}

\begin{tabular}{|c|c|c|c|c|c|c|c|c|c|}
\hline \multicolumn{10}{|c|}{$T S P^{d}$} \\
\hline $\mathrm{K} 1$ & 59 & 22.80 & 7.07 & 88.37 & 34.0 & $e$ & 30.4 & 58.9 & 38.0 \\
\hline $\mathrm{K} 2$ & 58 & 22.48 & 8.20 & 106.46 & 40.9 & $e$ & 30.0 & 71.0 & 37.5 \\
\hline K3 & 58 & 22.98 & 7.03 & 86.42 & 33.2 & $e$ & 30.6 & 57.6 & 38.3 \\
\hline $\mathrm{K} 4$ & 60 & 25.00 & 8.23 & 84.75 & 32.6 & $e$ & 33.3 & 56.5 & 41.7 \\
\hline $\mathrm{K} 5$ & 59 & 22.93 & 7.31 & 93.83 & 36.1 & $e$ & 30.6 & 62.6 & 38.2 \\
\hline PM10 & 36 & 19.24 & 7.59 & 56.87 & 37.9 & $e$ & 38.5 & 37.9 & 38.5 \\
\hline \multicolumn{10}{|c|}{ Lead } \\
\hline KI & 59 & $<0.0343$ & 0.0055 & 0.0576 & $e$ & $<3.6$ & $e$ & $e$ & $e$ \\
\hline $\mathrm{K} 2$ & 58 & $<0.0326$ & 0.0059 & $<0.0566$ & $e$ & $<3.6$ & $e$ & $e$ & $e$ \\
\hline K3 & 58 & $<0.0326$ & 0.0057 & $<0.0540$ & $e$ & $<3.5$ & $e$ & $e$ & $e$ \\
\hline $\mathrm{K} 4$ & 60 & $<0,0348$ & 0.0054 & 0.0582 & $e$ & $<3.6$ & $e$ & $e$ & $e$ \\
\hline K5 & 59 & $<0.0320$ & $<0.0050$ & $<0.0530$ & $e$ & $<3.3$ & $e$ & $e$ & $e$ \\
\hline PM 10 & 36 & $<0.0210$ & 0.0026 & $<0.0633$ & $e$ & $e$ & $e$ & $e$ & $e$ \\
\hline \multicolumn{10}{|c|}{ Chromium $^{g}$} \\
\hline $\mathrm{Kl}$ & 59 & $<0.0064$ & $<0.0028$ & 0.0095 & $e$ & $e$ & $e$ & $e$ & $e$ \\
\hline $\mathrm{K} 2$ & 58 & $<0.0062$ & $<0.0025$ & $<0.0094$ & $e$ & $e$ & $e$ & $e$ & $e$ \\
\hline K3 & 58 & $<0.0060$ & 0.0024 & $<0.0090$ & $e$ & $e$ & $e$ & $e$ & $e$ \\
\hline $\mathrm{K} 4$ & 60 & $<0.0063$ & $<0.0024$ & $<0.0098$ & $e$ & $e$ & $e$ & $e$ & $e$ \\
\hline K5 & 59 & $<0.0059$ & $<0.0024$ & $<0.0088$ & $e$ & $e$ & $e$ & $e$ & $e$ \\
\hline PM10 & 36 & $<0.0059$ & $<0.0029$ & $<0.0105$ & $e$ & $e$ & $e$ & $e$ & $e$ \\
\hline \multicolumn{10}{|c|}{ Nickel } \\
\hline $\mathrm{KI}$ & 59 & $<0.0101$ & $<0.0028$ & $<0.0157$ & $e$ & $e$ & $e$ & $e$ & $e$ \\
\hline $\mathrm{K} 2$ & 58 & $<0.0098$ & 0.0030 & $<0.0157$ & $\boldsymbol{e}$ & $e$ & $e$ & $e$ & $e$ \\
\hline K3 & 58 & $<0.0097$ & $<0.0024$ & $<0.0150$ & $e$ & $e$ & $e$ & $e$ & $e$ \\
\hline $\mathrm{K} 4$ & 60 & $<0.0104$ & 0.0025 & $<0.0158$ & $e$ & $e$ & $e$ & $e$ & $e$ \\
\hline K5 & 59 & $<0.0094$ & $<0.0024$ & $<0.0147$ & $e$ & $e$ & $e$ & $e$ & $e$ \\
\hline PM 10 & 36 & $<0.0093$ & $<0.0032$ & $<0.0176$ & $e$ & $e$ & $e$ & $e$ & $e$ \\
\hline \multicolumn{10}{|c|}{ Uranium $^{h}$} \\
\hline KI & 59 & $<0.00023$ & 0.00004 & 0.00246 & $e$ & $e$ & $<0.2$ & $e$ & $e$ \\
\hline $\mathrm{K} 2$ & 58 & $<0.00042$ & 0.00005 & 0.00614 & $e$ & $e$ & $<0.3$ & $e$ & $e$ \\
\hline K3 & 58 & $<0.00014$ & 0.00003 & 0.00018 & $e$ & $e$ & $<0.1$ & $e$ & $e$ \\
\hline K4 & 60 & $<0.00021$ & 0.00006 & 0.00122 & $e$ & $e$ & $<0.1$ & $e$ & $e$ \\
\hline K5 & 59 & $<0.00015$ & 0.00003 & 0.00044 & $e$ & $e$ & $<0.1$ & $e$ & $e$ \\
\hline PM10 & 36 & $<0.00012$ & $<0.00003$ & 0.00072 & $e$ & $e$ & $e$ & $e$ & $e$ \\
\hline
\end{tabular}

${ }^{a}$ Refer to Fig. 3.20 for monitor locations.

${ }^{b}$ The $24-h$ values are based on individual $24-\mathrm{h}$ maximum concentrations. The quarterly values are based on the maximum quarterly average concentration for the year. The yearly values are based on annual average concentration.

TSP averages are the annual geometric mean. $\mathrm{PM} 10, \mathrm{~Pb}, \mathrm{Cr}, \mathrm{Ni}$, and $\mathrm{U}$ are the annual arithmetic mean.

${ }^{d} \mathrm{TSP}$ primary standards are $260 \mu \mathrm{g} / \mathrm{m}^{3} / 24 \mathrm{~h}$ and 75 annual geometric mean. Secondary standards are $150 \mu \mathrm{g} / \mathrm{m}^{3} / 24 \mathrm{~h}$ and 60 annual geometric mean for the state of Tennessee. PM10 primary and secondary standards are $150 \mu \mathrm{g} / \mathrm{m}^{3} / 24 \mathrm{~h}$ and 50 annual arithmetic mean.

eNot applicable.

The primary standard for lead is $1.5 \mu \mathrm{g} / \mathrm{m}^{3}$ quarterly arithmetic mean.

8 There are no ambient standards for chromium or nickel.

${ }^{4} S t a n d a r d$ for the public for natural uranium is $1 \times 10^{-1} \mathrm{pCi} / \mathrm{m}^{3}$ annual arithmetic mean, which converts to $0.15 \mu \mathrm{g} / \mathrm{m}^{3}$ annual arithmetic mean. There are no Tennessee state standards for uranium. 
1992 Environmental Report Vol. 1, Oak Ridge

Table 3.16. 1992 K-25 Site ambient air sampling quarterly lead results

\begin{tabular}{|c|c|c|c|c|c|c|c|}
\hline \multirow[t]{2}{*}{ Monitor" } & \multicolumn{4}{|c|}{$\begin{array}{l}\text { Quarterly average concentrations } \\
\qquad\left(\mu \mathrm{g} / \mathrm{m}^{3}\right)\end{array}$} & \multicolumn{2}{|c|}{$\begin{array}{l}\text { Range of qtr. averages } \\
\qquad\left(\mu \mathrm{g} / \mathrm{m}^{3}\right)\end{array}$} & \multirow{2}{*}{ Percent of standard' } \\
\hline & 1st Qtr. & 2nd Qtr. & 3rd Qtr. & 4th Qir. & Min & Max & \\
\hline \multicolumn{8}{|c|}{ Lead } \\
\hline $\mathrm{K} 1$ & 0.0163 & $<0.0511$ & $<0,0536$ & $<0.0173$ & 0.0163 & $<0.0536$ & $<3.6$ \\
\hline K2 & 0.0147 & $<0.0510$ & $<0.0534$ & $<0.0165$ & 0.0147 & $<0.0534$ & $<3.6$ \\
\hline $\mathrm{K} 3$ & 0.0127 & $<0.0498$ & $<0.0521$ & $<0.0158$ & 0.0127 & $<0.0521$ & $<3.5$ \\
\hline K4 & 0.0151 & $<0.0506$ & $<0.0543$ & $<0.0194$ & 0.0151 & $<0,() 543$ & $<3.6$ \\
\hline K5 & $<0.0132$ & $<0.0495$ & $<0.0501$ & $<0.0187$ & $<0.0132$ & $<0.0501$ & $<3.3$ \\
\hline PMIO & $<0.0077$ & $<0.0601$ & $<0.0612$ & $<0.0043$ & $<0.0077$ & $<0.0612$ & $d$ \\
\hline
\end{tabular}

"Refer to Fig. 3.20 for monitor locations.

bead concentration averages are the quarterly arithmetic mean.

'The primary standard for lead is $1.5 \mu \mathrm{g} / \mathrm{m}^{3}$ quarterly arithmetic mean.

"Not applicable; there are no PM10 lead standards.

calculated and would represent an impact on the annual standard of only about $0.3 \%$.

\subsection{Meteorological Monitoring}

A network of meteorological observation towers provides data on the meteorological conditions and the transport and diffusion qualities of the atmosphere on the reservation. Data collected at the towers are used in routine dispersion modeling to predict impacts from facility operations and as input to emergency-response atmospheric models used in the event of accidental releases from a facility. Data from the towers are also used to support various research and engineering projects.

\subsubsection{Description}

The meteorological monitoring network, depicted in Fig. 3.21, consists of one 60-m (200-ft) tower (MT1) and one $30-\mathrm{m}(100-\mathrm{ft})$ tower at the K-25 Site (MT7); one 100-m (330-ft) tower (MT2) and two 30-m (100-ft) towers (MT3 and MT4) at ORNL; and one 100-m (330-ft) tower (MT5) and one 60-m (200-ft) tower (MT6) at the Y-12 Plant.

(Measurements in feet are exact; metric values are approximate.)

Data are collected at different levels to determine the vertical structure of the atmosphere and the possible effects of vertical variations on releases from facilities. At all towers, data are collected al $10 \mathrm{~m}(32.8 \mathrm{ft})$ and at the top of the tower. At the $100-\mathrm{m}(330-\mathrm{ft})$ towers, data are collected at intermediate [30-m (100-ft)] levels as well. At each measuring level at each tower, temperature, wind speed, and wind direction are measured; humidity and atmospheric stability (a measure of the dispersive capability of the atmosphere) are also measured at each tower. Barometric pressure is measured at one tower at each plant. Precipitation and solar radiation are measured at MT2 at ORNL.

Data from the towers are collected by a dedicated control computer at each site. The towers are polled and data are checked for validity against a predetermined set of parameters, summarized, and filed on disk. Fifteen-minute and hourly values are stored at each site for a running $24-\mathrm{h}$ period. Only hourly data are routinely stored beyond $24 \mathrm{~h}$. The meteorological monitoring data from all towers are checked quarterly, and summaries of data are developed as wind roses such as the data presented in Fig. 3.22. Quarterly calibration of the instruments is conducted for each facility by an outside contractor.

Fifteen-minute and hourly data are used directly at each facility computer for emergency response purposes such as input to dispersion models. Annual dose estimates are calculated using archived data (i.e., either hourly values or summary tables of 
OANL-DWG 87M-7052R4

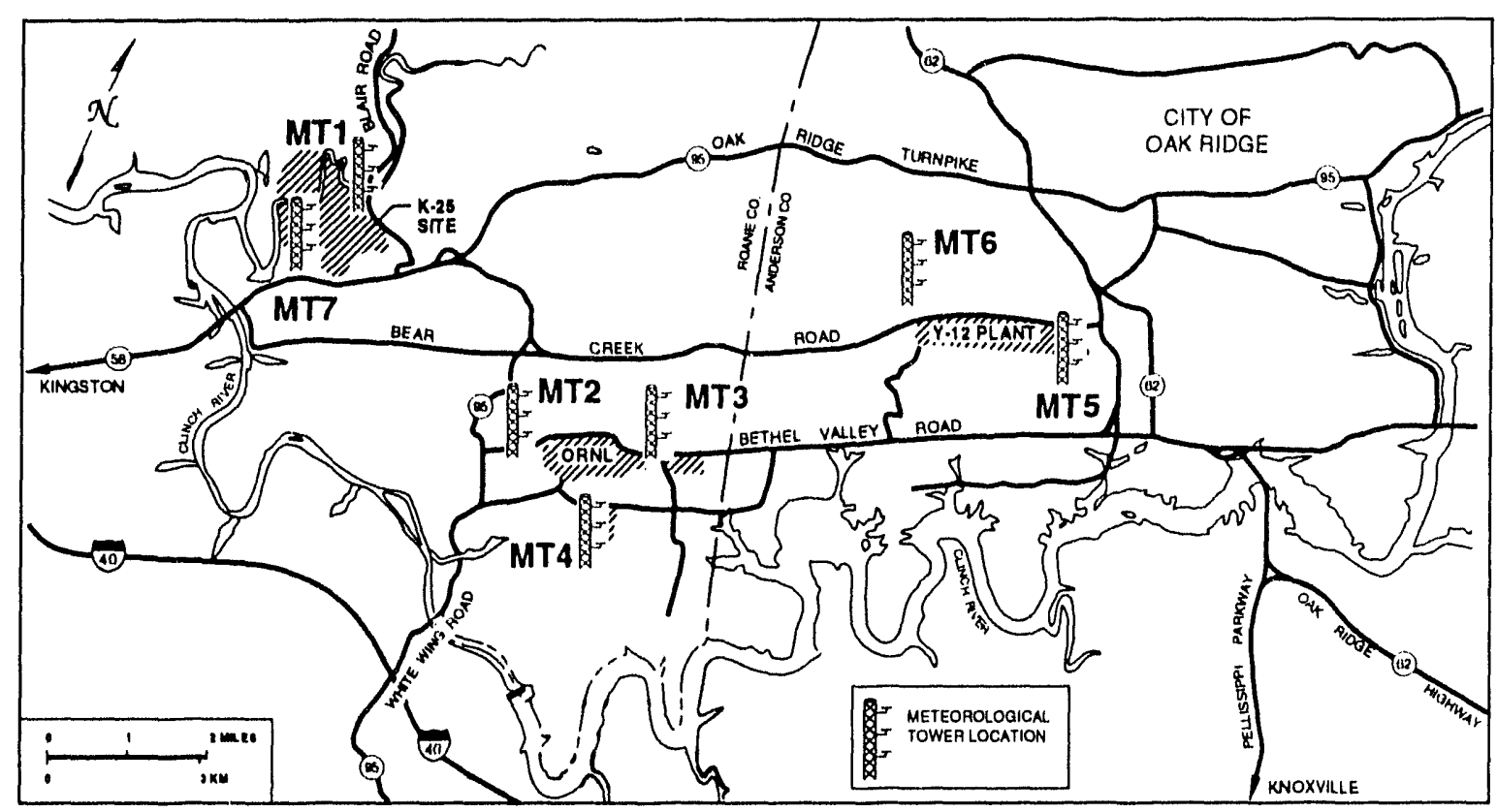

Fig. 3.21. ORR meterological monitoring network.

atmospheric conditions). Data quality is checked using predetermined values, and out-of-range parameters are marked invalid (not input to the dispersion models).

In 1992 improvements were made to the two towers at the Y-12 Plant. Improved lightning protection involved installing new lightning rods and additional down-lead cables and extending the grounding mats. In addition, battery-operated backup power supplies were installed to provide continued operation of the sensors, data loggers, and central computer in the event of a power outage.

\subsubsection{Summary}

The data presented in Fig. 3.22 are from the 100-m tower at the east end of the Y-12 Plant (MT5). Wind roses from all tower locations are presented in Figs. 3.1-3.16 of Vol. 2. The information contained in Fig. 3.22 is useful in describing the meteorological conditions of the reservation.

Prevailing winds are generally up-valley from the southwest and west-southwest, or down-valley from the northeast and east-northeast. This pattern is the result of the channeling effect of the ridges flanking the site. Winds in the valleys tend to follow the ridges, with limited cross-ridge flow. These conditions are dominant over the entire reservation, with the exception of the K-25 Site, which is located in a relatively open area that has a more varied flow. However, somewhat weaker valley flows are noted in the K-25 Site area, particularly in locations near the Clinch River.

The winds measured on the reservation are dominated by low-wind-speed conditions at the surface level. This characteristic is noted at all tower locations, as is the increase in wind speed with height at which the measurements are made. This activity is typical of tower locations and is important when selecting appropriate data for input to dispersion studies.

The atmosphere over the reservation is dominated by stable conditions on most nights and in early morning hours. These conditions, coupled with the low wind speeds and channeling effects of the valleys, result in poor dilution of material emitted from the facilities. These features are captured in the 


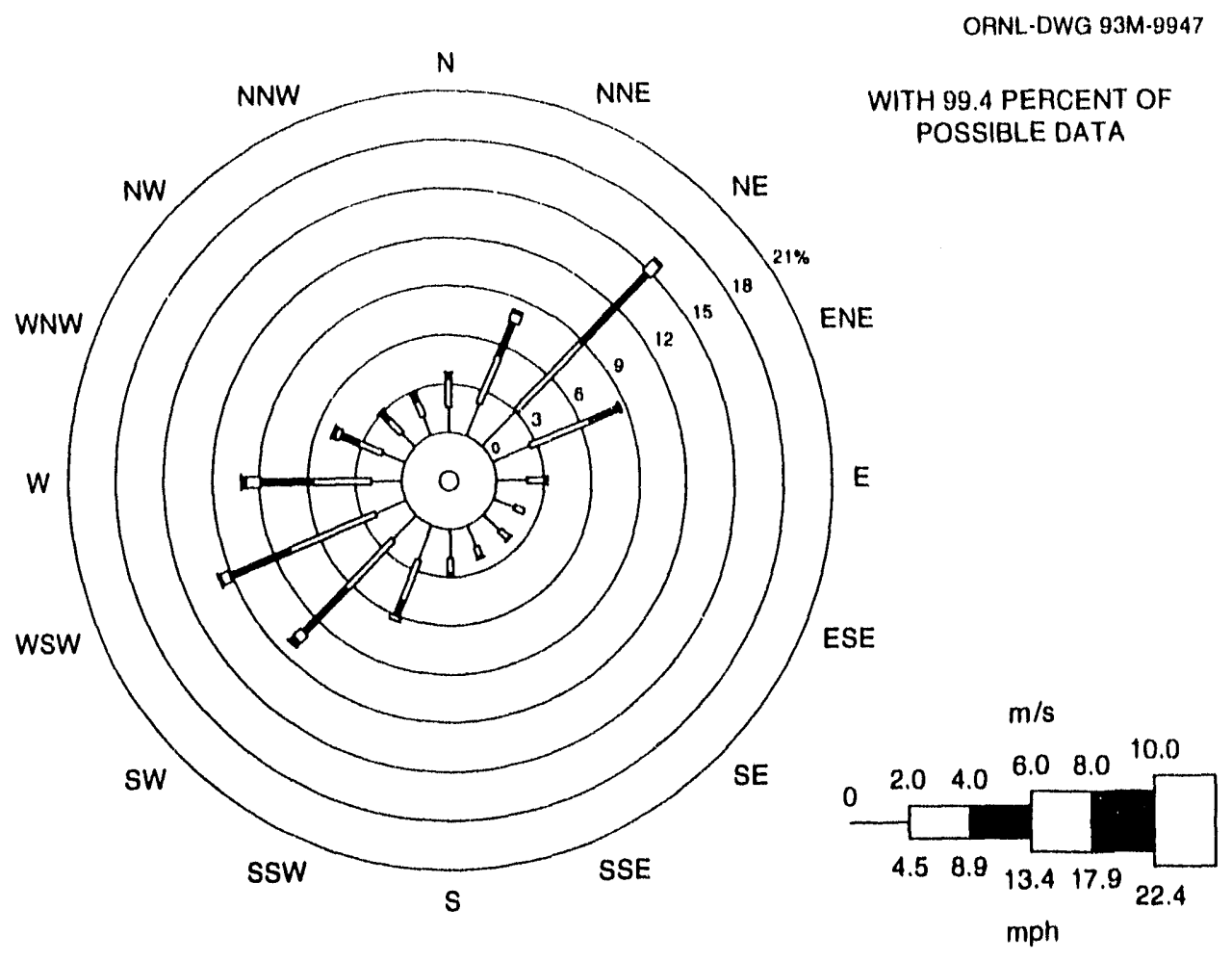

Fig. 3.22. 1992 wind rose for Y-12 Plant tower MT5 (east) (100-m level), with $99.4 \%$ of possible data.

data input to the dispersion models and are reflected in the modeling studies conducted for each facility.

Precipitation data from tower MT2 are used in stream flow modeling and in certain research efforts by various divisions. The data indicate the variability of regional precipitation, with high winter rainfall amounts resulting from frontal storms and uneven, but occasionally intense, summer rainfall associated with thunderstorms.

The average data capture efficiency across all 16 tower levels and locations was $96.4 \%$. The maximum capture efficiency was $99.4 \%$, and the minimum capture efficiency was $93.1 \%$.

\subsection{External Gamma Radiation}

External gamma radiation measurements are made to determine if routine radioactive effluents from ORR are increasing external radiation levels significantly above normal background levels.

\subsubsection{Sample Collection and Analytical Procedures}

In 1991, external gamma radiation measurements (exposure rates) were recorded on a near real-time data acquisition system at ORNL and reservation perimeter air monitoring stations. In February, 1992, station locations were changed to coincide with the new ambient air locations. Measurements are recorded weekly at five of the ten ambient air stations: 39, 40, 42, 46, and 48 (Fig. 3.23). In addition, measurements are still collected at the DOE museum (station 41).

\subsubsection{Results}

Table 3.17 presents the data for the individual stations: the number of measurements, the maximum value, the minimum value, the average, and the standard error. The average value was $7.6 \mu \mathrm{R} / \mathrm{h}$. Typical values for cities in the contiguous United 


\section{Environmental Report Vol. 1, Oak Ridge}

States are usually between 5 and $20 \mu \mathrm{R} / \mathrm{h}$. The median value published by EPA (1989) for cities in the United States during 1989 was $9.3 \mu \mathrm{R} / \mathrm{h}$, with $75 \%$ of the values between 8.2 and $12.2 \mu \mathrm{R} / \mathrm{h}$. (The distribution is positively skewed.) Any contribution (0) the external gamma signature by ORNL or the other facilities is not distinguishable at these ORR PAM locations.

\subsection{References}

American National Standards Institute, Inc. (ANSI), 1969 (R1982). American National Standard Guide to Sampling Airborne Radioactive Materials in Nuclear Facilities, ANSI N13.1.

O. W. Hermann and R. M. Westfall, "ORIGEN-S: SCALE System Module to Calculate Fuel
Depletion, Actinide Transmutation, Fission Product Buildup and Decay, and Associated Radiation Source Terms," Sect. 7 of SCALE: A Modular Code System for Performing Standardized Computer Analysis for Licensing Evaluation, NUREG/CR-(02()0, Rev. 4 (ORNL/NUREG/CSD-2/R4), Vol. II (Draft, March 1992).

U.S. Department of Energy (DOE), 1991.

Environmental Regulatory Guide for

Radiological Effluent Monitoring and

Environmental Surveillance, DOE/EH-()173T,

Washington, D.C.

U.S. Environmental Protection Agency (FPA). 1989.

Environmental Radiation Data, Reports 57-.59.

Eastern Environmental Radiation Facility, Montgomery, Ala.

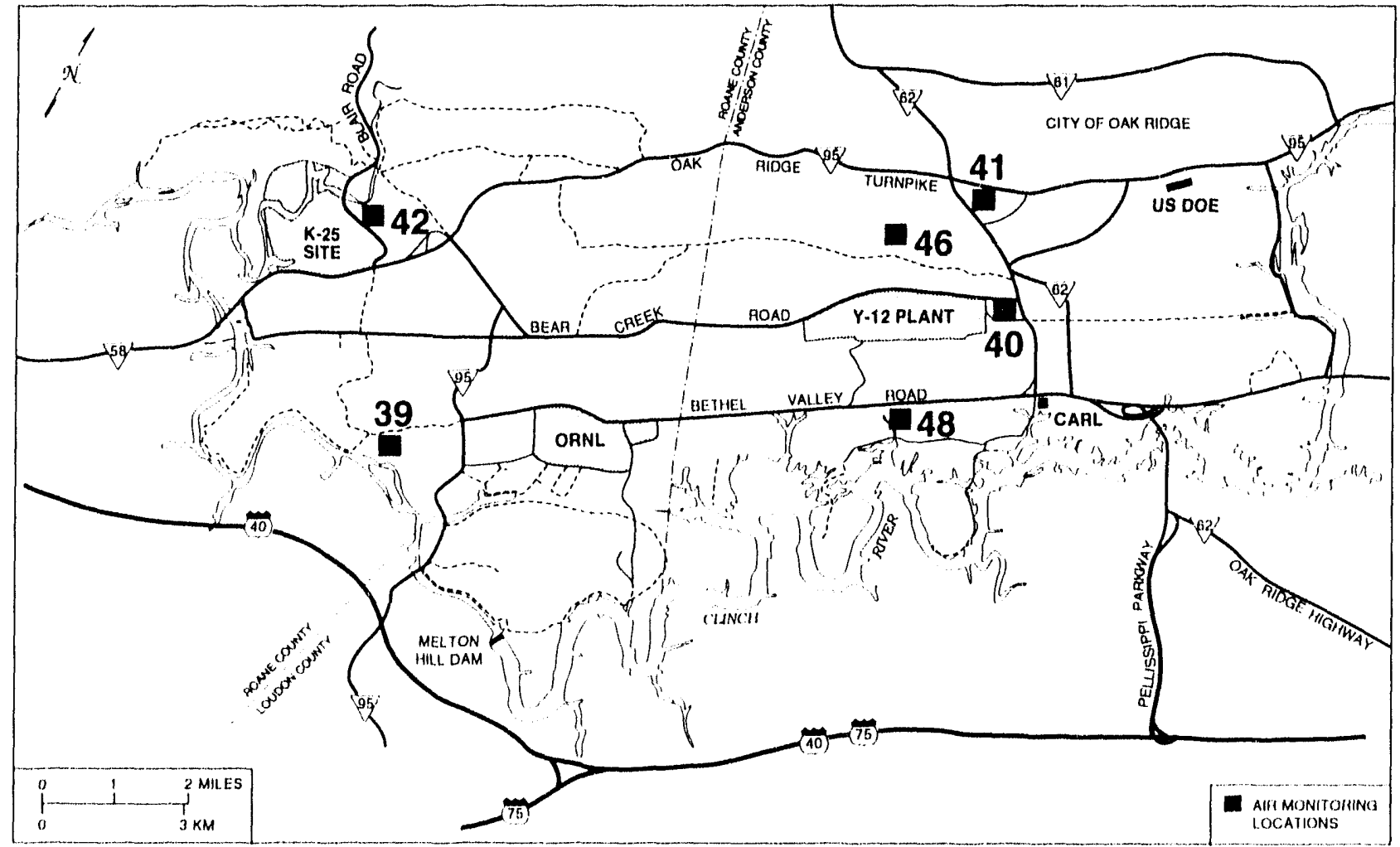

Fig. 3.23. ORR external gamma measurement locations. 
1992 Environmental Report Vol. 1, Oak Ridge

Table 3.17. External gamma radiation measurements at ORR perimeter air monitoring stations, 1992

\begin{tabular}{|c|c|c|c|c|c|}
\hline \multirow{2}{*}{ Location ${ }^{\prime \prime}$} & \multirow{2}{*}{$\begin{array}{l}\text { Number of } \\
\text { measurements }\end{array}$} & \multicolumn{4}{|c|}{ Exposure rate $(\mu \mathrm{R} / \mathrm{hr})$} \\
\hline & & $\operatorname{Max}$ & Min & Av & $\begin{array}{l}\text { Standard } \\
\text { error" }\end{array}$ \\
\hline 39 & 42 & 11 & 10 & 10 & 0.034 \\
\hline 40 & 46 & 8.4 & 7.8 & 8.0 & 0.017 \\
\hline 41 & 51 & 5.1 & 4.0 & 4.6 & 0.024 \\
\hline 42 & 13 & 10 & 7.3 & 7.6 & 0.21 \\
\hline 46 & 30 & 9.0 & 8.5 & 8.7 & 0.020 \\
\hline 48 & 43 & 8.6 & 6.7 & 7.2 & 0.087 \\
\hline Average & 255 & 11 & 4.0 & 7.6 & 0.13 \\
\hline
\end{tabular}

"See Fig. 3.23.

${ }^{b}$ Standard deviation of the nean. 


\section{SURFACE WATER}

4.1 Surface Water Monitoring Program Goals . . . 4-5

4.2 Regulatory Authorities . . . . . . . . . . 4-5

4.3 Monitoring Program Overview . . . . . . . 4-5

4.3.1 Referenco Surface Waters . . . . . . 4. 4-5

4.3.2 ORR Surface Waters Receiving

Effluents ................ 4-7

4.3.3 ORR Off-Reservation Surface

Waters .............. . . . . 4-7

4.3.4 Effluents and Ambient Waters ..... 4.7

4.41992 Monitoring Program Results . . . . . . . 4-8

4.4.1 Y-12 Plant . . . . . . . . . . . . . . 4-8

4.4.2 Oak Ridge National Laboratory . . . . 4-18

4.4.3 K-25 Site . . . . . . . . . . . 4-28

4.5 References . . . . . . . . . . . . . . . . 4-37 


\section{Environmental Report Vol. 1, Oak Ridge}

\section{Surface Water}

The surface water regime of the ORR consists of the Clinch River, which forms the reservation boundary to the south and west; a series of subbasins of the Clinch River from Brashear Creek just below the K-25 Site to Scarboro Creek east of the Y-12 Plant; and the East Fork Poplar Creek basin, which forms the hydrologic boundary of the reservation to the north and east (Fig. 1.14). Four of the subbasins of the Clinch River are affected by operations of the facilities of the ORR. The Y-12 Plant is located in the Bear Creek and East Fork Poplar Creek subbasins. ORNL is located in the White Oak Creek subbasin, which includes Melton Branch. The K-25 Site is located in the Poplar Creek subbasin, which includes Mitchell Branch. Figure 4.1 shows the Clinch River, the ORR boundary, and the affected major subbasins of the Clinch River. Raccoon Creek, which is west of ORNL, also has been affected by the reservation, but not by current operations.

The inherent quality of surface water in the vicinity of the $O R R$ is influenced by the geochemistry and soil-water interactions of the subbasins. As discussed in Sect. 1.4 (Geology) and shown in Fig. 1.11, the surface features and surface geology of the ORR are formed by the repetition of stratigraphic units of the Rome Formation, Conasauga Group, Knox Group, and the Chickamauga Group. These units contain various amounts of sandstones, siltstones, shales, dolomites, and limestones. Interactions of groundwater with the unique collection and composition of geologic units in each subbasin result in unique surface water chemistry for each subbasin.

The surface water and geochemical relationships are summarized by McMaster (1967). The report provides data for 29 area streams, including Bear Creek, East Fork Poplar Creek, White Oak Creek, Melton Branch, and Poplar Creek upstream of the
ORR. The emphasis of the sampling program was low, medium, and high base-flow conditions (i.e., stream flow that originates as groundwater versus overland runoff). Samples of this type will show the maximum impact of geochemistry on surface water. The information from this report is useful today because the geochemical impac's upon surface water change very slowly with time.

Data in the McMaster report show that the surface waters originating in the ORR subbasins affected by the facilities are of a carbonatebicarbonate type with little or no influence from natural sulfates, nitrates, or chloride. The major cation in Melton Branch and Bear Creek is calcium at 65 to $80 \%$; magnesium contributes 15 to $25 \%$. This is characteristic of base flow derived from limestone formations. In contrast, White Oak Creek cations consist of $45 \%$ calcium and $55 \%$ magnesium, which are typical percentages for base flow derived from dolomite. Contributions of sodium and potassium to the total cations for these three streams are less than $10 \%$. East Fork Poplar Creek has an ion composition that is unique among the streams on the ORR. Total cations consist of $50 \%$ calcium, $30 \%$ sodium and potassium, and $20 \%$ magnesium. The anions consist of $65 \%$ carbonate-bicarbonate, $20 \%$ chloride, and $15 \%$ sulfate. East Fork Poplar Creek also originates in a limestone formation; the presence of sodium, potassium, and sulfate is probably a consequence of operations at the $Y-12$ Plant.

The data for Poplar Creek show the influence of the Cumberland Plateau geology. The anions for this stream are $55 \%$ carbonate-bicarbonate, $40 \%$ sulfate, and $5 \%$ nitrate and chloride. The major cations consist of $60 \%$ calcium and $30 \%$ magnesium. This type of surface water is generally derived from a shale-siltstone-sandstone geology. The contribution of sulfate to the ion balance is probably influenced by 


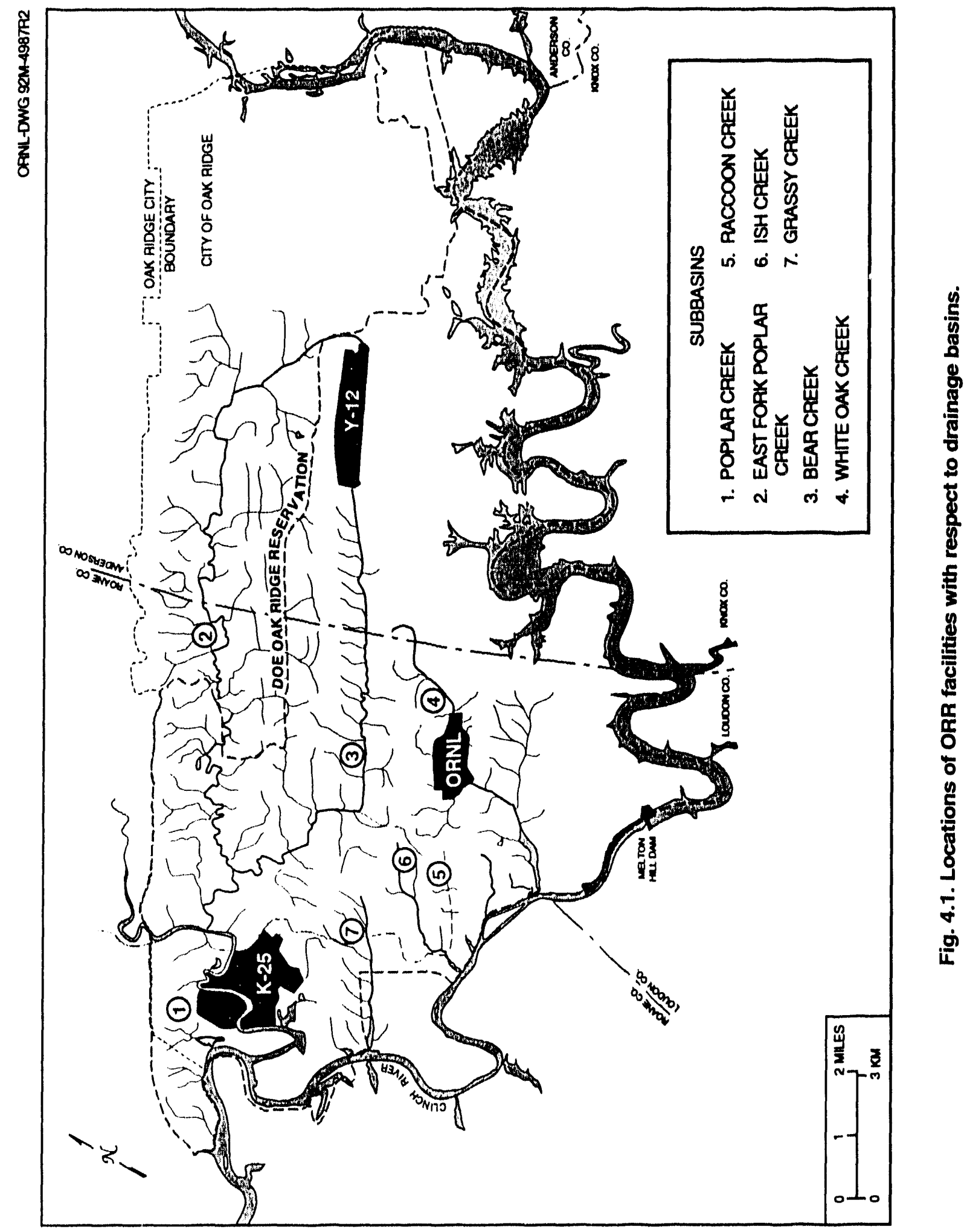




\section{Environmental Report Vol. 1, Oak Ridge}

surface coal mining activity on the Cumberland Plateau (McMaster 1967).

\subsection{Surface Water Monitoring Program Goals}

The purpose of the surface water monitoring program at the ORR is to assess the impacts of the facility effluents upon natural receiving waters and to estimate the potential impacts of these effluents on human health and the environment. These goals are addressed through effluent monitoring and environmental surveillance.

Effluent monitoring is defined as the collection and analysis of effluents to characterize and quantify contaminants and to demonstrate compliance with applicable standards. In this definition "effluent" typically refers to a point source that emanates from a process; effluent monitoring samples are collected from point source discharges.

Environmental surveillance is the collection and analysis of environmental media for the purpose of assessing potential impacts of facilities on members of the public and the environment. Environmental surveillance samples for surface waters consist of ambient water samples taken from the receiving streams. The facilities on the ORR also include diffuse effluent sources resulting from historic waste disposal and operational practices. These effluents are released through interactions of groundwater and surface water. The impacts of diffuse sources are integrated into the monitoring program through environmental surveillance samples collected downstream of the facilities. Figure 4.2 depicts the locations of surveillance sampling for surface waters in the receiving streams.

\subsection{Regulatory Authorities}

The body of regulations promulgated by the EPA to control impacts to surface water quality by toxic and hazardous chemicals are collectively known as the Clean Water Act (CWA) regulations. These regulations include the National Pollutant Discharge Elimination System (NPDFS) requirements. EPA Region IV has delegated authority for NPDES to the state of Tennessee. The bases for the NPDES permit requirements are the stream classifications and general water quality criteria authorized by the CWA regulations and established by the state. The classifications of the streams on and around the reservation are provided in Vol. 2, Table 1.3. The intent of NPDES permits is to establish effluent contamination limits that protect the classified uses of the surface waters.

Certain DOE orders address the control of radioactive constituents in effluents and ambient waters. DOE Order 5400.5 establishes criteria for radioactive effluents and dose conversion factors for exposure assessments. This order has been drafted as federal regulation 10 CFR 8.34; after the final rule making, this regulation will be enforceable in the same manner as the EPA regulations. DOE Order 5400.6 has been converted into the Emvirommental Regulatory' Guide for Radiological Effluent Monitoring and Environmental Surveillance (DOE/EH-0173T), a regulatory guide in support of 10 CFR 834. This document provides detailed technical guidance and requirements for effluent monitoring and environmental surveillance for radionuclides.

\subsection{Monitoring Program Overview}

Surface water monitoring on the ORR is conducted through the sampling and analysis of four functionally distinct types of water: reference surface waters, ORR surface waters receiving effluents, off-reservation surface waters, and effluents. The information presentations and discussions are organized by these functional types. All of the data summary tables are located in Vol. 2 so the reader can easily scan the data while reading the text. Where a single sampling location serves more than one function, the data are combined and presented in a single table to provide a complete data picture.

\subsubsection{Reference Surface Waters}

Sites for sampling reference surface waters are located upstream of the various facilities on the ORR These data can be used to assess water quality prior to the impacts of the ORR. The term "reference" is used instead of "background" because the latter typically implies an environmental medium that is pristine or unaffected by human activities. The Clinch River is the major surface water system that is affected by the ORR and many human activities upstream of the reservation. The net impact of the 
1992 Environmental Report Vol. 1, Oak Ridge

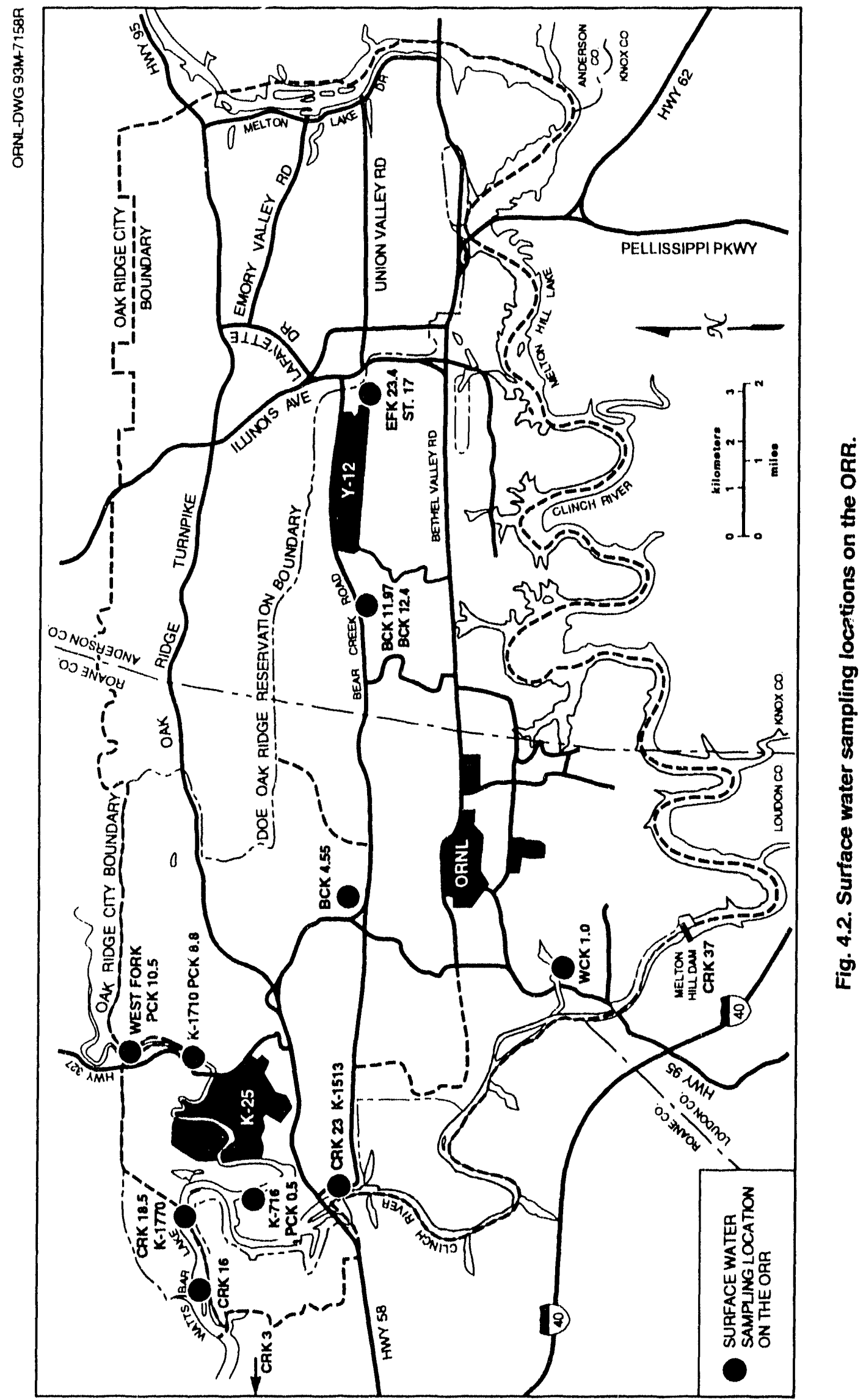


ORR can be evaluated by comparing the reference data to information from samples collected downstream of the facilities.

\subsubsection{ORR Surface Waters Receiving Effluents}

Natural streams on the ORR receive effluents directly from discharge points. The effluent-receiving waters on the ORR include Bear Creek, McCoy Branch, Rogers Quarry, and East Fork Poplar Creek (EFPC) at the Y-12 Plant, White Oak Creek (WOC) and Melton Branch (MB) at ORNL, and Poplar Creek and Mitchell Branch at the K-25 Site. Samples from these streams are used to assess the impacts of the facilities on the natural water quality and to determine the contaminant concentrations in the streams prior to their dilution in the Clinch River. Field measurements and sample collections are carried out at various effluent sources and on receiving streams on the ORR.

\subsubsection{ORR Off-Reservation Surface Waters}

Natural surface waters off the ORR are affected by the facilities through the integration of discharges from the affected basins. Samples of these waters provide empirical information regarding the concentrations of contaminants from the ORR in the Clinch and Tennessee rivers.

\subsubsection{Effluents and Ambient Waters}

Liquid discharges from facility processes and storm water runoff from areas such as roofs and parking lots are called effluents. Under the requirements of the CWA, an NPDES permit has been issued to each of the three Oak Ridge facilities; these permits specify the effluent monitoring program for each of these point sources. There are as many as seven components to the NPDES permits at the Oak Ridge plants.

First, a plan for monitoring effluent characteristics is a primary requirement under the permit. Each plan must include methods for gathering basic information, as appropriate to the individual monitoring point, such as flow, temperature, $\mathrm{pH}$, biochemical oxygen demand (BOD), total suspended solids (TSS), oil and grease (O\&G), and fecal coliform. This part of the permit also includes specific contaminant monitoring requirements for organics and inorganics.

Next, the Y-12 Plant and ORNL are required under the special conditions of their NPDES permits to monitor ambient water locations and to assess the impacts of the facilities upon the receiving waters at or near the facility boundaries. Ambient water samples are typically analyzed for parameters identified in the NPDES effluent characteristics monitoring plans. The NPDES permit for the K-25 Site does not require this component; however, the site does have an ambient water-monitoring program.

The Y-12 Plant and ORNL must also have a radiological monitoring plan (RMP) designed to monitor a representative sample of outfalls that have the potential to discharge radioactivity to ambient waters. This plan typically includes effluent points and ambient water sampling locations. It coincides with the requirements of the DOE orders. The NPDES permit for the K-25 Site does not require this component; however, radiological monitoring is included in the ambient program.

A fourth aspect of each site's NPDES permit is their toxicity control and monitoring programs (TCMPs). Each TCMP assesses the toxic impact of treatment facilities and ambient waters by exposing freshwater animals to water samples collected from the monitoring points. The results of the tests are used to estimate the water's no-observed-effect concentration (NOEC).

Two EPA-approved toxicity tests are used to estimate a water's NOEC: (1) the fathead minnow (Pimephales promelas) larval survival and growth test and (2) the Ceriodaphnia survival and reproduction test. These two tests, which are static renewal tests (i.e., the test solutions are replaced daily for each species), are described in detail by Horning and Weber (1985). A water's NOEC is computed by comparing the responses of the animals exposed to a contaminant-free water (control water) with those of animals exposed to various concentrations of the water (dilutions are made with the control water). The NOEC is the concentration of water (expressed as a percentage of full strength) that does not adversely affect either fathead minnow larvae survival and growth or Ceriodaphnia survival and reproduction. The higher the NOEC, the less toxic and, therefore, the better the quality of the 
water. If a water's NOEC is less than $100 \%$, the NOEC is compared with the estimated effluent concentration in the receiving stream to predict whether the wastewater will adversely affect aquatic biota in the receiving streams.

Biological monitoring and abatement programs (BMAPs) were developed to demonstrate that the interim effluent limits established by the NPDES permits for each facility protect the classified uses of the receiving streams (e.g., growth and propagation of fish and aquatic life). Information from the programs can also be used to evaluate remedial actions and new pollution abatement facilities from the perspective of ecological recovery in the affected waters.

Each BMAP consists of (1) ambient water toxicity testing conducted in the same manner as the TCMP, (2) contaminant bioaccumulation studies, (3) biological indicator studies including measurements of selected biochemical parameters and histopathological analyses, and (4) ecological community surveys of fish and benthic invertebrates. These tasks use a variety of techniques, including laboratory bioassays, manipulative field experiments, and biotic surveys, to assess ecological effects at different levels of biological organization. Results for this program are provided and discussed in Sect. 6, Biological Monitoring.

Also required for the Y-12 Plant and ORNL NPDES permits, the polychlorinated biphenyls monitoring plan (PCB Plan) specifically addresses the presence of PCBs in effluents and ambient waters to identify and eliminate any sources of $\mathrm{PCB}$ discharge to receiving streams. The ORNL plan includes monitoring of sediment only. Sediment data associated with these programs are reported and discussed in Sect. 7, Soil and Sediment Monitoring. An additional requirement for the ORNL NPDES permit is a mercury monitoring plan (Mercury Plan). The Mercury Plan specifically addresses the presence of mercury in effluents and ambient waters to identify and eliminate any sources of mercury discharging to receiving streams. Sediment data associated with this program are reported and discussed in Sect. 7, Soil and Sediment Monitoring.

\subsection{Monitoring Program Results}

\subsubsection{Y-12 Plant}

\subsubsection{Reference Surface Waters}

Originating within the plant site are the three streams that are impacted by past and present $\mathrm{Y}-12$ Plant operations (EFPC, McCoy Branch, and Bear Creek). Consequently, it is not possible to sample and analyze the waters of these streams prior to their being affected by the facility. However, streams on the ORR not affected by the Y-12 Plant operations are used for comparison purposes.

\subsubsection{ORR Surface Waters Receiving Effluents}

Routine surface water monitoring that is not required by the NPDES permit is performed at the Y-12 Plant site for a variety of reasons. Various radiological and nonradiological parameters are monitored at the sites shown in Fig. 4.3.

Monitoring results are compared with state water quality criteria and with DOE order requirements. Nonradiological data are compared with the State of Tennessee Water Quality Criteria, where a criterion exists for each parameter. The most restrictive of either the Freshwater Fish and Aquatic Life Criterion Maximum or the Recreation ( $10^{-5}$ risk factor for carcinogens) for Organisms Only standards were used. Radiological data are compared with derived concentration guides (DCGs) published in DOE Order 5400.5 The DCGs are estimates of the rate of exposure to a given radionuclide via one exposure pathway that would result in an effective dose equivalent of 100 mrem per year to "reference man," as defined by the Internal Commission of Radiation Protection Publication 23. Radiological data are reported as percentage of the DCG for a given isctope. In the event that a sum of the DCG percentages for each location ever exceeds $100 \%$, an analysis of the best available technology to reduce 


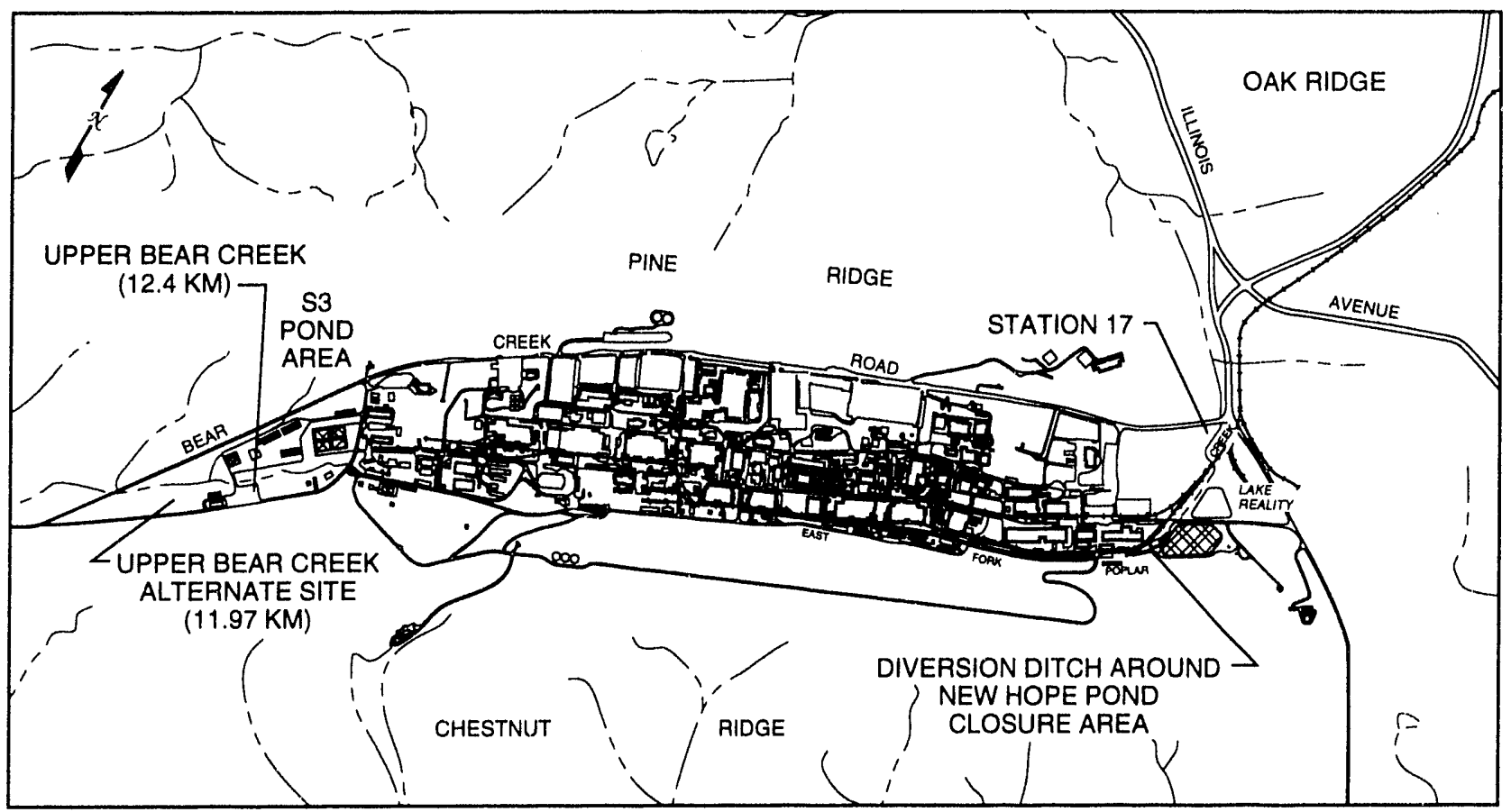

Fig. 4.3. Y-12 Plant non-NPDES routine surface water monitoring sites.

the radionuclide signature would be required as specified in DOE Order 5400.1.

Kilometer 12.4 (mile 7.7) on upper Bear Creek is monitored in response to Section IV, Part 4, of a memorandum of understanding agreed to by DOE, EPA, and TDEC. This site, where the creek first approaches Bear Creek Road, was agreed upon as a point in the stream that is characteristic of the effects of the seepage of the S-3 ponds. Because of decreased flow at this site since the closure of the S-3 ponds, a new site at kilometer 11.97 is also being monitored and has been proposed as a replacement site. The analytical data from both these sites have been compared, and changes in the monitoring routine were proposed. These changes should be implemented in 1993. Analytical data are reported monthly to TDEC as an attachment to the discharge monitoring report (DMR) required by NPDES. These sites were monitored once per week for the radiological and nonradiological parameters shown in Tables 4.1-4.4 in Vol. 2. For both locations, all radiological results were well below DCGs listed in DOE Order 5400.5 , with ${ }^{237} \mathrm{~Np}$ being the only radionuclide exceeding $2 \%$ of a DCG $(3.77 \%$ at $\mathrm{km}$
11.97 and $2.35 \%$ at $\mathrm{km} \mathrm{12.4).} \mathrm{Figure} 4.4$ shows total uranium and nitrate data from 1987 to 1992 for Upper Bear Creek site at kilometer 12.4 .

A sampling point is located in the diversion ditch around the New Hope Pond Closure Area. Samples are taken here on a weekly basis for the radiological parameters shown in Table 4.5 in Vol. 2. In addition, Station 17, located near the junction of Bear Creek and Scarboro roads, is used to monitor EFPC downstream of Lake Reality but prior to its leaving the easternmost Y-12 Plant boundary. Weekly samples were obtained at Station 17 for the radiological and nonradiological parameters listed in Tables 4.6 and 4.7 of Vol. 2 .

In like manner these data are compared with the State of Tennessee Water Quality Criteria, where a criterion exists for each parameter, and to DCGs. All radiological results are well below DCGs, with no single radionuclide exceeding $2 \%$ of the DCG.

Bear Creek kilometer 4.55 (Fig. 4.1), also designated as NPDES outfall 304 , is also monitored weekly for radiological parameters. This location is the westernmost monitoring location on Bear Creek as the creek leaves the $\mathrm{Y}-12$ boundary. Rogers 


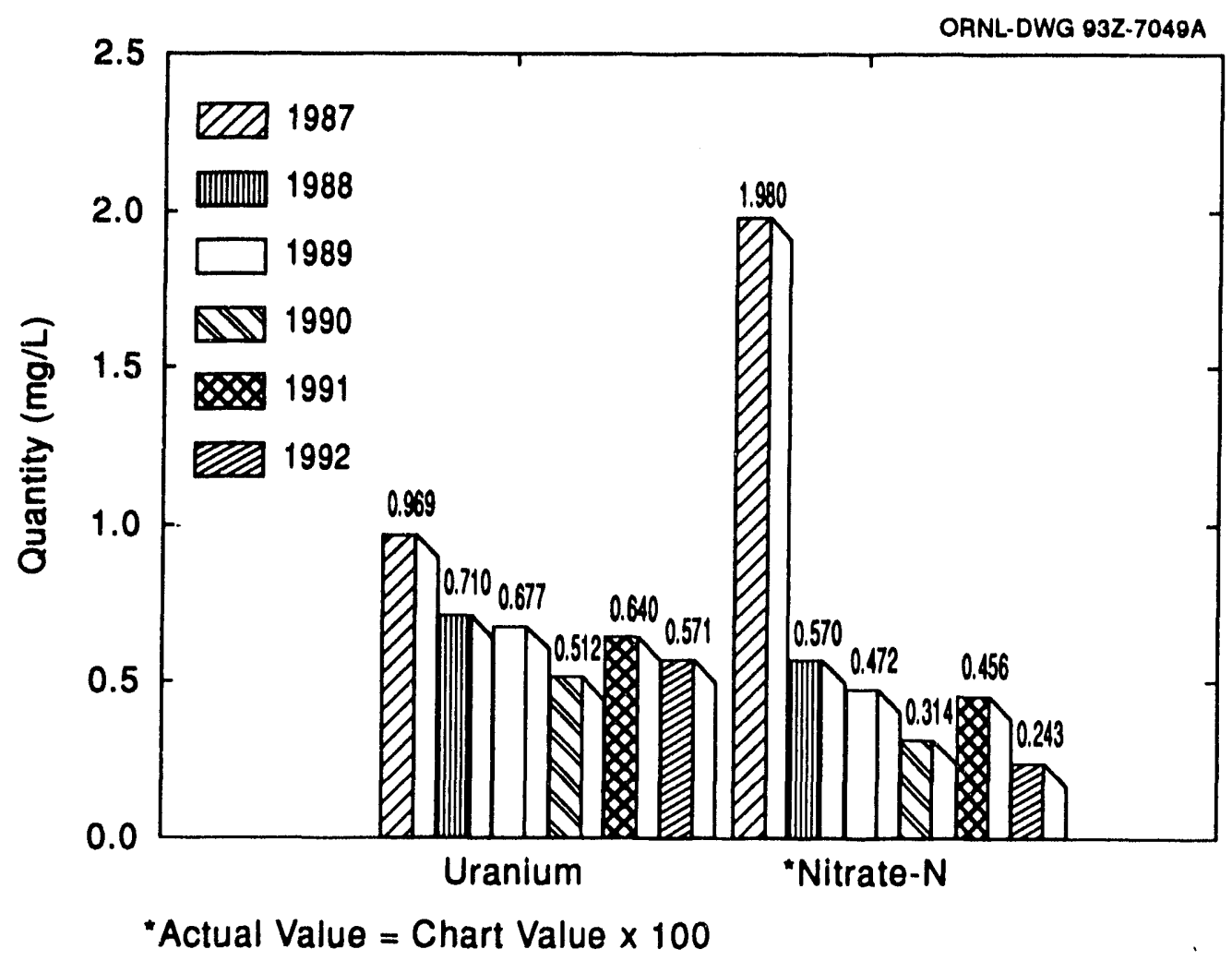

Fig. 4.4. Upper Bear Creek (BCK 12.4) trend chart, 1987-1992.

Quarry, which carries flow of McCoy Branch, and also designated NPDES outfall 302, is also monitored for radiological parameters. All radiological results are also well below DCGs at these locations, with no single radionuclide exceeding $2 \%$ of the DCG.

Table 4.8 in Vol. 2 shows the total uranium and associated curies released from the Y-12 Plant at the easternmost monitoring station, Station 17 on Upper East Fork Poplar Creek, and the westernmost monitoring station at Bear Creek kilometer 4.55 (NPDES outfall 304). The total uranium from these two points was $240 \mathrm{~kg}$ or 0.15 curies. Tables containing data from radiological analyses accompany their respective NPDES tables in Vol. 2.

Grab samples were obtained twice per day for mercury, 24-h composite samples were obtained every day of the week, and 72-h composites were collecied over the weekends.

\subsubsection{ORR Off-Reservation Surface Waters}

Data sampling and analyses of off-reservation surface waters were completed by ORNL staff and are discussed in Sect. 4.4.2.

\subsubsection{Effluents}

Wastewater effluents from the Y-12 Plant are discharged in two primary ways: to the sanitary sewer for treatment under an industrial user's permit or to surface waters under an NPDES permit.

The Y-12 Plant is permitted to discharge domestic wastewater to the city of Oak Ridge Sewage Treatment Plant under Industrial User's Permit No. 001. This user's permit allows the Y-12 Plant to discharge wastewater to be treated at the Oak Ridge Wastewater Treatment Facility through two main sewage lines into the Oak Ridge sanitary sewer system in accordance with effluent limitations, monitoring requirements, and other conditions set forth in the permit. The radiological and nonradiological parameters monitored and the results obtained for these sewer lines are listed in Tables 4.9-4.12 of Vol. 2. In this case reference values used for comparison are taken from the City of Oak Ridge Industrial User's Permit. Samples from the sanitary sewer are collected from the City Monitoring Station and from the Union Valley Station. The contribution from the $Y-12$ Plant to the

\section{4-10 Surface Water}




\section{Environmental Report Vol. 1, Oak Ridge}

sewer system can be calculated by subtracting the input from the Union Valley Station, which does not have any Y-12 Plant wastes associated with it, from the results of the City Station, which is directly downstream of the Y-12 Plant and Union Valley. The nonradiological and radiological results from this calculation are shown in Vol. 2, in Tables 4.13 and 4.14 , respectively. No radionuclide exceeds $1 \%$ of the DCG in the Y-12 Plant sanitary sewer. The Union Valley Station has a single result higher than $2 \%$ of the DCG $\left({ }^{238} \mathrm{U}\right.$ was $\left.2.5 \%\right)$.

The Y-12 Plant is permitted to discharge wastewater to East Fork Poplar Creek under NPDES Permit No. 0002968. Table 4.1 details the permit requirements and compliance record for each outfall in 1992. Development of a radiological monitoring plan for the Y-12 Plant is required by the NPDES permit. This plan was developed and submitted to TDEC in 1987. Monitoring activities under this plan began during the third quarter of 1987; it was revised in August 1992 to better characterize the radiological components of the plant effluents, to reflect changes in plant operations, and to complement the philosophy of "as low as reasonably achievable" (ALARA) for radioactive discharges in liquid effluents per DOE Order 5400.5. Consistent with this philosophy, the Y-12 Plant will continue to operate in a manner that complements the ALARA principle. Y-12 Plant ALARA program includes an aggressive plan to identify and minimize sources or radioactive discharges via the monitoring programs.

In addition to in-stream monitoring on Bear Creek and East Fork Poplar Creek and the sanitary sewer, waste treatment facilities and other source discharges at the Y-12 Plant are monitored for radiological dischar:as.

The treatment facilities that were monitored are shown in Fig. 4.5. They include the Central Pollution Control Facility (CPCF), the WETF, the Steam Plant Wastewater Treatment Facility (SPWTF), and the Plating Rinsewater Treatment Facility (PRTF).

Outfalls from these treatment plants are identified as NPDES outfalls 501,502,503, and 504, respectively. The combined discharge of CPCF and PRTF is identified as NPDES outfal: 501/504.

One additional treatment facility, the Groundwater Treatment Facility (GWTF), whose outfall is identified as NPDES outfall 512, was added to the revised radiological monitoring plan in late
1992. All radiological data for all treatment facilities were well below the DCGs of DOE Order 5400.5. The GWTF is the only treatment facility where any results were greater than $2 \%$ of a DCG, with ${ }^{234} \mathrm{U}$ being $6.3 \%$ and ${ }^{238} \mathrm{U}$ being $25 \%$ of the DCG.

Radiological monitoring of point and area source discharges included outfalls 109, 135, and 147. These data are presented in Tables 4.15, 4.16, and 4.17 of Vol. 2. None of these outfalls exceeded $2 \%$ of the DCG for any radionuclide. With full implementation of the revised radiological monitoring plan in 1993 , these three point source discharges will be dropped from the monitoring program in lieu of in-stream monitoring points downstream of the outfalls.

Over the past few years, significant changes in the interpretation of existing environmental legislation have impacted the environmental management program at the Y-12 Plant. Until 1977, EPA had total responsibility for enforcing the CWA at federal facilities such as the Y-12 Plant. Under the EPA, the Y-12 Plant had one NPDES permit with four perimeter outfalls: one at the outlet of New Hope Pond, one west of the main plant site on Bear Creek (at Highway 95), one at the outlet of Rogers Quarry, and one at the outlet of Kerr Hollow Quarry. While operating under the EPA NPDES permit, the Y-12 Plant regularly achieved compliance with the effluent discharge criteria.

In 1977, amendments to the Federal Water Pollution Control Act (FWPCA) allowed the states to establish their own water quality criteria. By law, these criteria took precedence over any EPA-issued NPDES permits. The current NPDES permit issued May 25, 1985, is a reflection of the 1977 amendments to the FWPCA and the Y-12 Federal Facilities Compliance Agreement (FFCA) signed by EPA and DOE on April 17, 1985. This current NPDES permit combines water quality and industrial best available technology (BAT) effluent limitations for the metal finishing and steam electric power generation industries with emphasis on biological and toxicological monitoring. The Y-12 Plant is committed to achieving effluent characteristics that are better than those specified by BAT. The effluent limitations for each treatment facility may be adjusted if the treated effluent results in in-stream toxicity as determined by TCMP or if EFPC does not display a healthy ecological system as determined by BMAP. 
Table 4.1. 1992 NPDES compliance at the Y-12 Plant

\begin{tabular}{|c|c|c|c|c|c|c|c|}
\hline \multirow[b]{2}{*}{$\begin{array}{l}\text { Discharge } \\
\text { point }\end{array}$} & \multirow[b]{2}{*}{$\begin{array}{l}\text { Effluent } \\
\text { parameter }\end{array}$} & \multicolumn{4}{|c|}{ Effluent limits } & \multirow{2}{*}{$\begin{array}{c}\text { - Percent } \\
\text { of } \\
\text { compliance }\end{array}$} & \multirow{2}{*}{$\begin{array}{c}\text { Number } \\
\text { of } \\
\text { samples }\end{array}$} \\
\hline & & $\begin{array}{l}\text { Daily } \\
\text { av } \\
(\mathrm{kg} / \mathrm{d})\end{array}$ & $\begin{array}{l}\text { Daily } \\
\max \\
(\mathrm{kg} / \mathrm{d})\end{array}$ & $\begin{array}{c}\text { Daily } \\
\text { av } \\
\text { (mg/L) }\end{array}$ & $\begin{array}{l}\text { Daily } \\
\max \\
(\mathrm{mg} / \mathrm{L})\end{array}$ & & \\
\hline \multirow[t]{5}{*}{301 (Kerr Hollow Quarry) } & Lithium & & & & 5.0 & 100 & 15 \\
\hline & $\mathrm{pH}$ (standard units) & & & $a$ & 8.5 & 100 & 15 \\
\hline & Total suspended solids & & & 30.0 & 50.0 & 100 & 15 \\
\hline & Temperature $\left({ }^{\circ} \mathrm{C}\right)$ & & & & 30.5 & 100 & 15 \\
\hline & Zirconium & & & & 3.0 & 100 & 15 \\
\hline \multirow[t]{5}{*}{302 (Rogers Quarry) } & Oil and grease & & & 10.0 & 15.0 & 100 & 53 \\
\hline & $\mathrm{pH}$ (standard units) & & & $a$ & 8.5 & 99 & 53 \\
\hline & Settleable solids (mL/L) & & & & 0.5 & 100 & 53 \\
\hline & Total suspended solids & & & 30.0 & $50.0^{b}$ & 100 & 53 \\
\hline & Temperature $\left({ }^{\circ} \mathrm{C}\right)$ & & & & 30.5 & 100 & 53 \\
\hline \multirow[t]{2}{*}{304 (Bear Creek) } & Oil and grease & & & 10.0 & 15.0 & 100 & 53 \\
\hline & $\mathrm{pH}$ (standard units) & & & $a$ & 8.5 & 100 & 53 \\
\hline \multirow[t]{4}{*}{307 (West Borrow Area) } & Temperature $\left({ }^{\circ} \mathrm{C}\right)$ & & & & & 100 & 4 \\
\hline & pH (standard units) & & & & & 100 & 4 \\
\hline & Oil and grease & & & & & 100 & 4 \\
\hline & Total suspended solids & & & & & 100 & 4 \\
\hline \multirow[t]{4}{*}{308 (East Borrow Area) } & Temperature $\left({ }^{\circ} \mathrm{C}\right)$ & & & & & 100 & 4 \\
\hline & $\mathrm{pH}$ (standard units) & & & & & 100 & 4 \\
\hline & Oil and grease & & & & & 100 & 4 \\
\hline & Total suspended solids & & & & & 100 & 4 \\
\hline \multirow{13}{*}{$\begin{array}{l}501 \text { [Central Pollution } \\
\text { Control Facility (CPCF-I)] }\end{array}$} & Cadmium, total & 0.07 & 0.19 & 0.26 & 0.69 & 100 & 23 \\
\hline & Chromium, total & 0.5 & 0.75 & 1.71 & 2.77 & 100 & 23 \\
\hline & Copper, total & 0.6 & 0.9 & 2.07 & 3.38 & 100 & 23 \\
\hline & Cyanide, total & 0.2 & 0.33 & 0.65 & 1.20 & 100 & 23 \\
\hline & Lead, total & 0.12 & 0.19 & 0.43 & 0.69 & 100 & 23 \\
\hline & Nickel, total & 0.65 & 1.1 & 2.38 & 3.98 & 100 & 23 \\
\hline & Oil and grease & 7.1 & 14.2 & 26.0 & 52.0 & 100 & 23 \\
\hline & $\mathrm{pH}$ (standard units) & & & $a$ & 9.0 & 100 & 23 \\
\hline & Silver, total & 0.07 & 0.12 & 0.24 & 0.43 & 100 & 23 \\
\hline & Temperature $\left({ }^{\circ} \mathrm{C}\right)$ & & & & 30.5 & 100 & 23 \\
\hline & Total suspended solids & 8.5 & 16.4 & 31.0 & 60.0 & 100 & 23 \\
\hline & Total toxic organics & & 0.6 & & 2.13 & $91^{c}$ & 23 \\
\hline & Zinc, total & 0.4 & 0.7 & 1.48 & 2.61 & 100 & 23 \\
\hline \multirow{13}{*}{$\begin{array}{l}502 \text { West End Treatment } \\
\text { Facility (WETF) }\end{array}$} & Cadmium, total & 0.07 & 0.019 & 0.26 & 0.69 & 100 & 54 \\
\hline & Chromium, total & 0.50 & 0.75 & 1.71 & 2.77 & 100 & 54 \\
\hline & Copper, total & 0.60 & 0.92 & 2.07 & 3.38 & 100 & 54 \\
\hline & Cyanide, total & 0.2 & 0.33 & 0.65 & 1.20 & 100 & 54 \\
\hline & Lead, total & 0.12 & 0.19 & 0.43 & 0.69 & 100 & 54 \\
\hline & Nickel, total & 0.65 & 1.10 & 2.38 & 3.98 & 100 & 54 \\
\hline & Oil and grease & 7.1 & 14.2 & 26.0 & 52.0 & 100 & 54 \\
\hline & $\mathrm{pH}$ (standard units) & & & $a$ & 9.0 & 100 & 54 \\
\hline & Silver, total & 0.07 & 0.12 & 0.24 & 0.43 & 100 & 54 \\
\hline & Temperature $\left({ }^{\circ} \mathrm{C}\right)$ & & & & 30.5 & 100 & 54 \\
\hline & Total suspended solids & 8.5 & 16.4 & 31.0 & 60.0 & 98 & 54 \\
\hline & Total toxic organics & & 0.6 & & 2.13 & 100 & 19 \\
\hline & Zinc, total & 0.4 & 0.7 & 1.48 & 2.61 & 100 & 54 \\
\hline
\end{tabular}


Table 4.1 (continued)

\begin{tabular}{|c|c|c|c|c|c|c|c|}
\hline \multirow[b]{2}{*}{$\begin{array}{c}\text { Discharge } \\
\text { point }\end{array}$} & \multirow[b]{2}{*}{$\begin{array}{l}\text { Effluent } \\
\text { parameter }\end{array}$} & \multicolumn{4}{|c|}{ Effluent limits } & \multirow[b]{2}{*}{$\begin{array}{c}\text { Percent } \\
\text { of } \\
\text { compliance }\end{array}$} & \multirow[b]{2}{*}{$\begin{array}{l}\text { Number } \\
\text { of } \\
\text { samples }\end{array}$} \\
\hline & & $\begin{array}{l}\text { Daily } \\
\text { av } \\
(\mathrm{kg} / \mathrm{d})\end{array}$ & $\begin{array}{l}\text { Daily } \\
\max \\
(\mathrm{kg} / \mathrm{d}) \\
\end{array}$ & $\begin{array}{c}\text { Daily } \\
\text { av } \\
(\mathrm{mg} / \mathrm{L})\end{array}$ & $\begin{array}{l}\text { Daily } \\
\text { max } \\
(\mathrm{mg} / \mathrm{L})\end{array}$ & & \\
\hline \multirow{8}{*}{$\begin{array}{l}503 \text { (Steam Plant Wastewater } \\
\text { Treatment Facility) }\end{array}$} & Chromium, total & 0.38 & 0.38 & 0.20 & 0.20 & 100 & 158 \\
\hline & Copper, total & 1.89 & 1.89 & 1.0 & 1.0 & 100 & 158 \\
\hline & Iron, total & 1.89 & 1.89 & 1.0 & 1.0 & 99 & 158 \\
\hline & Zinc, total & 1.89 & 1.89 & 1.0 & 1.0 & 100 & 158 \\
\hline & Oil and grease & 28.4 & 37.9 & 15.0 & 20.0 & 99 & 157 \\
\hline & Total suspended solids & 57.0 & 189.0 & 30.0 & 100.0 & 100 & 158 \\
\hline & Temperature $\left({ }^{\circ} \mathrm{C}\right)$ & & & & 30.5 & 100 & 158 \\
\hline & $\mathrm{pH}$ (standard units) & & & $a$ & 9.0 & 100 & 158 \\
\hline $\begin{array}{l}\text { Category I outfalls } \\
\text { (precipitation runoff and } \\
\text { small amounts of } \\
\text { groundwater }\end{array}$ & $\mathrm{pH}$ (standard units) & & & $a$ & 8.5 & 100 & 30 \\
\hline \multirow[b]{2}{*}{$\begin{array}{l}\text { Category Il outfalls } \\
\text { cooling waters, condensate, } \\
\text { precipitation runoff, and } \\
\text { building, roof, and founda- } \\
\text { tion drains; }\end{array}$} & pH (standard units) & & & $a$ & 8.5 & 100 & 86 \\
\hline & Temperature ${ }^{d}\left({ }^{\circ} \mathrm{C}\right)$ & & & & & 100 & 86 \\
\hline $\begin{array}{l}\text { Category III outfalls } \\
\text { (process wastewaters) }\end{array}$ & $\mathrm{pH}$ (standard units) & & & $a$ & 8.5 & 100 & 40 \\
\hline $\begin{array}{l}\text { Category IV outfalls } \\
\text { (untreated process } \\
\text { wastewaters) }\end{array}$ & $\mathrm{pH}$ (standard units) & & & $a$ & 8.5 & 95 & 107 \\
\hline \multirow{13}{*}{$\begin{array}{l}504 \text { Plating Rinsewater } \\
\text { Treatment Facility }\end{array}$} & Cadmium, total & 0.07 & 0.019 & 0.26 & 0.69 & 100 & 15 \\
\hline & Chromium, total & 0.50 & 0.75 & 1.71 & 2.77 & 100 & 15 \\
\hline & Copper, total & 0.60 & 0.92 & 2.07 & 3.38 & 100 & 15 \\
\hline & Cyanide, total & 0.2 & 0.33 & 0.65 & 1.20 & 100 & 15 \\
\hline & Lead, total & 0.12 & 0.19 & 0.43 & 0.69 & 100 & 15 \\
\hline & Nickel, total & 0.65 & 1.10 & 2.38 & 3.98 & 100 & 15 \\
\hline & Oil and grease & 7.1 & 14.2 & 26.0 & 52.0 & 100 & 15 \\
\hline & $\mathrm{pH}$ (standard units) & & & $a$ & 9.0 & 100 & 15 \\
\hline & Silver, total & 0.07 & 0.12 & 0.24 & 0.43 & 100 & 15 \\
\hline & Temperature $\left({ }^{\circ} \mathrm{C}\right)$ & & & & 30.5 & 100 & 15 \\
\hline & Total suspended solids & 8.5 & 16.4 & 31.0 & 60.0 & 100 & 15 \\
\hline & Total, toxic organics & & 0.6 & & 2.13 & 100 & 15 \\
\hline & Zinc, total & 0.4 & 0.7 & 1.48 & 2.61 & 100 & 15 \\
\hline \multirow{13}{*}{$\begin{array}{l}\text { 501/504 (Combined discharge } \\
\text { Central Pollution Control } \\
\text { Facility and Plating } \\
\text { Rinse Water Treatment } \\
\text { Facility) }\end{array}$} & Cadmium, total & 0.07 & 0.019 & 0.26 & 0.69 & 100 & 8 \\
\hline & Chromium, total & 0.50 & 0.75 & 1.71 & 2.77 & 100 & 8 \\
\hline & Copper, total & 0.60 & 0.92 & 2.07 & 3.38 & 100 & 8 \\
\hline & Cyanide, total & 0.2 & 0.33 & 0.65 & 1.20 & 100 & 8 \\
\hline & Lead, total & 0.12 & 0.19 & 0.43 & 0.69 & 100 & 8 \\
\hline & Nickel, total & 0.65 & 1.10 & 2.38 & 3.98 & 100 & 8 \\
\hline & Oil and grease & 7.1 & 14.2 & 26.0 & 52.0 & 100 & 8 \\
\hline & $\mathrm{pH}$ (standard units) & & & $a$ & 9.0 & 100 & 8 \\
\hline & Silver, total & 0.07 & 0.12 & 0.24 & 0.43 & 100 & 8 \\
\hline & Temperature $\left({ }^{\circ} \mathrm{C}\right)$ & & & & 30.5 & 100 & 8 \\
\hline & Total suspended solids & 8.5 & 16.4 & 31.0 & 60.0 & 100 & 8 \\
\hline & Total toxic organics & & 0.6 & & 2.13 & 100 & 8 \\
\hline & Zinc, total & 0.4 & 0.7 & 1.48 & 2.61 & 100 & 8 \\
\hline
\end{tabular}


Table 4.1 (continued)

\begin{tabular}{|c|c|c|c|c|c|c|c|}
\hline \multirow[b]{2}{*}{$\begin{array}{l}\text { Discharge } \\
\text { point }\end{array}$} & \multirow[b]{2}{*}{$\begin{array}{l}\text { Effluent } \\
\text { parameter }\end{array}$} & \multicolumn{4}{|c|}{ Effluent limits } & \multirow[b]{2}{*}{$\begin{array}{l}\text { Percent } \\
\text { of } \\
\text { compliance }\end{array}$} & \multirow[b]{2}{*}{$\begin{array}{c}\text { Number } \\
\text { of } \\
\text { samples }\end{array}$} \\
\hline & & $\begin{array}{l}\text { Daily } \\
\text { av } \\
(\mathrm{kg} / \mathrm{d})\end{array}$ & $\begin{array}{l}\text { Daily } \\
\max \\
(\mathrm{kg} / \mathrm{d})\end{array}$ & $\begin{array}{l}\text { Daily } \\
\text { av } \\
\text { (mg/L) }\end{array}$ & $\begin{array}{l}\text { Daily } \\
\text { max } \\
(\mathrm{mg} / \mathrm{l})\end{array}$ & & \\
\hline $\begin{array}{l}623 \text { (Steam Plant fly } \\
\text { ash sluice water) }\end{array}$ & $\mathrm{pH}$ (standard units) & & & $a$ & 8.5 & 100 & 15 \\
\hline $\begin{array}{l}506(9204-3 \text { sump } \\
\text { pump oil) }\end{array}$ & $\begin{array}{l}\text { Temperature }\left({ }^{\circ} \mathrm{C} \text { ) }\right. \\
\text { Oil and grease } \\
\mathrm{pH} \text { (standard units) }\end{array}$ & & & $\begin{array}{r}10.0 \\
a\end{array}$ & $\begin{array}{r}30.5 \\
15.0 \\
8.5\end{array}$ & $\begin{array}{l}100 \\
98^{\circ} \\
98\end{array}$ & $\begin{array}{l}53 \\
53 \\
53\end{array}$ \\
\hline $\begin{array}{l}508 \text { (Experimental mobile } \\
\text { wastewater treatment } \\
\text { facility) }\end{array}$ & $\begin{array}{l}\text { Mercury, total } \\
\text { pH (standard units) } \\
\text { Total suspended solids }\end{array}$ & & & $\begin{array}{c}0.002 \\
a \\
30.0\end{array}$ & $\begin{array}{l}0.004 \\
9.0 \\
45.0\end{array}$ & $\begin{array}{l}f \\
f \\
f\end{array}$ & $a$ \\
\hline $\begin{array}{l}510 \text { (Waste Coolant } \\
\text { Processing Facility) }\end{array}$ & $\begin{array}{l}\text { Biochemical oxygen } \\
\text { demand } \\
\text { Oil and grease } \\
\text { pH (standard units) } \\
\text { Temperature }\left({ }^{\circ} \mathrm{C}\right) \\
\text { Total suspended solids }\end{array}$ & 1.33 & 2.65 & $\begin{array}{r}15.0 \\
a \\
30.0\end{array}$ & $\begin{array}{r}20.0 \\
9.0 \\
30.5 \\
50.0\end{array}$ & $\begin{array}{l}f \\
f \\
f \\
f \\
f\end{array}$ & \\
\hline $\begin{array}{l}512 \text { (Groundwater } \\
\text { 'Treatment Facility) }\end{array}$ & $\begin{array}{l}\text { Oil and grease } \\
\text { Iron, total } \\
\text { pH (standard units) } \\
\text { PCBs }\end{array}$ & & & $\begin{array}{l}a \\
a \\
a\end{array}$ & $\begin{array}{l}15 \\
1.0 \\
9.0\end{array}$ & $\begin{array}{r}100 \\
100 \\
100 \\
97\end{array}$ & $\begin{array}{c}37 \\
37 \\
\text { continuous } \\
37\end{array}$ \\
\hline $\begin{array}{l}\text { Miscellaneous discharges } \\
\text { (cooling tower blowdown) }\end{array}$ & $\begin{array}{l}\text { Chromium, total } \\
\text { Copper, tolal } \\
\text { Free available chlorine } \\
\text { pH (standard units) } \\
\text { Temperature }\left({ }^{\circ} \mathrm{C} \text { ) }\right. \\
\text { Zinc, total }\end{array}$ & & & $\begin{array}{c}0.5 \\
0.2 \\
a \\
35 \\
0.5\end{array}$ & $\begin{array}{c}1.0 \\
1.0 \\
0.5 \\
8.5 \\
38 \\
1.0\end{array}$ & $\begin{array}{l}100 \\
100 \\
100 \\
100 \\
100 \\
100\end{array}$ & $\begin{array}{l}69 \\
69 \\
69 \\
69 \\
69 \\
69\end{array}$ \\
\hline $\begin{array}{l}\text { Miscellaneous discharges } \\
\text { (demineralizers) }\end{array}$ & $\begin{array}{l}\text { pH (standard units) } \\
\text { Total suspended solids }\end{array}$ & & & $30^{a}$ & $\begin{array}{l}8.5 \\
50\end{array}$ & $\begin{array}{l}f \\
f\end{array}$ & \\
\hline
\end{tabular}

"Not applicable.

${ }^{b}$ Limil not applicable during periods of increased surface runoff resulting from precipitation.

"Two total toxic organics samples were not analyzed properly.

"Temperature shall be controlled such that the stream temperature standards delineated in the General Water Quality Criteria for the Definition and Control of Pollution in the Waters of Tennessee, as amended, are not violated as a result of this discharge.

${ }^{e}$ One analysis was not performed according to appropriate protocol because of a laboratory administrative error.

fNo discharge.

Another condition of the $Y-12$ NPDES permit is the development and implementation of a PCB Plan for the Y-12 Plant. This plan specifies sampling locations and frequencies to identify PCB sources. A summary of these data can be found in Table 4.18 in Vol. 2.

The Y-12 Plant NPDES-permitted outfalls are identified in Table 4.19 in Vol. 2. This permit requires sampling and analysis at 14 serially numbered outfalls, about 195 categorized outfalls, and about 30 miscellaneous discharges. Analytical results for Y-12 Plant NPDES discharge points for 1992 are summarized in Tables 4.20-4.47 in Vol. 2. These data were compared with the appropriate NPDES limits when a limit exists for each parameter. Outfalls 302 (Rogers Quarry) and 304, which are 


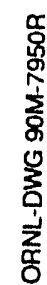
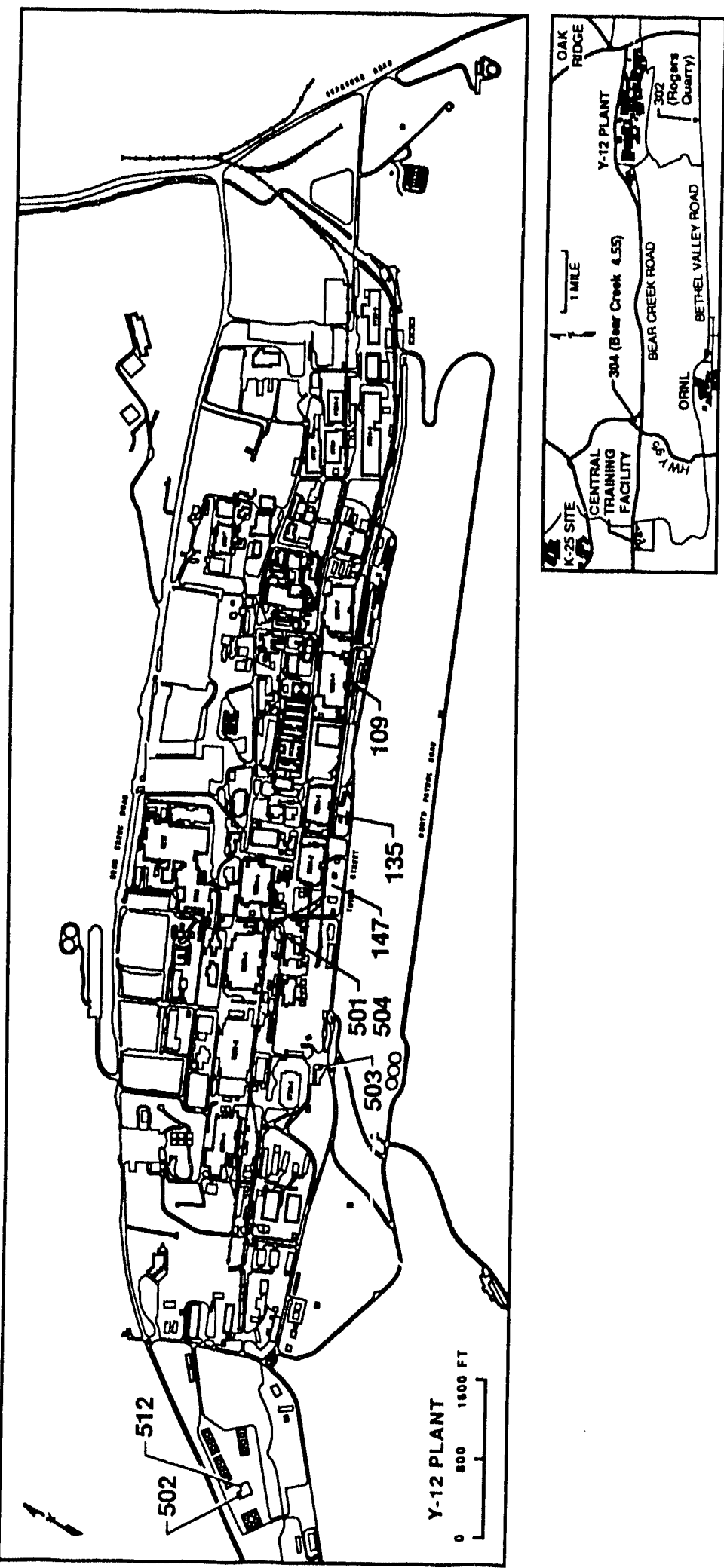

동

은 
considered in-stream sampling points for McCoy Branch and Bear Creek, respectively, are also compared with the State of Tennessee Water Quality Criteria, where a criterion exists for each parameter. The most restrictive of either the Freshwater Fish and Aquatic Life Criterion Maximum or the Recreation (10 ${ }^{5}$ risk factor for carcinogens) for Organisms Only standards were used. Radiological data are compared with derived concentration guides (DCGs) published in DOE Order 5400.5 .

Discharges from the $\mathrm{Y}-12$ Plant processes affect water quality and flow in EFPC before entering the Clinch River. Discharge of coal bottom ash slurry to the McCoy Branch watershed from the Y-12 steam plant occurs only when coal is in use. Bear Creek water quality is affected by area source runoff and groundwater discharges. The Y-12 Plant is committed to providing treatment for a variety of wastewaters discharged to area streams. Discharges allowed under the permit include storm drainage, cooling water. cooling tower blowdown, and treated process wastewaters, including effluents from wastewater treatment facilities. Sumps that collect groundwater inflow in building basements are also permitted for discharge to the creek.

The existing Y-12 Plant NPDES Permit expired in May 1990. An application for permit renewal was submitted to TDEC/EPA in November 1989, and an addendum to this application was submitted in February 1993 to TDEC. This addendum contains an extensive collection of proposed monitoring points and subsequent categories. This collection consists of 33 Category II outfalls, 12 category III outfalls (process wastewater only), 6 treatment facilities, and 1 ash sluice. Process wastewater is defined as the combination of any of the following types of wastewater:

- once-through contact cooling water,

- cooling tower blowdown,

- steam condensate,

- discharges through a previously monitored NPDES permit point,

- periodic discharges regulated under best management practices or other administrative control, or

- discharges regulated by an approved wate: management plan.
Thirty-one Category 1 outfalls (precipitation runoff) were included in the $Y-12$ Plant general storm water permit application submitted to TIDEC in October 1992.

A network of storm drains that discharge into ElPPC covers the entire area of the $Y-12$ Plant. This system gathers rainfall from the adjacent hillsides, parking areas, roof drains, and the flow from the testing of the fire protection system. In the past, interconnecting with the storm drainage system were numerous discharges and laboratory drains within the buildings, building floor drains, and drains from accumulation tanks outside the buildings. Efforts to improve the water quality of streams receiving $\mathrm{Y}-12$ Plant discharges are ongoing and have resulted in eliminating numerous process discharges to EFPC.

There are 18 major cooling tower systems and 6 small air-conditioning towers currently in operation at the Y-12 Plant. About 1380 million $L$ (359 million gal) per year of water are required as makeup for the 18 major cooling tower systems. About 550 million L (143 million gal) per year are discharged as blowdown into EFPC, and 830 million L (216 million gal) are lost as evaporation.

In 1992 the Y-12 Plant reduced NPDES noncompliance by more than $50 \%$ from 1991 (Fig. 4.6). The most significant reduction in noncompliances was achieved at Rogers Quarry. In 1991 there were 19 NPDES noncompliances at Rogers Quarry due to elevated $\mathrm{pH}$ caused by algae growth in the quarry. As ambient temperatures increase in the spring, the algae begin to grow and consume $\mathrm{CO}_{2}$, which decreases the amount of carbonic acid formed in the quarry and causes a slightly elevated $\mathrm{pH}$. This is a natural phenomenon and occurs in most lakes and ponds in East Tennessee. In 1992 there was one noncompliance at Rogers Quarry. This drastic reduction was accomplished with the installation of a subsurface discharge pipe at the outlet of the quarry. The subsurface discharge pipe allows the discharge of deeper, $\mathrm{CO}_{2}$-rich, cooler water. This action has eliminated $\mathrm{pH}$ and temperature noncompliances at the quarry. Another significant improvement made in the area of NPDES noncompliances has been a $67 \%$ reduction in the number of noncompliances at $Y-12$ Plant wastewater treatment facilities. This reduction can be attributed primarily to the increase in treatment-facility operator control. The most

\section{4-16 Surface Water}




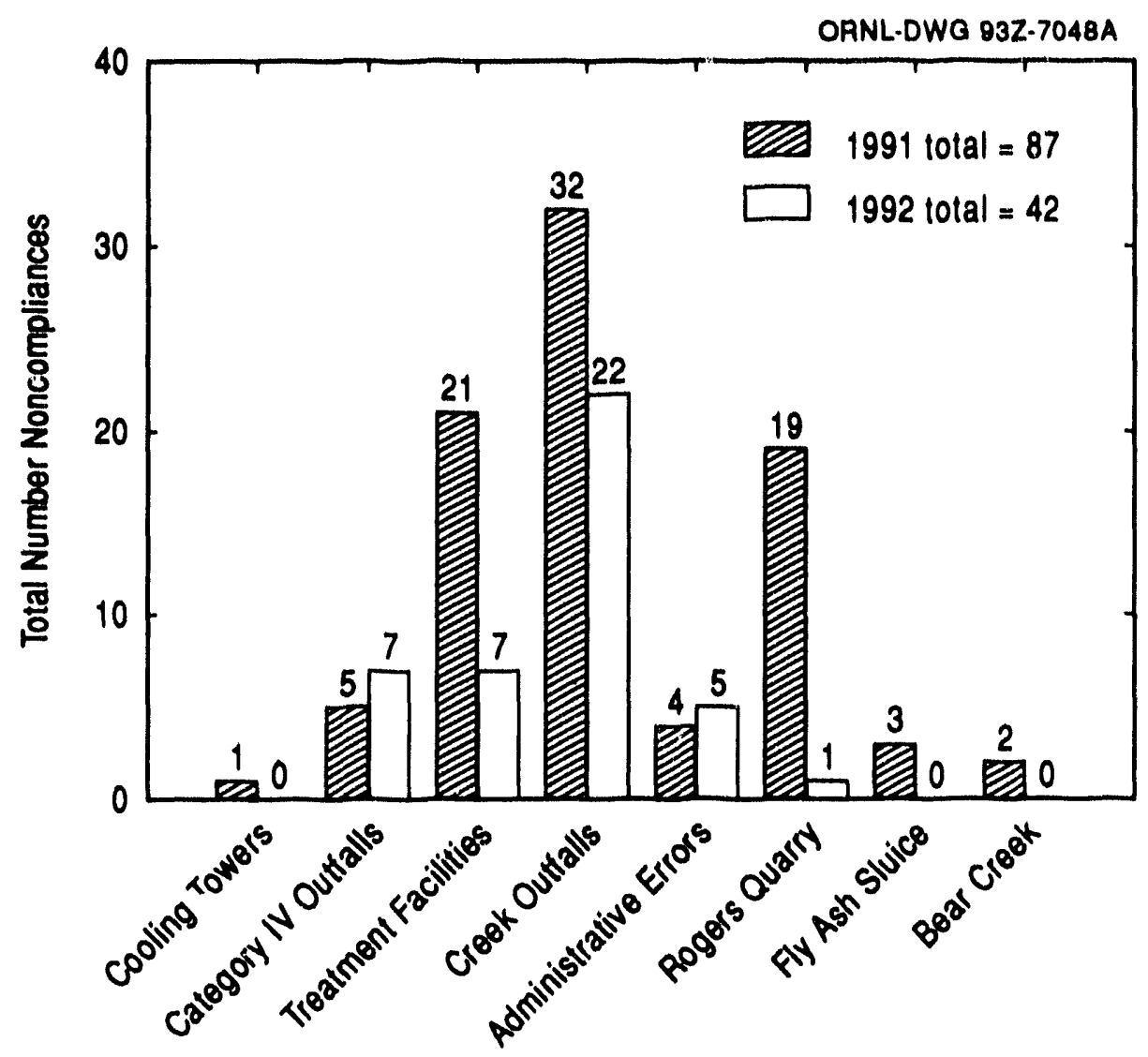

Fig. 4.6. Y-12 Plant NPDES noncompliance status comparison and sources of noncompliances.

significant area of NPDES noncompliances is from creek outfalls.

More than $50 \%$ of the NPDES noncompliances that occurred at the $Y-12$ Plant were observations made at outfalls located directly on the bank of East Fork Poplar Creek; however, there has been a $30 \%$ reduction in these types of noncompliances since 1991, even in the midst of increased surveillance along East Fork Poplar Creek.

Two full-time employees walked along the bank of East Fork Poplar Creek three times per day, from the north-south pipes to Lake Reality, looking for changes in creek conditions or visible discharges from outfalls (e.g., foam or oil sheen). In addition, a field crew of fisheries biologists surveyed East Fork Poplar Creek from the Bear Creek Road crossing to the north-south pipes each work day in 1992. The observable excursions occurring in 1992 consisted primarily of discharges of visible foam or oil sheens.

Most of the foam noncompliances are considered to have occurred as a result of numerous sinks being tied to the storm sewer system. Minor discharges of soap into sinks tied to the storm sewer can result in an observation of foam at the outfall.

An extensive building-drain identification survey has been conducted in an effort to determine the discharge destination of all of the sinks, water fountains, and floor drains in more than 120 buildings within the Y-12 Plant. Additionally, a drain-rerouting project is under way to reroute numerous sinks from the storm sewer to the sanitary sewer. Administrative controls are in place at locations known to have sinks tied to the storm sewer in an effort to eliminate the discharge of soaps and other foaming agents to East Fork Poplar Creek until permanent fixes can be implemented. Most oil sheen noncompliances were the result of parking-lot runoff or other minor spill incidents. The Y-12 Plant has an aggressive spill prevention and response program than includes a comprehensive spill prevention control and countermeasures plan.

In accordance with Part III of the NPDES permit issued to the $\mathrm{Y}-12$ Plant, the plant is required to develop and implement a TCMP. Under the TCMP, various permitted discharges are evaluated for 


\section{Environmental Report Val. 1, Oak Ridge}

toxicity. Results of the toxicity tests fron: six wastewater treatment facilities (CPCF, WETF, SPWTF, PRTF, Building 9204-3 oil/water separator, and (iWTF), one cooling tower, and two Category IV discharges (the evaporator condensate from the lithium process and the Building 9202 catch basin) are given in Table 4.48 of Vol. 2. For each wastewater, the table shows the date the test was conducted, the no-observed effect concentration (NOEC) for fathead minnows and Ceriodaphnia, and the in-stream waste concentration.

Treated effluent from the GWTF was not toxic (NOEC $=100 \%$ ) to fathead minnows, and had an NOEC of $25 \%$ for Ceriodaphnia. Because the in-stream waste concentration for the GWTF is calculated to be $1.9 \%$, it is unlikely that the treated effluent from the GWTF would adversely affect the aquatic biota in East Fork Poplar Creek. Effluent from the Building 9204-3 oil water separator was not toxic to either fathead minnows or Ceriodaphnia (NOEC $=100 \%)$. The treated effluent from the CPCF had an NOEC of $50 \%$ for fathead minnows and $12 \%$ for Ceriodaphnia. The calculated in-stream waste concentration of CPCF effluent in East Fork Poplar Creek is $1.2 \%$. Therefore, it is unlikely that treated effluent from the CPCF would adversely affect the aquatic biota in East Fork Poplar Creek. The condensate from the evaporators used in the lithium process had an NOEC of $<3 \%$ for fathead minnows and $6 \%$ Ceriodaphnia. The NOECs for both fathead minnows and Ceriodaphnia were greater than the calculated in-stream waste concentration of this discharge. Therefore, it is unlikely that the discharge of condensate from the lithium process would adversely impact the aquatic biota in East Fork Poplar Creek.

\subsubsection{Oak Ridge National Laboratory}

\subsubsection{Data Presentation}

Presentations of data throughout the report follow the convention of flagging data that are statistically significant with an asterisk $\left({ }^{*}\right)$. Data that are not significantly different from zero are presented without a tlag.

Some nonradionuclide results are returned from the analytical laboratory with prefixes associated with the values. "<" (less than) or "U" (undetected) indicates the value was below the analytical detection limit.

In statistical summaries, when at least one of the results contributing to the average is less than the detection limit, the average value is identified with the (tilde) $\sim$ prefix.

When results are reported as undetected ("U') or not quantifiable ("<"), the sample mean and standard error of the mean are affected by these values; they become "biased"--biased high for the mean and low for the standard error of the mean. That is, the sample standard error of the mean is estimating something smaller than the true standard error.

A further consequence of the bias is an increased likelihood that a population mean will be declared greater than zero in a statistical test using the biased sample mean and standard error. A statistically significant result may be a consequence of the number of values below the detection limit. If. however, there were a number of values above the detection limit, the conclusion that the true mean is greater than zero may be valid even though the estimate of true mean is biased.

\subsubsection{Reference Surface Waters}

The net impact of ORNL is evaluated by comparing the reference data with information from samples collected downstream of the facilities. Monthly surface water samples are collected at two sampling locations to determine contamination levels before the influence of ORNL activities. One sampling location is Melton Hill Dam above ORNL's main discharge point into the Clinch River (Fig. 4.7). The other sampling location is White Oak Creek headwaters above any ORNL, discharge points to White Oak Creek (Fig. 4.7).

Analyses were performed to detect classical, inorganic, and organic pollutants in the water. Classical pollutants are indicated by conductivity, temperature, turbidity, pH, total dissolved solids, total suspended solids, and oil and grease. Inorganic parameters are indicated by metal and anion analysis. The presence of organic pollutants is indicated by results from total organic carbon (' $\mathrm{TOC}^{\circ}$ ) analysis. $\|^{\prime}$ the TOC result is greater than $5 \mathrm{mg} / \mathrm{l}$, analyses for volatile and semivolatile organic compounds is conducted. Tables 4.49 and 4.50 in Vol. 2 provide 
ORNL.DWG 92M-6985R

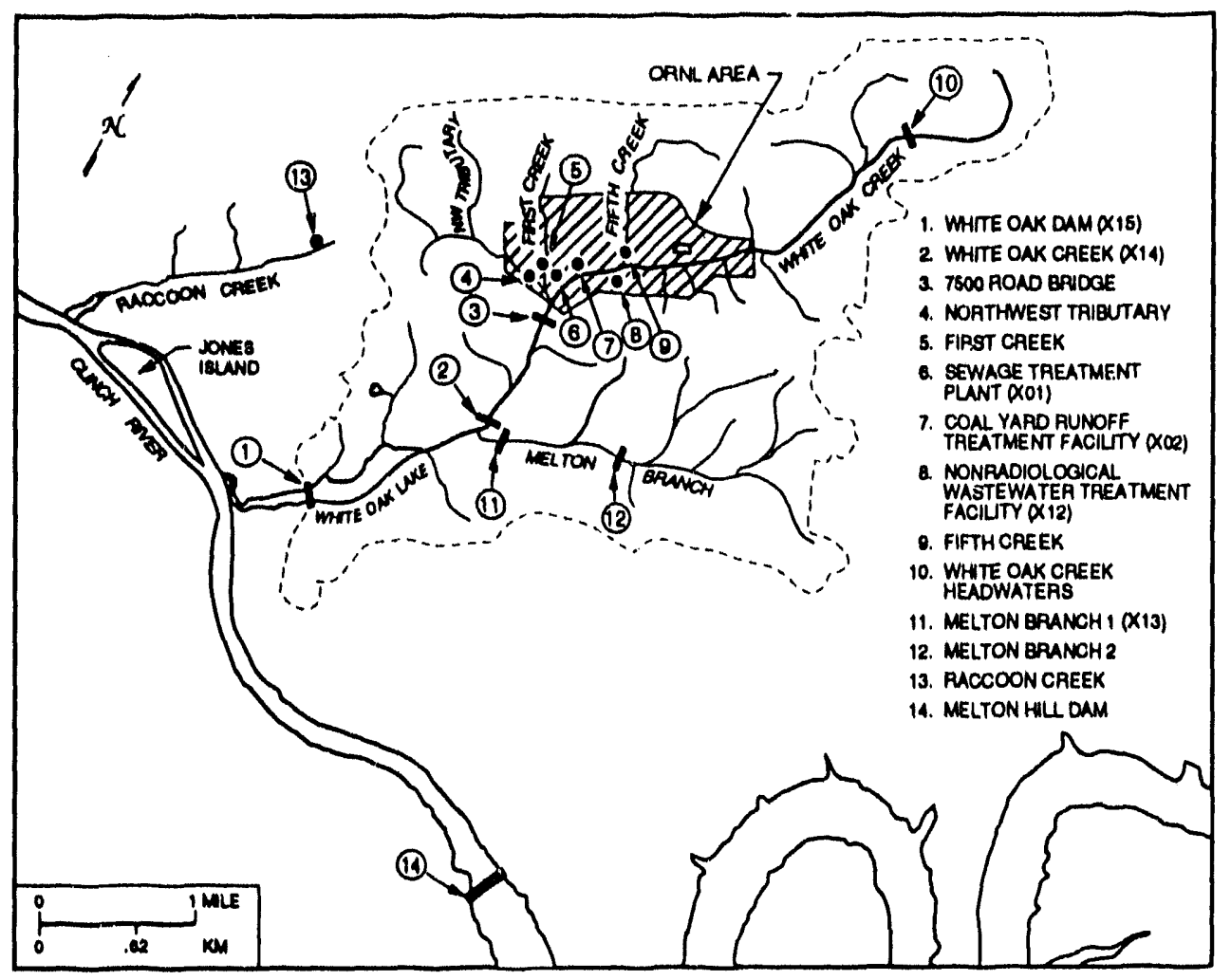

Fig. 4.7. ORNL surface water, NPDES, and reference sampling locations.

sampling and analysis plans for the reference locations.

Tables 4.51 and 4.52 in Vol. 2 contain summaries of the analytical results. There were no high levels of organic compounds detected by the TOC analysis at either location, as indicated by the average value of $2.2 \mathrm{mg} / \mathrm{L}$ at Melton Hill Dam and by the average value of $1.3 \mathrm{mg} / \mathrm{L}$ at White Oak Creek headwaters. The entries in the column for average concentration that are significantly greater than zero are followed by an asterisk. In performing the "significantly greater than zero" test for nonradionuclides, the various prefixes associated with the observed data are disregarded. Thus, the reader should consider the number of detected values to assess the practical significance of the statistical test result. The last column in the table contains the average as a percentage of a reference value when the following are true: (a) the analyte is a contaminant or an indicator of contamination, (b) the analyte has a reference value (excluding turbidity, temperature, and
$\mathrm{pH}$ ), and (c) the observed average is significantly greater than zero. The reference values listed are relevant National Primary or Secondary Drinking Water standards (see Table 5.1, Vol. 2). The standards are used only for comparison purposes because neither of the locations is a source of drinking water.

Inorganic analytical results can show a wide range of detection limits. This results from a dilution that must be made to some of the water samples. When a given sample contains an element in a concentration that is higher than the inductively coupled plasma (ICP) equipment can accurately measure, this compound can cause a spectral interference with other elements. The sample must then be diluted to bring the interfering element into a range that the equipment can accurately measure. The resulting analytical values from the ICP process must be adjusted by the dilution factor. This dilution factor must also be applied to the detection limit value for each element. 


\section{Environmental Report Vol. 1, Oak Ridge}

There is a reasonably good agreement between analytes measured at White Oak Creek headwaters and Melton Hill Dam. At White Oak Creek headwaters, the only average concentrations that exceeded the secondary drinking water standards are aluminum, iron, and manganese. At Melton Hill Dam, the only average concentrations that exceeded the secondary drinking water standards are aluminum and iron. Concentrations of these magnitudes are commonly associated with the hydrogeology of the Clinch River basin.

In addition, samples are collected and analyzed for radionuclides. Sampling and analysis plans for radionuclides for the reference locations can be found in Table 4.53 in Vol. 2. Results are reported in Tables 4.54 and 4.55 in Vol. 2.

\subsubsection{ORNL Surface Waters Receiving Effluent}

Water samples are collected for radiological analyses at off-site and on-site locations, at background or reference locations, in streams on the ORNL site, and from all process discharge point sources. A summary of locations, analyses that are conducted, and frequencies of sample collection and analysis for all radiological samples is provided in Table 4.53 in Vol. 2.

Derived concentration guides (DCGs) are estimates of the concentration of a given radioisotope for one exposure pathway (i.e., drinking water) that would result in an effective dose equivalent of 100 mrem ( $1 \mathrm{mSv}$ ) per year to "reference man," as defined by the International Commission of Radiological Protection Publication 23. These values have been published in DOE Order 5400.5 and are used here as a means of standardized comparison for effluent points with different isotope signatures. The calculation of percent of the DCG does not imply that effluent points or ambient water sampling stations at ORNL are sources of drinking water.

The sum of DCG percentages for each of the effluent points and ambient water stations is less than $100 \%$. In the event that a sum ever exceeds $100 \%$, an analysis of the best available technology to reduce the signature would be conducted as specified in DOE Order 5400.5.

Melton Hill Dam and White Oak Creek headwaters, two locations above ORNL discharge points, serve as references for other water sampling locations at the ORNL site. Water samples are collected from the reference sites and from six on-site streams: White Oak Creek, Melton Branch, First Creek, Fifth Creek, Northwest Tributary, and Raccoon Creek (Fig. 4.7). Sampling for radiological analyses is conducted at six ambient stations around ORNL and at five NPDES locations. The six ambient stations are

- 7500 Road Bridge,

- First Creek,

- Fifth Creek,

- Melton Branch 2,

- Northwest Tributary, and

- Raccoon Creek.

The five NPDES stations are

- Sewage Treatment Plant (X01),

- Nonradiological Wastewater Treatment Facility (X12),

- Melton Branch 1 (X13),

- White Oak Creek (X14), and

- White Oak Dam (X15).

Summary statistics for each radionuclide at each surface water sampling location are given in Table 4.54 in Vol. 2. The average concentration is expressed as a percentage of the DCG (when one exists) in the last column of this table. As shown in Table 4.54, gruss beta and gross alpha were significantly greater than zero at Melton Hill Dam and White Oak Creek headwaters. Only three ambient stations showed average radionuclide concentrations greater than 5\% of the appropiate DCG with no average radionuclide concentration exceeding $30 \%$ of its DCG. Total radioactive strontium was the only radionuclide concentration greater than $5 \%$ of DCG at the three ambient stations.

Locations that are sampled for nonradioactive chemicals under the requirements of the NPDES permit are also sampled for radionuclides (Fig. 4.7). Radiological analysis and the frequency of analysis are given in Table 4.55 , Vol. 2, which also contains a summary of the concentrations for each of these locations during this year. Average radionuclide concentrations that are significantly greater than zero and greater than $5 \%$ of DCG are tolal radioactive 


\section{Environmental Report Vol. 1, Oak Ridge}

strontium at the Sewage Treatment Plant, Nonradiological Wastewater Treatment Facility, Melton Branch 1, White Oak Creek, and White Oak Dam; tritium at Melton Branch 1 and White Oak Dam; and ${ }^{137} \mathrm{Cs}$ at the Nonradiological Wastewater Treatment Facility. No radionuclide average concentration at the NPDES points exceeded $40 \%$ of its DCG.

The discharge to the Clinch River of radioactive contaminants from ORNL is affected by the stream flows. Monthly flows in Melton Branch (as measured at station Melton Branch 1), White Oak Creek (as measured above its confluence with Melton Branch and at White Oak Dam), and the Clinch River (as measured at Melton Hill Dam) are given in Table 4.56 in Vol. 2. Clinch River flows are regulated by a series of TVA dams, one of which is Melton Hill Dam. The flow in Melton Branch is usually less than one-third of that in White Oak Creek. The monthly ratio of flow in White Oak Creek (measured at White Oak Dam) to flow in the Clinch River (measured at Melton Hill Dam) is reported in the last column of the table. The ratios given were calculated daily and averaged for the month. If complete mixing is assumed, this ratio gives an indication of the dilution factor that may be expected for potential contaminants entering the Clinch River from White Oak Creek. During 1992, the ratio values ranged from 0.0033 to 0.016 .

\subsection{Mercury in the Aquatic Environment}

In the mercury monitoring program at ORNL, samples of surface water and stream sediment in the Bethel and Melton valleys are collected semiannually and analyzed for mercury content. This monitoring is conducted to comply with the CWA and ORNL's NPDES permit. The primary purpose of this eifort is to identify, locate, and minimize all mercury contamination in ORNL discharge to the aquatic environment.

In earlier years, before stringent regulations came into effect, some contaminants reached various streams primarily as the results of accidental spills or leakages. Most of the mercury spills occurred from 1954 through 1963, during a period when ORNL was involved with OREX and METALLEX separation processes. Most of this activity occurred in and around buildings 4501,4505 , and 3592 . These processes are no longer in operation at ORNL. During the time of operation, an unknown number of mercury spills took place. The spills were cleaned up; however, some quantities of mercury escaped and reached the surrounding environment. The sampling locations in the mercury monitoring program have been placed in areas surrounding known mercury spills. Sampling locations have also been placed near outfalls from building areas with a history of mercury concern and outfalls from storage areas, spill areas, road and parking lot drains. A.dditional sampling locations have been placed downstream from the outfalls and drains to determine the extent to which any mercury is being transported in the surface water and sediment. The surface water sampling locations are shown on Fig 4.8. in this volume, and analytical results are summarized in Table 4.57 in Vol. 2. The sediment data are presented in Sect 7.

In 1992, water samples were collected in triplicate at 13 locations in June and December. Samples were collected by the manual grab method and placed in 1-L polyethylene containers with polyethylene caps. In the laboratory, samples were analyzed for total mercury content by manual cold vapor atomic absorption.

Table 4.57 in Vol. 2 shows the maximum, minimum, and average concentrations of mercury at each sampling location. The standard error of the mean is also included. The Tennessee Water Quality (TWQ) standard for the protection of fish and aquatic life is $2.4 \mu \mathrm{g} / \mathrm{L}$ (ppb) for the acute criteria. In the table, the percentage TWQ column shows the reported maximum concentration for each sampling location as a percentage of this limit. The highest value reported was $3.2 \mu \mathrm{g} / \mathrm{L}$, at outfall 367 on Fifth Creek. The next highest value, $0.26 \mu \mathrm{g} / \mathrm{L}$, occurred at outfall 106 on White Oak Creek. The maximum concentrations at all other sampling locations were $0.17 \mu \mathrm{g} / \mathrm{L}$ or less.

\subsubsection{2 $P C B$ in the Aquatic Environment}

The program to collect water samples for $\mathrm{PCB}$ analysis was dropped in 1992. In previous years, the concentrations of PCBs in water were below the analytical detection limit at all sampling locations, with the exception of results that were estimated 


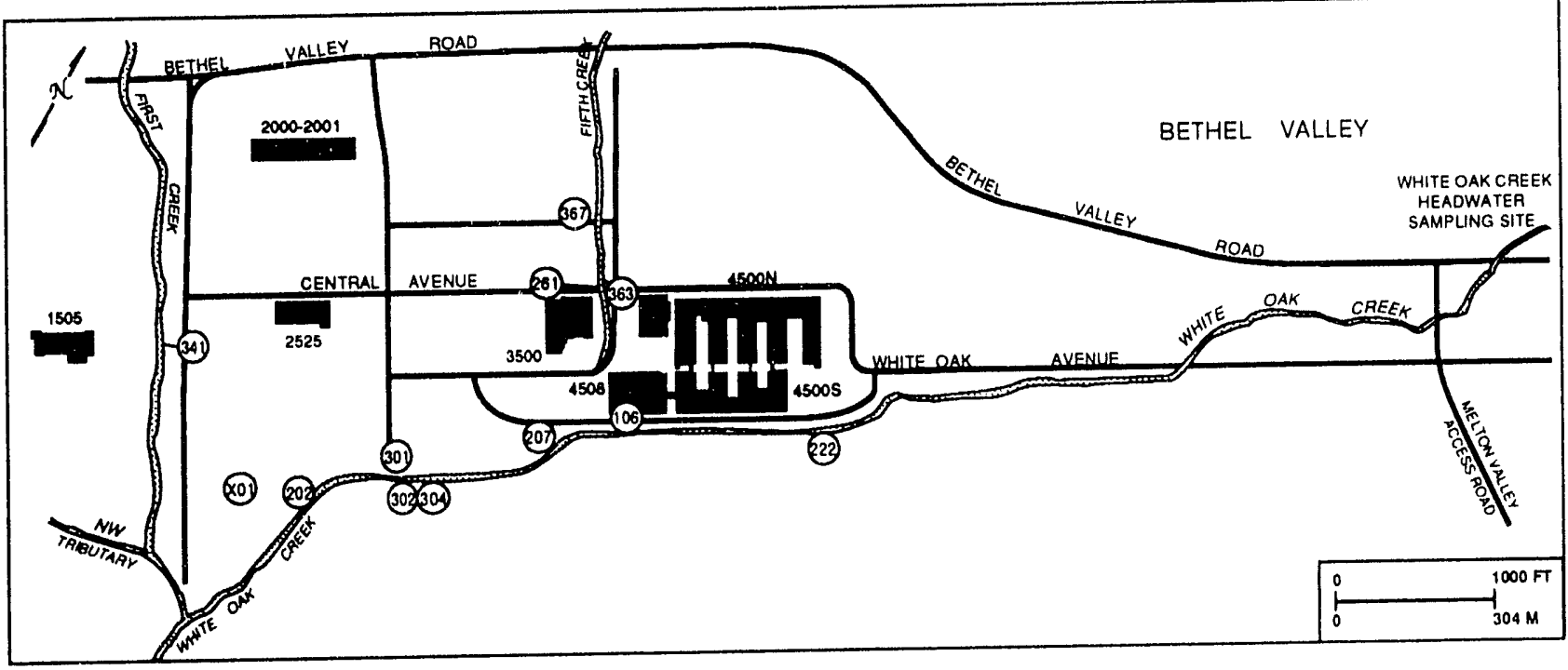

Fig. 4.8. Surface water sampling locations for mercury monitoring in the ORNL main plant area.

(below the limit of quantitation) by the laboratory or that were suspect because of sample contamination in laboratory preparation (in 1989).

\subsubsection{Off-Reservation Surface Waters}

The ORNL program for assessing impacts to the Clinch and Tennessee rivers consists of empirical data from samples taken at the Kingston and Gallaher potable water treatment plants (Fig. 4.9). Treated water sampies are collected weekly and are analyzed quarterly. Table 4.58 of Vol. 2 contains a summary of the concentrations for each location.

At Gallaher, gross beta, tritium, and total radioactive strontium were significantly greater than zero but at levels no greater than $18 \%$ of the EPA primary drinking water standards (40 CFR 141, as amended). At Kingston, gross beta and gross alpha were significantly greater than zero but at levels no greater than $7 \%$ of the EPA drinking wat: $:$ standards. Total uranium at Gallaher was significantly greater than zero; drinking water standards for total uranium have been proposed but have not yet been established. At Kingston, ${ }^{137} \mathrm{Cs},{ }^{60} \mathrm{Co}$, and total uranium were significantly greater than zero; drinking water standards for ${ }^{137} \mathrm{Cs},{ }^{60} \mathrm{Co}$, and total uranium have not been escablished. The laboratory method used for total uranium does not permit a test of significance for the maximum and minimum, but the average concentrations at Gallaher and Kingston are less than $0.9 \%$ of the gross alpha standard. The total uranium measurement is converted to an activity by assuming natural abundance of uranium isotopes ${ }^{234} \mathrm{U},{ }^{235} \mathrm{U}$, and ${ }^{238} \mathrm{U}$.

\subsubsection{Effluents}

The ORNL NPDES permit (TN0002941) became effective on April 1, 1986. (See Table 4.59, Vol. 2 for a list of CRNL NPDES-permitted outfalls.) Table 4.2 details the permit limits and compliance record for each outfall in 1992. The existing permit expired in March 1991; the conditions of the expired permit remain in effect until a new permit is negotiated. The permit renewal application was submitted in September 1990 and awaits action from TDEC. Recent indications from TDEC are that a renewed permit will be issued in 1993.

ORNL's current NPDES permit requires that point-source outfalls be sampled prior to their discharge into receiving waters or before mixing with any other wastewater stream. Numeric and aesthetic effluent limits have been placed on these outfalls, which are the Sewage Treatment Plant (X01), the Coal Yard Runoff Treatment Facility (X02), the Nonradiological Wastewater Treatment Facility

\section{4-22 Surface Water}


1992 Environmental Report Vol. 1, Oak Ridge

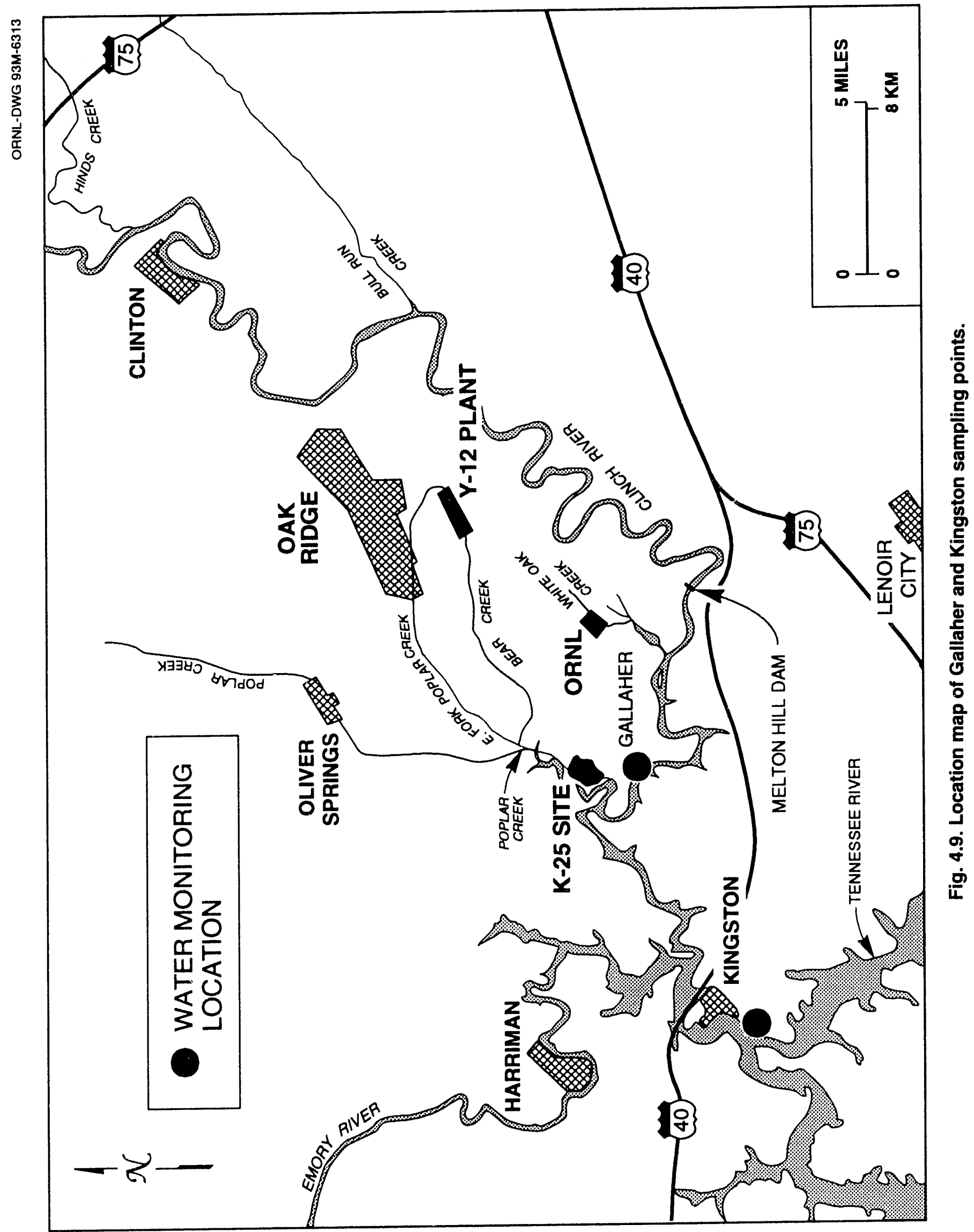




\section{Environmental Report Vol. 1, Oak Ridge}

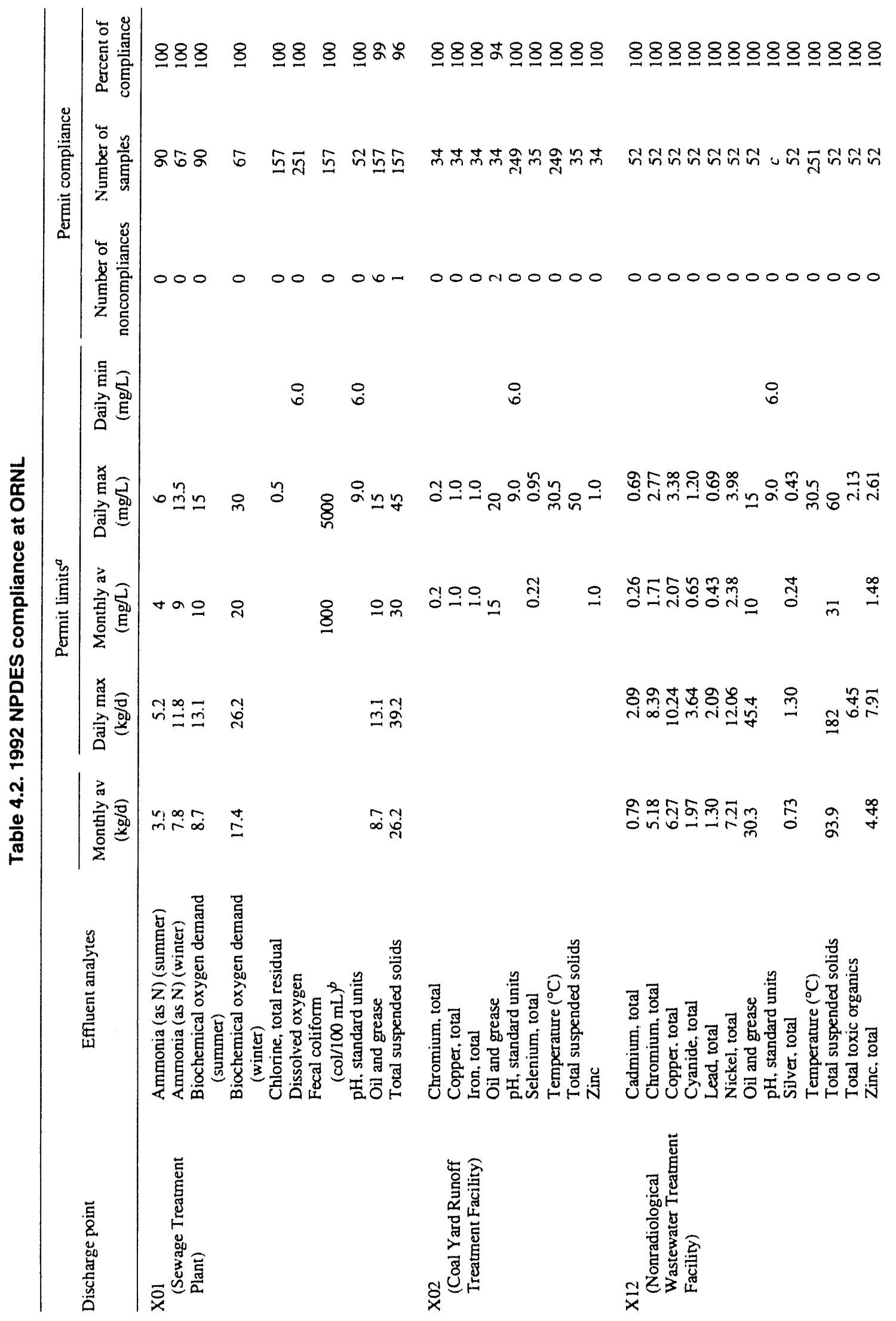


1992 Environmental Report Vol. 1, Oak Ridge

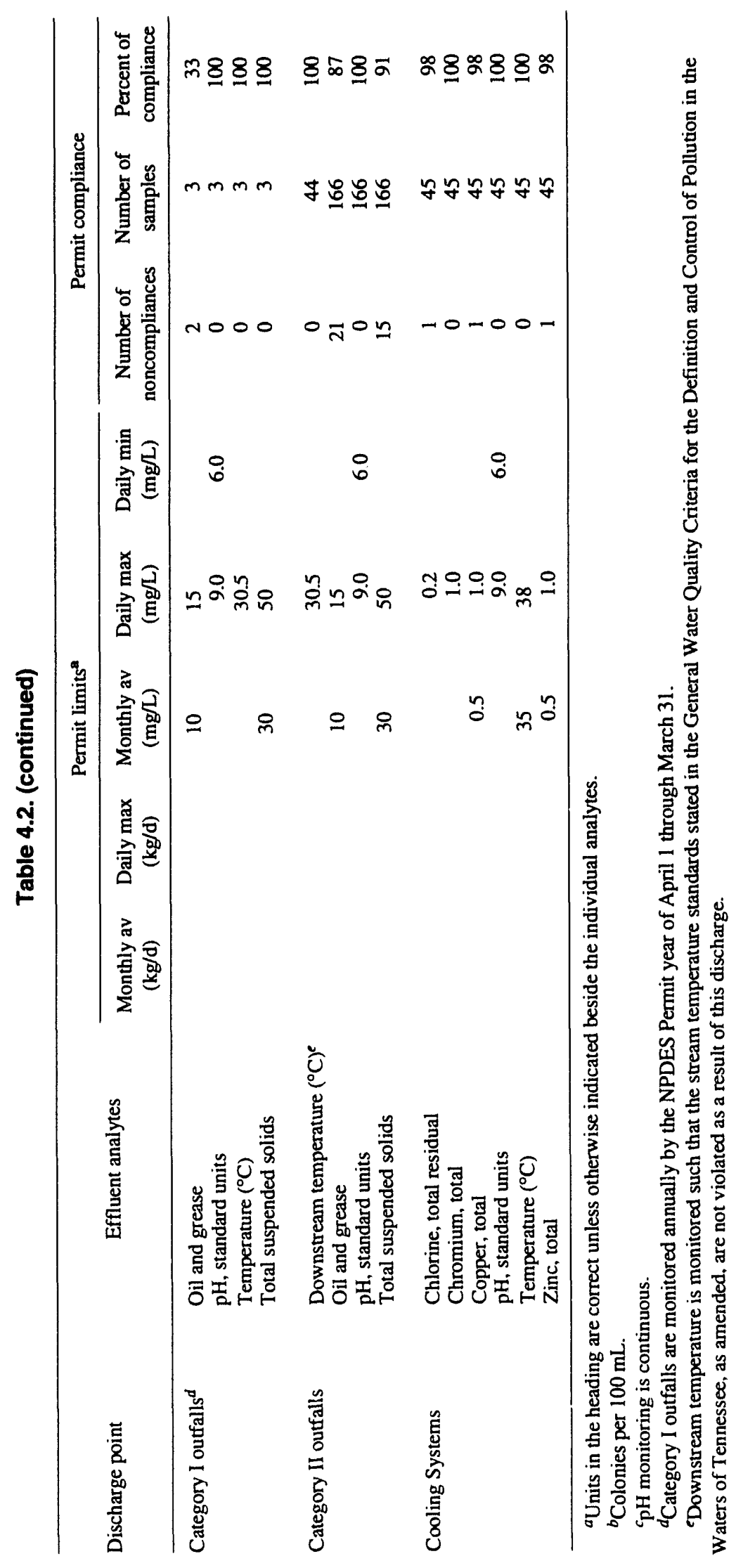




\section{Environmental Report Vol. 1, Oak Ridge}

(X12) (Fig. 4.7), Category I outfalls, Category II outfalls, and Cooling Systems. Ambient sampling points are located in the streams as reference points or for additional information. The ambient locations are Mclton Branch (X13), White Oak Creek (X14), and White Oak Dam (X15) (Fig. 4.7). Category III outfalls are monitored and carry aesthetic limits. Sampling and analysis frequencies at these locations are varied, as indicated by the sampling and analysis plans located in Tables 4.60-4.69 in Vol. 2.

Compliance with the NPDES permit for the last 4 years is summarized by the major effluent locations in Fig. 4.10. A summary listing of the ORNL NPDES compliance is given in Table 4.2. The table provides a list of the discharge points, effluent analytes, permit limits, number of noncompliances, number of samples, and the percent of compliance for 1992. The percent of compliance is determined by the following equation: \% compliance $=100-I$ (number of noncompliances/number of samples $) \times 1001$.

At $\mathrm{X} 01$, the six oil and grease exceedences occurred when three high daily values resulted in mass load (kilograms per day) and monthly average exceedences. No certain cause was established, but personnel implemented more stringent influent criteria and recurrence has not been experienced. The total suspended solids exceedence occurred when an operator was called away on an emergency and was unable to provide continuous attention to the sand filters, which resulted in a small amount of partially treated wastewater being carried over into the effluent piping from the clarifier. The wastewater passed into the contact chlorine chamber, where it automatically received chlorination before being discharged to the drainage ditch. The measured concentration multiplied by the total flow for that day to determine compliance with the mass-load limit resulted in a mass-load excursion. STP managerial personnel counseled sewage treatment plant supervisors and operators to minimize the potential for a recurrence.

At $\mathrm{X} 02$, the two oil and grease exceedences occurred when one high value resulted in a monthly average exceedence. The incident was investigated, but no certain cause was established for the exceedence.

At $X 12$, all analytes were $100 \%$ in compliance.

At the Category I and II outfalls, the oil and grease and total suspended solids exceedences were attributed to storm water runoff flushing of parking

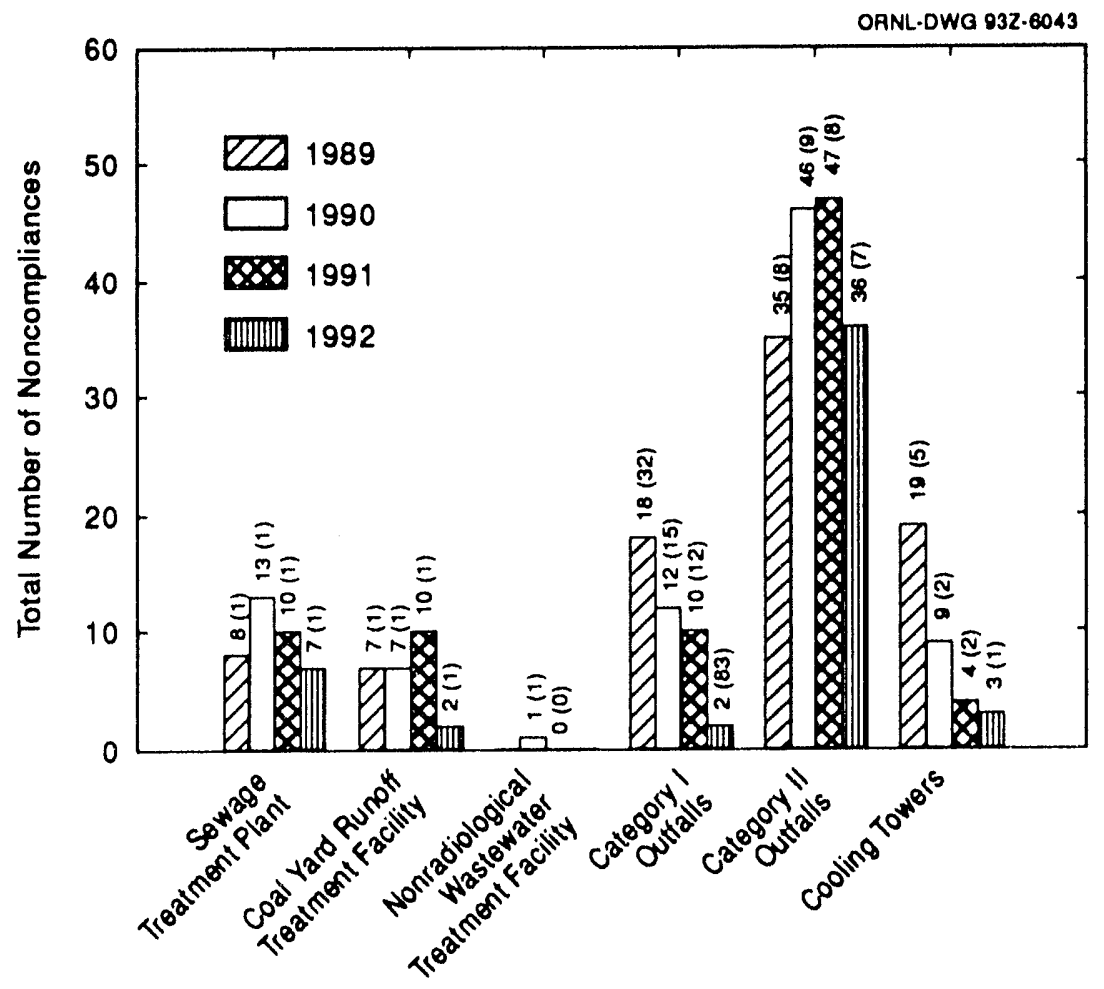

Fig. 4.10. ORNL NPDES noncompliance status comparison and sources of noncompliances. 
lots or streets. Category I and II outfalls include storm drains and parking lot and roof drains that are not contaminated by any known activity, nor do they discharge through any oil/water separator or other treatment facility or equipment. During rain events, waters from the parking lots and surrounding areas wash into these outfalls, carrying oil, grease, and other residue. This situation frequintly results in oil and grease and total suspended solids exceedences. Best management practices including frequent street sweeping are in place to help avoid these exceedences.

At the cooling systems, the copper and zinc exceedences were attributed to oxidation of copper and galvanized cooling tower components during the inactive winter period. Because of administrative error, the chlorine exceedence occurred when the blowdown discharge valve from the tower was opened before the chlorine concentration in the tower had dissipated to an acceptable level. ORNL personnel revised cooling tower maintenance procedures to guard against a recurrence.

Data collected for the NPDES permit are summarized monthly for reporting to DOE and the state of Tennessee. These summaries are submitted to DOE in the Monthly Discharge Monitoring Reports and are available upon request. Summary tables of results from sampling for the NPDES permit are found in Tables 4.70-4.80 of Vol. 2.

\subsubsection{Toxicity Control Monitoring Program}

Under the Toxicity Control Monitoring Program, wastewater from the Sewage Treatment Plant, the Coal Yard Treatment Facility, and the

Nonradiological Wastewater Treatment Facility was evaluated for toxicity. In addition, two ambient, in-stream sites were evaluated; one site is located on Melton Branch (NPDES permit point X13) and the other on White Oak Creek (permit point X14; see Fig. 4.7). The results of the toxicity tests of wastewaters from the three treatment facilities and the two ambient stream sites are given in Table 4.81 of Vol. 2. This table provides, for each wastewater and ambient water, the month the test was conducted, sample treatment, if any, and the wastewater's no-observed-effect concentration (NOEC) for fathead minnows and Ceriodaphnia. The NOEC is the concentration that did not reduce survival or growth of fathead minnows, or survival or reproduction of Ceriodaphnia. Average water quality measurements obtained during each toxicity test are shown in Table 4.82 of Vol. 2.

During 1992 the Coal Yard Runoff Treatment Facility was tested three times and the Sewage Treatment Plant and Nonradiological Wastewater Treatment Facility were tested twice each. The Coal Yard Runoff Treatment Facility wastewater's NOECs were $25 \%, 50 \%$, and $100 \%$ for fathead minnows and $12 \%, 25 \%$, and $50 \%$ for Ceriodaphnia. The wastewater's in-stream waste concentration ranged from $0.6 \%$ to $1.3 \%$ (based on critical low flow of White Oak Creek). Because the in-stream waste concentration was consistently lower than the NOEC, it is unlikely that wastewater from the Coal Yard Runoff Treatment Facility adversely affected the aquatic biota of White Oak Creek during 1992. The Sewage Treatment Plant wastewater's NOEC for Ceriodaphnia was 25\% in April and October. No fathead minnow tests were conducted for the Sewage Treatment Plant as per guidelines in the NPDES permit. The in-stream waste concentration of the Sewage Treatment Plant was lower than the NOEC for both tests conducted in 1992. Therefore, it is unlikely that the wastewater from the Sewage Treatment Plant adversely affected the aquatic biota of White Oak Creek. Full-strength wastewater from the Nonradiological Wastewater Treatment Facility was not toxic to Ceriodaphnia during the June and December tests; therefore, no in-stream waste concentration was calculated on the Nonradiological Wastewater Treatment Facility for 1992. Fathead minnow testing was discontinued as allowed in the NPDES permit guidelines.

During 1992 the Melton Branch (X13) site was tested seven times, and the White Oak Creek (X14) site was tested ten times. Water from X13 was not toxic to Ceriodaphnia in 1992; however, Ceriodaphnia reproduction was reduced (NOEC $<100 \%$ ) in three tests of water from X14 (June, August, and October). Confirmatory tests of X14 conducted in July, September, and November showed the water to be nontoxic; thus the toxicity was transient. Fathead minnow survival or growth was lower than controls (NOEC $<100 \%$ ) during three tests of X13 (February, April, and August) and X14 (February, April, and October). A confirmatory test conducted in March indicated toxicity (NOEC 


\section{Environmental Report Vol. 1, Oak Ridge}

$<100 \%)$ to fathead minnows exposed to full-strength nontreated water from sites X13 and X14.

To evaluate whether or not minnow mortality in the ambient water samples might be caused by a fungal or bacterial pathogen, water from X 13 and $\mathrm{X} 14$ was exposed to ultraviolet light for a $15-\mathrm{min}$ period. In the March test, survival of the minnows in the water treated with ultraviolet light was not different from the controls (NOEC $=100 \%$ ) in either site. In April 1992 fathead minnow survival was reduced in the full-strength nontreated and ultraviolet-treated water from $\mathrm{X} 13$ and $\mathrm{X} 14$ (NOEC $<100 \%)$. Although ultraviolet treatment did not improve survival, results of the Ceriodaphnia test and fathead minnow growth test provided evidence that the samples were not toxic. It was hypothesized that the ultraviolet light exposure (15-min) was insufficient to completely remove the suspected pathogen; and the exposure period was increased to 20 min. Tests of water from sites X13 and X14 showed improved fathead minnow survival or growth in water treated with ultraviolet light.

A complete summary of Ceriodaphnia survival and reproduction and fathead minnow survival and growth in the ambient waters of White Oak Creek and its tributaries is included in the Seventh Annual Report on the ORNL Biological Monitoring and Abatement Program (in press).

\subsubsection{K-25 Site}

\subsubsection{Reference Surface Waters}

Reference surface waters of the K-25 Site are sampled and analyzed for the site monitoring program as required by DOE Order 5400.1. The purpose is to document the K-25 Site's impact to the public and environment, if any, and to differentiate the impacts, if any, from other ORR operations.

From January 1 through September 1992 the K-25 Site monitoring program for perimeter surface water consisted of the following. Grab samples were collected once a quarter at the Clinch River, West Fork Poplar Creek, and Mitchell Branch. Monthly 24-h composites were taken at K-1513, K-716, $\mathrm{K}-1710$, and $\mathrm{K}-1770$. All samples were analyzed for radionuclides and water quality parameters.

On October 1, 1992, the K-25 Site monitoring program was changed to include outfalls K-1007-B,
K-1700, and K-901-A, which had been previously sampled for NPDES but was no longer required by the new permit (Table 4.83, Vol. 2). Sampling was discontinued at K-1513, K-1770, Clinch River, and Mitchell Branch. This was changed to avoid duplication of sampling and analysis due to the implementation of the ORR Environmental Monitoring Plan, which includes these points. Weekly 24-h flow proportional samples were taken and composited monthly for analysis of radioactivity at K-1515-C, K-1203, K-1007-B, K-901-A, and K-1700. Quarterly 24-h composite samples were taken at K-1007-B, K-901-A, K-1700, West Fork Poplar Creek, K-716, and K-1710 and analyzed for radioactivity, general water quality parameters and nutrients, metals/inorganics, volatile organic compounds, pesticides, and PCBs.

Figure 4.11 shows the surface water sampling locations for NPDES and the site monitoring program until September 30, 1992. Figure 4.12 shows the surface water locations that were sampled as part of the site monitoring program from October 1 to December 31, 1992. Tables 4.84-4.91 of Vol. 2 summarize the data taken at these points. For parameters other than radioactivity, the results reported in the tables are those parameters above the detection limits. The 1992 data does not indicate any effects from the K-25 Site operations to the perimeter surface water.

\subsubsection{ORR Surface Waters Receiving Effluents}

The isotopic analyses for radioactivity in both ambient surface water and NPDES programs are based on past and current plant operations. Samples are collected and analyzed for radiological constituents along with NPDES samples (Fig. 4.13). Each K-25 Site location is listed in Tables 4.92 and 4.93 , Vol. 2, along with the sampling frequency and sampling method. A new NPDES permit went into effect on October 1, 1992. Table 4.92, Vol. 2, is valid until September 30, 1992; Table 4.93 is valid for October I through December 31, 1992.

The K-25 Site's original mission was uranium enrichment. Until the 1950s, activities were very specific, and uranium was the principal radionuclide introduced into the plant area. During the 1950s, reactor return feed material was processed at the plant, and this activity introduced transuranic and 
ORNL.DWG 88M-7724R4

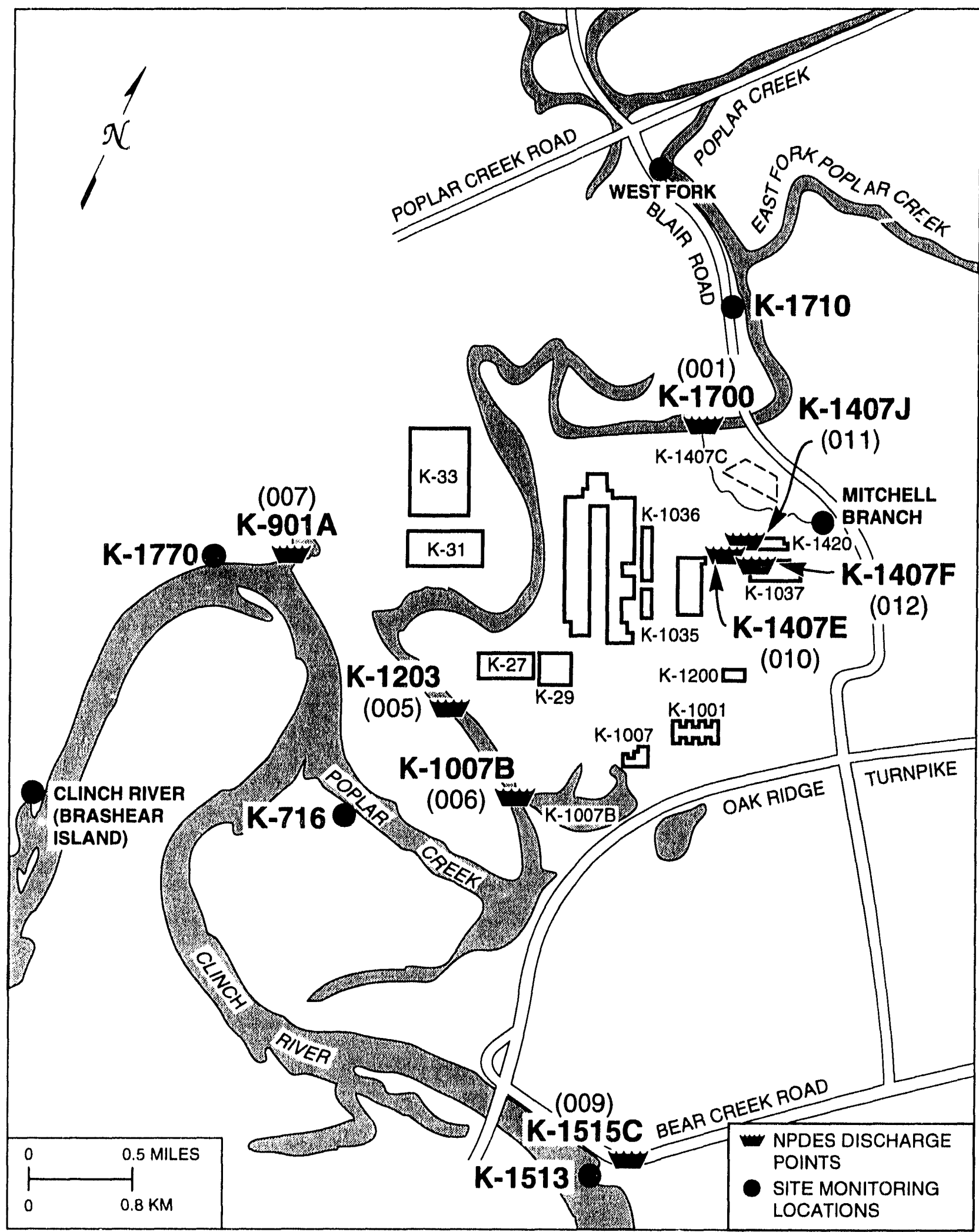

Fig. 4.11. K-25 Site surface water monitoring locations (January 1 through September 30, 1992). 
ORNL.DWG 93M-52.86R2

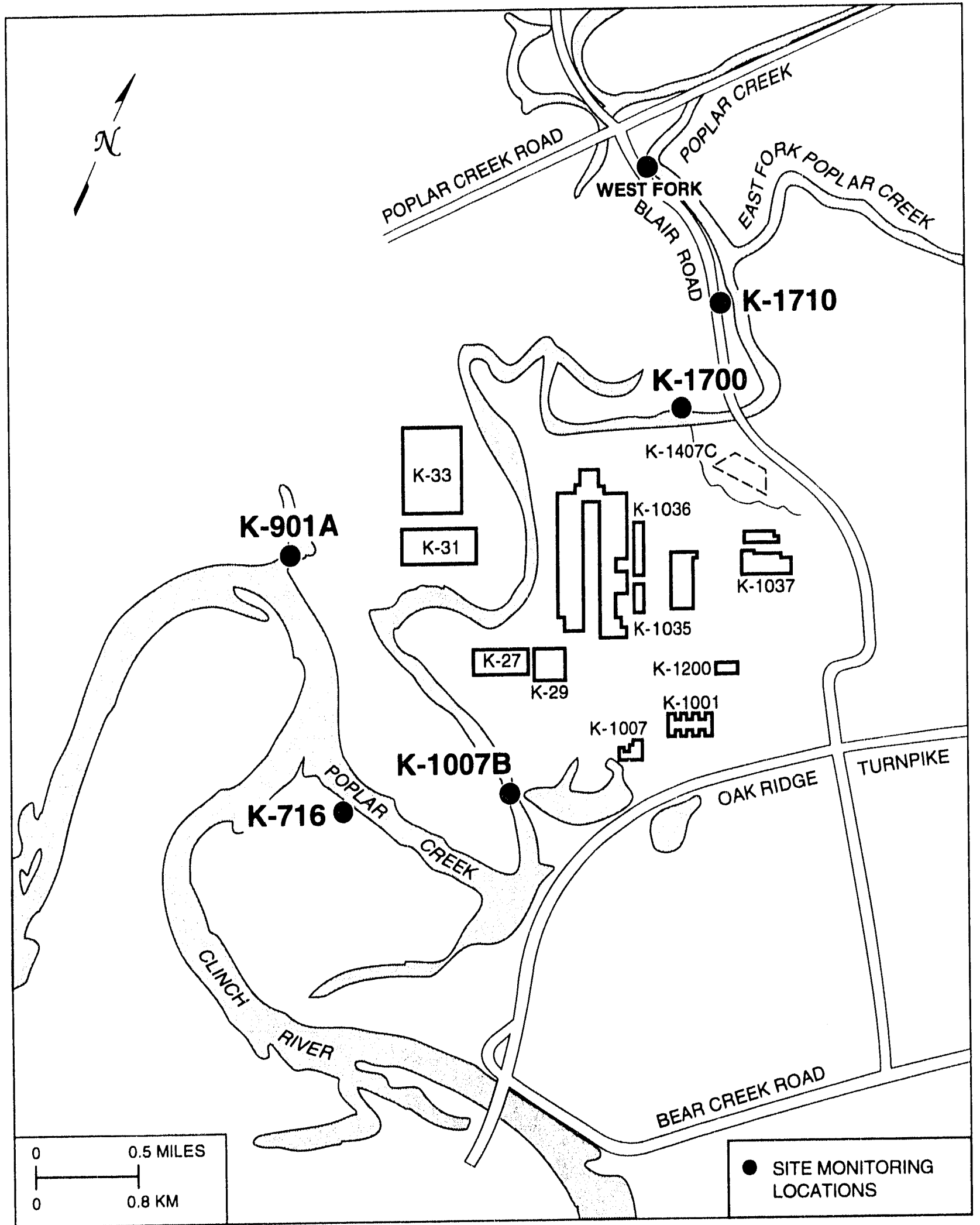

Fig. 4.12. K-25 Site surface water monitoring locations for the site monitoring program (October 1 to December 31, 1992). 
ORNL.DWG 93M-6302

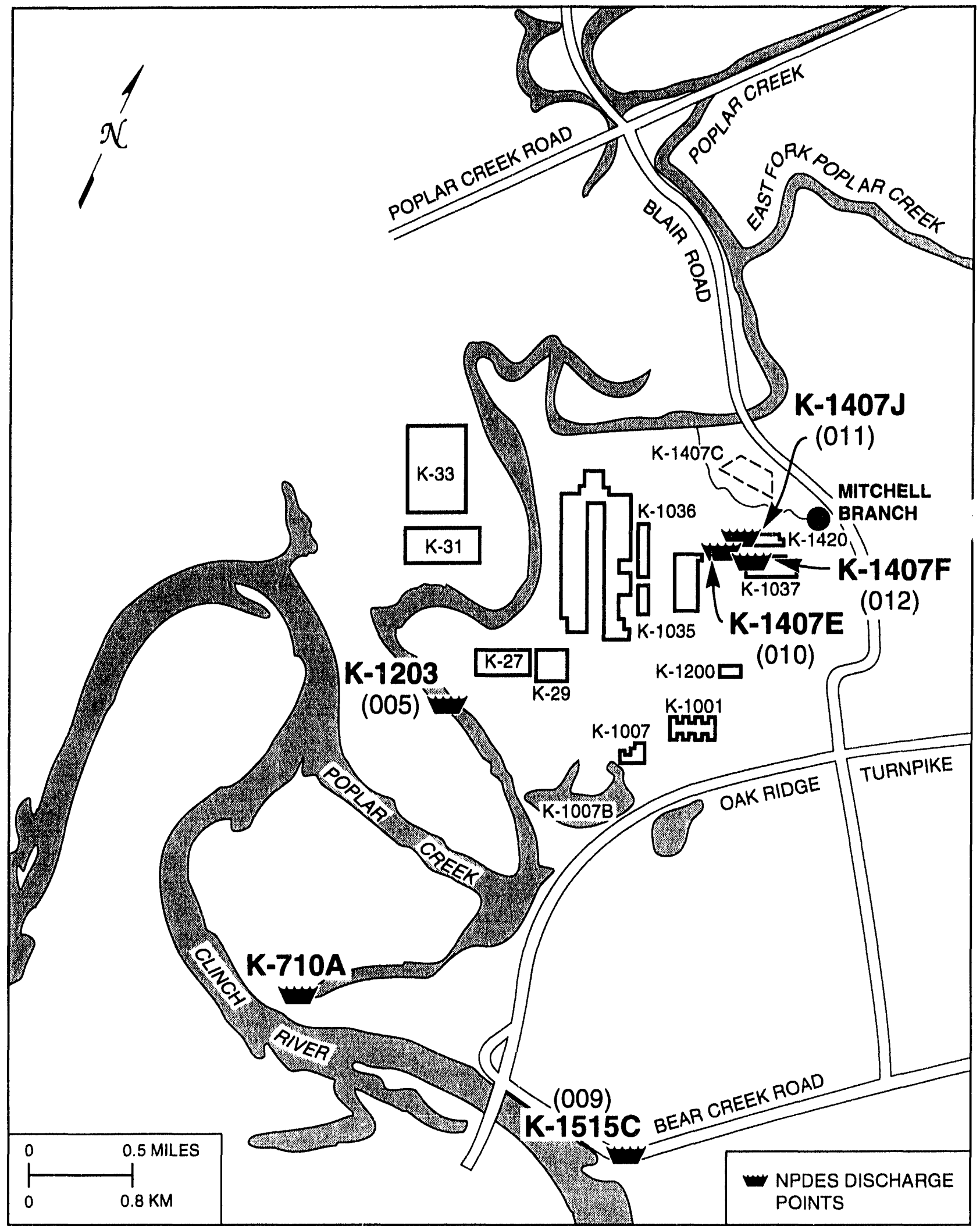

Fig. 4.13. K-25 Site NPCES major outfalls (October 1 to December 31, 1992). 
fission products into the plant facilities. The radioisotopes specifically encountered were technetium, cesium, neptunium, and plutonium. The uranium enrichment process has now been shut dow'n, and radioactive materials are no longer being introduced into the process. If additional isotopes are introduced to the plant site, monitoring of effluents will be reassessed.

The K-1700 and K-1407-J NPDES points (Fig. 4.11 ) have the greatest potential for radioactive emissions because of the facilities operating nearby. The K-1203 sewage plant has the second greatest potential for radioactive emissions, followed by the K-1407-E/F ponds. K-1007-B and K-901-A ponds have the least potential because no process effluents entering these ponds should contain radioactivity. The K-1515-C NPDES point receives backwash from the sanitary water plant. The intake for this facility is on the Clinch River; therefore the potential for contamination from the K-25 Site does not exist, although contamination from the Clinch River may concentrate in the filter backwash.

Through September 1992 under the expired permit, all NPDES discharge points (with the exception of K-1515-C) were grab sampled monthly for total alpha, beta, and gamma activity. If any monthly total activity values were above $30 \mathrm{pCi} / \mathrm{L}$, an isotopic analysis was conducted on the monthly grab sample. Isotopic analyses include identification and quantification of ${ }^{2.34} \mathrm{U},{ }^{235} \mathrm{U},{ }^{236} \mathrm{U},{ }^{2.38} \mathrm{U},{ }^{99} \mathrm{Tc},{ }^{137} \mathrm{Cs}$, ${ }^{237} \mathrm{~Np},{ }^{238} \mathrm{Pu}$, and ${ }^{2.34} \mathrm{Pu}$. These data were transmitted quarterly to the state with the DMRs. Beginning October 1, 1992, as part of the K-25 Site Environmental Surveillance Program, isotopic analyses are performed on monthly composite samples taken at all NPDES discharge points with the exception of K-1515-C. In accordance with the renewed NPDES permit, only the K-1407-J outfall $(011)$ is monitored for total uranium, total radioactivity, and isotopes analysis for NPDES reporting purposes.

Most values are well below the DCGs, and the sum of the fractions of the DCGs are all less than 1.0 (Table 4.84, Vol. 2).

\subsubsection{ORR Off-Reservation Surface Waters}

Sampling and data analysis of off-reservation surface waters were completed by ORNL staff and are discussed in Sect. 4.4.2.

\subsubsection{Effluents}

NPDES effluent monitoring is specified in the K-25 Site NPDES permit TN0002950. With written authorization from TDEC, the site operated under an expired permit until October 1992, when a renewed permit was issued. The renewed permit deleted outfalls 001 (K-1700), 006 (K-1007-B), 007 (K-901-A), and 008 (K-710). Outfalls 012 (K-1407-F Pond), 013 (K-1513 Intake), 014 (CNF discharge to Clinch River), as well as all 139 storm drains on the site were added as outfalls in the renewed permit.

The current NPDES permit for the K-25 Site has 7 major outfalls and 139 storm drain outfalls. Table 4.3 details the permit requirements and compliance records for each outfall in 1992. Samples are collected at three of the seven outfalls and at all of the storm drains. Two of the major outfalls, 010 and 012 , are currently inactive and do not discharge except in extremely heavy rainfall. A compliance schedule included in the permit requires cessation of discharges from these outfalls by October 1, 1994. Outfall 013 is the K-1513 sanitary water intake backwash filter. Although no monitoring is required at this outfall, routine inspections are conducted to ensure no unsightly debris or scum is discharged during backwash operations. Outfall 014 is a permitted outfall for the discharge of effluent from the Central Neutralization Facility to the Clinch River. This effluent is currently discharged to Poplar Creek through outfall 011; however, the permit requires that discharges to Poplar Creek cease and discharges to the Clinch River through Outfall 014 be initiated by April 1996. This compliance schedule will be met by extension of the pipeline that currently carries the effluent to Poplar Creek. Overall, a $99.9 \%$ compliance rate was maintained with the NPDES permit during 1992. 
1992 Environmental Report Vol. 1, Oak Ridge

Table 4.3. 1992 NPDES compliance at the K-25 Site

\begin{tabular}{|c|c|c|c|c|c|c|c|}
\hline \multirow[b]{2}{*}{$\begin{array}{l}\text { Discharge } \\
\text { point }\end{array}$} & \multirow[b]{2}{*}{$\begin{array}{l}\text { Effluent } \\
\text { parameters }\end{array}$} & \multicolumn{4}{|c|}{ Effluent limits } & \multirow[b]{2}{*}{$\begin{array}{l}\text { Number of } \\
\text { noncom- } \\
\text { pliances }\end{array}$} & \multirow[b]{2}{*}{$\begin{array}{c}\text { Percent } \\
\text { compliance }\end{array}$} \\
\hline & & $\begin{array}{l}\text { Daily } \\
\text { av } \\
\text { (mg/L) }\end{array}$ & $\begin{array}{l}\text { Daily } \\
\max \\
(\mathrm{mg} / \mathrm{L})\end{array}$ & $\begin{array}{l}\text { Daily } \\
\text { av } \\
(\mathrm{kg} / \mathrm{d})\end{array}$ & $\begin{array}{l}\text { Daily } \\
\max \\
(\mathrm{kg} / \mathrm{d})\end{array}$ & & \\
\hline $\begin{array}{l}001 \\
\text { K-1700 discharge }\end{array}$ & $\begin{array}{l}\text { Aluminum } \\
\text { Chromium } \\
\text { Nitrate-N } \\
\text { Suspended solids }{ }^{a} \\
\text { Oil and grease } \\
\text { pH, standard units } \\
\text { Lead } \\
\text { Zinc } \\
\text { Color }\end{array}$ & $\begin{array}{l}0.050 \\
30 \\
10^{b} \\
\\
0.0080 \\
0.12\end{array}$ & $\begin{array}{l}1.0 \\
0.080 \\
20 \\
50 \\
15 \\
6.0-9.0 \\
0.93 \\
1.5 \\
c\end{array}$ & $\begin{array}{l}0.80 \\
470 \\
160 \\
\\
0.12 \\
1.86\end{array}$ & $\begin{array}{c}16 \\
1.2 \\
310 \\
780 \\
230 \\
\\
14 \\
246\end{array}$ & 4 & $\begin{array}{r}96 \\
100 \\
100 \\
100 \\
99 \\
100 \\
100 \\
100 \\
d\end{array}$ \\
\hline $\begin{array}{l}005 \\
(\text { K-1203 sanitary } \\
\text { treatment facility })^{e}\end{array}$ & $\begin{array}{l}\text { Ammonia nitrogen } \\
\text { BOD } \\
\text { Chlorine, residual } \\
\text { Dissolved oxygen } \\
\text { Fecal coliform, } \\
\text { No./100 mL } \\
\text { pH, standard units } \\
\text { Suspended solids } \\
\text { Settleable solids, } \\
\text { mL/ } \\
\text { Unpermitted } \\
\text { discharge- } \\
\text { untreated sewage }\end{array}$ & $\begin{array}{l}\stackrel{5.0}{15}^{5.0^{b}} \\
200^{-}\end{array}$ & $\begin{array}{c}7.0 \\
20 \\
0.24 \\
400 \\
\\
6.0-9.0 \\
45 \\
0.50 \\
d\end{array}$ & $\begin{array}{l}12 \\
37\end{array}$ & $\begin{array}{l}17.3 \\
49.5\end{array}$ & $\begin{array}{l}1 \\
2\end{array}$ & $\begin{array}{r}100 \\
100 \\
99 \\
100 \\
99 \\
\\
100 \\
100 \\
99 \\
\\
d\end{array}$ \\
\hline $\begin{array}{l}006 \\
\text { (K-1007-B } \\
\text { holding pond) }\end{array}$ & $\begin{array}{l}\text { COD } \\
\text { Chromium, total } \\
\text { Dissolved oxygen } \\
\text { Fluoride } \\
\text { Oil and grease } \\
\text { pH, standard units } \\
\text { Suspended solids }\end{array}$ & $\begin{array}{l}20 \\
5.0^{h} \\
1.0 \\
10 \\
30\end{array}$ & $\begin{array}{l}25 \\
0.050 \\
1.5 \\
15 \\
6.0-9.0 \\
50\end{array}$ & $\begin{array}{c}120 \\
6.1 \\
61 \\
182\end{array}$ & $\begin{array}{l}150 \\
0.30 \\
9.1 \\
91 \\
304\end{array}$ & 1 & $\begin{array}{r}99 \\
100 \\
100 \\
100 \\
100 \\
100 \\
100\end{array}$ \\
\hline $\begin{array}{l}007 \\
\text { (K-901-A holding } \\
\text { pond) }\end{array}$ & $\begin{array}{l}\text { Chromium, total } \\
\text { Fluoride } \\
\text { Oil and grease } \\
\text { pH, standard units } \\
\text { Suspended solids } \\
\text { Dissolved oxygen } \\
\text { Visible solids }\end{array}$ & $\begin{array}{c}1.0 \\
10 \\
30 \\
5^{b}\end{array}$ & $\begin{array}{l}0.05 \\
1.5 \\
15 \\
6.0-10 \\
50 \\
\\
c\end{array}$ & $\begin{array}{c}4.2 \\
42 \\
125\end{array}$ & $\begin{array}{c}0.68 \\
6.3 \\
63 \\
\\
210\end{array}$ & $\begin{array}{l}2 \\
6\end{array}$ & $\begin{array}{r}98 \\
100 \\
100 \\
100 \\
98 \\
98 \\
d\end{array}$ \\
\hline $\begin{array}{l}009 \\
\text { (K-1515-C sanitary } \\
\text { water plant) }\end{array}$ & $\begin{array}{l}\text { Suspended solids }{ }^{a} \\
\text { Aluminum } \\
\text { Sulfate } \\
\text { pH, standard units }\end{array}$ & $\begin{array}{l}30 \\
5.0\end{array}$ & $\begin{array}{r}50 \\
10 \\
1400 \\
6.0-9.0\end{array}$ & $\begin{array}{l}34 \\
5.7\end{array}$ & $\begin{array}{r}51 \\
11 \\
1600\end{array}$ & & $\begin{array}{l}100 \\
100 \\
100\end{array}$ \\
\hline Storm drain & $\begin{array}{l}\text { Unpermitted } \\
\text { Discharge }\end{array}$ & & $c$ & & & 4 & $d$ \\
\hline
\end{tabular}




\section{Environmental Report Vol. 1, Oak Ridge}

Table 4.3 (continued)

\begin{tabular}{|c|c|c|c|c|c|c|c|}
\hline \multirow[b]{2}{*}{$\begin{array}{c}\text { Discharge } \\
\text { point }\end{array}$} & \multirow[b]{2}{*}{$\begin{array}{c}\text { Effluent } \\
\text { parameters }\end{array}$} & \multicolumn{4}{|c|}{ Effluent limits } & \multirow[b]{2}{*}{$\begin{array}{l}\text { Number of } \\
\text { noncom- } \\
\text { pliances }\end{array}$} & \multirow[b]{2}{*}{$\begin{array}{c}\text { Percent } \\
\text { compliance }\end{array}$} \\
\hline & & $\begin{array}{c}\text { Daily } \\
\text { av } \\
\text { (mg/L) }\end{array}$ & $\begin{array}{l}\text { Daily } \\
\max \\
(\mathrm{mg} / \mathrm{L})\end{array}$ & $\begin{array}{l}\text { Daily } \\
\text { av } \\
(\mathrm{kg} / \mathrm{d})\end{array}$ & $\begin{array}{c}\text { Daily } \\
\max \\
(\mathrm{kg} / \mathrm{d})\end{array}$ & & \\
\hline $\begin{array}{l}011 \\
(\mathrm{~K} \mid 407-\mathrm{J})^{f, g}\end{array}$ & $\begin{array}{l}\text { Cadmium } \\
\text { Chromium } \\
\text { Copper } \\
\text { Lead } \\
\text { Silver } \\
\text { Zinc } \\
\text { Cyanide } \\
\text { TTO } \\
\text { Oil and grease } \\
\text { Nickel } \\
\text { TSS } \\
\text { PCB, } \mu g / L \\
\text { pH, standard units }\end{array}$ & $\begin{array}{c}0.26 \\
1.71 \\
2.07 \\
0.43 \\
0.24 \\
1.48 \\
0.65 \\
\\
26 \\
2.38 \\
31\end{array}$ & $\begin{array}{l}0.69 \\
2.77 \\
3.38 \\
0.69 \\
0.43 \\
2.61 \\
1.20 \\
2.13 \\
52 \\
3.98 \\
60 \\
0.014 \\
6.0-9.0\end{array}$ & & & & $\begin{array}{l}100 \\
100 \\
100 \\
100 \\
100 \\
100 \\
100 \\
100 \\
100 \\
100 \\
100 \\
100 \\
100\end{array}$ \\
\hline $\begin{array}{l}010 \\
(\mathrm{~K}-1407-\mathrm{E} \text { and } \\
\mathrm{K}-1407-\mathrm{F})\end{array}$ & $\begin{array}{l}\text { Temperature } \\
\text { TSS } \\
\text { Oil and grease } \\
\text { Chromium } \\
\text { Copper } \\
\text { Iron } \\
\text { Zinc } \\
\text { PCB }(\mu \mathrm{g} / \mathrm{L}) \\
\text { pH, standard units }\end{array}$ & $\begin{array}{l}15 \\
0.2 \\
1.0 \\
1.0 \\
1.0\end{array}$ & $\begin{array}{l}30.5 \\
50 \\
20 \\
0.2 \\
1.0 \\
1.0 \\
1.0 \\
0.014 \\
6.0-9.0\end{array}$ & & & & $\begin{array}{l}100 \\
100 \\
100 \\
100 \\
100 \\
100 \\
100 \\
100\end{array}$ \\
\hline
\end{tabular}

${ }^{a}$ Limit applicable only during normal operations. Not applicable during periods of increased discharge due to surface runoff resulting from precipitation.

bDaily minimum.

"No discharge.

Not applicable.

'Because of the small flow rates at the K-710-A sanitary treatment facility (discharge point W'27), a rapid sand filter was installed May 1, 1978, climinating the surface discharge and the need for monitoring.

fDuring the characterization of this effluent point more data are obtained and reported but are not subject to limits at this time.

sPermit limits for Discharge Point 011 are monthly averages.

All process water discharges from the plant pass through an NPDES monitoring point. Storm drains at the site are grouped into four categories in accordance with the potential for pollutants that may occur in the storm drain discharges. Monitoring is conducted weekly, monthly, quarterly, or semiannually for each category, with those storm drains with the highest potential for pollutants being sampled the most frequently. There are only six storm drain outfalls in the category requiring weekly monitoring and a compliance schedule is included in the permit requiring compliance with chlorine limitation at these outfalls by October 1, 1993. Chlorine is the primary pollutant in these storm drain discharges because of the presence of cooling water and sanitary water in the discharges. Efforts are under way to meet the compliance schedule by removing the chlorinated discharges or dechlorinating the effluent prior to entry into the receiving streams. A storm water pollution prevention plan is also a requirement of the renewed NPDES permit. This plan will be implemented by October 1, 1993, and will identify methods to reduce and eliminate the potential for discharges of pollutants through the storm drain outfalls (Table 4.94, Vol. 2).

Since the K-25 Site has been in standby mode, the major decreases in liquid discharges have been the result of the elimination of blowdown from both 
the recirculating cooling water ( $\mathrm{RCW}$ ) system and the centrifuge development cooling towers and a decrease in sewage effluent. The discharges are described according to their NPDES outfalls in Tables 4.95-4.103 of Vol. 2. Individual parameters are listed by annual values. The variety of parameters measured at $\mathrm{K}-1407-\mathrm{J}$ is required to characterize this effluent for new treatment facilities' discharges. Most organics are below detection limits. Figure 4.14 summarizes the K-25 NPDES noncompliances. Each $\mathrm{K}-25$ Site location is listed in Tables 4.91 and 4.92 of Vol. 2 along with sampling frequency and sample type. All analyses are performed according to EPA-approved procedures.

The K-25 Site operates one sanitary sewage system-an extended aeration treatment plant with a rated capacity of $2.3 \mathrm{million} \mathrm{L} / \mathrm{d}(0.6 \mathrm{Mgd})$ and a current use of about $1.1 \mathrm{million} \mathrm{L} / \mathrm{d}(0.3 \mathrm{Mgd})$. Treated effluent from the main plant is discharged into Poplar Creek through NPDES outfall 005.

Because of their remoteness and low volume of use, outlying facilities such as the power house area, rifle range, and water treatment plant use septic tanks with drain fields. The power house area has a packaged treatment plant with a rated caracity of $76,000 \mathrm{~L} / \mathrm{d}(19,760 \mathrm{gal} / \mathrm{d})$; however, this $\mathrm{f} a$,ility has been shut down and is scheduled for decontamination and decommissioning. It has been deleted from the renewed NPDES permit.

Surface runoff within the K-25 Site is drained by Mitchell Branch, Poplar Creek, and the Clinch River.

There are 15 cooling towers at the K-25 Site, but only 5 are active. The remaining ten are scheduled for decontamination and decommissioning. Only two of the active five cooling towers regularly discharge blowdown to the storm drain system. These discharges are monitored at the appropriate storm drains under the requirements of the renewed NPDES permit.

As required by the 1986 NPDES permit modification, the K-1407-B Pond was removed from service in November 1988, and the permitted NPDES point was split to accommodate the two effluent streams from the Central Neutralization Facility (CNF). One stream contains small quantities of uranium contamination from the uranium recovery facility, metals from the metal cleaning facility, and effluents from the TSCA Incinerator; the other contains only coal pile and steam plant effluents.
These wastestreams receive treatment at the CNF before discharge. In November 1988, the coal pile effluents and steam plants began discharging through $\mathrm{K}-1407-\mathrm{E}$ and $\mathrm{K}-1407-\mathrm{F}$ ponds (NPDES outfalls 010 and 012). The coal pile was removed in 1991, thereby eliminating coal pile runoff. A compliance schedule in the NPDES permit requires cessation of discharges from these ponds by October 1, 1994. In September 1989, the K-1407-J discharge was redirected from Mitchell Branch to Poplar Creek (NPDES outfall 011) to eliminate any impact to the Mitchell Branch aquatic community.

A compliance schedule in the NPDES permit requires cessation of discharges to Poplar Creek by April 1996. At that time, K-1407-J discharges will be re-routed to the Clinch River via NPDES outfall 014.

In March 1991, following verbal approval from TDEC, discharge from the K-1407-E and -F ponds was ceased as a routine operation. Instead, the coal pile and steam plant wastewaters were routed through the CNF for additional treatment and discharged through the K-1407-J settling basins to Poplar Creek. This treatment and discharge scenario was implemented because of the inability to effectively remove the iron in the wastewater with treatment and discharge through K-1407-E and -F ponds and to reduce the impact to Mitchell Branch resulting from the discharge of the effluent from these ponds. Monitoring of the K-1407-J settling basin effluent was increased to include parameters characteristic of the coal pile and steam plant wastewaters and this supplemental data was reported on the monthly DMRs. Monitoring requirements for outfall 011 in the renewed NPDES permit were developed to address the characteristics of the steamplant wastewater.

It is believed that noncompliances for aluminum at $\mathrm{K}-1700$, chemical oxygen deman: (COD) and dissolved oxygen at $\mathrm{K}-1007-\mathrm{B}$, as well as noncompliances for suspended solids and dissolved oxygen at K-901-A, are all caused by natural phenomena. These noncompliances occurred before October 1, 1992. With reissuance of the permit at that time, these outfalls were removed from the permit, ard storm drain outfalls that discharge into the ponds were added.

The remaining noncompliances were processrelated conditions or administrative problems and were addressed individually. When noncompliances 


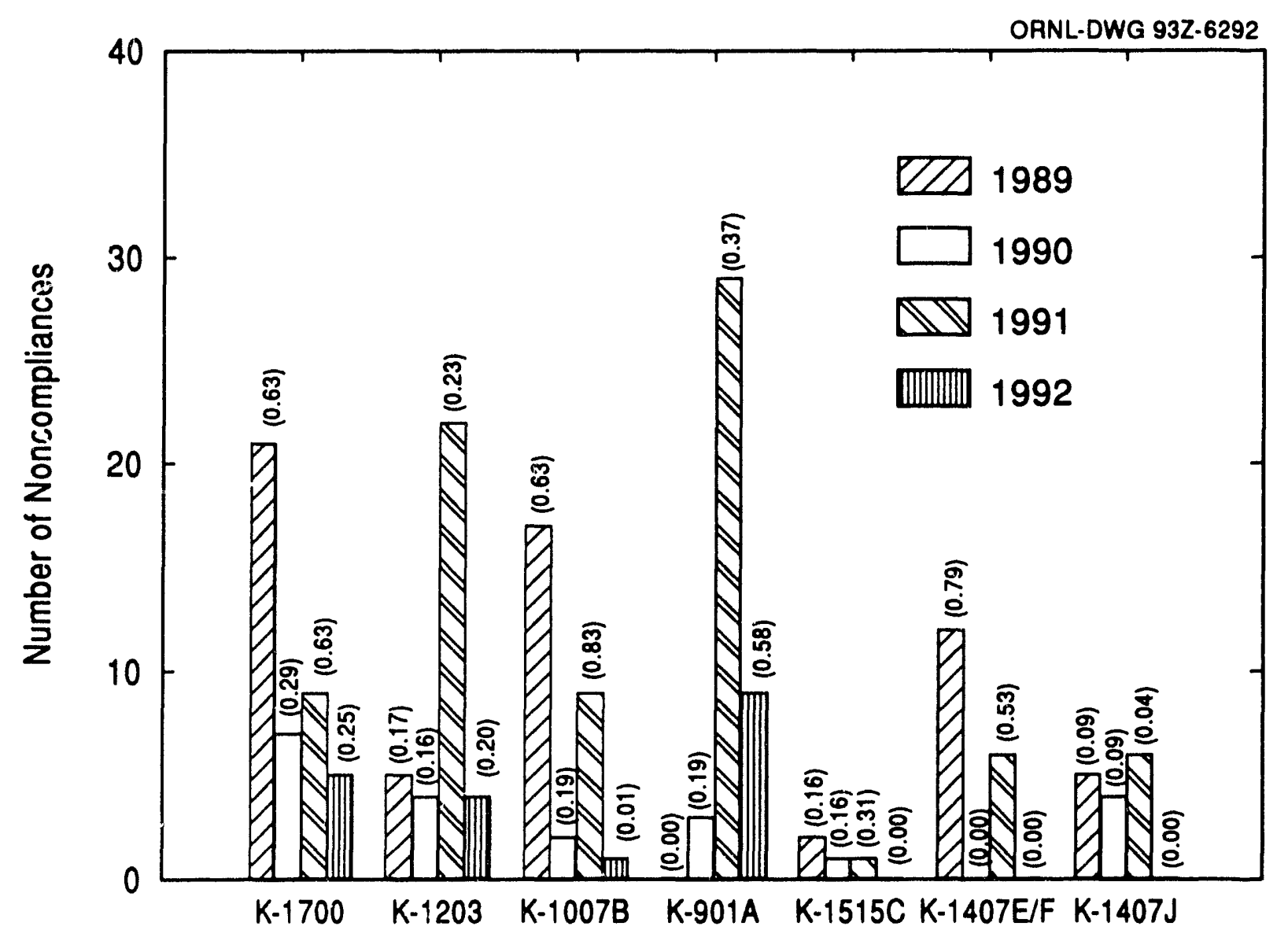

Fig. 4.14. K-25 Site NPDES compliance.

of this type occurred, procedures and field activities were reviewed, projects were initiated, and changes were made to help eliminate future occurrences.

Four unpermitted discharges to storm drains and visible sheen on receiving waters occurred because of spills, pipeline breaks, and inappropriate storm drain connections.

All NPDES noncompliances were reported under the Occurrence Reporting System (ORS). Corrective actions to prevent reoccurrence were documented and tracked under the ORS.

In accordance with Part IV of the 1986 NPDES permit modification issued to the K-25 Site, the plant was required to develop and implement a TCMP. This requirement continued under the renewed permit. Under the TCl.1P, wastewater from the $\mathrm{K}-1407-\mathrm{J}$ basins were : valuated for toxicity every 2 months.
The results of the toxicity tests of wastewaters from K-1407-J are given in Table 4.104 of Vol. 2. This table provides, for each wastewater, the month the test was conducted and the wastewater's NOEC for fathead minnows and Ceriodaphnia. Average water quality measurements obtained during each toxicity test are shown in Table 4.105 of Vol. 2.

Wastewater from the K-1407-J Basin was tested six times during the year. The NOEC for the fathead minnows was always $100 \%$, and it was never less than 50\% for Ceriodaphnia. Beginning in September 1989, this wastewater was discharged to Poplar Creek where it has an in-stream waste roncentration of about $1 \%$. Therefore, it is unlikely that this wastewater will adversely affect the aquatic bivia in Poplar Creek.

Wastewater from both the K-1407-J Basin and the K-1203 Sewage Treatment Plant were tested as part of the toxicity testing task of the Biological

\section{4-36 Surface Water}




\section{Environmental Report Vol. 1, Oak Ridge}

Monitoring and Abatement Program. These tests used both fathead minnows (Pimephales promelas) and the water flea Ceriodaphnia spp. to measure toxicity of the effluent. The new NPDES permit issued in October 1992 required some changes in the toxicity testing program compared with previous practice. The most significant changes included the addition of $\mathrm{K}-1203$ to the program and an alteration in reporting data. Previously, data had been reported in the form of no-observed-effect concentrations (NOECs). The new program requires reporting data in the form of no-observed-effect limits (NOELs). The new program requires reporting data in the form of no-observedeffect limits (NOELs) and lethal concentrations for $50 \%$ of the test organisms $\left(\mathrm{LC}_{50} \mathrm{~S}\right)$.

Because the new permit was issued in October, only a single test series was run under the terms of the new permit. Effluent from K-1407-J was tested five times. The NOEC was $100 \%$ for the fathead minnows on four occasions, and both the NOEL and the $L C_{50}$ for the fathead minnows was $75 \%$ on the fifth test. NOEC values for the Ceriodaphnia spp. range from 100 to $25 \%$ at $\mathrm{K}-1407-\mathrm{J}$, and the NOEL and the $\mathrm{LC}_{50}$ was $75 \%$ on the fifth test. The single test run on K-1203 effluent provided a NOEL and the $L_{C_{(1)}}$ was $75 \%$ on the fifth test. The single test run on K-1203 effluent provided a NOEL and $\mathrm{LC}_{50}$ of $100 \%$ for both Ceriodaphnia spp. and fathead minnows. All of the toxicity results for these two outfalls were well within the limits specified by the NPDES permit.

\subsection{References}

Horning, W. B., II, and C. I. Weber. 1985. Short-Term Methods for Estimating the Chronic Toxicity of Effluents and Receiving Waters to Freshwater Organisms, EPA/600/4-85/014.

McMaster, W. N. 1967. Hydrologic Data for the Oak Ridge Area, Tennessee. U.S. Geological Survey Water Supply Paper 1839-N.

U.S. Department of Energy. January 1991. Environmental Regulatory Guide for Radiological Effluent Monitoring and Environmental Surveillance, DOE/EH-0173T. 


\section{GROUNDWATER}

5.1 Groundwater Hydrology . . . . . . . . . . . . . . 5-3

5.1.1 Hydrogeologic Framework of the ORR ............. 5-3

5.1.2 Groundwater Flow ... . . . . . . . . 5 5-7

5.1.3 Groundwater Monitoring Considerations ............ . . 5-7

5.2 Regulatory Requirements . . . . . . . . 5-8

5.2.1 Comprehensive Environmental Response, Compensation, and Liability

Act (CERCLA) . . . . . . . . . . . . 5-8

5.2.2 RCRA Interim Status and Permit Monitoring Programs . . . . . . . . . 5-8

5.2.3 RCRA 3004(u) Monitoring

Program .............. 5-10

5.2.4 Groundwater Surveillance Monitoring

Program on the ORR ........ 5-10

5.3 Groundwater Monitoring at the Y-12 Plant . . 5-10

5.3.1 Upper East Fork Poplar Creek Hydrogeologic Regime . . . . . . . . 5 5-20

5.3.2 Bear Creek Hydrogeologic

Regime ............... . 5-31

5.3.3 Chestnut Ridge Hydrogeologic

Regime . . . . . . . . . . . . . 5-39

5.4 Oak Ridge National Laboratory . . . . . . . 5-48

5.4.1 Background ... . . . . . . . . . 5-48

5.4.2 ORNL 1992 Groundwater Quality

Well Installation, Development, and

Sampling Activities . . . . . . . . . . 5-53 
1992 Environmental Report Vol. 1, Oak Ridge

5.4.3 ORNL Groundwater Monitoring Results . . . . . . . . . . . . 5 5-54

5.4.4 Future ORNL Groundwater Quality Monitoring Activities . . . . . . . . 5 5-59

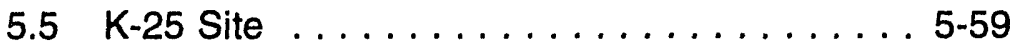

5.5.1 Background . . . . . . . . . . . 5-59

5.5.2 K-25 Site Hydrogeology . . . . . . . 5 5-61

5.5.3 Current Groundwater Monitoring . . . 5 5-61

5.5.4 Groundwater Monitoring Results . . . 5-62

5.5.5 Future K-25 Site Groundwater

Program Activities . . . . . . . 5 5-68

5.6 Plugging and Abandonment . . . . . . . . 5-68

5.6.1 Y-12 Plant . . . . . . . . . . . . 5-68

5.6.2 Oak Ridge National Laboratory . . . . 5-68

$5.6 .3 \quad$ K-25 Site . . . . . . . . . . . . 5-68

5.7 Off-Site Monitoring $\ldots \ldots \ldots \ldots \ldots \ldots$ 5-70

5.8 References . . . . . . . . . . . . . . 5-70 


\section{Groundwater}

The quality of the nation's groundwater resources is a serious and pressing issue, and public awareness of the need to protect these resources has increased dramatically in the last decade. Public sentiment is reflected in legislation enacted by Congress mandating that actions be taken to protect water resources from contamination. These statutes have been codified into regulations by the U.S. Environmental Protection Agency (EPA) and equivalent programs on the state level. Two such programs promulgated by Congress and administered by the state of Tennessee and the EPA are the Resource Conservation and Recovery Act (RCRA) and the Comprehensive Environmental Response, Compensation, and Liability Act (CERCLA). Specifically targeting the protection of groundwater from contamination by hazardous wastes, these regulations guide groundwater monitoring at the U.S. Department of Energy (DOE) plants in Oak Ridge.

Groundwater suitable for most uses is potentially available nearly everywhere in Tennessee. Although in the Oak Ridge area the majority of the population does not rely on groundwater for potable supplies (approximately $94 \%$ of households in the surrounding five county area utilize public water sources), groundwater does provide for some domestic, municipal, farm, irrigation, and industrial uses. Consequently, groundwater must be viewed as both a potential pathway for exposure to hazardous wastes, and as a means for contaminant transport. Monitoring programs established on the Oak Ridge Reservation (ORR) are intended to comply with established regulatory requirements and to assess groundwater contamination and transport on and off the ORR.

The following sections provide an overview of groundwater hydrology on the ORR, a summary of regulatory requirements for groundwater monitoring, a description of the groundwater monitoring systems established for the ORR, and a discussion of groundwater monitoring results for 1992.

\subsection{Groundwater Hydrology}

The following discussion provides an overview of current understanding of groundwater occurrence and flow on the ORR in order to provide a rationale for groundwater monitoring programs on the reservation. This discussion is global in nature and is based upon the recently developed conceptual model for the ORR (Solomon et al. 1992; Moore and Toran, 1992).

\subsubsection{Hydrogeologic Framework of the ORR}

Groundwater on the ORR occurs both in the unsaturated zone as transient, shallow subsurface stormflow and as an underlying unconfined water table aquifer. An unsaturated, or vadose, zone of variable thickness separates the stormflow zone and water-table aquifer. Near surface-water features, the water-table aquifer is found at shallow depths; aiong the ridge tops or near other high topographic areas, the water-table aquifer is continuous to depths of several hundred meters. In low-lying areas where the water table occurs near the surface, the stormflow zone and saturated zone are indistinguishable.

Several distinct flow intervals occur within the water table aquifer-the uppermost water table interval, the intermediate interval, the deep interval, and the aquiclude, which is defined by a transition to saline water (Fig. 5.1). The divisions within the saturated zone are vertically gradational and are not separated by distinct boundaries, but reflect an overall decrease in flux (rate of flow) with depth. The greatest flux is associated with the stormflow zone 


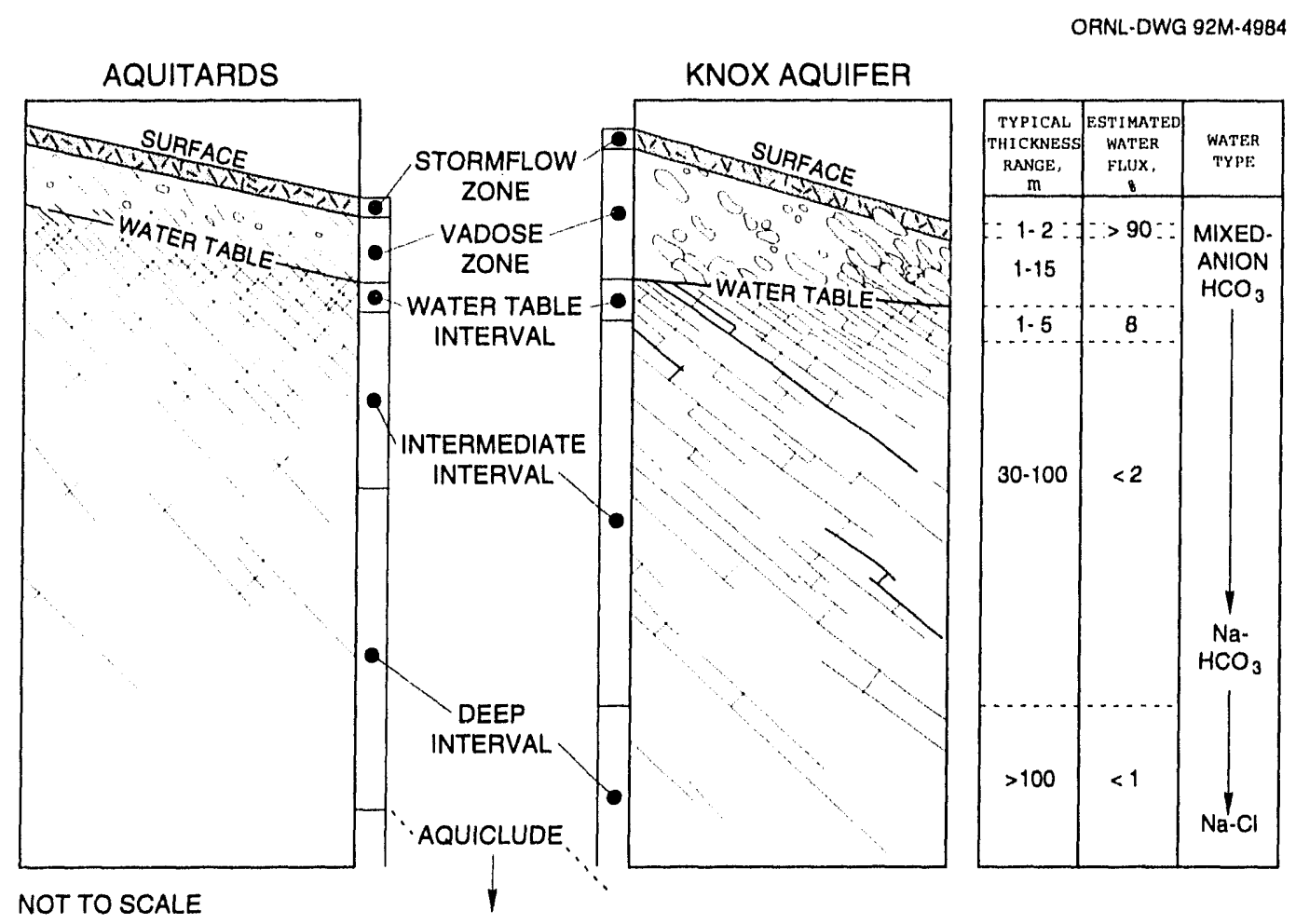

Fig. 5.1. Schematic vertical relationships of flow zones of the ORR, estimated thicknesses, water flux, and water types.

and the smallest with the deep zone. Water does not flow in the aquiclude.

Because of the inherent differences between bedrock types (and therefore saprolites and soils developed through in-place weathering of bedrock), two broad hydrologic units are identified on the ORR: aquitards and the Knox aquifer. Figure 5.2 is a generalized map showing surface distribution of the Knox aquifer and the ORR aquitards. Although there are some similarities in geologic and hydrologic characteristics of these units, many fundamental differences exist. Most waste areas on the ORR are located in areas underlain by the aquitards.

The Knox Group and the Maynardville Limestone of the Conasauga Group, both consisting of massive carbonate rocks, constitute the Knox aquifer. A combination of fractures and solution conduits in this aquifer control flow over substantial areas, and relatively large quantities of water may move relatively long distances. Active groundwater flow occurs at greater depth in the Knox aquifer and flow paths are significantly longer than in the aquitards. The Knox aquifer is the primary source of base flow in many streams, and all large springs on the ORR discharge from the Knox aquifer. Yields of some wells penetrating larger solution conduits are reported to exceed $1000 \mathrm{gal} / \mathrm{min}$.

The remaining geologic units (the Rome Formation, the Conasauga Group below the Maynardville Limestone, and the Chickamauga Group) constitute the aquitards, which consist mainly of siltstone, shale, sanditone, and thinly bedded limestone of low to very low permeability; nearly all groundwater flow in the aquitards occurs through fractures. The typical yield of a well in the aquitards is less than $1 \mathrm{gal} / \mathrm{min}$, and the base flows of streams draining areas underlain by the aquitards are poorly sustained.

\subsubsection{Unsaturated Zone Hydrology}

A vadose zone exists throughout the ORR except where the water table is near land surface (such as along perennial stream channels). The thickness of the vadose zone is greatest beneath ridges, and thins toward valley floors. Beneath ridges underlain by the Knox aquifer (Copper Ridge, Chestnut Ridge, McKinney Ridge, and Blackoak Ridge), the vadose

\section{5-4 Groundwater}




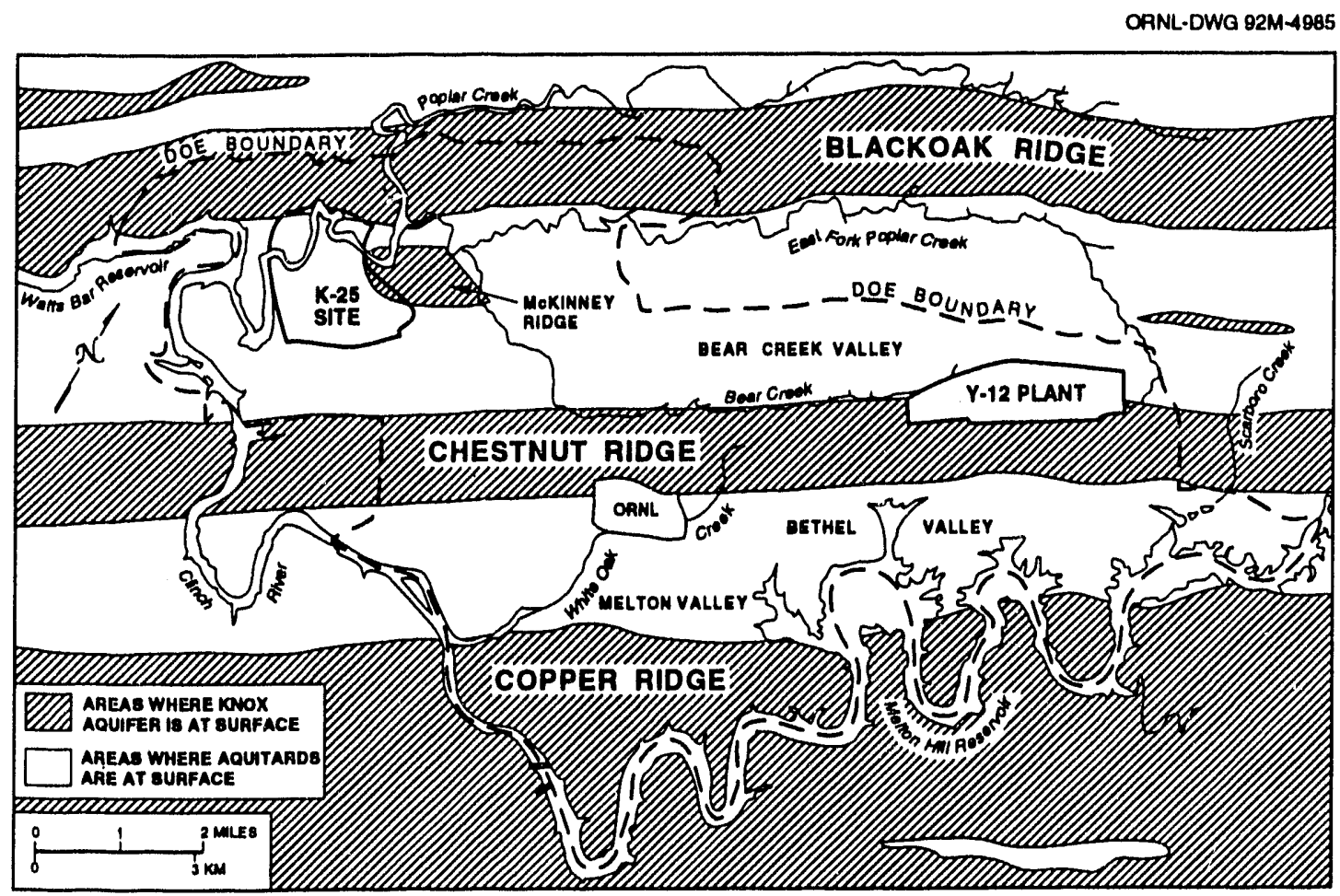

Fig. 5.2. Map showing the Knox Aquifer and the aquitards on the Oak Ridge Reservation.

zone commonly is greater than $30 \mathrm{~m}$ (100 ft) thick, whereas beneath ridges underlain by the Rome Formation (Haw Ridge and Pine Ridge) the vadose zone is typically less than $15 \mathrm{~m}(50 \mathrm{ft})$ thick. The regolith consists of clay and silt derived from the weathering of bedrock materials and which has significant water storage capacity. Most recharge through the vadose zone is episodic and occurs along fractures and large pores that may become saturated during rain events, even though surrounding micropores remain unsaturated and contain trapped air. During recharge events, flow paths in the vadose zone are complex, controlled by the orientation of the materials, fractures, and pore channels. Between recharge events, flow rates decrease dramatically, and water movement is predominantly vertical, driven by gravity toward the water table. Typically by design, wastes generated on the ORR are placed within the vadose zone.

Groundwater occurs in the vadose zone as localized, transient, perched water lenses of limited extent (particularly in the areas of the Knox aquifer) and as transient, shallow, subsurface stormflow.

In undisturbed, naturally vegetated areas on the ORR, roughly $90 \%$ of the infiltrating precipitation does not reach the water table, but travels through the 1 to $2 \mathrm{~m}$-deep stormflow zone, which approximately corresponds to the root zone. Because of the permeability contrast between the stormflow zone and the underlying vadose zone, the stormflow zone partially or completely saturates during rainfall events, and then water flows laterally, following very short flowpaths to adjacent streams. When the stormflow zone becomes completely saturated, overland flow occurs. Between rainfall events, as the stormflow zone drains, flow rates decrease dramatically and water movement becomes nearly vertical toward the underlying water table.

The transmissive capability of the stormflow zone is attributed to large pores (root channels, worm bores, relict fractures) that comprise only $0.2 \%$ of the total void volume of the stormflow zone. Because most of the water mass resides within less transmissive small pores, movement of solutes from large pores into small pores substantially reduces contaminant migration rates relative to fluid velocities in the large pores. Stormflow is primarily a transport mechanism in undisturbed or vegetated areas where it intersects shallow waste sources. However, whereas most buried wastes are below the 


\section{Environmental Report Vol. 1, Oak Ridge}

stormflow zone, a commonly observed condition known as bathtubbing can occur in some trenches, in which the excavation fills with water and may overflow into the stormflow zone. All stormflow ultimately discharges to streams on the ORR.

\subsubsection{Saturated Zone}

As shown in Fig. 5.1, the saturated zone on the ORR can be divided into four vertical distinct flow zones-an uppermost water table interval, an intermediate zone, a deep zone, and an aquiclude. Available evidence indicates that most water in the saturated zone in the aquitards is transmitted through a 1- to 6-m-thick layer of closely spaced, well-connected fractures near the water table (the water table interval) as shown on Fig. 5.3.

The range of seasonal fluctuations in depth to the water table and in rates of groundwater flow vary significantly across the reservation. In the areas of the Knox aquifer, seasonal fluctuations in water levels average $5.3 \mathrm{~m}(17 \mathrm{ft})$, and mean discharge from the active groundwater zone is typically $85 \mathrm{gal} / \mathrm{min} / \mathrm{mile}^{2}$. In the aquitards of Bear Creek Valley, Melton Valley, East Fork Valley, and Bethel Valley, seasonal fluctuations in water levels average $5 \mathrm{ft}$ and typical mean discharge is $26 \mathrm{gal} / \mathrm{min} / \mathrm{mile}^{2}$.

As in the stormflow zone, the bulk of water mass in the groundwater zone resides within the micropores of blocks of the rock matrix, which are bounded by fractures. Diffusive exchange between water in matrix pores and water in fractures reduces contaminant migration rates relative to water velocities in the fractures. For example, the leading edge of a geochemically nonreactive contaminant mass such as tritium migrates along fractures at a typical rate of $3 \mathrm{ft} / \mathrm{d}$; however, the center of mass of a contaminant plume typically migrates at a rate less than $0.2 \mathrm{ft} / \mathrm{d}$.

In the irtermediate interval, groundwater flow paths are a product of fracture density and orientation. In this interval groundwater movement occurs primarily in permeable fractures that are poorly connected in three dimensions. In the Knox aquifer a few cavity systems control groundwater movement in this zone, but in the aquitards the bulk of flow is through fractures along which permeability may be increased by weathering.

In the aquitards, chemical characteristics of groundwater change from mixed-cation- $\mathrm{HCO}_{3}$ water type at shallow depth to a $\mathrm{Na}-\mathrm{HCO}_{3}$ water type at deeper levels. This transition, not marked by a distinct change in rock properties, serves as a useful marker and can be used to distinguish the more active intermediate groundwater interval from the sluggish flow of the deep interval. There is evidence of similar change with depth in the chemical characteristics of water in the Knox aquifer. Although the geochemical

ORNL-DWG 92M-4986

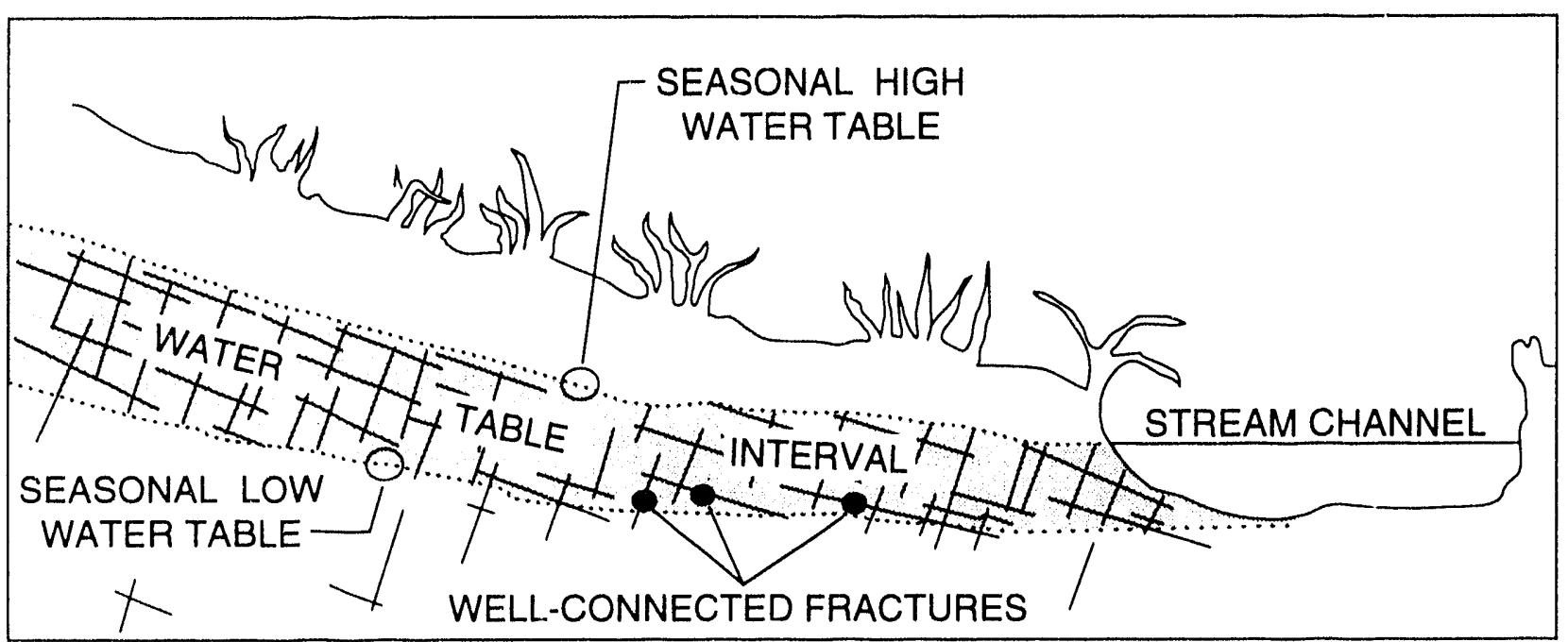

Fig. 5.3. Cross section showing the water table.

\section{5-6 Groundwater}


mechanism responsible for this change in water types is not quantified, it most likely is related to water residence time.

Hydrologically active fractures in the deep interval are significantly fewer in number and shorter in length than in the other intervals, and the spacing is greater. Wells finished in the deep interval of the ORR aquitards typically yield less than $0.3 \mathrm{gal} / \mathrm{min}$ and thus are barely adequate for water supply.

In the aquitards, saline water characterized by total dissolved solids (TDS) ranging up to $275,000 \mathrm{mg} / \mathrm{L}$ and chlorides generally in excess of $50,000 \mathrm{mg} / \mathrm{L}$ (ranging up to $163,000 \mathrm{mg} / \mathrm{L}$ ) lies beneath the deep interval of the groundwater zone, delineating an aquiclude. Chemically, this water resembles brines typical of major sedimentary basins, but its origin is not known. The chemistry does suggest extremely long residence times (i.e., very low flow rates) and little or no mixing with shallow groundwater.

The aquiclude has been encountered at depths of 125 and $244 \mathrm{~m}$ (400 and $800 \mathrm{ft}$ ) in Melton and Bethel valleys, respectively, and it is believed to approach $305 \mathrm{~m}(1000 \mathrm{ft})$ in portions of Bear Creek Valley underlain by aquitard formations. Depth to the aquiclude in areas of the Knox aquifer is not known but is believed to be greater than $366 \mathrm{~m}(1200 \mathrm{ft})$; depth to the aquiclude has not been established in the vicinity of the K-25 Site.

\subsubsection{Groundwater Flow}

Many factors influence groundwater flow on the ORR. Topography, surface cover, geologic structure, and lithology exhibit especially strong influence on the hydrogeology. Variations in these features result in water flux variations; average flux rates for the aquitards and the Knox aquifer formations are shown in Fig. 5.1. As an example, the overall decrease in open fracture density with depth results in a decreased groundwater flux with depth.

Bedding-plane and strike-parallel fracture orientations give rise to preferential groundwater movement along strike, toward cross-cutting tributary drainageways.

The topographic relief characteristic of the ORR is sufficient to induce the majority of active subsurface flow to remain shallow on the ORR. U.S.
Geological Survey modeling (Tucci 1992) suggests $95 \%$ of all groundwater flow occurs in the upper 15 to $30 \mathrm{~m}$ ( 50 to $100 \mathrm{ft}$ ) of the saturated zone in the aquitards. As a result, flow paths in the active-flow zones (particularly in the aquitards) are relatively short, and nearly all groundwater discharges to local surface water drainages on the ORR. Conversely, in the Knox aquifer, it is believed that a few solution conduit flow paths may be considerably longer, perhaps as much as $1.6 \mathrm{~km}$ ( 2 miles) long in the along-strike direction. However, no evidence at this time substantiates the existence of any deep, regional flow off the ORR or between basins within the ORR in either the Knox aquifer or the aquitards.

Migration rates of contaminants transported in groundwater are strongly influenced by natural chemical and physical processes in the subsurface (including diffusion, adsorption, etc.). Peak concentrations of solutes, including contaminants such as tritium moving from a waste area, for instance, can be delayed for several to many decades in the aquitards, even along flow paths as short as a few hundred feet. The processes that naturally retard contaminant migration and store contaminants in the subsurface are likely to be less effective in the Knox aquifer than in the aquitards due to flow along solution features.

\subsubsection{Groundwater Monitoring Considerations}

Because of the complexity of the hydrogeologic framework on the ORR, groundwater flow and therefore contaminant transport is largely unpredictable on a local scale. Consequently, plume delineation in the classical sense using monitoring wells (such as between two given wells) is not feasible on the ORR. Bulk solute transport via groundwater within the ORR can best be assessed over time by monitoring surface water quality because stormflow and the majority of groundwater discharge to surface water drainages on the ORR. Whereas the large number of wells on the ORR provide for characterization of groundwater quality, the combination of the existing monitoring well network and surface water monitoring programs provides sufficient monitoring of groundwater contamination. 


\subsection{Regulatory Requirements}

\subsubsection{Comprehensive Environmental Response, Compensation, and Liability Act (CERCLA)}

CERCLA regulations include groundwater monitoring as one of several aspects of a broadly scoped remedial investigation/feasibility study (RI/FS), unlike the RCRA regulations, which detail requirements for specific groundwater monitoring programs. The RI/FS process represents a two-pronged approach to contamination assessments at CERCLA sites. The remedial investigation is the data collection mechanism of the FS effort. Accordingly, the RI emphasizes data collection and site characterization.

A number of waste management units formerly listed as interim status units or solid waste management units (SWMUs) regulated under RCRA Section 3004(u), in addition to other non-RCRA tanks and sites, have been identified. In addition, integrator operable units (OUs) have been designated for media (groundwater, surface water, floodplain sediments) that have received contamination and either provide potential transport or exposure pathways, or act as secondary sources.

Like the RCRA facility investigation process for SWMUs, the specific requirements for groundwater monitoring during a CERCLA remedial investigation are not explicitly defined in the regulations but are recommended in guidance documents prepared by the EPA. Thus, specific details regarding monitored parameters, monitoring frequency and duration, and the monitor-well network are developed on a site-by-site basis, and are contained in an RI work plan submitted to appropriate regulatory agency for approval befure the investigation is initiated. When a sufficient amount of data have been generated to support the FS, groundwater monitoring efforts are reevaluated.

Groundwater monitoring related to source OUs and PA/SI efforts is deferred to the integrator OUs. Monitoring in the context of source OUs is conducted only to the extent from which a determination may be made whether the OU is contributing to groundwater contamination. Monitoring is addressed on a site-specific basis for those units for which no integrator OU has been identified (the Chestnut
Ridge Hydrogeologic Regime of the Y-12 Plant, for example). Monitoring to document effectiveness of remedial measures will be conducted as required under interim or final records of decisions.

\subsubsection{RCRA Interim Status and Permit Monitoring Programs}

RCRA, as amended, recognizes three distinct programs that require groundwater studies: RCRA interim status, FiCRA permit monitoring programs, and the RCRA 3004(u) program. Interim status requirements app!y to facilities that treat, store, or dispose of hazardous waste if the facilities existed on November 19, 1980, or if the facilities became subject to permitting requirements because of new regulatory requirements. The facilities remain in interim status until a Part B operating or postclosure permit is issued. Two types of groundwater monitoring may be required while a facility is under interim status:

- Detection monitoring [defined in $40 \mathrm{CFR}$ 265.91, 40 CFR 265.92, and TN 1200-1-11-.05(6)] may be required to determine if hazardous waste or hazardous waste constituents have entered the ground water underlying the facility.

- Assessment monitoring [defined in $40 \mathrm{CFR}$ 265.93(a) and TN 1200-1-11-.05(6)(d)] will then be required to define the rate, extent, and concentration of hazardous waste or hazardous waste constituents that have entered the groundwater from a facility suspected of or known to be leaking.

Interim status facilities must file a Part B operating perınit application or postclosure permit application to the regulatory authority. At the time of issuance of the permit, a facility shifts from an interim status monitoring program to the appropriate permit monitoring program required in the facility permit, as illustrated in Fig. 5.4. Where no groundwater contamination has been found, detection monitoring will continue with minor modifications [40 CFR 264.98 and TN 1200-1-11.06(b)(i)]. Sites with groundwater contamination will begin either compliance monitoring or corrective action

\section{5-8 Groundwater}




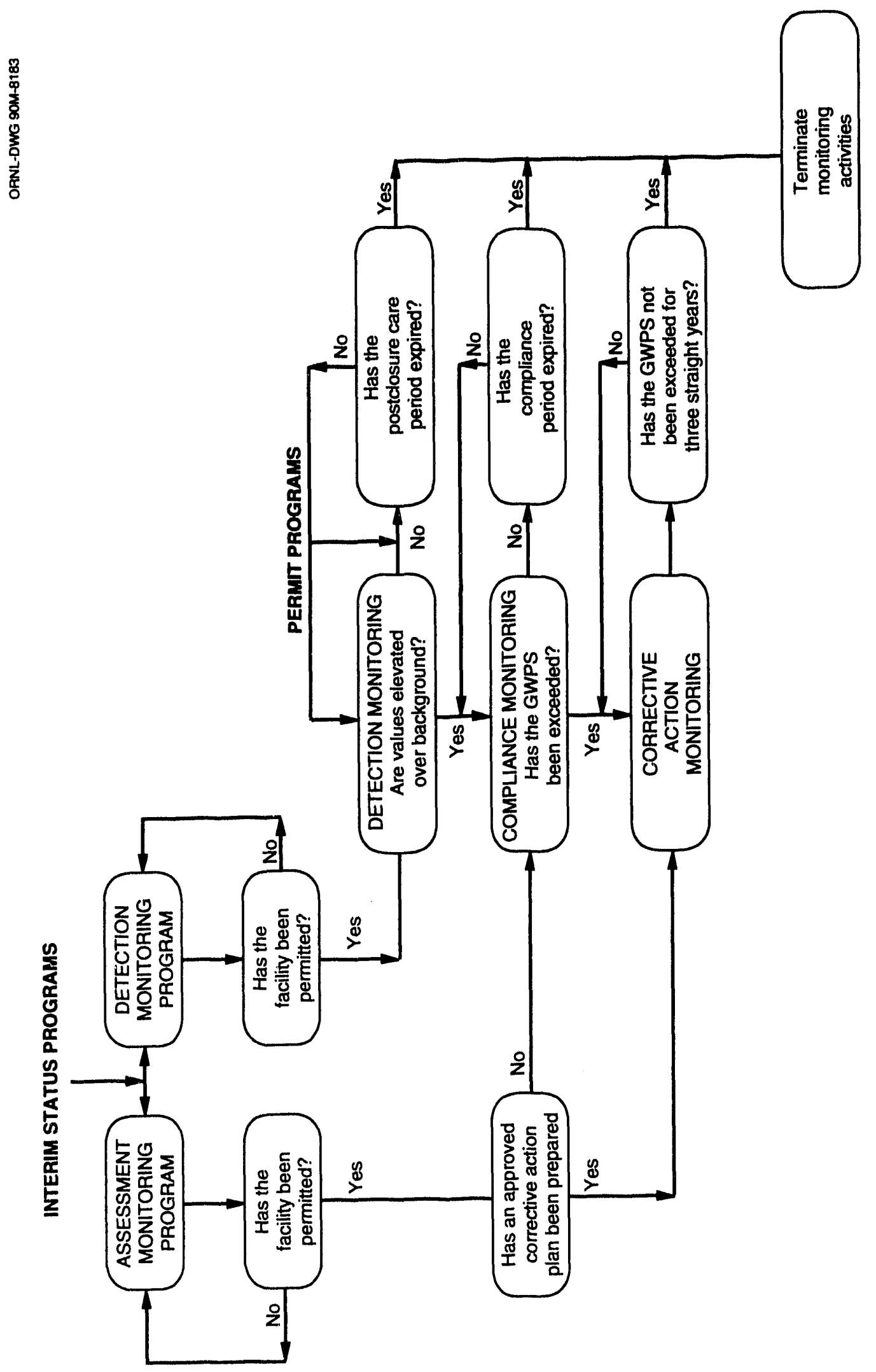

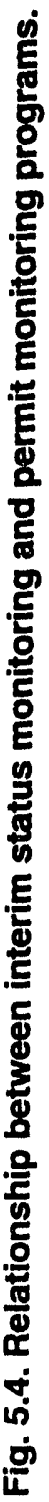




\section{Environmental Report Vol. 1, Oak Ridge}

monitoring depending on whether an approved corrective action plan is ready to be implemented.

\subsubsection{RCRA 3004(u) Monitoring Program}

Section 3004(u) was added to RCRA as an amendment in 1984 to require corrective action for all releases of hazardous constituents from any solid waste management unit at any facility seeking a permit. The 3004(u) program requires that sites be characterized to determine whether a threat to human health and/or the environment exists. Should a review of available data indicate a potential for contamination, groundwater monitoring would be necessary to evaluate that medium as an exposure pathway and for design of corrective measures.

The regulatory status and pertinent data regarding the current groundwater monitoring program being conducted at each hazardous waste unit are summarized for the Y-12 Plant, ORNL, and the K-25 Site in later sections of this report.

\subsubsection{Groundwater Surveillance Monitoring Program on the ORR}

The technical objectives of groundwater monitoring under either the detection or assessment monitoring programs are similar in nature:

- collect piezometric head (water level) measurements to support estimates of the rate and direction of groundwater flow;

- obtain representative water samples from the geologic strata;

- determine the reference water chemistry of each hydrogeologic unit from analysis of samples collected upgradient of waste disposal areas;

- evaluate the current impact of waste disposal activities on the groundwater through a comparison of analyses from samples collected upgradient and downgradient of the disposal area or through changes in values at a given location over time (Table 5.1, Vol. 2);

- identify the hazardous waste or hazardous waste constituent(s) present should contamination be detected; and
- delineate the extent of contamination and the rate of migration.

The groundwater surveillance monitoring program being implemented at the DOE facilities has been designed to obtain full compliance with regulatory requirements and the aforementioned technical objectives. Site-specific regulatory monitoring programs are supported technically by site characterization and regional studies of the geohydrologic and chemical aspects of the flow system. Quality control procedures for every aspect of data collection and analysis have been established, and data bases are used to organize and distribute analytical results.

Thus, the grouridwater surveillance monitoring program for the ORR, while disposal site- and facility-specific, contains a number of common components that are interrelated and coordinated to allow both time- and cost-effective project management.

\subsection{Groundwater Monitoring at the Y-12 Plant}

The Y-12 Plant Comprehensive Groundwater-Monitoring Plan (Geraghty and Miller 1990) has been developed and is being implemented. This plan represents a more coherent and comprehensive approach than the previous monitoring strategy and responds to the following recent changes in site definition and regulation:

- in 1992, the negotiation of a federal facility agreement for the Oak Ridge Reservation was completed,

- the reservation has been placed on the National Priorities List,

- The Exit-Pathway Monitoring Program is now part of the overall groundwater monitoring program,

- CERCLA has replaced RCRA as the lead regulatory requirement, and

- RCRA is now considered to be an "applicable or relevant and appropriate requirement."

The comprehensive plan takes into account the natural systems (hydrology, topography, and geology) that control the rate of contaminant

\section{5-10 Groundwater}




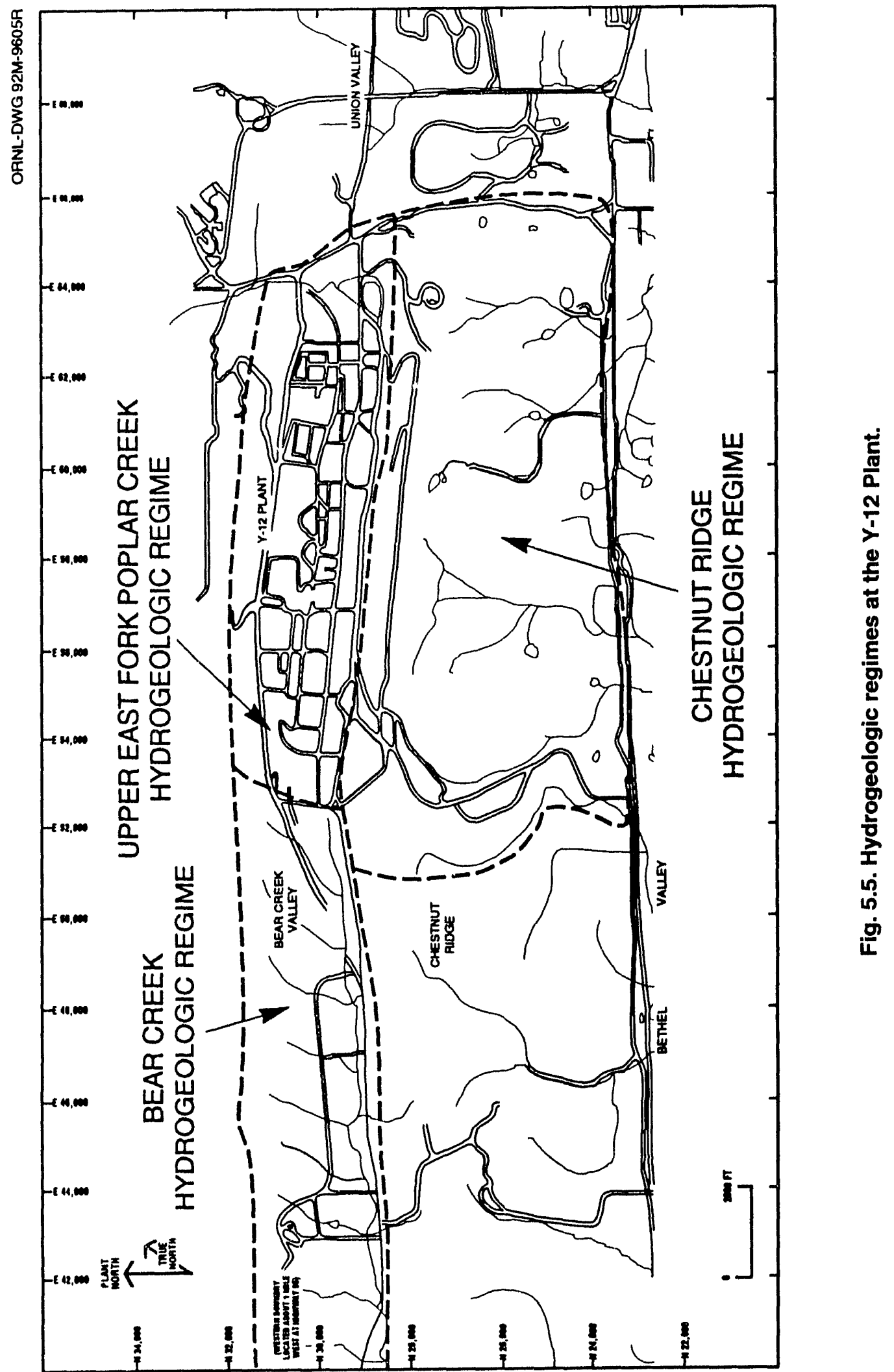




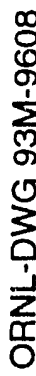

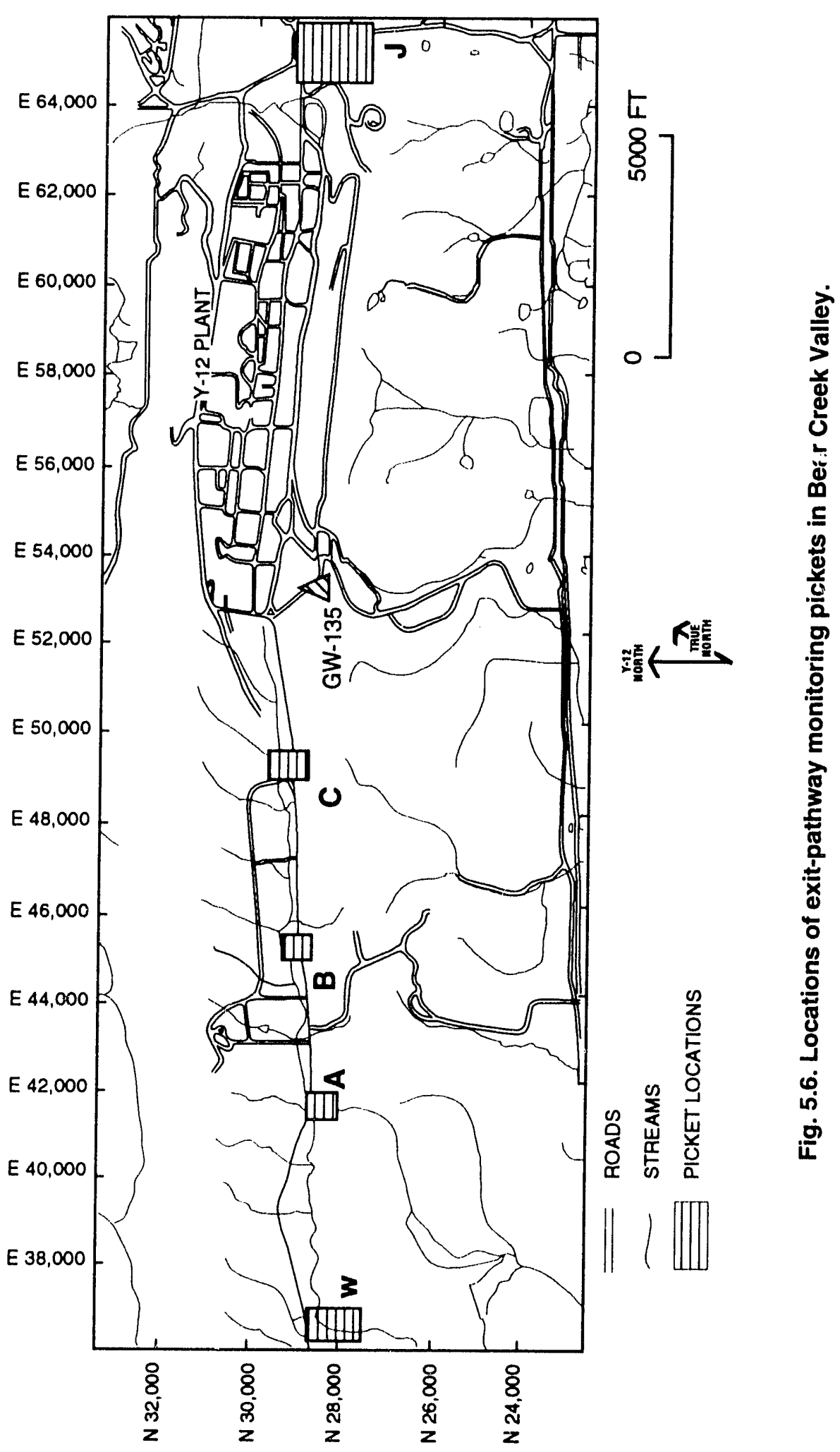


Table 5.1. Description of surface-water and spring monitoring stations included in the Exit-Pathway Monitoring Program

\begin{tabular}{ll}
\hline \multicolumn{1}{c}{ Monitoring station } & \multicolumn{1}{c}{ Description } \\
\hline NT 13 (Background) & $\begin{array}{l}\text { Tributary that enters Bear Creek at BCK } 6.76 \\
\text { and represents drainage from a relatively undisturbed } \\
\text { catchment that has not been impacted by waste-disposal } \\
\text { activities in Bear Creek Valley. }\end{array}$ \\
BCK 0.63 & $\begin{array}{l}\text { Upstream of the confluence with East Fork Poplar Creek. } \\
\text { Represents essentially all surface-water discharge from } \\
\text { the Bear Creek watershed. }\end{array}$ \\
BCK 4.55 & $\begin{array}{l}\text { Location of NPDES monitoring site 304. Site represents } \\
\text { surface-water discharge from at least one area of the } \\
\text { Bear Creek floodplain known to be contaminated with uranium } \\
\text { and PCBs. }\end{array}$
\end{tabular}

BCK $9.40 \quad$ Represents surface-water discharge from area of Bear Creek watershed impacted by waste-disposal activities.

BCK 11.97

Represents surface-water discharge from area of S-3 Site, Rust Spoil Area, and Spoil Area I. Includes discharge from Tributary NT-1 and Spring SS-1, which probably receives groundwater inputs from S-3 Site contamination.

SS-1 Located on south side of Bear Creek at the confluence with NT-1, near headwaters of Bear Creek

SS-4

Discharges on southside of Bear Creek Road at contact between the Knox Group and the Maynardville Limestone. Location is about $500 \mathrm{ft}$ west of exit-pathway Picket B.

SS-5 Large spring located on south side of Bear Creek Road near contact between the Knox Group and the Maynardville Limestone. Location is coincident with exit-pathway Picket A.

SS-6 Discharges on north side of Bear Creck Road; location is within the Maynardville Limestone about $500 \mathrm{ft}$ west of exit-pathway Picket $W$.

SS-8

Large spring located at junction of Bear Creek Road and TN 95 near Station BCK 4.55, within the Maynardville Limestone. Westernmost spring monitored under the exitpathway program.

the Nolichucky Formation near the S-3 site, but do show convergent flow to the Maynardville Limestone. This observation is consistent with the hypothesis that the Maynardville Limestone is a hydraulic drain for Bear Creek Valley. Within the Maynardville, flow directions have not been definitively determined, but flow is apparently horizontal with a local downward component. Flow along-valley is to the east from the $S-3$ ponds area to Scarboro Road.
Groundwater samples obtained from GW-134 contain elevated nitrate concentrations in comparison to known background levels observed elsewhere in Bear Creek Valley. The downdip migration of contaminated water from the $\mathrm{S}-3$ ponds is hypothesized to be responsible for the nitrate contamination. Infiltration of dense acidic wastewater through the unlined base of the ponds resulted in immediate reactions (primarily with calcite) in limestone intervals within the Nolichucky Formation. It is further hypothesized that the very reactive, dense

\section{5-14 Groundwater}


1992 Environmental Report Vol. 1, Oak Ridge

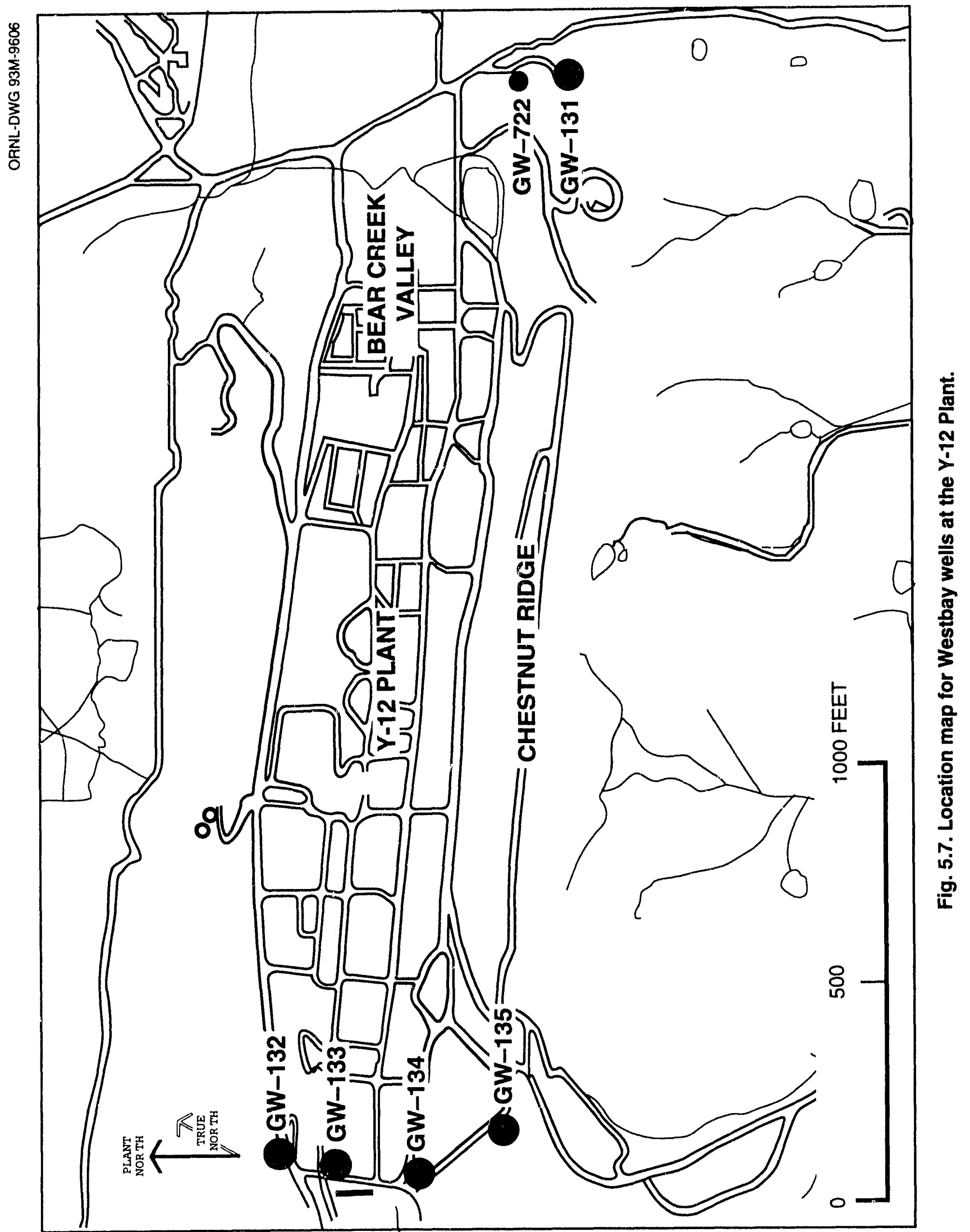




\section{Environmental Report Vol. 1, Oak Ridge}

wastewater was able to preferentially and aggressively attack calcite vein fillings and limestone beds and to proceed to migrate down the structural dip. The presence of an additional volume of water in the groundwater system (the wastewater) locally elevates the fluid pressure, and the increased pressures are expected to dissipate very slowly, apparently on the order of years. This process could explain the presence of the anomalous pressure bulge observed in GW-134. Because the source of the elevated fluid pressure no longer exists, the flow system is expected ultimately to return to a static pre-S-3 ponds configuration.

The Westbay monitoring technology is also being used by the Y-12 Plant ER Program to characterize dense, nonaqueous-phase liquids (DNAPLs) in the vicinity of the Bear Creek Burial Grounds. In January 1990, accumulations of DNAPLs were discovered at depths of about $83.5 \mathrm{~m}$ ( $274 \mathrm{ft}$ ) below ground surface along the southern border of Burial Ground A-South within the Bear Creek Burial Grounds Hazardous Waste Disposal Unit at the Y-12 Plant. A preliminary investigation was initiated to obtain information on the mode of occurrence and distribution of the DNAPLs and to determine its behavior in fractured rock such as that underlying the Bear Creek Burial Grounds.

The primary constituent found in DNAPL samples recovered from the discovery monitoring wells in the burial grounds area is perchloroethylene (PCE), with lesser amounts of trichloroethylene (TCE) and other chlorinated solvents.

Movement of DNAPLs in fractured rocks is complex and difficult, if not impossible, to quantify with certainty. Depending on the fracture patterns within a rock mass, the pathways of downward movement of DNAPLs may be direct or indirect. At the Bear Creek Burial Grounds site, the pathways are likely indirect. Because of the complex geology of the area and uncertainty as to the quantities and location(s) of DNAPL release(s), the pathways of DNAPL migration and the present subsurface configuration of DNAPL accumulations cannot be determined.

Given the history of the Bear Creek Grounds, where DNAPLs were disposed of a number of years ago, DNAPL migration is not likely to be occurring at present. The situation is expected to remain static as long as the hydrogeological system in the immediate vicinity of the DNAPL occurrences is not hydraulically disturbed. In recognition of this constraint, ongoing characterization activities are following a conservative strategy designed to define the outer extent of the dissolved plume. The Westbay technology has been used for this purpose by installing five new wells downdip and down gradient of the area of known DNAPL contamination. As of March 1992, three wells had been installed, and drilling activities had been completed on the remaining two wells. Only preliminary pressure and hydraulic conductivity data have been collected to date on the three completed wells.

Since 1989, groundwater-monitoring reports have been issued for each of the three regimes. The list of analytes in Table 5.2, prepared from data collected from 1987 to 1990 , establishes a standardized suite of analytical parameters for all samples collected at the Y-12 Plant. The list contains the groundwater constituents detected at concentrations above background levels or in excess of applicable water quality standards. Additional uranium isotopic data and radiochemical measurements were taken at selected sites to further define background water quality and to confirm previous results.

In CY 1992, 64 new groundwater monitoring wells were installed. Table 5.3 lists the regimes and number of monitoring wells installed. The monitoring objectives for the wells are divided into three categories: Category I wells installed to obtain additional data to delineate the extent of groundwater contamination: Category II sites, wells, which monitor potential exit pathways for groundwater contamination; and Category III wells, installed as new or replacement monitoring wells for compliance monitoring purposes at specific regulated units.

Groundwater quality at the Y-12 Plant has been affected by four types of contaminants: nitrate, volatile organic compounds, metals, and radionuclides. Of these, nitrate and volatile organic compounds are the most common, although data obtained since 1988 suggest that the extent of some radionuclides may also be significant. Trace metals, the least extensive groundwater contaminants, generally occur in a small area of low $\mathrm{pH}$ groundwater at the west end of the plant in the vicinity of the $\mathrm{S}-3$ Site.

Additional monitoring wells installed in 1992 continue to better define groundwater quality at the

\section{5-16 Groundwater}


1992 Environmental Report Vol. 1, Oak Ridge

Table 5.2. Summary of the groundwater surveillance program at the Y-12 Plant, 1992

\begin{tabular}{ccc}
$\begin{array}{c}\text { Hydrogeologic regime/waste } \\
\text { disposal site }\end{array}$ & $\begin{array}{c}\text { Number of } \\
\text { wells }\end{array}$ & Analytical parameters $^{a}$ \\
\hline
\end{tabular}

Bear Creek Hydrogeologic Regime

Background

Bear Creek Springs

Bear Creek Surface Water

Exit Pathway-Traverse A

Exit Pathway-Traverse B

Exit Pathway-Traverse C

Exit Pathway-Traverse W

Lysimeter Demo

Oil Landfarm

Rust Spoil Area

S-3 Ponds

Spoil Area I

Y-12 Burial Grounds

Background

Beta-4 Security Pit

Exit Pathway-Traverse J

Grid E-1

Grid G-1

Grid G-2

Grid J-1

Grid J-2

Grid J-3

Grid K-1

Grid K-2

Grid K-3

J-Primary

New Hope Pond

Rust Garage Area

S-2 Site

S-3 Ponds

U. S. Geological Survey Sites

Undergrd. Storage Tank Pgm.

Waste Coolant Facilities

Ash Disposal Basin

Chestnut Ridge Security Pits

East Chestnut Ridge Waste Pile

Kerr Hollow Quarry
34

14

5

5

3

6

8

2

24

2

8

6

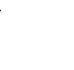

\section{East Fork Poplar Creek Hydrogeologic Regime \\ East Fork Poplar Creek Hydrogeologic Regime}


Table 5.2 (continued)

\begin{tabular}{|c|c|c|}
\hline $\begin{array}{l}\text { Hydrogeologic regime/waste } \\
\text { disposal site }\end{array}$ & $\begin{array}{l}\text { Number of } \\
\text { wells }\end{array}$ & Analytical parameters ${ }^{a}$ \\
\hline Landfill Il & 3 & $\begin{array}{l}\text { Standard }+\mathrm{AOC}+\mathrm{TOX}+\mathrm{TOC}+ \\
\mathrm{COD}+\mathrm{CY}\end{array}$ \\
\hline Landfill II Expansion (Landfill VI) & 7 & $\begin{array}{l}\text { Standard }+\mathrm{AOC}+\mathrm{TOX}+\mathrm{TOC}+ \\
\mathrm{COD}+\mathrm{CY}\end{array}$ \\
\hline Landfill III (Chestnut Ridge Borrow Area Waste Pile) & 7 & $\begin{array}{l}\text { Standard + AOC }+ \text { TOX }+ \text { TOC }+ \\
\text { COD }+C Y\end{array}$ \\
\hline Landfill IV & 5 & $\begin{array}{l}\text { Standard }+\mathrm{AOC}+\mathrm{TOX}+\mathrm{TOC}+ \\
\mathrm{COD}+\mathrm{CY}\end{array}$ \\
\hline Rogers Quarry & 4 & Standard + BNA \\
\hline Sediment Disposal Basin & 8 & $\begin{array}{l}\text { Standard + BNA + TOC }+ \text { TOX }+ \\
\text { CON }+ \\
\mathrm{PH}+\mathrm{PHE}\end{array}$ \\
\hline United Nuclear Site & 6 & Standard $+{ }^{234} U,{ }^{235} U,{ }^{238} U$ \\
\hline
\end{tabular}

"Standard AAS metals: $\mathrm{Cd}, \mathrm{Cr}, \mathrm{Pb}, \mathrm{ICP}$ metals scan, CVAA, $\mathrm{Hg}$, fluorometric U, lab specific conductance, lab pH, total suspended solids, total dissolved solids, turbidity; major anions: carbonate and bicarbonate alkalinities, fluoride, chloride, nitrate, sulfate, gross alpha and beta activity, volatile organic compounds; field mmmts.: specific conductance, temperature, dissolved oxygen, redox, water level, AOC additional organic compounds: acrolein, acrylonitrile, ethanol, ethyl methacrylate, iodomethane, 2-chloroethyl vinyl ether, dibromomethane, trichlorofluoromethane, 1,4-dichloro-2-butene, 1,2,3-trichloropropane, dichlorodifluoromethane, BNA semi-volatile organic compounds; COD chemical oxygen demand; CON specific conductance replicates; $\mathrm{CY}$ cyanide; $\mathrm{PH}$ pH replicates; $\mathrm{PHE}$ phenol; TOC total organic carbon; TOX total organic halide; TPH total petroleum hydrocarbons.

\section{Table 5.3. Y-12 Plant monitoring wells installed in 1992}

\begin{tabular}{lccc}
\hline $\begin{array}{l}\text { Monitoring } \\
\text { objective }\end{array}$ & $\begin{array}{c}\text { Bear Creek } \\
\text { regime }\end{array}$ & $\begin{array}{c}\text { East Fork } \\
\text { regime }\end{array}$ & $\begin{array}{c}\text { Chestnut Ridge } \\
\text { regime }\end{array}$ \\
\hline Category I & 0 & 47 & 0 \\
Category II & 8 & 3 & 0 \\
Category III & 3 & 0 & 3 \\
\hline
\end{tabular}

"Includes above-grade storage facility in the Bear Creek regime and the Chestnut Ridge Security Pits ( 2 wells), and Sanitary Landfill II (I well) in the Chestnut Ridge regime.

Y-12 Plant. In the Bear Creek regime, horizontal plume boundaries are defined in the bedrock formations that lie directly beneath waste disposal units. Additional data have been acquired regarding the vertical extent of these plumes. In the East Fork regime, plume boundaries in both horizontal and vertical directions have not been completely defined; however, a grid-based monitoring well network has recently been completed and will provide new data. The security pits is the only known source of groundwater contamination in the Chestnut Ridge regime. Horizontal plume boundaries at the security pits are generally defined, although the vertical extent of contamination has yet to be established.
More than 200 contaminated units have been identified at the Y-12 Plant site resulting from past waste management practices. Many of these sites have been grouped into operable units (OUs) based on priority and common assessment and CERCLA-driven remediation requirements. Eleven OUs constitute 31 units within the plant area and its surrounding environs. Each of the Bear Creek and East Fork regimes are associated with an integrated surface water and groundwater $O U$. The remaining nine OUs are source control OUs within the Bear Creek, Upper East Fork Poplar Creek, and Chestnut Ridge hydrologic regimes. Groundwater contamination in the Chestnut Ridge Hydrologic regime is associated with each source OU (Fig. 5.8).

The remaining units have been grouped into the Y-12 Study Area and constitute lower priority units that will be investigated under CERCLA as Preliminary Assessments/Site Investigations (PA/SIs). New OUs or additions to existing OUs will be made if the degree of contamination determined by the PA/SI warrants further conduct of a remedial investigation/feasibility study.

Two OUs have been defined for groundwater and surface water contained within the Bear Creek and

\section{5-18 Groundwater}




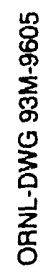

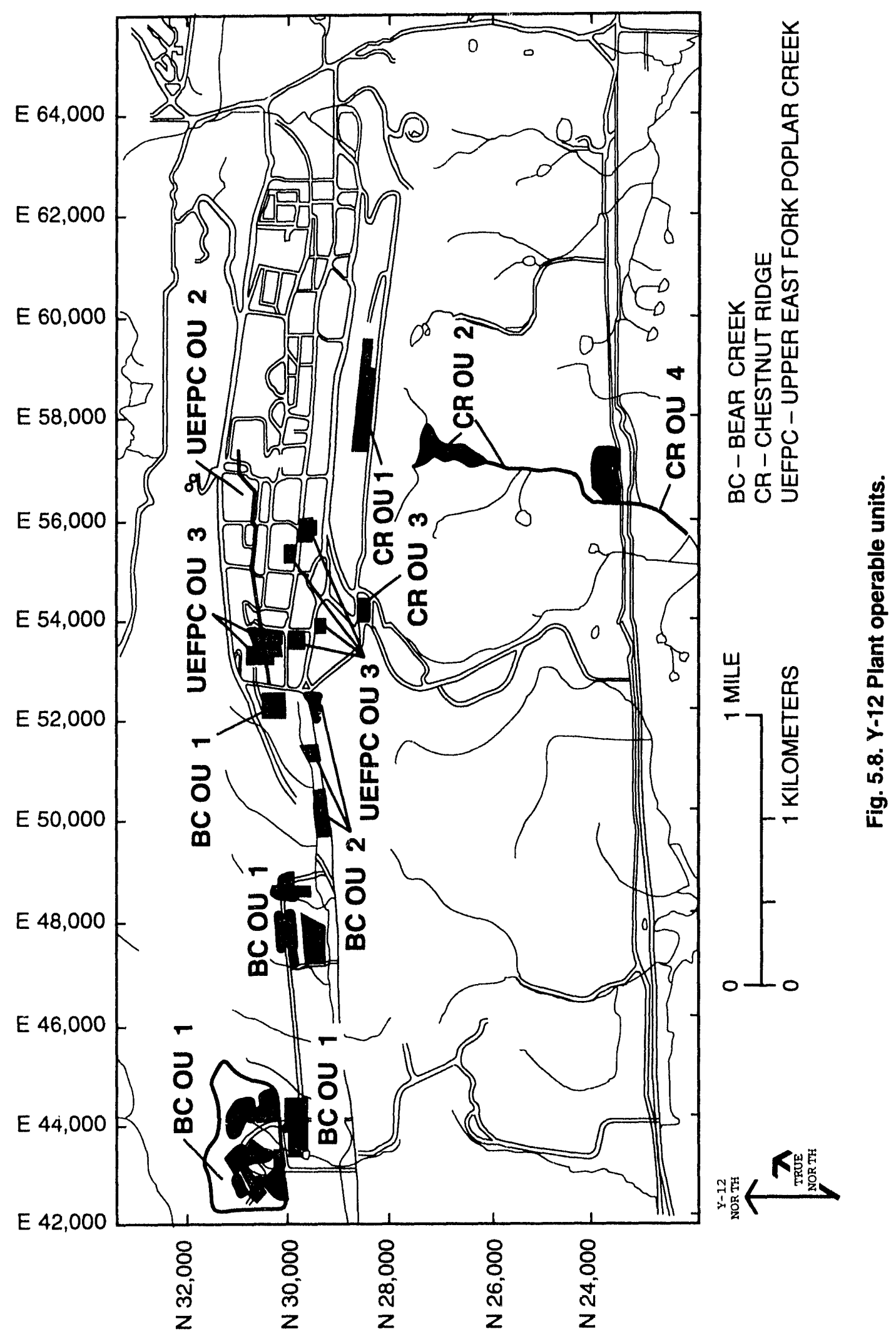




\section{Environmental Report Vol. 1, Oak Ridge}

East Fork regimes. Groundwater will be investigated separately because of the overlapping nature of source plumes and because of the observation that most plumes share a common hydrologic unit for off-site transport. Also, many releases to groundwater are historical, and the resulting plumes are no longer likely to be associated with the original source. As the groundwater plumes are defined, they will be associated with sources to the extent practical.

The following sections contain (1) descriptions operable units and waste sites on each of the three $Y-12$ hydrogeologic regimes and (2) summaries of the groundwater-monitoring results for each regime.

Tables 5.2-5.45 presented in Vol. 2 contain analytical summaries for all monitoring wells included within the comprehensive monitoring plan. The tables show all analytical parameters that exceeded detection limits in CY 1992. Analytical data from multiport-instrumented coreholes are currently maintained in a separate data base and are not presented in the summary tables. These data may be found in Dreier et al. (1993) pending incorporation into the groundwater monitoring program historical data base.

\subsubsection{Upper East Fork Poplar Creek Hydrogeologic Regime}

The East Fork regime encompasses the $Y-12$ Plant complex, extending west from New Hope Pond. It is separated from the Bear Creek regime by a topographic and hydrologic border located near the west end of the plant. The waste management sites and petroleum fuel underground storage tanks in the East Fork regime that are addressed in this document are shown on Fig. 5.9.

\subsubsection{Waste Sites and Storage Tanks}

\subsection{Upper East Fork Poplar Creek Operable Unit 1}

Upper Last Fork Poplar Creck OU 1 consists of both surface water and ground water components of the hydrogeologic system within the East Fork regime. Numerous sources of contamination to both the surface water and groundwater flow systems exist within the plant area. Infiltration from the S- 3 Ponds Waste Management Area dominates groundwater contamination in the western portion of the hydrologic regime. In addition to potential surface water and groundwater contamination sources identified in Upper East Fork Poplar Creek OUs 1, 2 , and 3 , most of the potentially contaminated units making up the Y-12 Study Area are within the East Fork regime. Potential surface water contamination associated with the storm sewer system and East fork mercury use areas is of primary interest and will be addressed in this OU.

The storm sewer system consists of an extensive array of storm drains that gather runoff from the main plant area in catch basins located across the plant. In addition, this drainage system, which was once connected to process equipment, discharged untreated waste streams. The storm sewer network contains several miles of drainage pipes and culverts that range up to 72-in. diam. Upper East Fork Poplar Creek begins near the middle of the Y-12 Plant and is fed primarily from storm sewer system discharges. Surface-water runoff from the $Y-12$ production areas and groundwater seepage are additional sources of Upper East Fork Poplar Creek flow.

From 1955 through 1963, a column-exchange process involving large quantities of mercury was employed to separate lithium isotopes. The mercury use areas include building and other facilities that have been designated as possible sources of mercury contamination because of known, suspected, or presumed releases. The area of investigation includes drainages associated with the following buildings and adjoining areas: 9201-2, 9201-5, 9204-4, 9292,

9733-1, 9733-2, and mercury flask storage areas and deflasking facilities.

Surface water and groundwater within the East Fork regime will be characterized and treated as an integrator OU distinct from source-term OUs contributing contamination. This approach is warranted because (1) efforts to establish the horizontal and vertical extent of groundwater contaminant plumes from individual sites indicate that the plumes are significantly intermingled, making assessment and potential remedial actions of individual plumes impractical, and (2) the units share a common exit pathway from the hydrologic system that is best addressed by a comprehensive approach. Where site-specific groundwater or surface water data are needed to better identify the source or to support a screening-level risk assessment,

\section{5-20 Groundwater}




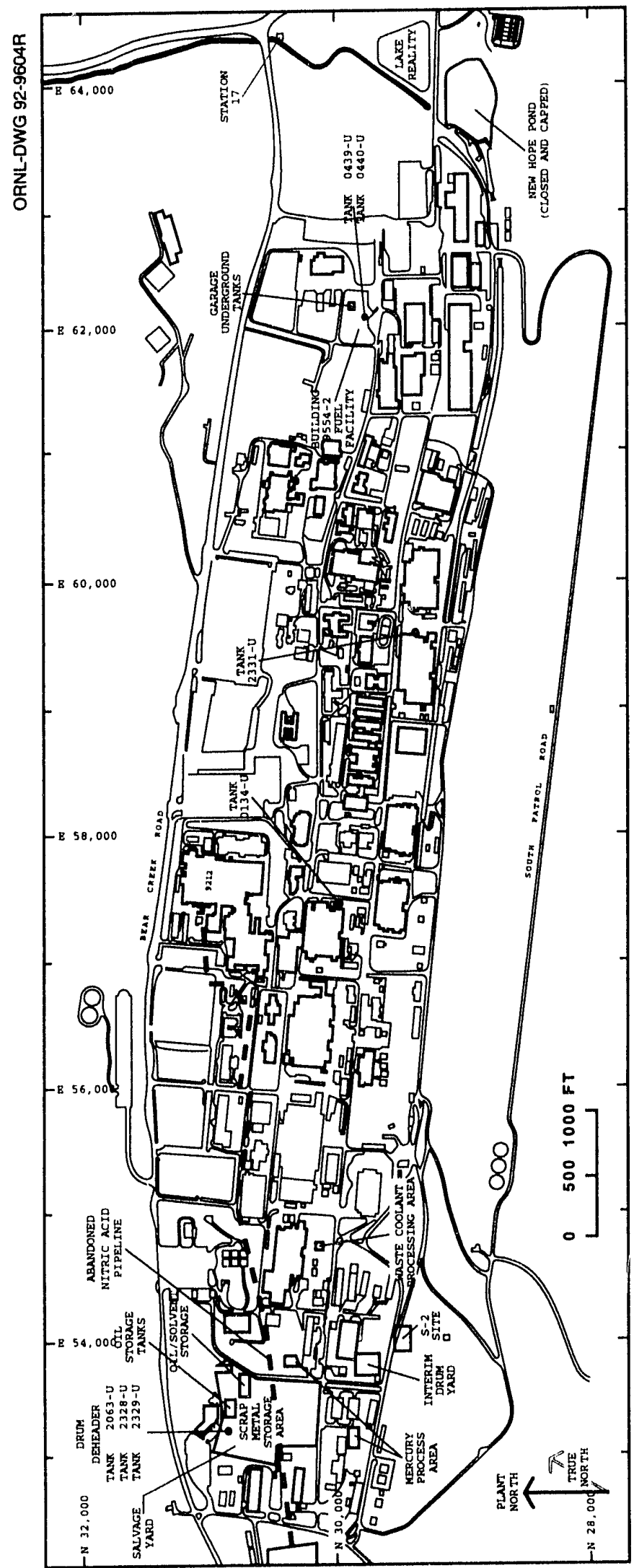

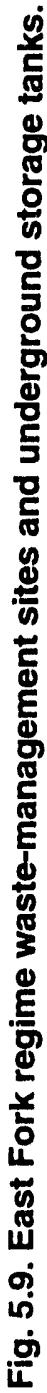


groundwater or surface water assessment activities (e.g., piezometers or well points) may be conducted during the remedial investigation/feasibility study process for the source control OUs.

\subsection{Upper East Fork Poplar Creek Operable Unit 2}

Upper East Fork Poplar Creek OU 2 is the abandoned Nitric Acid Pipeline, which was used between 1951 and 1983 to transport a waste stream made up of nitric acid and depleted uranium from Building 9215 to the S-3 Ponds for disposal. Numerous leaks have been determined, with the earliest in 1951 at a weld about $350 \mathrm{ft}$ east of the discharge point.

The primary exposure pathways associated with the Nitric Acid Pipeline are soil contamination resulting from absorptions from leaked solutions, groundwater contamination resulting from waste solutions infiltrating to the ground water table, and surface-water contamination resulting from groundwater seeps. Nitrate and uranium are the primary contaminants of concern. A small section of the pipeline lies within the Bear Creek Regime.

\subsection{Upper East Fork Poplar Creek Operable Unit 3}

Upper East Fork Poplar Creek OU 3 consists of the S-2 Site; the area around Building 81-10; the Coal Pile Trench; the Salvage Yard Oil and Oil/Solvent Storage Areas, Scrap Metal Storage Area, and Drum Deheader; and the Machine Coolant Storage Tanks and Waste Coolant Processing Facility.

\section{Waste Coolant Processing Area}

The Waste Coolant Processing Area is used to treat waste coolants collected from various shops within the plant complex. A biodegradation facility and the treatment basin/effluent drain field within the area were closed in accordance with a RCRA closure plan (Stone and McMahon 1988). The Tennessee Department of Environment and Conservation (TDEC) certified final closure of the biodegradation facility in 1988.

\section{The S-2 Site}

The S-2 Site was an unlined earthen reservoir used from 1945 to 1951 for percolation, evaporation, or neutralization of an unknown quantity of liquid wastes. Waste materials reportedly included nitrates of copper, nickel, and chromium; diethyl ether and pentaethers; nitric, hydrochloric, and sulfuric acids; sulfates; dibutyl carbinol and tributyl phosphates; aluminum nitrate; hydrogen fluoride; cadmium; natural and enriched uranium; and cyanide compounds (Kimbrough 1986). The site was closed in 1951, the remaining liquids were neutralized, and the reservoir was filled with soil and seeded with grass (Haase 1987).

\section{Salvage Yard Scrap Metal Storage Area}

The Salvage Yard Scrap Metal Storage Area has been used from 1950 to the present for the storage of scrap metal, some of which contains low levels of depleted or enriched uranium. Some minor contamination of surficial soils at the site has been reported (Welch et al. 1987).

\section{Oil/Solvent Drum Storage Area}

Before being closed, the Salvage Yard Oil/Solvent Drum Storage Area consisted of two storage areas: the east drum storage area and the west Jrum storage area. Each area was closed as described in respective RCRA closure plans (Welch 1986, Lind and Welch 1989, Welch 1989). Waste oils containing chlorinated organics, uranium and/or beryllium, chlorinated organic solvents, and nonchlorinated flammable solvents were stored in drums on site, and leaking drums and spills have been documented ( $V^{\prime}$ elch et al. 1987).

\section{Oil Storage Tanks}

Operation of the Salvage Yard Oil Storage tanks began in 1978 when a 6,000-gal tank was installed to store oil contaminated with polychlorinated biphenyls (PCBs). A 5,000-gal tank was added to the site in 1980. Both tanks were surrounded by an earthen dike and were emptied in 1986 (Welch 1986). Spills and leaks have occurred but were contained within the diked area (Welch et al. 1987).

\section{5-22 Groundwater}




\section{Environmental Report Vol. 1, Oak Ridge}

\section{Drum Deheader}

The Salvage Yard Drum Deheader, operaied from 1959 to 1989 was used to cut off the tops and to crush empty drums collected from various locations throughout the Y-12 Plant. Three tanks (2063-U, 2328-U, and 2329-U) at this site had the potential to contaminate groundwater. They all exceeded the maximum allowable leak rate established under the TDEC regulations and were excavated. Soil near the tanks contained elevated concentrations of cadmium, lead, and mercury and detectable levels of volatile organics and PCBs (Stone 1989a).

\section{Building 81-10}

Building 81-10 was not monitored during 1992 . It is being managed as part of the Environmental Restoration Program.

\section{Coal Pile Trench}

The Coal Pile Trench is a 50,000- $\mathrm{ft}^{2}$ earthen trench located beneath a coal pile west of the Y-12 Steam Plant. The trench was used to dispose of uranium and depleted uranium alloys, molybdenum, thiourea, carbon support forms, and other nonuranium materials. Because of the presence of the coal pile, there is no access to the soil overlying the trench. The primary concern at this time is groundwater contamination from trench leachate, which will be addressed in Upper East Fork Poplar Creek OU 1.

\section{Interim Drum Yard}

The Interim Drum Yard is currently a graveled, covered, and diked outdoor storage area previously used to store drums containing various hazardous, mixed, and nonhazardous wastes, including sludge containing chromium, mercury-contaminated wastes, chlorinated and nonchlorinated organics, and plating solutions. Materials contaminated with PCBs are not currently stored at the site but have been in the past. A small portion of the site has been closed in accordance with a TDEC-approved RCRA closure plan (Willoughby et al. 1988). Waste has been removed from the remaining portion, and the yard has been scheduled for closure by the Environmental Restoration organization.

\subsection{Other: Sites}

\section{New Hope Pond}

New Hope Pond was constructed in 1963 to regulate the quality and flow of water in Upper East Fork Poplar Creek before the water exited the grounds of the Y-12 Plant. Operation of New Hope Pond ceased in 1988, and final closure was certified by TDEC in 1990 . Sediment in New Hope Pond contained PCBs, mercury, and uranium but did not exhibit the characteristics of a hazardous waste (Kimbrough and McMahon 1988a, Kimbrongh and McMahon 1988b, Saunders 1983). Lake Reality, which replaced New Hope Pond, began operation in 1988. Water from Upper East Fork Poplar Creek enters Lake Reality from an extension of the New Hope Pond inlet diversion ditch and exits through a weir in the west berm.

\section{Beta-4 Security Pits}

The Beta-4 Security Pits site was used from 1968 to 1972 for classified disposal of uranium and uranium alloys, scrap metal containing depleted and enriched uranium, organic compounds, acids, and miscellaneous debris (Welch et al. 1987).

\section{Underground Storage Tanks}

Several petroleum fuel underground storage tanks are located within the East Fork regime. Investigations to assess product releases from these tanks are performed in accordance with the rules of TDEC (TDEC Divisiun of Underground Storage Tanks). Descriptions of the underground storage tanks are provided in the following sections.

\section{Rust Garage Area}

The Rust Garage, originally used as a vehicle and equipment maintenance shop, is currently used as a paint shop. Four petroleum fuel underground storage tanks were located at the site: 1222-U, 2082-U, 1219-U, and 2068-U. All four tanks at the site were excavated in 1989. Industrial products used on site include lubricating oil, gasoline, diesel fuel, hydraulic fluid, antifreeze, battery acid, and mineral spirits.

A bulk-oil storage platform and an elevated gasoline tank are located south of the garage, and a 
wash pad is located on the east side of the building. Gasoline and diesel fuel releases associated with operation of the underground storage tanks have been reported. Because of their proximity and similar operational history, product releases have been evaluated under a single investigation for the site, which started in 1987. Free product has been recovered from one piezometer at the site (Geraghty and Miller, Inc. 1988a).

Monitoring wells were installed at the site in 1990 as part of a underground storage tank site investigation (Eaton and Van Ryn 1991). A corrective action plan was submitted to TDEC in May 1992; TDEC approval is pending. Groundwater remediation at Rust Garage potentially may be conducted with the CERCLA remediail strategy envisioned for the pervasive $S-3$ ponds plume.

\section{Garage Underground Tanks}

The Garage Underground Tanks (one diesel and one leaded gasoline) went into service in 1944 at the site of the old Building 9754 Fuel Facility; an unleaded-gasoline tank was added in 1975. They were converted to store liquid waste oil in 1978. These tanks were removed in 1989 , and the site is undergoing RCRA closure. The smaller dispenser tanks that were gravity fed by the liquid bulk storage tanks will be closed in conjunction with the corrective actions undertaken at the Building 9754-2 Fuel Facility (Stone 1989b).

Tank 2331-U. Tank 2331-U was a 560-gal steel tank installed in 1973 to store gasoline. In 1988, a leak test indicated that the tank was leaking; service was discontinued until its removal in the same year. A corrective action plan was submitted to TDEC in July 1992; approval is pending.

Tank 0134-U. A steel tank used to store gasoline for emergency electrical power at Building 9204-2, Tank 0134-U was installed in the mid-1960s and was removed from service in 1982. When the tank was excavated in 1989, several holes were observed in the sides of the tank, and volatile organics were present in the local soil and groundwater. A monitoring well was installed within the tank pit to detect and recover leaked fuel. An additional well was installed in 1990 as part of an ongoing underground storage tank investigation. A corrective action plan was submitted to TDEC in August 1992; approval is pending.

\section{4/9754-2 Fuel Facilities}

The 9754-2 Fuel Facility, used from 1978 to 1989 to dispense gasoline and diesel fuel, had two underground storage tanks: (0439-U and 0440-U). A revised Correction Action Plan (CAP) was submitted to TDEC in July 1992 for the East End Fuel Station, Buildings 9754 and 9754-2. The corrective action plan contains the characterization and remedial information required by TDEC for an underground storage tank site having petroleum-contaminated soil and/or groundwater. TDEC approval of the corrective action plan is pending.

\subsubsection{Discussion of Monitoring Results}

The objectives of the 1992 groundwatermonitoring program in the East Fork regime were (1) to further define contaminant plume boundaries and (2) to expand the exit-pathway monitoring well network in the Maynardville Limestone.

\subsection{Plume Delineation}

The primary groundwater contaminants in the East Fork regime are nitrate, volatile organic compounds, trace metals, and radionuclides. Sources of nitrate, trace metals, and radionuclides are the S-2 Site, the abandoned nitric acid pipeline, and the S-3 Site. Although it is located west of the hydrologic divide that separates the East Fork regime from the Bear Creek regime, the S-3 Site has contributed to groundwater contamination in the western part of the regime. A mound in the water table created by the disposal of large volumes of liquid wastes during operation of the S-3 Site (formerly the S-3 ponds) allowed contaminants to move into areas east of the current hydrologic divide.

Sources of volatile organic compounds in the East Fork regime include the S-3 Site, several sites located within the Y-12 Salvage Yard, the Waste Coolant Processing Area, and several petroleum underground storage tanks (Fig. 5.10).

Concentrations of volatile organic compounds in the East Fork regime have remained relatively constant since 1988.

\section{5-24 Groundwater}


1992 Environmental Report Vol. 1, Oak Ridge

ORNL-DWG 93M-8679

GW-337

WASTE COOLANT PROCESSING AREA

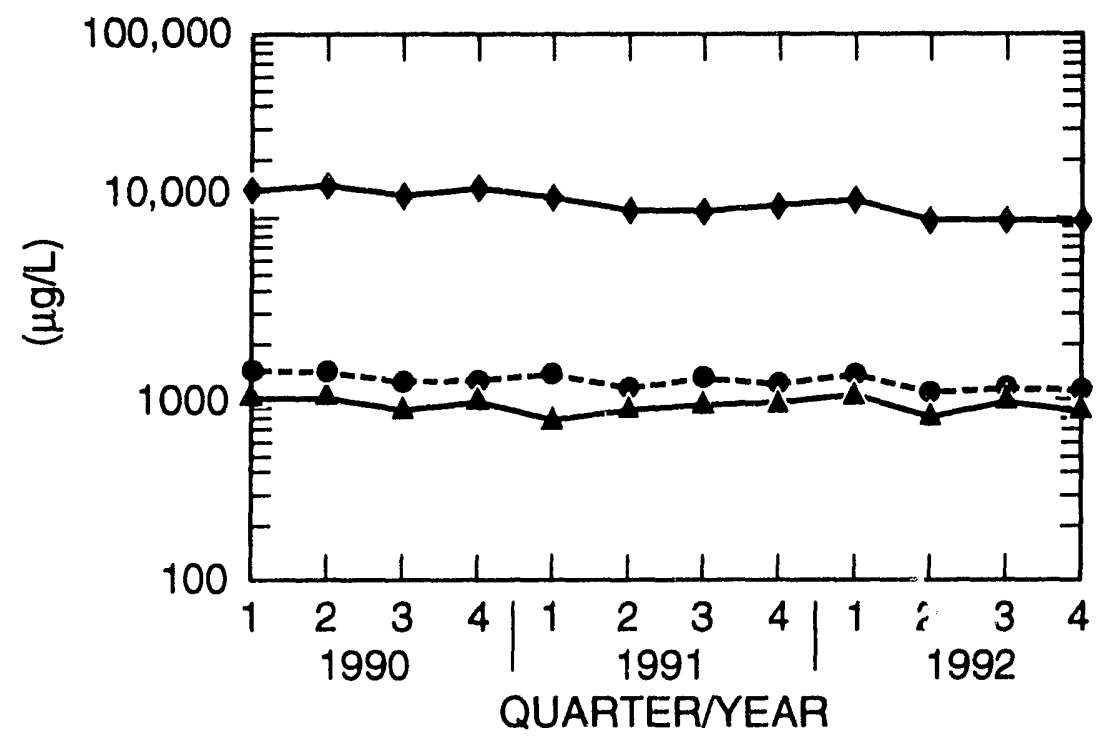

GW-383

NEW HOPE POND

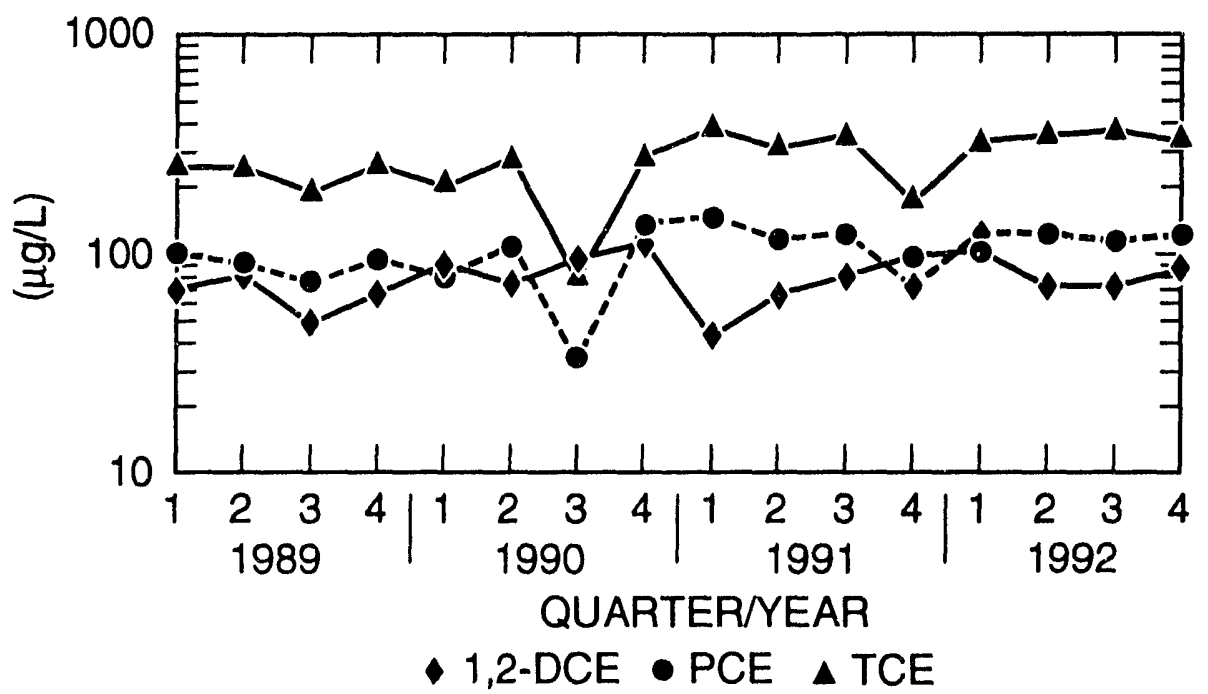

Fig. 5.10. Volatile organic compounds in groundwater in selected wells in the East Fork regime. 


\section{Environmental Report Vol. 1, Oak Ridge}

\subsection{Nitrate}

Nitrate concentrations exceeded the $10 \mathrm{mg} / \mathrm{L}$ maximum contamination level during 1992 in a large part of the western portion of the East Fork regime (Fig. 5.11). Groundwater containing nitrate concentrations as high as $10,000 \mathrm{mg} / \mathrm{L}$ occurs in the unconsolidated zone and at shallow bedrock depths just east of the S-3 Site.

The real extent of the nitrate plume is essentially defined in the unconsolidated zone and the shallow bedrock zone. In both zones, the ritrate plume extends about $2500 \mathrm{ft}$ eastward from the S-3 Site to just downgradient of the S-2 Site. Nitrate has traveled farthest in groundwater in the Maynardville Limestone.

The influence that buried stream channels and subsurface drains have on nitrate movement in the unconsolidated zone is evident. These features provide permeable conduits that promote groundwater flow and contaminant transport.

\subsection{Trace Metals}

Concentrations of barium, cadmium, chromium, lead, and mercury exceeded maximum contamination levels during 1992 in samples collected from monitoring wells at the S-2 Site, the Y-12 Salvage Yard, the Waste Coolant Processing Area, the 9754 and 9754-2 Fuel facilities, and New Hope Pond. Elevated concentrations of these metals were most commonly reported for groundwater samples collected from wells monitoring the unconsolidated zone. Groundwater at shallow bedrock depths contained elevated metals concentrations near the Y-12 Salvage Yard, the S-2 Site, and at New Hope Pond (Table 5.26, Vol. 2).

\subsection{Volatile Organic Compounds}

Because of the many source areas, volatile organic compounds are the most widespread groundwater contaminants in the East Fork regime (Fig. 5.12). Dissolved volatile organic compound plumes in the regime generally consist of two types of compounds: chlorinated solvents and petroleum hydrocarbons. The highest concentrations of dissolved chlorinated solvents (about $17 \mathrm{mg} / \mathrm{L}$ ) are found at the Waste Coolant Processing Area and the highest dissolved concentrations of petroleum hydrocarbons (about $85 \mathrm{mg} / \mathrm{L}$ ) occur in groundwater in the Y-12 Salvage Yard near the Rust Garage Area.

The 1992 monitoring results generally confirm 1990 and 1991 findings of a continuous dissolved volatile organic compounds plume in groundwater in the unconsolidated zone that extends about $4,000 \mathrm{ft}$ eastward from the S-3 Site to Tank $2331-U$. Additionally, the 1992 data confirm preliminary 1990 results and 1991 data identifying the Fire Training Facility as a volatile organic compounds source area. Isolated "pockets" of volatile organic compounds in the unconsolidated zone also are present in groundwater at the Building 9754 and 9754-2 Fuel facilities and New Hope Pond.

Results obtained during previous years suggest that New Hope Pond is not the source of volatile organic compounds in the wells at the site. Data obtained during 1992 support this observation. Groundwater sampled from exit-pathway monitoring wells installed upgradient of the site contains the same volatile organic compounds found in wells downgradient of the site. The upgradient source of these volatile organic compounds has not been established.

\subsection{Radionuclides}

As in the Bear Creek regime, the primary alpha-particle emitting radionuclides are uranium, isotopes of radium, neptunium, and americium. The primary beta-particle-emitting radionuclide is technetium

Groundwater with gross alpha activity above $15 \mathrm{pCi} / \mathrm{L}$ occurs in scattered points within the East Fork regime (Fig. 5.13). Gross alpha activity consistently above $15 \mathrm{pCi} / \mathrm{L}$ occurs only in two wells near the Salvage Yard and the S-2 Site (GW-633 and GW-251, respectively), one well (GW-204) at Tank 0134-u, and one well west of New Hope Pond (GW-605). Previous data have also suggested an area of elevated gross alpha activity west of New Hope Pond. Gross alpha activity exceeding the maximum contamination level is most extensive in groundwater in the unconsolidated zone. During 1992, in bedrock-monitoring wells, gross alpha activity exceeded $15 \mathrm{pCi} / \mathrm{L}$ only at one location, west of New Hope Pond.

Elevated gross beta activity in groundwater in the East Fork regime shows a similar pattern as that observed for gross alpha activity (Fig. 5.14). In

\section{5-26 Groundwater}




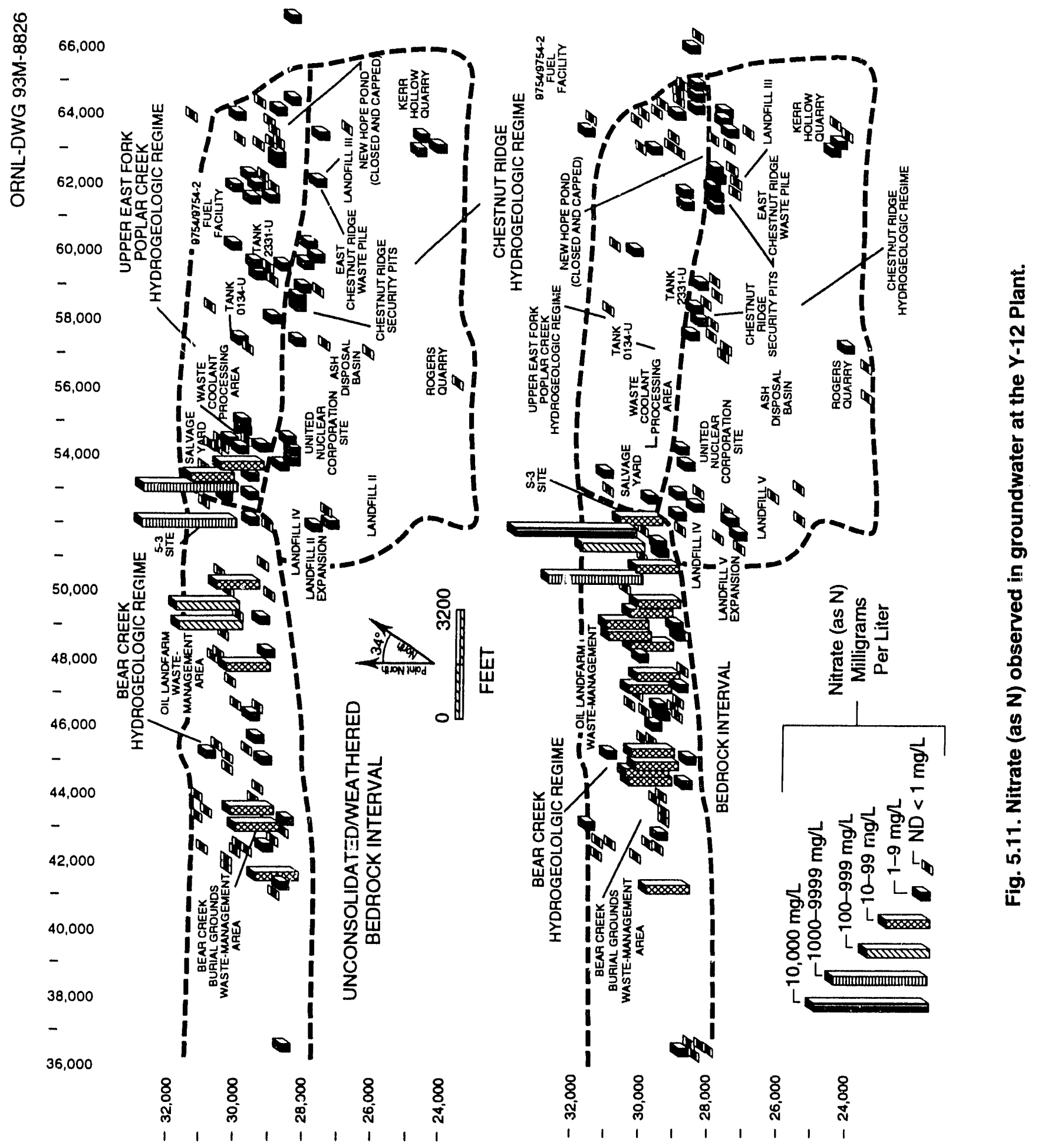




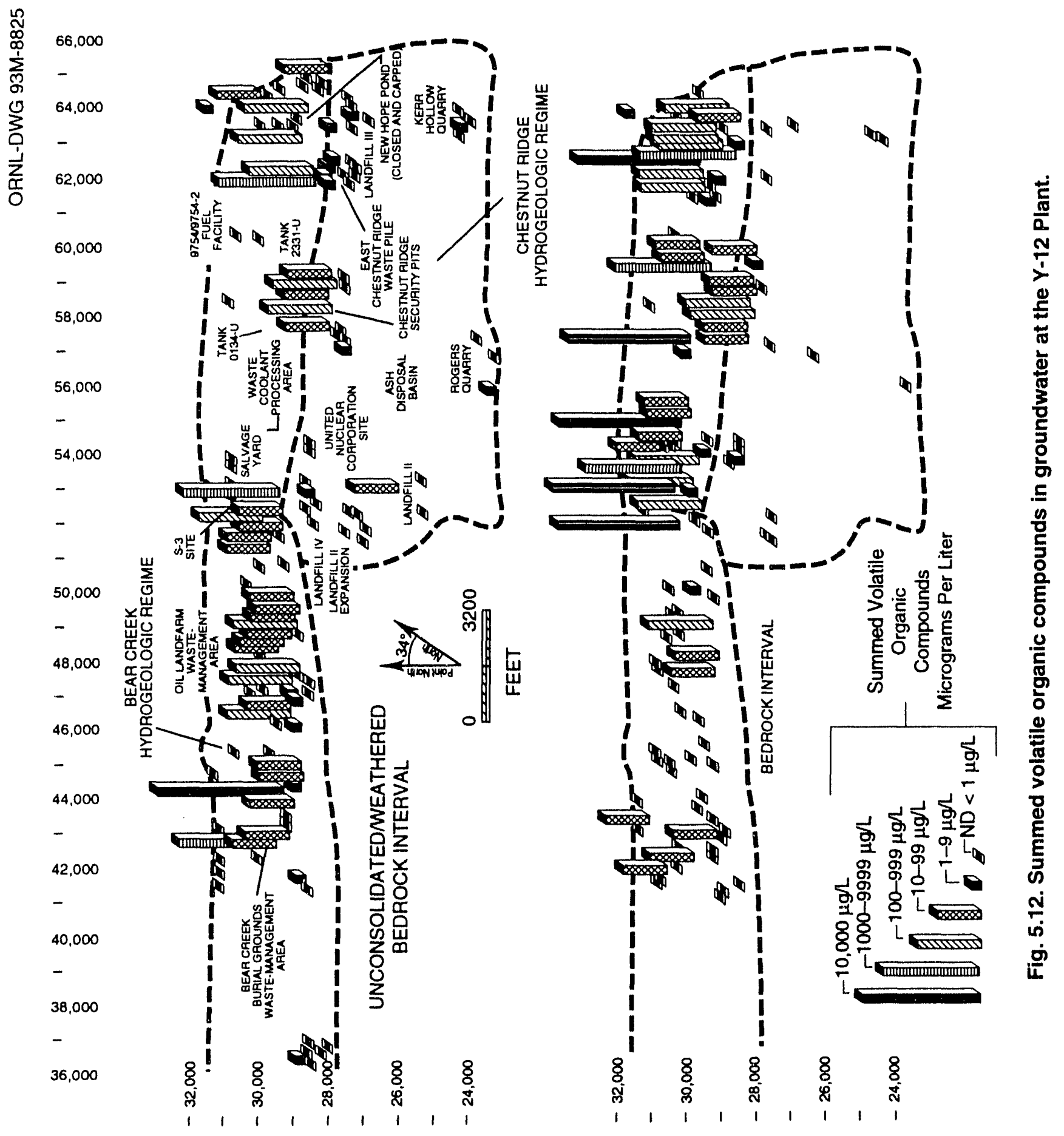




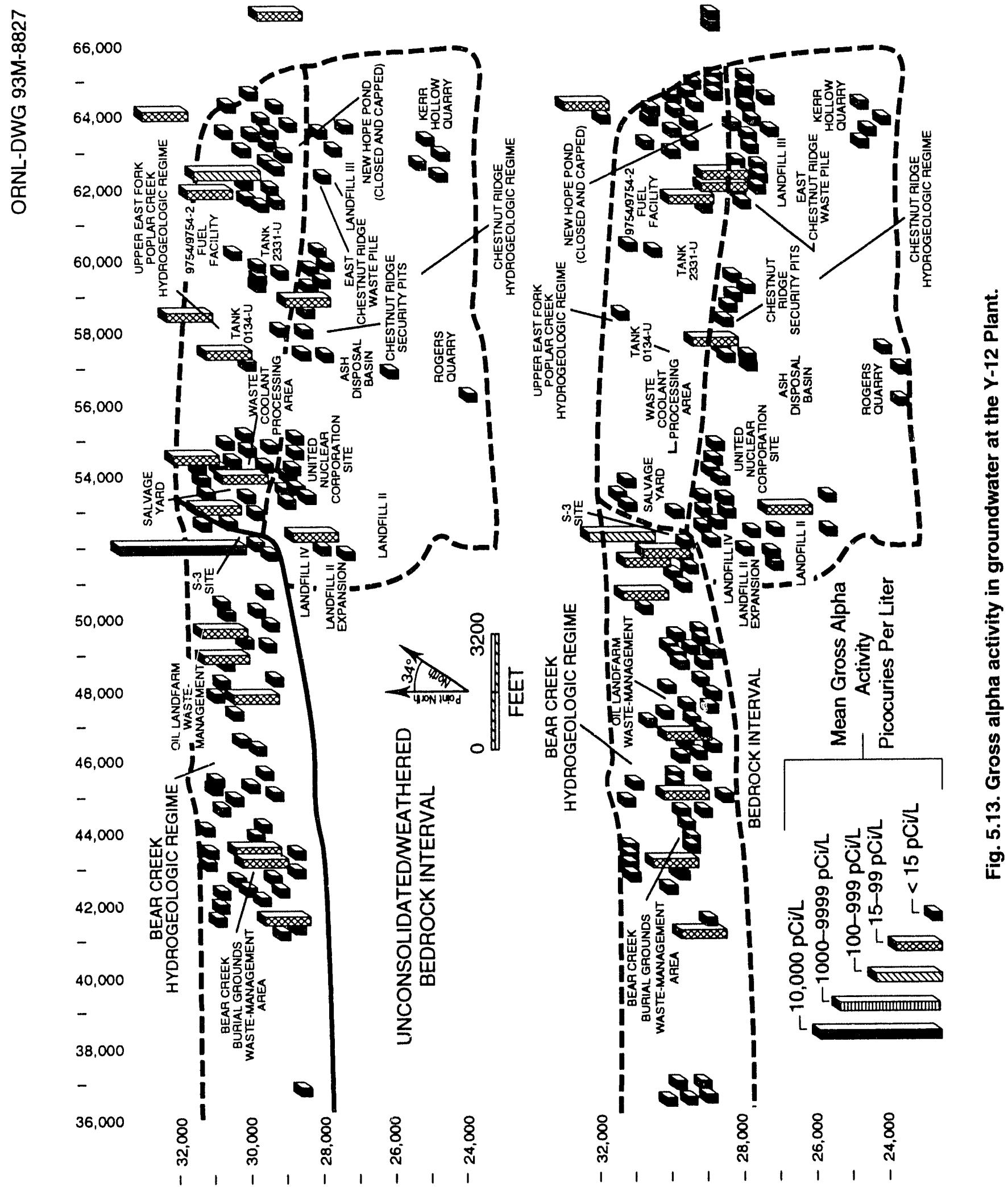



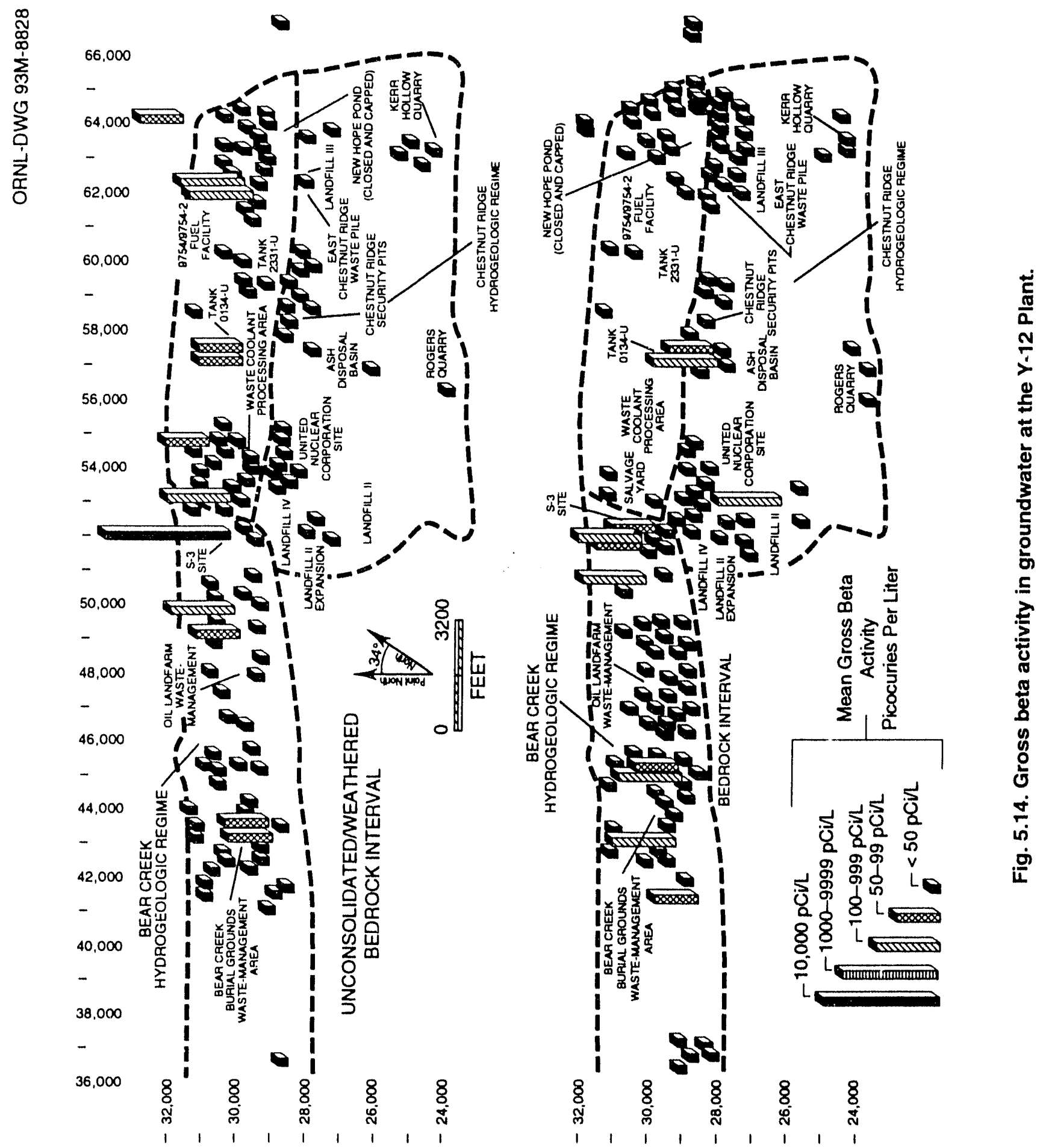
general, gross beta activity exceeds $50 \mathrm{pCi} / \mathrm{L}$ in groundwater in scattered locations throughout the regime. Gross beta activity consistently above $50 \mathrm{pCi} / \mathrm{L}$ occurred only in the western part of the regime, near the Salvage Yard.

\subsection{Exit-Pathway Monitoring}

Only groundwater in the Maynardville Limestone and uppermost Nolichucky Shale are monitored as part of the exit-pathway monitoring in the East Fork regime. Surface-water quality in Upper East Fork Poplar Creek is regularly monitored in accordance with various National Pollution Discharge Elimination System (NPDES) permits. As in the Bear Creek regime, efforts to expand the exit-pathway monitoring well network in the Maynardville Limestone were continued during 1992, and three wells (GW-733, GW-734, and GW-735) were installed along one strike-perpendicular traverse across the formation (Fig. 5.15).

\subsubsection{Bear Creek Hydrogeologic Regime}

Located west of the Y-12 Plant in Bear Creek Valley, the Bear Creek regime is bound to the north by Pine Ridge and to the south by Chestnut Ridge. The regime encompasses the portion of Bear Creek Valley extending from the west end of the Y-12 Plant to Highway 95. Figure 5.16 shows the Bear Creek regime and the locations of its waste management sites.

\subsubsection{Waste Sites and Storage Tanks}

\subsection{Bear Creek Operable Unit 1}

Bear Creek OU 1 comprises the following units: S-3 Ponds, Sanitary Landfill I, Boneyard/Burnyard, the Oil Landfarm, and the Bear Creek Burial Grounds (including Oil Retention Ponds 1 and 2). These units were used until the 1980 s as the primary area for the disposal of various types of hazardous and nonhazardous wastes generated at the Y-12 Plant.

\section{The S-3 Site}

The S-3 Site, constructed in 1951, originally consisted of four unlined surface impoundments.
Wastes discharged into the ponds contained nitric and other acids, nitrate wastes, pickling and plating wastes, machine coolants, caustic solutions, depleted uranium in nitric acid solution, technetium in raffinate and condensate. Waste disposal at the site ceased in 1984 (Geraghty and Miller, Inc. 1988b). In 1988 the ponds were closed as a landfill in accordance with a TDEC-approved RCRA closure plan (Energy Systems 1988b). TDEC certified final closure of the site in 1990. Primary contaminants were nitrates and uranium, with lesser concentrations of heavy metals and organic solvents.

\section{The Oil Landfarm}

The Oil Landfarm consisted of three areas where waste oils and coolants were applied to nutrient-adjusted soil during the dry months of the year (April to October) to enhance biodegradation. These oils and coolants contained beryllium compounds, depleted uranium, PCBs, and volatile organic compounds. About 1 million gal of waste oil were applied to soils at the site between 1973 and 1982 (Geraghty and Miller, Inc. 1988b). In 1989 the site was covered with a low-permeability engineered cap in accordance with a TDEC-approved RCRA closure plan (Energy Systems 1988c). TDEC certified final closure of the site in 1990.

\section{Sanitary Landfill I}

Sanitary Landfill I was a TDEC-permitted site for disposal of nonhazardous wastes generated at the Y-12 Plant, including paper, cardboard, plastics, rubber, wood, brush, organic refuse, textile products, and asphalt roofing materials. Waste disposal at Sanitary Landfill I was terminated in 1982, and the site was graded, capped, and closed in 1983, in accordance with a TDEC-approved closure plan (Bailey 1983).

\section{Boneyard/Burnyard}

The Boneyard/Burnyard consists of about 8 acres used from 1943 to 1970 as a disposal site for waste from the Y-12 Plant. Burning and disposal of debris and sanitary, metallic, chemical, and radioactive wastes are known to have occurred. The site has been abandoned and is predominantly covered with grassy vegetation. The southeastern portion of this site is overlain by the Hazardous Chemical disposal area, 
ORNL-DWG 93M-8678

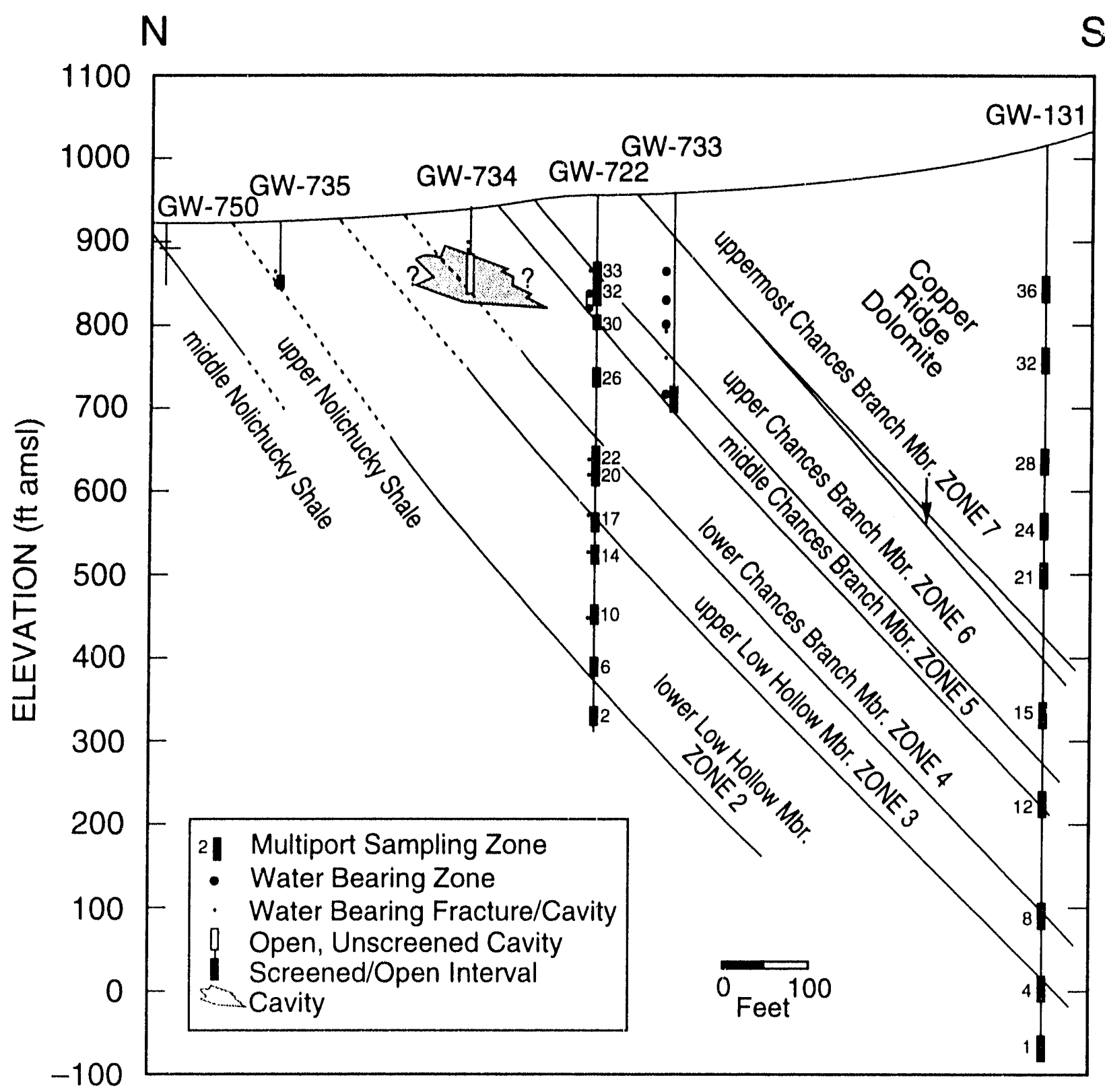

Fig. 5.15. Exit-pathway monitoring wells at Picket J. 


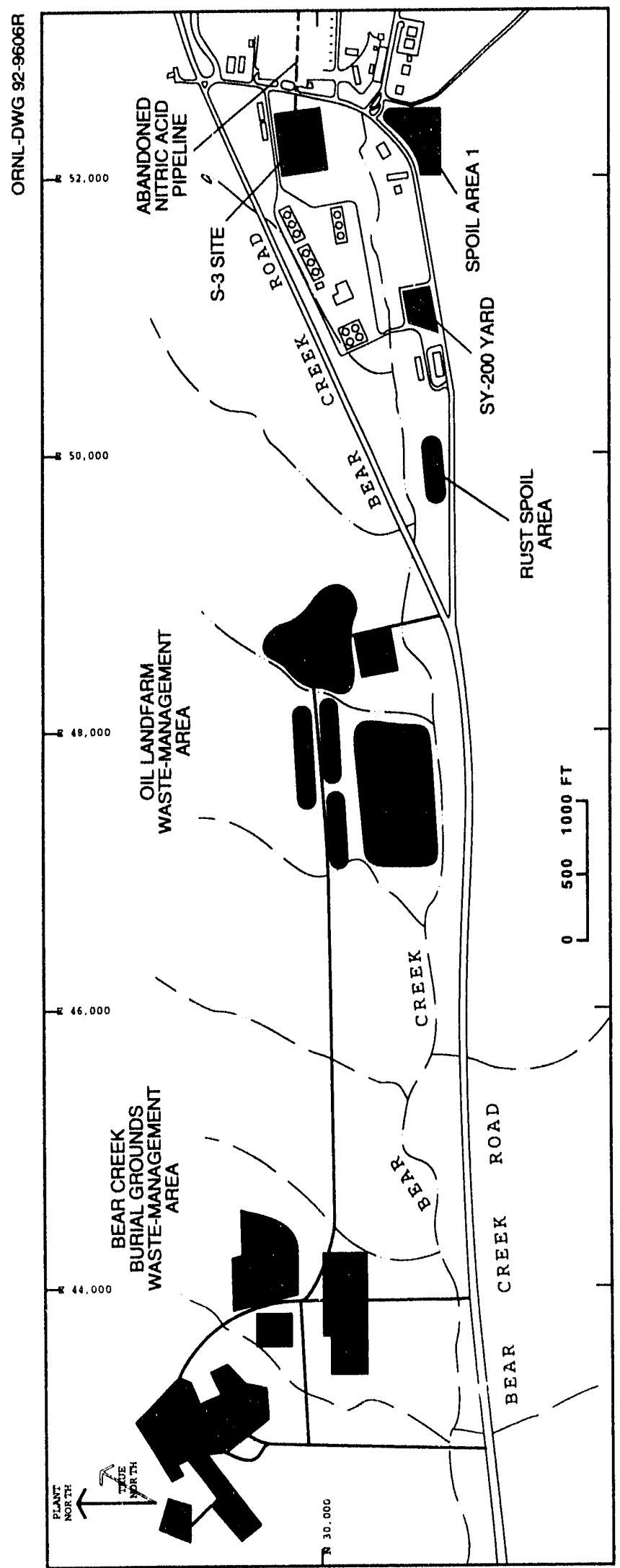

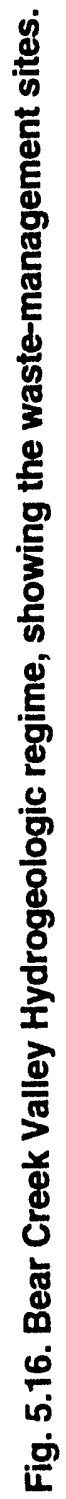




\section{Environmental Report Vol. 1, Oak Ridge}

now considered to be part of the Boneyard/Burnyard The Hazardous Chemical Disposal Area (about 2 acres) was used for releasing compressed gas from cylinders with leaking or damaged valves and for disposal of reactive or explosive laboratory chemicals. Laboratory chemicals disposed at the site included acids, bases, organics, water-reactive compounds, and shock-sensitive compounds such as picric acid. the Hazardous Chemical Disposal Area is presently covered with a RCRA-type cap.

\section{Bear Creek Burial Grounds Waste Management Area}

The Bear Creek Burial Grounds waste management area includes several waste disposal units designated Burial grounds $A$ (North and South), $B, C, D, E$, and J, and two ponds (Oil Retention ponds Nos. 1 and 2). Each disposal unit consisted of multiple trenches used for disposal of liquid and/or solid wastes. Perforated stand-pipes in some trenches were used for liquid waste disposal; rock and gravel were backfilled to support the standpipes and to maximize the drainage rate. Oil Retention ponds No. 1 and 2 were constructed to collect oils seeping from disposal trenches in Burial grounds A South and A North, respectively.

Burial grounds $\mathrm{A}$ (North and South) and C primarily received liquid wastes that generally consisted of waste oils and coolants, spent solvents, and mop waters. Solid wastes disposed at the site included salts, metals (primarily beryllium and uranium) and metal oxides, metal saw-fines, and asbestos. All hazardous waste disposal activities ceased in 1991.

Burial grounds A (North and South) and $C_{\text {, and }}$ the two Oil Retention ponds were closed in 1988 and 1989 in accordance with TDEC-approved RCRA closure plans (Energy Systems 1988d and Energy Sy stems 1988e). TDEC certified final closure of Burial Ground A (North and South) in 1989. Certification of final closure of Burial Ground $\mathrm{C}$ was requested from TDEC in 1990. TDEC certified final closure of Oil Retention ponds No. 1 and 2 in 1990. Volatile organics in soil resulting from groundwater transport are of primary concern.

The nature and extent of soil contamination within each of the listed units in Bear Creek OU and the nature and extent of sediment and surface water contamination within each associated tributary to Bear Creek will be determined during the CERCLA investigation.

\subsection{Bear Creek Operable Unit 2}

Bear Creek OU 2 consists of the Rust Spoil Area, Spoil Area 1, and the SY-200 Yard.

\section{Rust Spoil Area}

The Rust Spoil Area was used between 1975 and 1983 for the disposal of solid wastes generated during various renovation, maintenance, and construction operations at the Y-12 Plant.

Nonradioactive construction debris disposed of at the site is estimated at less than 100,000 cubic yards, composed of soil fill, masonry, and concrete with steel reinforcement steel; however, materials containing solvents, asbestos, mercury, and uranium also may have been disposed at the site (Battelle 1989b). Closure of the site was completed in 1984 in accordance with a TDEC-approved closure plan (MCI 1983). An earlier RCRA facility investigation plan for the site contains a detailed discussion of its operational history (Battelle 1989b). Soil contamination is of primary concern.

\section{Spoil Area I}

Spoil Area I has been used since about 1980 for disposal of nonradioactive construction debris. TDEC permitted the site in 1986 for disposal of rubble and other noncombustible, stable solid wastes (TDEC 1986). The site has received about 100,000 cubic yards of debris, including asphalt, brick, concrete, roofing materials, brush, steel reinforcement steel, rock, and tile. An earlier RCRA facility investigation plan prepared for the site contains a detailed discussion of its operational history (Battelle 1989a). Although plant controls eliminated the disposal of hazardous and radioactive wastes, past plant practices indicate that some of the construction material may have been contaminated with trace amounts of asbestos, mercury, beryllium, thorium, and uranium.

\section{SY-200 Yard}

The SY-200 Yard, which operated from the 1950) to 1986, was a gravel-covered area used for temporary storage of equipment, machinery, and miscellaneous items. Records indicate that waste 
materials were not disposed of or stored at the site. An earlier RCRA facility investigation plan for the site contains a detailed discussion of its operational history (Geraghty and Miller 1989b). Soil contamination is of primary concern.

\subsection{Bear Creek Operable Unit 3}

Bear Creek OU 3 consists of the Bear Creek floodplain sediments. Bear Creek's headwaters are just west of the Y-12 Plant, and the creek flows westward through Bear Creek Valley until it exits near State Highway 95. Bear Creek has received contaminated surface water and groundwater discharges from past waste management practices in the Bear Creek and S-3 waste management areas. Contamination of Bear Creek has been drastically reduced since these operations ceased in the mid 1980s and many of the disposal units closed.

Principal contaminants remaining in floodplain soils and sediments are PCBs, uranium, and cadmium.

\subsection{Bear Creek Operable Unit 4}

Bear Creek OU 4 addresses contamination within the coupled groundwater/surface water system and downstream transport of Bear Creek channel deposits. The area of interest within Bear Creek Valley extends west from a topographic high near the west end of the Y-12 Plant (S-3 Waste Management Area) to the point where Bear Creek exits the valley near State Highway 95. Potential sources of groundwater, surface water, and sediment contamination are being addressed in Bear Creek OUs 1, 2, and 3.

Groundwater and surface water within the Bear Creek regime will be characterized and remediated as an integrator OU distinct from the contaminated units. This approach is warranted because (1) efforts to establish the horizontal and vertical extent of groundwater contaminant plumes from individual sites indicate that the plumes are significantly intermingled, making assessment and remediation of individual plumes impractical, and (2) the sites share an exit pathway from the hydrologic system, which is best addressed by a comprehensive approach. Where site-specific groundwater or surface water data are needed to better identify the source or to support a screening-level risk assessment, ground water or surface water assessment activities (e.g., piezometers or well points) may be conducted during the remedial investigation/feasibility study process for the source control OUs. The primary groundwater contaminants in the Bear Creek regime are nitrates, volatile organic compounds, radionuclides, and (to a lesser extent) trace metals. DNAPLs have been discovered at a depth of $270 \mathrm{ft}$ below the Bear Creek Burial Grounds. The DNAPLs consist primarily of perchloroethylene, trichloroethyleis: 1,1,1-trichloracetic acid, and high concentrations of PCBs.

Channel sediments are included in this integrator OU rather than in Bear Creek OU 3 because, once in the stream channel, sediments are directly coupled with the surface water flow pathway. Floodplain sediments are considered a source term for contaminants entering Bear Creek and not part of this operable unit.

\subsubsection{Discussion of Monitoring Results}

Groundwater monitoring efforts in the Bear Creek regime during 1992 were the same as those for the East Fork regime: (1) to delineate contaminant plume boundaries and (2) to expand the network of exit-pathway monitoring wells in the Maynardville Limestone. Results of monitoring data are presented in Table 5.2, Vol. 2.

\subsection{Plume Delineation}

The primary groundwater contaminants in the Bear Creek regime are nitrate, trace metals, volatile organic compounds, and radionuclides. The S-3 Site is the primary source of nitrate, radionuclides, and trace metals. Another nitrate source area lies near the eastern end of the Oil Landfarm waste management area. Sources of volatile organic compounds include the S-3 Site, the Rust Spoil Area, Oil Landfarm waste management area, and the Bear Creek Burial Grounds waste management area; the latter two sites are the principal sources.

Contaminant plume boundaries are essentially defined in the bedrock formations that directly underlie many waste disposal areas in the Bear Creek regime, particularly the Nolichucky Shale. The elongated shape of the contaminant plumes in the Bear Creek regime is the result of transport of the contaminants parallel to strike in the Maynardville Limestone. A review of historical data suggests that, in general, contaminant concentrations in the Bear 
Creek regime have remained relatively constant since 1986. Certain contaminants at specific sites, however, exhibit non-steady-state concentration patterns, as exemplified by PCE at the S-3 Site and alpha activity at the Oil Landfarm (Fig. 5.17).

\subsection{Nitrate}

Unlike most of the other groundwater contaminants, nitrate moves with the ground water relatively unimpeded. The limits of the nitrate plume probably define the maximum extent of subsurface contamination in the Bear Creek regime.

Data obtained during 1992 indicate that mitrate concentrations exceed the $10 \mathrm{mg} / \mathrm{L}$ maximum contamination level in an area that extends west from the S-3 Site for several thousand feet down the Bear Creek Valley (Fig. 5.11). During 1992, the highest nitrate concentrations occurred within $1,000 \mathrm{ft}$ of the S-3 Site in groundwater in the unconsolidated zone and at shallow depths (less than $100 \mathrm{ft}$ below the ground surface) in the Nolichucky Shale.

The horizontal extent of the nitrate plume is essentially defined in groundwater in the upper part of the aquifer (less than $100 \mathrm{ft}$ below the ground surface). Data obtained from exit-pathway monitoring wells installed during 1991 and 1992 suggest that the nitrate plume in groundwater within bedrock in the Maynardville Limestone extends farther down Bear Creek Valley than previously thought.

Vertical plume boundaries are not as well defined. Typically, nitrate concentrations exceed the maximum contamination level in groundwater in the upper $300 \mathrm{ft}$ of the aquifer. Below this depth nitrate concentrations exceed $10 \mathrm{mg} / \mathrm{L}$ in an area immediately down-dip (south) of the S-3 Site. Data obtained since 1986 suggest that the nitrate plume in this area extends more than $500 \mathrm{ft}$ below the ground surface.

\subsection{Trace Metals}

Barium, cadmium, chromium, lead, and mercury have been identified from previous monitoring as the principal trace metal contaminants in groundwater in the Bear Creek regime. During 1992 the concentrations of these metals exceeded maximum contamination levels or natural (background) levels primarily in low $\mathrm{pH}$ ground water at shallow depths near the S-3 Site. Disposal of acidic liquid wastes at this site reduced the $\mathrm{pH}$ of the groundwater, which allows the metals to remain in solution. Elsewhere in the Bear Creek regime, where more neutral $\mathrm{pH}$ conditions prevail, only sporadic occurrences of elevated trace metal concentrations are evident.

Based on the 1992 data, the highest concentrations of the principal trace metal contaminants, except chromium, were reported for samples from wells at the S-3 Site. Groundwater near this site contained the highest concentrations of barium, cadmium, lead, and mercury in the Bear Creek regime. Barium, chromium, and lead were detected above maximum contaminant levels in filtered samples from several monitoring wells in the Bear Creek Burial Grounds and Oil Landfarm waste management areas. These findings are consistent with previous data.

Other trace metal contaminants in the Bear Creek regime are beryllium, boron, cobalt, copper, nickel, strontium, and uranium. Concentrations of these metals most commonly exceed background levels in ground water near the S-3 Site. Scattered monitoring locations in the vicinity of the Bear Creek Burial Grounds and Oil Landfarm waste management areas also had concentrations of specific trace metals above background levels. The number and concentrations of constituents, however, were less than those at the S-3 Site. Selected stream and spring locations also exhibited total uranium concentrations above background values.

\subsection{Volatile Organic Compounds}

Like nitrate, volatile organic compounds are widespread in groundwater in the Bear Creek regime (Fig. 5.12). The primary compounds are tetrachloroethene, trichloroethene, 1,2-dichloroethene, 1,1,1-trichloroethane, and 1,1-dichloroethane. In most areas the volatile organic compounds are dissolved in the groundwater, but nonaqueous phase accumulations of tetrachloroethene and trichloroethene occur in bedrock more than $250 \mathrm{ft}$ below the Bear Creek Burial Grounds waste management area.

Groundwater in the unconsolidated zone that contains detectable levels of volatile organic compounds occurs primarily within about $1,000 \mathrm{ft}$ of the source areas. The highest volatile organic compounds concentrations (greater than

\section{5-36 Groundwater}


1992 Environmental Report Vol. 1, Oak Ridge

ORNL-DWG 93M-8680R
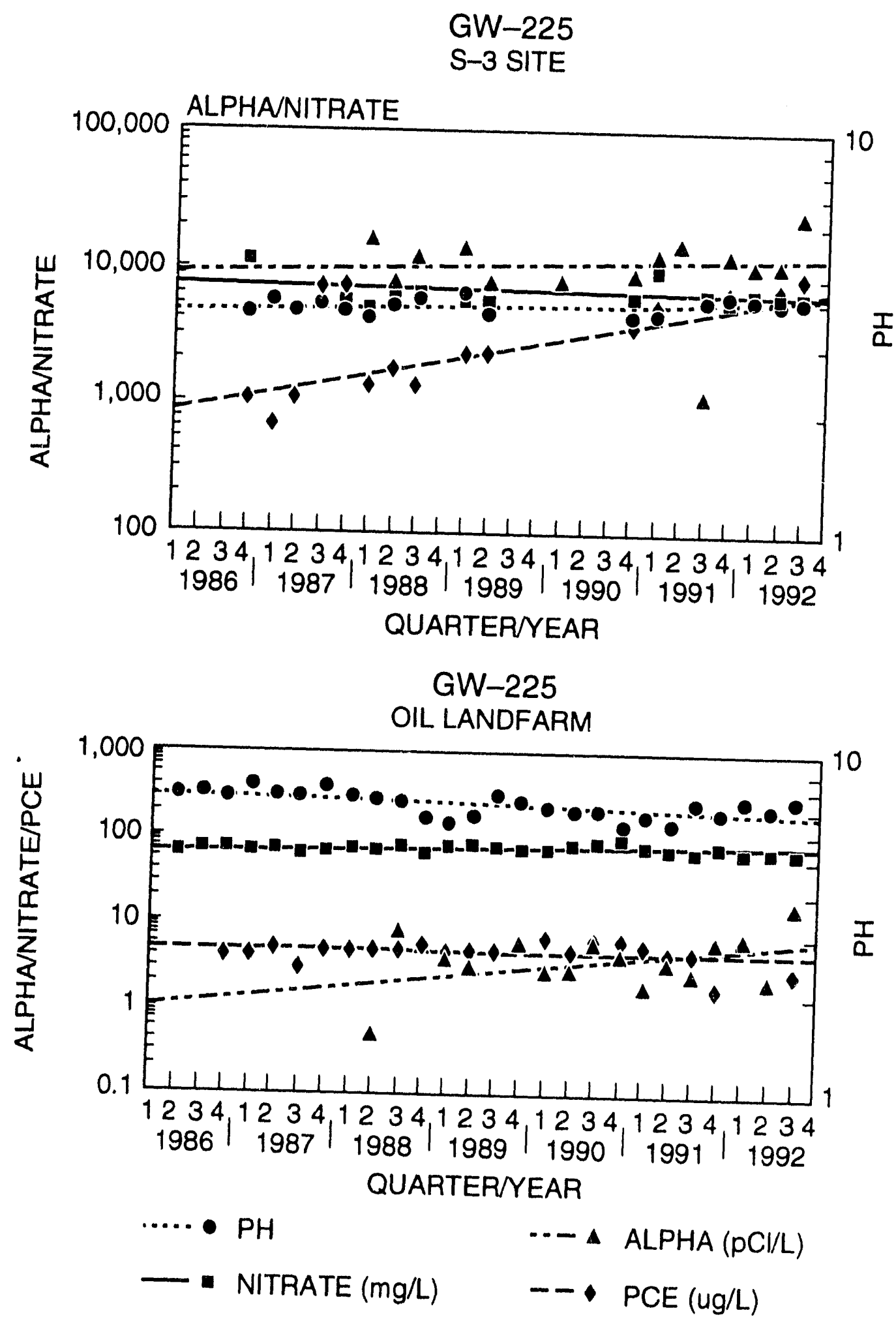

Fig. 5.17. Concentrations of selected contaminants in monitoring wells GW-243 and GW-225 in the
Creek regime. 
$10,000 \mathrm{mg} / \mathrm{L}$ ) in the unconsolidated zone occur at the Bear Creek Burial Grounds waste management area.

The extent of the dissolved volatile organic compounds plumes is slightly greater in the underlying bedrock. Although the plumes generally do not extend more than $1,000 \mathrm{ft}$ from the source areas in groundwater in the low permeability formations that underlie many waste sites, significant transport of the volatile organic compounds has occurred in the Maynardville Limestone.

Data obtained from exit-pathway monitoring wells installed during 1991 and 1992 show that the volatile organic compounds plume in the Maynardville Limestone extends farther west than previously reported. In the vicinity of the water table, an apparently continuous dissolved volatile organic compounds plume extends for about $7,000 \mathrm{ft}$ westward from the S-3 Site to just west of the Bear Creek Burial Grounds waste management area. Volatile organic compounds are also present in the bedrock intervals of both the Miaynardville Limestone and lower Conasauga Group formations, but data obtained during 1992 show discontinuous areas of occurrence confined to the vicinity of the Bear Creek Burial Grounds and Oil Landfarm waste management areas.

\subsection{Radionuclides}

Uranium, neptunium, americium, and naturally occurring isotopes of radium $\left({ }^{226} \mathrm{Ra}\right)$ have been identified as the primary alpha-particle-emitting radionuclides in the Bear Creek regime. Technetium is the primary beta-particle-emitting radionuclide in the regime, but tritium and isotopes of strontium also may be present in groundwater near the S-3 Site.

Evaluations of the extent of these radionuclides in groundwater in the Bear Creek regime during 1992 were based primarily on measurements of gross alpha activity and gross beta activity. If the annual average gross alpha activity in groundwater samples from a well exceeded $15 \mathrm{pCi} / \mathrm{L}$ (the maximum contamination level for gross alpha activity), then one or more of the alpha-emitting-radionuclides were assumed to be present in the groundwater monitored by the well. A similar rationale was used for annual average gross beta activity that exceeded $50 \mathrm{pCi} / \mathrm{L}$.

As shown on Fig. 5.13, ground water with elevated levels of gross alpha activity occurs in the water table interval in the vicinity of the S-3 Site, the
Bear Creek Burial Grounds, and the Oil Landfarm waste management areas. In the bedrock interval gross alpha activity exceeds $15 \mathrm{pCi} / \mathrm{L}$ in groundwater in the Nolichucky Shale near the S-3 Site and the western sides of the Bear Creek Burial Grounds and the Oil Landfarm waste management areas. Data obtained from exit-pathway wells installed in 1991 and 1992 show that gross alpha activity in groundwater in the Maynardville Limestone exceeds the maximum contamination level for several thousand feet west of the S-3 Site. Elevated gross alpha activities were observed in six exit pathway spring and stream monitoring locations.

The extent and distribution of gross beta radioactivity in groundwater in the unconsolidated zone are about the same as those of gross alpha radioactivity (Fig. 5.14). During 1992 gross beta activity exceeded $50 \mathrm{pCi} / \mathrm{L}$ within the water table interval in the Maynardville Limestone from south of the S-3 Site to the west of the Oil Landfarm waste management area. Within the intermediate bedrock interval in the Maynardville Limestone, the elevated gross beta activity extends as far west as does gross alpha activity, possibly as far as the western portion of the Bear Creek Burial Grounds waste management area. Elevated gross beta activity was observed in two spring and two stream locations that also exhibited elevated gross alpha activity.

\subsection{Exit-Pathway Monitoring}

Exit-pathway monitoring began in 1989 to provide data on the quality of groundwater and surface water exiting the Bear Creek regime. The Maynardville Limestone is the primary exit pathway for groundwater. Bear Creek, which flows across the Maynardville Limestone in much of the Bear Creek regime, is the principal exit pathway for surface water. Various studies have shown that surface water in Bear Creek and groundwater in the Maynardville Limestone are hydraulically connected. Efforts to cxpand the exit-pathway monitoring well network in the Maynardville Limestone were continued during 1992. Eight additional, shallower wells were installed along 2 dip-parallel traverses, or pickets, which were started in 1991. These wells, located along Pickets C and $W$ (Fig. 5.6), were drilled to intercept specific stratigraphic zones, thought to be susceptible to dissolution, that were encountered during initial drilling efforts in 1991. New wells include GW-736,

\section{5-38 Groundwater}


GW-737, GW-738, GW-739, and GW-740 at Picket C (Fig. 5.18) and GW-714 and GW-715 at Picket W (Fig. 5.19).

Groundwater quality data obtained during 1992 from the exit-pathway monitoring wells suggest that the horizontal and vertical extent of groundwater contamination in the Maynardville is greater than previously reported. Nevertheless, the 1992 data obtained from wells located along the westernmost picket (Picket $W$ ) indicated that contaminated ground water generally does not occur beyond the western side of the Bear Creek Burial Grounds waste management area.

Surface water samples were collected quarterly from a northern tributary of Bear Creek (the background location), from five springs that discharge groundwater to the creek, and from four points along the main creek channel (Fig. 5.20). A preliminary review of the 1992 data indicates that spring discharges and water in upper reaches of Bear Creek contain many of the compounds found in the groundwater; however, the concentrations in the creek and spring discharges decrease rapidly with distance downstream of the waste disposal sites.

Nitrate concentrations in Bear Creek exceeded the maximum contamination level during 1992 from south of the S-3 Site to west of the Bear Creek Burial Grounds at BCK 9.40. Nitrate concentrations at BCK 4.55, at the junction of Bear Creek Road and Highway 95 , averaged $5.2 \mathrm{mg} / \mathrm{L}$. The average nitrate concentration in surface water samples collected from the farthest downstream point (BCK 0.63), which is located just upstream of the confluence of Bear Creek and East Fork Poplar Creek, was $5.1 \mathrm{mg} / \mathrm{L}$, below the maximum contamination level but above background (about $0.2 \mathrm{mg} / \mathrm{L}$ ). Average nitrate concentrations in spring discharges decreased from an average of $45.4 \mathrm{mg} / \mathrm{L}$ at SS- 1 to nondetectable at SS-6.

Low concentrations of volatile organic compounds (less than $10 \mathrm{mg} / \mathrm{L}$ ) were detected in surface water samples and spring discharge samples collected from the upper reaches of Bear Creek (at BCK 9.40). Compounds detected in samples from the creek were trichloroethene and 1,2 dichloroethene. Spring discharge at SS-1 also contained trace amounts of tetrachloroethene. Each of these compounds are primary components of the volatile organic compounds plumes in groundwater in the regime.
Based on the 1992 data, uranium and strontium are the most common trace metal contaminants in Bear Creek. Concentrations of both metals exceeded background levels throughout reaches of the creek upstream of BCK 9.40. Moreover, uranium concentrations in the creek exceeded background levels at the farthest downstream sampling point (BCK 0.63). Uranium concentrations in spring effluents exceed background levels as far west as the SS-5 location.

Annual average gross alpha activity exceeded $15 \mathrm{pCi} / \mathrm{L}$ at all the sampling points along Bear Creek, with the exception of $\mathrm{BCK} 0.63$, and in spring discharges west as far as SS-5. Gross beta activity exceeded $50 \mathrm{pCi} / \mathrm{L}$ at $\mathrm{BCK} 9.40$ and $\mathrm{BCK} 11.97$ and was above background levels at the sampling stations downstream of BCK SS-4 and was above background levels at SS-5.

\subsubsection{Chestnut Ridge Hydrogeologic Regime}

The Chestnut Ridge regime is south of the $\mathrm{Y}-12$ Plant, and is flanked to the north by Bear Creek Valley and to the south by Bethel Valley Road (Fig. 5.2). The regime encompasses the portion of Chestnut Ridge extending from a gap in the ridge located southeast of the eastern end of the Y-12 Plant to a drainage basin on the ridge located just west of the Centralized Sanitary Landfill II.

Four categories of sites are located within the Chestnut Ridge regime: (1) RCRA interim status units, (2) RCRA 3004u solid waste management units and solid waste disposal units, (3) TDEC-permitted solid waste disposal facilities, and (4) CERCLA OUs. Of the waste disposal sites located in the Chestnut Ridge regime, only the Chestnut Ridge Security Pits have been confirmed as a source for groundwater contamination.

\subsubsection{Site Descriptions}

The following sections contain brief descriptions of the operable units and waste-management sites in the Chestnut Ridge regime. The locations of these sites are shown on Fig. 5.21. 


\section{PICKET C}

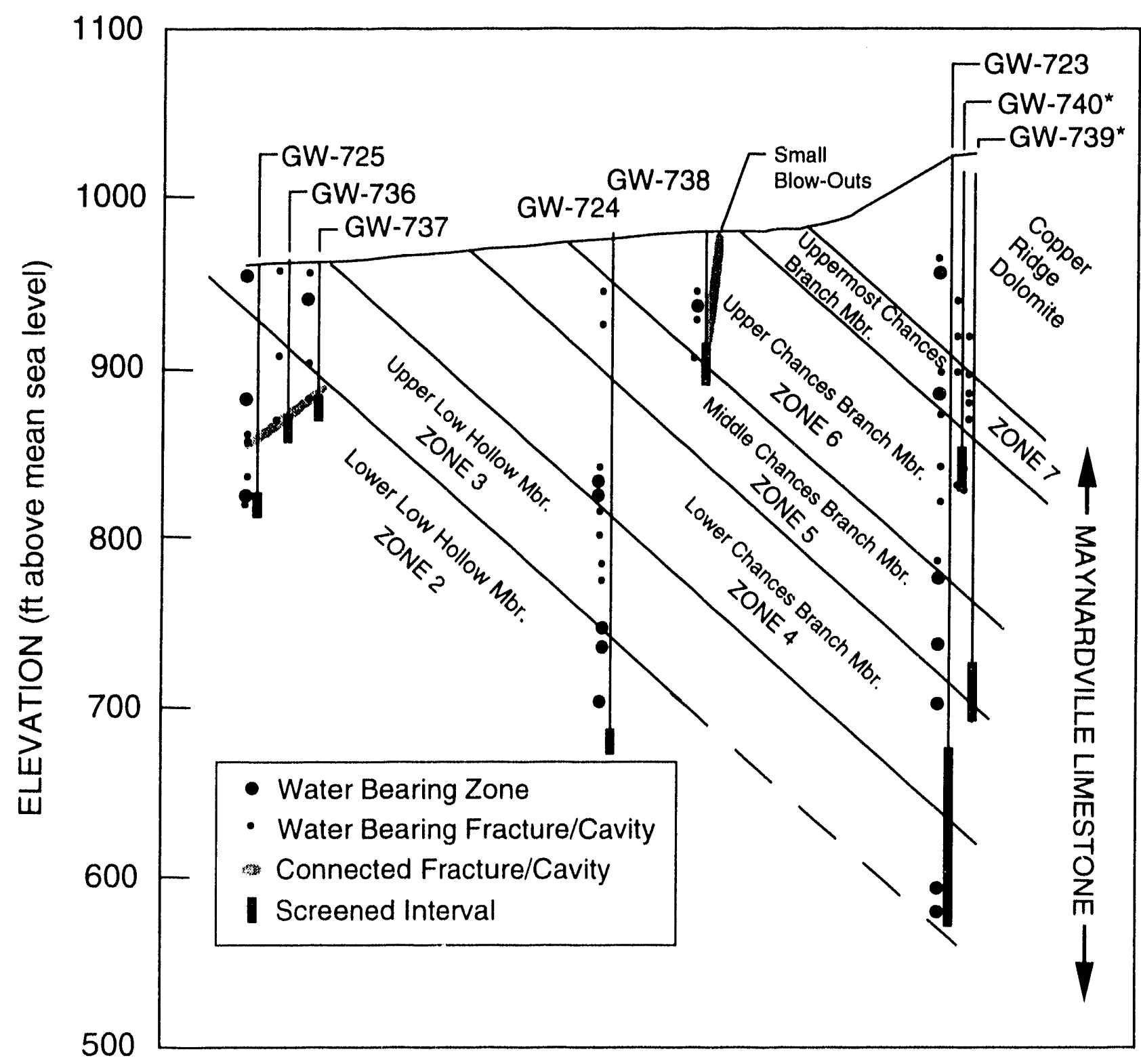

Fig. 5.18. Exit-pathway monitoring wells at Picket C. 


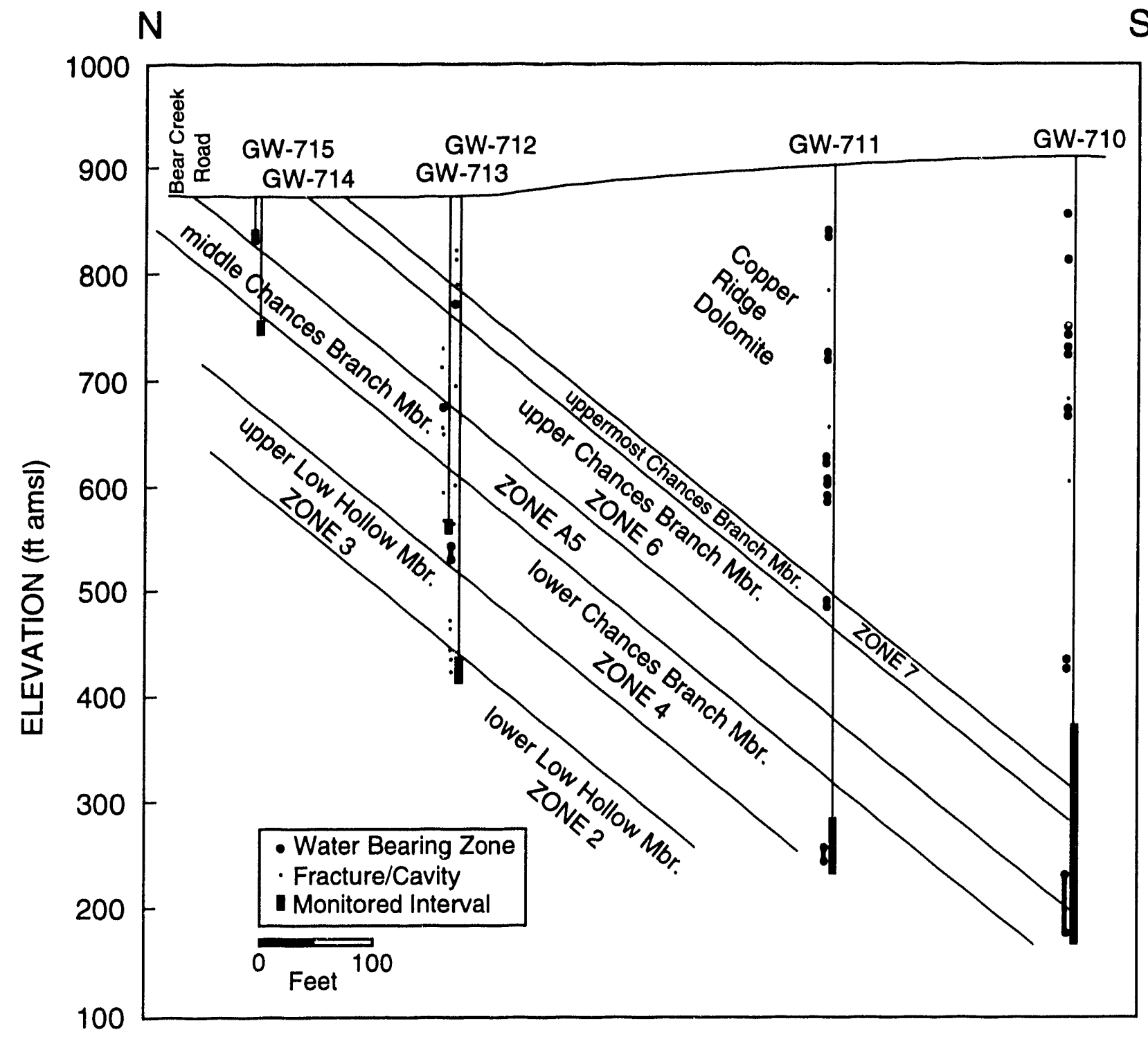

Fig. 5.19. Exit-pathway monitoring wells at Picket W. 
1992 Environmental Report Vol. 1, Oak Ridge

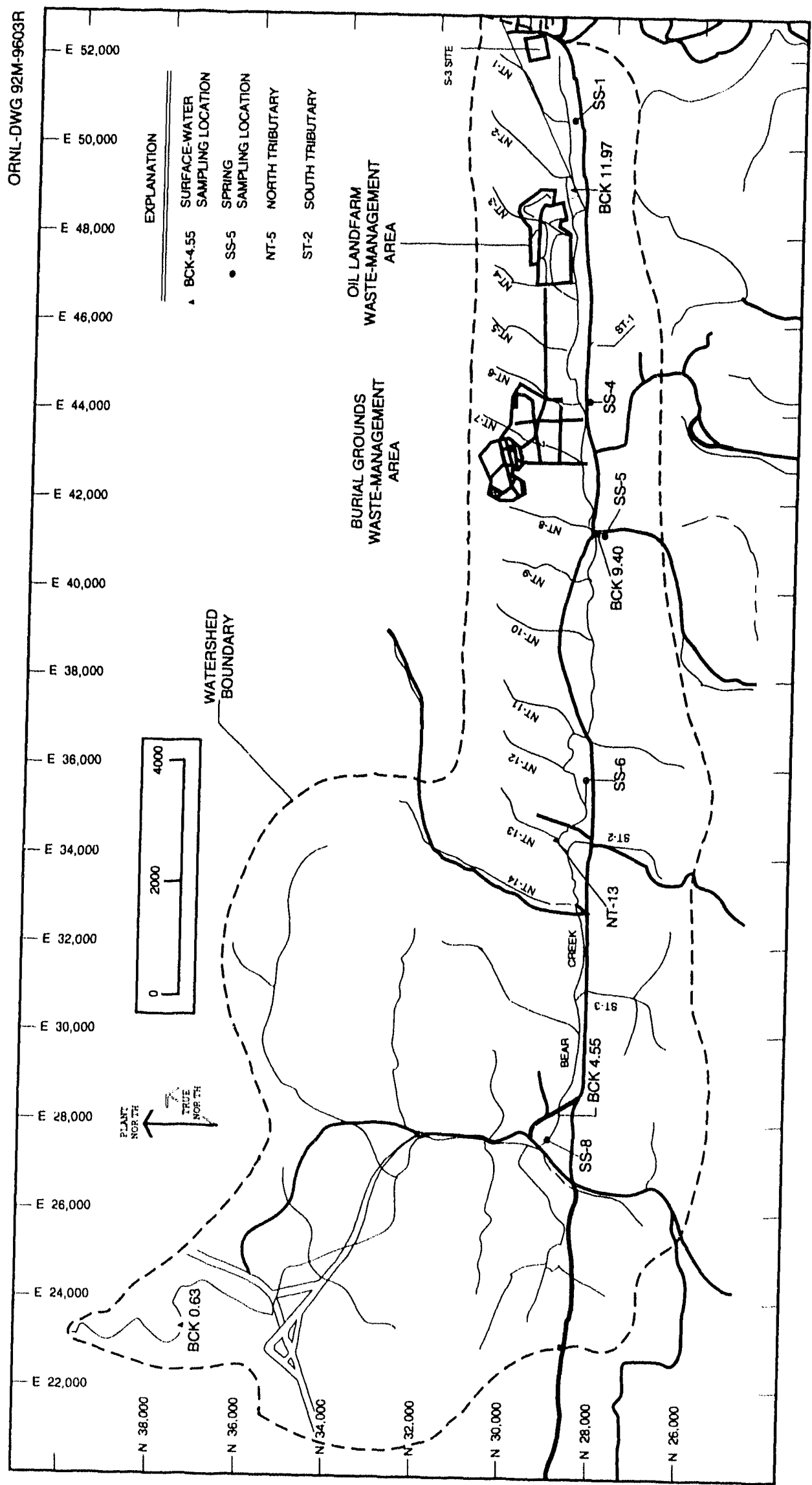

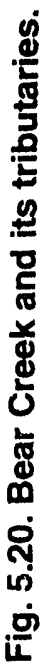




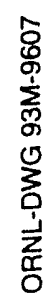

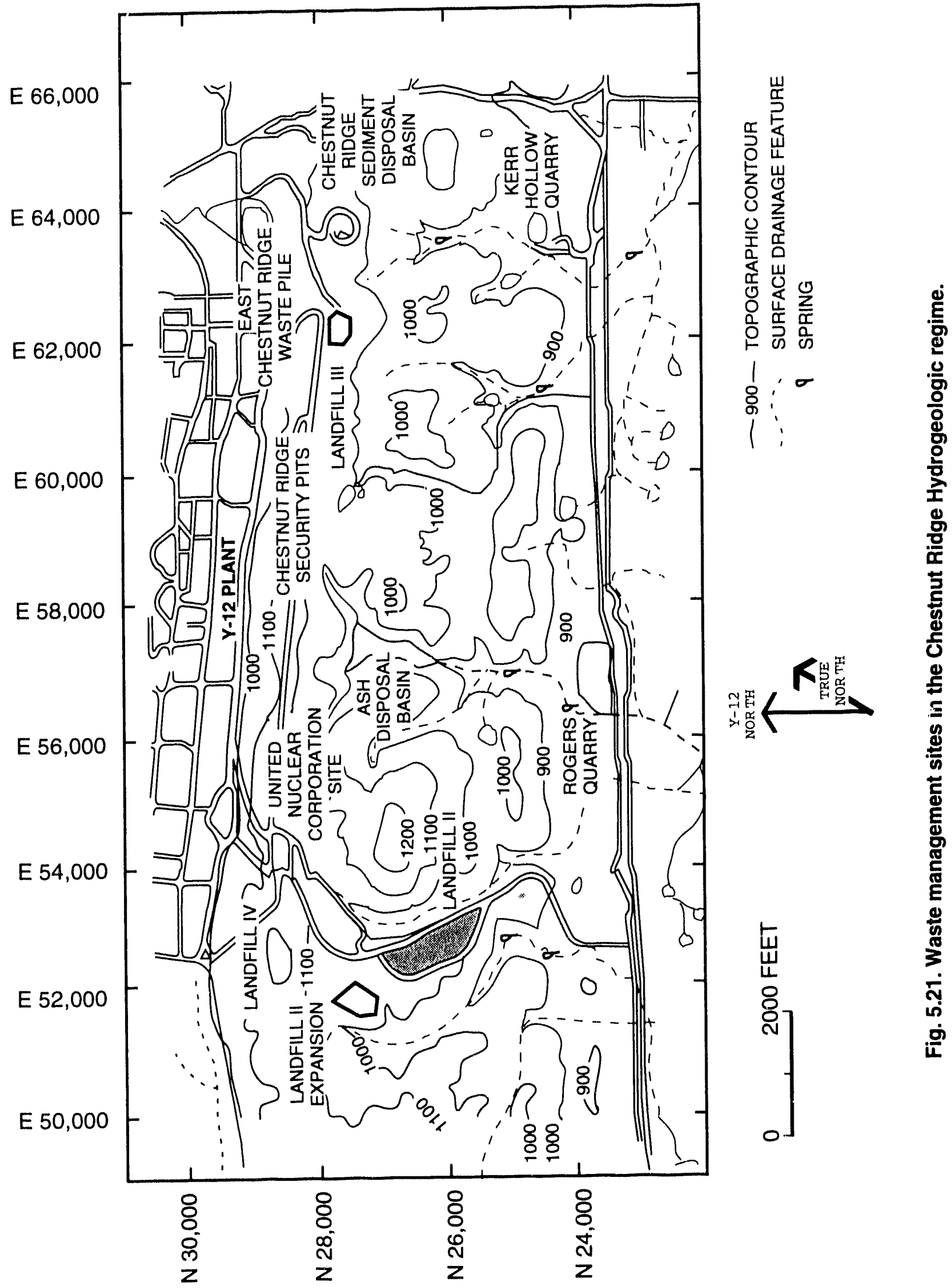




\subsection{Chestnut Ridge Operable Unit 1}

Operable Unit 1 consists of the Chestnut Ridge Security pits that were operated between 1973 and 1988. When in operation, the site was a series of trenches used for the disposal of classified hazardous and nonhazardous wastes. Typically, several trenches were opened simultaneously to allow for the segregation of wastes in separate cells. After a trench was filled, it was covered with 6 to 12 in. of soil. Particularly reactive materials were disposed in six auger holes, located at the eastern end of the site (Butz and Stoner 1983).

The security pits contain an estimated 3,950 tons of waste materials. Detailed waste inventories are classified, but an unclassified inventory listed ten major waste types: acids, fiberglass, beryllium, biological material, debris, heavy metals, inorganics, organics, thorium, and uranium (Energy Systems 1984). Disposal of hazardous waste in the security pits ceased in 1984; disposal of nonhazardous waste ceased in 1988. Closure of the site is described in a TDEC-approved RCRA closure plan and involved the construction of a low-permeability cap over the disposal trenches (Energy Systems 1988f). The site was certified closed by TDEC in 1989. Groundwater impacts from the disposal operations are the primary focus of this OU.

\subsection{Chestnut Ridge Operable Unit 2}

Chestnut Ridge OU 2 consists of the Filled Coal Ash Pond (Ash Disposal Basin) and Upper McCoy Branch. The Filled Coal Ash Pond is situated within the McCoy Branch watershed about $0.8 \mathrm{~km}(0.5$ mile $)$ south or the Y-12 steam plant. By 1967, the pond filled, spilling sediments directly into McCoy Branch. From 1967 to 1989, ash was carried within McCoy Branch to Rogers Quarry, about $0.8 \mathrm{~km}$ ( 0.5 mile) downstream of the Coal Ash Pond. Impacts to surface water, stream sediments, and groundwater from metals, including uranium and major ions, are of concern.

Impacts to surface water, stream sediments, and groundwater from metals, including uranium and major ions, are of concern. Biomonitoring of aquatic organisms in McCoy Branch and Roger's Quarry has shown a biological impact potentially from the ash pond operations.

\subsection{Chestnut Ridge Operable Unit 3}

The United Nuclear Corporation (UNC) Site received nitrate-contaminated low-level radioactive wastes and contaminated equipment packaged in 55-gal drums and in boxes. About 30,000 barrels of waste were placed in the site (Grutzeck 1987). Waste disposal at the site ceased in 1984. Groundwater quality data obtained since 1985 do not suggest groundwater contamination at the site (Early 1989). A record of decision was signed in 1991. The site was capped and closed in 1992 in accordance with an approved CERCLA record of decision and a RCRA closure plan. Prior to cap construction, contaminated soils from the off-site Elza Gate Site cleanup were placed as fill into the UNC disposal site.

\subsection{Chestnut Ridge Operable Unit 4}

Chestnut Ridge OU 4 consists of Rogers Quarry and Lower McCoy Branch. Rogers Quarry is situated within the McCoy Branch watershed about 1 mile south of the Y-12 Plant. The quarry, which is about $1150 \times 250 \times 2.75 \mathrm{ft}$, was the source of construction materials in the 1940s and 1950s. The quarry filled with water and was abandoned with quarrying equipment in place in the early 1960s. Disposal of fly ash and bottom ash from the Y-12 steam plant into the quarry began in the 1960s. the quarry was also used for disposal of other plant process materials.

Lower McCoy Branch begins at the surface water discharge point of Rogers Quarry and ends at the McCoy Branch embayment in the Clinch River/ Melton Hill Lake.

Impacts to surface water, stream sediments, and groundwater from metals, including uranium and major ions, are of concern. Biomonitoring of aquatic organisms in Rogers Quarry has shown a biological impact potentially from ash disposal operations.

\section{5-44 Groundwater}




\subsection{Other Waste Sites}

\section{Chestnut Ridge Sediment Disposal Basin}

Beginning in 1973, The Chestnut Ridge Sediment Disposal Basin received soil and sediment that was periodically dredged from New Hope Pond. Soils and sediments removed from New Hope Pond contained PCBs, mercury, and uranium. Results of extraction procedure toxicity analyses showed that the soils did not exhibit the characteristics of a hazardous waste. During 1987 and 1988 the disposal basin also received mercury-contaminated soils from several locations in the Y-12 Plant. In 1989 the disposal basin was closed in accordance with a TDEC-approved RCRA closure plan. TDEC certified final closure on 1989. Groundwater monitoring is continuing under RCRA interim status, pending resolution of RCRA/CERCLA integration and the necessity of a RCRA post-closure permit.

\section{Kerr Hollow Quarry}

The Kerr Hollow Quarry was a source of stone construction material in the 1940 s until it filled with water and was abandoned. From the early 1950s the quarry was used for the disposal of reactive materials from the $\dot{Y}-12$ Plant and ORNL. Disposal of these materials at the site ceased in November 1988. The site is currently undergoing closure under RCRA. Groundwater monitoring is continuing under RCRA interim status pending resolution of RCRA/CERCLA integration and the necessity of a RCRA post-closure permit.

\section{East Chestnut Ridge Waste Pile}

The East Chestnut Ridge Waste Pile is a lined RCRA-permitted hazardous waste storage facility constructed in 1987 as a storage site for contaminated soils from the Y-12 Plant. The site is located in the western portion of the Chestnut Ridge regime near the Chestnut Ridge Sediment Disposal Basin.

\section{Industrial Landfill II}

Industrial Landfill II, also known as the Y-12 Plant Centralized Sanitary Landfill II, is a TDEC-permitted solid waste disposal facility. It is used as a disposal site for combustible and decomposable solid wastes, including scrap metal, glass, paper products, plastics, wood, organic garbage, textile products, asphalt roofing materials, and special wastes such as asbestos and beryllium oxide. The landfill has been expanded, but the expanded area has not received any wastes. Groundwater monitoring at the site is performed in accordance with a monitoring plan approved by the TDEC. Monitoring results obtained since 1982 show that groundwater both up-gradient and down-gradient of the site contains low levels of volatile organic compounds.

\section{Industrial Landfill III}

Industrial Landfill III, also known as the Chestnut Ridge Borrow Area Waste Pile, was constructed as a storage facility for soils removed from the Oak Ridge Civic Center properties and the Oak Ridge Sewer Line Beltway. Soils in both areas contained mercury and other metals (and possibly some volatile organic compounds) that originated from the Y-12 Plant. Results of Extraction Procedure Toxicity analyses indicated that the soils do not exhibit the toxicity characteristic of a hazardous waste. A soil-sampling plan designed to determine if the soils are toxic hazardous wastes based on results of Toxicity Characteristic Leaching Procedure testing was submitted to TDEC for review in 1991 (Science Applications International Corporation 1991). Groundwater quality monitoring has been performed since 1986; contaminant releases to the groundwater system have not been detected.

\section{Industrial Landfill IV}

Industrial Landfill IV is a TDEC-permitted solid waste disposal facility that has operated since 1989 for disposal of nonhazardous, nonradioactive industrial wastes, including cardboard, plastics, rubber, scrap metal, wood, paper, and special wastes. Groundwater quality monitoring has been performed at the site since 1987, and contaminant releases to groundwater have not been detected.

\subsubsection{Discussion of Monitoring Results}

Groundwater quality data obtained in the Chestnut Ridge regime during 1992 support previous monitoring results. The full suite of tests is applied to 


\section{Environmental Report Vol. 1, Oak Ridge}

the Chestnut Ridge regime; however, volatile organics and trace metals are the only categories in which findings currently consistently exceed background levels. Gross alpha and beta activities sporadically exceeded screening levels in samples taken from wells at the Chestnut Ridge Security Pits, Industrial Landfill III, and in wells up-gradient of Landfill II. No discernable pattern or consistency to the data was noted.

\subsection{Plume Delineation}

The horizontal extent of the volatile organic compounds plume at the Chestnut Ridge Security Pits is reasonably well defined in the water table and shallow bedrock zones (Fig. 5.12). Groundwater quality data obtained during 1992 do not suggest any significant changes in the overall composition or extent of the volatile organic compounds plume at the site.

There are two distinct volatile organic compounds plumes in groundwater at the security pits. In the western portion of the site the volatile organic compounds plume is characterized by high concentrations of 1,1,1-trichloroethane.

Tetrachloroethene is a principal component of the volatile organic compounds plume in the eastern portion of the site. The distinct difference in the composition of the plume is probably related to differences in the types of wastes disposed in the eastern and western trench areas.

\subsection{Nitrate}

Nitrate concentrations were within background levels in all wells.

\subsection{Trace Metals}

Trace metal concentrations sporadically exceeded maximum contamination levels only in a few wells.

\subsection{Volatile Organic Compounds}

Efforts to delineate the extent of volatile organic compounds in groundwater at the security pits (previously discussed) have been in progress since 1987. A review of historical data suggests that volatile organic compound concentrations in groundwater at the site have generally decreased since 1988 (Fig. 5.22).

\subsection{Radionuclides}

Gross alpha (four wells) and gross beta (two wells) activities were above 15 and $50 \mathrm{pCi} / \mathrm{L}$, respectively, in samples from a maximum of one quarter during 1992. In addition, samples from two wells exhibited elevated gross alpha activities during two quarters in 1992.

\subsection{Exit-Pathway Monitoring}

Exit-pathway monitoring in the Chestnut Ridge regime follows a different approach from that for the other two regimes. Contaminant and groundwater flow paths in the karst bedrock underlying the regime are not best identified through conventional monitoring techniques. The comprehensive plan, therefore, presents a rationale for using dye-tracer studies to identify exit pathways. Based on the results of dye-tracer studies, springs and surface streams that represent discharge points for groundwater can be identified for water quality monitoring.

A dye-tracer study was initiated and completed in 1992 (SAIC 1993), primarily to confirm results of an initial study conducted in 1990 (Geraghty and Miller, Inc., 1990). The 1992 study used the same dye injection well near the Chestnut Ridge Security Pits and many of the same monitoring points as did the 1990 study. The primary differences included an expanded monitoring network and the use of two fluorescent dyes to verify dye detection.

Results of the second tracer-dye study showed no conclusive occurrences of dyes at the monitoring points and did not corroborate data for detection points in the first study. The 1992 study also showed that the injection well was inappropriate because dye-uptake rates by the formation were inadequate. It is likely that the dye-uptake rates are inadequate because the source well is not screened in a flow conduit interconnected to the rest of the system. A formal comparison report is currently under preparation to examine results of both studies and to provide recommendations for improvements for future dye-tracer studies in this regime.

\section{5-46 Groundwater}


1992 Environmental Report Vol. 1, Oak Ridge

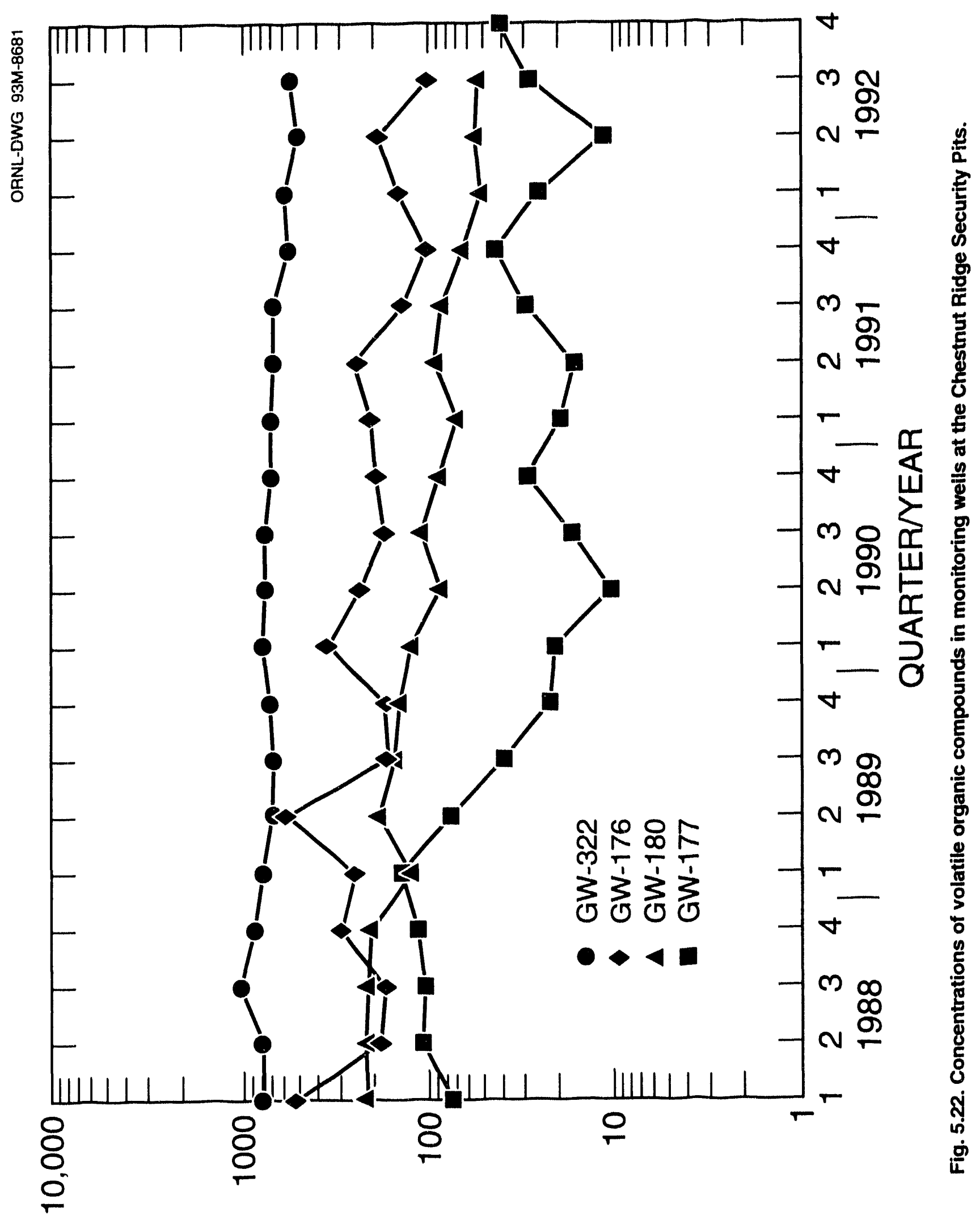

(7/6n) sวo^ a 


\subsection{Oak Ridge National Laboratory}

\subsubsection{Background}

The groundwater monitoring program at ORNL consists of a network of wells of two basic types and functions: (1) water quality monitoring wells built to RCRA specifications and used for site characterization and compliance purposes, and (2) piezometer wells used to characterize groundwater flow conditions. ORNL has established an Environmental Restoration Pro gram to provide comprehensive management of sites where past and current research, development, and waste management activities may have resulted in residual contamination of facilities or the environment. Individual monitoring and assessment is assumed to be impractical for each of these sites because their boundaries are indistinct and there are hydrologic interconnections between many of them. Consequently, the concept of waste area groupings (WAGs) was developed to facilitate evaluation of potential sources of releases to the environment. A WAG is a grouping of multiple sites that are geographically contiguous and/or occur within hydrologically defined areas. WAGs allow the establishment of a suitably comprehensive groundwater and surface water monitoring system in a far shorter time than that required to deal with every facility, site, and solid waste management unit individually. Some WAGs share common boundaries, but each WAG represents distinct small drainage areas within which similar contaminants may have been introduced. Monitoring data from each WAG will be used to direct further groundwater studies aimed at addressing individual sites or units within a WAG as well as contaminant plumes that extend beyond the perimeter of a WAG.

At ORNL, 20 WAGs were identified by the RCRA Facilities Assessment. Thirteen of these have been identified as potential sources of groundwater contamination. Additionally, there are a few areas where potential remedial action sites are located outside the major WAGs. These individual sites have been considered separately (instead of expanding the area of the WAG). Water quality monitoring wells are being established around the perimeter of the WAGs determined to have a potential for the release of contaminants. Table 5.4 lists the 20 WAGs at ORNL and the number of potential remedial action sites within each WAG. Figure 5.23 shows the location of each of the 20 WAGs.

In 1992, some of the WAGs were aggregated into two administrative categories, the Bethel Valley Operable Unit and the Melton Valley Operable Unit. Each of these operable units is composed of the WAGs in its respective valley. This was done to provide a comprehensive picture of the groundwater in each valley. The Bethel Valley Operable Unit includes WAGs 1, 3, and 17, while the Melton Valley Operable Unit includes WAGs $2,4,5,6,7,8$, and 9.

\subsubsection{WAG 1}

WAG 1, the ORNL main plant area, contains about one-half of the remedial action sites identified to date by the Environmental Restoration Plan. WAG 1 lies within the Bethel Valley portion of the White Oak Creek (WOC) drainage basin. The boundaries of the basin extend to the southeast and northeast along Chestnut Ridge and Haw Ridge. The WAG boundary extends to the water gap in Haw Ridge. The total area of the basin in Bethel Valley is about 2040 acres. The location of WAG 1 is shown in Fig. 5.23. Bedrock beneath the main plant area is limestone, siltstone, and calcareous shale facies of the Ordovician Chickamauga Group (see Sect. 1.4).

Most of the WAG 1 sites were used to collect and to store low-level waste (LLW) in tanks, ponds, and waste treatment facilities, but some also include landfills and spill and leak sites identified during the last 40 years. Because of the nature of cleanup and repair, it is not possible to determine which spill or leak sites still represent potential sources of release. Most of the solid waste management units are related to ORNL's solid and liquid radioactive waste management operations.

\subsubsection{WAG 2}

WAG 2 is composed of WOC discharge points and includes the associated floodplain and subsurface environment. It represents the major drainage system for ORNL and the surrounding facilities. WAG 2 consists of two solid waste management units: one is the area encompassed by the stream channels of White Oak Creek and Melton Branch and the other

\section{5-48 Groundwater}


1992 Environmental Report Vol. 1, Oak Ridge

Table 5.4. Summary of ORNL waste area groupings, 1992

\begin{tabular}{|c|c|c|}
\hline WAG & Description & $\begin{array}{l}\text { Number } \\
\text { of sites }{ }^{a}\end{array}$ \\
\hline 1 & Main plant area & 117 \\
\hline 2 & White Oak Creek/White Oak Lake & 2 \\
\hline 3 & SWSA 3 & 3 \\
\hline 4 & SWSA 4 & 3 \\
\hline 5 & SWSA 5 & 28 \\
\hline 6 & SWSA 6 & 3 \\
\hline 7 & LLW pits and trenches area & 19 \\
\hline 8 & Melton Valley area & 35 \\
\hline 9 & Homogeneous reactor experiment (HRE) area & 13 \\
\hline 10 & Hydrofracture injection wells and grout sheets & $4^{b}$ \\
\hline 11 & White Wing scrapyard & 1 \\
\hline 12 & Closed contractors' landfill & 1 \\
\hline 13 & Environmental research areas & 2 \\
\hline 14 & Tower Shielding Facility (TSF) & 2 \\
\hline 15 & ORNL facilities at Y-12 Plant & 14 \\
\hline 16 & Health Physiç Research Reactor area & 5 \\
\hline 17 & ORNL services area & 8 \\
\hline 18 & Consolidated fuel reprocessing area & 10 \\
\hline 19 & Hazardous waste treatment and storage facility & 8 \\
\hline \multirow[t]{3}{*}{20} & Oak Ridge land farm & 1 \\
\hline & Total & 279 \\
\hline & Additional Sites & \\
\hline$c$ & Surplus-contaminated facilities & 29 \\
\hline
\end{tabular}

"Source: July 18, 1991, letter from Lanny Bates, Director Environmental Restoration, to Robert Sleeman, DOE-OR.

${ }^{b}$ Principal sites located underground beneath WAG 5.

cNot applicable.

includes White Oak Lake, White Oak Dam, and the embayment. The location of WAG 2 is shown in Fig. 5.23.

In addition to natural drainage, White Oak Creek has received treated and untreated effluents and reactor cooling water from ORNL activities since 1943. Controlled releases include those from the Nonradiological Wastewater Treatment Facility, the sewage treatment plant, and a variety of process waste holdup ponds throughout the ORNL main plant area (WAG 1). It also receives groundwater discharge and surface drainage from WAGs $3,4,5,6,7,8,9$, and 17.

There is little doubt that WAG 2 represents a source of continuing contaminant release (radionuclides and/or hazardous chemicals) to the Clinch River. While it is known that WAG 2 receives groundwater contamination from other WAGs, the extent to which WAG 2 may be contributing to groundwater contamination is yet to be determined.

\subsubsection{WAG 3}

WAG 3 is located in Bethel Valley about $1 \mathrm{~km}$ (0.6 mile) west of the main plant area (Fig. 5.23). WAG 3 is composed of three solid waste management units: solid waste storage area (SWSA) 3, the Closed Scrap Metal Area (1562), and the currently operating Contractors' Landfill (1554).

SWSA 3 and the Closed Scrap Metal Area are inactive landfills known to contain radioactive solid wastes and surplus materials generated at ORNL from 1946 to 1979. Burial of solid waste ceased at this site in 1951; however, the site continued to be used as an above-ground scrap metal storage area until 1979. Sometime during the period from 1946 to 1949, radioactive solid wastes removed from SWSA 2 were buried at this site. In 1979, most of the scrap metal stored above ground at SWSA 3 was either transferred to other storage areas or buried on 


\section{Environmental Report Vol. 1, Oak Ridge}

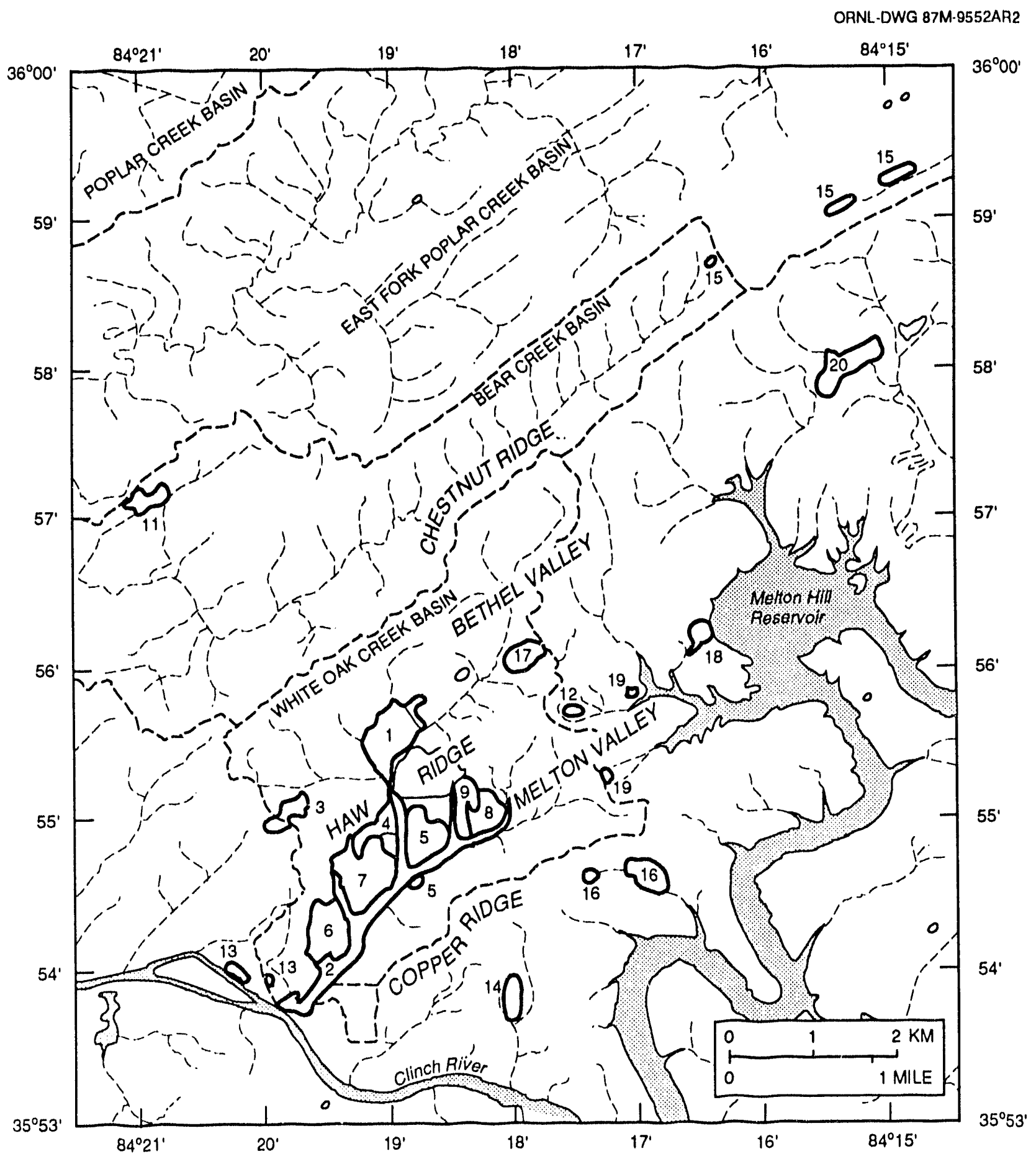

Fig. 5.23. Locations of ORNL waste area groupings (WAGs). 
site in a triangular-shaped disposal area immediately south of SWSA 3.

Records of the composition of radioactive solid waste buried in SWSA 3 were destroyed in a fire in 1961. Sketches and drawings of the site indicate that alpha and beta-gamma wastes were segregated and buried in separate areas or trenches. Chemical wastes were probably also buried in SWSA 3 because there are no records of disposal elsewhere. Although the information is sketchy, the larger scrap metal equipment (such as tanks and drums) stored on the surface at this site was also probably contaminated. Because only a portion of this material is now buried in the Closed Scrap Metal Area, it is not possible to estimate the amount of contamination that exists in this solid waste management unit.

The Contractors' Landfill was opened in 1975 and is used to dispose of various uncontaminated construction materials. No contaminated waste or asbestos is to be buried at the site. ORNL disposal procedures require that only non-RCRA, nonradioactive solid wastes are to be buried in the Contractors' Landfill.

\subsubsection{WAG 4}

WAG 4 is located in Melton Valley about $0.8 \mathrm{~km}$ ( 0.5 mile) southwest of the main ORNL plant site (Fig. 5.23). It is comprised of the SWSA 4 waste disposal area, liquid low-level waste (LLLW) transfer lines and the experimental Pilot Pit Area (Area 7811).

SWSA 4 was opened for routine burial of solid radioactive contaminated wastes in 1951. From 1955 to 1963, Oak Ridge was designated by the Atomic Energy Commission as the Southern Regional Burial Ground; as such, SWSA 4 received a wide variety of poorly characterized wastes (including radioactive waste) from about 50 agencies. These solid wastes consisted of paper, clothing, equipment, filters, animal carcasses, and related laboratory wastes. About $50 \%$ of the waste was received from sources outside of Oak Ridge facilities. Wastes were placed in trenches, shallow auger holes, and in piles on the ground, for covering at a later date.

LLLW was transported from storage tanks at the main ORNL complex to waste pits and trenches in Melton Valley (WAG 7), and later to the hydrofracture site, through underground transfer lines from 1954 to 1975. The Pilot Pit Area (Area 7811) was constructed for use in pilnt-scale radioactive waste disposal studies from 1955 to 1959: three large concrete cylinders containing experimental equipment remain embedded in the ground. A control building and asphalt pad have been used for storage through the years.

\subsubsection{WAG 5}

WAG 5 is located directly south of the ORNL main plant in Melton Valley (Fig. 5.23). Geologically, WAG 5 is within the White Oak Mountain thrust block and is underlain by strata of the Middle to Late Cambrian Conasauga Group. This WAG contains 28 sites, 13 of which are tanks that were used to store LLLW prior to disposal by the hydrofracture process. WAG 5 also includes the surface facilities constructed in support of both the old and new hydrofracture facilities. The largest land areas in WAG 5 are devoted to SWSA 5 and the Transuranic Waste Storage Area. The remaining sites are support facilities for ORNL's hydrofracture operations, two LLW pipeline leak/spill sites, and an impoundment in SWSA 5 used to dewater sludge from the original Process Waste Treatment Facility. At present, LLW tanks at the new hydrofracture facility are being used to store evaporator concentrates pending a decision regarding ultimate disposal of these wastes.

SWSA 5 was used to dispose of solid LLW generated at ORNL from 1959 to 1973. From 1959 to 1963 the burial ground served as the Southeastern Regional Burial Ground for the Atomic Energy Commission. At the time SWSA 5 burial operations were initiated, a portion of the site, about 10 acres, was set aside for the retrievable storage of transuranic wastes.

The WAG 5 boundary includes the old and new hydrofracture installations. Because Melton Branch flows between the old and new hydrofracture facilities, the new hydrofracture facility has a separate boundary.

\subsubsection{WAG 6}

WAG 6 consists of three solid waste management units: (1) SWSA 6, (2) the emergency waste basin, and (3) the explosives detonation trench. The location of WAG 6 is shown in Fig. 5.23. SWSA 6 is located 
in Melton Valley, northwest of White Oak Lake and southeast of Lagoon Road and Haw Ridge. The site is about $2 \mathrm{~km}$ ( 1.2 miles) south of the main ORNL complex. Waste burials at the 68 -acre site were initiated in 1973 when SWSA 5 was closed. Various radioactive and chemical wastes were buried in trenches and auger holes. The einergency waste basin was constructed in 1961 to provide storage of wastes that could not be released from ORNL to White Oak Creek. The basin is located northwest of SWSA 6 , and has a capacity of 15 million gal. To date the basin has not been used. Radiological sampling of the small drainage from the basin has shown the presence of some radioactivity. The source of this contamination is not known.

WAG 6 was the first IVAG to be investigated at ORNL by the Environmental Restoration Program. The RCRA Facility Investigation Report for WAG 6 has been completed and is documented in a RCRA Facility investigation report (Energy Systems 1991).

\subsubsection{WAG 7}

WAG 7 is located in Melton Valley about $1.6 \mathrm{~km}$ (1 mile) south of the ORNL main plant area

(Fig. 5.23). The major sites in WAG 7 are the seven pits and trenches used from 1951 to 1966 for the disposal of liquid LLW. WAG 7 also includes a decont Imination facility, three leak sites, a storage area containing shielded transfer tanks and other equipment, and seven fuel wells used to dispose acid solutions primarily containing enriched uranium from Homogeneous Reactor Experiment fuel.

\subsubsection{WAG 8}

WAG 8 is located in Melton Valley, south of the main plant area (Fig. 5.23), and is composed of 35 solid waste management units that are associated with the reactor facilities in Melton Valley. The solid waste management units consist of active LLLW collection and storage tanks, leak/spill sites, a contractors soils area, iadioactive waste ponds and impoundments, chemical and sewage waste treatment facilities, a chemical-waste SWSA, and a mixed-waste SWSA. WAG 8 includes the Molten Salt Reactor Experiment facility and the High Flux Isotope Reactor, the Transuranium Processing Plant, and the Thorium-Uranium Recycle Facility.
Radioactive wastes from these facilities are collected in on-site LLLW tanks and periodically pumped to the main plant area (WAG 1) for storage and treatment. The waste includes demineralizer backwash, regeneration effluents, decontamination fluids, experimental coolant, and drainage from the compartmental areas of filter pits.

\subsubsection{WAG 9}

WAG 9 is located in Melton Valley about $1 \mathrm{~km}$ (0.6 miles) southeast of the ORNL main plant area (Fig. 5.23) and northeast of WAG 8. WAG 9 is composed of three solid waste management units: the Homogeneous Reactor Experiment pond, which was used from 1958 to 1961 to hold contaminated condensate and shield water from the reactor; LLLW collection and storage tanks, which were used from 1957 to 1986; and a septic tank that has been used since 1950 for the treatment of sewage from Building 7501.

Because of the small number of groundwater monitoring wells in WAG 8 ( 9 wells) and WAG 9 (2 wells), they are sampled together. The analytical results for the two WAGs are also reported together.

\subsubsection{WAG 10}

WAG 10 consists of the injection wells and grout sheets associated with two hydrofracture process experimental locations: the Old Hydrofracture Facility and the New Hydrofracture Facility. The facilities themselves are associated with WAGs 5,7 , and 8.

Hydrofracture Experiment Site 1 is located within the boundary of WAG 7 (south of Lagoon Road) and was the site of the first experimental injection of grout (October 1959) as a testing program for observing the fracture pattern created in the shale and for identifying potential operating problems. Injected waste was water tagged with ${ }^{137} \mathrm{Cs}$ and ${ }^{141} \mathrm{Ce}$. Grout consisted of diatomaceous earth and cement.

Hydrofracture Experiment Site 2 is located about $0.8 \mathrm{~km}(0.5$-mile) south of the 7500 (experimental reactor) area (WAG 8 ). The second hydrofracture experiment was designed to duplicate, in scale, an actual disposal operation; however, radioactive tracers were used instead of actual waste. Water 
tagged with ${ }^{137} \mathrm{Cs}$, cement, and bentonite were used in formulating the grout.

The Old Hydrofracture Facility is located about 1.0 mile southwest of the main ORNL complex near the southwest corner of WAG 5. The facility, commissioned in 1963, served as a pilot plant to demonstrate the feasibility of permanent disposal of liquid radioactive waste in impermeable shale formations by hydrofracture methods. Wastes used in the experiments included concentrated LLLW, ${ }^{90} \mathrm{Sr}$, ${ }^{137} \mathrm{Cs},{ }^{244} \mathrm{Cm}$, transuranics, and other unidentified radionuclides.

The New Hydrofracture Facility is located $900 \mathrm{ft}$ southwest of the Old Hydrofracture Facility on the south side of Melton Branch. The facility was constructed to replace the Old Hydrofracture Facility and to serve as the operational LLLW waste disposal system for ORNL. Wastes used in the injections were concentrated LLLW and sludge removed from the Gunite tanks, ${ }^{90} \mathrm{Sr},{ }^{137} \mathrm{Cs},{ }^{244} \mathrm{Cm}$, transuranics, and other nuclides.

\subsubsection{WAG 11}

The White Wing Scrap Yard (WAG 11), a largely wooded area of about 30 acres, is located in the McNew Hollow area on the western edge of East Fork Ridge (Fig. 5.23). It is $1.4 \mathrm{~km}$ (0.9 miles) east of the junction of White Wing Road and the Oak Ridge Turnpike. Geologically, the White Oak thrust fault bisects WAG 11. Lower-Cambrian-age strata of the Rome Formation occurs southwest of the fault and overlies the younger Ordovician-age Chickainauga Limestone northeast of the fault. There is only one solid waste management unit in WAG 11.

The White Wing Scrap Yard was used for the aboveground storage of contaminated material from ORNL, the K-25 Site, and the Y-12 Plant. The material stored at the site by ORNL consisted largely of contaminated steel tanks; trucks; earth-moving equipment; assorted large pieces of steel, stainless steel, and aluminum; and reactor cell vessels removed during the cleanup of Building 3019 at ORNL.

The area began receiving material (primarily metal, glass, concrete, and trash with alpha, beta, and gamma contamination) in the early 1950 s. Information regarding possible hazardous waste contamination has not been found. The precise dates of material storage are uncertain, as is the time when the area was closed to further storage. In 1966, efforts were begun to clean up the area by the disposal of contaminated materials in ORNL's SWSA 5 and by the sale of uncontaminated material to an outside contractor for scrap. Cleanup continued at least into 1970, and removal of contaminated soil began in the same year. Some scrap metal, concrete, and other trash are still located in the area. Numerous radioactive areas, steel drums, and PCB-contaminated soil were identified during surface radiological investigations conducted during 1989 and 1990 at WAG 11 . The amount of material or contaminated soil remaining in the area is not known.

\subsubsection{WAG 17}

WAG 17 is located about $1.6 \mathrm{~km}$ ( 1 mile) directly east of the ORNL main plant area. This area has served as the major craft and machine shop area for ORNL since the late 1940s. The area includes the receiving and shipping departments, machine shops, carpenter shops, paint shops, lead-burning facilities, garage facilities, welding facilities, and material storage areas that are required to support ORNL's routine and experimental operations. It is composed of eight solid waste management units; a former septic tank now used as a sewage collection/pumping station for the area and seven tanks used for waste oil collection and storage and for storage of photographic reproduction wastes.

\subsubsection{ORNL 1992 Groundwater Quality Well Installation, Development, and Sampling Activities}

Groundwater quality monitoring wells for the WAGs are designated as upgradient or downgradient (perimeter), depending on their location relative to the general direction of ground water flow. Upgradient wells are located to provide groundwater samples that are not expected to be affected by possible leakage from the site. Downgradient wells are positioned along the perimeter of the site to detect possible groundwater contaminant migration from the site. One hundred seventy-three perimeter monitoring wells have been installed for the WAGs. As remedial investigations proceed, characterization wells will be installed inside the WAG perimeters to investigate contaminant transport. There are no groundwater 


\section{Environmental Report Vol. 1, Oak Ridge}

quality monitoring wells installed in WAG 10. The injection wells previously described are located in WAGs 5, 7, and 8; plugging and abandonment of them was initiated in 1992.

SWSA 6 is the only currently operating disposal area for low-level radioactive waste at ORNL. Interim-status assessment monitoring of groundwater under RCRA regulations was conducted semiannually during 1992. The remaining WAGs are currently remedial action sites regulated under RCRA 3004(u), which does not specify sampling schedules. ORNL samples groundwater quality at the remaining WAGs on a rotation basis. A summary of the groundwater surveillance program is presented in Table 5.5.

In December 1989, a groundwater quality assessment plan was submitted through DOE for transmittal to TDEC and EPA. The plan describes the general field investigation approach for assessment monitoring and the detailed sampling and analysis plan to be used in defining the horizontal and vertical extent of the contaminant plume, characterization of contaminants, and rates and directions of movement. The annual Groundwater Quality Assessment Report for SWSA 6 for 1991 was submitted to TDEC in
March 1992. The report recommended continuing the sampling strategy based on results of the analyses. Eight wells were sampled quarterly for volatile organics and radioactivity parameters. Two wells were determined not to reflect groundwater conditions at SWSA 6 , and were reassigned to the WAG 2 network after first quarter of 1992. The data for these wells are reported as part of WAG 2. The other 16 wells were recommended to be sampled quarterly for indicator parameters. This was done during first quarter 1992. On the basis of a recommendation by TDEC in April 1992, the parameters for the semiannual assessment wells were modified to be the same as the parameters for the quarterly assessment wells.

\subsubsection{ORNL Groundwater Monitoring Results}

ORNL groundwater data are summarized for each WAG in Tables 5.46-5.55 of Vol. 2. The results for detected analytes are presented by well type (i.e., upgradient and downgradient). Each table presents the number of times an analyte was detected out of the total number of samples, summary statistics for

Table 5.5. Summary of the groundwater surveillance program at ORNL, 1992

\begin{tabular}{|c|c|c|c|c|}
\hline WAG & $\begin{array}{l}\text { Regulatory } \\
\text { status }\end{array}$ & $\begin{array}{l}\text { Upgradient } \\
\text { wells }\end{array}$ & $\begin{array}{c}\text { Downgradient } \\
\text { wells }\end{array}$ & $\begin{array}{l}\text { Parameters } \\
\text { monitored }^{a}\end{array}$ \\
\hline 1 & $3004(u)$ & 3 & 24 & Standard \\
\hline 2 & $3004(u)$ & 12 & 8 & $\begin{array}{l}\text { Standard + ammonia, } \\
\text { total cyanide, } \\
\text { total sulfide }\end{array}$ \\
\hline 3 & $3004(u)$ & 3 & 12 & Standard \\
\hline 4 & $3004(\mathrm{u})$ & 4 & 11 & Standard \\
\hline 5 & $3004(u)$ & 2 & 20 & Standard \\
\hline 6 & $\begin{array}{l}\mathrm{RCRA}^{b} \text { _assessment } \\
\text { monitoring }\end{array}$ & 7 & 17 & $\begin{array}{l}\text { Volatile organics + } \\
\text { alkalinity, gross alpha, } \\
{ }^{3} \mathrm{H},{ }^{137} \mathrm{Cs},{ }^{60} \mathrm{Co} \text {, } \\
\text { total rad } \mathrm{Sr}+\text { standard } \\
\text { field measurements }\end{array}$ \\
\hline 7 & $3004(u)$ & 2 & 14 & Standard \\
\hline 8 and 9 & $3004(u)$ & 2 & 9 & Standard \\
\hline & $3004(u)$ & 6 & 5 & Standard \\
\hline 17 & $3004(u)$ & 4 & 4 & Standard \\
\hline
\end{tabular}

${ }^{a}$ Standard: volatile and semi-volatile organics; total organic carbon; total organic halide; metals by inductively coupled plasma (ICP); mercury by atomic absorption; arsenic, lead, antimony, selenium, and thallium by atomic absorption (earlier in the year these were analyzed by ICP mass spectrometry); anions (bromide, chloride, fluoride, nitrate, phosphate, and sulfate); total phenolics; total suspended solids; total dissolved solids; alkalinity; gross alpha and beta; ${ }^{3} \mathrm{H} ;{ }^{137} \mathrm{Cs}$ and ${ }^{60} \mathrm{Co}$; and total radioactive $\mathrm{Sr}$.

Standard field measurements: $\mathrm{pH}$, conductivity, turbidity, oxidation/reduction potential, temperature, dissolved oxygen.

'The appropriate regulatory authority at SWSA 6 in WAG 6 is RCRA. The regulatory authority is expected to change to CERCLA, with RCRA as an applicable and appropriate requirement.

\section{5-54 Groundwater}


all samples where at least one resu': Nils detected, and the number of values that exceeded regulatory reference values. Various prefixes with different meanings precede the maxima and minima: " $U$ " (was not detected at that level), "<" (could not be quantified below that level), "J" (below quantification, estimated), " $B$ " (found in the associated laboratory blank), "JB" (estimated and found in associated laboratory blank), "E" (value exceeded instrument calibration range, estimated), and " $Y$ " (value from reanalysis after dilution when calibration range was exceeded). Five times the analytical detection limit was used as a rough rule for assessing the presence of organic contaminants.

All radionuclide values are corrected for background. A radionuclide value is determined to be significantly greater than zero when the value exceeds 1.645 times its estimated standard error.

In statistical summaries, when at least one of the results contributing to the average is less than the detection limit, the average value is identified with the tilde $(\sim)$ prefix.

When results are reported as undetected ("U") or not quantifiable ("<"), the sample mean and standard error of the mean are affected by these values; they become "biased"-biased high for the mean and low for the standard error of the mean. That is, the sample standard error of the mean is estimating something smaller than the true standard error.

A further consequence of the bias is an increased likelihood that a population mean will be declared greater than zero in a statistical test using the biased sample mean and standard error. A statistically significant result may be a consequence of the number of values below the detection limit. If, however, there were a number of values above the detection limit, the conclusion that the true mean is greater than zero may be valid even though the estimate of true mean is biased.

With respect to the volatile organic results, a number of the wells had vinyl chloride results of "U $10 \mu \mathrm{g} / \mathrm{L}$." As individual results they appear to exceed the primary drinking water standard of $2 \mu \mathrm{g} / \mathrm{L}$ and, in the summary tables in Vol. 2, these are included in the number of values exceeding a reference value. A better way to interpret the individual results is that vinyl chloride was undetected and that the instrument used in the analysis was able to detect vinyl chloride accurately at or above $10 \mu \mathrm{g} / \mathrm{L}$. It is unlikely that vinyl chloride was present in the sample; an estimated value (i.e., a value less than 10 , accompanied by a "J" prefix) would have been returned by the laboratory if the instrument detected vinyl chloride. The instances where this situation occurs are noted in the textual description of the results.

Groundwater and its related quality are not regulated like other environmental media (e.g., surface water by NPDES, air by the Clean Air Act). Consequently, there are no mandated groundwater quality criteria. In an effort to provide a basis for evaluation of analytical results and for assessment of groundwater quality at ORNL WAGs, drinking water limits and DOE derived concentration guides have been used in preparation of the data tables in Vol. 2 and their related discussions in Vol. 1 . It should be emphasized that, although drinking water limits are used herein, it is unrealistic to assume that members of the public are going to drink groundwater from ORNL WAGs.

Sampling and analyses have been conducted for several years at WAG 6 and WAG 1 . WAG 6 is an active disposal area, and WAG 1 is considered a high-priority location for investigation. The investigations at the other WAGs have been initiated to collect preliminary data. They are lower-priority sites and consequently are represented by less information at this time.

\subsubsection{WAG 1 Results}

The perimeter wells in WAG 1 have been sampled seven times, most recently during January and February 1992. A summary of the analytical results is presented in Table 5.46, Vol. 2. One well was dry during the sampling period; results for the remaining 26 wells are summarized in the table.

Radionuclides have been detected in a number of the wells: ${ }^{3} \mathrm{H}$, total radioactive strontium, gross alpha, and gross beta activities above drinking water limits. The highest levels of radioactivity continue to be observed in Well 812, located in the northwest plant area. Gross alpha activity $(300 \mathrm{pCi} / \mathrm{L}$ unfiltered and filtered) has been determined in the past to consist mainly of ${ }^{234} \mathrm{U},{ }^{235} \mathrm{U}$, and ${ }^{238} \mathrm{U}$; however, alpha isotopic analyses were not performed in 1992. Gross beta activity at Well $812(14,000 \mathrm{pCi} / \mathrm{L}$ unfiltered, $13,000 \mathrm{pCi} / \mathrm{L}$ filtered) apparently consists mainly of 


\section{Environmental Report Vol. 1, Oak Ridge}

total radioactive strontium $(8,400 \mathrm{PCi} / \mathrm{L}$ unfiltered, $7,800 \mathrm{pCi} / \mathrm{L}$ filtered). The other wells containing elevated gross beta activity are located in the southwest plant area and in the western plant area, where observed concentrations of total radioactive strontium exceeded the drinking water limit for ${ }^{91} \mathrm{Sr}$. Concentrations of ${ }^{3} \mathrm{H}(30,000 \mathrm{pCi} / \mathrm{L})$ at well $830 \mathrm{in}$ the southwest plant area exceeded drinking water limits.

Most of the wells show evidence of volatile organic contamination; however, most of this contamination was also detected in the laboratory blanks or was at levels within five times the analytical detection limit, and did not exceed regulatory limits. Benzene was detected at three wells slightly above Tennessee water quality criteria but within five times the analytical detection limit. Table 5.46 in Vol. 2 shows 23 exceedences of vinyl chloride at downgradient wells; all but one of these are "U $10 \mu \mathrm{g} / \mathrm{L}$ " values. (See the beginning of Sect. 5.4 .3 for an explanation.) The value that is detected is less than five times the analytical detection limit for vinyl chloride. None of the results for metals exceeded the primary drinking water standards.

\subsubsection{WAG 2 Results}

The 18 original perimeter wells at WAG 2 were sampled for the second time during June and July 1992. Wells 1243 and 1244 were sampled as part of WAG 6 in the first quarter and then as part of WAG 2 in June and July. A summary of the analytical results is presented in Table 5.47 of Vol. 2. The results for 1992 sampling are similar to results from 1991 sampling.

At WAG 2, most of the downgradient wells are to the west and downstream. The upgradient wells are to the east and upstream. As was discussed in Sect 5.4.1.2. WAG 2 receives contamination from many other WAGs, and this seems to be reflected in the data for many of the WAG 2 wells. For example, four of the WAG 2 wells that exhibited high levels of ${ }^{3} \mathrm{H}$ are located south of and downgradient of WAGs 5 , 6 , and 8 . All of the WAG 2 wells show evidence of radioactive contamination, including gross alpha and gross beta activity and ${ }^{3} \mathrm{H}$. In addition to the four wells that had elevated levels of ${ }^{3} \mathrm{H}$, gross alpha activity slightly above primary drinking water limits was detected at Well $1244(21 \mathrm{pCi} / \mathrm{L}$ filtered, $17 \mathrm{pCi} / \mathrm{L}$ unfiltered), west of WAG 7. Well 1244 also had gross beta activity above primary drinking water limits $(1,200 \mathrm{pCi} / \mathrm{L}$ unfiltered, $970 \mathrm{pCi} / \mathrm{L}$ filtered) and ${ }^{61} \mathrm{C} O \mathrm{O}$ in excess of $\mathrm{DOE}$ derived concentration guides $(430 \mathrm{pCi} / \mathrm{L}$ unfiltered, $380 \mathrm{pCi} / \mathrm{L}$ filtered). At Well 1191, south of WAG 6 , the elevated gross beta activity concentration $(1,600 \mathrm{pCi} / \mathrm{L}$ unfiltered, $1,400 \mathrm{pCi} / \mathrm{L}$ filtered) apparently consists mainly of total radioactive strontium $(860 \mathrm{pCi} / \mathrm{L}$ unfiltered, $810 \mathrm{pCi} / \mathrm{L}$ filtered). The elevated levels of ${ }^{3} \mathrm{H}$ and total radioactive strontium in the perimeter wells at White Oak Dam are believed to be the result of surface water underflow at the dam, not groundwater contamination.

Low levels of volatile organic contamination were detected at more than half of the wells. With the exception of Well 1190, which is south of and downgradient of WAG 6 , most of this contamination was also detected in the laboratory blanks or was at levels within five times the analytical detection limit, and did not exceed regulatory limits. Well 1190 exhibited elevated levels of 1,1-dichloroethene, benzene, chlorobenzene, toluene, and trichloroethene; the 1,1-dichloroethene, benzene, and trichloroethene values were in excess of Tennessee general water quality criteria.

Nitrate $(11 \mathrm{mg} / \mathrm{L}$ unfiltered) was detected at a level slightly above primary drinking water limits at upgradient Well 1244. Chromium $(1.0 \mathrm{mg} / \mathrm{L}$ unfiltered) was detected above Tennessee general water quality criteria at Well 1192 south of WAG 6. Arsenic was detected in the unfiltered samples above Tennessee general water quality criteria at two wells. No other wells had results for metals that exceeded regulatory limits.

\subsubsection{WAG 3 Results}

The perimeter wells at WAG 3 were sampled for the second time during August and September 1992. A summary of the analytical results is presented in Table 5.48 in Vol. 2. Well 1247 was dry during the sampling period; results for the remaining 14 wells are summarized.

WAG 3 is located on a north-facing slope with its upgradient wells to the south. The long axis of the site runs east to west; consequently, most of the downgradient wells are along the northern border.

\section{5-56 Groundwater}


Total radioactive strontium is present along the entire northern perimeter of the site. Values exceeding the primary drinking water limit were observed at four wells. Apparently, the gross beta signatures are mainly attributable to total radioactive strontium. The data for the eastern and northeastern boundaries show evidence radioactive contamination, including ${ }^{3} \mathrm{H}$ and gross alpha activity. The data for the northwest boundary show the presence of ${ }^{3} \mathrm{H}$; Well 994 had ${ }^{3} \mathrm{H}$ concentrations in excess of the primary drinking water limit. A few of the wells had volatile organics detected but at levels within five times the analytical detection limit. Trichloroethane was detected at $10 \mu \mathrm{g} / \mathrm{L}$ at one well. This is two times the analytical detection limit but still exceeds the primary drinking water limit. None of the results for metals exceeded the primary drinking water standards. Fluoride was detected at a level slightly above primary drinking water limits at one western downgradient well.

\subsubsection{WAG 4 Results}

The perimeter wells at WAG 4 were sampled for the third time during October and November 1992. A summary of the analytical results is presented in Table 5.49 in Vol. 2. WAG 4 is located on a south-facing slope with its upgradient wells to the north. The long axis of the site runs east to west. Consequently, the downgradient wells are along the southern border. All of the WAG boundaries show evidence of radioactive contamination, including gross alpha activity, gross beta activity, and ${ }^{3} \mathrm{H}$. The eastern boundary shows the highest levels of radioactivity, with ${ }^{3} \mathrm{H}$ values as high as $7,800,000 \mathrm{pCi} / \mathrm{L}$.

Concentrations of 1,1-dichloroethene, 1,2-dichloroethene, trichloroethene, and vinyl chloride are present on the eastern boundary. In particular, two wells show levels of 1,2-dichloroethene up to $930 \mu \mathrm{g} / \mathrm{L}, 1,1$-dichloroethene up to $10 \mu \mathrm{g} / \mathrm{L}$, trichloroethene up to $140 \mu \mathrm{g} / \mathrm{L}$, and vinyl chloride up to $1,000 \mu \mathrm{g} / \mathrm{L}$. Table 5.49 (Vol. 2) shows 11 exceedences of vinyl chloride at downgradient wells; nine of these are "U $10 \mu \mathrm{g} / \mathrm{L}$ " values. (See the beginning of Sect. 5.4 .3 for an explanation.)

Fluoride was detected at a level that exceeded primary drinking water limits at one eastern downgradient well, and nitrate was detected at a level that exceeded primary drinking water limits at a southeastern downgradient well.

\subsubsection{WAG 5 Results}

The perimeter wells at WAG 5 were sampled most recently during September and October 1992. A summary of the analytical results is presented in Table 5.50 in Vol. 2. (In addition to the following discussion of WAG 5 results, the discussion of WAG 2 results raises the possibility of contamination of WAG 2 from WAG 5.) Wells in WAG 5 have been sampled three times. The results for 1992 sampling are similar to results from previous sampling.

WAG 5 is the main source of ${ }^{3} \mathrm{H}$ seepage to Melton Branch. Tritium contamination is particularly prevalent on the southern and western boundaries, with values ranging from $1,100,000 \mathrm{pCi} / \mathrm{L}$ to 240,000,000 pCi/L.

Total radioactive strontium appears to be the major beta emitter (other than ${ }^{3} \mathrm{H}$ ) found in WAG 5 groundwater. It is found mainly on the southern perimeter; concentrations range up to $890 \mathrm{pCi} / \mathrm{L}$.

Alpha activity above drinking water standards was observed in only one well on the northwestern boundary of the WAG. One upgradient well exceeded regulatory limits for total radioactive strontium (14 pCi/L).

Volatile organic compounds were detected on the southern and western boundaries, including 1,2-dichloroethene, vinyl chloride, trichloroethene, and benzene. Several wells exceeded drinking water standards for these contaminants. Table 5.50 in Vol. 2 shows 20 exceedences of vinyl chloride at downgradient wells; 15 of these are "U $10 \mu \mathrm{g} / \mathrm{L}$ " values. (See the beginning of Sect. 5.4.3 for an explanation.)

The highest levels of concern were vinyl chloride, which was measured at $6,400 \mu \mathrm{g} / \mathrm{L}$; 1,2-dichloroethene at $5,200 \mu \mathrm{g} / \mathrm{L} ;$ trichloroethane at $26 \mu \mathrm{g} / \mathrm{L}$; and benzene at $33 \mu \mathrm{g} / \mathrm{L}$, in Well 978 on the western boundary.

\subsubsection{WAG 6 Results}

Eight of the perimeter wells at WAG 6 are of major concern with respect to volatile organic and radioactive contamination, and they were sampled during each quarter in 1992 . The remaining 16 wells 
were sampled during liebruary to March and July to August 1992. A summary of the analytical results is presented in lables 5.51 and 5.52 in Vol. 2. (In addition to the following discussion of WAG 6 results, the discussion of WA $i 2$ results raises the possibility of contamination of WAC 2 from WA $(6$.$) Results obtained during the 1992$ sampling periods were comparable to those obtaned duting 1988 and 1989 defection monitoring and 1990 and 1991 assessment monitoring.

The eight wells of major eoneern are wells on the northeastern perimeter or are additional wells east of SWSA 6. Volatile organic compound contamination is apparently isolated in the area around Wells 842 and 841 . During 1992, 1,2-dichloroethane $(7 \mu \mathrm{g} / \mathrm{L}$. to $10 \mu \mathrm{g} / \mathrm{L}$.), carbon tetrachloride $(34 \mu \mathrm{g} / \mathrm{l}, 1042 \mu \mathrm{g} / \mathrm{L})$, and trichloroethane $(160 \mu \mathrm{g} / \mathrm{l}$, 10 $200 \mu \mathrm{g} / \mathrm{l}$ ) were detected al Well 842 above drinking water limits.

Elevated levels of ${ }^{3} \mathrm{H}$ are found along the eastern and southern perimeters, maximum concentrations ranging from 32,000$) \mathrm{pCi} / \mathrm{L}$ to $1,800,0(0) \mathrm{pCi} / \mathrm{L}$.

\subsubsection{WAG 7 Results}

'lhe perimeter wells at WAG 7 were sampled for the third time during April and May 1992. A

summary of the analytical results is presented in lable 5.53 of $\mathrm{Vol}, 2$.

Tritium was detected in more than half of the wells hut is highest along the western perimeter next 10 SWSA 6 (up to 890,000 pCi/l. alt Well 1076). Compared with previous years, 'H appears to be decreasing at some of the wells.

Ciross bela was detected at a level exceeding primary drinking water levels at one upgradient well, probably altributable to the "Co also detected at the well. Analyses for "le were performed on samples from four wells; levels defected downgradient ranged from $26 \mathrm{pCi} / \mathrm{l} .107,600 \mathrm{pCi} / \mathrm{L}$.

Some volatile organics were detected at some of the wells but the values were within five times the analytical detection limit. Selenium was detected above Tennessee general water quality criteria at one downgradient well. No other wells had results for metals that exceeded regulatory limits. Huoride and nitrate were detected at levels that exeeeded primary drinking water limits all three downgradient wells.

\subsubsection{WAGs 8 and 9 Results}

The perimeter wells at WA is 8 and 9 were sampled for the second time during May and June 1992. A summary of the analytical results is presented in Table $5.54 \mathrm{in} \mathrm{Vol.} \mathrm{2.} \mathrm{(In} \mathrm{addition} \mathrm{to} \mathrm{the}$ following discussion of WAGis 8 and 9 results, the discussion of $W \wedge(; 2$ results raises the possibility of contamination of WAG 2 from WAGs 8 and 9.)

The two upgradient wells are localed north of the WAGs. TWo of the downgradient wells are localed northwest of the WAGs, Iwo are located south of WAG 8 , and the remaining four are between WACis 8 and 9 .

All of the perimeter wells show evidence of radioactive contamination. On the northwest perimeter, Well 1088 has 'H contamination $(57,000 \mathrm{pCi} / \mathrm{l}$ ) and Well 1087 has total radioactive strontium contamination (up to $590 \mathrm{pCi} / \mathrm{L}$.). 'l'otal radioactive strontium levels exceed the drinking water limits at the wells between the WAGis (up to $1,100 \mathrm{pCi} / \mathrm{L}$ at Well 1097). The data for two of the wells between the WAGs indicate the presence of gross beta activity attributable to lotal radioactive strontium.

Although volatile organics were detected at downgradient wells, the values were within five times the analytical detection limit. None of the data for the upgradient wells show evidence of volatile organic contamination. The results for metals do not exceed the primary drinking water standards.

\subsubsection{WAG 11 Results}

The second sampling of WAC 11 was initiated in December 1992 and was completed in January 1993. The data will be reported in the Oak Ridge Reservation Environmental Report for l993.

\subsubsection{WAG 17 Results}

The perimeter wells at WA $; 17$ were sampled for the second time during April 1992. A summary of the analytical results is presented in Table $5.55 \mathrm{in}$ Vol. 2. WAC 17 is located on a northwest-facing slope, with its upgradient wells on the eastern border and downgradient wells on the western border. 'The

\section{5-58 Groundwater}




\section{Environmental Report Vol. 1, Oak Ridge}

data for the eastern and western boundaries show evidence of radioactive contamination, including gross alpha activity, gross beta activity, and ${ }^{3} \mathrm{H}$. Gross alpha activity of $23 \mathrm{pCi} / \mathrm{L}$ and $21 \mathrm{pCi} / \mathrm{L}$ were the only values to exceed drinking water limits. The data for the southeastern and southwestern boundaries show evidence of volatile organic contamination. The contamination is primarily in one well. The pollutants include trichloroethene, vinyl chloride, benzene, 1,2-dichloroethene, 1,1-dichloroethene, and tetrachloroethene. None of the results for metals exceeded the primary drinking water standards. Table 5.55 in Vol. 2 shows four exceedences of vinyl chloride; three of these were "U $10 \mu \mathrm{g} / \mathrm{L}$ " values. (See the beginning of Sect. 5.4.3 for an explanation.)

\subsubsection{Future ORNL Groundwater Quality Monitoring Activities}

The groundwater quality assessment plan for SWSA 6 will continue to be implemented in 1993. Eight wells will be sampled quarterly to further understand the extent of contamination at SWSA 6. The remaining wells at SWSA 6 will be sampled semiannually during 1992.

The planned sequence for sampling and analysis of groundwater from the remaining nine WAGs is based on the nature and inventory of contaminants at the WAG; near-term release potential; position relative to other potential, hydrologically upgradient sources; regulatory considerations; and costs and funding availability. It is anticipated that a reduced list of parameters will be monitored beginning in October 1993.

The Environmental Monitoring Plan for the Oak Ridge Reservation, approved in September 1992, establishes an ORNL perimeter surveillance monitoring plan. Plant perimeter surveillance monitors the exit pathways that groundwater would travel from the ORNL site to reach the accessible environment (off-reservation). It is designed to monitor any effects ORNL had on local/off-reservation groundwater and/or surface water quality, consistent with the objectives found in DOE Order 5400.1.

\section{$5.5 \quad$ K-25 Site}

\subsubsection{Background}

Groundwater monitoring is conducted at the Oak Ridge K-25 Site to provide for the protection of groundwater resources consistent with federal, state, and local requirements, and in accordance with DOE orders and corporate policy. These requirements consist of support for the K-25 Environmental Restoration Program and compliance with DOE order requirements for environmental monitoring. Groundwater monitoring in support of ER is conducted to fulfill the objectives of RCRA, CERCLA, and Federal Facility Agreement (FFA) requirements. Other programs that are supported through DOE orders include Facilities Decontamination and Decommissioning and Low-Level Waste Disposal. Groundwater monitoring has been integrated to develop an effective plant-wide groundwater monitoring strategy.

Groundwater effluent monitoring at K-25 is focused primarily on investigating and characterizing sites for remediation under RCRA and CERCLA. In the past, activities under CERCLA investigations were conducted for individual SWMUs or groupings of SWMUs. As a result of the FFA, the principal driver at the K-25 Site is CERCLA.

In accordance with the FFA, the potentially contaminated units were grouped into 14 Source OUs and 1 Ground water OU. The Groundwater OU was designated as encompassing Source OUs and areas that may contain unknown waste sites or groundwater contamination plumes (Fig. 5.24). It covers approximately 1200 acres and is bound on the south by Tennessee Highway 58, on the east by Blair Road, on the north by Black Oak Ridge, and on the west by the Clinch River. A plan to characterize K-25 hydrogeology, issued in June 1992, outlines tasks necessary to support an assessment of the groundwater. Previous evaluations of groundwater flow systems at K-25 have specifically addressed the hydrogeology proximal to waste source areas. Hydrogeologic characterization activities are currently und :r way to compile historical records, 
ORNL-DWG 93M-9618

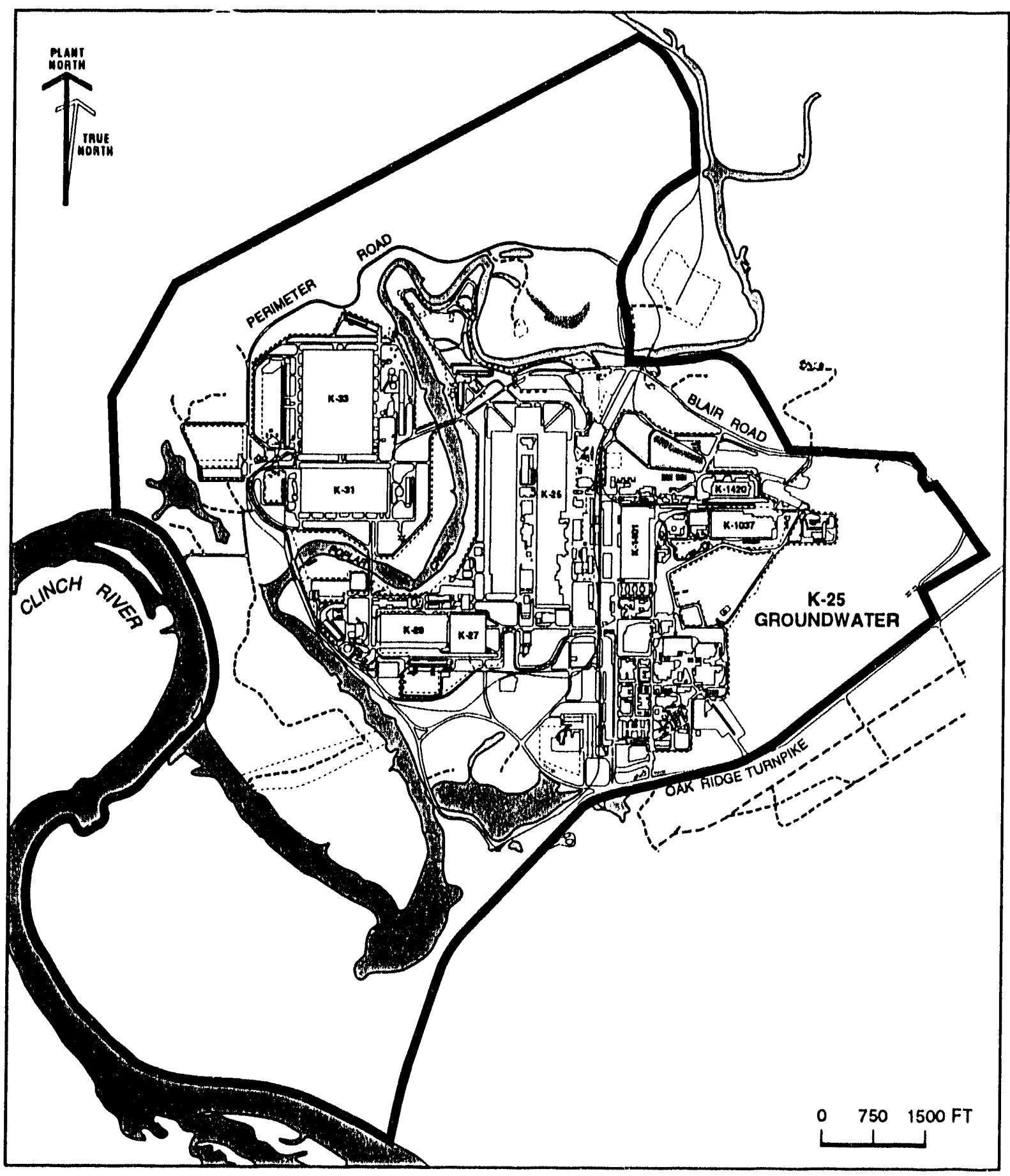

Fig. 5.24. K-25 Site Groundwater Operable Unit. 


\section{Environmental Report Vol. 1, Oak Ridge}

including aerial photos, subsurface data from engineering records, and historical analytical data.

The need for and extent of groundwater investigations at each Source OU will be determined on a case-by-case basis. At certain OUs, interim actions for groundwater contamination may be proposed and implemented by the Source OU project manager through coordination with the $\mathrm{GW}$ project manager and the GW Program.

\subsubsection{K-25 Site Hydrogeology}

Current data indicate that both the unconsolidated zone water table and the bedrock piezometric surface at K-25 generally follow a subdued replica of the present plant topography. Much of the K-25 Site has been cut and filled extensively during building construction. The unconsolidated zone is significantly influenced by the preconstruction surface topography with groundwater flowing generally toward Mitchell Branch, Poplar Creek, and the Clinch River. It is unknown whether there is a significant storm-flow component within the shallow groundwater flow in unconsolidated deposits mantling carbonates or noncarbonates, as described in other ORR areas.

Planned activities for 1993 include the installation and operation of continuous water level recording devices in ten existing bedrock wells within the Groundwater OU. These devices will identify rapid water level fluctuations in the bedrock zone that are not reflected during the current quarterly measurement schedule. The identification of these fluctuations is critical to properly monitor groundwater quality in support of Groundwater OU activities.

Thirty-four percent of historical carbonate borings encountered cavities, two with cave deposits, revealing the presence of an extensive karst conduit network within the Groundwater OU. Cavities depicted on foundation boring logs also document a well-developed carbonate aquifer at the K-25 Site. The presence of additional solution cavities near the K-25 Site, including stream-worn cobbles brought up from a solution conduit, also support the existence of a mature conduit system.

The pathways of these solution conduits are very important, as groundwater and contaminants in carbonate aquifers typically converge to conduits where the hydraulic head is lowest. Conceptually, the pattern of the K-25 solution conduit system (cives) is most likely that of branchwork calves. This is a dendritic cave netwoik, with tributaries converging toward higher-order passages that become fewer and larger in the downstream direction. Groundwater typically follows prominent fracture sets (e.g.. northeast and southeast) and bedding planes, following the steepest descent pathway available, trending continuously downward generally down the stratal dip. Once base level is reached, conduit passage geometries are no longer similar to rectilinear canyons but instead become phreatic strike-oriented passages. These conduits act as convergent flow integrators, channelling infiltration and percolation water from the upper part of the percolation zone through fractures, dissolutionally enlarged fractures, and conduits to one or more spring discharge points. Tracer tests are required to determine flow direction, destination, and velocity of this groundwater within the larger context of the karst groundwater basin.

Groundwater flow, and possibly contaminant transport, can occur along these coalescing flow paths. Rapid groundwater flow is typically present in such carbonate aquifers. It is thus necessary to monitor the dynamics of these systems hourly, rather than quarterly monitoring of water level and water chemistry. A systematic approach to defining the hydrogeology of unconsolidated, noncarbonate, and carbonate K-25 aquifers has been put forth and is now in the first phase of implementation.

\subsubsection{Current Groundwater Monitoring}

Presently, 206 groundwater quality monitoring wells exist at K-25. During 1992, two wells were added to the Groundwater Program when existing boreho!es were converted to monitoring wells. In the past, one-hundred ninety-one of these wells have been sampled for an extended list of baseline monitoring parameters. The remaining wells are scheduled for baseline monitoring in FY 1994. Baseline monitoring is conducted during the first year of service of new, permanent or long-term groundwater monitoring wells installed at the K-25 Site and is necessary to establish a baseline of water quality at new wells. Baseline monitoring consists of four consecutive quarters of sampling for an extensive list of constituents. The extensive list of parameters is justified on the basis of uncertainty 
about the kinds of contaminants that may be encountered in any particular location at the K-25 Site.

\subsubsection{Exit-Pathway Well Surveillance Monitoring}

Exit-pathway groundwater surveillance will be conducted at convergence points where groundwater flows from relatively large areas of the plant and converges before discharging to surface water locations. The perimeter groundwater surveillance network for K-25 is illustrated in Fig. 5.25. At each of the convergence points, groundwater monitoring in both the unconsolidated zone and the bedrock will be supported by monitoring of the surface water. Existing wells have been incorporated into the perimeter surveillance network wherever possible. Four environmental surveillance wells are planned for installation during 1993 to complete the eight well perimeter groundwater surveillance network. Baseline sampling of these wells will begin in FY 1994.

The parameters to be monitored for perimeter groundwater surveillance, after baseline monitoring is complete, are the key indicator contaminants and gross alpha and gross beta radioactivity, which will be analyzed as trend indicators. These key indicators are volatile organic contaminants (VOCs), total uranium, ${ }^{99} \mathrm{Tc}$, and fluoride. VOCs are appropriate indicator contaminants for the K-25 Site because potential VOC contamination sources are distributed widely at K-2.5 and several VOCs have been observed to be quite mobile in the K-25 hydrogeologic environment. Field measurements of other water quality indicators (such as $\mathrm{pH}$, specific conductance, dissolved oxygen content, and oxidation/reduction potential) will be conducted as specified in K-25 Site sampling protocols.

\subsubsection{RCRA Monitoring}

The K-1407-B and K-1407-C Ponds were granted RCRA interim status by TDEC and detection monitoring was implemented at both sites in January 1986 and performed in accordance with the interim slatus RCRA requirements defined under TDEC Rule 1200-1-11-.05(6). Interim status groundwater quality assessment monitoring was initiated at each site in November 1987 in response to statistically significant increases in specific conductance and total organic halogens. The statistical increases in these parameters subsequently were determined to be false positives, and a modified detection monitoring program was approved for the K-1407-C Pond in July 1988 and for K-1407-B Pond in March 1989. Also approved was a change from assessment monitoring to a modified interim status detection monitoring program. The modified detection program was designed to avoid false positive indications from increases in specific conductance, which were demonstrated to be caused by the presence of nonhazardous constituents, and total organic halogens, which were demonstrated to be attributable to a source other than the regulated units. The $\mathrm{K}-1407-\mathrm{B}$ and $\mathrm{K}-1407-\mathrm{C}$ Ponds are scheduled for clean closure under RCRA. Ai that time, the ponds will be subject immediately to CERCLA compliance.

\subsubsection{Groundwater Monitoring Results}

Samples from many wells throughout the plant area indicate high concentrations of iron and manganese in the groundwater. In general, these constituents are not considered in assessing contamination of the area because they occur naturally in high concentrations in the underlying geologic formations.

A summary of 1992 groundwater monitoring data for the K-25 Site is presented in Tables 5.56-5.63 of Vol. 2. These data tables include the parameters for the concentrations above detection limits that were detected. The reference values used in the table refer to the most recent maximum contaminant levels and primary and secondary drinking water standards, and other comparable standards. Sampling took place within specified well groupings, which encompass previously identified SWMUs (Table 5.6).

\subsubsection{Well Grouping 1}

\subsection{K-1407-B and K-1407-C Interim Status Units}

The K-1407-B and K-1407-C Ponds are located in the northeast section of the Oak Ridge K-25 Site. Neither pond is currently in operation. The K-14()7-B Pond was a 2.3-million-gal surface impoundment used for settling precipitates from neutralized metals, 
ORNL.DWG 93M-9617

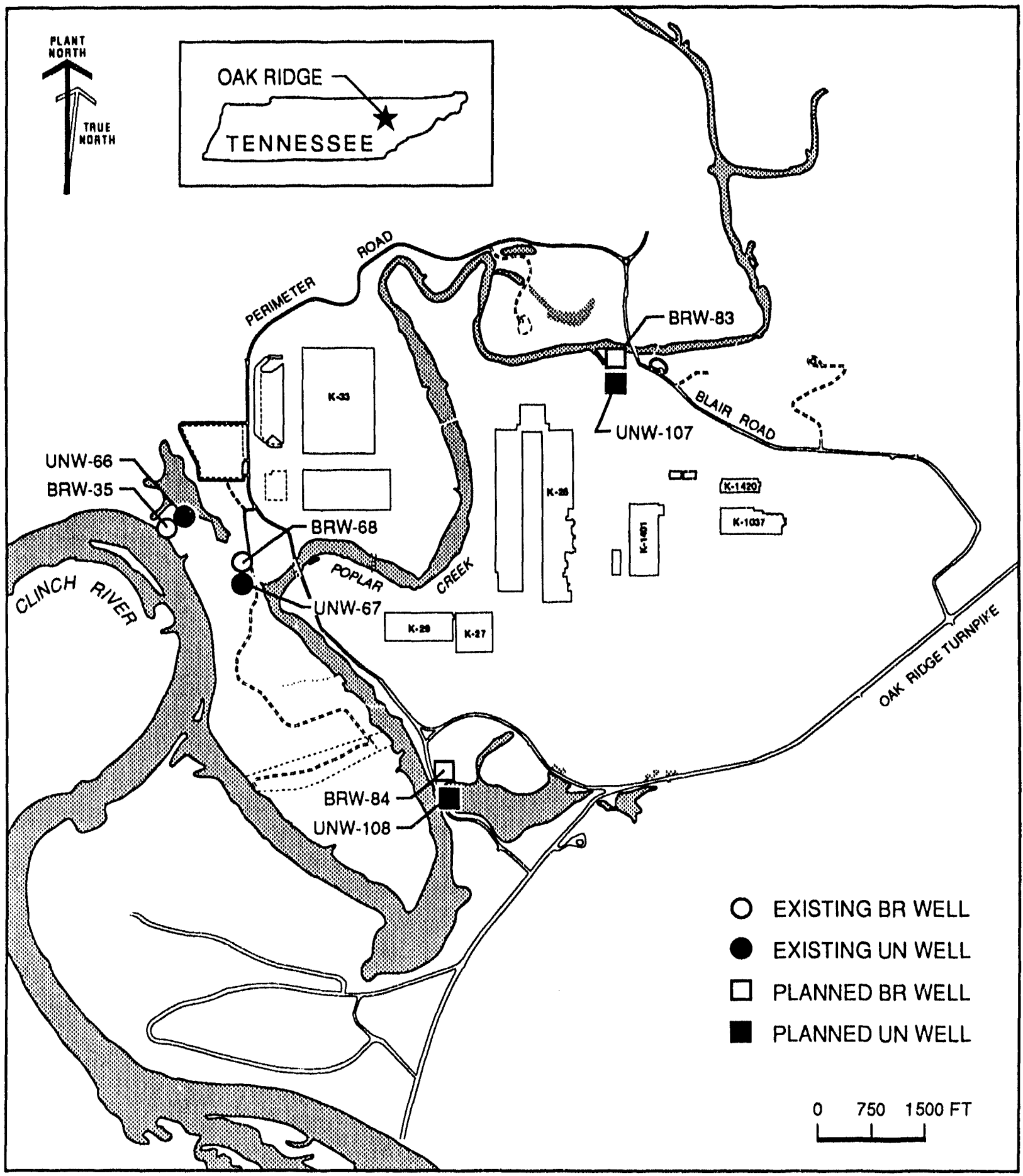

Fig. 5.25. Proposed exit pathway groundwater surveillance well locations at the K-25 Site. 
Table 5.6. Summary of K-25 Site well groupings

\begin{tabular}{|c|c|c|c|}
\hline Well grouping & Description & $\begin{array}{l}\text { Waste management } \\
\text { sites }\end{array}$ & $\begin{array}{c}\text { Number of } \\
\text { wells }\end{array}$ \\
\hline 1 & K-1700) Area & $\begin{array}{l}\text { K-1407-A } \\
\text { K-1407-B } \\
\text { K-1407-C } \\
\text { K-1070-B } \\
\text { K-1401 } \\
\text { K-1413 } \\
\text { K-1420 } \\
\text { K-1070-C,D } \\
\text { K-1503 }\end{array}$ & 53 \\
\hline 2 & K-1004 Area & $\begin{array}{l}\text { K-1070-C,D } \\
\text { K-1414 } \\
\text { K-1004-J } \\
\text { K-1004-Drain } \\
\text { K-1004-L } \\
\text { K-1004-N } \\
\text { K-1007 }\end{array}$ & 57 \\
\hline 3 & K-1099 Area & K-1099 & 1 \\
\hline 4 & K-1064 Area & K-1064-G & 12 \\
\hline 5 & K-i410 Area & K-1410 & 2 \\
\hline 6 & K-1232 Area & $\mathrm{K}-1232$ & 6 \\
\hline 7 & K-27/29 Area & $\begin{array}{l}\text { K-27/29 } \\
\text { K-832-H } \\
\text { K-1203 }\end{array}$ & 12 \\
\hline 8 & $\mathrm{~K}-1070-\mathrm{F}$ & K-1070-F & 5 \\
\hline 9 & K-31/33 & $\begin{array}{l}\text { K-31 } \\
\text { K-33 } \\
\text { K-862-E } \\
\text { K-892-G,H } \\
\text { K-892-J }\end{array}$ & 22 \\
\hline 10 & K-901-A Area & $\begin{array}{l}\text { K-901-A } \\
\text { K-1070-A }\end{array}$ & 18 \\
\hline 11 & K-770 Area & $\mathrm{K}-770$ & 7 \\
\hline 12 & K-720 Area & K-720 & 6 \\
\hline 13 & K-1085 Arca & $\mathrm{K}-1085$ & 5 \\
\hline
\end{tabular}

cleaning solutions, uranium decontamination solutions, and neutralized coal pile runoff. Liquids in the K-1407-B Pond were drained in October 1988, and removal of the remaining sludge was completed in August 1989. The K-1407-C Pond was a 1.3-million-gal surface impoundment used for disposal of corrosive and nonhazardous wastes. Liquids in this pond were drained in mid-1987 and sludge removal was completed in November 1988.

\subsection{K-1413 Process Lines and Sumps}

The K-1413 Area includes four components: the K-1413-C Neutralization Pit, two smaller pits (sumps) located to the north and east of the K-1413 building, the lines from the pits to the K-1401 Acid Line, and the storm drains in the vicinity of the $\mathrm{K}-1413$ building. The capacity of the sumps is about 
500 to $1000 \mathrm{gal}$ ( 1893 to $3785 \mathrm{~L}$ ) each. Corrosive wastewater and metal hydroxides drain from the two sumps to K-1407-A for neutralization. Potential contaminants at the site include organic solvents and uranium from early uranium fluorination activities at the site.

\subsection{K-1401 Acid Line and Degreaser Tanks}

The $\mathrm{K}-1401$ acid line is an underground vitreous clay pipeline used to transport corrosive fluids from the K-1491 degreaser tanks to the K-1407-A Neutralization Pit for neutralization. The K-1401 degreaser tanks are stainless steel tanks in brick-lined pits within a large concrete structure in the K-1401 building. Equipment is lowered into the tanks for degreasing, and trichloroethane is used as the solvent. Both of these facilities are still in use.

\subsection{K-1420 Oil Storage Area and Process Lines}

The K-1420 oil storage area consists of a paved area $50(15.2 \mathrm{~m})$ by $275 \mathrm{ft}(84 \mathrm{~m})$, located $75 \mathrm{ft}$ $(23 \mathrm{~m})$ north of the $\mathrm{K}-1420$ building.

Uranium-contaminated oil is stored at the facility in 19-L (5-gal) buckets for transfer to 209-L (55-gal) drums and is then transported to the waste-oil decontamination facility inside K-1420. The K-1420 process lines are underground pipelines that connected K-1420 to the K-1407-B Pond for transport of radioactive liquid. One of the abandoned pipelines was found to contain PCBs, mercury, and uranium.

\subsection{K-1503 Neutralization Pit Description}

The K-1503 Neutralization Pit was used for neutralization of corrosive liquids generated in water-softening operations in the past. Currently, it is used only as a sump for temporarily holding of corrosive liquids. It is approximately $10 \mathrm{ft}^{2} \times 12 \mathrm{ft}$ deep $\left(3.1 \mathrm{~m}^{2} \times 3.7 \mathrm{~m}\right.$ deep $)$.

\subsection{Results}

Only K-1407-B and K-1407-C Pond wells were sampled in well grouping 1. At K-1407-B Pond, an average 0.0075 milligrams per liter $(\mathrm{mg} / \mathrm{L})$ unfiltered cadmium concentration reported fọr the unfiltered sample collected from well UNW-5 in March 1992 exceeded the $0.005 \mathrm{mg} / \mathrm{L}$ primary drinking water standard and was statistically higher (at the 0.01 significance level) than the 1986 baseline avelage for the well. As per the requirements of TDEC Rule 1200-1-11-.05(6)(d)3(ii), groundwater in the well was resampled in May 1992 to confirm the apparent increase in the total cadmium concentration. The unfiltered cadmium concentration reported for the May 1992 groundwater sample $(0.0035 \mathrm{mg} / \mathrm{L})$ was below the primary drinking water standard. Additionally, results of the within-well test showed no statistically significant difference between the May 1992 result and the 1986 baseline average unfiltered cadmium concentration determined for the well.

Average unfiltered manganese concentrations reported for samples collected from UNW-5 in March $(21.1 \mathrm{mg} / \mathrm{L})$ and September $(23 \mathrm{mg} / \mathrm{L}) 1992$ were statistically higher than the 1986 baseline manganese concentration $(5.6 \mathrm{mg} / \mathrm{L})$ determined for upgradient well UNW-1. Manganese concentrations 1 unfiltered samples from well UNW-5 have historically exceeded the 1986 baseline concentration for upgradient well UNW-1. The elevated concentrations in well UNW-5 are believed to possibly reflect natural manganese concentrations or migration from an upgradient source area.

The $\mathrm{pH}$ of the groundwater sample collected from UNW-3 in September 1992 (as determined by the average of four replicate measurements) was 8.1 standard units. This average $\mathrm{pH}$ was statistically higher at the 0.01 significance level than the 1986 baseline average for upgradient well UNW-1 (6.5 standard units). In November 1992, ground water in well UNW-3 was resampled to confirm this apparent increase in $\mathrm{pH}$. The average of four replicate measurements for this sample was 7.07 standard units, which was not statistically different from either the 1986 baseline $\mathrm{pH}$ for the well or the 1986 baseline $\mathrm{pH}$ for upgradient well UNW-1.

The September 1992 unfiltered manganese $(18 \mathrm{mg} / \mathrm{L})$ concentration and average specific conductance $(1,429.25$ micromhos per centimeter $[\mu \mathrm{mho} / \mathrm{cm}])$ reported from the sample collected from upgradient well UNW-1 were statistically higher than the 1986 baseline values determined for the well $(5.6 \mathrm{mg} / \mathrm{L}$, and $449.19 \mu \mathrm{mho} / \mathrm{cm}$, respectively). These 
results are consistent with historical data for the well and have been interpreted to represent contaminant migration from an upgradient source area. Gross alpha results above the reference value are reported in unfiltered samples; only one filtered result exceeded the reference value. Elevated gross beta values have been reported for both unfiltered and unfiltered radiological samples. The results reported above the reference value of $50 \mathrm{pCi} / \mathrm{L}$ originate from one K-1407-B Pond well.

At K-1407-C Pond, unfiltered manganese concentrations in samples collected from UNW-9 in March $(14.2 \mathrm{mg} / \mathrm{L})$ and September $(12 \mathrm{mg} / \mathrm{L})$ were statistically higher than the 1986 baseline concentration $(1.111 \mathrm{mg} / \mathrm{L})$ determined from upgradient well UNW-6. Similar unfiltered manganese concentrations have historically been reported for samples collected from UNW-9 and have been interpreted as natural variations in manganese concentrations.

\subsubsection{Well Grouping 5}

\subsection{K-1410 Neutralization Pit}

The K-1410 Neutralization Pit is a 15,800-gal (59,803-L) concrete tank used from 1975 to 1979 for the neutralization of nickel-plating solutions before discharge to Poplar Creek. Some of the other chemicals known to be included are nickel sulfate, degreaser bath, acid, and corrosive solutions. WAG 5 monitoring wells were not sampled in 1991.

\subsection{Results}

Although two wells exist in this area, only the bedrock well was sampled in 1992. The unconsolidated zone well was dry when sampling was attempted. Results indicate that the unfiltered gross beta value is slightly above the reference value of $50 \mathrm{pCi} / \mathrm{L}$, and a trichloroethene result of $40 \mu \mathrm{g} / \mathrm{L}$ also exceeded a reference value. No additional constituents of concern were detected during this sampling event.

\subsubsection{Well Grouping 6}

\subsection{K-1232 Chemical Recovery Facility}

K-1232 is a RCRA facility consisting of eight above-ground steel tanks and four in-ground concrete tanks used for $\mathrm{pH}$ adjusiment and chemical precipitation of hazardous wastes. Because the unit treats wastes in tanks, it is not subject to RCRA groundwater monitoring. Potential contaminants include nitrates, heavy metals, organics, and uranium.

\subsection{Results}

The contaminants detected in groundwater samples collected through 1992 include both solvents and heavy metals. The solvent most likely to pose a concern for this area is trichloroethene. This substance was detected in five out of the six samples collected from this area, but was above drinking water standards in two samples. Fluoride was also detected in most samples, with the average results at $4.3 \mathrm{mg} / \mathrm{L}$. Elevated gross alpha and gross beta results are reported for unfiltered radiological samples, but these samples are below reference values for filtered results.

\subsubsection{Well Grouping 8}

\subsection{K-1070-F Old Contractor's Burial Ground}

The K-1070-F Old Contractor's Burial Ground was used from 1974 to 1978 and once in 1982 for disposal of construction/demolition debris such as dirt and rock, scrap, roofing material, concrete, asphalt, and asbestos.

\subsection{Results}

Historically, heavy metals and solvents have been detected in groundwater samples collected from wells at this site. One historical occurrence of these results in a concentration above the drinking water standard may have been due to increased detection levels for those samples. Four laboratory $\mathrm{pH}$ results exceeded the drinking water standard, which has an 
upper limit of 8.5 , although the average laboratory value was calculated at 7.75 . One uranium result exceeded the reference value of $0.02 \mathrm{mg} / \mathrm{L}$.

\subsubsection{Well Grouping 9}

\subsection{K-31/3 RCW Lines}

Two recirculating cooling water ( $\mathrm{RCW}$ ) lines are being investigated for possible groundwater contamination caused by leakage. RCW lines are underground steel pipes that circulated treated cooling water between the cooling tower basins and the process buildings. Potential contaminants include chromium, zinc, phosphate, other heavy metals, and radioactivity.

\subsection{K-862-E, K-892-G, H-892-J Cooling Tower Basins}

These locations are designated as cooling tower basins and are also being evaluated for possible groundwater contamination.

\subsection{Results}

Of the sampies taken in 1992 , only $\mathrm{pH}$, radioactivity, and one volatile organic compound exceeded drinking water standards. The average of laboratory $\mathrm{pH}$ results was reported as 7.5 , which is within the reference range of 6.5 to 8.5 . A trichloroethene value of $15 \mu \mathrm{g} / \mathrm{L}$ was reported above the reference value of $5 \mu \mathrm{g} / \mathrm{L}$. Unfiltered radioactivity results for gross alpha and beta exceeded reference values; one filtered result for beta exceeded the $50-\mathrm{pCi} / \mathrm{L}$ reference value. The calculated average gross alpha and beta values fall below the references.

\subsubsection{Well Grouping 10}

\subsection{K-901-A Holding Pond}

The K-901-A Holding Pond is a surface impoundment of approximately 5 acres located adjacent to the Clinch River. The pond was built in the early 1970s and was in use until 1985 for settling chromium-hydı oxide (trivalent chromium) precipitates generated by electrochemical treatment of chromated RCW blowdown. The pond contains sludge composed of these chromium-hydroxide precipitates along with lead, nickel, copper, and uranium.

\subsection{K-1070-A Contaminated Burial Ground}

The K-1070-A Contaminated Burial Ground was used from the late 1940s to 1976 for disposal of unclassified low-level radioactive solid and mixed chemical waste. The wastes were emptied into auger holes and trenches or buried in drums. Potential contaminants include radioactivity, heavy metals, and some organics and oils.

\subsection{Results}

Fifteen volatile organic constituents were detected from wells in this area, but only five were reported in concentrations above reference values. Of those, only trichloroethene exceeded the drinking water standard in all samples. Radioactivity values for unfiltered and dissolved gross beta activity exceeded $50 \mathrm{pCi} / \mathrm{L}$ in most samples, with the highest value reported at $220 \mathrm{pCi} / \mathrm{L}$.

\subsubsection{Well Grouping 12}

\subsection{K-720 Fly Ash Pile}

The K-720 Fly Ash Pile is located southwest of the K-25 Site near the east bank of the Clinch River. Fly ash was generated during the 1940s and 1950s by the nearby coal-powered steam plant. The pile covers an area of 10 to 15 acres ( 4 to 6 ha). Potential contaminants include heavy metals, sulfates, and radioactivity.

\subsection{Results}

Of the samples collected in 1992, only pH and radioactivity values exceeded drinking water standards. The calculated average gross alpha and beta values fall below these references. Sixteen of the 24 laboratory $\mathrm{pH}$ results are below the lower drinking water limit. 


\subsubsection{Well Grouping 13}

\subsection{K-1085 Firehouse Burn Area}

The K-1085 Firehouse Burn Area was used in the mid-1940s as a firehouse, garage, and fuel station. From the late 1940s to 1960 , the area was used for fire training by burning waste oil in metal pans and excavated pits. Potential contaminants include waste oils, solvents, and heavy metals/uranium that may have contaminated the oils and petroleum products.

\subsection{Results}

Samples collected to date have not indicated the presence of any of the anticipated contaminants in this area. Out of six samples, only one result for unfiltered gross alpha, gross beta, and $\mathrm{pH}$ was above drinking water standards. Unfiltered uranium and fluoride were reported in three out of six samples, but were detected below references value limits.

\subsubsection{Future K-25 Site Groundwater Program Activities}

Few, if any, of the existing wells are considered to provide water quality data truly representative of background conditions upgradient of the K-25 Site. This lack of background water quality data makes interpretation of chemical data from existing wells difficult. Eight proposed background wells have been located with the intent of intercepting each of the primary geologic units underlying the K-25 Site (Fig. 5.26). An unconsolidated zone well will be paired with a bedrock well at each of four locations.

Four additional monitoring wells are proposed to complete the exit pathway surveillance monitoring network needed to intercept groundwater as it exits the K-25 Site. These four well pairs will be installed as two unconsolidated and bedrock well pairs.

\subsection{Plugging and Abandonment}

An open borehole or well may provide a potential route for surface contamination to enter previously uncontaminated groundwater. Transfer or spread of contamination from one zone to another occurs when an open borehole provides a pathway for contaminated water in an aquifer to enter or mix with that in an uncontaminated aquifer. Mixing in the subsurface can confuse monitoring results and spread contamination. To minimize the potential for groundwater cross-contamination, a program was initiated to identify, plug, and abandon unused, unnecessary, or damaged boreholes.

\subsubsection{Y-12 Plant}

During 1992 a total of 27 wells and borings were plugged and abandoned at the Y-12 Plant. Of the 27 wells that were plugged and abandoned, 15 were monitoring wells and 12 were piezometers. All wells and borings were plugged and abandoned in accordance with the Monitoring Well Plugging and Abandonment Plan for the Department of Energy Y-12 Plant, Oak Ridge, Tennessee (HWS, Inc. 1991).

\subsubsection{Oak Ridge National Laboratory}

During 1992 a total of 63 wells and boreholes were plugged and abandoned as part of the SWSA 6 Environmental Resioration Division activities. All wells were plugged and abandoned according to procedures developed previously. At SWSA 6, 113 monitoring wells required for adequate closure will be retained at the site and approximately 592 remaining wells will be plugged and abandoned.

Plans are being developed for plugging and abandonment of other unneeded or unsuitable monitoring wells at other locations in the ORNL complex. Preliminary well identification and plugging and abandonment procedures were developed for ORNL sites other than WAGs 5, 6, and 10. Well plugging and abandonment activities addressing other ORNL sites besides SWSA 6 are scheduled to begin during 1993.

\subsubsection{K-25 Site}

There were no wells plugged and abandoned at the K-25 Site during 1992, and currently none are scheduled for this activity. All existing wells are currently maintained under a quarterly well inspection program. Any well that is deemed unserviceable during these inspections is identified for plugging and abandonment.

\section{5-68 Groundwater}




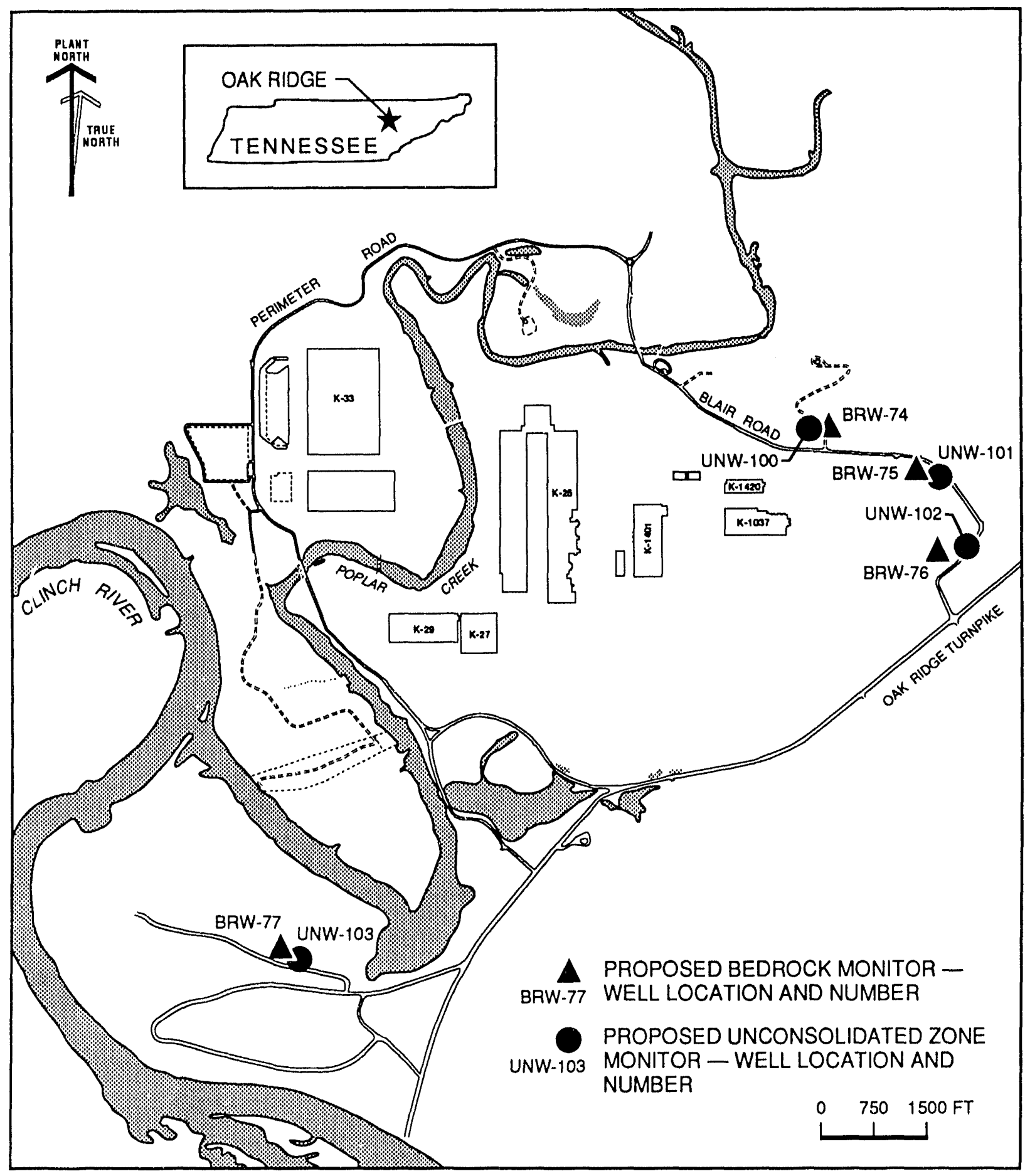

Fig. 5.26. Proposed background well locations at the K-25 Site. 


\subsection{Off-Site Monitoring}

In 1989, ORNL implemented a long-term, off-site residential drinking water quality monitoring program. The objective of the program, designed in conjunction with Energy Systems' Environmental Compliance (EC) Organization and the DOE Environmental Protection Division, is to document water quality from groundwater sources near the ORR and to monitor the potential impact of DOE Oak Ridge Operations Office (DOE-ORO) operations on the quality of these groundwater sources.

Twenty-one wells were selected on the basis of their proximity to the ORR and a representative distribution of sources from the different geologic formations of the area. Two U.S. Geological Survey wells located in Union Valley were dropped from this program in 1991; they are now included in the Y-12 Plant perimeter groundwater program. The remaining 19 wells are sampled semiannually.

In 1992, sampling events occurred in February and August. Two wells were not included in the August event; one well is no longer functional, and scheduling could not be arranged for the other.

Parameters used for monitoring include volatile organics; selected atomic absorption metals (As, $\mathrm{Hg}$, $\mathrm{Pb}, \mathrm{Se}$ ); inductively coupled argon plasma metals; anions (fluoride, chloride, sulfate, nitrate, and nitrite); and the radioactive parameters: gross alpha activity, gross beta activity, total radioactive strontium, ${ }^{99} \mathrm{Tc},{ }^{3} \mathrm{H}$, and radionuclides observed in a gamma scan. These data are presented in Table 5.64 of Vol. 2.

One of the wells had fluoride concentrations that exceeded primary drinking water standards in both sampling events. The high fluoride and accompanying high $\mathrm{pH}$ most likely result from natural chemical reactions that can occur in deep wells that penetrate the Conasauga geologic group.

Radionuclide concentrations listed for the off-site groundwater sampling locations are well below drinking water standards.

Organic compounds were detected, but none were measured at levels near a primary drinking water standard. No values from off-site wells exceeded EPA's general risk assessment guidelines of ten times the detection limit for common laboratory contaminants or five times the detection limit for other organic compounds. In the August 1992 sampling event, samples of tap water were collected to represent the quality of tap water from two major local sources of public-utility-supplied drinking water. Results from analysis of the tap water samples are presented in Table 5.65, Vol. 2. Neither of the tap water samples produced results exceeding any regulatory standards.

\subsection{References}

Bailey, J. K. 1983. Closure Plan for the Y-12 Centralized Sanitary Landfill I, Y-IA 160 (revised), Union Carbide Corporation, Nuclear Division, Department of Energy Y-12 Plant, Oak Ridge, Tenn.

Battelle Columbus Division. 1989a. RCRA Facility Investigation Plan, Spoil Area I (D-107), Oak Ridge Y-12 Plant, Y/TS-363 R 1. Prepared for Martin Marietta Energy Systems, Inc., Oak Ridge, Tenn.

Battelle Columbus Division. 1989b. RCRA Facility Investigation Plan, Rust Spoil Area (D-106), Oak Ridge Y-12 Plant, Oak Ridge, Tennessee, Y/TS-354 R1. Prepared for Martin Marietta Energy Systems, Inc., Oak Ridge, Tenn.

Battelle Columbus Division. 1988. RCRA Facility Investigation Plan, Filled Coal Ash Pond (D-112), Oak Ridge Y.12 Plant, Y/TS-411. Prepared for Martin Marietta Energy Systems, Inc., Oak Ridge Tenn.

Butz, T. R. and H. H. Stoner. 1983. Disposal of United Nuclear Company Materials at the Y-12 Plant, Health, Safety, and Environmental Affairs Division, Union Carbide Corporation, Y-12 Plant, Oak Ridge, Tenn.

Dreier, R. B., T. O. Early, and H. L. King. 1993. Results and Interpretations of Groundwater Data Obtained from Multiport-Instrumented Core Holes (GW-131 through GW-135), Fiscal Years 1990 and 1991, Y/TS-803.

Early, T. O. 1989. Proposed Groundwater Monitoring Plan for the United Nuclear Corporation Waste Disposal Site at the Y-12 Plant, Y/TS-539/1, Oak Ridge National Laboratory, Oak Ridge, Tenn.

Eaton, J. M. and E. M. Ingram. 1991. Site Investigation Report and Corrective Action Plan for the Former Y-12 Fuel Station at Buildings 9754 and 9754-2, Oak Ridge Y-12 Plant, Y/SUB/91-TJ997C/6. Prepared by Science 


\section{Environmental Report Vol. 1, Oak Ridge}

Applications International Corporation for Martin Marietta Energy Systems, Inc., Oak Ridge, Tenn.

Eaton J. M. and F. R. Van Ryn. 1991. Site Investigation Report for Underground Storage Tanks 1219-U, 1222-U, 2068-U, and 2082-U at the Rust Garage Facility, Oak Ridge Y-12 Plant, Y/SUB/91-TJ997C/3. Prepared by Science Applications International Corporation for Martin Marietta Energy Systems, Inc., Oak Ridge, Tenn. Geraghty \& Miller, Inc. 1990a A Study of Ground-Water Flow from the Chestnut Security Pits using a Fluorescent Dye Tracer. Prepared for Martin Marietta Energy Systems, Inc. (Y/SUB/90-00206C/6).

Geraghty \& Miller, Inc. 1992 (March), February 1992 Ground-Water Levels at the Oak Ridge K-25 Site: Oak Ridge, Tennessee, Report No. K/SUB/90-NH989/9.

Geraghty \& Miller, Inc. 1990b. Comprehensive Groundwater Monitoring Plan for the Department of Energy Y-I2 Plant, Oak Ridge, Tennessee, Y/SUB/90)-00206C/5.

Geraghty \& Miller, Inc. 1989 (Dec.). Groundwater Quality at the Oak Ridge Gaseous Diffusion Plant, Final Report, K/SUB/85-22224/11.

Geraghty \& Miller, Inc. 1989a. RCRA Facility Investigation Plan, Abandoned Nitric Acid Pipeline, Oak Ridge Y-12 Plant, Y/TS-59. Prepared for Martin Marietta Energy Systems, Inc., Oak Ridge, Tenn.

Geraghty \& Miller, Inc. 1989b. Development of Ground-Water Flow Models for the S-3 Waste Management Area, Y-12 Plant, Y/SUB/89-00206C-1, Prepared for Martin Marietta Energy Systems, Inc., Oak Ridge, Tenn.

Geraghty \& Miller, Inc. 1989c. Tracer Study of the Hydrologic System of Upper Bear Creek, Y-12 Facility, Y/SUB/89-00206C/. Prepared for Martin Marietta Energy Systems, Inc., Oak Ridge, Tenn.

Geraghty \& Miller, Inc. 1989d. Development of Contaminant Transport Models for Four

Constituents at the S-3 Site, Y-12 Plant, Y/SUB/89-00206C/C/3. Prepared for Martin Marietta Energy Systems, Inc., Oak Ridge, Tenn. Geraghty \& Miller, Inc. 1988a. Findings of Gasoline Seepage Study at the Rust Garage Area of the Y-12 Plant. Prepared for Martin Marietta Energy
Systems, Inc. (Letter report to L. L. McCauley), Oak Ridge, Tenn.

Geraghty \& Miller, Inc. 1988b. Post Closure Permit Application for the S-3 Ponds Waste Management Area at the Y-12 Plant, Y/SUB/87-00206C/IIRI. Prepared for Martin Marietta Energy Systems, Inc., Oak Ridge, Tenn.

Geraghty \& Miller, Inc. 1988c. Post Closure Permit Application for the Oil Landfarm Waste Management Area at the Y.12 Plant, Y/SUB/87-00206C/12. Prepared for Martin Marietta Energy Systems, Inc., Oak Ridge, Tenn.

Geraghty \& Miller, Inc. 1988d. Post Closure Permit Application for the Burial Grounds Waste Aianagement Area at the Y-12 Plant, Y/SUB/87-00206C/12. Prepared for Martin Marietta Energy Systems, Inc., Oak Ridge, Tenn.

Grutzeck, M. 1987. United Nuclear Corporation's Y-12 Plant Site: Final Report, Y/SUB/86-23729/1, Pennsylvania State University, Materials Research Laboratory. Prepared for Martin Marietta Energy Systems, Inc., Oak Ridge, Tenn.

Haase, C. S. 1987. RCRA Facility Investigation Plan for the S-2 Site (D-103) at the Oak Ridge $Y-12$ Plant, Y/TS-349, Martin Marietta Energy Systems, Inc., Oak Ridge, Tenn.

HWS, Inc. 1991. Monitoring Well Plugging and Abandonment Plan for the Department of Energy Y-12 Plant, Oak Ridge, Tennessee. Prepared for Martin Marietta Energy Systems, Inc., Y/SUB/91-YP507C/6.

Kimbrough, C. W. 1986. Phase IInstallation Assessment of Inactive Hazardous Waste Disposal Sites at the Y-12 Plant, Y/TS-114, Martin Marietta Energy Systems, Inc., Oak Ridge, 'Tenn.

Kimbrough, C. W., and L. W. McMahon. 1988 a. RCRA Appendix IX Sampling and Analysis Project at the Oak Ridge Y-12 Plant: Disposal Basin Field Sampling Plan and Field Data, Y/SUB/88-97376/1, Oak Ridge, Tenn.

Kimbrough, C. W., and L. W. McMahon. 1988b. RCRA Appendix IX Sampling and Analysis Project at the Oak Ridge Y.12 Plant: New Hope Pond Analytical Data Summary, Y/WUB/88-97376/2, Oak Ridge, Tenn.

King, H. L., C. S. Haase, and D. L. LaRue. 1989. Groundwater Investigation Drilling Program 


\section{Environmental Report Vol. 1, Oak Ridge}

Fiscal Years 1986, 1987, and 1988; Y-12 Plant, Y/SUB/89-E4371V/2. Prepared by C-E

Environmental, Inc. for Martin Marietta Energy Systems, Inc., Oak Ridge, Tenn.

Lee Wan \& Associates, Inc. 1989 (Revised). Post Closure Permit Application for the New Hope Pond Site at the Y-12 Plant. Prepared for Martin Marietta Energy Systems, Inc. (Draft), Oak Ridge, Tenn.

Lind, D. E. and S. H. Welch. 1989. Closure Plan for the Final Closure of the Salvage Yard Oil/Solvent Drum Storage Area (S-020) at the U.S. DOE Y-12 Plant, Y/TS-382/R2, Martin Marietta Energy Systems, Inc., Oak Ridge, Tenn.

MCI Consulting Engineers, Inc. 1983. Closure Plan for Rust Engineering Y-12 Spoil Area, Oak Ridge, Tennessee. Prepared for Union Carbide Corporation, Nuclear Division. Included as Appendix B in RCRA Facility Investigation Plan, Rust Spoil Area (D-106), Oak Ridge Y-12 Plant, Oak Ridge, Tenn.

Martin Marietta Energy Systems, Inc. 1991. RCRA Facility Investigation Report for Waste Area Grouping 6 at Oak Ridge National Laboratory, ES/ER-22/VI-V6, ORNL/ER/Sub-87/99053/5/V1-V6, Environmental Restoration Program, Oak Ridge National Laboratory, Oak Ridge, Tenn.

Martin Marietta Energy Systems, Inc. 1989. RCRA Facility Investigation Plan for Bear Creek, U.S. Department of Energy Y-12 Plant, Y/TS-417. Prepared by Martin Marietta Energy Systems, Inc., Oak Ridge, Tenn.

Martin Marietta Energy Systems, Inc. 1988a. Revised Closure Plan for New Hope Pond. Y/TS-389, Y-12 Plant Environmental Management Department, Health, Safety, Environment and Accountability Division, Oak Ridge Y-12 Plant, Oak Ridge, Tenn.

Martin Marietta Energy Systems, Inc. 1988b. Revised RCRA Closure Plan for the S-3 Ponds, Y/TS-393. Prepared by the Y-12 Plant Environmental Management Department; Health, Safety, Environment, and Accountability Division, Oak Ridge, Tenn.

Martin Marietta Energy Systems, Inc. 1988c. Revised RCRA Closure Plan for the Oil Landfarm, Y/TS-394. Prepared by the Y-12 Plant Environmental Management Department; Health,
Safety, Environment, and Accountability Division, Oak Ridge, Tenn.

Martin Marietta Energy Systems, Inc. 1988d. Revised RCRA Closure Plan for the Bear Creek Burial Grounds, Y/TS-395. Prepared by the Y-12 Plant Environmental Management Department; Health, Safety, Environment, and Accountability Division, Oak Ridge, Tenn.

Martin Marietta Energy Systems, Inc. 1988e. Revised RCRA Closure Plan for the Oil Retention Ponds, Y/TS-392. Prepared by the Y-12 Plant Environmental Management Department; Health, Safety, Environment, and Accountability Division, Oak Ridge, Tenn.

Martin Marietta Energy Systems, Inc. 1988f. Revised RCRA Closure Plan for the Chestnut Ridge Security Pits, Y/TS-391, Oak Ridge Y-12 Plant, Oak Ridge, Tenn.

Martin Marietta Energy Systems, Inc. 1984. Inventory of Disposals Conducted in the Chestnut Ridge Security Pits, Y-12 Plant, Y/TS-191, Oak Ridge, Tenn.

Moore, G. K. 1987 (Nov.). Geology and Hydrology of WAG 11: Whitewing Scrapyard (draft).

Moore, G. K., and L. E. Toran. Supplement to a Hydrologic Framework for the Oak Ridge Reservation, Oak Ridge, Tennessee, ORNL/TM-12191, Martin Marietta Energy Systems, Inc., Oak Ridge, Tenn.

Murphy, F. 1989. RCRA Facility Investigation Plan, Waste Coolant Processing Facility (T-038), Y-12 Plant, Y/TS-358 RI, Martin Marietta Energy Systems, Inc. Oak Ridge, Tenn.

Ogden, A. E. 1992. Methods for Predicting the Directions of Contaminant Transport in Flat-Lying and Folded Carbonate Rocks, Tennessee Water Resources Symposium (5th, Nashville, Tenn., Oct 1992), pp 16-20 in Proceedings, American Water Resources Association, Nashville, Tenn.

Palmer, A. N. 1991. "Origin and Morphology of Limestone Caves," Geological Society of America Bulletin, 103, 1-21.

PEER Consultants. 1989. RCRA Facility Investigation Plan for East Fork Poplar Creek and the Oak Ridge Sewer Line Beltway, Oak Ridge Y-12 Plant, Y/TS-366 R1. Prepared for Martin Marietta Energy Systems, Inc., Oak Ridge, Tenn. 
Poling, R. S., Rubin, P. A., and Lemiszki, P. J. 1992. Hydrogeologic Characterization Plan for the Oak Ridge K-25 Site; Oak Ridge, Tenn. Prepared for Martin Marietta Energy Systems, Inc., K-25 Plant, Report No. K/EM-1.

Quinlan, J. F. 1990. "Special Problems of Ground-Water Monitoring in Karst Terranes," pp 275-304 in Nielsen, D. M. and Johnson, A. I., eds. Ground Water and Vadose Zone Monitoring, American Society for Testing and Materials (ASTM) Special Technical Publication 1053. ASTM, Philadelphia.

Rubin, P. A. 1992. Land-Use Planning and Watershed Protection in Karst Terranes, Hydrogeology, Ecology, Monitoring, and Management of Ground Water in Karst Terranes Conference (3rd, Nashville, Tenn., Dec. 1991), pp 769-793 in Proceedings. National Ground Water Association, Dublin, Ohio.

Rubin, P. A. and Lemiszki, P. J. 1992. Structural and Stratigraphic Controls on Cave Development in the Oak Ridge Area, Tennessee, Tennessee Water Resources Symposium (5th, Nashville, TN., Oct. 1992), Proceedings. American Water Resources Association, Nashville, Tenn.

Rubin, P. A., Lemiszki, P. J., and Poling, R. S. 1992. Strategy for Definition and Protection of East Tennessee Karst Groundwater Basins. Abs. and paper: Fifth Tennessee Water Resources Symposium, Nashville, Tenn.

Saunders, M. B. 1983. Leachability of Samples for New Hope Pond Disposal Basin, Y/DS-81, Rev. 1, Oak Ridge, Tenn.

Science Applications International Corporation. 1991. Chestnut Ridge Borrow Area Waste Pile Work Plan, Y/SUB/91-99928C/1. Prepared for Martin Marietta Energy Systems, Inc., Oak Ridge, Tenn.

Science Applications International Corporation. 1993. Final Report of the Second Dye-Tracer Test at the Chestnut Ridge Security Pits, Y-12 Plant, Oak Ridge, Tennessee. Prepared for Martin Marietta Energy Systems, Inc. (Y/SUB/93-99928C/Y10/1).

Smith, R. E., N. J. Gilbert, and C. E. Sams. 1983. Stability Analysis of Waste Disposal Facilities at the Y-12 Plant, Y/SUB/83-49712/1. Prepared for Martin Marietta Energy Systems, Inc., Oak Ridge, Tenn.
Solomon, D. K., et al. 1992. Status Report: A Hydrologic Framework for the Oak Ridge Reservation, Prepared for the Energy Systems Groundwater Program Office, ORNL/TM-12026, Oak Ridge, Tenn.

Solomon, D. K., G. K. Moore, L. E. Toran, R. B. Dreier, and W. M. McMaster. 1992. Status Report: A Hydrologic Framework for Oak Ridge Reservation. ORNL/TM-12026. Oak Ridge National Laboratory. Oak Ridge, Tenn.

Stansfield, R. G. and D. D. Huff. 1992. Well Plugging and Abandonment Plan for ORNL WAG 6. Oak Ridge National Laboratory, ORNL/ER-82, Oak Ridge, Tenn.

Stone, J. E. 1989a. Initial Site Characterization and Free Product Removal Report for Underground Storage Tanks 2063-U, 2328-U, and 2329-U at the Salvage Yard Drum Deheader, Oak Ridge, Y-12 Plant, Y/TS-566, Martin Marietta Energy Systems, Inc., Oak Ridge, Tenn.

Stone, J. E. 1989b. Site Investigation Plan for the former Y.12 Plant Fuel Stations at Buildings 9754 and 9754-2, Oak Ridge Y-12 Plant, Y/TS-588, Martin Marietta Energy Systems, Inc., Oak Ridge, Tenn.

Stone, J. E. 1989c. Phase II Free Product Removal Report for Underground Storage Tanks 0439-U and 0440-U at the Building 9754-2 Gasoline Station, Oak Ridge Y-12 Plant, Y/TS-567, Martin Marietta Energy Systems, Inc., Oak Ridge, Tenn.

Stone, J. E. 1989d. Free Product Removal Report for Underground Storage Tank 2331-U at Building 9201-1, Oak Ridge Y-12 Plant, Y/TS/569, Martin Marietta Energy Systems, Inc., Oak Ridge, Tenn.

Stone, J. E. 1989e. Initial Site Characterization Report for Underground Storage Tank 0134-U, Building 9204-2, Oak Ridge Y-12 Plant, Y/TS-565, Martin Marietta Energy Systems, Inc., Oak Ridge, Tenn.

Stone, J. E. 1989f. Free Product Removal Report for Underground Storage Tank O134-U at Building 9204-2, Oak Ridge Y-12 Plant, Y/TS-593, Martin Marietta Energy Systems, Inc., Oak Ridge, Tenn.

Stone, J. E. and L. W. McMahon. 1988. Waste Machine Coolant Biodegradation Facility, Summary of Closure Under Rules Governing Hazardous Waste Management in Tennessee, Y/TS-457/3, Martin Marietta Energy Systems, Inc., Oak Ridge, Tenn. 


\section{Environmental Report Vol. 1, Oak Ridge}

Tennessee Department of Health and Environment. 1986. Letter from T. Tiesler, Director of the Division of Solid Waste Management, to J. L. Foutch, U. S. Department of Energy Oak Ridge Operations, January 13, 1986.

Tucci, P., 1992. Hydrology of Melton Valley at Oak Ridge National Laboratory, Tennessee. U.S. Geological Survey Waters Resources Investigations report 92-4131. Nashville, Tenn.

Turner, R. R., M. A. Bogle, E.A. Zeighami, and T.M. Mercier. 1989. RCRA Facility Investigation Plan, Mercury Use Areas (S-127), Oak Ridge Y-12 Plant, Y/TS-597, Martin Marietta Energy Systems, Inc. Oak Ridge, Tenn.

Welch, S. H. 1989. Initial Site Characterization and Free Product Removal Report for Underground Storage Tanks 0439-U and 0440-U at Building 9754-2, Oak Ridge Y-12 Plant, Y/TS-560.

Prepared by Science Applications International
Corporation for Martin Marietta Energy Systems, Inc., Oak Ridge, Tenn.

Welch, S. H. 1986. Salvage Yard Oil/Solvent Drum Storage Area (S-020): Closure Plan (Revised), Oak Ridge Y-12 Plant, Y/TS-212/1R, Martin Marietta Energy Systems, Inc., Oak Ridge, Tenn. Welch, S. H., C. S. Haase, C.W. Kimbrough, and T.M. Mercier. 1987. Solid Waste Management Unit !nformation for Y-12 Plant RCRA 3004(u) Facility Assessment, Volumes $I, I I$, and III, Y/TS-273, Martin Marietta Energy Systems, Inc., Oak Ridge, Tenn.

Willoughby, M., D. E. Bohrman, and M. W. Sherrill. 1988. Hazardous Waste Storage Area, Southern Portion of Interim Drum Yard (S-()30), Summary of Partial Closure Under Rules Governing Hazardous Waste Management in Tennessee, Y/TS-347/7, Martin Marietta Energy Systems, Inc., Oak Ridge, Tenn. 


\section{BIOLOGICAL MONITORING}

6.1 Milk $\ldots \ldots \ldots \ldots \ldots \ldots \ldots \ldots \ldots, 6,3$
6.1.1 Sample Collection and Analytical
Procedures ............... 6-3
6.1 .2 Results . . . . . . . . . . . . 6-3

6.2 Fish $\ldots \ldots \ldots \ldots \ldots \ldots \ldots \ldots \ldots \ldots \ldots \ldots$

6.2.1 Sample Collection and Analytical

Procedures ............... 6-3

6.2.2 Results ................ 6-5

6.3 ORR Deer Population $\ldots \ldots \ldots \ldots \ldots \ldots$ 6.6 . . . .

6.4 Vegetation $\ldots \ldots \ldots \ldots \ldots \ldots \ldots \ldots \ldots$ 6.6

6.4.1 Food Crops . . . . . . . . . . . . . . 6 6-6

6.4 .2 Hay ................. 6-7

6.5 Biological Monitoring and Abatement

Programs (BMAPs) . . . . . . . . . . . . . 6 6-7

6.5.1 Monitoring Contaminant Concentrations ............. 6-7

6.5.2 Indications of Ecological Recovery in Three Receiving Streams near

DOE Oak Ridge Facilities . . . . . . . 6 6-14

6.5.3 Effects of Effluent Dechlorination on Clams in East Fork Poplar Creek . . . . . . . . . . . . . 6-17

6.5.4 Changes in Trace Element Concentrations in Largemouth Bass Following Elimination of Fly Ash Discharge to Rogers Quarry ... . . . 6-17

6.5.5 Radioactivity in Largemouth Bass from White Oak Lake . . . . . . . . . 6 6-19

6.5.6 Radioactivity in Resident Canada Geese . . . . . . . . . . . . . 6-20

6.6 References . . . . . . . . . . . . . . . . . . . . . . 6-20 


\section{Biological Monitoring}

Air and water are the principal dispersal media for Oak Ridge DOE facility releases. However, the environmental surveillance programs also include biotic media that may be affected by these releases or that may provide pathways of exposure to people. This section gives a summary of the media sampled, the types of analyses performed, and the sampling and analysis frequencies for the biological samples.

\subsection{Milk}

Ingestion is one of the pathways of exposure to radioactivity for humans. Radionuclides can be transferred from the environment to people via food chains such as the grass-cow-milk pathway. Milk is a potentially significant source to humans of some radionuclides deposited from airborne emissions because of the relatively large surface area that can be grazed daily by a cow, the rapid transfer of milk from producer to consumer, and the importance of milk in the diet.

\subsubsection{Sample Collection and Analytical Procedures}

The 1992 milk sampling program consisted of monthly grab samples collected from five locations in the vicinity of the ORR. Figure 6.1 shows the locations of the stations.

Milk samples are analyzed at ORNL for ${ }^{|3|} \mid$ by gamma spectrometry and for total radioactive strontium $\left({ }^{87} \mathrm{Sr}\right.$ and ${ }^{91} \mathrm{Sr}$ ) by chemical separation and low background beta counting.

\subsubsection{Results}

The concentrations of total radioactive strontium in milk are summarized for the 1992 data in Table 6.1. Radioactivity measurements are reported as the net activity, or the difference between the gross activity and instrument background. $A$ value is declared greater than zero and considered to be a detected value if it exceeds 1.645 times its estimated standard error. There were no detected concentrations of ${ }^{13 !} I$ in 1992. The average values for total radioactive strontium were converted to effective dose equivalents and are presented in Sect. 2 of this report. The location-specific data are included in Table 6.1 of Vol. 2. These results are consistent with data from previous years.

\subsection{Fish}

Fish ingestion is another pathway for contaminant uptake in humans. Prior to 1985, five species of fish were measured for PCBs, mercury, and radionuclide concentrations: bluegill, catfish, bass, carp, and crappie. The highest mercury and PCB concentrations were found in carp, and the next highest were found in bluegill. For several of the radionuclides, concentrations were highest in bluegill. Because of this and because of the large number of available fish, bluegill were collected during 1992 for tissue analysis to estimate concentrations for dose assessment models. Additional information on bioaccumulation of contaminants in fish is provided in the discussion of the Biological Monitoring and Abatement Programs (BMAPs), Sect, 6.5.

\subsubsection{Sample Collection and Analytical Procedures}

Bluegill (Lepomis macrochirus) were collected by ORNL once during the year for muscle tissue analyses of metals, pesticides, PCBs, and radionuclides (Fig. 6.2). Sampling locations include 


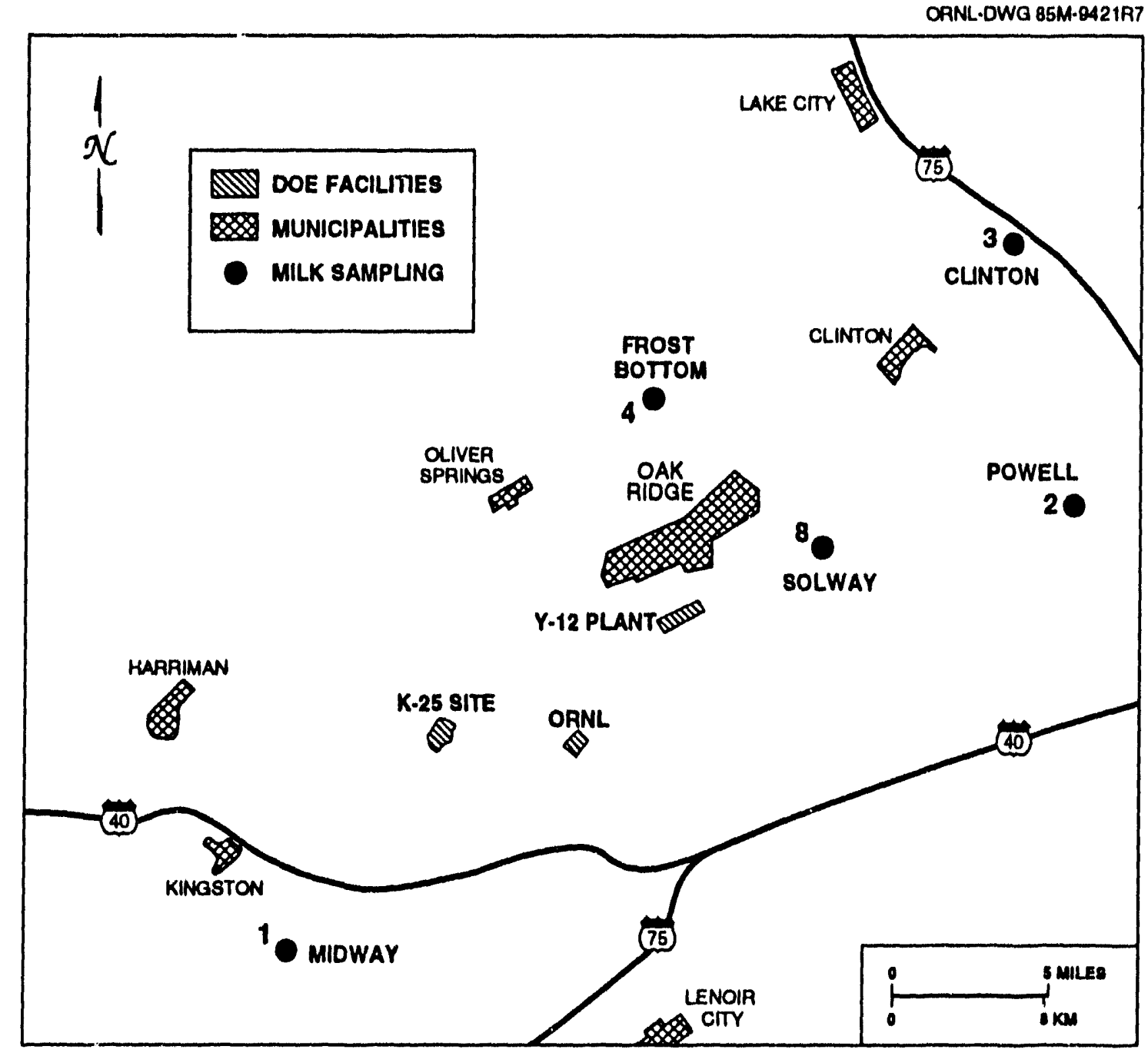

Fig. 6.1. Map showing milk sampling stations.

Table 6.1. 1992 radionuclide concentrations in raw milk ${ }^{a}$

\begin{tabular}{lccccc}
\hline Analysis & $\begin{array}{c}\text { Number detected/ } \\
\text { number of } \\
\text { samples }\end{array}$ & Max & Detected concentration (pCi/L) & Av & $\begin{array}{c}\text { Standard } \\
\text { errorb }\end{array}$ \\
\cline { 3 - 7 } & $0 / 46$ & $c$ & $c$ & $c$ & $c$ \\
Total Srd & $42 / 46$ & 8.1 & 0.59 & $3.3^{e}$ & 0.29 \\
\hline
\end{tabular}

"See Fig. 6.1 for sampling locations.

${ }^{b}$ Standard error of the mean.

'Not applicable.

${ }^{d}$ Total radicactive strontium $\left({ }^{89} \mathrm{Sr}+{ }^{90} \mathrm{~S} r\right)$.

${ }^{e}$ A verage is significantly greater than zero at $95 \%$ confidence level.

\section{6-4 Biological Monitoring}


ORNL.DWG 93M-5468

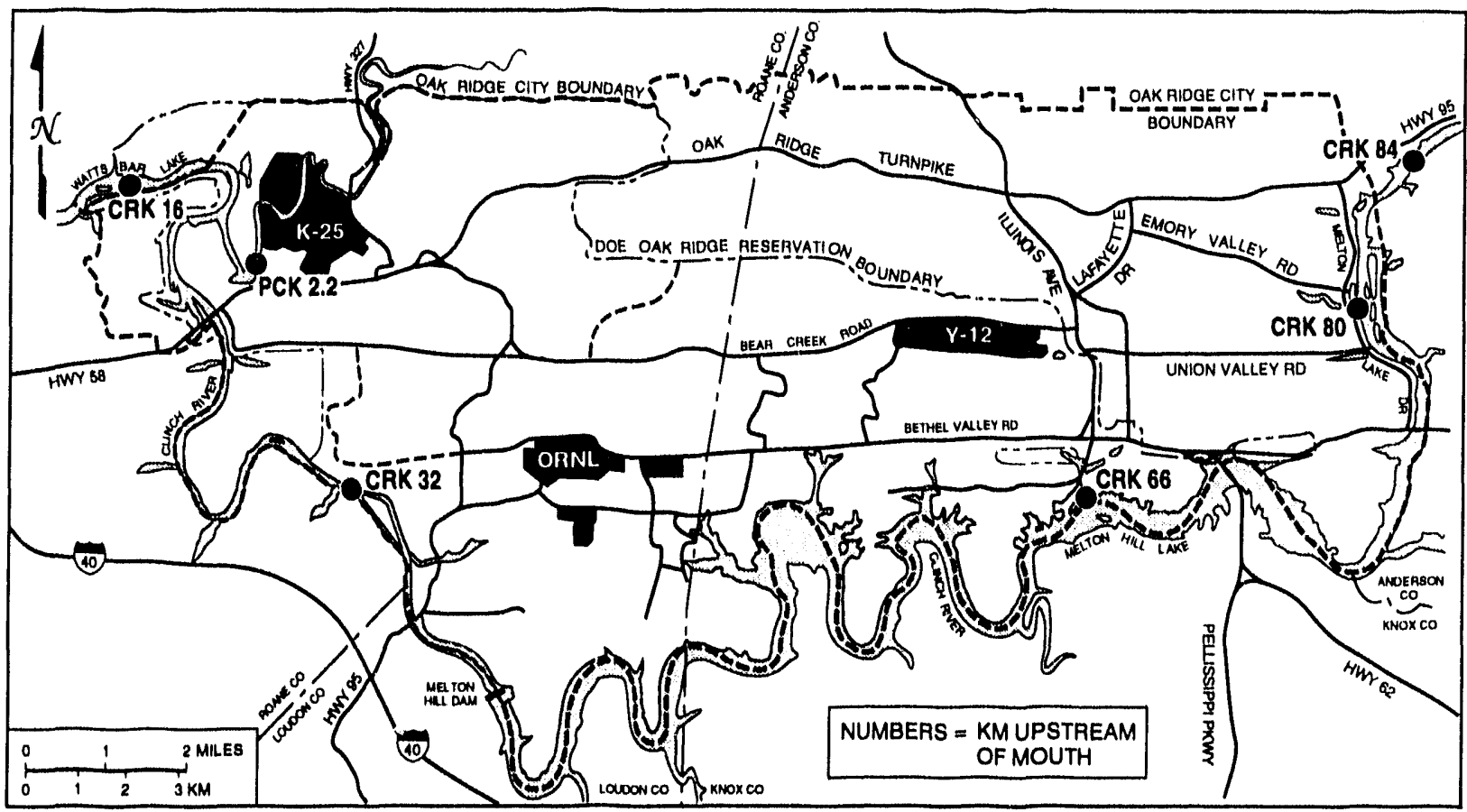

Fig. 6.2. Fish sampling locations along Clinch River.

- Melton Hill Reservoir above all DOE inputs, Andersón County Filtration Plant (CRK 84);

- Melton Hill Reservoir, Oak Ridge Marina (CRK 80);

- Melton Hill Reservoir above city of Oak Ridge water intake (CRK 66);

- Clinch River downstream from ORNL (CRK 32);

- Clinch River downstream from all DOE inputs (CRK 16); and

- Poplar Creek downstream from the K-25 Site (PCK 2.2).

The radionuclides of primary concern at ORNL regarding fish consumption are total radioactive strontium and ${ }^{137} \mathrm{Cs}$. These two isotopes typically result in the highest dose to humans from ingestion of fish. Radioactivity analysis requires that fish samples be ashed; only edible portions of the fish are included in the ashing process. Three composite samples of bluegill from each site were prepared and submitted for analysis for radionuclides. The composite samples are ashed and analyzed by gamma spectroscopy and radiochemical techniques for the radionuclides that contribute most of the potential radiation dose to humans. The radionuclides sought are ${ }^{137} \mathrm{Cs},{ }^{60} \mathrm{Co}$, and total radioactive strontium $\left({ }^{80} \mathrm{Sr}+{ }^{90} \mathrm{Sr}\right)$. Six large individual bluegili were collected at each site and submitted for analysis for metals, pesticides, and PCBs. Each fish was filleted, and the muscle tissue was used for analysis.

The ash typically constitutes $1 \%$ of the original sample. DOE Order 5400.1 requires that concentrations be reported in picocuries per gram of ash weight. The 1992 concentration radionuclide data have also been converted to a wet weight basis.

\subsubsection{Results}

Summary concentrations of metals, pesticides, PCBs, and radionuclides in fish collected from the six sampling locations are given in Tables 6.2 through Tables 6.7 in Vol. 2.

For all six locations, most metals, pesticides, and PCBs were below the analytical detection limit. 


\section{Environmental Report Vol. 1, Oak Ridge}

Analytes that were above the analytical detection limit in at least one of the six individual samples are summarized in Table 6.2.

For radionuclides, individual concentrations that are significantly greater than zero are considered as detected. Analytes that were detected in at least one of the three composite samples were ${ }^{137} \mathrm{Cs}$ (CRK 84 and 80 ) and ${ }^{137} \mathrm{CS}$ and total radioactive strontium (CRK 32, 16, and PCK 2.2). Information regarding potential health impacts associated with these data is provided in Sect. 2.

\subsection{ORR Deer Population}

The eighth annual DOE-Tennessee Wildlife Resources Agency-managed deer hunts were held during the final quarter of 1992. Analytical Chemistry Division (ACD) personnel assisted by student members of the Wildlife Society (University of Tennessee chapter) performed most of the necessary operations at the checking station. The radiological surveillance of the harvest continues to be the responsibility of $A C D$ personnel.

The basic conduct of the managed hunts for 1992 was similar to those of previous years. One archery hunt was held (October 17-.18) as were two shotgun/muzzle-loader hunts (November $14-15$ and December 12-13). During the archery hunt 130 deer . were taken, and 390 were killed during the two gun hunts. From the total harvest of 520 animals, 284 $(54.6 \%)$ were bucks and $236(45.4 \%)$ were does. The 1992 hunt was the largest hunt since 1987, when 530 deer were harvested. The heaviest buck had 9 antler points and weighed $177 \mathrm{lb}$. The greatest number of points (12) were found on a buck that weighed $131 \mathrm{lb}$. The heaviest doe weighed $116 \mathrm{lb}$.

Soft tissue (liver or muscle) radioactivity concentrations of ${ }^{137} \mathrm{Cs}$ continued to be low and acceptable. None of the harvest exceeded $1.0 \mathrm{pCi} / \mathrm{g}$. (The confiscation limit is $5 \mathrm{pCi} / \mathrm{g}$.) The maximum concentration of ${ }^{137} \mathrm{Cs}$ was $1.4 \mathrm{pCi} / \mathrm{g}$. Strontium-90 concentrations in bone exceeded $30 \mathrm{pCi} / \mathrm{g}$ (the confiscation limit) in 12 deer, which is $2.3 \%$ of the 520 harvested.

\subsection{Vegetation}

\subsubsection{Food Crops}

The availability of contaminants to the consumers will be more directly assessed through the analysis of food crops rather than grass. As $p i$ "t of the new Environmental Monitoring Plan for the Oak Ridge Reservation a Food Crop program was implemented in CY 1992. Soil plots were established at nine ambient air stations (the Loudon Dam station was not included). Crops will be grown and analyzed in CY 1993.

Table 6.2. Metals, pesticides, and PCBs in fish at ORNL sampling locations

\begin{tabular}{|c|c|}
\hline Location & Analytes \\
\hline \multicolumn{2}{|r|}{ Metals } \\
\hline $\begin{array}{l}\text { CRK } 84,80, \text { and } 66 \\
\text { CRK } 32 \\
\text { CRK } 16 \\
\text { PCK } 2.2\end{array}$ & $\begin{array}{l}\text { Arsenic, mercury, selenium, zinc } \\
\text { Arsenic, copper, lead, mercury, selenium, zinc } \\
\text { Arsenic, lead, mercury, selenium, zinc } \\
\text { Arsenic, lead, selenium, zinc }\end{array}$ \\
\hline \multicolumn{2}{|r|}{ Pcsticides } \\
\hline $\begin{array}{l}\text { CRK } 84,80, \text { and } 66 \\
\text { CRK } 32,16 \text {, and PCK } 2.2\end{array}$ & $\begin{array}{l}\text { Heptachlor } \\
4,4^{\prime} \text {-DDT, Heptachlor }\end{array}$ \\
\hline \multicolumn{2}{|r|}{ PCBs } \\
\hline $\begin{array}{l}\text { CRK } 84 \\
\text { CRK } 80 \text { and } 66 \\
\text { CRK } 32,16 \text {, and PCK } 2.2\end{array}$ & $\begin{array}{l}\text { Aroclor }-1242, \text { Aroclor }-1254 \\
\text { Aroclor }-1254 \\
\text { Aroclor }-1242, \text { Aroclor }-1260\end{array}$ \\
\hline
\end{tabular}

\section{6-6 Biological Monitoring}


For an initial food crop study in CY 1992 , tomatoes, turnips, and leaf lettuce, which had been grown near three ambient air stations, were purchased. The three stations were 35,39 , and 46 . These stations represent the areas of the maximum exposed individual for each facility.

\subsubsection{Sample Collection and Analytical Procedures}

Turnips, leaf lettuce, and tomatoes were collected from gardens as near as possible to the target ambient air stations, but outside the ORR. Figure 6.3 shows the location of these stations.

Samples were analyzed for tritium, total radioactive strontium, gross alpha and beta, gamma emitters, and uranium, plutonium, thorium, and beryllium isotopes.

\subsubsection{Results}

Concentrations are summarized in Table 6.3 These data, along with data from the initial soil plot plantings in CY 1993, will form a baseline for comparison of data and trending in future years.

\subsubsection{Hay}

A hay program was implemented in CY 1992 as part of the new Environmental Monitoring Plan for the ORR. A more extensive program is planned for CY 1993.

For the initial program hay was only available from one identified sampling area which was area 2 . Figure 6.4 shows the location of sampling sites.

\subsubsection{Sample Collection and Analytical Procedure}

Hay was collected from bales in area 2. Samples were analyzed for gross alpha and beta, gamma emitters, and fluorides.

\subsubsection{Results}

Concentrations are summarized in Table 6.4. These data do not indicate any impact from ORR facilities. These data, along with data from CY 1993 (full study), will form a baseline for comparison of data and trending in future years.

\subsection{Biological Monitoring and Abatement Programs (BMAPs)}

\subsubsection{Monitoring Contaminant Concentrations}

The BMAPs mandated by National Pollution Discharge Elimination System (NPDES) permits at the Y-12 Plant, ORNL, and the K-25 Site each contain tasks concerned with monitoring the accumulation of contaminants in the biota of receiving watess. The primary objectives of these studies are (1) to identify substances that accumulate to undesirable levels in biota as a result of discharges from DOE facilities, (2) to determine the significance of those discharges relative to other sources in determining contaminant concentrations in biota in receiving waters, and (3) to provide a baseline measure of biotic contamination to use in evaluating the effectiveness of any future remedial measures.

Elevated concentrations (relative to local reference sites) of mercury and polychlorinated biphenyls (PCBs) in biota are associated with discharges at all three facilities. Concentrations of these substances in redbreast sunfish (Lepomis auritus) have been monitored twice yearly at five sites in East Fork Poplar Creek (EFPC) downstream from the Y-12 Plant (Fig. 6.5) since 1985. A clear trend of decreasing mercury concentrations in sunfish with increasing distance below the New Hope Pond/Lake Reality discharge remains apparent (Fig. 6.6), and the mean concentrations of mercury in fish at specific sites have not exhibited an increasing or decreasing trend relative to concentrations observed in the mid-1980s except at East Fork Poplar Creek kilometer (EFK) 23.4, the site nearest the Y-12 Plant. Lower mercury concentrations were observed in redbreast sunfish at EFK 23.4 in 1990-1992 than were typical of the 1986-1989 period. Mercury concentrations were consistently lower in fish at EFK 23.4 than in fish from the next site downstream. It is not known whether the decrease in mean mercury concentrations at EFK 23.4 is a consequence of reduced mercury discharges via EFPC, a result in changes in the biological processing of mercury associated with ecological changes (i.e., the construction and colonization of Lake Reality), or a return to "normal" levels of contamination following 
1992 Environmental Report Vol. 1, Oak Ridge

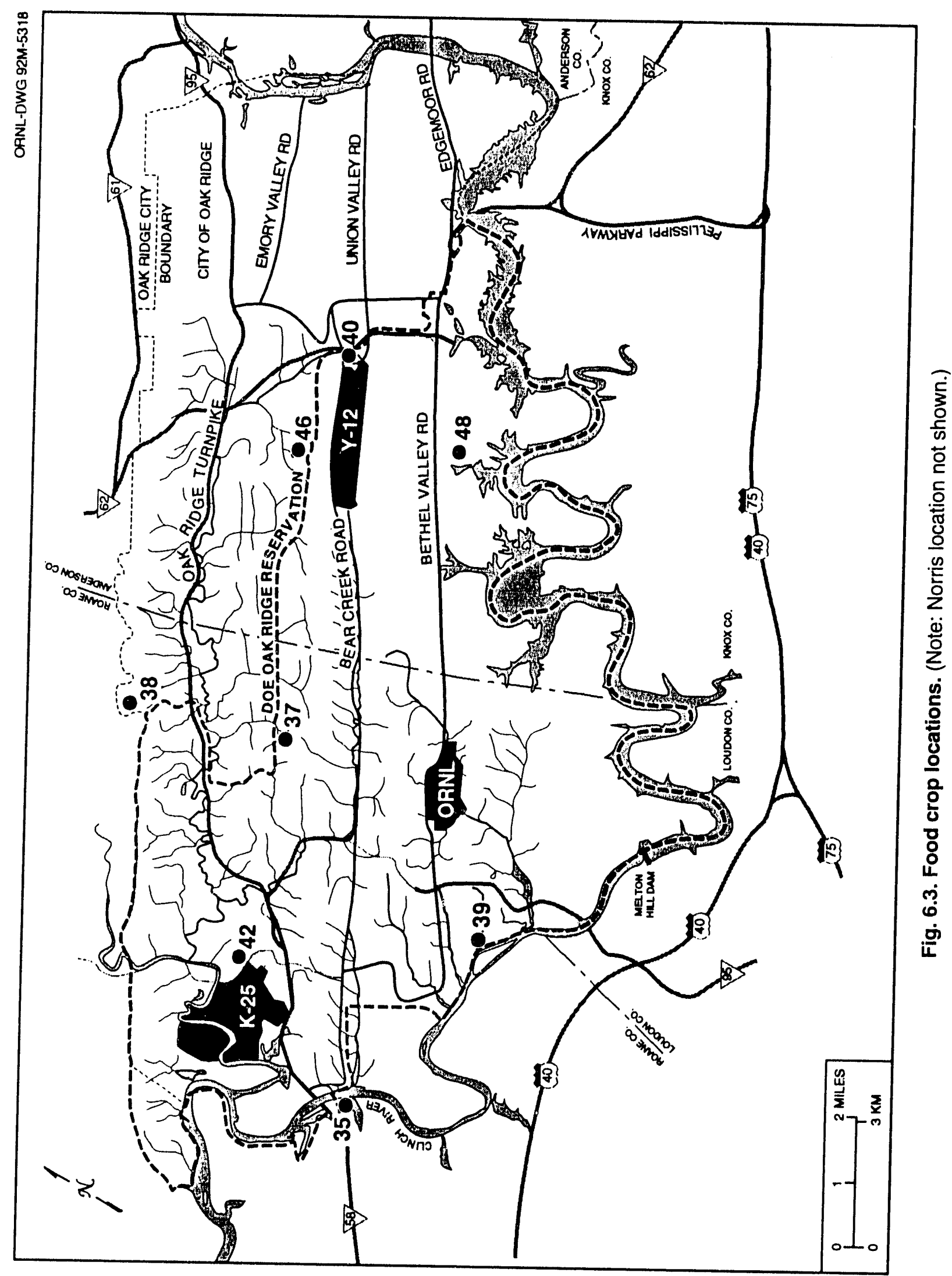


1992 Environmental Report Vol. 1, Oak Ridge

Table 6.3. 1992 Oak Ridge Reservation food crop radiological results

\begin{tabular}{|c|c|c|c|c|c|}
\hline $\begin{array}{l}\text { Food } \\
\text { crop }\end{array}$ & $\begin{array}{l}\text { Sample } \\
\text { size }\end{array}$ & $\begin{array}{l}\text { Sampling } \\
\text { date }\end{array}$ & Analysis & $\begin{array}{l}\text { Value }^{a} \\
(\mathrm{pCi} / \mathrm{g})\end{array}$ & Uncertainty \\
\hline \multicolumn{6}{|c|}{ Y-12 Plant } \\
\hline $\begin{array}{l}\text { Tomatoes } \\
\text { Tomatoes } \\
\text { Tomatoes } \\
\text { Tomatoes } \\
\text { Tomatoes } \\
\text { Greens } \\
\text { Greens } \\
\text { Greens } \\
\text { Greens } \\
\text { Greens } \\
\text { Greens } \\
\text { Turnips } \\
\text { Turnips } \\
\text { Turnips } \\
\text { Turnips } \\
\text { Turnips } \\
\text { Turnips }\end{array}$ & $\begin{array}{l}1 \\
1 \\
1 \\
1 \\
1 \\
1 \\
1 \\
1 \\
1 \\
1 \\
1 \\
1 \\
1 \\
1 \\
1 \\
1 \\
1\end{array}$ & $\begin{array}{c}8 / 7 \\
8 / 7 \\
8 / 7 \\
8 / 7 \\
8 / 7 \\
10 / 19 \\
10 / 19 \\
10 / 19 \\
10 / 19 \\
10 / 19 \\
10 / 19 \\
11 / 9 \\
11 / 9 \\
11 / 9 \\
11 / 9 \\
11 / 9 \\
11 / 9\end{array}$ & $\begin{array}{l}\text { G-Beta } \\
{ }^{40} \mathrm{~K} \\
{ }^{234} \mathrm{U} \\
{ }^{235} \mathrm{U} \\
{ }^{238} \mathrm{U} \\
{ }^{7} \mathrm{Be} \\
{ }_{\mathrm{G}}-\mathrm{Beta} \\
{ }^{40} \mathrm{~K} \\
{ }^{228} \mathrm{Th} \\
{ }^{234} \mathrm{U} \\
{ }^{238} \mathrm{U} \\
\mathrm{G}^{-B e t a} \\
{ }^{40} \mathrm{~K} \\
{ }^{228} \mathrm{Th} \\
{ }^{230} \mathrm{Th} \\
{ }^{234} \mathrm{U} \\
{ }^{238} \mathrm{U}\end{array}$ & $\begin{array}{l}0.86^{*} \\
2.19^{*} \\
0.01^{*} \\
0.00^{*} \\
0.00^{*} \\
0.1^{*} \\
4.86^{*} \\
5.41^{*} \\
0.01^{*} \\
0.01^{*} \\
0.00^{*} \\
2.43^{*} \\
3.51^{*} \\
0.00^{*} \\
0.00^{*} \\
0.01^{*} \\
0.01^{*}\end{array}$ & $\begin{array}{l}0.43 \\
0.11 \\
0.00 \\
0.00 \\
0.00 \\
0.06 \\
0.81 \\
0.27 \\
0.00 \\
0.00 \\
0.00 \\
0.54 \\
0.27 \\
0.00 \\
0.00 \\
0.01 \\
0.01\end{array}$ \\
\hline \multicolumn{6}{|c|}{ ORNL } \\
\hline $\begin{array}{l}\text { Tomatoes } \\
\text { Tomatoes } \\
\text { Tomatoes } \\
\text { Tomatoes } \\
\text { Greens } \\
\text { Greens } \\
\text { Greens } \\
\text { Greens } \\
\text { Greens } \\
\text { Greens } \\
\text { Greens } \\
\text { Greens } \\
\text { Turnips } \\
\text { Turnips } \\
\text { Turnips } \\
\text { Turnips } \\
\text { Tumips } \\
\text { Turnips } \\
\text { Turnips }\end{array}$ & $\begin{array}{l}1 \\
1 \\
1 \\
1 \\
1 \\
1 \\
1 \\
1 \\
1 \\
1 \\
1 \\
1 \\
1 \\
1 \\
1 \\
1 \\
1 \\
1 \\
1\end{array}$ & $\begin{array}{c}8 / 7 \\
8 / 7 \\
8 / 7 \\
8 / 7 \\
10 / 19 \\
10 / 19 \\
10 / 19 \\
10 / 19 \\
10 / 19 \\
10 / 19 \\
10 / 19 \\
10 / 19 \\
11 / 9 \\
11 / 9 \\
11 / 9 \\
11 / 9 \\
1119 \\
11 / 9 \\
11 / 9\end{array}$ & $\begin{array}{l}\text { G-Beta } \\
{ }^{40} \mathrm{~K} \\
{ }^{228} \mathrm{Th} \\
{ }^{234} \mathrm{U} \\
{ }^{7} \mathrm{Be} \\
\mathrm{G}-\mathrm{Beta} \\
{ }^{40} \mathrm{~K} \\
{ }^{228} \mathrm{Th} \\
{ }^{230} \mathrm{Th} \\
{ }^{232} \mathrm{Th} \\
{ }^{234} \mathrm{U} \\
{ }^{238} \mathrm{U} \\
\mathrm{G}-\mathrm{Beta} \\
{ }^{40} \mathrm{~K} \\
{ }^{228} \mathrm{Th} \\
{ }^{230} \mathrm{Th} \\
{ }^{232} \mathrm{Th} \\
{ }^{234} \mathrm{U} \\
{ }^{238} \mathrm{U}\end{array}$ & $\begin{array}{l}1.78^{*} \\
2.65^{*} \\
0.00^{*} \\
0.01^{*} \\
0.16^{*} \\
3.24^{*} \\
5.95^{*} \\
0.01^{*} \\
0.00^{*} \\
0.00^{*} \\
0.02^{*} \\
0.00^{*} \\
2.11^{*} \\
2.49^{*} \\
0.01^{*} \\
0.00^{*} \\
0.00^{*} \\
0.01^{*} \\
0.00^{*}\end{array}$ & $\begin{array}{l}0.49 \\
0.11 \\
0.01 \\
0.00 \\
0.04 \\
0.54 \\
0.27 \\
0.00 \\
0.00 \\
0.00 \\
0.01 \\
0.00 \\
0.54 \\
0.38 \\
0.00 \\
0.00 \\
0.00 \\
0.00 \\
0.00\end{array}$ \\
\hline \multicolumn{6}{|c|}{$K-25$ Site } \\
\hline $\begin{array}{l}\text { Tomatoes } \\
\text { Tomatoes } \\
\text { Tomatoes } \\
\text { Tomatoes } \\
\text { Tomatoes } \\
\text { Greens } \\
\text { Greens } \\
\text { Greens } \\
\text { Greens } \\
\text { Greens } \\
\text { Greens } \\
\text { Greens } \\
\text { Turnips } \\
\text { Turnips } \\
\text { Turnips } \\
\text { Tumips } \\
\text { Turnips } \\
\text { Turnips } \\
\text { Turnips }\end{array}$ & $\begin{array}{l}1 \\
1 \\
1 \\
1 \\
1 \\
1 \\
1 \\
1 \\
1 \\
1 \\
1 \\
1 \\
1 \\
1 \\
1 \\
1 \\
1 \\
1 \\
1\end{array}$ & $\begin{array}{c}8 / 7 \\
8 / 7 \\
8 / 7 \\
8 / 7 \\
8 / 7 \\
10 / 19 \\
10 / 19 \\
10 / 19 \\
10 / 19 \\
10 / 19 \\
10 / 19 \\
10 / 19 \\
11 / 9 \\
11 / 9 \\
11 / 9 \\
11 / 9 \\
11 / 9 \\
11 / 9 \\
11 / 9\end{array}$ & $\begin{array}{l}{ }^{60} \mathrm{Co} \\
\mathrm{G}-\mathrm{Beta} \\
{ }^{40} \mathrm{~K} \\
{ }^{230} \mathrm{Th} \\
{ }^{234} \mathrm{U} \\
{ }^{7} \mathrm{Be} \\
{ }_{\mathrm{G}}-\mathrm{Beta} \\
{ }^{40} \mathrm{~K} \\
{ }^{228} \mathrm{Th} \\
{ }^{230} \mathrm{Th} \\
\text { Total-Sr } \\
{ }^{234} \mathrm{U} \\
\mathrm{G}-\mathrm{Beta} \\
{ }^{40} \mathrm{~K} \\
{ }^{228} \mathrm{Th} \\
\mathrm{Total}-\mathrm{Sr} \\
{ }^{234} \mathrm{U} \\
235 \mathrm{U} \\
{ }^{238} \mathrm{U}\end{array}$ & $\begin{array}{l}0.01^{*} \\
1.19^{*} \\
2.43^{*} \\
0.00^{*} \\
0.01^{*} \\
0.11^{*} \\
3.51^{*} \\
5.68^{*} \\
0.00^{*} \\
0.00^{*} \\
0.07^{*} \\
0.01^{*} \\
2.65^{*} \\
2.97^{*} \\
0.01^{*} \\
0.10^{*} \\
0.02^{*} \\
0.01^{*} \\
0.01^{*}\end{array}$ & $\begin{array}{l}0.01 \\
0.43 \\
0.14 \\
0.00 \\
0.00 \\
0.05 \\
0.54 \\
0.27 \\
0.00 \\
0.00 \\
0.07 \\
0.00 \\
0.59 \\
0.27 \\
0.01 \\
0.09 \\
0.01 \\
0.00 \\
0.00\end{array}$ \\
\hline
\end{tabular}

${ }^{a}$ An asterisk $(*)$ indicates statistical significance at the $95 \%$ level. 


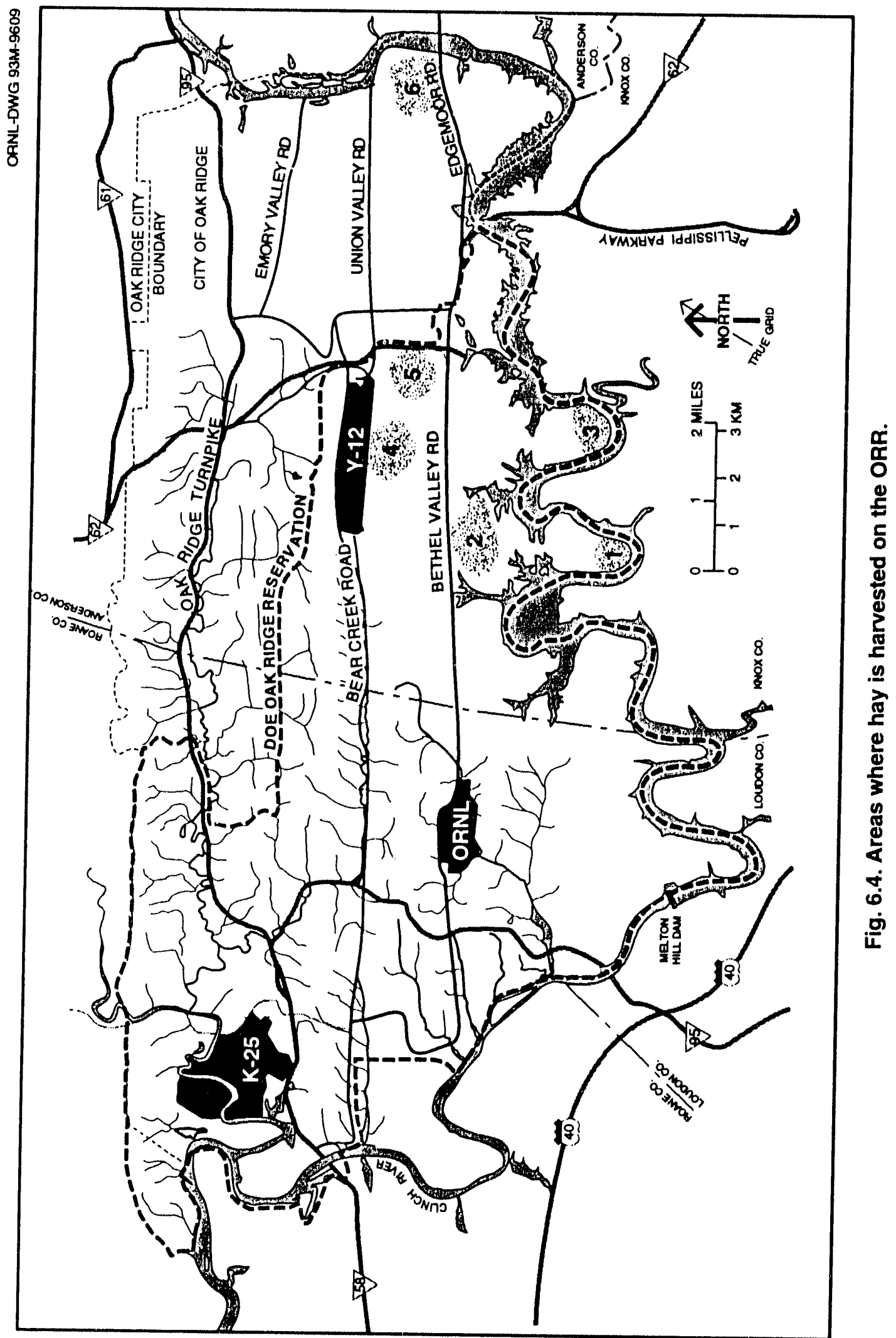


Table 6.4. 1992 Oak Ridge Reservation hay radiological results ${ }^{a}$

\begin{tabular}{cclcc}
\hline $\begin{array}{c}\text { Sample } \\
\text { size }\end{array}$ & $\begin{array}{c}\text { Sampling } \\
\text { date }\end{array}$ & Analysis & $\begin{array}{c}\text { Significant value }^{a} \\
(\mathrm{pCi} / \mathrm{g})\end{array}$ & Uncertainty \\
\hline 1 & $10 / 2$ & ${ }^{7} \mathrm{Be}$ & 1.19 & 0.43 \\
1 & $10 / 2$ & Gross-Beta & 6.22 & 0.54 \\
1 & $10 / 2$ & ${ }^{40} \mathrm{~K}$ & 10.54 & 0.81 \\
1 & $10 / 2$ & Fluoride & $2.20^{b}$ & \\
\hline
\end{tabular}

${ }^{a}$ An asterisk $(*)$ indicates statistical significance at the $95 \%$ level.

${ }^{b}$ Units for fluoride are $\mathrm{mg} / \mathrm{g}$.

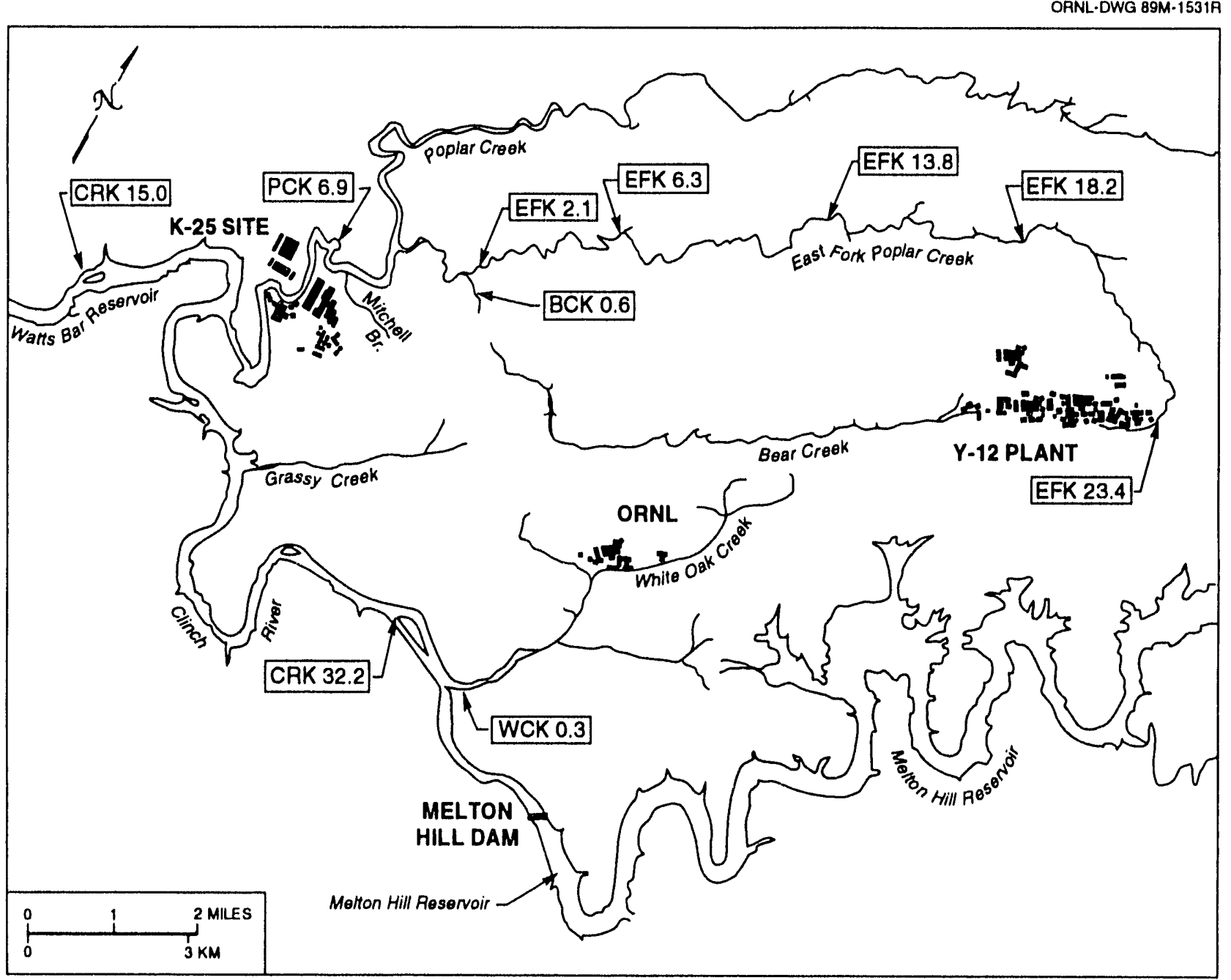

Fig. 6.5. Locations of channel catfish and redbreast sunfish collection sites for BMAP bioaccumulation studies. 
ORNL-DWG 93M-9599

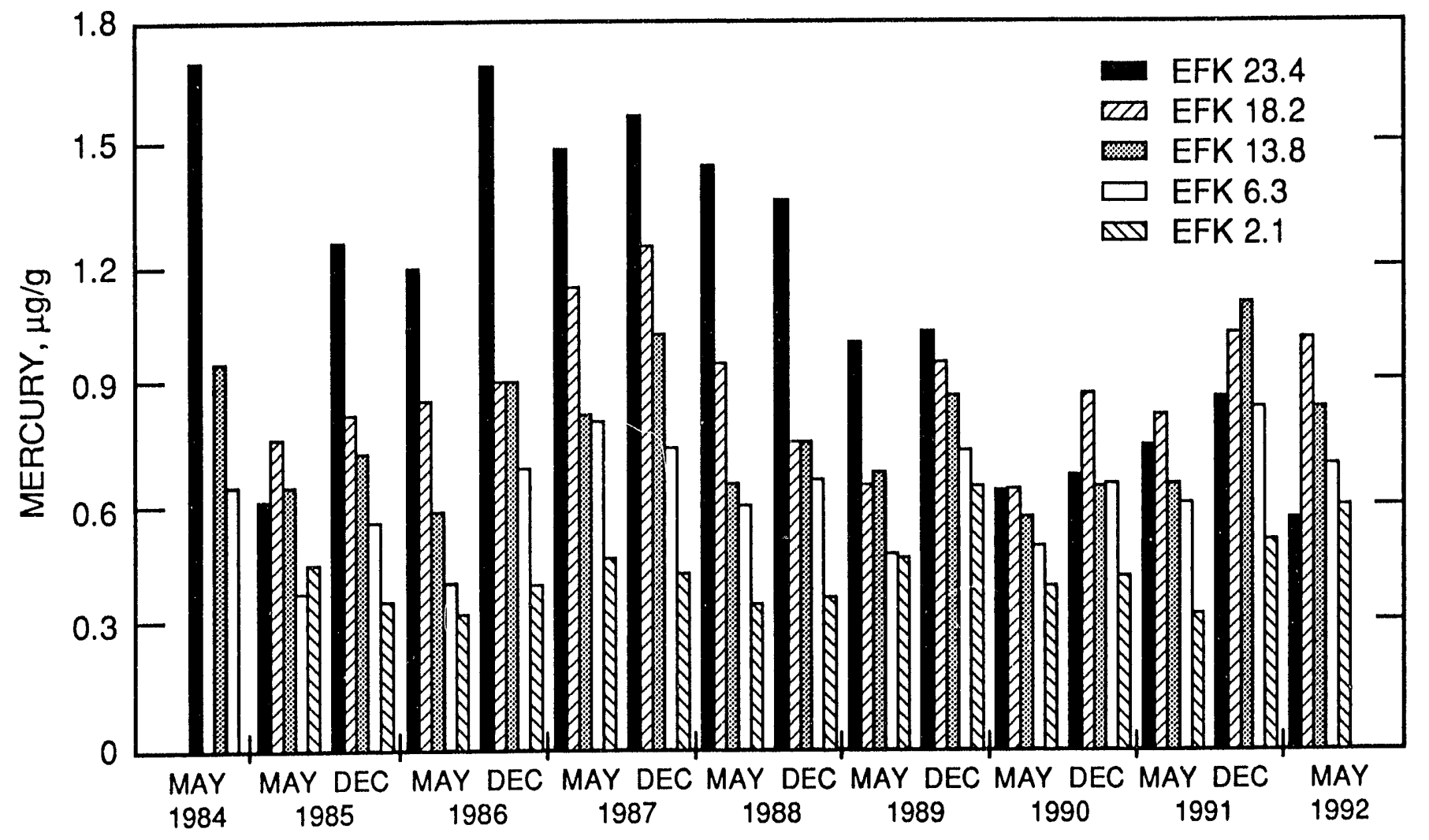

Fig. 6.6. Average concentrations of mercury in redbreast sunfish $(n=8)$ collected at sites in East Fork Poplar Creek, 1984-1992. The 1984 data are from the Oak Ridge Task Force study (TVA 1985).

a period of disturbance related to construction/ remediation activities.

A similar pattern of decreasing concentrations with distance downstream is apparent for PCBs in redbreast sunfish (Fig. 6.7). PCB concentrations found in EFPC sunfish in 1990-1992 fell within the range observed in previous years. As a result of the colonization of Lake Reality and EFPC upstream from Lake Reality following its construction, it was possible to obtain sunfish from sites upstream from EFK 23.4. Redbreast sunfish from EFPC above Lake Reality and bluegill from Lake Reality contained PCB concentrations in Dec 91/May 92 similar to fish at EFK 23.4, averaging $0.67 \mu \mathrm{g} / \mathrm{g}$. The high concentrations in fish at sites in upper EFPC indicate the importance of the industrialized portion of the Y-12 Plant as a source in relation to contaminated sediment and soil downstream from Lake Reality.

Bluegill and other sunfish collected in 1991-1992 were again found to indicate the presence of multiple sources of PCB and mercury contamination (Figs. 6.8 and 6.9) on the ORR. Elevated concentrations of mercury were clearly evident in fish from EFPC, Poplar Creek, Bear Creek, Mitchell Branch, and White Oak Creek (WOC). Mean mercury concentrations in fish in 1991-1992 on the ORR were similar to those observed in 1990. The highest mean concentrations continued to be in fish from EFPC, where the U.S. Food and Drug Administration (FDA) action limit of $1 \mu \mathrm{g} / \mathrm{g}$ was exceeded at two sites (EFK 18.2 and EFK 13.8).

The mean $\mathrm{PCB}$ concentrations in sunfish were elevated in WOC, EFPC, Bear Creek, lower Poplar Creek, and Mitchell Branch (Fig. 6.9). The highest PCB concentrations were found in fish from Mitchell Branch at the K-25 Site (MIK 0.2), EFPC immediately downstream of the Y-12 plant (EFK 23.4), and the WOC drainage (WCK 3.5, WOL, NTK 0.2) at ORNL. The mean PCB concentrations in fish from Bear Creek in 1991-1992 were

\section{6-12 Biological Monitoring}




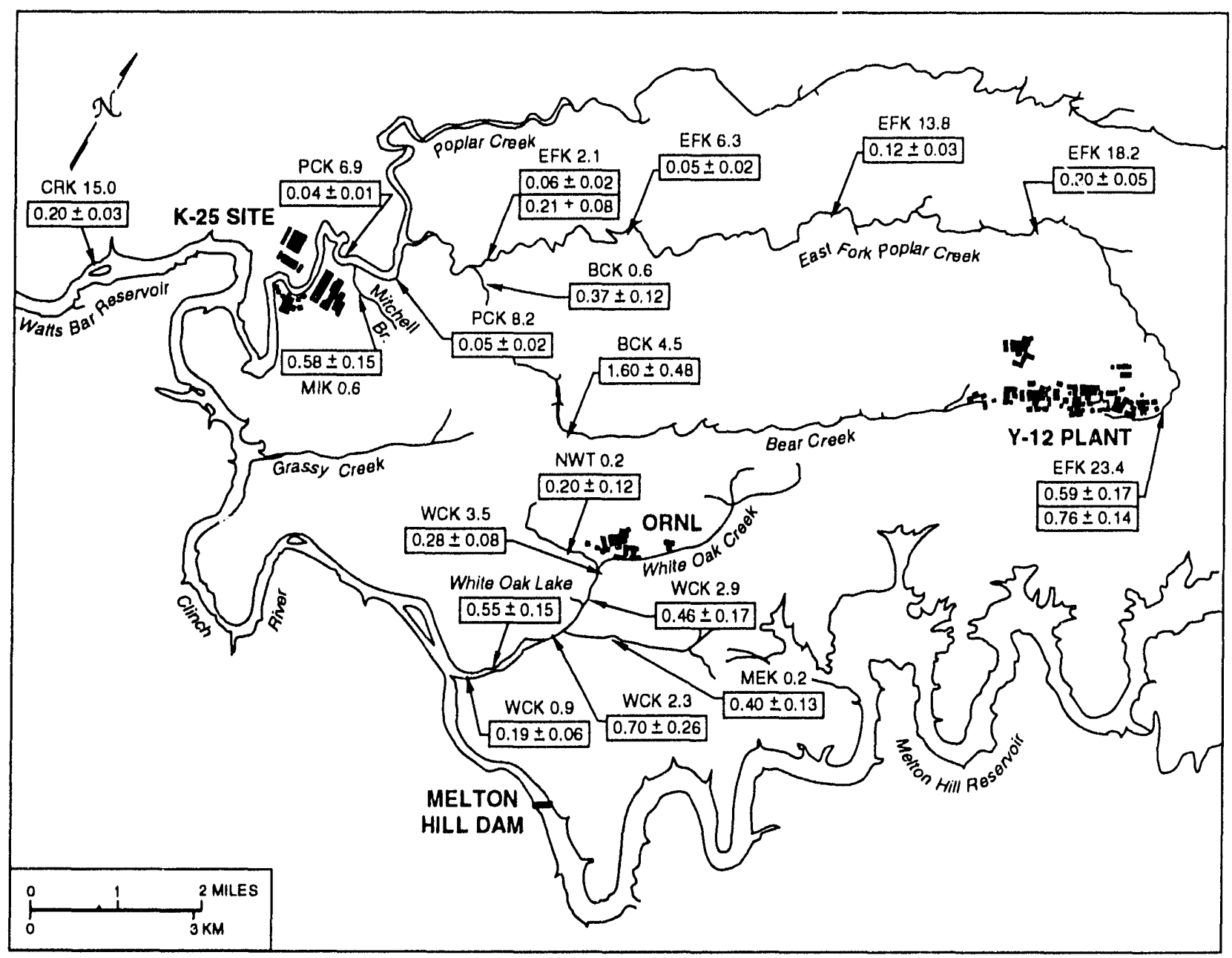

Fig. 6.7. Average concentrations of PCBs in redbreast sunfish $(n=8)$ collected semiannually at sites in East Fork Poplar Creek, 1985-1992.

substantially lower than those observed previously. At the other sites on the ORR, mean PCB concentrations in 1991-1992 were similar to concentrations observed in previous years.

Sunfish serve as good indicators of PCB contamination, particularly in small streams close to specific sources, but they do not accumulate PCBs to the extent that longer-lived, larger, fattier fish such as catfish and carp do. Channel catfish (Ictalurus punctatus) have been found to contain PCBs approaching the FDA limit $(2 \mu \mathrm{g} / \mathrm{g})$ in several reservoirs in East Tennessee, including Watts Bar Reservoir (TVA 1985). As a result of finding that PCB concentrations exceeded the FDA limit in all channel catfish collected in WOC embayment in 1984 by the Oak Ridge Task Force, annual PCB monitoring in this species was initiated in 1986.

Routine collection sites are depicted in Fig. 6.5; sites were selected to provide the ability to distinguish the relative importance of $\mathrm{PCB}$ sources in the WOC and Poplar Creek drainages in contributing to $\mathrm{PCB}$ concentrations in Clinch River catfish. The pattern of PCB contamination in channel catfish did not change considerably over the 1986-1992 period, despite some occasional year-to-year fluctuations in contaminant levels (Table 6.5). As in previous years, the highest mean PCB concentration in catfish was in fish from WOC embayment. The low PCB concentrations in catfish from the Clinch River just downstream of WOC (CRK 32.2) in 1992 suggest that the flow restrictor at the mouth of WOC was an effective barrier to movement of channel catfish in 


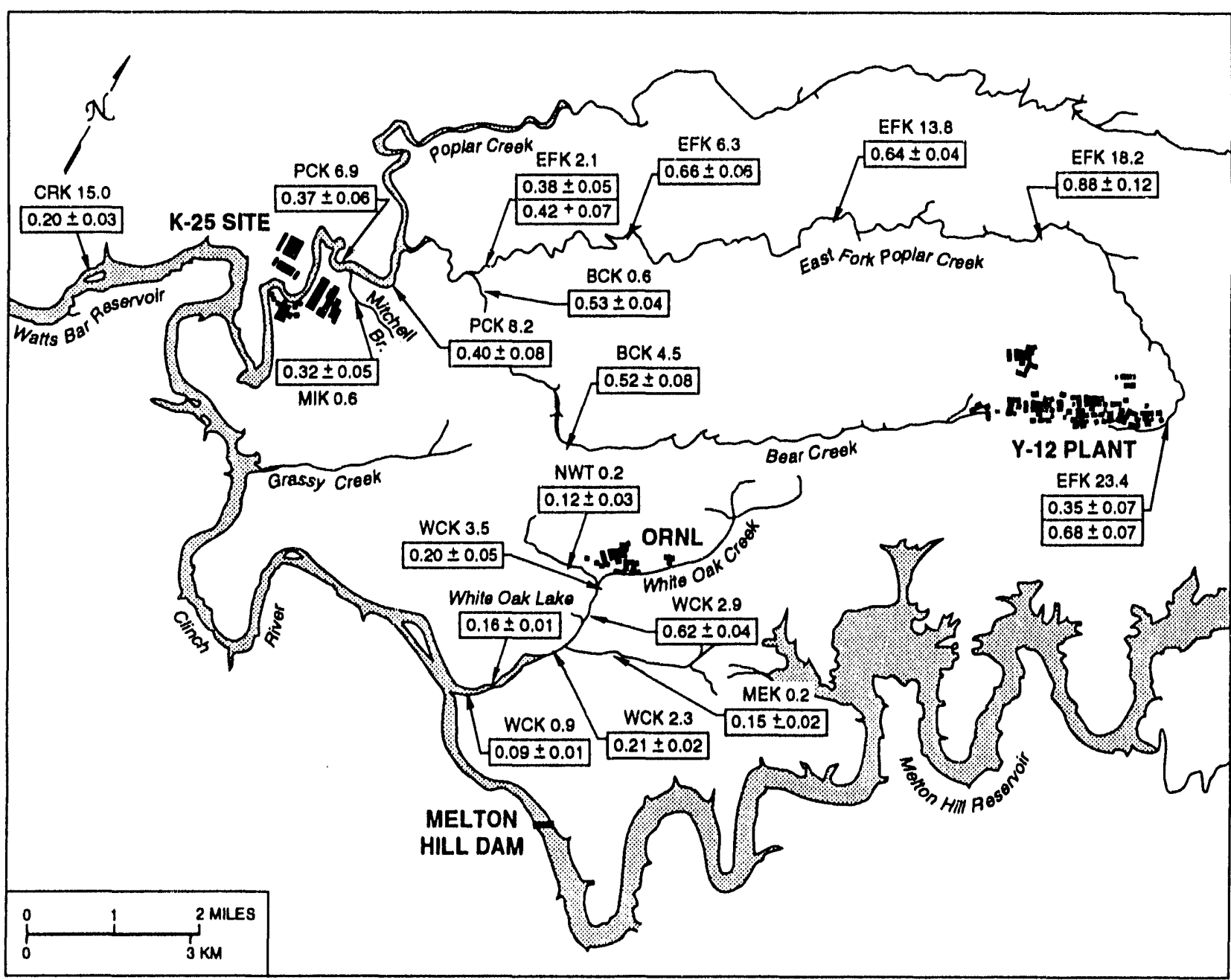

Fig. 6.8. Average concentrations ( $\pm 1 \mathrm{SE})$ of mercury $(\mu \mathrm{g} / \mathrm{g}$, wet weight) in sunfish collected in fall 1990 at sites on the ORR. Fish are redbreast sunfish (L. auritus) at MIK 0.6, EFK sites (bottom values where two appear) and WCK 2.3; rock bass (Ambloplites rupestris) at BCK sites; and bluegill ( $L$. macrochirus) at the remaining sites.

and out of the contaminated embayment. However, a similarly low PCB concentration was reported for channel catfish at CRK 32.2 in 1990 . Continued monitoring of channel catfish will help to evaluate the long term effect of the flow restrictor at the mouth of WOC on PCB contamination in Clinch River biota.

Chlordane contamination was again observed in clams placed in cages in WOC in 1992. As was also the case in previous years, chlordane was not elevated in fish collected from WOC. Mean chlordane concentrations in caged clams have steadily decreased since 1988 at most sites, suggesting that elevated chlordane concentrations in WOC clams was the result of an episodic input and not a chronic release.

\subsubsection{Indications of Ecological Recovery in Three Receiving Streams near DOE Oak Ridge Facilities}

The BMAPs for the three DOE Oak Ridge facilities include a task to assess the impacts of plant operations on fish communities of receiving streams. A major component of this task is the estimation of fish abundance at selected sites. Abundance (as

\section{6-14 Biological Monitoring}




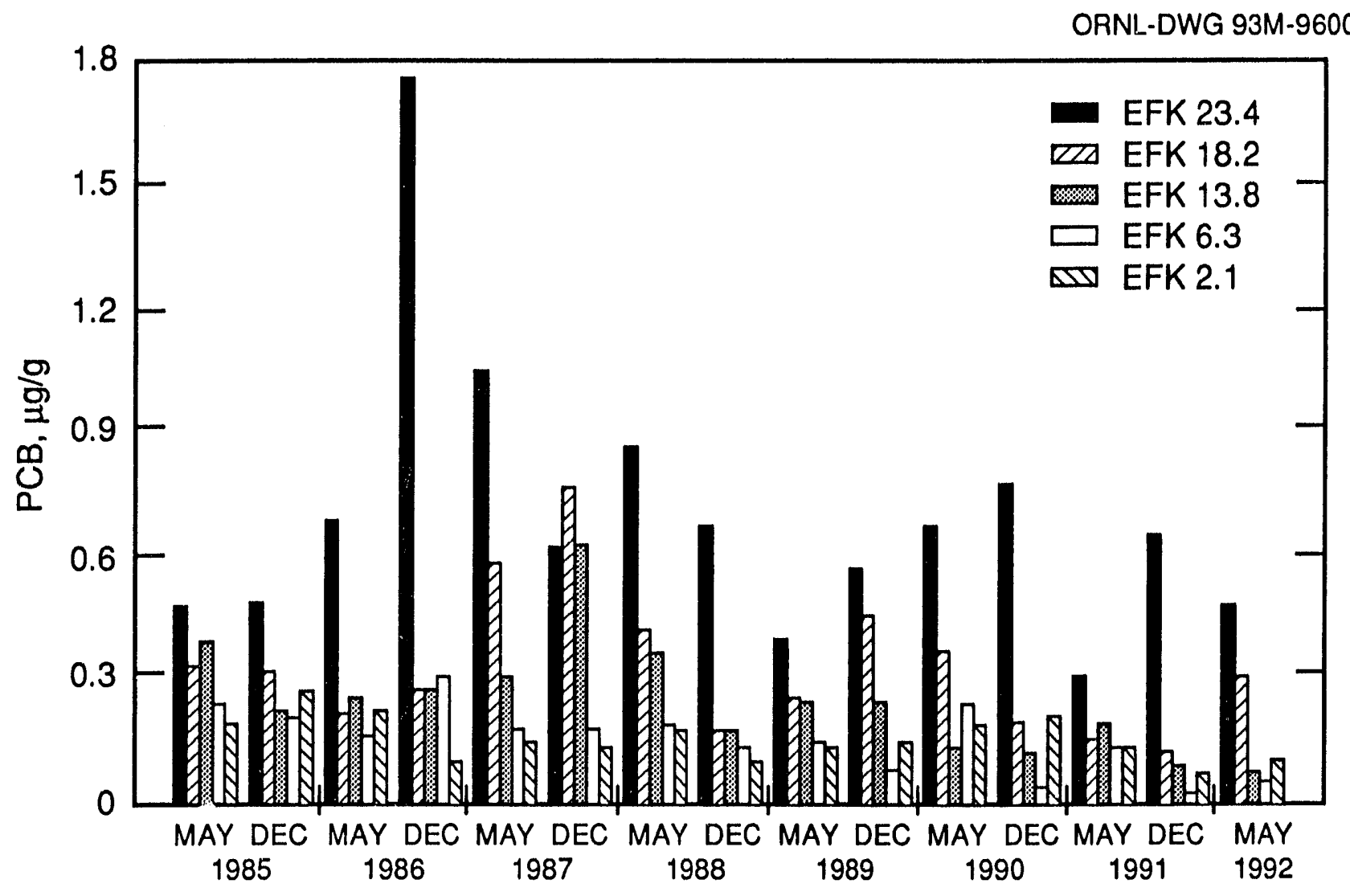

Fig. 6.9. Average concentrations ( $\pm 1 \mathrm{SE}$ ) of $\mathrm{PCB}(\mu \mathrm{g} / \mathrm{g}$, wet weight) in sunfish collected in 1985-1992 at sites on the ORR. Fish are redbreast sunfish ( $L$. auritus) at MIK 0.6 , EFK sites (bottom values where two appear) and WCK 2.3; rock bass (Ambloplites rupestris) at BCK sites; and bluegill ( $L$. macrochirus) at the remaining sites.

Table 6.5. Changes from 1986 to 1992 in average concentrations of PCBs $(\mu \mathrm{g} / \mathrm{g}$, wet $w t$ ) and fraction of fish exceeding the Food and Drug Administration (FDA) limit, for channel catfish from White Oak Creek embayment (WCK), the Clinch River (CRK), lower Poplar Creek (PCK), and Melton Hill Reservoir (MHR)

\begin{tabular}{|c|c|c|c|c|c|c|c|}
\hline Site & 1986 & 1987 & 1988 & 1989 & 1990 & 1991 & 1992 \\
\hline \multicolumn{8}{|c|}{ PCBs } \\
\hline WCK 0.3 & 1.30 & 1.59 & 0.96 & 1.54 & 3.56 & 3.60 & 3.29 \\
\hline CRK 32.2 & 1.01 & 1.61 & 0.58 & 1.20 & 0.31 & 1.38 & 0.36 \\
\hline MHR & 0.46 & 0.81 & 0.52 & 0.28 & 0.41 & 0.29 & 0.34 \\
\hline PCK 6.9 & & & 0.71 & 1.07 & 0.92 & 0.68 & 0.54 \\
\hline CRK 15.0 & & & 0.50 & 0.79 & 0.88 & 1.08 & 1.27 \\
\hline \multicolumn{8}{|c|}{ Fraction over FDA limit } \\
\hline WCK 0.3 & $3 / 12$ & $2 / 8$ & $2 / 8$ & $4 / 8$ & $4 / 8$ & $6 / 8$ & $5 / 8$ \\
\hline CRK 32.2 & $0 / 8$ & $2 / 8$ & $1 / 8$ & $1 / 8$ & $0 / 8$ & $1 / 8$ & $0 / 8$ \\
\hline MHR & $0 / 6$ & $1 / 7$ & $0 / 10$ & $0 / 8$ & $0 / 8$ & $0 / 8$ & $0 / 8$ \\
\hline PCK 6.9 & & & $0 / 8$ & $1 / 8$ & $1 / 8$ & $0 / 8$ & $0 / 8$ \\
\hline CRK 15.0 & & & $0 / 9$ & $1 / 8$ & $1 / 8$ & $1 / 8$ & $2 / 8$ \\
\hline
\end{tabular}




\section{Environmental Report Vol. 1, Oak Ridge}

measured by density per unit area) reflects the ecological suitability of a site for fish and can be used to identify both short-and long-term impacts on the community and any recovery of the community resulting from remedial actions. Estimates of fish community abundance have been made twice yearly (spring and fall) since 1985. Data for several monitoring sites are plotted in Fig. 6.10, including EFPC at EFK 23.4, Bear Creek at BCK 12.4, and WOC at WCK 3.9.

The site at EFK 23.4 is located just downstream of the Y-12 Plant and below the outfall of Lake Reality, a small, lined basin. Fish abundance was extremely low during the first year of monitoring, but a large increase was observed in fall 1986. During 1985-1986, the Central Pollution Control Facility became operational at the Y-12 Plant. For the next 4 years, fish abundance remained relatively stable (2 to $4 \mathrm{fish} / \mathrm{m}^{2}$ ). By November 1988 , two additional waste treatment facilities were added at the $Y-12$ Plant, and flow was routed through the newly constructed Lake Reality while the old basin (New Hope Pond) was eventually closed and capped. A second, large increase in density occurred in fall 1990, which may have been associated with the maturation of Lake Reality and an increase in the export of nutrients and food downstream. Presently, the densities of fish just below the lake have stabilized at a level that is among the highest observed in BMAP. Although still occasionally impacted by adverse water quality, the recovery of the fish community in this reach of stream suggests there has been an overall improvement in water quality below the Y-12 Plant.

The site at BCK 12.4 is located in the headwaters of Bear Creek just below the S-3 ponds. The ponds, which were capped in 1989 , consisted of four 0.40 -ha, unlined basins constructed in 1951 for the disposal of nitrate wastes (nitric acid and nitrate salts); they were designed to maximize evaporation and percolation rates. Recovery of the fish community at BCK 12.4 was much slower that at EFK 23.4 due to the greater degradation of water quality and to the adverse impacts of high sediment loading. By fail 1989, however, a substantial increase was observed in both fish abundance and the number

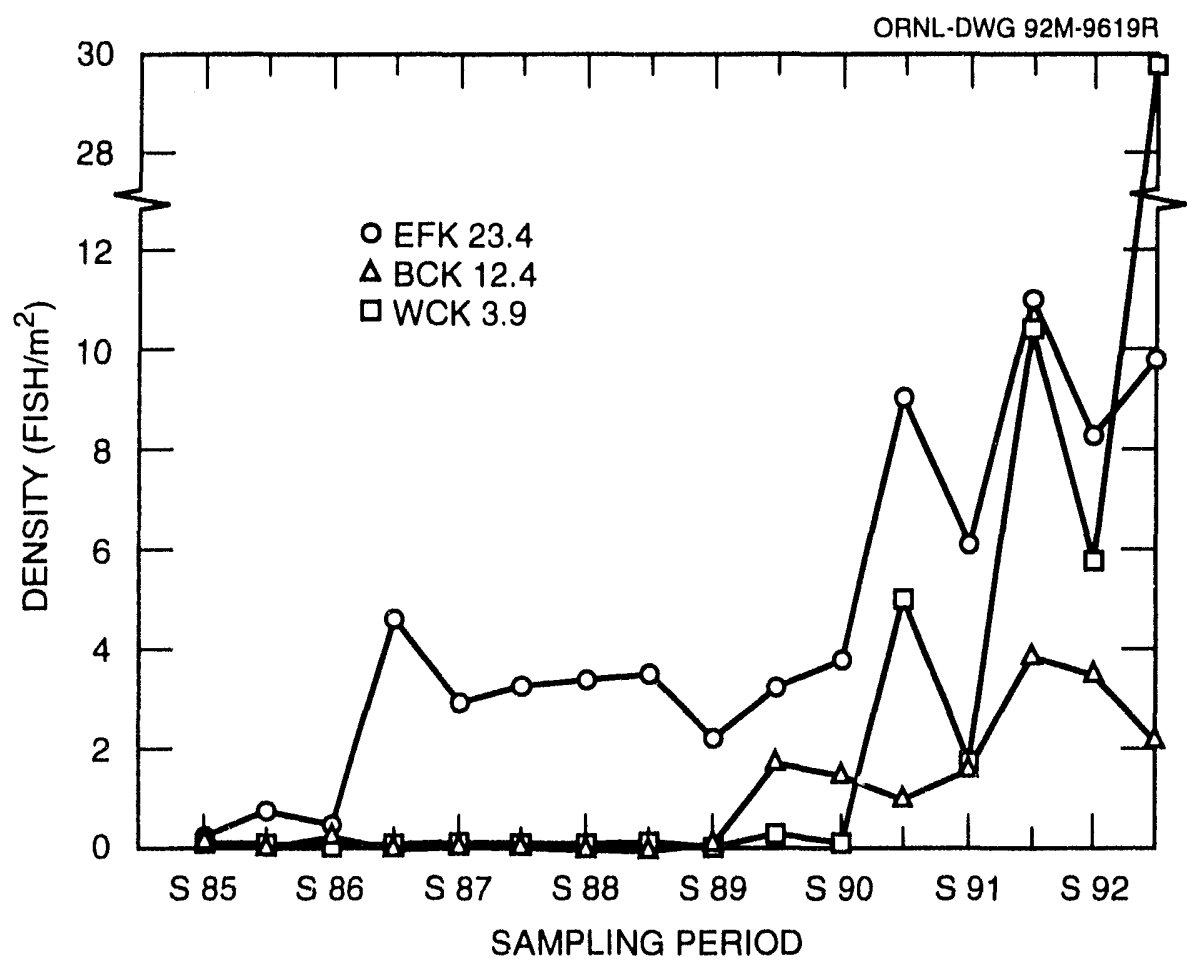

Fig. 6.10. Fish community density at East Fork Poplar Creek site EFK 23.4, Bear Creek site BCK 12.4, and White Oak Creek site WCK 3.9, spring 1985 to fall 1992.

\section{6-16 Biological Monitoring}


of species. In 1991 and 1992, fish abundance varied within a range of densities typical for smaller streams. Further recovery of the fish community at BCK 12.4 would be indicated by greater species richness and may depend as much on improvements in physical habitat as improvements in water quality.

Unlike EFK 23.4 and BCK 12.4, the site at WCK 3.9 is located at ORNL within the main plant area and downstream of several tributary streams. Until fall 1990, density never exceeded $0.3 \mathrm{fish} / \mathrm{m}^{2}$. However, on March 30, 1990, a new wastewater treatment facility became operational at ORNL, eliminating many untreated discharges to WOC. High fish densities were observed at WCK 3.9 in 1991; and in fall 1992, density reached the highest level ever observed at a BMAP site. The dramatic increase in abundance at WCK 3.9 resulted from an increase in density of one species, the central stoneroller (Campostoma anomalum). This species is a grazing herbivore that benefitted from the high algal biomass associated with the nutrient enrichment downstream of the wastewater treatment facility. If recovery continues at WCK 3.9, additional species and a more balanced representation of species abundances should be observed.

The BMAP sampling revealed a similar pattern of recovery at all three sites. Each site is located just downstream of plant operations and has received significant adverse impacts in the past. Improvements in waste disposal operations, including construction of new treatment facilities and closure of settling basins, reduced the instream toxicity at each site. Changes in water quality resulted in noticeable increases in fish community abundance and often fish species richness. Increased abundance is the first stage in the recovery of a stressed community, indicating conditions that are favorable for successful reproduction and survival of the more tolerant fish species.

\subsubsection{Effects of Effluent Dechlorination on Clams in East Fork Poplar Creek}

Since initiating the BMAP for EFPC in 1985 , chlorine has been implicated as one of the major factors (1) contributing to instream toxicity and (2) adversely impacting the benthic macroinvertebrate and fish communities in the upper reaches of the stream just below the Y-12 Plant. When a chlorine abatement plan was developed and approved, a two-phase study was initiated to evaluate the ecological effects of dechlorination based on in situ exposures of fingernail clams (Sphaerium fabale) in EFPC at various distances from the Y-12 Plant. Phase I, which was initiated in February 1992, will provide a baseline on the response of the clams to conditions in upper EFPC prior to dechlorination.

Clams for the study were obtained from a nearby reference stream (Beaver Creek) in Knox County, Tennessee. The lengths of the clams were measured, and they were placed at three sites in EFPC and one site in the reference stream, where they remained for a period of 3 weeks. After the 3-week exposure period, clams were retrieved; mortality was noted; lengths were measured; and the original clams were replaced with freshly collected clams. A total of five exposure periods was used.

During the baseline Phase I study, excessive mortality was not observed at any site in EFPC, but clam growth at EFK 24.4 (located just downstream of Outfall 17 inside the Y-12 Plant) and EFK 23.4 (located about $100 \mathrm{~m}$ upstream of Bear Creek Road) was lower than at the reference site (Fig. 6.11). Even though the clams grew less at EFK 23.4 than at the reference site, the patterns of change in clam growth exhibited between exposure periods were similar at these two sites, in contrast to the pattern at EFK 24.4. That is, while clams grew very little during each of the 3-week exposure periods at EFK 24.4, clams at EFK 23.4 and the reference site grew and exhibited similar changes in the amount of growth between exposure periods. These results suggest that the clams at EFK 24.4 were exposed to an unidentified toxicant that inhibited growth, while growth at EFK 23.4 was only being suppressed due to some unknown factor (e.g., insufficient food or excessive temperatures). If chlorine was the primary factor inhibiting growth at EFK 24.4 during this baseline study, then the changes in growth between exposure periods at EFK 24.4 should approach those exhibited by clams at the reference site.

\subsubsection{Changes in Trace Element Concentrations in Largemouth Bass Following Elimination of Fly Ash Discharge to Rogers Quarry}

Fly ash discharges to Rogers Quarry were reduced in 1989 and were eventually eliminated 


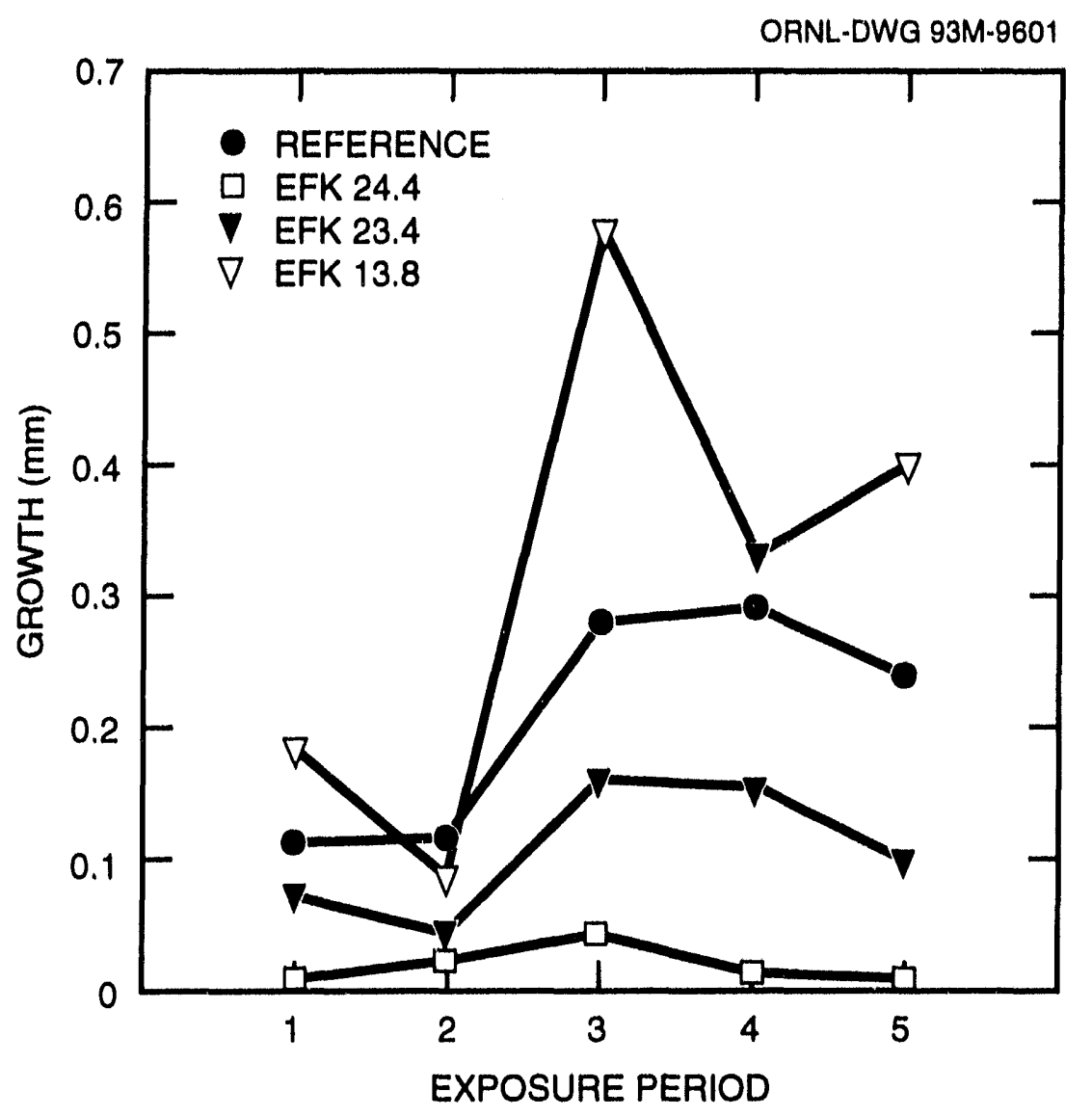

Fig. 6.11. In situ growth of fingernail clams (Sphaerium fabale) during five separate 3-week exposures at three sites on East Fork Poplar Creek and a reference site (Beaver Creek).

altogether by 1991. Fly ash contains substantial concentrations of trace elements that can be mobilized on contact with water. Of these, arsenic and selenium generate the most environmental concern due to their toxicity to fish and wildlife and their bioaccumulation potential. During the period of fly ash disposal in Rogers Quarry, concentrations of both arsenic and selenium in Rogers Quarry water were much higher than is typical of uncontaminated natural waters in east Tennessee. Following the cessation of fly ash discharges to the quarry, arsenic and selenium concentrations in water dropped to below analytical detection limits in NPDES monitoring.

Largemouth bass from Rogers Quarry were sampled in July 1990, 1991, and 1992 and analyzed for trace element contamination. Concentrations of arsenic in fish remained unchanged over that period, averaging $0.27 \mu \mathrm{g} / \mathrm{g}$ wet $w t$., more than a factor of ten higher than arsenic concentrations $(<0.025 \mu \mathrm{g} / \mathrm{g})$ in bass from nearby Lambert Quarry. Selenium concentrations in bass also changed little, averaging 3.0, 3.3, and $2.2 \mu \mathrm{g} / \mathrm{g}$ in 1990, 1991, and 1992, respectively, versus $0.71 \mu \mathrm{g} / \mathrm{g}$ in Lambert Quarry. Despite the elimination of trace element inputs, arsenic and selenium concentrations in bass have remained elevated above background levels.

The mean mercury concentration in bass collected from Rogers Quarry in July 1990 $(0.02 \mu \mathrm{g} / \mathrm{g})$ was the lowest observed in fish from any site in east Tennessee in monitoring conducted since 1985 for the BMAPs. Selenium is known to reduce the aquatic toxicity of mercury, and researchers have observed that excess selenium in the diet and exposure water acts to reduce the bioaccumulation of mercury. In Sweden, selenium has been intentionally added to mercury contaminated lakes in efforts to reduce mercury contamination in fish, with generally

\section{6-18 Biological Monitoring}


successful results. Mean mercury concentrations in Rogers Quarry bass have increased each year since the original sampling in $1990,100.05 \mu \mathrm{g} / \mathrm{g}$ in 1991 and $0.11 \mu \mathrm{g} / \mathrm{g}$ in 1992. These levels are still quite low and typical of background concentrations in this species. The results suggest that accumulated body burdens of selenium have little impact on mercury bioaccumulation, but the presence of elevated concentrations of selenium in food and/or water is capable of reducing mercury bioaccumulation in some waters in this region.

Bass from Lambert Quarry on the ORR, a reference site for the study, contained relatively high concentrations of mercury, averaging $0.93 \mu \mathrm{g} / \mathrm{g}$. At the present time, it is uncertain as to whether this represents contamination of the quarry or if it is typical for such systems in this geographical region.

\subsubsection{Radioactivity in Largemouth Bass from White Oak Lake}

Fish are integrators of contaminants that are found in aquatic ecosystems; however, many factors can influence the concentration of a contaminant in fish (e.g., species, position in the food web, contaminant type, chemical form). Cesium-137, which is distributed throughout all tissues of fish, is one of the most common radionuclides in White Oak Lake (WOL). Cesium-137 usually bioaccumulates up the foodchain, with the highest concentrations occurring in piscivorous species, such as largemouth bass (Micropterus salmoides), the top predatory fish in WOL.

Six largemouth bass were collected from the lake in March 1992. Flesh was removed from the vertebrae and both bone and fillets were analyzed for ${ }^{137} \mathrm{Cs}$ using a germanium detector. The six fish averaged $1138 \mathrm{~g}$ fresh weight (range 609-1725 g) and $41.8 \mathrm{~cm}$ total length (range $35.2-49.2 \mathrm{~cm}$ ). The mean concentration of ${ }^{137} \mathrm{Cs}$ in muscle and bone from these bass was 451 and $159 \mathrm{~Bq} / \mathrm{kg}$, respectively.

The concentrations of ${ }^{137} \mathrm{Cs}$ in the muscle were not related to eithar the size or sex of the fish, and were similar to the concentrations observed in eight largemouth bass collected from the lake in March 1991 (average weight $=1035 \mathrm{~g}$ ). The relationship

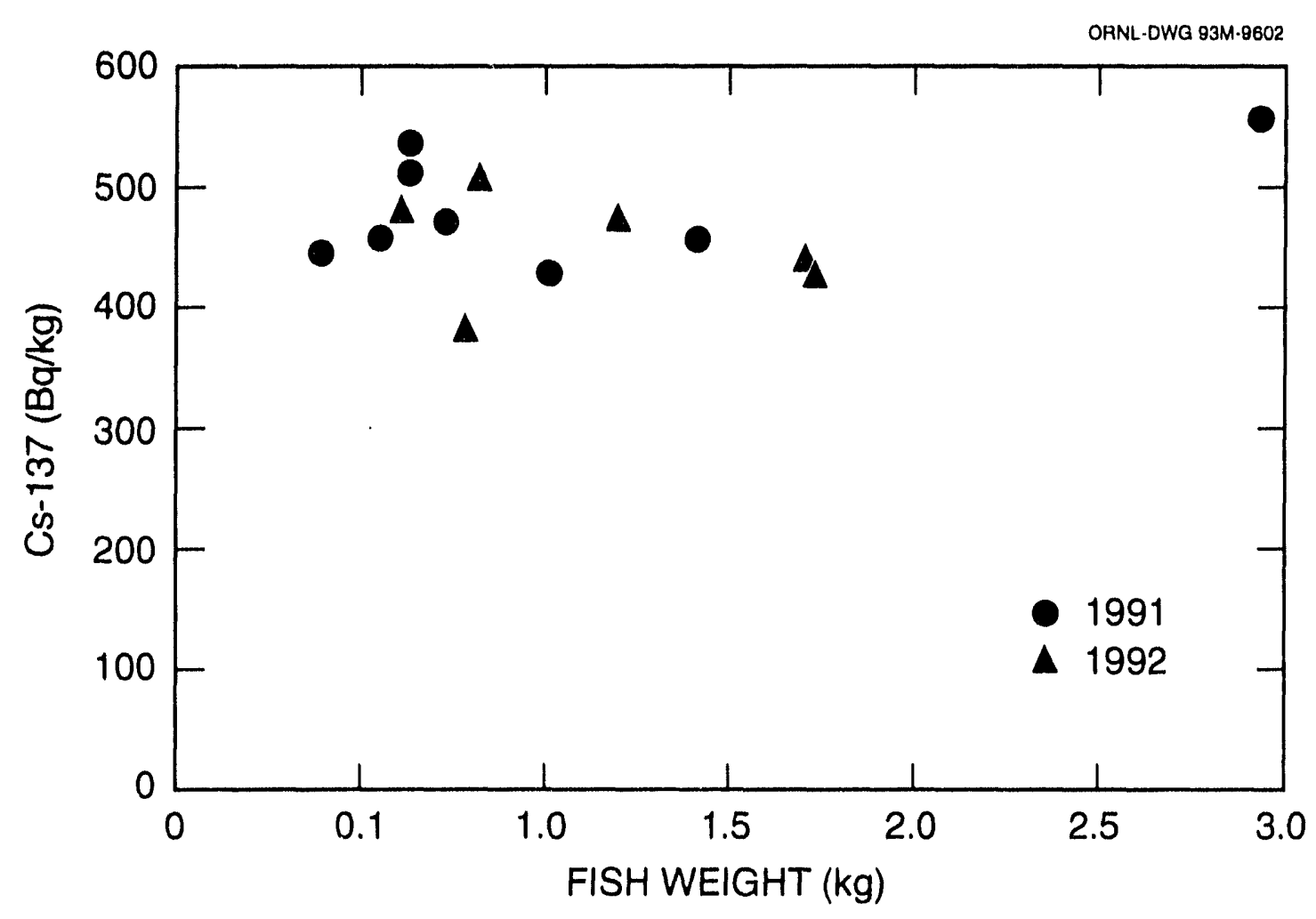

Fig. 6.12. Cesium-137 in fillets from largemouth bass collected in White Oak Lake. 
between concentration and weight for bass collected in 1991 and 1992 is shown in Fig. 6.12. The WOL ecosystem has been contaminated with ${ }^{137} \mathrm{Cs}$ for approximately 50 years, and these data indicate that the concentration of ${ }^{137} \mathrm{Cs}$ in the higher trophic levels of the aquatic food chain in WOL is relatively constant.

\subsubsection{Radioactivity in Resident Canada Geese}

Waterfowl are periodically collected from different sites on the ORR and analyzed for radiological and nonradiological contaminants. During the annual roundup of Canada geese for banding, which occurred in June 1992, five geese each from the K-25 Site, ORNL, and the Oak Ridge Marina were sacrificed, and samples of liver, muscle, and bone were analyzed for radionuclides. In addition, two geese were collected for contaminant analyses in April 1992 from the equalization basin (pond 3524) at ORNL.

The highest concentration of ${ }^{137} \mathrm{Cs}$ in Canada geese collected in 1992 was found in one of the two birds from pond 3524. Concentrations of ${ }^{137} \mathrm{Cs}$ in breast, liver, and bone were 159,89 , and $52 \mathrm{~Bq} / \mathrm{kg}$ fresh wt, respectively. In March 1990, a pair of geese using the same pond had the highest concentration of ${ }^{137} \mathrm{Cs}$ in breast tissue $(149,850$ and $105,894 \mathrm{~Bq} / \mathrm{kg}$ fresh wt) of any geese collected since waterfowl monitoring was initiated in 1988. These geese had been in the vicinity of the pond for the month of February and had been observed feeding on vegetation beneath the surface of the water.
The geese collected in 1992 had been observed in the vicinity of the pond for only two weeks during a time of the year (April) when outside sources of food were readily available. Although cables with streamers had been installed over the pond and the geese had been chased from the pond on several occasions, they persisted in their nesting activities. Ultimately, they were harvested to prevent them from accumulating radionuclides that might be transferred to humans.

Geese were collected at the K-25 Site, ORNL, and the Oak Ridge Marina during the 1992 roundup held on June 23 and 24. Samples of muscle, liver, and bone were analyzed for ${ }^{60} \mathrm{Co}$ and ${ }^{137} \mathrm{Cs}$. Only four of the 15 geese analyzed had detectable levels of ${ }^{137} \mathrm{Cs}$ in any of the tissues analyzed; two were collected at the K-25 Site and two at ORNL. In three of these four birds, ${ }^{137} \mathrm{Cs}$ was found in only one of the three tissues, while the goose from ORNL had detectable levels of ${ }^{137} \mathrm{Cs}$ in all samples (muscle, liver, and bone). The concentration of ${ }^{137} \mathrm{Cs}$ was $<37 \mathrm{~Bq} / \mathrm{kg}$ fresh weight in all samples. The geese collected during the June 1992 roundup had concentrations of ${ }^{137} \mathrm{Cs}$ that were at least a factor of four lower than the concentrations observed in the two geese collected from pond 3524 in April 1992.

\subsection{References}

Tennessee Valley Authority (TVA). 1985. Instream Contaminant Study, Task 4: Fish Sampling and Analysis, report to U.S. Department of Energy, Oak Ridge Operations Office, Tennessee Valley Authority Office of National Resources and Economic Development, Knoxville, Tenn. 


\section{SOIL AND SEDIMENT MONITORING}

7.1 Background $\ldots \ldots \ldots \ldots \ldots \ldots \ldots \ldots$

7.2 Soil $\ldots \ldots \ldots \ldots \ldots \ldots \ldots \ldots \ldots \ldots$

7.2.1 The Oak Ridge Reservation ..... . 7-3

7.2.2 Soil Sampling at the K-25 Site . . . . 7-4

7.3 Sediment $\ldots \ldots \ldots \ldots \ldots \ldots \ldots \ldots \ldots$ 7-4

7.3.1 Mercury Monitoring at ORNL . . . . 7-4

7.3.2 Polychlorinated Biphenyl (PCB)

Monitoring at ORNL . . . . . . . 7-8

7.3.3 Sediment Sampling at the

K-25 Site . . . . . . . . . . . . 7-8

7.4 Soil Management Plan . . . . . . . . . 7-10 


\section{Soil and Sediment Monitoring}

\subsection{Background}

The Background Soil Characterization Project (BSCP) is designed to provide background concentration data on potential contaminants (organic compounds, metals, and radionuclides) in natural soils with respect to the Oak Ridge Reservation (ORR). The objectives of the BSCP are to provide (1) baseline data for contaminated site assessment and (2) estimates of potential human health and environmental risks associated with background concentrations of hazardous material and other constituents in native soils.

The BSCP addresses variability of concentration levels in terms of (1) soil taxonomical types (series) occurring in different geologic formations, (2) soil sampling depths (horizons) within a specific soil profile, and (3) natural areal variations in soils both on site and off site that were developed in the same geologic formations. The BSCP data base is intended for unrestricted use, with recommendations on how to use the data for contaminated site assessment. In addition, the data can be used to provide estimates of any potential human health and environmental risks associated with background level concentrations of the potentially hazardous constituents.

Background soil characterization data will be used for three purposes. The first application is in differentiating between naturally occurring constituents and site-related contamination. This is a very important step in risk assessment because, if sufficient background data are not available, no constituent known to be a contaminant can be eliminated from the assessment even if the sampled concentration is measured at a minimum level. The second use of background data is in calculating baseline risks against which site-specific cont.mination risks [i.e., those associated with waste area groupings (WAGs)] can be compared. The third application is in establishing corrective action (cleanup) levels for contaminated soils in the ORR.

\subsection{Soil}

Soil provides an integrating medium that can account for contaminants released to the atmosphere, either directly in gaseous effluents or indirectly from resuspension of on-site contamination. Hence, soil sampling may be used to evaluate the long-term accumulation trends and to estimate environmental radionuclide inventories.

\subsubsection{The Oak Ridge Reservation}

A new soil program was implemented in CY 1992 as part of the new Environmental Monitoring Plan for the ORR. Soil plots were established at nine ambient air stations (Fig. 6.3).

For an initial study (soil from soil plots will be analyzed after 1 year), and in order to coordinate with the Food Crops Program, soil samples were collected at three ambient air stations, 35, 39, and 40 .

\subsubsection{Sample Collection and Analytical Procedures}

Soil samples were collected at three stations once during 1992. Table 7.1 provides a summary of locations sampled and frequencies of sampling. Because soil $\therefore d$ food crops are bing correlated, soil samples were not dried prior to analysis. Soil samples were analyzed for percentage of moisture; gross alpha and beta; gamma emitters; total radiological strontium; and uranium, thorium, beryllium, and plutonium isotopes. 
Table 7.1. Summary of collection and analysis frequencies of soil sampling in 1992

\begin{tabular}{lllll}
\hline \multicolumn{1}{c}{ Station $^{a}$} & \multicolumn{1}{c}{ Parameter } & $\begin{array}{l}\text { Collection } \\
\text { frequency }\end{array}$ & $\begin{array}{c}\text { Sample } \\
\text { type }\end{array}$ & $\begin{array}{c}\text { Analysis } \\
\text { frequency }\end{array}$ \\
\hline $\begin{array}{l}\text { Gallaher (35) } \\
\text { Cesium Field (39) } \\
\text { Scarboro (46) }\end{array}$ & $\begin{array}{l}\text { Alpha, beta, gamma, } \\
\text { uranium, plutonium, } \\
\text { strontium, thorium, beryllium }\end{array}$ & Annually & Grab & Annually \\
\hline
\end{tabular}

${ }^{a}$ See Fig. 3.18.

\subsubsection{Results}

Concentrations are summarized in Table 7.2. These data (along with data from the initial soil plot samples in CY 1993) will form a baseline for comparison of data and trending in future years.

\subsubsection{Soil Sampling at the K-25 Site}

Soil samples taken at points coinciding with ambient air monitoring stations of the K-25 Site are analyzed for radiological activity and other parameters once per calendar year. This is performed as part of the K-25 Site Environmental Surveillance Program, which assesses the impact of the site's operations on the public and on the environment as required by DOE Order 5400.1, "General Environmental Protection Program."

Soil samples were taken in December 1992 at the points illustrated in Fig. 7.1 as outlined in DOE/EH-0173T, Sect. 5.9.2.

The soil was analyzed for the following isotopes: ${ }^{99} \mathrm{Tc},{ }^{137} \mathrm{Cs},{ }^{234} \mathrm{U},{ }^{235} \mathrm{U},{ }^{236} \mathrm{U},{ }^{238} \mathrm{U},{ }^{237} \mathrm{~Np},{ }^{238} \mathrm{Pu}$, and ${ }^{239} \mathrm{Pu}$. Flurometric methods were used for total uranium, alpha spectrometry for uranium isotopes and transuranics, EPA-900 for alpha and beta activities, and gamma spectrometry for cesium. The results for samples taken in 1992 are shown in Table 7.3 (Vol. 1) and Table 7.1 (Vol. 2).

\subsection{Sediment}

\subsubsection{Mercury Monitoring at ORNL}

Samples of surface water and stream sediment in the Bethel and Meiion valleys are analyzed for mercury content. These analyses are done in compliance with the Clean Water Act (CWA) and
ORNL's National Pollution Discharge Elimination System (NPDES) permit. The primary purpose of this effort is to identify, locate, and minimize all mercury contamination in ORNL discharge to the aquatic environment.

In previous years, before stringent regulations came into effect, some contaminants reached various streams, primarily as a result of accidental spills or leakages. The majority of the mercury spills occurred from 1954 through 1963, during a period when ORNL was involved with the OREX and METALLEX separation processes. Most of this activity was conducted in and around Buildings 4501, 4505 , and 3592. These processes are no longer in operation at ORNL. During the time of operation, an unknown number of mercury spills took place. The spills were cleaned up; however, quantities of mercury escaped and reached the surrounding environment.

The sampling locations have been placed in areas surrounding known mercury spills. Sampling locations have also been placed near outfalls from building areas with histories of mercury concern and outfalls from storage areas, spill areas, and road and parking lot drains. Additional sampling locations have been placed downstream from the outfalls and drains to determine the extent to which any mercury is being transported in the surface water and sediment. The sediment sampling locations are shown in Fig. 7.2. The surface water sampling locations are shown in Fig 4.8.

Sediment samples were collected in triplicate at nine locations in June and December 1992. Samples were collected by manual grab method, placed in glass containers, and analyzed for total mercury content by manual cold vapor atomic absnrption.

Table 7.4 shows the maximum, minimum, and average concentrations of mercury at each sampling

\subsection{Soil and Sediment Monitoring}


Table 7.2. Average radiological results from air station soil samples ${ }^{a}$

\begin{tabular}{lccc}
\hline Analysis & $\begin{array}{c}\text { Sample } \\
\text { size }\end{array}$ & $\begin{array}{c}\text { Average } \\
(\mathrm{pCi} / \mathrm{g})\end{array}$ & Uncertainty \\
\hline
\end{tabular}

Station 35, Gallaher (percentage of soils $=75.0 \%$ )

$\begin{array}{llll}{ }^{7} \mathrm{Be} & 2 & 0.01 & 0.12 \\ { }^{60} \mathrm{Co} & 2 & 0.01 & 0.02 \\ { }^{137} \mathrm{Cs} & 2 & 0.24^{*} & 0.02 \\ \text { G-Alpha } & 2 & 3.05^{*} & 1.08 \\ \text { G-Beta } & 2 & 6.22^{*} & 1.44 \\ { }^{40} \mathrm{~K} & 2 & 8.51^{*} & 0.30 \\ { }^{238} \mathrm{Pu} & 2 & -0.03 & 0.02 \\ { }^{239} \mathrm{Pu} & 2 & 0.01 & 0.02 \\ { }^{228} \mathrm{Th} & 2 & 0.28^{*} & 0.02 \\ { }^{230} \mathrm{Th} & 2 & 0.17^{*} & 0.01 \\ { }^{232} \mathrm{Th} & 2 & 0.24^{*} & 0.01 \\ \text { Total-Sr } & 2 & 0.08^{*} & 0.03 \\ { }^{234} \mathrm{U} & 2 & 0.22^{*} & 0.01 \\ { }^{235} \mathrm{U} & 2 & 0.01^{*} & 0.00 \\ { }^{238} \mathrm{U} & 2 & 0.16^{*} & 0.01\end{array}$

Station 39, Cesium Field (percentage of soils $=66.1 \%$ )

$\begin{array}{llcl}{ }^{7} \mathrm{Be} & 2 & 0.02 & 0.20 \\ { }^{60} \mathrm{Co} & 2 & 0.01 & 0.03 \\ { }^{137} \mathrm{Cs} & 2 & 0.57^{*} & 0.03 \\ \text { G-Alpha } & 2 & 4.86^{*} & 1.25 \\ \text { G-Beta } & 2 & 12.43^{*} & 1.91 \\ { }^{40} \mathrm{~K} & 2 & 10.54^{*} & 0.43 \\ { }^{238} \mathrm{Pu} & 2 & 0.02 & 0.03 \\ { }^{239} \mathrm{Pu} & 2 & 0.06^{*} & 0.03 \\ { }^{228} \mathrm{Th} & 2 & 0.47^{*} & 0.02 \\ { }^{230} \mathrm{Th} & 2 & 0.27^{*} & 0.02 \\ { }^{232} \mathrm{Th} & 2 & 0.39^{*} & 0.02 \\ \text { Total-Sr } & 2 & 0.27^{*} & 0.04 \\ { }^{234} \mathrm{U} & 2 & 0.32^{*} & 0.02 \\ { }^{235} \mathrm{U} & 2 & 0.02^{*} & 0.00 \\ { }^{238} \mathrm{U} & 2 & 0.23^{*} & 0.01\end{array}$

Station 46, Scarboro (percentage of soils $=80.7 \%$ )

$\begin{array}{llcl}{ }^{7} \mathrm{Be} & 2 & -0.09 & 0.32 \\ { }^{60} \mathrm{Co} & 2 & 0.02 & 0.04 \\ { }^{137} \mathrm{Cs} & 2 & 0.14^{*} & 0.04 \\ \text { G-Alpha } & 2 & 3.05^{*} & 1.06 \\ \text { G-Beta } & 2 & 5.81^{*} & 1.53 \\ { }^{40} \mathrm{~K} & 2 & 10.27^{*} & 0.76 \\ { }^{238} \mathrm{Pu} & 2 & -0.01 & 0.03 \\ { }^{239} \mathrm{Pu} & 2 & -0.01 & 0.01 \\ { }^{228} \mathrm{Th} & 2 & 0.25^{*} & 0.01 \\ { }^{230} \mathrm{Th} & 2 & 0.15^{*} & 0.01 \\ { }^{232} \mathrm{Th} & 2 & 0.21^{*} & 0.01 \\ \text { Total-Sr } & 2 & 0.08^{*} & 0.03 \\ { }^{234} \mathrm{U} & 2 & 0.45^{*} & 0.02 \\ { }^{235} \mathrm{U} & 2 & 0.04^{*} & 0.01 \\ { }^{238} \mathrm{U} & 2 & 0.26^{*} & 0.02\end{array}$

${ }^{a}$ An asterisk $\left({ }^{*}\right)$ indicates statistically significant amounts that are greater than zero. 


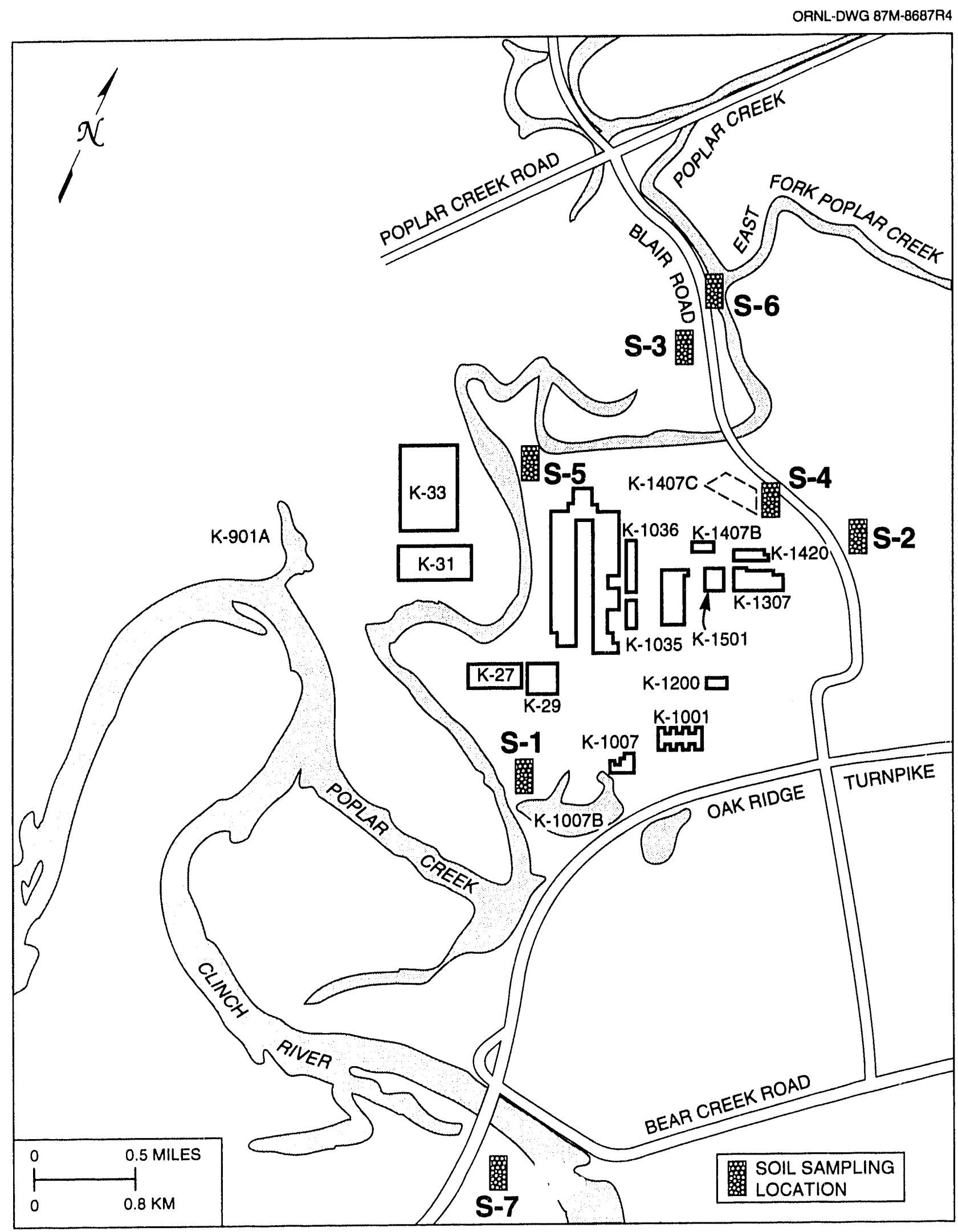

Fig. 7.1. Soil sampling locations around the K-25 Site. 
Table 7.3. 1992 summary of concentrations of radionuclides in soil samples taken at the K-25 Site ambient air monitoring stations

\begin{tabular}{|c|c|c|c|c|}
\hline \multirow{2}{*}{ Analyte } & \multirow{2}{*}{$\begin{array}{c}\text { Number of } \\
\text { samples }\end{array}$} & \multicolumn{3}{|c|}{ Concentration } \\
\hline & & Max & Min & Av \\
\hline G-Alpha & 7 & 2.1 & -5.1 & -1.8 \\
\hline G-Beta & 7 & 63.0 & -3.8 & 7.7 \\
\hline${ }^{234} \mathrm{U}$ & 7 & 0.63 & 0.0 & 0.3 \\
\hline${ }^{235} U$ & 7 & 0.37 & -0.079 & 0.1 \\
\hline${ }^{238} \mathrm{U}$ & 7 & 0.38 & 0.0 & 0.15 \\
\hline${ }^{99} \mathrm{Tc}$ & 7 & 57.0 & -23.0 & 28.0 \\
\hline $234 \mathrm{mpa}$ & 7 & 145.0 & -77.0 & 21.0 \\
\hline${ }^{234} \mathrm{Th}$ & 7 & 27.0 & -12.0 & 0.74 \\
\hline${ }^{137} \mathrm{Cs}$ & 7 & 0.71 & -38.0 & -5.2 \\
\hline${ }^{237} \mathrm{~Np}$ & 7 & 0.63 & -0.26 & -0.038 \\
\hline${ }^{238} \mathrm{Pu}$ & 7 & 0.0 & -0.26 & -0.16 \\
\hline${ }^{239} \mathrm{Pu}$ & 7 & 0.21 & -0.26 & -0.13 \\
\hline Total uranium $(\mu \mathrm{g} / \mathrm{g})$ & 7 & 4.2 & 1.8 & 3.0 \\
\hline
\end{tabular}

${ }^{a} \mathrm{All}$ units are given in $\mathrm{pCi} / \mathrm{g}$ unless otherwise noted.

ORNL.DWG 92M.13531R

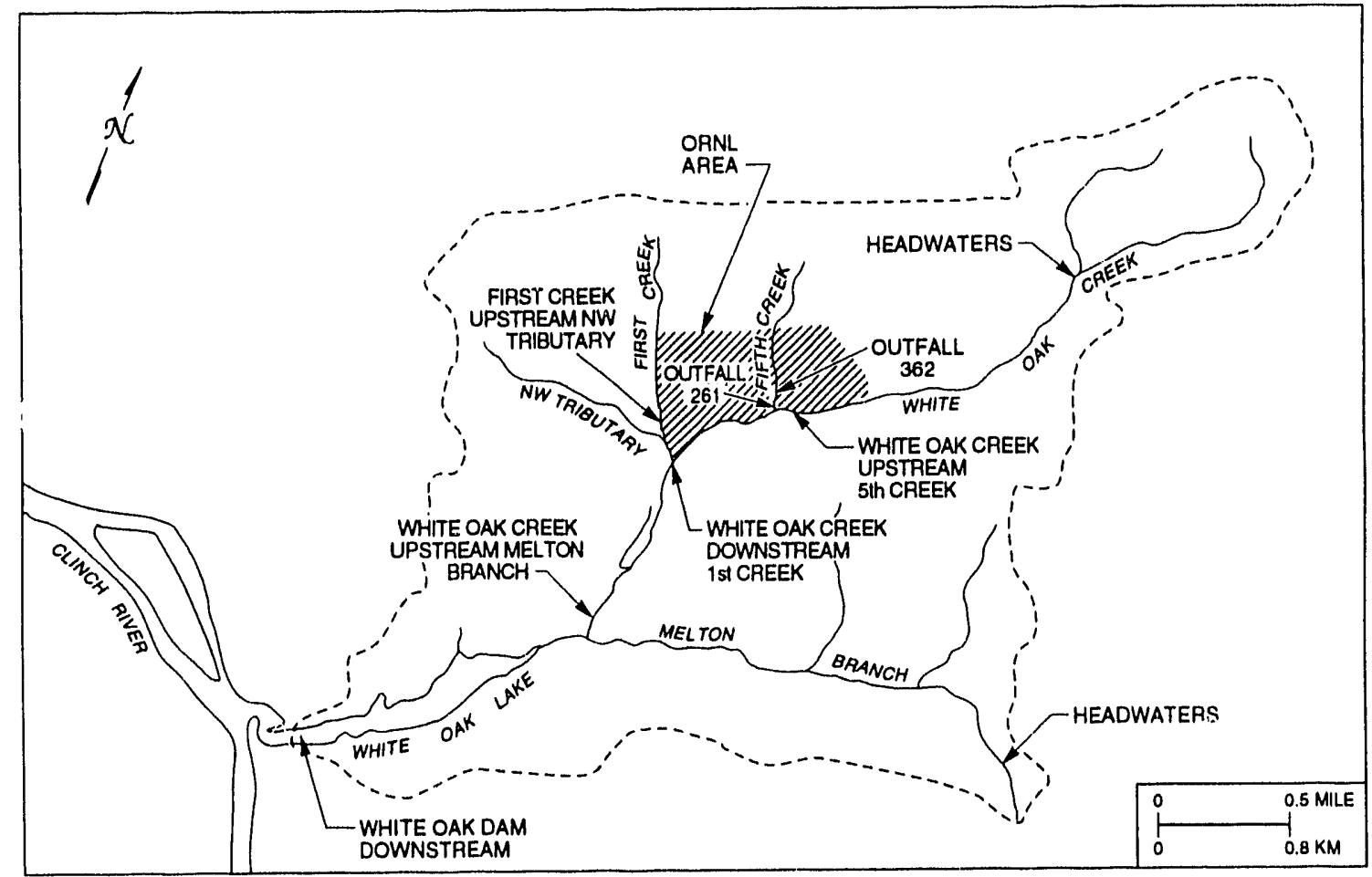

Fig. 7.2. Sediment sampling locations for mercury monitoring in the immediate ORNL area.

location. The standard error of the mean is also included. There is no established state or U.S. Environmental Protection Agency (EPA) standard for mercury in sediment. The highest concentrations of mercury were measured in the samples from Fifth Creek, with averages of $98 \mu \mathrm{g} / \mathrm{g}$ and $25 \mu \mathrm{g} / \mathrm{g}$, respectively, at the two locations. Two sites on White Oak Creek had average concentrations of $2.9 \mu \mathrm{g} / \mathrm{g}$ and $3.0 \mu \mathrm{g} / \mathrm{g}$. The average concentrations of mercury at all other sampling locations were much lower, ranging from $0.019 \mu \mathrm{g} / \mathrm{g}$ to $0.2 \mu \mathrm{g} / \mathrm{g}$. The mercury 


\section{Environmental Report Vol. 1, Oak Ridge}

Table 7.4. ORNL 1992 concentrations of mercury in sediment

\begin{tabular}{|c|c|c|c|c|c|}
\hline \multirow{2}{*}{ Stream site ${ }^{u}$} & \multirow{2}{*}{$\begin{array}{l}\text { No. detected/ } \\
\text { No. total }\end{array}$} & \multicolumn{4}{|c|}{ Concentration $(\mu \mathrm{g} / \mathrm{g})$} \\
\hline & & Max & Min & $A v^{b}$ & Standard error ${ }^{c}$ \\
\hline $\begin{array}{l}\text { 1st Creek } \\
\text { Upstream Northwest Tributary }\end{array}$ & $6 / 6$ & 0.15 & 0.039 & $0.069 *$ & 0.016 \\
\hline $\begin{array}{l}\text { 5th Creek } \\
\text { Outfall } 261 \\
\text { Outfall } 362\end{array}$ & $\begin{array}{l}6 / 6 \\
6 / 6\end{array}$ & $\begin{array}{r}210 \\
61\end{array}$ & $13^{6.6}$ & $\begin{array}{l}98^{*} \\
25^{*}\end{array}$ & $\begin{array}{l}29 \\
7.4\end{array}$ \\
\hline $\begin{array}{l}\text { Melton Branch } \\
\text { Headwaters }\end{array}$ & $6 / 6$ & 0.025 & 0.012 & $0.019^{*}$ & 0.0024 \\
\hline $\begin{array}{l}\text { White Oak Creek } \\
\text { Upstream 5th Creek } \\
\text { Downstream 1st Creek } \\
\text { Headwaters } \\
\text { Upstream Melton Branch } \\
\text { Downstream White Oak Dam }\end{array}$ & $\begin{array}{l}6 / 6 \\
6 / 6 \\
6 / 6 \\
6 / 6 \\
6 / 6\end{array}$ & $\begin{array}{l}6.1 \\
4.5 \\
0.79 \\
0.062 \\
0.067\end{array}$ & $\begin{array}{l}1.1 \\
2.3 \\
0.058 \\
0.017 \\
0.029\end{array}$ & $\begin{array}{l}2.9^{*} \\
3.0^{*} \\
0.20 \\
0.031^{*} \\
0.038^{*}\end{array}$ & $\begin{array}{l}0.92 \\
0.32 \\
0.12 \\
0.0069 \\
0.0060\end{array}$ \\
\hline
\end{tabular}

${ }^{a}$ See Fig. 7.2.

${ }^{b}$ Average concentrations significantly greater than zero are identified by an *.

${ }^{c}$ Standard error of the mean.

results for 1992 are consistent with data from previous years.

\subsubsection{Polychlorinated Biphenyl (PCB) Monitoring at ORNL}

Duplicate sediment samples were collected at ten locations (Figs. 7.3 and 7.4) in May and July of 1992. The samples from each location were analyzed for aroclors 1016, 1221, 1232, 1242, 1248, 1254, and 1260 in compliance with the CWA and ORNL's NPDES permit. There are currently no regulatory guidelines for PCB concentrations in stream sediment. Table 7.5 summarizes the concentrations of each aroclor detected over all sampling locations. Laboratory quantitation limits vary for sediment samples. Only three locations had results above detection limits. The maximum concentration of $1400 \mu \mathrm{g} / \mathrm{kg}$ was reported for aroclor- 1254 on White Oak Creek, upstream of the weir at 7500 Road Bridge. This location represents the area of maximum sediment deposition and collectively represents all potential releases. Results for all other sediment samples were either below detection limits or estimated by the analytical laboratory. Data summaries of PCBs at each sampling location are provided in Table 7.2 of $\mathrm{Vol}$. 2. Although the types of aroclors detected are similar to those detected in 1991, results are higher, some by a factor of 2 .
However, results for aroclors detected in 1992 are similar in magnitude to those obtained in 1990.

\subsubsection{Sediment Sampling at the K-25 Site}

Sediment samples taken at points coinciding with surface water sampling locations of the K-25 Site are analyzed for radiological activity and other parameters once per calendar year. This is performed as part of the Environmental Surveillance Program, which assesses the impact of the site's operations to the public and environment as required by DOE Order 5406.1, "General Environmental Protection Program."

Sediment samples were taken in December 1992 at the points illustrated in Fig. 7.5 at the turbulent area of the discharges, when applicable. Sampling was performed as outlined in DOE/EH-0173T, Sect. 5.12.2.

The sediment was analyzed for the following isotopes: ${ }^{99} \mathrm{Tc},{ }^{137} \mathrm{Cs},{ }^{234} \mathrm{U},{ }^{235} \mathrm{U},{ }^{236} \mathrm{U},{ }^{238} \mathrm{U},{ }^{237} \mathrm{~Np}$, ${ }^{238} \mathrm{Pu}$, and ${ }^{239} \mathrm{Pu}$. Fluorometric methods were used for total uranium, alpha spectrometry for uranium isotopes and transuranics, EPA-900 for alpha and beta activities, and gamma spectrometry for cesium. Results are reported in Table 7.6.

Other analyses were performed on the sediment to detect total recoverable metals (see Table 7.7),

\section{7-8 Soil and Sediment Monitoring}


OANL.DWG 92M-13529

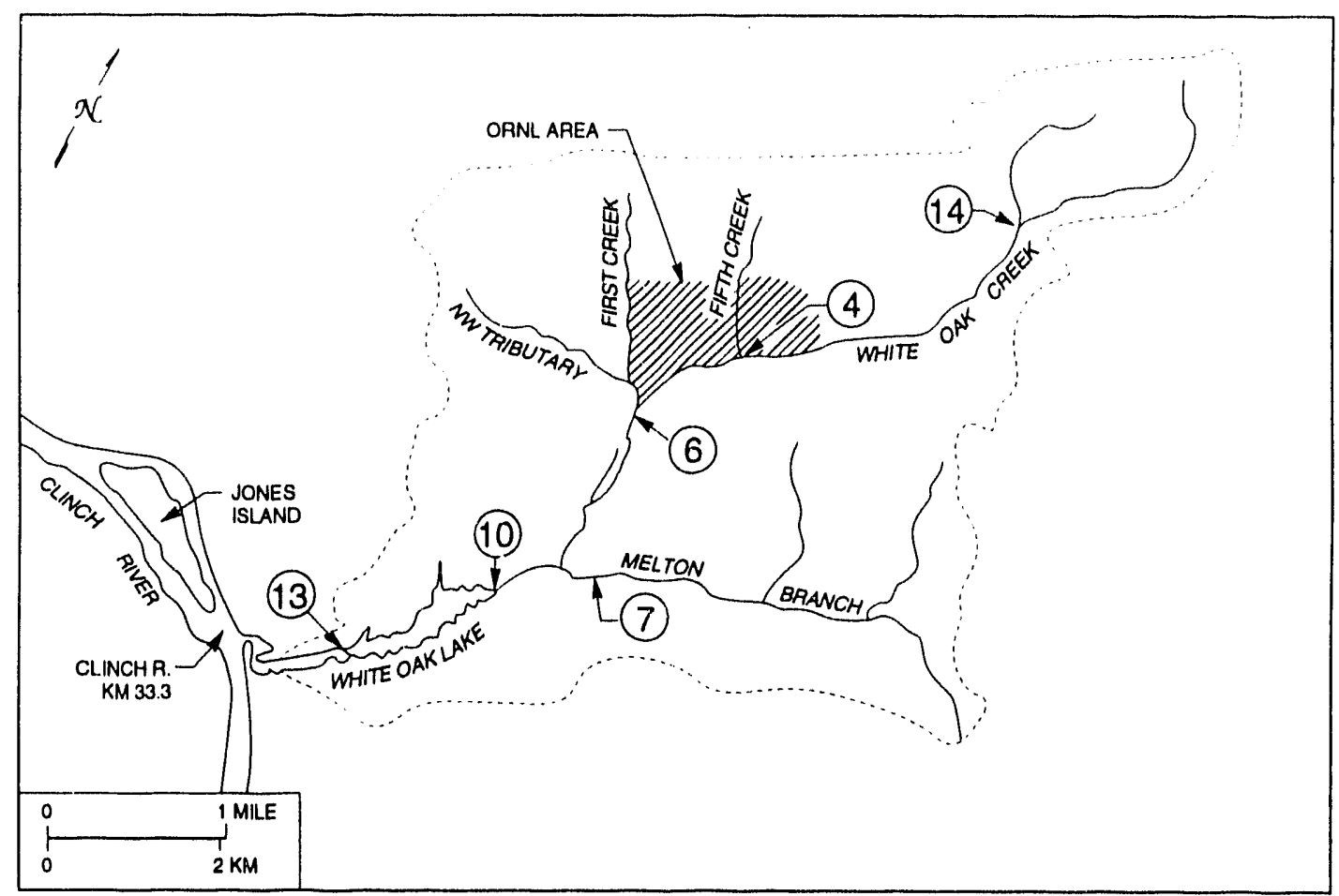

Fig. 7.3. Sampling locations for PCB monitoring in the immediate ORNL area.

ORNL.OWG 92M-13530

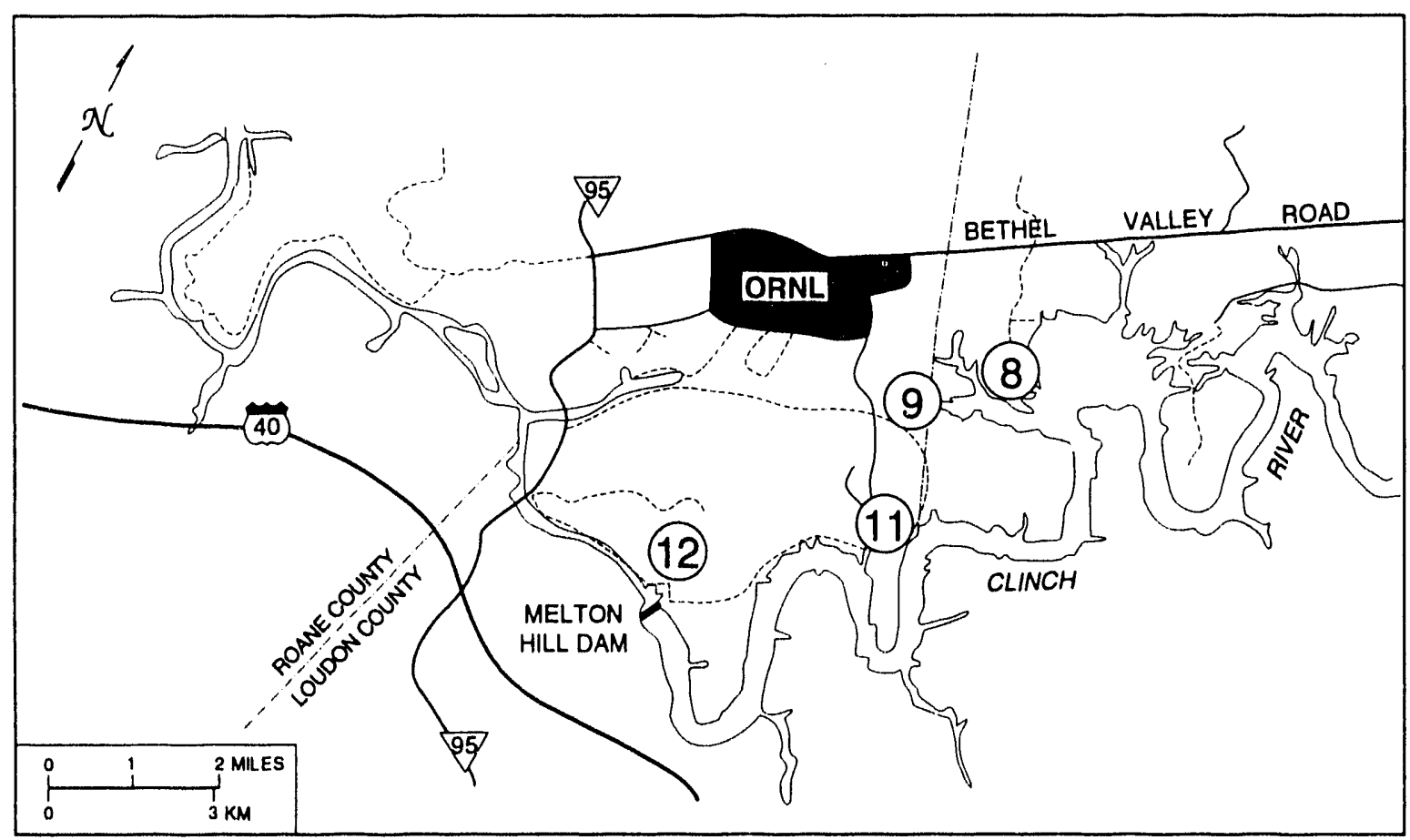

Fig. 7.4. Sampling locations for PCB monitoring in the greater ORNL area. 


\section{Environmental Report Vol. 1, Oak Ridge}

Table 7.5. Summary of ORNL PCB concentrations detected in sediment in the ORNL area, 1992

\begin{tabular}{lccccc}
\hline Analysis & $\begin{array}{c}\text { Number } \\
\text { detected }\end{array}$ & $\begin{array}{c}\text { Number } \\
\text { of } \\
\text { samples }\end{array}$ & Max & Min & Concentration $(\mu \mathrm{g} / \mathrm{kg})$ \\
\hline Aroclor-1016 & 0 & 40 & & & $\begin{array}{c}\text { Standard } \\
\text { error }\end{array}$ \\
Aroclor-1242 & 0 & 40 & & 590 & 900 \\
Aroclor-1254 & 6 & 40 & 1400 & 180 & 620 \\
Aroclor-1260 & 6 & 40 & 1200 & & 130 \\
Aroclor-1221 & 0 & 40 & & & 190 \\
Aroclor-1232 & 0 & 40 & & & \\
Aroclor-1248 & 0 & 40 & & & \\
\hline
\end{tabular}

${ }^{a}$ Standard error of the mean.

chlorinated pesticides, PCBs, and semivolatile organic compounds.

Results from sediment samples taken from the K 25 Site for 1992 are shown in Tables 7.6 and 7.7 (Vol. 1) and in Tables 7.3 and 7.4 (Vol. 2)

\subsection{Soil Management Plan}

A Soil Management Plan for the Y-12 Plant has been prepared to provide technical guidance for maintaining regulatory compliance for soils disturbed during routine construction projects. This guidance is based on an integration of regulatory requirements concerning the Resource Conservation and Recovery Act (RCRA); Comprehensive Environmental Response, Compensation, and Liability Act
(CERCLA); Toxic Substances Control Act (TSCA); and Atomic Energy Act (AEA) regulations.

The plan will be used as a tool for making the best soil management decision for an individual construction project. A set of decision trees was developed. The regulatory basis for each decision tree is presented in the plan. A "clean" soil decision tree based on logical, site-specific, conservative measures is also included. The decision trees address different types of regulatory areas (i.e., areas controlled by specific regulatory programs such as CERCLA operable units and study areas, RCRA solid waste management units, and hazardous waste management units).

The plan was issued to DOE Y-12 Site Office in January 1993.

Table 7.6 Summary of concentrations of radioisotopes detected in sediment samples taken at the K-25 Site

\begin{tabular}{lccc}
\hline $\begin{array}{c}\text { Parameter } \\
(\mathrm{pCi} / \mathrm{g})\end{array}$ & Maximum & Minimum & Average \\
\hline Alpha & 6.49 & -12.3 & -3.560 \\
Beta & 43.8 & -2.91 & 5.39 \\
${ }^{234} \mathrm{U}$ & 1.630 & 0.00 & 0.295 \\
${ }^{235} \mathrm{U}$ & 2.480 & -0.004 & 0.746 \\
${ }^{238} \mathrm{U}$ & 0.889 & 0.00 & 0.216 \\
${ }^{99} \mathrm{Tc}$ & 152 & -39.3 & 43.67 \\
${ }^{234 m} \mathrm{~Pa}$ & 204 & -116 & 38 \\
${ }^{234} \mathrm{Th}$ & 12.7 & -14.1 & -2.37 \\
${ }^{137} \mathrm{Cs}$ & 0.982 & -0.299 & 0.215 \\
${ }^{237} \mathrm{~Np}$ & 0.714 & -0.276 & -0.076 \\
${ }^{238} \mathrm{Pu}$ & 0.00 & -0.276 & -0.212 \\
${ }^{239} \mathrm{Pu}$ & 0.00 & -0.276 & -0.178 \\
\hline
\end{tabular}


ORNL.DWG 92M-160K

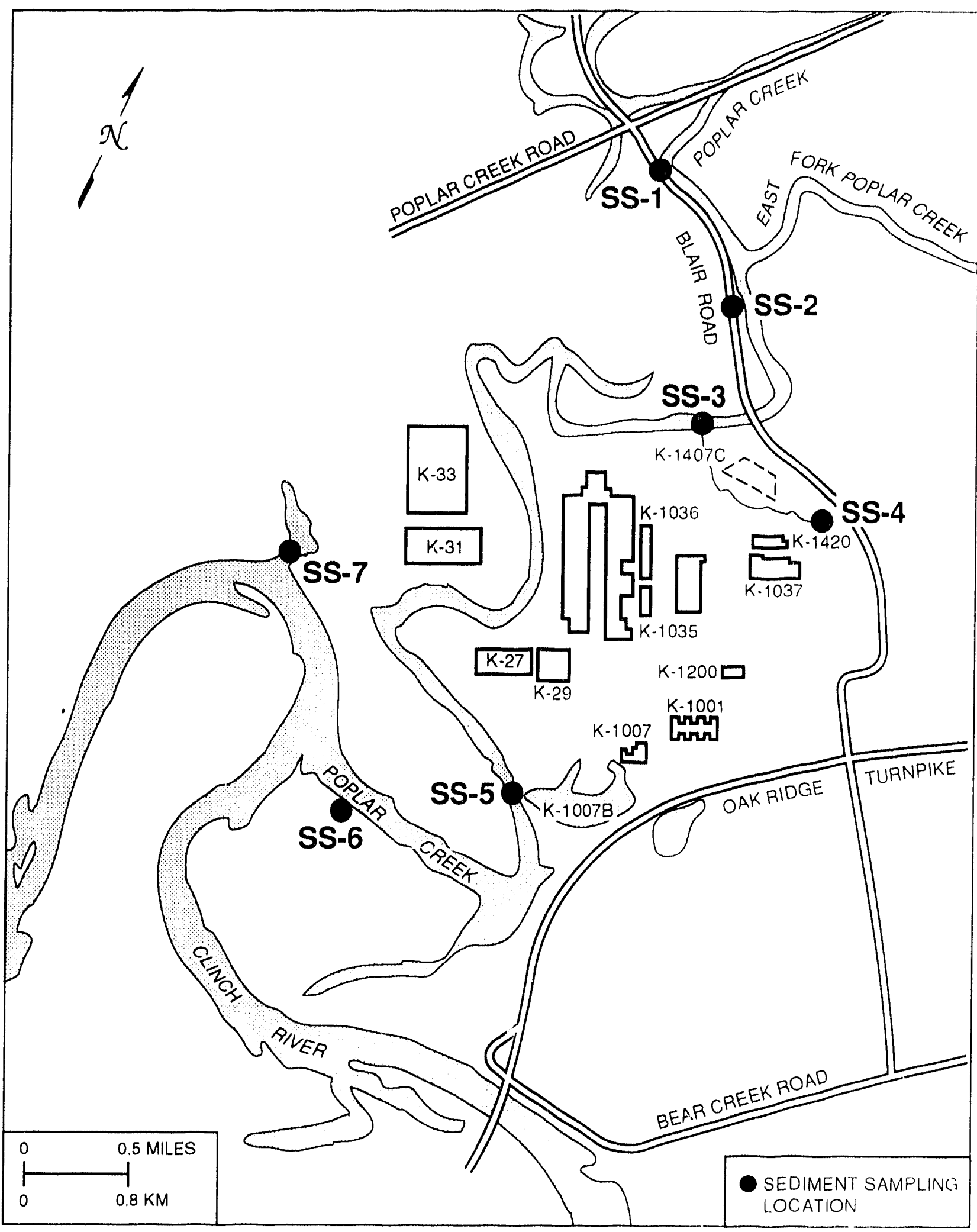

Fig. 7.5. Sediment sampling locations in the vicinity of the K-25 Site. 
1992 Environmental Report Vol. 1, Oak Ridge

Table 7.7 Summary of concentrations of parameters detected in sediment samples taken at the K-25 Site

\begin{tabular}{lccc}
\hline $\begin{array}{c}\text { Parameter } \\
(\mu g / g)\end{array}$ & Maximum & Minimum & Average \\
\hline Uranium & 15.0 & 1.4 & 4.0 \\
Arsenic & 11.0 & 1.2 & 4.8 \\
Cadmium & 0.84 & 0.14 & 0.29 \\
Lead & 101 & 4.6 & 25.4 \\
Selenium & 1.8 & 0.3 & 1.16 \\
Thallium & 3.7 & 0.6 & 2.33 \\
Mercury & 1.4 & 0.029 & 0.46 \\
Aluminum & 5,600 & 3,300 & 4,243 \\
Antimony & 48 & 4.2 & 32.7 \\
Barium & 61 & 27 & 41.6 \\
Beryllium & 1.4 & 0.18 & 0.78 \\
Boron & 9.9 & 1.5 & 5.1 \\
Calcium & 5,500 & 1.7 & 1,552 \\
Chromium & 57 & 4.7 & 25.1 \\
Cobalt & 28 & 2.8 & 10.4 \\
Copper & 29 & 3.3 & 11.9 \\
Iron & 31,000 & 6,500 & 14,614 \\
Magnesium & 2,400 & 380 & 929 \\
Manganese & 1,700 & 150 & 663 \\
Molybdenum & 9.7 & 0.48 & 6.53 \\
Nickel & 49 & 4.1 & 16.4 \\
PCBs (Aroclor-1254) & 5.12 & 0.2 & 2.6 \\
Potassium & 1,200 & 420.0 & 827 \\
Silver & 5.8 & 0.25 & 3.91 \\
Sodium & 56 & 22.0 & 35.4 \\
Vanadium & 51 & 5.9 & 18.2 \\
Zinc & 89 & 12.0 & 47.7 \\
\hline
\end{tabular}




\section{SPECIAL STUDIES}

$8.1 \quad$ Y-12 Plarit $\ldots \ldots \ldots \ldots \ldots \ldots \ldots \ldots$ 8-3

8.1.1 Y-12 Plant Stratospheric Ozone Protection Plan ... . . . . . . . . . . 8-3

8.1.2 Y-12 Plant Voluntary Reduction of Hazardous Air Pollutants . . . . . . . 8 8-3

8.1.3 Y-12 Plant Stack 62 Emission Event . 8-4

8.1.4 Accidental Release of Hydrogen Fluoride . . . . . . . . . . . . . . . . . 8-4

8.1.5 Visible Emission Evaluations Conducted at the $Y-12$ Plant . . . . . . 8-4

8.1.6 Historical PCB Spills ... . . . . . . . 8-5

8.1.7 Dechlorination Work at Y-12 Plant . . 8-5

8.1.8 Non-Point-Source Pollution Control . . 8-6

8.1.9 Water Corrective Action Program ... 8-6

8.2 Oak Ridge National Laboratory . . . . . . . 8 8-7

8.2.1 ORNL Waste Area Groupings Ranked According to Human Health Risks . . . 8-7

8.2.2 Clinch River Remedial Investigations:

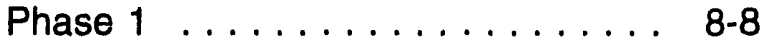

8.2.3 Mapping Soil Contaminated with Heavy Metals . . . . . . . . . . . . . 8 8-8

8.2.4 Contaminated-Sediment Transport in the White Oak Creek Catchment During Floods $8-8$

8.2 .5 Co-Metabolic Techniques Bioreactor Demonstration Project . . . . . . . . . . 8-9

8.2.6 Environmental Restoration . . . . . . 8-10

8.2.7 Miscellaneous ORNL Spills . . . . . . 8-12 
8.3 K-25 Site . . . . . . . . . . . . . . . . . 8-14

8.3.1 Dechlorination in Mitchell Branch . . 8-14

8.3.2 Stack and Vent Survey . . . . . . . . 8-14

8.3.3 TSCA Air Monitoring Station

Relocation .............. . 8-15

8.3.4 CFC Equipment Replacement Plan . . 8-15

8.3.5 Pond Waste Management Program

Air Emissions . . . . . . . . . . 8-15

8.3.6 K-25 Site Ambient Air Monitoring

Program Review Against DOE Order

and Regulatory Requirements . . . . 8 8-16

8.3.7 K-25 Site PM10 Ambient Air Monitoring

Program Review . . . . . . . . . 8-16

8.3.8 Oak Ridge K-25 Site Ambient Air

Monitoring Semiannual Report,

January 1, 1992-June 30, $1992 \ldots$. . 8-16

8.4 References . . . . . . . . . . . . . . . . 8-17 


\subsubsection{Y-12 Plant Stack 62 Emission Event}

During the weekend of November 7 and 8, 1992 , a significant release of depleted uranium was detected from Stack 62, which serves a process hood in the H-i Foundry facility in Building 9998. The hood currently has high efficiency particulate air (HEPA) filtration although the hood was not originally built for a HEPA filtered exhaust. The HEPA filters were successfully leak tested in place in December 1987 and May 1991. Records indicate that caulking was required to achieve a successful in-place leak test in May 1991. Actions required to obtain the successful test in December 1987 are unknown.

A visual inspection of the prefilters and HEPA filters indicated that the filters appeared to be in good condition and there was no evidence of leakage or filter rupture. There was no dust build-up in the exhaust duct beside the HEPA filters. The exhaust duct downstream from the HEPA filters was inspected at two places and there was no visible material inside the duct. An in-place leak test was conducted on the HEPA filters. The east filter passed; however, the west filter did not pass because a slight leak was detected that was over the failure limit. An engineering project has been initiated to replace the existing HEPA filters with an acceptable HEPA filter system that will allow in-place leak testing.

Operations served by Stack 62 have been shut down until this upgrade is completed. The emission level did not exceed any regulatory limits or dose standards.

\subsubsection{Accidental Release of Hydrogen Fluoride}

On January 24,1992 , at about 7:00 p.m., the hydrogen fluoride (HF) supply system failed, releasing a total of $650 \mathrm{lb}$ of $\mathrm{HF}$ in the Dock 8 area of Building 9212 at the Y-12 Plant. Seventeen personnel were affected by exposure to HF vapors. Based on initial medical evaluations, no acute or long-term effects to the employees are expected. However, several employees were scheduled to continue to undergo evaluation to ensure that no lasting effects had been experienced.

A combination of two events allowed the liquid and gaseous HF to spill onto the dock and surrounding area. The pressure relief disk, intended to protect the vaporizer and the relief valve, ruptured. In addition, a valve, which is intended to provide a pressure path for the pipe volume between the rupture disk and the pressure relief valve, was inadvertently left open. This was caused in part by failure to follow the operating procedure for the HF system. The release continued until personnel were able to close the valve upstream of the rupture disk. The operation of the HF supply systems located in Buildings 9212 and 9206 at the Y-12 Plant were suspended pending the results of an investigation of this occurrence.

The environmental impacts of the release were confined to increased airborne concentrations of HF with negligible effects, chemical etching of the dock and roadway, and the generation of six 55-gal drums of calcium oxide (burnt lime) and cleanup waste. The lime was applied on the day following the incident to neutralize any remaining HF in the area. This lime residue was later collected and sampled to determine fluoride content. The severity of the impacts were reduced by the cold air temperature, stable atmospheric conditions, wind direction during the release, and the reduced on-site population because of the time of day. However, the standard for average concentrations of $\mathrm{HF}$ for a $24-\mathrm{h}$ period, as specified by TDEC, was exceeded near the release site.

The need for a new HF supply and distribution system had been recognized before this incident, and construction was ongoing. The new system, which at the time of the incident was about $80 \%$ complete at Building 9212, will undergo extensive design evaluation and operational readiness reviews before the commencement of this operation. In addition, training and operating procedures, emergency preparedness, and overall conduct of maintenance and operations will be thoroughly ensured before operations are resumed. The HF supply system in Building 9206 has been disconnected; that operation will not resume.

\subsubsection{Visible Emission Evaluations Conducted at the Y-12 Plant}

A number of air permits issued for the $Y-12$ Plant by the TDEC Air Pollution Board include conditions limiting visible emissions to $0 \%$ or $20 \%$ opacity as determined by Tennessee Visible Emissions Evaluations Method 3 and Method 2, respectively. Visible-emissions determinations from air emission 
sources regulated by these permit conditions must be conducted by an observer certified in accordance with criteria approved by the Tennessee Air Pollution Control Board. The visible emissions training program and field testing is designed to prepare qualified observers whose determinations of plume opacity will be accurate and minimally affected by variable field conditions. Certifications, which are granted by instructors approved by TDEC, are valid for 6 months.

TDEC does not require operators of emission sources that include visible emission conditions to conduct routine visible-emissions readings or periodic reporting of Tennessee Visible Emissions Evaluations. However, as a Best Management Practice, the Y-12 Plant Clean Air Program staff conduct periodic Tennessee Visible Emissions Evaluations on certain emission points. Emission points selected were based on the following criteria:

- The nature of the process is such that visible emissions are possible from stacks serving combustion, high temperature heat-treating or incineration processes, large-scale grinding processes, chemical processes that could emit visible gases, or processes handling large quantities of finely divided particulate material. Stacks selected according to these criteria are as follows:

- Stacks 1, 6, 7, 9, and 10, Building 9215;

- Stack 13, Building 9206;

- Stacks 33, 36, and 42, Building 9212;

- Stack 75, Building 9201-5; and

- Stacks 85 and 88, Building 9204-4.

- Historical data identify stacks where visible emissions have occurred. Stacks selected according to this criterion are as follows:

- Stack 201 serving the classified waste shredder located at Building 9720-32;

- Stacks 427,469, and 643 serving lime silos;

- Stack 576 serving grit blasting process located at Building 9738; and

- Stack 676 serving carpenter shop located at Building 9720-6.

Visible emission determinations for the identified emission points are conducted annually by Y-12 Plant personnel certified in using the TDEC-approved methods and forms. These determinations are available for inspection in current air permit files for each emission source.

\subsubsection{Historical PCB Spills}

Historical PCB spills are defined in 40 CFR 761.120 , as those occurring prior to May 4, 1987. The EPA recognizes that historical spills will require site-by-site evaluation because of the probability of more pervasive PCB contamination. In addition, old spills are generally more difficult to clean up than fresh spills (especially on porous surfaces such as concrete). Therefore, spills occurring before May 4 , 1987, are to be decontaminated to requirements established at the discretion of the EPA.

Surveys of several areas at the Y-12 Plant have revealed $\mathrm{PCB}$ concentrations in excess of allowable levels. The sources of the contamination were removed prior to May 4, 1987, therefore constituting historical spills. Three such areas are Building 9215 M-Wing, Building $9215 \mathrm{O}-\mathrm{Wing}$ and 3rd Mill, and the Building 9202 trench. After attempts to clean the areas were not successful, a contractor, EnClean, was contracted to perform PCB extraction for the Building $9215 \mathrm{O}-\mathrm{Wing}$ and 3rd Mill areas.

The extraction process employs a surfactant that attracts and pulls PCBs in concrete and other porous surfaces. The chemicals are noncorrosive, nonflammable, and biodegradable. The contractor succeeded in lowering the PCB concentrations in the Building $9215 \mathrm{O}$-Wing and 3 rd Mill areas to below regulatory levels set by EPA $\left(10 \mu \mathrm{g} / 100 \mathrm{~cm}^{2}\right)$ with about $80 \%$ of the samples revealing less than detectable PCB levels.

EnClean will be used to clean other PCB-contaminated areas at the Y-12 Plant.

\subsubsection{Dechlorination Work at Y-12 Plant}

Chlorine levels in East Fork Poplar Creek have long been known to be detrimental to aquatic life. The chlorine sources are discharges of once-through cooling water and cooling-tower blowdown. A dechlorination project was established in 1990, systems designed in 1991, and systems placed in operation in late 1992 to address the need for reduced levels of chlorine. These actions were initiated in anticipation of a new NPDES permit (expected to be 


\section{Environmental Report Vol. 1, Oak Ridge}

issued in mid-1993), which is expected to establish a chlorine discharge limit for outfalls on East Fork Poplar Creek.

Systems I and II use sodium bisulfite (38\% solution) to treat chlorine, based on observed levels and a desired control level of $20 \mathrm{ppb}$. System 1 became operational on November 30, 1992, and System II on December 29, 1992. System I treats the water emerging from the north-south Pipes and outfall 135, which represent the beginning of the waters of the state and which approximates $69 \%$ of the total flow in East Fork Poplar Creek. System II treats outfall 21 and represents about $9 \%$ of the flow in East Fork Poplar Creek.

Each System basically consists of a small prefabricated building $(12,12 \mathrm{ft})$ that contains bulk storage of sodium bisulfite, a holding tank, metering pumps, electronic controls, a chlorine analyzer, digital and strip chart recorders, and miscellaneous piping, heaters, and fans. Outfall 135 and 21 flow rate is monitored. Pre-chlorine levels are monitored and used for control in System II. System II uses a split system, in that the chlorine analyzer is remotely located from the main building.

Chlorine levels have significantly been reduced since these Systems began operation. Typical cooling water supplied to the Y-12 Plant has chlorine levels of 1400 to $1600 \mathrm{ppb} ; 200 \mathrm{ppb}$ is the minimum requirement for drinking water. Typical chlorine levels at the North/South Pipe of 300 to $500 \mathrm{ppb}$ are being controlled to $20 \mathrm{ppb}$, except for some infrequent spiking. Chlorine levels exiting Lake Reality (and the Y-12 Plant) are well below $50 \mathrm{ppb}$, which is considered the lower detection limit by TDEC.

Snail survival testing at the North/South Pipe has shown dramatic increases from zero surviving in early 1992 to almost 90\% surviving in January 1993. No fish kills attributed to chlorine have occurred since the systems began operation.

A System III is being planned for operation in late 1993 or early 1994. This System will treat outfall 109, which represents another 10\% of East Fork Poplar Creek flow and is the next highest chlorine loader.

In addition to $\mathrm{m}$ ijor treatment systems, individual processes that discharge significant quantities of cooling water and do not discharge through System I, II, or III are being modified with tablet dechlorinators. These small units use compressed tablets of sodium bisulfate for treatment and are controlled based on flow rate. About 20 to 25 such units are planned for installation in 1993 and 1994. All new or rerouted cooling water discharges must be treated by major dechlorination systems or tablet units.

\subsubsection{Non-Point-Source Pollution Control}

The 1985 NPDES permit for the Y-12 Plant included requirements for the development and implementation of a Best Management Practices (BMP) Plan. An explicit requirement of the BMP Plan is to update the Y-12 Plant Area Source Management Control Proposal entitled Evaluation and Interim Management of Area Source Discharges to East Fork Poplar Creek (EFPC), dated February 15,1984 . Storm water event monitoring was conducted in 1988-89 and 1991-92 to identify contaminants and their concentrations. These measurement events were conducted at various outfalls on East Fork Poplar Creek, and the list of compounds analyzed for was extensive.

These data have been analyzed and two reports issued: Feasibility Study of Besi Management Practices for Non-Point Source Pollution Control of Parking Lots at The Oak Ridge Y-12 Plant, 1992, and Feasibility Study of Best Management Practices for Non-Point Source Pollution Control at The Oak Ridge Y-12 Plant, February 1993. The data from these reports are being used to develop and execute site specific sampling exercises in 1993 for parking lots, selected roofs, scrap yard(s), hillside runoff, and other sites of specific interest (to be determined). These data will be combined to into an enhanced feasibility report in support of a FY-1997 Line Item. A new area source sampling plan, with limited, but targeted analysis of contaminarits, will be prepared for execution in FY 1994.

\subsubsection{Water Corrective Action Program}

In 1989, a group of studies and projects were initiated to correct present surface water compliance concerns, improve water quality of East Fork Poplar Creek, and ensure compliance in anticipation of more stringent conditions of the renewed NPDES permit. The abatement of chlorine in once-through

\section{8-6 Special Studies}


noncontact cooling waters and control of area source pollution are two major components of the corrective action program (Sects. 8.17 and 8.18). Studies using dye to trace storm drain and sanitary sewer line connections were conducted during 1992 and now have been completed. Projects to reroute drains, particularly sinks and water fountains, and to plug building floor drains verified as being tied to the storm drain system, are proceeding in buildings throughout the plant. Several projects that remove steam condensate, noncontaminated cooling waters, and sources of stormwater inflow from the sanitary sewer system were placed under way in 1992 and will continue in 1993. Field surveys to produce as-built drawings of the drain systems are also under way.

The $\mathrm{Y}-12$ Plant is also retrofitting four major recirculatory cooling towers with ozonation units to reduce or totally eliminate blowdown to the receiving stream. This effort will further reduce the chlorine loading on East Fork Poplar Creek. To ensure compliance to the NPDES permit, a feasibility study of process options for each of the five on-site wastewater treatment systems has been completed. A conceptual design report for the selected modifications was initiated in early 1993.

\subsection{Oak Ridge National Laboratory}

\subsubsection{ORNL Waste Area Groupings Ranked According to Human Health Risks}

Because finances are limited, it has become necessary to evaluate contaminated sites to determine which areas pose the greatest potential threat to the environment. Potential impacts to human health and the environment can be evaluated through risk assessment calculations, and results have been obtained for the ORNL WAGs by means of deterministic calculations and additional calculations based on uncertainty analyses.

Four radionuclides $\left({ }^{60} \mathrm{Co},{ }^{137} \mathrm{Cs},{ }^{90} \mathrm{Sr}\right.$, and $\left.{ }^{3} \mathrm{H}\right)$ were selected for ranking the WAGs because these contaminants are believed to bc among the most important at all ORNL WAGs. The assessment endpoint was the maximum exposed individual at two receptor locations: on site (at WAG 2) and off site (at Clinch River mile 9.5). It is believed that most of the contaminants discharge from runoff and groundwater to on-site surface waters. For that reason, measured concentrations and flow rates of on-site surface waters were used to estimate current and future health risks from surface waters associated with each WAG.

The formulation and parameters recommended by the National Council on Radiation Protection and the International Atomic Energy Agency for generic screening calculations were adopted in this work and, when necessary, were adjusted to reflect site-specific climate and behavior patterns. Human health risks associated with contaminants released from the WAGs were calculated and summed over the following pathways: vegetable, fish, beef, water, and milk consumption; shoreline exposure; and ground exposure from irrigation.

The uncertainty of risk-assessment parameters can cause large differences in deterministic calculations. For that reason, the overall effects of parameter uncertainty were considered when calculating the health risks associated with WAGs. Uncertainty analyses are needed to rank waste sites reliably according to potential health risks associated with exposure to site contaminants. The results of the study indicate that the WAGs should be considered for further investigation, or remediation, in the following order: (1) WAG 1; (2) WAGs 2, 6, 7 (as one combined WAG), and WAG 4; (3) WAGs 3, 5, and 9 (WAGs 3, 5, and 9 are indistinguishable; and (4) WAG 8. The uncertainty analysis indicated that ${ }^{137} \mathrm{Cs}$ is the doninant contaminant contributing to potential health risks over all pathways, and the greatest ${ }^{137} \mathrm{Cs}$ contribution to risk was through tish ingestion.

Several parameters contributing to the uncertainty in the total calculated health risk at each WAG are common among all WAGs. Most notable is the factor used to convert radiation dose to health risk. Ambiguity in the rankings is reduced by holding these parameters cunstant to account for only the uncertainty in parameters unique to a particular WAG. Additional calculations using only the uncertainty in contaminant concentrations indicated that the WAGs should be ranked in the following order: (1) WAG 1; (2) WAGs 2, 6, and 7 (combined) and WAG 4; (3) WAG 5; (4) WAG 9; (5) WAG 3; and (6) WAG 8. 


\subsubsection{Clinch River Remedial Investigations: Phase 1}

The Clinch River Remedial Investigation is designed to address the transport, fate, and distribution of waterborne contaminants released from DOE Oak Ridge Reservation and to assess potential risks to human health and the environment associated with these contaminants. The contaminants reicased since the early 1940s include a variety of radionuclides, metals, and organic compounds. Primary areas of investigation are Melton Hill Reservoir, the Clinch River from Melton Hill Dam to its confluence with the Tennessee River, Poplar Creek, and Watts Bar Reservoir. The receiving river-reservoir system encompasses 140 river miles in length and 44,000 acres in surface area and is used for municipal water supply, sport fishing, navigation, boating, swimming, tourism, and residential development. The contaminants identified in the Clinch River/Watts Bar Reservoir downstream of the reservation are those associated with the water, suspended particles, deposited sediments, aquatic organisms, and wildlife feeding on aquatic organisms.

A phased remedial investigation of the Clinch River/Watts Bar Reservoir system is under way to (1) define the nature and extent of the off-site contamination, (2) evaluate associated environmental and human health risks, and (3) preliminarily identify and evaluate potential remediation alternatives.

Phase 1 of the Clinch River Remedial Investigation was a preliminary sampling and analysis of fish, sediment, and water in selected areas of the Clinch River/Watts Bar Reservoir system chosen to represent differing levels of media contamination. Specifically, Phase I was designed to (1) obtain high-quality data to confirm existing historical data for contaminant levels in fish, sediment, and water; (2) determine the range of contaminant concentrations present; (3) identify specific contiminants of concern; and (4) establish the reference (background) concentrations for those contaminants. Previously, scoping studies were conducted to provide an initial determination of contaminant distribution in the sediments of Watts Bar Reservoir (Olsen et al. 1992) and to assess preliminarily potential human health and ecological risk (Suter 1991; Hoffman et al. 1991).

\subsubsection{Mapping Soil Contaminated with Heavy Metals}

Superfund sites typically include areas where the soil is contaminated with heavy metals such as lead, arsenic, mercury, and cadmium. A good screening method can greatly reduce the cost of site characterization by reducing the number of soil samples sent to the laboratory. The LPA has had considerable success using commercially available portable X-ray fluorescence analyzers to map metals contamination.

To further increase the efficiency of X-ray fluorescence screening, EPA sponsored a 3-year work-for-others contract to interface an $X$-ray fluorescence analyzer with the Ultrasonic Ranging and Data System (USRADS) developed at ORNL by researchers in ORNL's Health and Safety Research and Instrumentation and Controls divisions. USRADS automatically tracks the position of a surveyor by using an array of microphones distributed over the survey area to determine the location of an ultrasonic transmitter carried in the surveyor's backpack. The backpack also contains a radio transmitter that broadcasts the results. The surveyor's position is calculated and displayed on a portable computer operated from a mobile base station (van or trailer).

As currently configured, each time the portable $X$-ray fluorescence analyzer completes a measurement the location of the surveyor is determined and stored on a hard disk along with the data received by radio. Because metal concentrations and measurement locations are available in the field, a soil-sampling strategy can be developed on site. The completed system was demonstrated to the EPA in February 1992, and the final project report is in progress.

\subsubsection{Contaminated-Sediment Transport in the White Oak Creek Catchment During Floods}

During the past 49 years, operations and waste-disposal activities at ORNI, have resulted in the contamination of parts of the White Oak Creek catchment. The highest risk to human health and the environment is presented by particle-reactive contaminants and are associated with the soils and sediments in the White Oak Creek drainage system.

\section{8-8 Special Studies}


The erosion of these sediments during floods results in the transport of contaminants both within the catchment and off site into the Clinch River. It should be pointed out that sediment moving from the White Oak Creek Embayment into the Watts Bar Reservoir has been reduced by the completion of a cofferdam in 1992.

A data-collection program and a modeling investigation are being used to estimate the magnitude of contaminated sediment transport during floods and to develop strategies for controlling the off-site transport of contaminants. A nested series of models will predict the movement of sediment from subcatchments to the main channels and floodplain, and will link with models for transport in the Clinch River. Results from several storms sampled during the 1991-92 winter indicate that nonlinear relationships exist between precipitation intensity, streamflow, suspended sediment concentration, particle size of suspended sediment, and contaminant concentration. Therefore, predictions of off-site transport of particle-reactive contaminants during extreme floods and future land-use changes cannot be based on the extrapolation of field measurements made during moderate floods. Instead, these nonlinear relationships will be simulated for extreme flood conditions by means of computer models that are currently being developed.

Although driven by the need to predict the transport of contaminated sediments under future conditions, the modeling effort requires a new application of basic principles of streamflow generation and sediment dynamics, and the results of model development and testing have implications for both basic and applied uses.

\subsubsection{Co-Metabolic Techniques Bioreactor Demonstration Project}

The Co-Metabolic Techniques Bioreactor Demonstration Project is being conducted by ORNL staff, with the support of K-25 Site staff, on the K-25 Site. This project is a test of two types of biological treatment systems (bioreactors) designed to remove organic contaminants from groundwater on DOE sites. The principal compound targeted for removal is trichloroethylene (TCE).

Because large volumes of TCE were used until the 1980s for degreasing and dry-cleaning operations, it is one of the most commonly found groundwater contaminants in the United States. Groundwater at several DOE sites has been found to be contaminated with TCE and other organic compounds, including solvents such as perchloroethene, carbon tetrachloride, chlorinated ethanes, and benzene. The techniques being tested on the K-25 Site are among the most promising for removal of these contaminants from groundwater.

Methods that employ two groups of microorganisms, methane utilizers and toluene utilizers, are currently being investigated for TCE removal. Both methods are based on co-metabolic degradation, the fortuitous degradation of a target contaminant (such as TCE) by naturally occurring microorganisms that use another compound as a growth substrate.

Laboratory and bench-scale TCE degradation by methane utilizers has been demonstrated by several research groups, including the ORNL team conducting this demonstration project. Use of toluene utilizers in TCE removal was first demonstrated in studies at the EPA Gulf Breeze Laboratory, and more recently by other groups.

Remedial alternatives tested in the demonstration project may prove to be both more effective and less costly than other existing alternatives (such as chemical or ultraviolet oxidation or carbon adsorption). Results will help to optimize the in situ TCE bioremediation activities currently being conducted at the DOE Savannah River Integrated Demonstration Project. It will also provide the basis for scaleup of both methods for remediation of solvent-contaminated groundwater at other DOE facilities. Through technology transfer, these methods will be made available to the private sector for broader remediation of TCE groundwater contamination.

The project began in April 1990. The first bioreactor operated between September and November 1991, was placed on standby, and then resumed operation in June 1992. In September 1992 the first operating campaign was completed, and a draft interim operational report was submitted to DOE. The system is currently on standby awaiting restart in April 1993.

The project is being conducted by ORNL, staff, with support from staff of the K-25 Site, through the Energy Systems Waste R\&D Programs Office for the DOE Environmental Restoration and Waste 
Management Program's Office of Technology Development. Supplemental funding for the demonstration, as well as the loan of the initial bioreactor unit to be tested, is being provided by the Air Force Civil Engineering Support Agency (Tyndall Air Force Base, Florida). Throughout the project, the Energy Systems Office of Technology Transfer communicates the results of the demonstration to DOE and to private vendors. Planning is under way to demonstrate the second bioreactor system in collaboration with a private environmental biotechnology firm (Envirogen, Inc., Lawrenceville, New Jersey).

\subsubsection{Environmental Restoration}

\subsubsection{Clinch River}

The Clinch River temedial investigation focuses on the portions of the Clinch and Tennessee rivers that may have been adversely affected by contaminants released from the ORR during the time from the mid-1940s to the present. The Melton Hill Reservoir and the Clinch River, downstream from Melton Hill Dam, form the southern and eastern boundaries of the ORR. The Clinch River enters the Tennessee River system of multipurpose impoundments near Kingston, Tennessee, $34 \mathrm{~km}$ downstream from the Oak Ridge complex. Watts Bar Reservoir is located on the Tennessee River just below its confluence with the Clinch River and is the first impoundment downstream of the ORR. The area being investigated includes Melton Hill Reservoir, the Clinch River (from Melton Hill Dam to Kingston), and the Watts Bar Reservoir.

The contaminants released from the ORR originate from research, industrial, and waste-disposal activities conducted at ORNL, the Y-12 Plant, and the K-25 Site. The contaminants released from these facilities include a variety of radionuclides, metals, and organic compounds. Some liquid wastes are discharged to streams on the ORR that drain into the Clinch River; however, much of the waterborne contamination is derived from seepage into the shallow groundwater from old waste-storage pits and trenches. The contaminants of concern in the river-reservoir system were determined by preliminary human-health-risk screening that employed a variety of exposure pathways. PCBs were identified as contaminants of concern through fish ingestion. Arsenic, chromium, mercury, selenium, zinc, ${ }^{137} \mathrm{Cs}$, and ${ }^{60} \mathrm{Co}$ constitute a risk only if deep-channel sediments are dredged and are placed on land.

\subsubsection{Oak Ridge Institute for Science and Education (ORISE)}

\subsection{South Campus Facility}

The South Campus Facility operable unit (OU) is located within the city limits of Oak Ridge. It is bounded by Bethel Valley Road to the north, State Highway 62 to the east, Haw Ridge and the Clinch River to the south, and a fenceline about $100 \mathrm{~m}$ west of Pumphouse Road to the west.

A research facility operated by ORISE, the South Campus Facility was established in 1948 to study the accidental irradiation of cattle that occurred during the testing of the first atomic bomb near Alamogordo, New Mexico. The scope of research soon included studies on the introduction and migration of radicisotopes in the food chain and various other agricultural problems.

The boundaries of the South Campus Facility encompass about 25 buildings and 90 acres of pasture land, but there is no enclosing fence. Access to the facility property is generally unrestricted. Although several signs are posted to limit access, no fences or barriers exist to preclude access.

No documented evidence is available as to waste composition or quantity that may have been released to the environment at this location. Limited data exist, however, that identify potential hazardous waste sources and pathways. In addition, previous analytical data indicate the presence of target compound list organics in the groundwater. A remedial investigation was initiated in FY 1993.

Facility areas investigated include the wastewater treatment plant, ponds, various laboratories, and animal containment facilities. Contaminants of concern include radionuclides and target compound-list and analyte-list metals.

\subsection{Freels Bend Area}

The Freels Bend Area was used to support research conducted at the South Campus Facility. This area is located southwest of the facility and is

\section{8-10 Special Studies}


bounded on three sides by the Clinch River. Control herds of some animals (and ancillary barns and outbuildings) were maintained on pasture land here.

The research facilities included the Low Dose Rate Irradiation Facility and the Variable Dose Rate Irradiation Facility. Each of these facilities was used to irradiate test animals that were subsequently observed for exposure effects. The sources were removed from the low-dose facility; however, six sealed ${ }^{60} \mathrm{Co}$ sources are stored at the variable dose facility.

A reported disposal area for animal carcasses and miscellaneous wastes exists on the Freels Bend Area (Animal Burial Site I).

Access to the 250 acres of the Freels Bend Area is restricted and not open to the general public although the area is not fenced and is accessible from the Clinch River. The entrance to the access road is blocked with a locked bar gate.

Freels Bend Area sites to be investigated include those associated with the irradiation-facility and animal burial location. Contaminants of concern include radionuclides, organics, and metals.

\subsubsection{Lower East Fork Poplar Creek Operable Unit}

\subsection{Description}

The Lower East Fork Poplar Creek OU extends from the outfall at Lake Reality at the Y-12 Plant boundary downstream to the stream's confluence with Poplar Creek. Upper East Fork Poplar Creek originates within the Y-12 Plant and extends to the Lake Reality outfall. The Lower East Fork Poplar Creek site consists of the $23-\mathrm{km}$ stream and an associated 550-acre floodplain.

As a result of the loss to the environment of contaminants associated with lithium processing operations at the $\mathrm{Y}-12$ Plant, East Fork Poplar Creek became contaminated with mercury and trace levels of other metals, organics, and radionuclides. Since 1953, as much as 2.4 million lb of mercury are thought to have been released. About 75 metric tons of this material may still be in the floodplain soils.

The Sewer Line Beltway was constructed by the city of Oak Ridge during 1982 and 1983 and contains over 10 miles of sanitary interceptor sewers and force mains. In certain instances, East Fork Poplar Creek floodplain soils were used to provide topsoil. No records were kept to document the backfill procedures and locations; however, all accessible areas of the Sewer Line Beltway have been sampled.

\subsection{Accomplishments}

Four batches of biological tissues were shipped to Radian Laboratory in Austin, Texas, for analysis of organics. The Nuclear Services Center at North Carolina State University in Raleigh will perform the analyses for metals.

Work continues on refining the human health risk assessment model for the Baseline Risk Assessment. An "open-use" classification was added in lieu of an agricultural and homesteader exposure pathways. The open-use classification will be the basis for evaluating exposure to receptors who make casual use of the open land along the creek (e.g., hikers, trespassers).

Preparation of the remedial investigation report has been completed. All feasibility studies, including low-temperature thermal description and a General Electric proprietary chemical extraction method, have been completed. Drafts of Sects. 3, 4 (through 4.2), and 5.2 of the feasibility study/environmental impact statement were completed.

The data verification/validation of all neutron activation analysis data packages for mercury concentration in the floodplain soil was completed. An ecological risk assessment of Lower East Fork Poplar Creek was presented to the U.S. Fish and Wildlife Service.

An additional treatability study of a General Electric patent mercury removal process was initiated. Current land-use and analyte maps for use in the feasibility study were completed.

\subsection{Concerns}

Because of a 3 -month delay in receiving neutron activation analytical results, the feasibility study/environmental impact study schedule is in jeopardy. For that reason, there is a possible delay in the feasibility study/environmental impact study schedule. The feasibility study/environmental impact statement subcontractor is attempting to absorb the delay and maintain the schedule. 


\subsection{Scheduled Activities for Next Quarter}

The final treatability study report will be submitted to DOE and EPA. A resource-leveled life-cycle baseline will be completed. A remedial investigation report briefing will be given to DOE-HQ, and a risk assessment briefing to EPA Region IV. The FY 1995 Activity Data Sheet will be prepared, and the FY 1995 funding validation will be completed. Work will continue on the feasibility study/environmental impact statement. The Girl's Club soil CERCLA removal action will begin.

\subsubsection{Biological Monitoring and Abatement Program}

The Biological Monitoring and Abatement Programs (BMAPs) mandated by NPDES permits at the Y-12 Plant, ORNL, and the K-25 Site each contain tasks concerned with monitoring the accumulation of contaminants in the biota of receiving waters. The primary objectives of these studies are (1) to identify substances that accumulate to undesirable levels in biota as a result of discharges from DOE facilities, (2) to assess the significance of those discharges relative to other sources in determining contaminant concentrations in biota in receiving waters, and (3) to provide a baseline measure of biotic contamination to use in evaluating the effectiveness of any future remedial measures.

\subsubsection{Miscellaneous ORNL Spills}

During 1992, ORNL had a total of 132 spills or releases of various types of materials (Figs. 8.1-8.3) compared with 109 for 1986,92 for 1987,119 for 1988, 91 for 1989,135 for 1990, and 125 for 1991 . ORNL has defined a spill as any material outside its containment vessel. A spill is not necessarily a release to the environment; it may be to the floor, a laboratory bench, or a secondary containment structure. Emphasis is placed on spill reporting and investigation to prevent any environmental releases. Members of the ORNL Office of Environmental Compliance and Documentation investigated each spill or release to determine the environmental impact, to provide input for reducing any harmful effects, and to assist with cleanup efforts. Cleanup activities were conducted by staff members of the

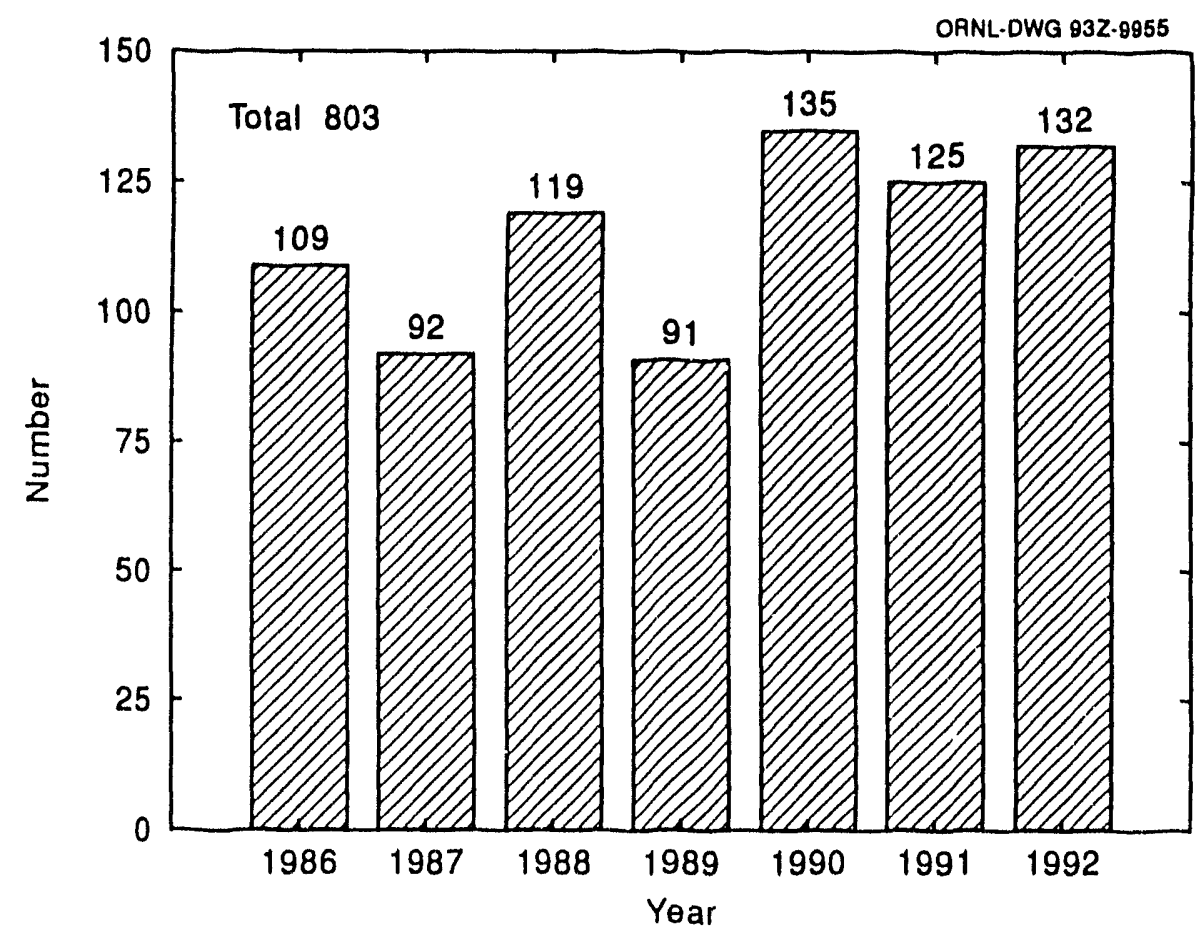

Fig. 8.1. ORNL spill summary, 1986-1992. 


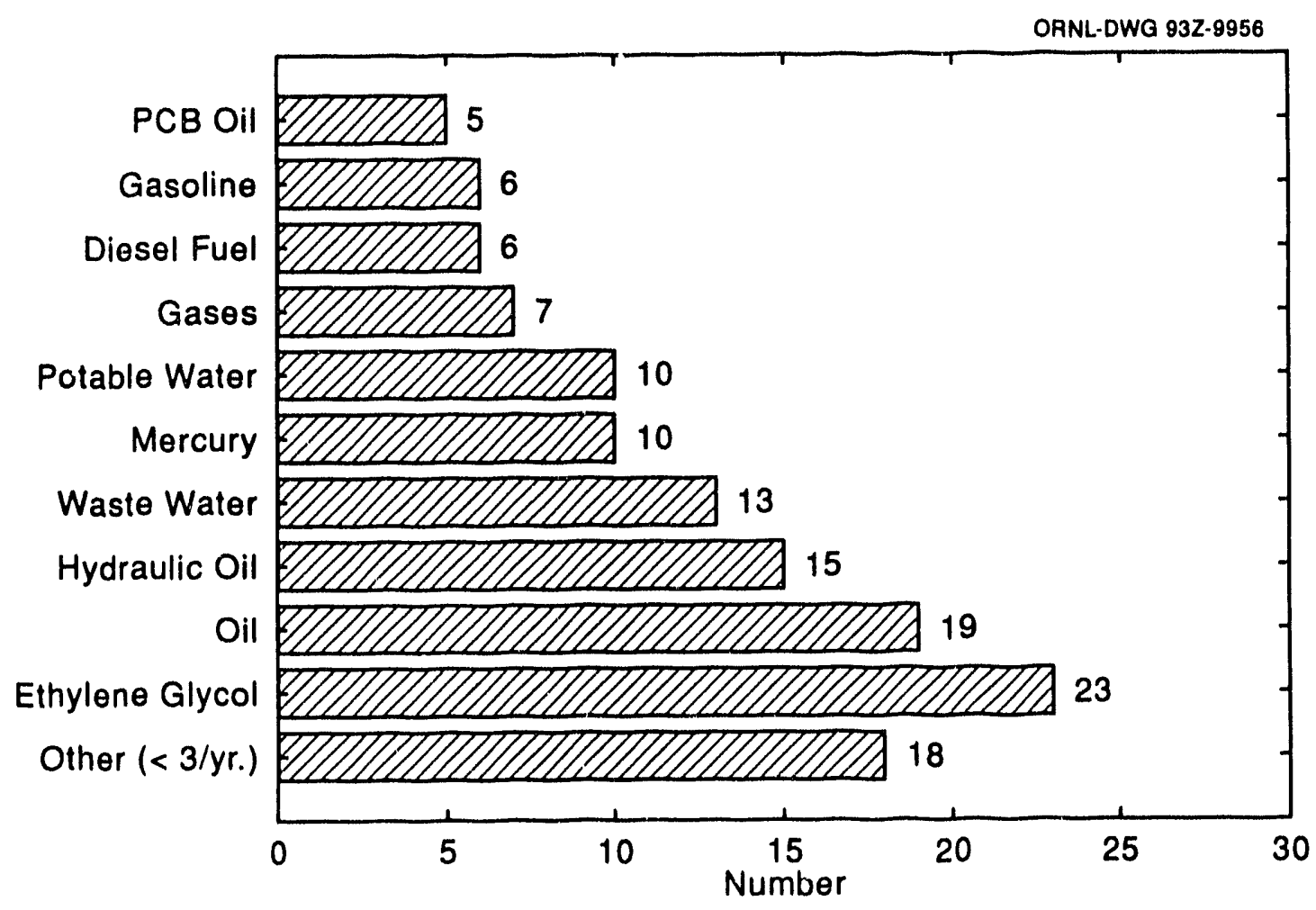

Fig. 8.2. ORNL spill summary, material frequency.

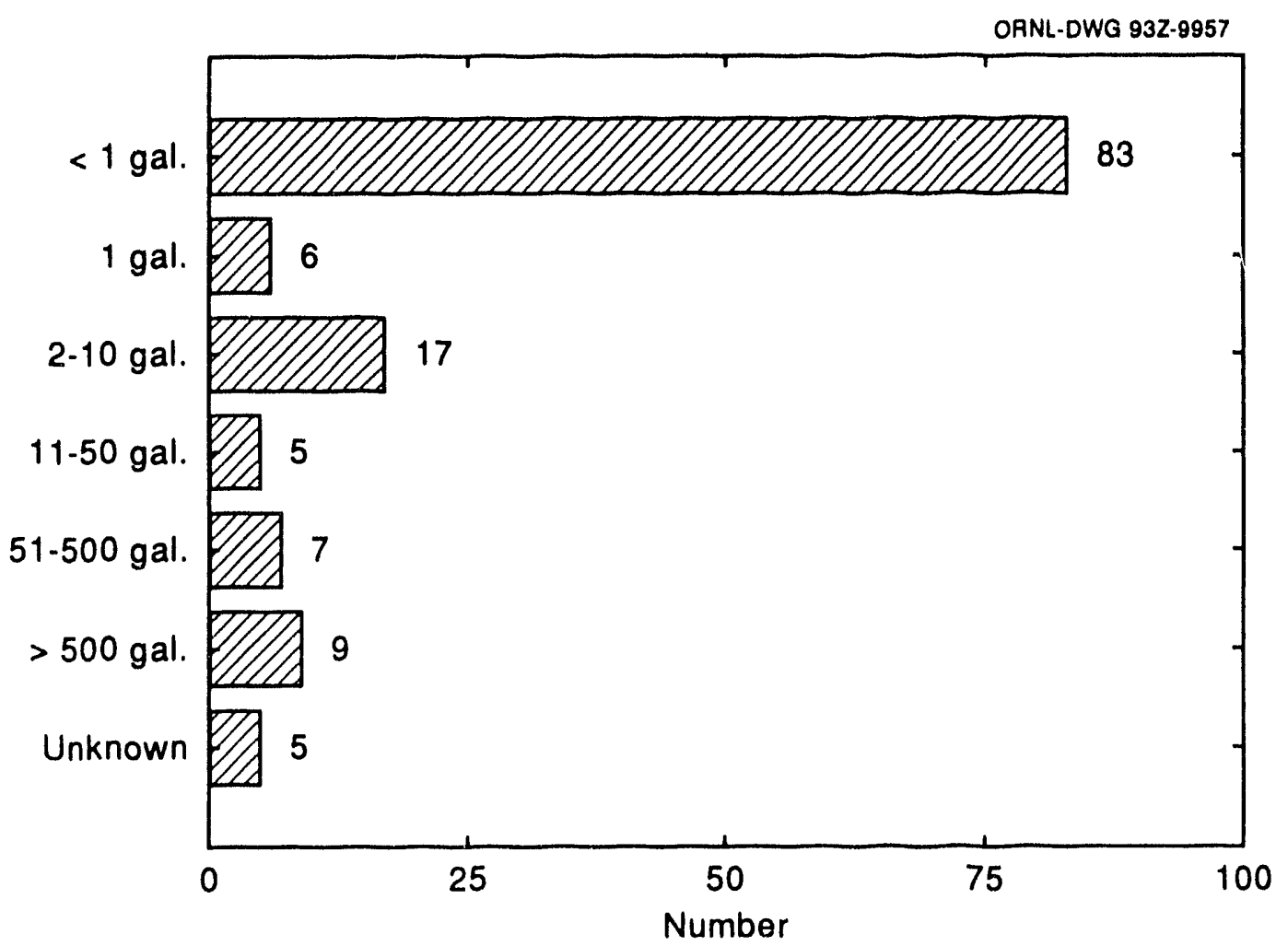

Fig. 8.3. ORNL spill summary, volume frequency. 
ORNL Hazardous Waste Operations Group. All cleanup materials were disposed of according to ORNL procedures.

ORNL reports all spills via the electronic mail system to various levels of ORNL management as soon as possible after the spill; updates are provided as necessary. This reporting system has resulted in an increased awareness of spills by ORNL staff members. Additional reporting, if required, is done under ORNL Occurrence Reporting System as required by DOE Order 5000.3A, Occurrence Reporting and Processing of Operations Information.

As in previous years, many of the spills involved petroleum products. Of the 132 spills, 83 were less than a gallon in quantity, and 9 were greater than $500 \mathrm{gal}$; most of the spills over $500 \mathrm{gal}$ were potable water.

\section{$8.3 \quad K-25$ Site}

\subsubsection{Dechlorination in Mitcheli Branch}

Elevated levels of total residual chlorine (TRC) were identified as the major source of toxicity in Mitchell Branch through monitoring efforts associated with the BMAP for the stream and through investigations conducted in response to fish kills that occurred there in 1988 and 1990. The fish kills were attributed to the inadvertent activation of a backup cooling system that used sanitary (drinking) water containing between 1.0 and $2.0 \mathrm{mg} / \mathrm{L}$ TRC. The backup system was used for removal of waste heat. It discharged to Mitchell Branch through the storm drain system. As a result of the fish kills, the backup cooling system was manually valved off, and a nonchlorinated water source was established for the system.

Investigations of toxicity in the stream resulted in the identification of other sources of elevated TRC levels from continuous discharges of once-through cooling water from heating and air-conditioning systems that use sanitary water. Although the impact of these discharges was not significant enough to result in fish kills, they were estimated to contribute as much as $30 \%$ of the flow to Mitchell Branch under normal conditions. Because the stream is a zero-flow stream during periods of below-normal precipitation, once-through cooling waters can account for nearly
$100 \%$ of the stream's flow and thus significantly impact aquatic life.

An engineering project was designed to eliminate or reroute the cillorinated discharges to Mitchell Branch. The project identified several systems within three buildings that discharged chlorinated water to the stream. These discharges were rerouted from the storm drain system to other on-site systems. The project was completed in October 1992.

An interim, short-term project to remove the impact of the chlorinated water discharges was developed and initiated in June 1991. The project involved the installation of dechlorination units at three storm drains along Mitchell Branch that were identified as having elevated TRC levels in their effluent. The units are flow-through feeder systems that use sodium sulfite tablets to remove the TRC from the discharge. Written maintenance procedures were implemented to prevent failure of the units. The units were inspected daily, and routine sampling was conducted at the outfalls for TRC, sulfite, chemical oxygen demand, and dissolved oxygen to ensure that the feed rate of the tablets is controlled effectively. Repopulation of the middle reaches of Mitchell Branch, where fish and aquatic communities were not previously supported, occurred soon after activation of the units. The dechlorination units were deactivated following completion of the long-term engineering project in October 1992. The units will be reused at other locations at the K-25 Site where chlorinated discharges are identified as having an impact on other receiving streams.

\subsubsection{Stack and Vent Survey}

A stack and vent survey of 28 buildings at the K-25 Site was completed in June 1992. This survey was used to develop the minor source inventory of radiological emissions and will also be used in the development of the Title V Air Permit application. Field crews recorded stack height, stack diameter, potential pollutants, and source of potential pollutants for each stack and vent of the 28 buildings.

This information was reviewed and a list of 193 possible radiological sources was developed for further investigation. A data base of the stacks and vents was also developed. The data base was programmed to be able to print out three different reports: a summary of emissions from a building, emissions from a single source, and a summary of

\section{8-14 Special Studies}




\section{Environmental Report Vol. 1, Oak Ridge}

sources emitting a specific pollutant or pollutant group. This data base will be useful in characterizing all emissions from the $\mathrm{K}-25$ Site.

\subsubsection{TSCA Air Monitoring Station Relocation}

Two ambient air monitoring stations near the K-25 Site are dedicated to support of TSCA Incinerator operations. Siting studies carried out prior to incinerator startup were used as the basis for locating them in the direction of the K-25 Site's nearest resident and maximum exposed individual.

Industrial expansion westward in Bear Creek Valley to the Clinch River has introduced uncertainty when analyzing samples collected at TSCA2, the air monitoring station originally sited at the west end of Bear Creek Valley near the Gallaher Bridge. Since monitoring is being performed to quantify the TSCA Incinerator contribution to off-site chemical dose in the event of an unplanned release, it was determined that TSCA2 was no longer effective at its original location. The likelihood of outside industrial influences, plus the possibility of various other impacts on sample integrity due to public access to the monitoring station location, prompted a search for a new site.

Site surveys revealed an attractive location on the K-25 Site, and a dispersion modeling study of emissions from the incinerator provided additional confidence that the monitoring station should be moved to a location where it would sample TSCA incinerator emissions; at the same time it would continue to be representative of potential chemical dose in the direction of the maximum exposed individual off site. The TSCA 2 ambient air monitoring station relocation was completed during a scheduled incinerator maintenance period in December 1992.

\subsubsection{CFC Equipment Replacement Plan}

Future phaseout of the production of chlorofluorocarbon $(\mathrm{CFC})$ refrigerants and fire suppressants under the Clean Air Act Amendments, Title VI, Stratospheric Ozone Protection, prompted a study of the potential financial and operational impact at the K-25 Site. The Oak Ridge K-25 Site Response Plan to the Ban on the Production of
Chlorofluorocarbons (CFCs) (K/C-1571, January 1993) identifies the major pieces of refrigeration equipment and Halon fire suppression systems, which would be affected by a reduced supply and eventual unavailability of Class I CFC substances.

A strategy for converting to replacement substances and/or for replacing capital equipment was devcloped. The plan identifies anticipated funding requirements for the period FY 1993-1999, and it attempts to minimize the funding needs and the overall impact of the production ban by conscientiously managing the local supply of CFCs. Halons and refrigerants recovered during equipment conversion or replacement would be recycled for use in other compatible applications. The plan identifies interim actions (e.g., small equipment inventory), which might refine the potential cost and operations impact of the phaseout, and it establishes K-25 Site roles and responsibilities for implementing the program.

\subsubsection{Pond Waste Management Program Air Emissions}

The Pond Waste Management Project was formed to resolve compliance problems associated with the management of stabilized and raw sludge stored in drums at the K-25 Site. Two processes were selected to solve those problems. The stabilized drums would be decanted, and the raw sludge would be treated using a thermal dewatering process.

In order to demonstrate compliance with Tennessee Department of Environment and Conservation Air Pollution Control regulations and National Emission Standards for Radiological Emissions Other than Radon from Department of Energy Facilities, an analysis of the appropriate, relative, and applicable requirements was completed This analysis included characterizing the potential pollutants, estimating the release of these pollutants to the air, and modeling the release rate of the pollutants in order to predict the ambient air concentrations of each pollutant.

For the nonradiological air emissions the modeling results were compared with a reference ambient air cuncentration, and all nonradiological pollutants considered were below the level of concern. For the radiological emissions the potential emissions were determined using radionuclide 
characterization of the total quantity of sludge and criteria defined in 40 CFR 61 Appendix D. All actual emissions were calculated using this appendix except those for the drying operation. From the physical chemistry of various radionuclides in the sludge an exception to Appendix D was made for the drying operation. This protocol was submitted to EPA Region IV and was approved. The emissions were then modeled for effective dose equivalent (EDE) to the most affected individual for the K-25 Site. The entire EDEs from these processes were well below the administrative limit of $0.1 \mathrm{mrem}$.

\subsubsection{K-25 Site Ambient Air Monitoring Program Review Against DOE Order and Regulatory Requirements}

The Oak Ridge K-25 Site Ambient Air Monitoring Program Review documented the site ambient air monitoring system against DOE orders and regulatory requirements to identify any deficiencies. This was in response to the Tiger Team finding that the program does not ensure that representative samples are taken. The results of this review identified several deficiencies and proposed corrective actions necessary to both satisfy the Tiger Team finding and improve overall data quality and representation. This review established direction for upgrading and improving the present capabilities of the network. All procedures including but not limited to maintenance, sampling, analysis, QA/QC, and audits were reviewed. Any notable deficiencies of this program were identified, and proposed corrective actions were addressed. The proposed corrective actions would be addressed in stages to upgrade the existing network and to enhance data quality.

The second proposed stage would provide guidelines for necessary design and procedures modifications to bring ambient air monitoring station \#4 in line with all required state and federal probe-siting criteria-specifically, to address collocated sampling, multiple sampler spacing, and establishing the relationship for radionuclide sampling at heights other than $2 \mathrm{~m}$. The criteria for the placement of the PM10 monitor at this site would also be documented.

Stage three would address site selection criteria, additional platform modifications, and relocation or addition of more stations as defined by changing K-25 Site operations. Additions and modifications would be defined by regulatory requirements and computer-modeling results. Also, stations would include collocated sampler capability for precision measurements and would establish the relationship for radionuclide sampling at heights other than $2 \mathrm{~m}$. Other actions would address installation of possible security fencing and improved vegetation control.

The final stage of this review addressed emergency response and enhanced monitoring capabilities. Details would be defined to establish procedures for emergency activation of all samplers in response to any unplanned/accidental release at the K.-25 Site. An in-sector/out-sector (upwind/ downwind) collocated sampling proposal would be addressed to determine ambient pollutant levels not influenced by the K-25 Site. Independent auditing of samplers would be investigated.

\subsubsection{K-25 Site PM10 Ambient Air Monitoring Hrogram Review}

The Oak Ridge K-25 Site PM10 Ambient Air Monitoring Program Review documented the PM10 (particles with an aerodynamic diameter $\leq 10 \mu \mathrm{m}$ ) ambient air monitoring system against DOE orders and requirements to identify both a regulatory basis and any deficiencies with PM10 sampling and analysis. It provided an overview of the regulatory history that initiated the addition of the PM10 system. Also presented was a review of procedures, costs, and requirements for determining justification for its continuance.

PM10 monitoring recommendations based on this review include continuing PM10 sampling as currently defined by the existing ambient air monitoring program. Proposed changes and upgrades include discontinuing all metals and uranium analyses of PM10 samples, precision testing by collocating a second PM10 sampler, and reviewing siting criteria and justification annually.

\subsubsection{Oak Ridge K-25 Site Ambient Air Monitoring Semiannual Report, January 1, 1992-June 30, 1992}

This document was prepared to present the results of the Oak Ridge K-25 Site Ambient Air Monitoring Program sampling for the first half of CY 1992. During January 1 through June 30, 1992, 31 sampling periods of 24 hours every 6 days were

\section{8-16 Special Studies}




\section{Environmental Report Vol. 1, Oak Ridge}

conducted. Samples were taken to measure total suspended particles, total particle diameter $\leq 10 \mu \mathrm{m}$, lead, chromium (total), nickel, and uranium (total). Data were reviewed on the basis of "weekly" (24 hours every 6 days) and quarterly results and extrapolated for comparison with annual and other applicable standards. This evaluation also included comparison with the results of sampling during the same period of 1991 and proposed corrective actions and recommendations. Sampling results for the first half of the CY 1992 reporting period demonstrate full compliance with all applicable ambient air quality standards and demonstrate similar levels and trends as observed in the 1991 data.

\subsection{References}

Hoffman, F. O., B. G. Blaylock, M. L. Frank, L. A. Hook, E. L. Etnier, and S. S. Talmage.
1991. Preliminary Screening of Contaminants in the Off-Site Surface Water Environment Downstream of the U.S. Department of Energy Oak Ridge Reservation. ORNL/ER-9. Oak Ridge National Laboratory, Oak Ridge, Tenn.

Olsen, C. R., I. L. Larsen, P. D. Lowry, C. R. Moriones, C. J. Ford, K. C. Dearstone, R. R. Turner, B. L. Kimmel, and C. C. Brandt. 1992. Transport and Accumulation of Cesium-137 and Mercury in the Clinch River and Watts Bar Reservoir System. ORNL/ER-7. Oak Ridge National Laboratory, Oak Ridge, Tenn. Suter, G. W., II. 1991. Screening Level Risk Assessment for Off-Site Ecological Effects in Surface Waters Downstream from the U.S. Department of Energy Oak Ridge Reservation. ORNL/ER-8. Oak Ridge National Laboratory, Oak Ridge, Tenn. 


\section{SOLID WASTE MANAGEMENT PROGRAM}

9.1 Description $\ldots \ldots \ldots \ldots \ldots \ldots \ldots \ldots \ldots$ 9-3

9.1.1 Purpose ............... 9-3

9.1.2 Types of Wastes Generated ...... . 9-3

9.1.3 Regulations and Guidance . . . . . . 9. 9-4

9.1.4 Compliance Activities .......... 9.5

9.1.5 Program Strategy . . . . . . . . . . 9-6

9.2 Waste-Generating Activities . . . . . . . 9-13

9.2.1 Y-12 Plant ... . . . . . . . . . . 9-13

9.2.2 Oak Ridge National Laboratory . . . . 9-14

9.2.3 K-25 Site . . . . . . . . . . . . . 9-15

9.3 Waste Management Activities . . . . . . . 9-17

9.3.1 Waste Management System . . . . . . 9-17

9.3.2 Waste Management Facilities . . . . . 9-17

9.3.3 On-Site Treatment . . . . . . . . . . 9. 9-25

9.3.4 On-Site Waste Disposal Activities . . 9 9-25

9.3.5 Off-Site Waste Disposal . . . . . . . . 9-26

9.3.6 Waste Placed in Storage ... . . . 9. 9-26

9.4 References . . . . . . . . . . . . . . . . . . . . . 9-27 


\section{Solid Waste Management Program}

\subsection{Description}

\subsubsection{Purpose}

The goal of the solid waste management frogram is to handle solid wastes according to procedures that protect the health and safety of on-site personnel and the public, protect the environment, and minimize long-term liability. To meet this goal, the potential for environmental release of wastes must be minimized. Therefore, solid waste management activities are conducted in compliance with state and federal regulations and conform to good industry practices, which in some cases are more protective than the practices mandated by the regulations.

The solid waste management program encompasses treatment, storage, transportation, and disposal of nonhazardous, conventional radioactive, infectious, Toxic Substances Control Act (TSCA), mixed, and hazardous solid wastes. The terms "solid" and "hazardous" are used as defined in the Resource Conservation and Recovery Act (RCRA). A solid waste is a solid, liquid, or gas that is discarded, abandoned, or, in some cases, reused by recycling or burning for energy recovery. Hazardous wastes are a subset of solid wastes that RCRA designates and regulates as hazardous. Mixed wastes contain both hazardous and radioactive components.

\subsubsection{Types of Wastes Generated}

Following is a brief summary of the types of wastes generated at the Oak Ridge Reservation (ORR).

Industrial wastes. Industrial trash consisting of paper, wood, metal, glass, and plastic, coupled with large volumes of construction/ demolition debris and small volumes of sanitary/food wastes from cafeteria operations. Also included in this category is fly ash from steam plant operations and other special wastes. This is regulated by the Tennessee Solid Waste Management Act (TSWMA).

RCRA hazardous wastes. Solid wastes (including gases and liquids) that are defined as hazardous by RCRA regulations as a consequence of being a listed waste or having a hazardous characteristic. Hazardous wastes include chemicals that are characteristically hazardous or listed by RCRA in 40 CFR 261.30 and TN 1200-1-11.02(4). These wastes are managed in accordance with U.S. Department of Energy (DOE) Orders 5400.1 and 5400.3 and state and federal regulations. As a result of the May 1991 moratorium, all hazardous waste is considered mixed until the DOE "no rad added" performance objective can be met.

Mixed wastes. RCRA hazardous wastes that are also contaminated with low-levels of uranium or other radioactive material.

Polychlorinated biphenyl (PCB) wastes. PCB oils or materials that have been contaminated with PCBs. These are regulated by TSCA. These waste streams may or may not be radioactively contaminated. Radioactively contaminated waste cannot be disposed of through commercial disposal facilities. Any PCB waste that is radioactively contaminated is placed in storage pending future disposal at the K-1435 Incinerator.

Low-level radioactive wastes. Solid wastes (including liquids) that are composed of isotopically depleted uranium metal or oxide or that contain low levels of uranium or other radioactive contamination. LLW are managed according to DOE Order 5820.2A and the Atomic Energy Act.

Asbestos/beryllium oxide wastes. Solid wastes that have been contaminated with either asbestos or beryllium oxide, which classifies the waste as a 
special waste. The waste may also be contaminated with low levels of urarium or other radionuclides

Scrap metal. Derived primarily from demolition activities. The scrap may be either nonuranium contaminated or contaminated with low levels of uranium or other radionuclides.

Classified wastes. Classified wastes include liquid and solid streams containing materials that, for security reasons, are restricted by DOE criteria. Classified wastes are managed in accordance with DOE Order 5632.1. These wastes could be contaminated with low levels of radioactivity.

Treated Medical wastes. Medical and infectious wastes include contaminated bandages, sharps, and culture media. These wastes are placed in biological disposal containers and autoclaved to destroy any biologically active organisms. The treated waste is then landfilled at the Y-12 Centralized Sanitary Landfill II.

Nonhazardous wastes. All other types of wastes (including liquids) that are nonhazardous or nonradioactive, or both.

Material access area (MAA) wastes. Wastes that are removed from MAAs include combustible and compactible materials (such as paper, wood, and wipes) and noncombustible and noncompactible materials (dirt, concrete, block, and rubble). The waste contains low concentrations of enriched uranium and has been monitored to verify that the uranium concentrations are below levels of concern for accountability, recoverability, and security control.

\subsubsection{Regulations and Guidance}

This section describes the regulations that govern the management of solid waste and the DOE orders that complement these regulations.

\subsubsection{Federal and State Compliance}

RCRA, enacted in 1976, is the primary regulation governing solid waste management activities. RCRA regulates the generation, transportation, treatment, and disposal of hazardous wastes and regulates facilities that conduct these activities. Source materials, special nuclear materials, and by-product materials are excluded from RCRA. However, hazardous wastes that are contaminated with radioactive material are regulated by both RCRA and the Atomic Energy Act (AEA). Hazardous wastes are defined in RCRA by specific source lists, nonspecific source lists, characteristic hazards, and discarded commercial chemical product lists. Other portions of RCRA pertinent to the Oak Ridge installations include standards for accumulation areas; standards for transporters of hazardous waste; standards for owners and operators of hazardous waste treatment, storage, and disposal facilities; permit requirements for treatment, storage, or disposal of hazardous wastes; inspections; federal enforcement; hazardous waste site inventory; and corrective action requirements.

To stay in compliance with RCRA, the Oak Ridge installations must submit permit applications to environmental regulators for each hazardous waste treatment, storage, or disposal facility. Part A permit applications (interim status) were submitted in 1980 and have been revised periodically. Part B permit applications (operating) have been submitted or are being revised for RCRA units that will continue to operate after November 8,1992 . Treatment, storage, or disposal units obtain interim status through the Part A permit application and approval process and are required to meet the design and management standards for interim facilities set forth in RCRA. Facilities receive full permit status through the Part $B$ Permit application and approval. Facilities with interim status have the option to file for closure and cease operations instead of filing for a Part B permit application, which requires more stringent standards. Several of the DOE treatment, storage, and disposal facilities (TSDs) have already received Part B operating permits.

Revised or new RCRA Part A and Part B applications are submitted as new storage, treatment, or disposal units are needed for the management of hazardous wastes. TSCA governs the labeling, handling, and disposal of wastes or articles contaminated with PCBs. The Clean Water Act requires use of best management practices (BMPs) and compliance with the National Pollutant Discharge Elimination System (NPDES) permit, and

\section{9-4 Solid Waste Management Program}


the Clean Air Act requires compliance with air emissions standards.

\subsubsection{DOE Orders}

Management of radioactive wastes, mixed waste, waste by-products, and radioactively contaminated facilities is governed by DOE Order 5820.2A, which applies to all DOE elements, contractors, and subcontractors that manage radioactive waste as defined in the Atomic Energy Act of 1954 (as amended). Guidelines are provided for characterization, storage, and disposal of high-level radioactive wastes, low-level waste (LLW), transuranic (TRU) wastes, wastes contaminated with naturally occurring radionuclides, and decommissioning wastes.

Hazardous and mixed waste management at the Oak Ridge facilities is also conducted under DOE orders 5400.1 and 5400.3, as well as the Atomic Energy Act, RCRA, and its Tennessee equivalent, the Tennessee Hazardous Waste Management regulations. DOE Order 5400.1 requires that hazardous waste generated by DOE-funded activities be managed in an environmentally acceptable manner. DOE Order 5400.3 provides the requirements for hazardous waste management programs implemented at DOE-funded installations. The Atomic Energy Act of 1954, as amended, dictates provisions for establishing regulations that govern processing and use of source, by-product, and special nuclear materials; however, increasing involvement of the private sector in the treatment of low-level waste is becoming a part of the ongoing strategy, and the private sector is regulated under Nuclear Regulatory Commission regulations and licensing for transportation, storage, and disposal of radioactive material/wastes.

\subsubsection{Compliance Activities}

\subsubsection{Y-12 Plant}

The Y-12 Plant has submitted applications to state environmental regulatory agencies for all hazardous waste treatment, storage, and disposal facilities.

Information required for a Part B permit application includes general facility description, waste characterization, and analysis plans; information on processes generating the waste; procedures to prevent hazards; contingency plans; and closure and postclosure plans. The facilities are inspected regularly by the U.S. Environmental Protection Agency (EPA), the Tennessee Department of Environment and Conservation (TDEC), DOE, and/or internal auditors to ensure RCRA compliance. A National Pollutant Discharge Elimination System (NPDES) permit renewal application has been submitted to the state of Tennessee for approval. This permit suggests new monitoring limits and certain modification requests for new/existing facilities. Discharges from liquid treatment facilities are periodically sampled, according to permit requirements, for physical and chemical parameters, as well as being tested for toxicity.

Closure activities are under way on two disposal areas: Kerr Hollow Quarry and the Walk-in Pits. These activities are being pursued by the Environmental Restoration Organization.

Nonhazardous, nonradioactive solid waste disposal sites are permitted in accordance with the Tennessee Solid Waste Disposal Act. Permits have been issued for the Y-12 Centralized Sanitary Landfill II, the Y-12 Spoil Area I, and Industrial Waste Landfill IV. All regulated facilities are inspected periodically by the regulators. Discharges to surface waters are monitored in accordance with the plant's NPDES permit.

An environmental assessment (EA) for the $\mathrm{Y}-12$ Steam Plant Ash Disposal Project has been approved. The EA evaluates alternatives for disposal of dewatered bottom ash as well as for nonradioactive, nonhazardous, industrial, and sanitary wastes generated at the Y-12 Plant, the K-25 Site, and ORNL. The Y-12 Steam Plant Ash Disposal (SPAD) project includes the construction of Industrial Landfill $V$ and Construction/Demolition VII to replace Y-12 Central Sanitary Landfill II. The permit application documents for Industrial Landfill V (ILF V) have been submitted to TDEC. TDEC is in the process of issuing the ILF $V$ permit. The $\mathrm{Y}-12$ Plant has prepared permit application documents for a second constructional demolition landfill, Construction/Demolition Landfill VI (CDL VI). These documents have been submitted to TDEC. TDEC is in the process of issuing the permit for CDL VI. This unit has also been called "Landfill II 
Expansion" in environmental reports for previous years,

TSCA regulations govern the labeling, handling, and disposal of wastes that contain PCBs. PCB wastes that contain radioactive contamination cannot be disposed of by commercial facilities. These wastes will be disposed of at the K-1435 Incinerator.

\subsubsection{Oak Ridge National Laboratory}

Waste storage, treatment, and disposal activities are regulated by TDEC and EPA through interim status and operating permits. ORNL operates several hazardous waste treatment, storage, and disposal facilities, which operate under interim status, as well as the Hazardous Waste Storage Building (Building 7652) and the TRU Concrete Cask Storage Facility 7855, which operate according to two RCRA Part B permits granted by TDEC. Overall, ORNL expects to receive 4 Part $B$ permits for hazardous waste facilities, which will include revisions to the two existing permits. Several RCRA units are being closed or will initiate closure in CY 1992. Chemical and mixed wastes are regulated through these permits. Y-12's Centralized Sanitary Landfill II (SLF II) is used for the disposal of nonhazardous materials such as fly ash and construction debris. It operates under a permit from the TDEC Division of Solid Waste Management. Aqueous process wastes are treated on-site in the process wastewater treatment facility, which discharges to surface water through a monitored discharge point that must comply with ORNL's NPDES permit. The NPDES permit is regulated by TDEC and EPA.

Radioactive waste disposal must comply with DOE orders. RCRA requires that the potential for environmental release of radioactive materials be investigated and corrective actions taken. Therefore, all waste-handling activities are regulated and inspected for compliance by state and federal agencies as well as through internal audits.

TRU wastes generated at ORNL are being placed in retrievable storage. Current activities center around certification of contact-handled $(\mathrm{CH})$ waste, planning and designing of a repackaging and certification facility for remote-handled (RH) wastes, and planning for shipment of wastes to the Waste Isolation Pilot Plant (WIPP) in New Mexico.

\subsubsection{K-25 Site}

In accordance with a consent order with TDEC to update and combine Part B applications, the K-25 Site submitted RCRA Part B Permit Applications to TDEC by May 31, 1992. TDEC issued three RCRA permits for the K-25 Site in September 1992. These permits, which are currently under appeal, consist of (1) the K-1435 and K-1425 TSCA Incinerator storage and treatment units, (2) tank storage and treatment units, and (3) all other units at the site (primarily container storage). The permits were appealed because language in the permits requires waste received from off site to be from state-approved facilities. The TSCA Incinerator at the site is currently being operated under a RCRA Part B permit that was issued in 1987. A final permit for the TSCA Incinerator is expected to be issued in the near future.

TSCA regulations govern the labeling, handling, and disposal of wastes that contain PCBs. PCB wastes that contain radioactive contamination cannot be disposed of by commercial facilities. These wastes will be disposed of at the K-1435 Incinerator. Other environmental regulations also impact solid waste management activities. The Clean Water Act (CWA) requires the use of BMPs and compliance with NPDES. The Clean Air Act (CAA) requires permitting of air emissions.

\subsubsection{Program Strategy}

Overall corporate strategies for the management of radioactive, hazardous, $\mathrm{PCB}$, and mixed wastes have been developed for Energy Systems. These strategies are based on the following guiding principles:

- reduce the quantity of waste generated;

- minimize the amount of wastes stored on site;

- characterize the wastes prior to storage, processing, treatment, or disposal;

- use on-site storage where this can be shown to be safe and cost-effective until a final disposal option is selected;

- determine the effectiveness of promising technologies in the solution of local problems; and

- maximize the involvement of private-sector contractors in conducting technology 
demonstrations and in implementing successful technologies.

More specifically, the radioactive waste management program is based on the following technical assumptions:

- Waste will be segregated by half-life and hazard consistent with the ovcrall waste management strategy.

- The level of containment required and, therefore, the type of treatment and/or disposal required will be a function of the hazard, including potential mobility, of the waste.

- Engineered features cannot be relied on to contain long-half-life wastes without surveillance, remediation, and long-term maintenance.

- Management of long-half-life wastes must rely on concentration limits, natural features, and institutional control and/or perpetual care to provide for the maintenance of engineered features and to protect against intrusion.

TRU wastes will be managed in accordance with the TRU Waste Program strategy, which relies on certification and packaging at the site and shipment to WIPP for ultimate disposal.

LLW will be managed in accordance with DOE Order 5820.2A, "Radioactive Waste Management." The general strategy for management of LLW is being defined by the Energy Systems Waste Management Organization. This strategy includes the use of private-sector facilities for volume reduction of LLW. Volume reduction includes incineration and supercompaction with all residues/waste returned to DOE facilities for storage until final disposal.

The primary goal of the strategy for LLW is the management and ultimate disposal of solid radioactive waste in a manner that protects the environment and public health and safety at all times. For the disposal of LLW, the strategy establishes dose-based performance standards that protect the public, minimize releases, and reduce the probability for the need to do remedial actions after the disposal facilities are closed. The key components of the strategy are
- the dose-based performance standards for disposal of LLW,

- a waste-classification system for managing different wastes to meet the dose-based performance objectives,

- the planned use of engineered features and barriers,

- the waste-acceptance criteria (WAC) for each treatment, storage, and disposal site for achieving the dose-based performance standards for that specific site with appropriate engineered features,

- a waste-certification program for ensuring that the wastes for disposal meet the applicable WAC,

- the use of pathways analysis modeling to establish radionuclide concentration limits for the WACs and to predict whether a selected site and technologies will achieve the performance objectives, and

- phased implementation.

Using this general strategy, Energy Systems has proposed the following five classes of LLW:

1. Below regulatory concern (BRC) waste. LLW that is suitable for disposal in a sanitary/industrial landfill and will not expose any member of the public to an effective dose equivalent of more than $4 \mathrm{mrem} / y e a r$ at the time of disposal. Current limits of $35 \mathrm{pCi} / \mathrm{g}$ of uranium have been established for disposal of waste in landfills permitted by the state of Tennessee. Other radionuclides are not allowed.

2. Class L-I waste. LLW that is suitable for disposal using sanitary/industrial landfill disposal technology and will not expose any member of the public to an effective dose equivalent of more than $10 \mathrm{mrem} /$ year at the time of disposal.

3. Class L-II waste. L.LW primarily containing fission product radionuclides with half-lives of 30 years or less that is suitable for disposal in engineered facilities designed to isolate the waste from the environment and public for a period of time sufficient to allow for the decay of radionuclides to such a level that any member of the public will not be exposed to an effective dose equivalent of more than $10 \mathrm{mrem} /$ year. 


\section{Environmental Report Vol. 1, Oak Ridge}

4. Class L-III waste. LLW consisting of radionuclides that have long half-lives and will be disposed of in facilities having permanent intruder protection.

5. Class L-IV waste. LLW not suitable for disposal on the ORR and that would require either treatment to reduce the level of contamination to a level consistent with any of the other waste classifications or shipment to an off-site LLW disposal facility.

The general strategy to be followed for the management of hazardous, TSCA, radioactive, and mixed wastes will ensure the continuation of present management operations while simultaneously initiating a technology development and demonstration program for current and future problem waste streams. Fundamental to this general strategy are the following components: (1) waste stream identification and evaluation; (2)waste minimization/reduction; (3) on-site storage/treatment of RCRA hazardous wastes; (4) on-site storage/treatment of mixed wastes; (5) technology demonstrations; (6) delisting, detoxification, and mobility reduction; and (7) waste disposal activities.

The Hazardous Waste Development, Demonstration, and Disposal (HAZWDDD) Program developed a general classification system based on the RCRA and TSCA regulations (Fig. 9.1). Treatment options are evaluated for each category of problem waste using process flowcharts. Where technology currently exists, preferred treatment options are identified. When proven technologies do not exist, studies, evaluations, or technology demonstrations will be conducted. In general, the preferred treatment option for categories $A$ (ignitables), E (spent solvent), J (PCB wastes), L (medical/infectious waste), and $\mathrm{M}$ (combustibles) is incineration. For category D Toxicity Characteristic Leaching Procedure [(TCLP)-toxic wastes], the preferred option is stabilization (surface decontamination, followed by stabilization, for surface-contaminated wastes), and the preferred option for category $\mathrm{F}$ (sludges) is thermal treatment and/or stabilization. The preferred treatment option(s) for categories B (corrosives), C (reactives), $\mathrm{K}$ (poisons), $\mathrm{U}$ (unknown), and $\mathrm{Z}$ (hazardous, but not EPA-listed) depend on complete waste characterizations.
Liquid mixed wastes are currently being treated at the TSCA Incinerator or placed in interim storage until new technologies for treatment and disposal are identified and evaluated. Solid LLW, with the exception of some special-case wastes, is currently being containerized and shipped to a commercial facility for volume reduction prior to being placed in interim storage at the $\mathrm{K}-25$ Site. This waste will either be disposed in the proposed low-level waste disposal facility, certified for off-site disposal, or treated and the residue certified for off-site disposal.

Any off-site facility receiving this waste will be so licensed and permitted. A new reservation-wide treatment facility has been proposed for handling solid LLW produced from current operations or from planned environmental restoration (ER) activities. PCB waste is managed to ensure compliance with PCB regulations and to minimize the risk of Comprehensive Environmental Response, Compensation, and Liability Act (CERCLA) or civil liabilities. It is Energy Systems policy to comply with the letter and spirit of the PCB regulations. In certain instances where the intent of the rule can clearly be met but where the letter of the rule may create substantial hardships, the EPA regional administrator may be petitioned for a waiver. Such petitions will be made through DOE.

An environmental impact statement is presently being prepared that addresses the general waste management strategies and specific LLW disposal facilities on the ORR. DOE Order 5820.2A for radioactive and mixed waste management was issued in September 1988. The order has had and will continue to have a significant impact on radioactive and mixed waste management operations.

\subsubsection{Y-12 Plant}

Current strategy for solid waste management consists of pollution prevention, waste reduction, storage, treatment, delisting, and disposal. Each concept is an integral portion of the overall waste management strategy. Current disposals, however, are limited to the on-site disposal of industrial/sanitary waste. The use of commercial disposal facilities for disposal of hazardous wastes has been suspended until a program that meets the recently imposed DOE performance objective of "no added radioactive contamination (No Rad Added)"

\section{9-8 Solid Waste Management Program}




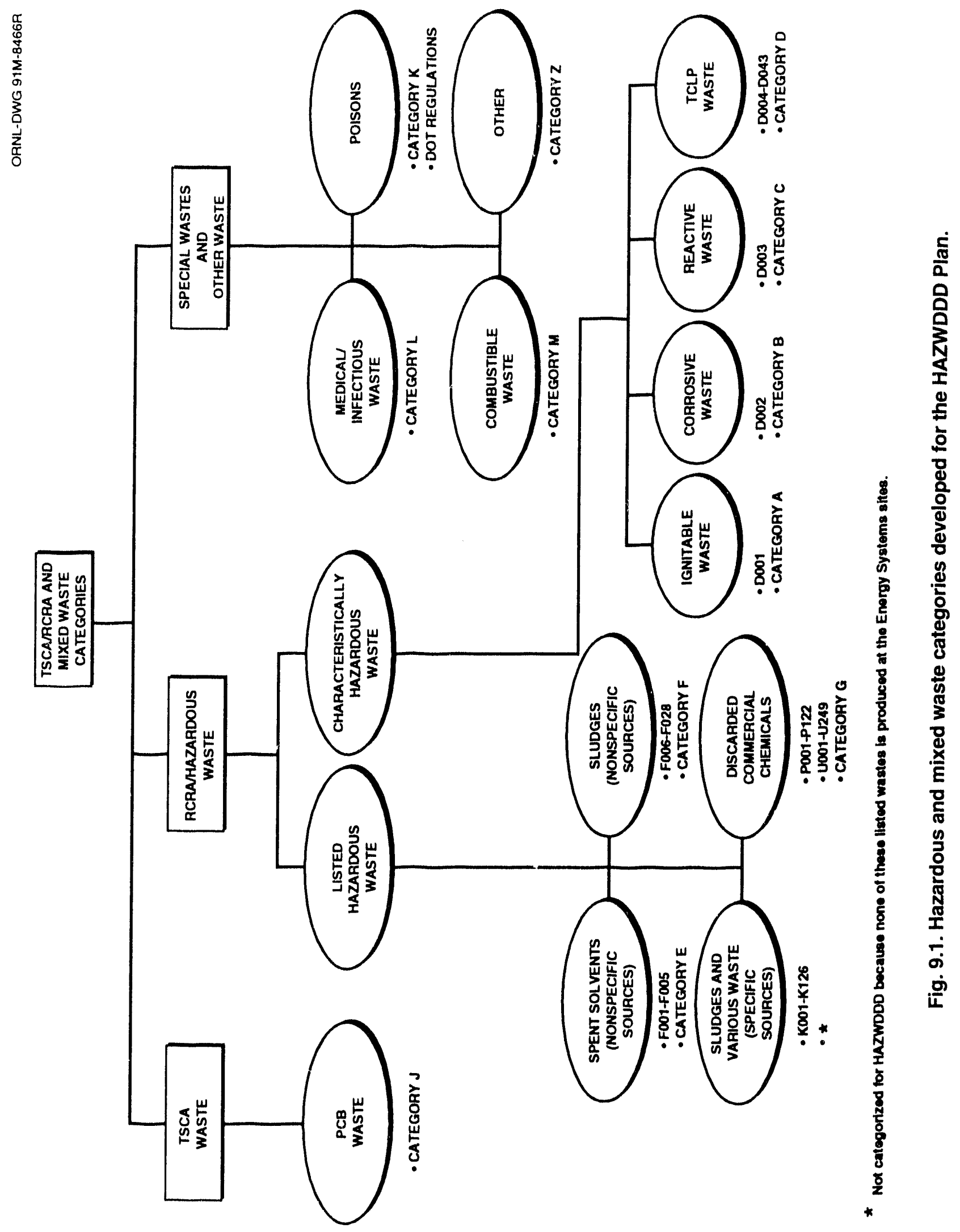


has been developed by Energy Systems and approved by DOE. The procedures composing this program have been drafted and submitted to DOE. DOE is currently evaluating these procedures. If the procedures are approved by DOE, an implementation plan will be initiated.

Mixed waste storage is necessary to ensure compliance with environmental regulations while treatment and disposal techniques are identified and implemented. The delisting process of certain wastes may be pursued where feasible. A proposed 1995 line item the Mixed Waste Treatment Facility (MWTF) is being proposed to treat mixed waste. This line item is part of the strategy to implement part of the Federal Facility Compliance Agreement (FFCA) for treatment of LDR wastes.

Solid waste as categorized at the Y-12 Plant is listed in Table 9.1. RCRA hazardous wastes remain candidates for commercial recovery or disposal programs; mixed wastes, which contain both RCRA

Table 9.1. Y-12 Plant waste generation summary for $1992^{a}$

\begin{tabular}{|c|c|}
\hline Waste & Quantity (kg) \\
\hline \multicolumn{2}{|c|}{ Sanitary/industrial一nonhazardous } \\
\hline Sulid $b$ & $5,541,201$ \\
\hline Liquid ${ }^{c}$ & $1,226,544$ \\
\hline CPCF/PRTF wastewaters & $1,699,082$ \\
\hline Steam Plant wastewaters & $171,296,717$ \\
\hline \multicolumn{2}{|l|}{ Asbestos/BeO } \\
\hline Solid uncontaminated & 420,192 \\
\hline Solid contaminated & 37,434 \\
\hline \multicolumn{2}{|l|}{ Hazardous } \\
\hline Solid & 48,795 \\
\hline Liquid & 712,250 \\
\hline BCBG leachate & $2,796,365$ \\
\hline \multicolumn{2}{|l|}{ Mixed } \\
\hline Solid & 176,487 \\
\hline Liquid & $1,524,082$ \\
\hline \multicolumn{2}{|l|}{ PCB } \\
\hline Solid & 42,434 \\
\hline Liquid & 55,624 \\
\hline \multicolumn{2}{|l|}{ PCB/uranium } \\
\hline Solid & 28,948 \\
\hline Liquid & 13,152 \\
\hline \multicolumn{2}{|l|}{ Low-level contaminated waste } \\
\hline Solid ${ }^{d}$ & 775,505 \\
\hline Liquid & 565,929 \\
\hline \multicolumn{2}{|l|}{ Scrap metal } \\
\hline Uncontaminated & 759,715 \\
\hline Contaminated & 649,429 \\
\hline Classified & 27,418 \\
\hline
\end{tabular}

aThe totals in this report do not include waste generated by Environmental Restoration activities.

${ }^{b}$ This includes construction/demolition spoil and fly ash. It does not include the uncontaminated asbestos and scrap metal listed in this table.

'This category consists of mop waters and other nonhazardous liquids.

${ }^{d}$ This does not include the contaminated asbestos and scrap metal listed in this table. 


\section{Environmental Report Vol. 1, Oak Ridge}

hazardous and radioactive components, may be candidates for commercial recycling, treatment, or disposal when commercial mixed waste facilities are available. Under the DOE "No Rad Added" performance objective; however, hazardous waste is being stored until approval to ship for off-site disposal has been granted by Energy Systems and DOE.

Ideally, after strategy implementation, most solid wastes that are generated will be conventional sanitary/industrial wastes. When this is not possible, prudent management will minimize the amount of other wastes present. Four major waste-minimization options are available at the $\mathrm{Y}-12$ Plant: segregation, material substitution, process innovation, and recycling or reuse. These options are not mutually exclusive and may be combined to suit the specific needs.

To characterize wastes properly and to determine the appropriate storage or disposal modes, a comprehensive system of administrative controls, inspections, sampling, analysis, and monitoring is used. Sampling and analytical programs are in place for hazardous, nonhazardous, TSCA, and mixed waste streams. In addition to characterization by sampling, low-level waste monitoring for bulk wastes is accomplished by means of external radiation monitors ơ by Health Physics personnel using applicable DOE guidelines.

Also, to improve characterization of potentially low-level radioactive waste streams, the $\mathrm{Y}-12$ Plant continues with procurement, installation, and testing of more effective waste monitoring equipment, including a crated waste assay monitor, gamma spectroscopy, and waste curie monitors.

A variety of disposal/storage options are available to manage the wastes generated at the $Y-12$ Plant. On-site treatment includes oxidation of uranium machine turnings; batch physicochemical treatment of liquid wastes; biodenitrification of aqueous nitrate waste; baling of solid, low-level radioactive wastes, and baling of solid, nonhazardous, nonradioactive wastes. On-site disposal capability includes shallow land burial for solid, noncontaminated, industrial waste and discharge through NPDES discharge points after treatment for aqueous wastes. Off-site disposal options will include disposal of hazardous waste by commercial vendors if the DOE "No Rad Added" performance objective can be met. Off-site treatment of LLW (non-RCRA/TSCA) is now being accomplished through a contract with a commercial treatment facility. After treatment (i.e.. incineration/supercompaction) the waste is stored at the K-25 Site or returned to the Y-12 Plant for storage. Long-term storage options include storage in warehouses, tanks, and vaults at the Y-12 Plant als well as storage of $Y-12$ Plant wastes in buildings at the K-25 Site. More detailed information on each of these options is presented in Sect. 9.3.2.

Several Y-12 Plant-sponsored technology demonstrations have been completed, including supercompaction, shape alteration, and the laboratory characterization task of the Uranium Lysimeter Demonstration. Demonstrations that were well into the planning or implementation phases in 1990, however, were halted in 1991 because of a lack of funding. These included a below-regulatory-concern demonstration and field testing of the Uranium Lysimeter.

The "below regulatory concern" (BRC) demonstration is no longer a viable project. Work on the uranium lysimeter project, however, was resumed in FY 1992 and current plans are to load it with uranium-contaminated waste in 1993. Technology demonstrations are being funded so that commercially available treatment processes can be tested on Y-12 Plant wastes. The technology demonstration program gives priority to waste streams for which no disposal outlet has been identified. The program will include full-scale commercial treatment efforts pending the outcome of treatability studies. Soils contaminated with mercury and/or chlorinated organic compounds are included in this program.

Demonstrations for removal of hazardous or radioactive constituents in soils have been completed. Results of the demonstrations will be evaluated for further use in applying this technology to larger-scale treatment projects.

A project is currently under way to evaluate the potential for delisting a sludge generated by hazardous wastewater treatment facilities at the Y-12 Plant. The preliminary sampling and analytical results were favorable, but the EPA suggested that at more rigorous sampling method he used. A new sampling method has been devised and tested. $\Lambda$ draft sampling plan has been written. 


\section{Environmental Report Vol. 1, Oak Ridge}

Demonstrations for the removal of hazardous and radioactive constituents in sludges from wastewater treatment facilities and from oils and solvents used at the Y-12 Plant have been completed. Final results indicate that conventional treatment technologies can be utilized to reduce one of the constituents so that the waste is no longer considered mixed.

\subsubsection{Oak Ridge National Laboratory}

Wastes are identified initially through their generating processes and can be grouped into the broad categories shown in Fig. 9.2. Although knowledge of the generating process often helps in identifying the waste constituents, this is not always sufficient to allow for proper waste handling. Therefore, more detailed waste characterization is often conducted before storage, treatment, or disoosal. Wastes are analyzed using standard EPA and DOE-approved analytical methods. In addition, all wastes are checked for radioactive contamination.

It is ORNL policy to minimize all categories of wastes by reducing waste volume and/or toxicity, thereby reducing the need for waste treatment and disposal and their potential environmental consequences. This reduction can be achieved through process modification, segregation, minimization, or recycling.

One example of process modification that effectively reduces the amount of hazardous waste generated is a procedural change in the Analytical Chemistry Division. Many chemical analyses are now done on small-volume samples using small volumes of solvents for extractions, which reduces the total volume of waste solvent generated.

Waste segregation is used to minimize the generation of solid low-level radioactively contaminated wastes. By providing collection barrels for both radioactive and nonradioactive wastes, the volume of wastes that requires handling as radioactive waste has been reduced. Before these procedures were implemented, radioactive and nonradioactive wastes were discarded in the same barrel. This contaminated the nonradioactive portion and required special disposal of an inflated amount of waste.

ORNL's procurement policy is an example of minimization. In the past, researchers took advantage of the reduced cost of bulk purchasing; however, the excess purchased was often discarded as waste. By purchasing only the quantity of a chemical needed, less waste is produced.

Examples of recycling include making unneeded chemicals available to others rather than discarding them as wastes; using acceptable waste corrosives in a neutralization facility in place of new acids and bases; and recovering silver from silver-bearing photographic wastes.

Despite these efforts, some wastes will be produced. Minimizing the impact on public health and the environment is the goal of the waste management program. To achieve this goal, some wastes, such as sanitary wastes, are treated on-site while others, such as low-level solid wastes, are disposed of on-site in solid waste storage areas (SWSAs). Off-site treatment is the best management

ORNL-DWG 89M-10471A

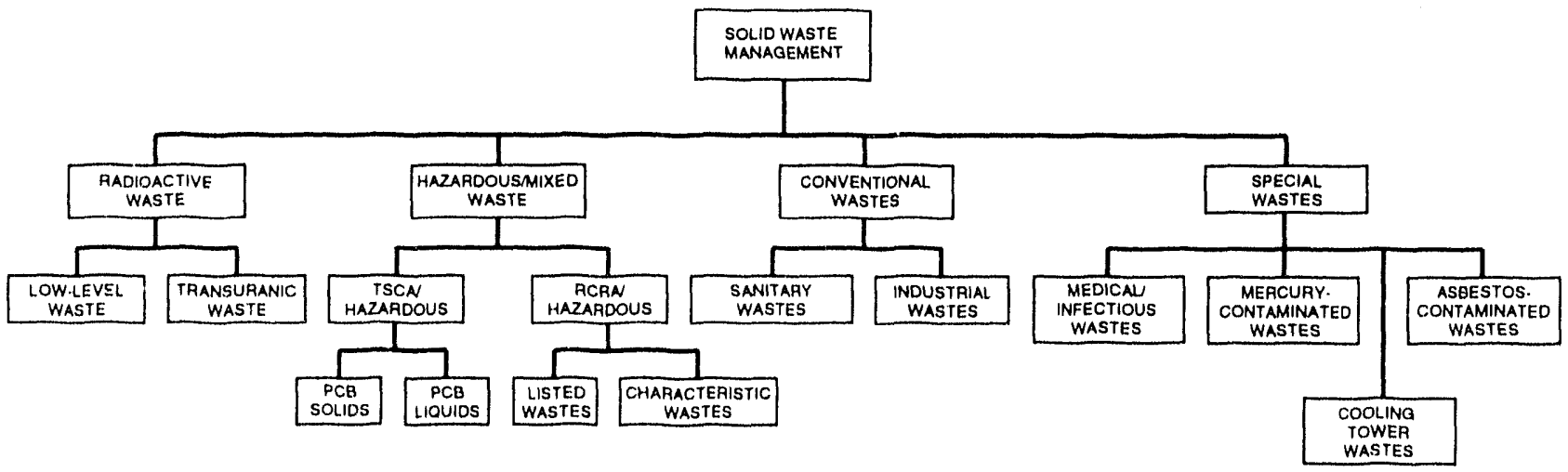

Fig. 9.2. Categories of solid waste sources and flow of mixed wastes.

\section{9-12 Solid Waste Management Program}


option for many hazardous and PCB-contaminated wastes. Most hazardous laboratory and PCB-contaminated wastes are incinerated in permilted facilities. Although more expensive than land disposal, destruction by iacineration is preferable. Transuranic waste and mixed waste are in long-term storage on-site until appropriate storage, treatment, or disposal options become available. Solid waste management strategies depend on the type of waste and are chosen because they are the most prudent approaches currently available.

\subsubsection{K-25 Site}

The strategy for the management of solid waste consists of treatment, storage, disposal, waste reduction, and/or delistings of all waste streams generated at the K-25 Site. Waste streams are evaluated using process knowledge and analytical waste characterization. Samples are collected and analyzed using EPA- and DOE-approved methods. Radioactive analyses are performed on an as-needed basis, with surveys and scans performed on suitable materials and configurations.

The K-25 Site policy mandates minimization of waste generated while achieving compliance with applicable environmental regulations. Five waste reduction options are used at the K-25 Site: segregation, material substitution, process innovation, mechanical volume reduction, and recycling/reuse. These options may be used alone or in combination to address specific goals.

The K-25 Site management supports the waste reduction program. Excellent examples of the program at work include the procedure for procuring hazardous materials, the use of waste assay monitors to reduce the volume of LLW requiring management (i.e., storage), and the conversion to gas-fired boilers to reduce opacity excursions and, in effect, reduce or eliminate fly ash production. In the past, hazardous materials were purchased in larger quantities to take advantage of the less expensive bulk rates. However, a hidden cost of this procurement inethod was the expense of disposal of the excess material. Current procedure for the purchase of hazardous materials requires the approval of the Plant Hazardous Materials Coordinator. This minimizes the purchase of excess hazardous materials, thus minimizing the need to dispose of excess quantities.
Several treatment, storage, and disposal options are available to manage the wastes generated at the $\mathrm{K}-25$ Site. On-site storage facilities are available for LLW, RCRA wastes, TSCA wastes, and mixed wastes. On-site treatment capabilities include the K-1435 TSCA Incinerator, the Central Neutralization Facility, and other facilities for neutralization and precipitation. The K-25 Site utilizes the Y-12 Plant Centralized Sanitary Landfill II for disposal of sanitary/industrial solid wastes. On-site disposal includes discharge of aqueous wastes through NPDES discharge points after treatment. Waste assay monitors have also been purchased and are being used to screen solid, potentially radioactive waste to determine the potential to manage it as sanitary/industrial waste. This, in effect, allows valuable storage space to be dedicated to those wastes actually requiring long-term management. All boilers at the K-25 Site steam plant have been converted to gas fired to eliminate opacity excursions; a secondary derived benefit of the conversions is the curtailment of fly ash production.

\subsection{Waste-Generating Activities}

\subsubsection{Y-12 Plant}

Waste-generating activities at the $\mathrm{Y}-12$ Plant result primarily from machining operations and from laboratory, maintenance, construction, demolition, and cleanup activities. In addition, plating waste solutions are generated by metal-plating operations, and reactive wastes and waste laboratory chemicals are generated from various laboratory activities. Liquid process wastes are generated from multiple processes throughout the plant. Sludges are generated as a result of treating process wastes at multiple sites, and waste oils and solvents are generated from machining and cleaning operations. Contaminated soil, soil solutions, and soil materials are generated from closure activities associated with RCRA closures. (See Table 9.1 in Vol. 2.) Construction/ demolition activities produce large volumes of contaminated and noncontaminated wastes, including lumber, concrete, metal objects, soil, and roofing materials. Wastes contaminated with hazardous constituents are also generated by construction/ demolition activities. 


\section{Environmental Report Vol. 1, Oak Ridge}

Machining operations use stock materials, including steel, stainless steel, aluminum, depleted uranium, and other metals to produce machine turnings and fines as a waste product.

The Y-12 Steam Plant produces steam by burning coal, which produces fly ash and bottom ash as a waste product.

Industrial trash, both noncontaminated and uranium contaminated, is generated by daily operations throughout the plant. These operations include janitorial services, floor sweeping in production areas, and production activities. These are only a few of the industrial-type activities at the Y-12 Plant that are generating waste streams at the site. A summary of waste generation for 1992 is given in Table 9.1.

\subsubsection{Oak Ridge National Laboratory}

Because ORNL is a research facility, it has many diverse waste-generating activities, each of which may produce only a small quantity of waste. Isotope production, utilities, and support functions such as photography are additional sources of waste. A summary of waste generation for 1992 is given in Table 9.2.

Hazardous wastes are generated in laboratory research, electroplating operations, painting and maintenance operations, descaling, demineralizer regeneration, and photographic processes.

Mixed wastes are generated by research projects and some facility operations. Facility renovation and demolition activities produce asbestos. Although the

Table 9.2. 1992 ORNL waste generation summary

\begin{tabular}{|c|c|c|}
\hline Waste & Volume $\left(\mathrm{m}^{3}\right)$ & Weight $(\mathrm{kg})$ \\
\hline Hazardous & & $53,151^{a}$ \\
\hline \multicolumn{3}{|l|}{ Sanitary } \\
\hline Radiological & ino.4 & 8,150 \\
\hline Nonradiological & 7,225 & \\
\hline Mixed & & 9,939 \\
\hline \multicolumn{3}{|l|}{ PCB } \\
\hline Radiological & & 8,581 \\
\hline Nonradiological & & 27,875 \\
\hline Total & & $36,456^{b}$ \\
\hline \multicolumn{3}{|l|}{ Transuranic } \\
\hline Contact handled & 10.42 & 2,540 \\
\hline Remote handled & 4.1 & 2,000 \\
\hline \multicolumn{3}{|l|}{ Low level } \\
\hline Waste water & $397,510 \mathrm{gal}$ & \\
\hline \multicolumn{3}{|l|}{ Asbestos } \\
\hline Radiological & 106.3 & 35,229 \\
\hline Nonradiological & & 15,315 \\
\hline \multicolumn{3}{|l|}{ Scrap metal } \\
\hline Radiological & 287.6 & 75,435 \\
\hline Nonradiological & & $24,164^{c}$ \\
\hline \multirow{2}{*}{\multicolumn{2}{|c|}{$\begin{array}{l}\text { Miscellaneous } \\
\text { Nonhazardous }\end{array}$}} & $36,970.09$ \\
\hline & & \\
\hline \multicolumn{3}{|l|}{ Miscellaneous } \\
\hline Radiological & 0 & 0 \\
\hline
\end{tabular}

${ }^{a}$ Policy mixed waste.

${ }^{b}$ Of this amount, $28,074 \mathrm{~kg}$ was classified as hazardous.

"Scrap metal placed in storage because of "no rad added" issue

\section{9-14 Solid Waste Management Program}


electrical system has been largely converted to a non-PCB system, PCB-contaminated wastes,

including fluorescent light ballasts and capacitors, are still occasionally discarded. EPA imposes restrictions on the disposal of waste containing PCBs.

Nonhazardous wastes result from ORNL maintenance and utilities. For example, the steam plant produces nonhazardous sludge. Scrap metals are discarded from maintenance and renovation activities and are recycled when appropriate. Construction and demolition projects also produce nonhazardous industrial wastes. All nonradioactive medical wastes are autoclaved to render them noninfectious and are sent to the Y-12 Plant Sanitary Landfill. Isotope production and research activities generate a variety of low-level radioactive and transuranic wastes, as shown in Table 9.3. Remedial action projects also produce wastes requiring proper management.

\subsubsection{K-25 Site}

Enrichment, maintenance, decontamination, and research and development $(R \& D)$ activities have generated a wide variety of waste at the K-25 Site. Until August 1985, the primary function of the site was the enrichment of uranium in the ${ }^{235} \mathrm{U}$ isotope. Uranium is the predominant radionuclide found in the K-25 Site waste streams.

Trace quantities of ${ }^{99} \mathrm{Tc},{ }^{237} \mathrm{~Np}$, and ${ }^{239} \mathrm{Pu}$ may have also been present in some of the waste streams because these radionuclides were present in $\mathrm{UF}_{6}$ reactor return feed material that was shipped to the K-25 Site for enrichment.

Solid low-level wastes are generated by discarding radioactively contaminated construction debris, wood, paper, asbestos, trapping media, and process equipment and by removing radionuclides from liquid and airborne discharges.

Currently, low-level solid wastes are being stored at the K-25 Site for future disposal.

All contaminated scrap motal is stored above ground at the K-770 scrap metal facility until further disposal methods are evaluated.

Sludges contaminated with low-level radioactivity were generated by settling and scrubbing operations and were stored in K-1407-B and $\mathrm{K}-1407 \mathrm{C}$. Sludges had been removed from these ponds, and portions were fixed in concrete at K-1419 and stored above ground at K-1417 Drum Storage Yard.
Table 9.3. 1992 ORNL radioactive waste data

\begin{tabular}{|c|c|}
\hline Radionuclides & Curies \\
\hline${ }^{109 m} \mathrm{Ag}$ & 5.000000 \\
\hline $110 \mathrm{~m} \mathrm{Ag}$ & 3.715000 \\
\hline${ }^{241} \mathrm{Am}$ & 3.297031 \\
\hline${ }^{243} \mathrm{Am}$ & 0.000635 \\
\hline $137 m \mathrm{Ba}$ & 0.277500 \\
\hline${ }^{14} \mathrm{C}^{\mathrm{Da}}$ & 0.030080 \\
\hline${ }^{41} \mathrm{Ca}$ & 0.680000 \\
\hline${ }^{109} \mathrm{Cd}$ & 5.000000 \\
\hline $113 m \mathrm{Cd}$ & 13.000000 \\
\hline${ }^{249} \mathrm{Cf}$ & 0.000077 \\
\hline${ }^{252} \mathrm{Cf}$ & 2.880679 \\
\hline${ }^{36} \mathrm{Cl}$ & 0.009350 \\
\hline${ }^{244} \mathrm{Cm}$ & 0.775404 \\
\hline${ }^{248} \mathrm{Cm}$ & 0.000000 \\
\hline${ }^{60} \mathrm{Co}$ & 288.257040 \\
\hline${ }^{51} \mathrm{Cr}$ & 0.085700 \\
\hline${ }^{134} \mathrm{Cs}$ & 4.396866 \\
\hline${ }^{136} \mathrm{Cs}$ & 1.381120 \\
\hline${ }^{137} \mathrm{Cs}$ & 1517.222708 \\
\hline${ }^{64} \mathrm{Cu}$ & 0.001400 \\
\hline${ }^{152} \mathrm{Eu}$ & 6.275960 \\
\hline${ }_{155}^{154} \mathrm{Eu}$ & 4.164940 \\
\hline${ }_{55}^{155} \mathrm{Eu}$ & 0.253000 \\
\hline $\begin{array}{l}{ }^{55} \mathrm{Fe} \\
{ }^{59} \mathrm{Fe}\end{array}$ & 0.001830 \\
\hline $\begin{array}{l}{ }^{59} \mathrm{Fe} \\
{ }^{153} \mathrm{Gd}\end{array}$ & 4.000000 \\
\hline $\begin{array}{l}{ }^{153} \mathrm{Gd} \\
{ }^{68} \mathrm{Ge}\end{array}$ & 0.052135 \\
\hline $\begin{array}{l}{ }^{68} \mathrm{Ge} \\
{ }^{3} \mathrm{H}\end{array}$ & 0.005340 \\
\hline${ }^{3} \mathrm{H}_{125}$ & 5.147826 \\
\hline $\begin{array}{l}{ }^{125} 5_{I} \\
13 I_{I}\end{array}$ & $\begin{array}{l}0.005539 \\
0.002010\end{array}$ \\
\hline $\begin{array}{l}{ }^{131} \mathrm{I} \\
{ }^{192} \mathrm{Ir}\end{array}$ & $\begin{array}{l}0.002010 \\
0.002930\end{array}$ \\
\hline $40 \mathrm{~K}$ & $\begin{array}{l}0.002930 \\
0.001168\end{array}$ \\
\hline${ }^{85} \mathrm{Kr}$ & 0.004030 \\
\hline${ }^{54} \mathrm{Mn}$ & 0.004300 \\
\hline${ }^{22} \mathrm{Na}$ & 0.002000 \\
\hline${ }^{63} \mathrm{Ni}$ & 0.017034 \\
\hline${ }^{237} \mathrm{~Np}$ & 0.082281 \\
\hline${ }^{191} \mathrm{Os}$ & 0.003230 \\
\hline${ }^{194} \mathrm{Os}$ & 0.005500 \\
\hline${ }^{32} \mathrm{p}$ & 0.001850 \\
\hline $33 \mathrm{p}$ & 0.001500 \\
\hline${ }_{231} \mathrm{~Pa}$ & 0.032300 \\
\hline${ }^{103} \mathrm{Pd}$ & 0.681700 \\
\hline${ }^{109} \mathrm{Pd}$ & 0.042000 \\
\hline${ }^{147} \mathrm{Pm}$ & 0.242435 \\
\hline${ }^{195 m} \mathrm{Pt}$ & 0.001840 \\
\hline${ }^{238} \mathrm{Pu}$ & 75.169002 \\
\hline${ }^{239} \mathrm{Pu}$ & 1.047896 \\
\hline${ }^{240} \mathrm{Pu}$ & 0.110000 \\
\hline${ }^{241} \mathrm{Pu}$ & 336.000007 \\
\hline${ }^{242} \mathrm{Pu}$ & 0.000003 \\
\hline${ }^{244} \mathrm{Pu}$ & 0.000001 \\
\hline${ }^{226} \mathrm{Ra}$ & 0.000545 \\
\hline${ }^{106} \mathrm{Ru}$ & 0.003100 \\
\hline${ }^{35} \mathrm{~S}$ & 0.002399 \\
\hline${ }^{90} \mathrm{Sr}$ & 139.558721 \\
\hline${ }^{182} \mathrm{Ta}$ & 0.005060 \\
\hline${ }^{99} \mathrm{Tc}$ & 0.000440 \\
\hline $228 \mathrm{Th}$ & 0.001415 \\
\hline${ }^{230} \mathrm{Th}$ & 0.001170 \\
\hline${ }^{232} \mathrm{Th}$ & 0.008146 \\
\hline $232 \mathrm{U}$ & 0.060000 \\
\hline${ }^{233} \mathrm{U}$ & 0.196936 \\
\hline${ }^{234} \mathrm{U}$ & 0.000364 \\
\hline${ }^{235} \mathrm{U}$ & 0.000345 \\
\hline${ }^{236} \mathrm{U}$ & 0.000067 \\
\hline${ }^{238} \mathrm{U}$ & 1.762698 \\
\hline${ }^{188} \mathrm{~W}$ & 0.003060 \\
\hline${ }^{90} Y^{r}$ & 0.001683 \\
\hline Total curies & 2420.978326 \\
\hline
\end{tabular}




\section{Environmental Report Vol. 1, Oak Ridge}

In 1989, during routine inspections of the drums of stabilized K-1407 pond sludge at the K-1417 Storage Facility, it was discovered that many of the drums had begun to corrode. Certain constituents contained in the sludge proved to be incompatible with the container material.

In September 1991 TDEC issued a Commissioner's Order against Energy Systems and DOE for RCRA violations regarding storage of drums at the K-25 Site. The order assessed a $\$ 96,004$ penalty against Energy Systems and also sought implementation of the corrective action plan previously submitted to TDEC by DOE and Energy Systems. This action was appealed in October 1991, and the penalty was ultimately set aside.

An action plan has been implemented to decant and/or dewater the mixed waste contained in the drums. Implementation of the Pond Waste Management Project (PWMP) action plan, coordinated with state and federal regulators, began in October 1991 and is continuing. A total of about 45,600 drums of stabilized sludge have been processed and placed in compliant storage, with completion of this phase occurring in October 1992. Of the 45,600 drums, roughly 8300 stabilized drums were removed from the K-25 vaults and processed by Energy Systems labor forces, and about 37,300 drums were processed by a subcontractor. These drums have been stored in existing facilities in Buildings K-31 and $\mathrm{K}-33$ and in new storage facilities constructed in the K-1065 area. Dewatering of the approximately 32,000 drums of raw sludge began in September 1992. The processing rate of the dewatering subcontractor was not adequate to meet regulatory milestones, and in early November the subcontractor proposed modifications to his process equipment to improve its performance. On November 14, 1992, a fatal accident occurred during installation of the equipment modifications. The subcontractor was put on stand-down pending the results of a DOE Type A Investigation. Discussions were held with the state and federal regulators to keep them informed of the project status, including plans for restart of the project.

As the $\mathrm{K}-25$ vaults are emptied of drums, the facilities are immediately turned over to the Mixed Waste Storage Expansion Project. The objective of this program is to prepare the vaults for storage of wastes covered under RCRA and of mixed wastes generated by $\mathrm{K}-25, \mathrm{ORNL}$, and $\mathrm{Y}-12$. The schedule calls for an average of one vault a month to be made available for this purpose. A total of 30 vaults are planned through 1994.

To prepare the vaults for storage of RCRA and mixed wastes, a process called BLASTRAC is used. This process decontaminates the vault floor and also allows adherence of an epoxy sealant. Polyvinyl chloride (PVC) containment dykes are installed, and the floor is coated with epoxy. As a result of this preparation, the vault contains any leaks that may occur from drums.

The primary generator of radioactively contaminated liquid waste is the K-1435 TSCA Incinerator. This waste stream is currently being treated at the K-1407-H Central Neutralization Facility (CNF).

Other waste streams generated at the K-25 Site include RCRA hazardous chemicals and materials, PCB articles and items, industrial/sanitary wastes, waste oils and solvents, and remedial action type wastes.

All waste streams generated at the K-25 Site are managed according to applicable state and federal regulations and DOE orders (see Table 9.4). Several waste management facilities are already in place. Changing laws and regulations have made it necessary to upgrade several facilities and to design and construct new facilities that reflect the most recent environmental technology.

\section{Table 9.4. K-25 Plant waste generation summary for 1992}

\begin{tabular}{lr}
\hline \multicolumn{1}{c}{ Waste } & Quantity \\
\hline Sanitary/industrial (tons) & 952 \\
Asbestos/BeO & \\
Uncontaminated $\left(\mathrm{m}^{3}\right)$ & 223 \\
Contaminated $\left(\mathrm{m}^{3}\right)$ & 10 \\
PCB $^{a}(\mathrm{~kg})$ & 549,012 \\
Mixed $^{b}(\mathrm{~kg})$ & $74,749,065$ \\
Low-level contaminated waste $^{b}\left(\mathrm{~m}^{3}\right)$ & 1,300 \\
\hline
\end{tabular}

"May include some hazardous waste.

${ }^{b}$ May include some PCB-tainted waste. 


\subsection{Waste Management Activities}

\subsubsection{Waste Management System}

Special forms specifically designed for each plant are used to document and track wastes. A list of these forms follows.

\begin{tabular}{|c|c|c|}
\hline$Y-12$ & Form UCN-2109 & $\begin{array}{l}\text { Request for Transfer, } \\
\text { Storage, and Disposal } \\
\text { of Wastes }\end{array}$ \\
\hline ORNL & Form UCN-13698 & Request for Disposal/ \\
\hline & Form UCN-2822 & Storage of Waste \\
\hline & Form TX -5352 & Materials and Equipment \\
\hline K-25 & Form UCN-12463 & $\begin{array}{l}\text { Request for Disposal/ } \\
\text { Storage of Waste } \\
\text { Materials and Equipment }\end{array}$ \\
\hline
\end{tabular}

Wastes must be adequately characterized through chemical analyses or process knowledge to determine appropriate treatment, storage, and disposal options. This is documented on the appropriate forms depending on waste type. Additional forms may be used at the sites to document special waste streams such as classified wastes, asbestos/beryllium oxide, and spoil materials.

A Health Physics staff member surveys the waste for radioactivity. Waste generation is reduced by recycling and segregation whenever feasible. The waste transportation group at each site checks the form for accuracy, assigns a hazard class and the EPA hazardous waste number, if appropriate, and transports the waste to the appropriate hazardous waste management facility. The waste operations groups maintain an inventory for each storage facility.

Information concerning waste generation, storage, transportation, and disposal activities is maintained on computerized and/or manual data bases. Data from the forms and other documentation are compiled to ensure compliance with all applicable state and federal regulations and to promote efficient waste management operations.

Computer-based data bases facilitate waste tracking and the generation of waste management reports. Hard copies of forms are kept on permanent file.

\subsubsection{Waste Management Facilities}

\subsubsection{Y-12 Plant}

\subsection{Nonhazardous}

The Y-12 Sanitary Landfill II (SLF II) is a TDEC-permitted facility that became operational in 1983. It serves the K-25 Site, ORNL, the Y-12 Plant, and other DOE prime contractors and their subcontractors in the Oak Ridge area. Combustibles, decomposable materials, and other industrial wastes are permitted for disposal in SLF II, as are certain special wastes such as asbestos, beryllium oxide, aerosol cans, fly ash, and others. Material that lends itself to baling is baled at 9720-25 to conserve landfill space. These materials are disposed of in large trenches, and a daily cover of 8 mil plastic or 6 in. of compacted soil is applied. This facility is operated as described in Report Y-EN 618, Design and Operating Procedures for the Y-12 Centralized Sanitary Landfill II, Rev. 7 (McDermott 1991). Modifications to operating procedures have been approved by TDEC. The closure plan for this facility has been submitted to, but not approved by, TDEC.

The Y-12 Spoil Area I is a shallow land burial facility for the disposal of noncontaminated rubble and construction spoil, including asphalt, brick, block, brush, concrete, dirt, rock, tile, and other similar materials. Although currently inactive, this TDEC-permitted facility was operated in accordance with Report Y/IA-167, Design and Operating Procedures for the Y-12 Spoil Area I (Bailey and Jones 1984). A closure plan for the facility has been approved by TDEC.

The Chestnut Ridge Borrow Area Waste Pile serves as a storage/disposal area for soils with low concentrations of mercury. It was operated in accordance with Report Y/TS-62, Design and Operating Procedures for the Chestnut Ridge Borrow Area Waste Pile (Energy Systems 1984). The facility is no longer active and is covered with a synthetic liner to provide run-on and runoff protection. 


\section{Environmental Report Vol. 1, Oak Ridge}

The Environmental Restoration organization is currently prepared to close this site under TDEC Solid Waste Management rules for special wastes.

Lake Reality is a lined containment basin with a surface area of about 2 acres. The pond serves to enhance the water quality of East Fork Poplar Creek downstream of the Y-12 Plant.

Industrial Landfill IV is a TDEC-permitted Class II landfill for disposal of nonhazardous, nonradioactive, classified solid wastes from the Y-12 Plant.

The salvage yard is used for the staging and public sale of nonradioactive, nonhazardous scrap metal. Sales have been suspended, however, until procedures to meet the DOE "No Rad Added" performance objective have been approved.

Oil Storage OD6 is a 113,562-L (30,000-gal) tank that was used to collect clean oils before sale to the public. This facility is no longer operational.

Rogers Quarry is used as a settling pond for bottom ash sluiced from the steam plant. The use of Rogers Quarry for ash settling will be discontinued when the SPAD line item is completed in FY 1994. At that time, bottom ash will be collected in a dedicated ash-handling system and disposed of in Industrial Landfill $\mathrm{V}$, which will be constructed under the SPAD project.

The Sludge Handling Facility (T-118) was designed and constructed to provide water filtration and sludge dewatering in support of a storm sewer cleaning and relining project. Filtered water was reused by the sewer-cleaning contractor, and the dewatered sludge was stored in specially constructed containers for future disposal. The facility began receiving material during the winter of 1986 and was removed from operation at the end of the project during the fall of 1987. The facility is currently being used to store containers of low-level waste.

The Plating Rinsewater Treatment Facility (PRTF) (T-036) provides neutralization, electrochemical treatment, chemical precipitation, carbon adsorption, and filtration for nonuranium plating rinse waters from plating operations. Sludge generated from treatment of the rinsewater is categorized as hazardous by virtue of its association with plating solutions.

The Steam Plant Wastewater Treatment Facility (SPWTF) provides flow equalization, $\mathrm{pH}$ adjustment, chemical precipitation, clarification, and sludge dewatering for coal pile runoff, ion-exchange regeneration wastewater, boiler blowdown, and demineralizer waste. The wastewater, which is considered to be RCRA-hazardous prior to treatment, is rendered nonhazardous by the SPWTF and discharged to East Fork Poplar Creek.

\subsection{RCRA Hazardous/Mixed}

The East Chestnut Ridge Waste Pile is a lined waste pile used for the storage of contaminated soils and spoil materials. The Part B permit for this facility is pending state approval. To control precipitation run on and run off, the remaining storage capacity has been temporarily filled with clean soil and the facility covered with clay.

Kerr Hollow Quarry was used for the disposal of water-reactive and shock-sensitive chemicals. The facility is currently being closed and remediated by the Environmental Restoration organization.

The RCRA Staging and Storage Facility is a compartmentalized warehouse used for the staging of RCRA wastes before off-site shipment.

Building 9720-9 is a warehouse used for storage of flammable as well as nonflammable hazardous waste and $\mathrm{PCB}$ waste.

Facility $9811-1$ (OD-7, OD-8) is a container and bulk liquid waste storage area. It stores mostly oils and solvents which are not flammable. These wastes are not considered PCB wastes, but may contain beryllium. Facility modifications and fire protection upgrade projects now in progress will bring these areas within DOE requirements.

The Interim Drum Yard is a gravel storage yard used to store drums of hazardous waste pending final disposition. A small portion of the yard has been closed in accordance with a TDEC-approved closure plan. Waste has been removed from the remaining portion, and the facility has been scheduled for closure by the Environmental Restoration organization.

The Biodenitrification Facility uses biodenitrification reactors and recovery/feed tanks to biologically denitrify uranium-contaminated liquid wastes.

The Cyanide Treatment Facility is a batch facility for the destruction of cyanide in plating wastes. The destruction occurs in drums under an exhaust hood. 
The Waste Coolant Processing Facility (WCPF) is a biodegradation and storage facility for waste coolants which may be low-level radioactive waste.

The West End Treatment Facility (WETF) is a wastewater treatment facility designed to biologically denitrify nitrate-bearing liquid wastes and to physicochemically treat the resulting solutions to remove inorganic contaminants. Unit operations at WETF include $\mathrm{pH}$ adjustment, degassing to precipitate uranium, flocculation and precipitation to remove heavy metals such as nickel and zinc, and carbon adsorption. WETF can treat about 2 million gal of wastewater per year. Effluent from WETF is discharged to East Fork Poplar Creek.

The Central Pollution Control Facility (CPCF) is a wastewater treatment facility that employs physicochemical unit processes to remove oil and grease, heavy metals, and trace organics from nonnitrate-bearing wastewaters generated at the Y-12 Plant. Up to 2 million gal of wastewater per year can be treated at the CPCF and discharged into East Fork Poplar Creek.

Building 9212 Tank Farm consists of tanks used to store acid and caustic wastes.

The Waste Oil/Solvent Storage Facility (OD-9) is a tank facility that provides 200,000 gal of bulk storage for uranium-contaminated oils and solvents and PCB-çontaminated materials as well as nonuranium contaminated materials.

The Liquid Organic Waste Storage Facility is a bulk and drum storage facility that provides $113,562 \mathrm{~L}(32,000 \mathrm{gal})$ of bulk storage and storage for about 120 drums of solvents.

\subsection{PCBs and $\mathrm{PCB} /$ Uranium}

The Y-12 Plant has several TSCA 1-year storage facilities. Many of these contain one or two containers. The following sections outline the major TSCA 1-year storage facilities located at the Y-12 Plant. Oil Drum Storage Area OD3 had two 22,712-L (6000-gal) tanks, which were used to store PCB-contaminated oils. These tanks are part of a larger area that also contained drums. All of the site has been closed with the exception of the tanks.

\section{Building 9418-9 Storage Tank}

Building 9418-9 contains a 14,000-gal, below-grade, diked tank used for storage of
PCB-contaminated mineral oil. The dike for this tank is 1 -ft-thick concrete with no drains and a sump pump.

\section{Waste Oil/Solvent Storage Facility (OD9)}

The Waste Oil/Solvent Storage Facility (OD9) is a permitted RCRA/TSCA hazardous waste storage facility. It consists of a diked area supporting five 40,000-gal tanks, a tanker transfer station with five centrifugal transfer pumps, and a drum storage area. Three tanks house PCB waste contaminated with uranium, one tank contains nonradioactive $\mathrm{PCB}$ wastes, and one tank holds RCRA hazardous wastes. Likewise, a diked and covered pad furnishes space for 64 drums. The diked area contains additional space for a sixth 40,000 -gal tank. This facility is projected to be used until the year 2010 because of the anticipated lack of disposal outlets for uranium-contaminated organic liquids. The fire-suppression system at this facility will be upgraded during FY 1994 to comply with DOE Order 5480.7 .

\section{Garage Oil Storage Tanks}

Three garage oil storage tanks have been drained and removed from the ground as part of a closure plan initiated in 1989. One of the three tanks formerly contained PCB-contaminated oil. Closure will be completed by the Environmental Restoration organization.

\section{Building 9404-7 PCB Drum Storage Facility}

Building $9404-7$ is a TSCA storage facility in which solid PCB-contaminated materials are the only wastes accepted. These wastes may also be contaminated with uranium. Storage of liquid and/or hazardous waste is not permitted. Storage containers must comply with the specifications of 40 CFR 761, 49 CFR 178.8, 178.82, and 178.115. The facility provides for spill containment and has a capacity for 496 drums. Building $9404-7$ is located south of Building 9204-1. 


\section{Environmental Report Vol. 1, Oak Ridge}

\section{RCRA/PCB Warehouse \\ (Building 9720-9)}

The RCRA/PCB Warehouse supplies a drum storage area for mixed and/or PCB wastes, including an area designed to contain flammable wastes. The western half, which contains space for about 1500 drums, stores both PCB and RCRA hazardous waste. However, a diking upgrade is planned to allow for the handling of RCRA wastes at the east end.

The facility's eastern half does not currently store RCRA wastes. Upgrades to the ventilation, diking, and fire-suppression systems (a separate project) will bring the facility into compliance with RCRA, TSCA, and DOE standards and will allow for mixed and PCB waste storage. The design of the generai upgrade modification project is complete and construction will begin in the second quarter of FY 1994.

\section{RCRA and PCB Container Storage Area (Building 9720-58)}

Building 9720-58 is a warehouse facility used to stage and store PCB-contaminated equipment (e.g., transformers, capacitors, and electrical switchgear) and nonreactive, nonignitable RCRA waste contaminated with uranium and/or potentially $P C B$. Waste containers received at Building 9720-58 include 30- and 55-gal drums, 330- and 660-gal portable tanks, B-25 boxes, and self-contained PCB equipment. An overhaul of the fire-suppression system is planned in order to meet requirements of DOE Order 5480.7. Also, improved ventilation and diking systems will be added during this project to conform with RCRA and TSCA standards. Construction is planned to begin the first quarter of FY 1995.

\section{Liquid Storage Facility (LSF)}

The LSF is a hazardous waste storage facility built during the Bear Creek. Burial Ground closure activities. The LSF, located in Bear Creek Valley about 2 miles west of the Y-12 Plant, is used for collection and storage of groundwater and other wastewaters received from the Seep Collection Lift Station, the Solids Storage Facility, tankers, polytanks, and the diked area rainwater accumulation. Feed streams may contain oil contaminated with
PCBs, volatile and nonvolatile organic compounds, and heavy metals. Processing and storage equipment include the following:

- two 75,000-gal bulk storage tanks,

- a 6,000-gal oil storage tank,

- a gravity oil/water separator,

- a filtering unit,

- a composite sampling station, and

- a tanker transfer station.

The wastewater travels through the gravity separator, cartridge filters, and composite sampling station prior to storage in the bulk tanks. A reinforced concrete dike surrounds all equipment to provide spill containment. After sufficient wastewater accumulates in the bulk storage tanks, it is processed at the Groundwater Treatment Facility. A new leachate collection system designed to collect and pump additional Burial Ground hazardous waste seepage to the LSF began operation in December 1992.

\section{Liquid Organic Waste Solvent Storage Facility (OD10)}

The Liquid Organic Waste Solvent Storage Facility (ODI0) contains four 6500-gal and two 3000-gal stainless steel tanks for storage of ignitable nonreactive liquids, including those contaminated with PCBs and uranium. In addition, a diked and covered storage area provides space for 120 drums of material. The facility is capable of segregating various spent solvents for collection and storage. Major solvent waste streams are transferred to tanks for incineration at the K-25 Site TSCA Incinerator. A fire suppression modification of this facility is in progress and is scheduled to be completed in FY 1994 to fulfill the requirements of DOE Order 5480.7.

\section{Solid Storage Facility (SSF)}

The SSF provides $17,500 \mathrm{ft}^{2}$ of storage space for PCB- and uranium-contaminated soil. The facility also contains a synthetic liner for leachate collection and leak detection system. Collected leachate is transferred to the Liquid Storage Facility for pretreatment. The SSF is currently undergoing the RCRA Part $B$ permitting process. 


\section{Oil Landfarm Soil Storage Facility}

This facility contains about $550 \mathrm{yd}^{3}$ of soil contaminated with PCBs and volatile organics. The soil was excavated from the Oil Landfarm and Tributary 7 in 1989. The soil is contained in a covered, double-lined concrete dike with a leak-detection system. The leak-detection system will soon be modified to enhance detection capabilities.

\subsubsection{Low-Level Radioactive Waste Burial Site}

Bear Creek Burial Ground, a shallow land burial facility, has been used primarily for the disposal of low-level uranium-contaminated waste although it has received RCRA and TSCA wastes. The last disposal here was during 1991. Only low-level uranium-contaminated trash was disposed of at that time. Shallow land burials in Bear Creek Burial Ground were terminated during June 1991. The facility was operated in accordance with Report Y/IA-169, Design and Operating Plan for the Extension of Y-12 Plant Burial Ground A for the Disposal of Low-Level Radioactive Solid Waste (Bailey and Manuel 1986).

The Above Grade Storage Facility (AGS) is being constructed to store LLW in lieu of shallow land disposal until proper disposal can be determined and/or developed. The Above Ground Storage Facility is located north of the Bear Creek Road and west of the Sanitary Landfill I Oil Landfarm Area. The AGS consists of six fabric enclosures that are used for weather protection of the metal strong tight containers containing solid low-level radioactive/ radioactive contaminated waste. No RCRA hazardous material and no liquids are allowed are allowed. The storage surface of each facility is a concrete pad sloped to sump (a closed trench deeper on cne end). The concrete pad also provides a solid working surface for forklift operations.

The Uranium Oxide Vaults (S-114) are two concrete vaults used for the storage of uranium oxide and metals.

The Waste Feed Preparation Facility compacts solid, uranium-contaminated wastes into bales for shipment to a commercial facility for volume reduction prior to being placed in interim storage at the K-25 Site.

\subsubsection{Oak Ridge National Laboratory}

\subsection{Nonradiological Waste Treatment}

RCRA-regulated and PCB wastes are managed in storage facilities until they can be shipped off site for treatment and/or disposal. Several RCRA facilities operate under interim status $(7651,7652,7653$, Tank $7830 \mathrm{~A}$ ) while permit applications are under review by TDEC. Others operate under interim status but are scheduled for initiating closure in 1992 (7025, 7555. New Hydrofracture Surface Facilities, and the Reactive Chemical Facility). The Hazardous Waste Storage Facility, Building 7652, permit application was approved by TDEC in October 1986.

PCB-contaminated and/or hazardous wastes are temporarily stored at Building 7507, and PCB-contaminated and/or mixed wastes are stored on the 7507W Storage Pad. TRU waste is stored in the TRU Retrievable Storage Facilities, 7823, 7826, 7834, 7855, and 7879.

Few hazardous wastes are treated in on-site facilities. The Chemical Detonation Facility treats small amounts of wastes that would be dangerous to transport off-site. Explosives such as aged picric acid are detonated in the detonation facility.

The landfill receives nonhazardous industrial materials such as fly ash and construction debris. Asbestos and general refuse are managed in the Y-12 Plant Sanitary Landfill. ORNL's SWSA 6 receives low-level solid radioactive waste, including radioactively contaminated asbestos.

Numerous satellite accumulation areas and several 90-day areas are used across ORNL for accumulating wastes by the generator until a sufficient quantity exists to be transferred to a permitted or interim-status storage facility.

\subsection{Mixed Waste Treatment}

\section{Existing Treatment Facilities}

Three facilities are currently treating mixed waste at ORNL: the Process Waste Treatment Plant (PWTP), the Liquid Low-Level Waste Evaporation Facility (LLLWEF), and the Melton Valley Low-Level Waste Immobilization Facility (MVLLWIF). One other treatment facility at ORNL, 


\section{Environmental Report Vol. 1, Oak Ridge}

the Nonradiological Wastewater Treatment Plant (NRWTP), is operating and could be used to treat mixed waste.

Process Waste Treatment Plant. The PWTP is designed to treat process wastewaters, groundwater, and evaporator condensate wastewaters that contain low levels of radioactivity. Small concentrations of radioactive materials have occasionally been processed in the PWTP. Process wastewaters may contain small quantities of radionuclides, metals, anions, and organic chemicals. Principal radioactive contaminants removed at the PWTP are ${ }^{91} \mathrm{Sr}$ and ${ }^{137} \mathrm{Cs}$.

The PWTP operates in continuous mode and contains a waste-receiving system, a clarification system, an ion-exchange system, an auxiliary zeolite ion-exchange system, and an effluent release system. In the waste-receiving system, wastewater is collected in unlined ponds or storage tanks and pumped to the PWTP. Wastewaters pass first through a clarification system that reduces the levels of calcium and magnesium in the wastewater before it enters the ion-exchange system. In the ion-exchange system, "'Sr is removed from the wastewater. If the wastewater has high levels of ${ }^{137} \mathrm{Cs}$, it is diverted to an auxiliary zeolite ion-exchange system for removal of the cesium. After removal of the radionuclides, the wastewater is routed to an effluent-release system, where it is neutralized and released to the NRWTP. Solids collected during processing are dewatered using a filter press and sent to storage.

Under normal operating conditions, the PWTP can process wastewater at a rate of $130 \mathrm{gal} / \mathrm{min}$. The design capacity for the PWTP is $200 \mathrm{gal} / \mathrm{min}$. The facility is not suited for treating high-level or alpha-contaminated wastewaters. Wastewaters treated at the PWTP can contain organic materials and low levels of radioactivity. The PWTP can treat waste streams with some heavy metals but not streams containing PCBs.

\section{Liquid Low-Level Waste Evaporation}

Facility. The LLLWEF treats liquid low-level waste streams using evaporation. The LLLWEF operates in a semicontinuous mode; waste is accumulated in collection tanks and transferred through underground piping to an evaporator system. In the evaporator system, the waste is concentrated in one of two evaporator units. Concentrated wastes from the evaporators are sent to tanks for storage. Evaporator condensates (i.e., distillates) containing trace quantities of radionuclides are transferred to the PWTP for future treatment. The design capacity for the LLLWEF is $28,000 \mathrm{gal} / \mathrm{d}$. The LLLWEF processes an average of 300 gal of liquid wastes per day under normal operating conditions. The facility can treat waste streams containing organic contaminants.

\section{Melton Valley Low-Level Waste} Immobilization Facility. The MVLLWIF is used to solidify liquid low-level radioactive wastes that have a $\mathrm{pH}>12.5$ and that contain some heavy metals. This liquid mixed waste is transferred to the MVLLWIF from tanks by interconnecting pipelines. Batches of waste are pumped from a liquid decantation system to a solidification system as required to provide adequate storage-tank capacity. The facility operates only on a campaign basis to provide adequate storage capacity. Solidification is currently performed using cementation. The solidified waste is contained in carbon steel liners placed in $1-\mathrm{ft}$-thick concrete casks stored near the site in aboveground storage. The MVLLWIF has an emission-control system to regulate radioactive air emissions. Design capacity for the MVLLWIF is $16,500 \mathrm{gal}$ of liquid waste per month. Under normal operating conditions, the MVLLWIF can process $2000 \mathrm{gal} / \mathrm{month}$ as required to provide adequate storage-tank capacity. The facility operates only on a campaign basis to provide adequate storage capacity. The facility cannot treat high-level waste, alpha-contaminated waste with transuranic activity levels greater than $100 \mathrm{nCi} / \mathrm{g}$, organic wastes, or PCBs.

\section{Nonradiological Wastewater Treatment} Plant. The NRWTP is designed to reduce pollutant concentrations in nonradiological wastewaters to levels acceptable for effluent discharge as determined by TDEC. The NRWTP operates in a continuous mode and involves physical and chemical processing steps. Waste enters the system through collection systems using a series of collection tanks, jet mixers for equalization, radiation monitors, and $\mathrm{pH}$ monitors and controllers. The facility contains a heavy-metal removal system, where the $\mathrm{pH}$ of the wastewater is raised to 10.5 in a clarifier. Polymers are added to induce flocculation and settling of the metal precipitates. After treatment for heavy metals, the wastewater is passed through a filtration system to remove particulates. The wastewater then passes 
through an air stripper for removal of volatile organics and then granular activated carbon columns to remove mercury. Solids collected during the process are dewatered and placed in $64-\mathrm{ft}^{3}$-capacity steel hoxes for interim storage.

\section{Planned Treatment Facilities}

Although no facility has been designated, remotely handled, and special-case transuranic solid, liquid, and sludge wastes must be packaged and certified to meet WIPP waste-acceptance criteria. About $90 \%$ of DOE's inventoried remotely handled transuranic waste is stored at ORNL. Operations would include the receipt of solid waste, mobilization and transfer of liquids and sludges, evaporation and solidification of slurries, examination of solid waste, certification and packaging of waste, and shipping of completed waste packages. Transuranic waste will be packaged to meet the WIPP waste-acceptance criteria and will not be treated to meet the land disposal restrictions (LDR) treatment standards.

\subsubsection{K-25 Site}

The K-770 scrap metal storage facility consists of a 2.8-ha (6.9-acre) tract of land used for storing low-level radioactively contaminated scrap metal. Ferrous and nonferrous materials are generated at the K-25 Site and transported to the storage yard. At present, only containerized material is being accepted at the contaminated scrap yard.

The K-770 clean scrap yard provides storage for nonradioactive scrap metal. The scrap metal is stockpiled at K-770 before being sold to the public.

The K-726 PCB storage facility is located inside the K-770 scrap yard. This facility consists of a diked concrete block building with about $225-\mathrm{m}^{2}\left(2430-\mathrm{ft}^{2}\right)$ of storage space and is used primarily for the storage of low-level uranium-contaminated PCB waste that may also contain combustible and/or flammable liquids but not RCRA wastes. The current management scheme for these wastes is treatment at the K-1435 Incinerator.

PCB storage consists of four areas for $\mathrm{PCB}-\mathrm{contaminated} \mathrm{soil} \mathrm{and} \mathrm{other} \mathrm{debris} \mathrm{(such} \mathrm{as}$ Zorball and tyvecs). A 12 -in. curb runs along the perimeter of the units to contain any spills or leaks that may occur.
The K-306-1 RCRA storage facility is a $288-\mathrm{m}^{2}$ $\left(3110-\mathrm{ft}^{2}\right)$ area used for radioactively contaminated RCRA/PCB waste. These wastes are also designated for treatment at the K-1435 incinerator. When the PCB waste is removed, this facility will be used for storage of RCRA waste sludges generated at the Y-12 Plant.

Low-level radioactive waste storage vaults used for storage of nonhazardous radioactive waste generated at the K-25 Site, the Y-12 Plant, and ORNL include Vault 6, Rubb-2, and K-1055-H.

K-306- $1-a$ is designated as a stand-alone $\mathrm{PCB}$ facility for only PCB storage.

The $\mathrm{K}-311-1$ container storage area provides storage for approximately 51 tons of lead wastes generated during previous $Y-12$ Plant operations. This facility is a $\left.225-\mathrm{m}^{2}(2400)-\mathrm{ft}^{2}\right)$ enclosed building. Stored wastes include lead ingots, lead slag, and lead carbonate contaminated with low-level radioactive contaminants.

The K-1417 casting and storage yard, which has a storage area of 1.2 ha ( 3 acres), is used for storage of drummed solidified sludges generated at the K-1419 facility. Casting activities can be performed either at K-1419 or in the casting area of K-1417. A truck and equipment washing system collects runoff and spills from the casting area.

The K-306-1 vault 23A hazardous waste storage facility provides storage capacity for about 3000 208-L (55-gal) drums and is used primarily for storing sludges generated during treatment of $\mathrm{Y}-12$ Plant wastewaters at either K-1232 or $\mathrm{Y}-12$ Plant facilities. The drums are sealed, labeled, identified, and inventoried either before or immediately following transport to K-306-1, vault $23 \mathrm{~A}$.

The K-305-6 vaults 19 and $19 B$ hazardous waste storage facility offers a storage capacity for 8050 208-L (55-gal) drums. This facility is also used primarily for the storage of K-25 pond waste sludges generated from the closure of the K-1407-B pond. The containers are sealed, labeled, identified, and inventoried either before or immediately following transport to K-305-6.

The K-1420-A flammable waste storage tank is a 113,562-L (30,000-gal) tank that was modified to store low-flash-point and high-vapor-pressure wastes. The waste types stored in this facility include flammable solvents, gasoline, and paint waste. Only drummed waste that has been identified can be stored 


\section{Environmental Report Vol. 1, Oak Ridge}

at this facility. The waste stored in this tank at the present and in the future will be disposed of at the $\mathrm{K}-1435$ Incinerator.

The $\mathrm{K}-1425$ waste oil/hazardous waste/PCB storage facility consists of container and tank storage areas. The container storage building capacity is 480 208-L (55-gal) drums, and the tank storage area consists of four $85,275-\mathrm{L}(22,500$-gal) tanks in a dike. Wastes stored in this facility include oils, solvents, water, and organics. These wastes may be RCRA regulated, contain PCBs, and/or be radioactively contaminated. Wastes stored in this facility are and will be treated at the K-1435 Incinerator.

The K-14.35 TSCA Incinerator consists of storage tanks, dikes, and the incinerator. The maximum storage capacity for waste is $1,040208-\mathrm{L}$ (55-gal) drums. The tank storage capacity is $3.48 \times 10^{5} \mathrm{~L}$ $\left(0.9 \times 10^{5} \mathrm{gal}\right)$. The incinerator $\mathrm{y}$ stem consists of a liquid, solid, and sludge feed system; a rotary kiln incinerator; and a secondary combustion chamber.

The wastes treated at this facility include oils, solvents, chemicals, sludges, and aqueous waste. The majority of waste treated at the K-1435 Incinerator cannot be treated by commercial incinerators because of radioactive contamination. All waste sent to K-1435 for incineration must be fully characterized and identified. DOE has approved a chain-of-custody system for all waste received from off-site.

The K.1302 gas cylinder storage facility has been designated for storage of compressed gas cylinders. These gases are commercial products that are to be discarded or treated. The facility has a maximum storage capacity of about $100 \mathrm{ft}^{3}\left(2.8 \mathrm{~m}^{3}\right)$ of gas.

The K-1036-A storage dike is used for solvents and waste oil storage. The oil has recently been determined to be regulated by RCRA, with possible radioactive contamination. This facility has a maximum waste storage capacity of about 2,000 208-L. (55-gal) drums. After proper characterization, this waste is designated for treatment at the K-1435 Incinerator.

Low-level storage vaults used for storage of nonhazardous radioactively contaminated waste generated at the K-25 Site include K-303-5, K-309-2, and vault 15A. The $\mathrm{K}-310-3$ low-level storage vault is used for storage of nonhazardous radioactively contaminated waste generated at the $\mathrm{Y}-12$ Plant. The $\mathrm{K}-31()-2$ low-level storage vault is used for storage of nonhazardous radioactively contaminated waste generated at ORNL. Vault 15A may also be used for storage of nonhazardous radioactively contaminated waste from ORNL and the Y-12 Plant.

The K-711 storage facility has a maximum storage capacity of about 1800 208-L (55-gal) drums. The majority of the wastes stored at K. 711 have been designated for treatment at the K-1435 Incinerator. and primarily consists of waste oils and solvents generated at the DOE facility at Fernald, Ohio, and at other DOE facilities.

The K-1202 storage tank facility is used for storage of flammable or nonflammable RCRA regulated liquids that are radioactively contaminated. These wastes are designated for treatment at the $\mathrm{K}-1435$ TSCA Incinerator.

The K-1025-C storage facility is used to store out-of-date or off-specification laboratory chemicals that will be disposed of through off-site commercial facilities. These wastes may be either RCRA or non-RCRA, but they must be nonradioactive and non-PCB wastes that are approved for off-site disposal.

The K-306-7 and the K-306-2 low-level storage vaults are used for storage of nonhazardous radioactively contaminated soil from the $\mathrm{Y}-12$ Plant.

$\mathrm{K}-31(0)-1$ vault in the $\mathrm{K}-25$ building is used to store RCRA regulated sludges and ash from the operation of the K-1035 incinerator.

$\mathrm{K}-31()-1$ Vault $2 \mathrm{~A}$ is being used for storage of RCRA, RCRA/fissile, and mixed wastes from the K-25 Site, the Y-12 Plant, and ORNL.

$\mathrm{K}-302-4$ vault 8 is being used for storage of RCRA and mixed wastes from the K-25 Site and the Y-12 Plant.

$\mathrm{K}-302-5$ is being used for storage of RCRA and mixed wastes from the K-25 Site and the Y-12 Plant.

Vault $8 \mathrm{~A}$ HW storage is located in the K-25 Building at the K-25 Site and is approximately $350 \mathrm{ft}$ by $50 \mathrm{ft}$ in area. It is used for the storage of hazardous wastes from the K-25 Site and the Y-12 Plant.

K-309-2 Vault 3A will be used for storage of RCRA and mixed wastes from the K-25 Site, the Y-12 Plant, and ORNL. Currently, empty PCB-contaminated containers are being stored in this area.

$\mathrm{K}-301-1$ vault 4 is approximately $200 \mathrm{ft}$ by $58 \mathrm{ft}$ in area and is divided into three even sections. An 
8 -in. curb runs between the sections, as well as along the perimeter of the unit, to contain any spills or leaks that may occur. The three individual sections are dedicated to storage of laboratory waste acids, bases, and organics.

$\mathrm{K}-301-1$ vault $4 \mathrm{~A}$ is approximately $170 \mathrm{ft}$ by $58 \mathrm{ft}$ in area. An 8-in. curb runs along the perimeter of the unit to contain any spills or leaks that may occur. The waste stored in this vault consists of sludges and incinerator ash.

$\mathrm{K}-301-2$ vault $4 \mathrm{~B}$ is approximately $200 \mathrm{ft}$ by $58 \mathrm{ft}$ in area. An 8-in. curb runs along the perimeter of the unit to contain any spills or leaks that may occur. The waste stored in this vault consists primarily of photographic waste (fixer, developer, and toner) and incinerator ash.

K-303-4 vault $10 \mathrm{~B}$ is approximately $360 \mathrm{ft}$ by $58 \mathrm{ft}$ in area and is used for the storage of PCB-contaminated soil and Zorball. An 8-inch curb runs along the perimeter of the unit to contain any spills or leaks that may occur.

$\mathrm{K}-309-3$ is being used for storage of RCRA, PCB, and mixed wastes from the K-25 Site, the Y-12 Plant, and ORNL.

$\mathrm{K}-306-3$ is being used for storage of RCRA, $P C B$, and mixed wastes from the K-25 Site, the $Y-12$ Plant, and ORNL.

The K-1407-H Waste Treatment Facility (WTF) or the Central Neutralization Facility (CNF) provides $\mathrm{pH}$ adjustment and chemical precipitation for several aqueous streams throughout the K-25 Site. The main purpose of the CNF is to treat wastewater to ensure compliance with the requirements of NPDES discharge limits on $\mathrm{pH}$, heavy metal concentrations, and suspended solids. The treatment system consists of two 25,000-gal reaction tanks and a 60,000-gal sludge-thickener tank. Acidic wastes are neutralized with a hydrated-lime slurry, and basic wastes are neutralized with sulfuric or hydrochloric acid. The hydrated lime bin and acid tanks are located at the facility. Waste streams from K-1435, K-1501, and miscellaneous laboratories and process operations are received at the CNF. Most of the radioactively contaminated wastewater treated at the CNF is generated at the K-1435 TSCA Incinerator from the wet scrubber blowdown. Treated effluents are discharged through the K-1407-J NPDES point. The contaminated sludges that precipitate in the sludge-thickener tank are stored in an approved aboveground storage area at the K-25 Site. The CNF is physically divided into two distinct sections for treating both hazardous and nonhazardous waste streams.

\subsubsection{On-Site Treatment}

Compaction/baling of solid, low-level, and uranium-contaminated wastes from the Y-12 Plant is conducted at the Waste Feed Preparation Facility. Dewatering is available for nonnitrate waste sludges at the CPCF and for nitrate waste sludges at the WETF. Wastewaters generated at the Y-12 Plant are typically treated at the West End Treatment Facility, the CPCF, the SPWTF, or the WCPF. The WCPF is designed to biologically degrade machine cutting coolants. Effluent from the WCPF is taken to the CPCF or WETF for final treatment and discharge. Cyanide destruction by batch reaction under a hood is performed at the Cyanide Treatment facility.

Oxidation of uranium machine turnings is performed at the Chip Oxidation Facility.

The on-site waste treatment quantities at the Y-12 Plant are shown in Table 9.1 of Vol. 2.

On-site treatment at ORNL includes elementary neutralization and detonation facilities. Quantities and types of wastes processed at ORNL during 1991 are presented in Table 9.2 in Vol. 2.

On-site treatment facilities at the K-25 Site include the K-1435 TSCA Incinerator, K-1407-H, and the CNF. The on-site waste-treatment quantity for the K-25 Site is shown in Table 9.3, Vol. 2. See Sect. 9.3.2.4 for descriptions of these treatment units.

Treatment of the current inventory of contaminated scrap metal at the K-25 Site (as well as at Portsmouth, Paducah, and Fernald DOE facilities) is expected to occur over the next 3 to 5 years as part of a comprehensive DOE Scrap Metal Program to be managed through the K-25 Site. Under this program, the scrap metal will be processed for beneficial reuse where possible or be size-reduced for disposal.

\subsubsection{On-Site Waste Disposal Activities}

On-site waste disposal quantities for ORNL in 1992 are shown in Table 9.4 in Vol. 2.

The only on-site disposal unit for ORNL is SWSA 6.

Currently, there are no on-site disposal facilities being operated at the K-25 Site. Energy Systems 


\section{Environmental Report Vol. 1, Oak Ridge}

Waste Management Organization has been established and assigned the responsibility to design, construct, and operate all new low-level waste disposal facilities for the ORR. This organization is physically lociated at the K-25 Site. The new LLW disposal facilities will be developed in concert with the strategy originally developed by LLWDDD and will serve waste generators from all three DOE facilities on the ORR. The Low-Level Waste Disposal Facilities (LLWDF) project will provide new disposal facilities at a new centralized location of the ORR for BRC, Class L-I, and Class L-II low-level wastes, providing capacity up to 40 years. The LLWDF will utilize state-of-the-art disposal technologies, including lined trenches with leachate collection treatment capabilities for BRC/Class L-I wastes and tumulus confinement disposal units for Class L-II wastes. As currently scheduled, these facilities are expected to be operational in 1996.

\subsubsection{Off-Site Waste Disposal}

All off-site disposals of hazardous wastes were halted in 1991 until procedures addressing a DOE performance objective of "No Rad Added" were developed by the sites and approved by DOE-HQ.

Incineration is the preferred method for off-site treatment or disposal of wastes, particularly PCB wastes; however, landfills and other types of disposal are used as needed. For instance, PCB-contaminated transformer carcasses cannot be incinerated and must be sent to a landfill.

Off-site disposal, as listed in Tables 9.5, 9.6, and 9.7 in $\mathrm{Vol}_{0} .2$, was arranged through the Transportation and Purchasing departments. Unless special circumstances warrant otherwise, all such disposals were awarded to the lowest qualified bidder. Commercial transporters or transportation provided by the disposal firm was used to move the waste from the site. All incoming and off-site shipments of wastes conformed to U.S. Department of Transportation (DOT) criteria for such shipments. The criteria included packaging, manifesting, and shipping requirements. All containers were required to meet DOT shipping requirements. Packages and vehicles were inspected and inventoried before shipment.

Contracts were made only with approved commercial disposal contractors to ensure safe and environmentally sound operations. Contractor approval was based on a site visit and evaluation that included scrutiny of areas such as financial strength, title transfer, management systems, historical use (Energy Systems, commercial, DOE, DOD), operations, design and equipment, compliance (regulator's opinion), public relations, and facility siting. Each commercial contractor was evaluated every year.

The K-770 clean scrap yard provides storage for nonradioactive scrap metal. The scrap metal is stockpiled at K-770 before being sold to the public.

\subsubsection{Waste Placed in Storage}

In some cases, wastes cannot be disposed of, either immediately or in the foreseeable future.

Storage requirements fall into two categories: short-term storage for those wastes awaiting off-site shipment or treatment, and long-term storage for wastes, such as mixed wastes, that are being stored pending future disposal decision.

Wastes are stored on-site for several reasons. Recyclable materials such as mercury and silver-bearing photographic wastes are stored before recycling, while other hazardous wastes are stored until sufficient quantity is accumulated for an off-site shipment. Mixed wastes are stored until the DOE performance objective has been met and incinerator capacity is available locally to destroy them or until other treatment and disposal methods can be identified for wastes which cannot be incinerated. Many of these wastes will be treated in the K-1435 TSCA Incinerator, which began operation in 1990.

Land disposal restrictions (LDR) waste, which includes RCRA mixed waste, has been stored in some areas at the K-25 Site for longer than 1 year. These wastes are currently subject to the land ban that permits storage only for accumulation of sufficient quantities to facilitate proper treatment, recycling, or disposal. This waste is being stored because of the nationwide shortage of treatment and disposal facilities for these types of waste. Private-sector technology demonstrations are being conducted that involve uranium extractions from sludge. The DOE Oak Ridge Operations Office (DOE-ORO) and EPA Region IV have signed an FFCA that details the steps needed to attain compliance.

Information on wastes stored at the three plants is given in Tables 9.8-9.13 in Vol. 2. 


\section{Environmental Report Vol. 1, Oak Ridge}

\subsection{References}

Bailey, J. K., C. L. Eutz, and J. L. Williams. 1989. Best Management Practices Plan for Waste Management Activities in the Bear Creck Burial Ground, Y/IA-210, Oak Ridge Y-12 Plant, Oak Ridge Tenn.

Bailey, J. K., and L. S. Jones. 1984. Design and Operating Procedures for the Y-12 Spoil Areal, Y/IA-167, Oak Ridge Y-12 Plant, Oak Ridge, Tenn.

Bailey, J. K., L. S. Jones, and J. L. Williams. 1989. Closure Plan for the United Nuclear Corporation Waste Disposal Site, Y/IA-200, Oak Ridge Y-12 Plant, Oak Ridge, Tenn.
Bailey, J. K., and M. A. Manuel. 1986. Design and Operating Plan for the Extension of $Y-12$ Plant Burial Ground A for the Disposal of Low-Level Radioactive Solid Waste, Y/IA-169, Oak Ridge Y-12 Plant, Oak Ridge, Tenn.

Martin Marictta Energy Systems, Inc. 1984. Design and Operating Procedure for Chestmut Ridge Borrow Area Waste Pile, Y/TS-62, Oak Ridge Y-12 Plant, Oak Ridge, Tenn.

McDermott, T. E. 1991. Design and Operating Procedures for the Y.12 Centralized Sanitary Landfill II, Y/EN-618, Oak Ridge Y-12 Plant, Oak Ridge, Tenn. 


\section{QUALITY ASSURANCE}

10.1 Field Sampling and Monitoring . . . . . . . . 10-4

10.1.1 Basic Concepts and Practices . . . . 10-4

10.1.2 Air Monitoring . . . . . . . . . . 10 10

10.1.3 Water Monitoring . . . . . . . . . 10-5

10.1.4 Soil and Sediment Sampling . . . . . . 10-5

10.1.5 Solid Waste Monitoring . . . . . . . . 10-5

10.1.6 Biological Monitoring . . . . . . . . . 10-6

10.2 Analytical Quality Assurance . . . . . . . . . 10-6

10.2.1 Internal Quality Control .. . . . . . . . 10-6

10.2.2 External Quality Control . . . . . . . 10.7

10.3 Audits, Reviews, and Assessments . . . . . 10-8

10.3.1 Y-12 Plant . . . . . . . . . . . . . 10-8

10.3.2 Oak Ridge National Laboratory . . . . 10-9

10.3.3 K-25 Site . . . . . . . . . . . . . . . 10-10 


\section{Quality Assurance}

The overall goal of a well-designed and well-implemented sampling and analysis program is to measure accurately what is really there. Environmental decisions are made on the assumption that analytical results portray, within known limits of accuracy and precision, the nature of a sample that is representative of the population sampled. Many factors act upon the sample to cause changes from its original state. Factors to consider as sources of error or variance include those associated with procedures and tools for sample collection; sample handling and preparation; preservation, storage, and transport; personnel and training requirements; analytical method accuracy; data reporting; and record keeping. Thus, quality assurance (QA) requires systematic control of all phases of the monitoring process.

Energy Systems installations participate in both internal and external quality control (QC) programs. Internally, QC is maintained through procedures and checks that include the following practices:

- use of standard operating procedures (SOPs) for sample collection and analysis;

- use of chain-of-custody and sample tracking procedures to ensure traceability, defensibility, and integrity of samples and data;

- instrument standardization, calibration, and verification;

- background measurements at the sample source and in the laboratory;

- resolution checks and detector alignment for determination of gamma emitter radionuclides;

- yield determinations for radiochemical procedures;

- duplicate analyses for precision checks;

- technician and analyst training;
- spiked and surrogate sample analysis to determine matrix effects;

- sample preservation, handling, and decontamination; and

- use of surveillance procedures.

Preparation of SOPs is a continually evolving process. In 1988 a document, Environmental Surveillance Procedures Quality Control Program, was established under the oversight of the U.S. Department of Energy Oak Ridge Operations Office (DOE-ORO) and the U.S. Environmental Protection Agency (EPA) for use by Energy Systems. This document contained sampling and QC procedures that addressed each of the issues in the preceding list. Because methods and technologies change rapidly, an evaluation and incorporation of these changes are now under way.

Each installation maintains SOPs, which are reviewed and updated periodically, for the collection and analysis of environmental samples. The analytical laboratories use certified standards from EPA or DOE or materials traceable to the National Institute of Standards and Technology (NIST) to establish accuracy, to calibrate instruments, to determine yields for radiochemical procedures, and to standardize methods.

The analytical laboratories have QA/QC personnel who monitor the quality of analytical data. These staff members administer a program that generates QC samples of known composition and concentration, and these samples are submitted to the laboratories on an established periodic basis. These samples are prepared using EPA, NIST, or other reliable materials and are submitted as samples of unknown value to the analyst. Additionally, organizations responsible for collecting environmental samples submit blank, equipment 


\section{Environmental Report Vol. 1, Oak Ridge}

rinse, duplicate, and spiked samples along with environmental samples to confirm the integrity of the samples and/or to validate analytical results. All sample collection activities are traceable through field records to the person collecting the sample and to the specific sampling equipment (if appropriate) used to collect that sample. All maintenance and calibration records for sampling equipment are also kept so that they are similarly traceable. These internal programs form the basis for ensuring reliable results on a day-to-day basis.

\subsection{Field Sampling and Monitoring}

\subsubsection{Basic Concepts and Practices}

Statistically based sampling is typically used because it is not possible to measure the total amount of a contaminant in environmental media. Samples of the media are collected and a representative contaminant concentration is estimated. An aggregate of sampling units into which an area is divided is called the population of sampling units. For example, if contaminants in pond sediments are of interest, then the population is the entire bottom sediment of the pond. If the bottom sediments are then divided into sampling units of equal size, the sampling units collectively constitute the entire population. A group of sampling units selected from the entire aggregate as representative of the whole population forms a sample (if they are composited) or a set of samples. The units forming a composite sample are typically of equal size, are taken within a defined period of time, and are selected to represent the whole population of sampling units.

The objectives of the program, namely, the precision, accuracy, and confidence levels expected of the data (data quality objectives), must be established to prescribe and apply the appropriate level of QC. Once adequate sampling designs and collection procedures are in place, the quality objective is to collect the sample according to the specified procedure without altering the true nature of the sample.

Because of changing technologies and regulatory protocols, training of field personnel is a continuing process. To ensure that qualified personnel are available for the array of sampling tasks within
Energy Systems, training programs by EPA as well as private contractors have been used to supplement internal training. Examples of topics addressed include

- planning, preparation, and record keeping for field sampling;

- well construction and groundwater sampling;

- surface water, leachate, and sediment sampling;

- soil sampling;

- stack sampling;

- decontamination procedures; and

- health and safety considerations.

Field QC samples are collected to evaluate the precision of the sample collection process, to assess the effectiveness of the decontamination of equipment used in the process, and to determine the extent of potential contamination acquired during the sampling event, or from sample preservation, site condition, transportation and storage prior to analysis,-where applicable. Generally, control samples collected to satisfy the reasons are field blanks, equipment rinses, duplicate samples, or trip blanks. Tables 10.1 and 10.2 of Vol. 2 provide examples of these types of field QC samples.

\subsubsection{Environmental Support Program}

The Analytical Environmental Support Group (AESG) at the K-25 Site is involved in the coordination and support for the implementation of analytical laboratory and field QA/QA for environmental studies for Energy Systems Environmental Restoration Division (ERD), the Analytical Projects Office, Work for Others programs, and the Army Materiel Command at the Rocky Mountain Arsenal (RMA). The group is also involved in several aspects of analytical chemistry consulting, sample collection consulting, and field geology. It has identified the $\mathrm{Q} A / Q C$ requirements for the Hazardous Waste Remedial Actions Program (HAZWRAP) and ER Division organizations. The group provides a sample proficiency evaluation; an auditing program for analytical laboratories; complete review services for all program documents (which include work plans, sampling and analysis plans, laboratory and project QA plans, final reports, 


\section{Environmental Report Vol. 1, Oak Ridge}

and analytical deliverables). In addition, it is currently implementing comprehensive field surveillances; training courses for QA of environmental analysis; and data validation for HAZWRAP, RMA, and ERD.

\subsubsection{Air Monitoring}

Ambient and stack emission air monitoring on the Oak Ridge Reservation (ORR) is accomplished for the environmentai programs in accordance with sampling and analytical procedures based on EPA protocols to ensure that the data obtained from sample analysis meet the data quality objective of the project or program. Several parameters are measured to provide general and specific information on air and stack emissions from site operations for compliance, process control, and improvements. For example, total suspended particulate (TSP), uranium, fluoride, and external gross gamma are parameters monitored in ambient air. Procedures for continuous sampling of stack emissions provide information for process controls and improvements.

Quality control of analytical processes and sample collection are routinely performed; field blanks and spiked samples are submitted with each set of ambient air samples specifically for fluoride analysis, and trip blanks are used where applicable. Analytical instruments and field sampling equipment are kept ready for use by routine preventive maintenance, calibration, and repair programs at the sites or by subcontract, examples of which are quarterly calibration certification of the meteorological tower sensors, quarterly calibration of TSP flowmeters, and weekly checks for the need to recalibrate TSP flowmeters.

Site sampling teams are trained in the sample collection process, which covers preparation for the sampling event, field activity record keeping, and the actual sample collection process. All air samples are taken under chain of custody to ensure the integrity of the samples collected.

\subsubsection{Water Monitoring}

Typically, all of the water monitoring for the ORR is encompassed by the environmental monitoring and surveillance program for permitted sources, non-point sources, and storm drains; groundwater monitoring and maintenance programs; and the biological monitoring program. These programs are designed to monitor processes at assigned outfalls in the National Pollution Discharge Elimination System (NPDES) permits, in surface waters on the ORR to ensure compliance with requirements and to be apprised of the status of the environment. The quality of the data provided for these programs is essential to management decision-making, and thus is under constant scrutiny. Quality control in the sample collection activity, field analysis, and the laboratory analysis is continuously improving.

Sample preservation, specified in the Code of Federal Regulations (40 CFR 136.3), is accomplished in accordance with site-specific sample collection procedures that were previously reviewed and concurred with by EPA and DOE-ORO. Waivers from requirements are requested, where feasible and applicable, and obtained through the DOE-ORO.

\subsubsection{Soil and Sediment Sampling}

Soil/sediment sampling is another area in which considerable variability exists in the way sampling plans are designed and samples are collected. The type of soil/sediment to be sampled, the objective of the sampling effort, the parameters of concern, and many other considerations must be taken into account before an adequate sampling plan can be developed.

The regulatory or scientific objectives of a soil sampling effort are reviewed prior to establishing the sampling approach to verify that the resulting data will meet the intended data quality objectives. Examples of such programs include the annual soil sampling program, where individually controlled soil plots at ambient air stations have been selected for analysis, and QA planning for soil analysis at the K-25 Site.

\subsubsection{Solid Waste Monitoring}

The solid waste monitoring activities are governed by Tennessee's Hazardous Waste Management Rules Chap. 1200-1-11, which is in conformance to $40 \mathrm{CFR}, \mathrm{Pt}$. 260-270.

The sampling procedures incorporate unified, up-to-date information on sampling procedures specified in the EPA's SW-846 manual (second and third editions) and applicable state and EPA documents. 


\section{Environmental Report Vol. 1, Oak Ridge}

\subsubsection{Biological Monitoring}

Standard protocols for the collection of biological monitoring, milk, and fish samples on the ORR required that Energy Systems in-house methods be developed, accepted by the regulators, and used. The QA/QC for analysis of the biological monitoring samples is handled by the internal laboratory QC program described in Sect. 10.2. Statistical considerations are used to manage data generated from all sample collection.

\subsection{Analytical Quality Assurance}

The Energy Systems analytical laboratories have well-established QA/QC programs, well-trained and highly qualified staff, and excellent equipment and facilities. Current, approved analytical methodologies employing good laboratory and measurement control practices are used routinely to ensure analytical reliability. The laboratories have always been involved in the handling and analysis of hazardous materials of high purity, for which strict accountability is required. The analytical laboratories conduct extensive internal QC programs with a high degree of accuracy, participate in several external QC programs, and use statistics to evaluate and to continuously improve performance. Thus, QA and $\mathrm{QC}$ are daily responsibilities of all employees.

\subsubsection{Internal Quality Control}

A key feature in analytical QA is quality control. Analytical activities are supported by the use of standard materials or reference materials (c.g., materials of known composition that are used in the calibration of instruments, methods standardization, spike additions for recovery tests, and other practices). Certified standards from NIST, EPA, or other DOE laboratories are used for such work. The laboratories operate under specific criteria for QA/QC activities documented at each installation. Additionally, separate $Q A / Q C$ documents relating to the analysis of environmental samples associated with regulatory requirements are consulted (see Tables 10.3 through 10.7 of Vol. 2 ).

Analytical laboratory information systems are used to store and track analytical data as well as personnel cerrification and training data, report results of analysis, record internal control data on known standards, calculate spike recoveries, and manage quality control activities.

Analyses are performed using EPA, American Society for Testing and Materials (ASTM), Standard Methods for the Examination of Water and Wastewater, or other approved procedures. Analysis methods and minimum QA requirements are dictated by state and EPA regulatory requirements, DOE orders, and established laboratory QA programs.

Radionuclide monitoring, an important responsibility for the Oak Ridge sites, is supported by analytical measurements generally derived from state-of-the-art methods and instrumentation. High-purity germanium detectors with standard counting configurations are used for identification of gamma-emitting radionuclides in environmental samples. Alpha-emitting radionuclides are identified with surface barrier alpha detectors, and gross alpha and beta activities are measured with proportional counting systems.

Quality control is ensured by using standard materials from NIST or other reliable sources for calibration, yield/efficiency determinations, spike recoveries, isotopic dilution, and other techniques. Backgrounds are measured periodically for corrections, and instrument responses and efficiencies are routinely established.

Nonradiological and classical wet chemical analysis methods are used to analyze environmental samples. Routine calibration and standardization, replicate analyses, spike additions, and analysis of blanks all support the internal QC efforts.

These internal QC programs are the mainstay of analytical data and are the basis for ensuring reliable results on a day-to-day and batch-to-batch basis. The total effort in these programs is at least $101020 \%$ of the laboratory effort (in accordance with I:PA expectations).

QA/QC measurement control programs external to the sample analysis groups have single, blind control samples submitted to the analytical laboratories to monitor performance. Reliable suppliers such as NIST', EPA, and DOE are the sources for these standards. The results of such periodic measurement programs are statistically evaluated and reported to the laboratories and their customers. Most reports are issued quarterly, and some laboratories compile annual summary reports.

\section{0-6 Quality Assurance}


These reports assist in evaluating the adequacy of analytical support programs and procedures. If serious deviations are noted by the QC groups, the operating laboratories are promptly notified so that corrective actions can be initiated, and problems can be resolved. QC data are stored in an easily retrievable manner so that they can be related to the analytical results they support.

\subsubsection{External Quality Control}

In addition to the internal programs, all Energy Systems installations are directed by DOE and expected by EPA regulators to participate in external QC programs. These programs generate data that are readily recognizable as objective packets of results. These packets give participating laboratories and government agencies a periodic view of performance. The sources of these programs are laboratories in the EPA, DOE, and commercial sector. Energy Systems participates in seven such programs.

\subsubsection{Environmental Protection Agency Contract Laboratory Program (CLP)}

The Contract Laboratory Program (CLP) is an EPA-administered qualification program for laboratories to do Superfund /Comprehensive Environmental Response, Compensation, and Liability Act (CERCLA)] program analyses. The program operates from the CLP-Sample Management Office at Alexandria, Virginia, in cooperation with the EPA Environmental Monitoring System Laboratory at Las Vegas (EMSL-LV) and EPA regions. The program qualifies laboratories for the determination of organic and inorganic contaminants in aqueous and solid hazardous waste materials and enforces stringent QA/QC requirements to ensure comparable data. These requirements are acceptable for investigative, remedial, and monitoring studies of Superfund (CERCLA) sites. Energy Systems has been involved in this type work since 1985. Analysis of quarterly performance evaluation (PE) samples is required to participate in this program. All sites now participate. Results of PE analysis are shown in Tables 10.8 through 10.13 of Vol. 2.

\subsubsection{Water Supply and Water Pollution Performance Quality Control Program}

The state of Tennessee certifies laboratories for drinking water analyses. To maintain its certification, a laboratory must meet a specified set of criteria relating to technical personnel, equipment, work areas, $\mathrm{QA} / \mathrm{QC}$, operating procedures, and the successful analysis of QC samples. These samples are routinely scheduled and supplied by the EPA-Cincinnati, and the results evaluated and furnished by EPA Region IV to the state. On-site audits are scheduled and performed by the state of Tennessee. All sites participate in this program. The results of all analyses are in Tables 10.14 through 10.22 of Vol. 2.

\subsubsection{NIOSH/Proficiency Analytical Testing Program}

The National Institute of Safety and Health (NIOSH) administers the Proficiency Analytical Testing (PAT) program as part of their American Industrial Hygiene Association (AIHA) certification process. The program rates analysis results as proficient or nonproficient when compared with results obtained by 60 reference laboratories. Currently, the K-25 Site and the Y-12 Plant have an AIHA certification. Results of the PAT analysis can be found in Tables 10.23 through 10.25 of Vol. 2.

\subsubsection{EPA EMSL-LV Discharge Monitoring Report Quality Assurance Study}

EPA conducts a national QA program in support of the NPDES permits, and it is mandatory to major permit holders. The EPA supplies the QC samples and furnishes the evaluated results to the permittee, who is required to report the results and any necessary corrective actions to the state of Tennessee. All sites participate. Results for the K-25 Site, ORNL, and the $\mathrm{Y}-12$ Plant are shown in Tables 10.26 through 10.28 of $\mathrm{Vol} .2$.

\subsubsection{EPA Intercomparison Radionuclide Control Program}

The EPA Intercomparison Radionuclide Control Program is administered by EMSL-L.V. The state of 


\section{Environmental Report Vol. 1, Oak Ridge}

Tennessee requires participation for drinking water certification of radionuclide analysis, and all sites are involved. These samples consist mainly of water and air filters. Results of analysis are furnished to the state for evaluation relative to the laboratory certification. When a laboratory fails to achieve an overall satisfactory rating, removal of that laboratory from certified status may result.

The EMSL-LV program calculates a normalized standard deviation for each laboratory based on all reported results. By their criteria, any reported value above three deviations is considered unacceptable. Certifications are valid for varying periods of time. Results for each site can be found in Tables 10.29 through 10.31 of Vol. 2.

\subsubsection{DOE Environmental Measurements Laboratory (EML) Quality Assessment Program}

A radionuclide Quality Assessment Program is administered by the DOE EML in New York. Various matrices, such as soil, water, air filters, and vegetation, are submitted semiannually for analysis of a variety of radioactive isotopes. All matrices, except air filters, are actual materials obtained from the environment at a DOE facility. A statistical report is submitted to the sites by EML for each period.

Because the detection limits and precision are counting equipment dependent, the parameters measured vary among laboratories. The samples are usually near the limit of detection for the equipment, therefore, results with ratio values of 0.5 to 1.5 as compared with reference values are acceptable data. Results for all sites are shown in Tables 10.32 through 10.36 of Vol. 2.

\subsubsection{Proficiency Environmental Testing (PET) Program}

The PET program was established by Energy Systems analytical laboratories personnel and Waste Management Coordination Office (WMCO) personnel at Fernald, Ohio, to meet the need for a QC program for all environmental analyses, and thus, all sites participate. The samples are supplied on a monthly basis by a commercial supplier at two concentration levels (high and low, as specified by each site). All data from each of the six laboratories are reported to the supplier. The commercial supplier provides a monthly report of the evaluated data to the site QA/QC managers. The report includes a percent recovery of the referenced value, deviation from the mean of all reported data, specific problems in a site lab, and other statistical information. A corporate report is also provided that compares the data from the Energy Systems laboratories with those of other corporate laboratories.

Statistical evaluation is performed by the supplier to determine acceptability of the analytical data. The criteria for evaluation are as follows: data reported within 1.96 standard deviations are acceptable, between 1.96 and 2.58 standard deviations are marginal, and greater than 2.58 standard deviations are unacceptable.

The results of analysis from all sites for this program are in Tables 10.37 through 10.46 of Vol. 2.

\subsection{Audits, Reviews, and Assessments}

\subsubsection{Y-12 Plant}

\subsubsection{External Regulatory}

Regulatory agencies conducted several assessments at the Y-12 Plant during 1992 (Table 10.47 of Vol. 2). Reviews conducted by the Tennessee Department of Environment and Conservation (TDEC) included Resource Conservation and Recovery Act (RCRA) inspections, a compliance evaluation inspection (CEI) of the groundwater monitoring program, Toxic Substances Control Act (TSCA) inspections, permitting inspections, and solid waste management compliance inspections. No major findings or areas of concern were identified during the assessments. Action plans have been developed to address any findings noted during the inspections.

\subsubsection{Tiger Team Assessment}

The Tiger Team Compliance Assessment of the Y-12 Plant was conducted from September 25 to October 20, 1989. During the assessment, 62 environmental findings were identified. As indicated in the Tiger Team's report, none of the problems identified was of a nature that indicated that 
continued operation of the facility would present an undue risk to public health or to the environment. Action plans have been developed for these findings. The Semiannual Status Report for the September 1989 Tiger Team Compliance Assessment (Y/AD-617/R-2) was issued in November 1992.

\subsubsection{Internal Reviews}

In addition to the EPA, TDEC, and DOE audits and reviews, the Y-12 Plant Organization performed numerous assessments and reviews of the environmental programs at the Y-12 Plant. These assessments and reviews focused on the environmental program, record keeping, QA programs, health and safety programs, sampling procedures, and siorage of toxic and hazardous wastes. In general, these assessments led to improved operating procedures and management practices.

The Y-12 Plant laboratory has a program for internal audits of methods, programs, and procedures. A system has been established for audit scheduling and reporting. Audit responses are logged, and corrective actions monitored. Analytical procedures are issued by the Laboratory Administrative Services Group to each laboratory area through a system of controlled methods manuals. The Y-12 Plant laboratory has begun the process of rewriting all procedures in a modified ASTM fcrmat.

\subsubsection{U.S. Department of Energy}

Activities are continuing to address findings identified during the DOE Headquarters (DOE-HQ) environmental survey. The preliminary report of findings was received from DOE-HQ in December 1987 , and an action plan to address the findings was submitted to DOE-ORO in February 1988.

DOE-ORO conducted an Environmental, Safety, Health, and QA appraisal of the Y-12 Plant in July 1990. In its report, the appraisal team noted 62 environmental findings. Action plans have been developed to address these findings.

\subsubsection{Oak Ridge National Laboratory}

In 1992, ORNL experienced numerous audits/inspections and reviews related to environmental sampling and data management, sample analysis, waste management, and QA. These audits and reviews consisted of audits by outside regulatory agencies such as EPA Region IV and TDEC, audits and reviews by DOE-ORO, and internal audits by Energy Systems. The Environmental Surveillance and Protection (ESP) Section has routine internal surveillances on procedures and fieldwork conducted by the Measurements Assurance Group of the Office of Environmental, Safety, and Health Compliance.

\subsubsection{External Regulatory Assessments}

Table 10.48 of Vol. 2 summarizes the major environmentally related audits and reviews of ORNL by outside regulatory agencies. Of the nine audits conducted by regulatory agencies, no new findings were identified. Areas of potential concern and observations have been resolved or are scheduled for resolution pending availability of resources.

\subsubsection{Tiger Team Assessment}

From October 22, 1990, to November 30, 1990, a group of approximately 80 specialists representing DOE-HQ conducted a Tiger Team assessment of ORNL's Environment, Safety and Health Program. The environmental subteam reviewed compliance with ORNL procedures, Energy Systums procedures, DOE orders, and federal/state regulations pertaining to environmental protection. A total of 70 deficiencies were identified; 43 representer nonconformance with procedura! and/or regulatory requirements and 27 involved best management practices.

An action plan that addressed corrective measures for each of the Tiger Team findings was prepared, and, after a number of revisions, it was approved by former DOE Secretary Watkins on October 19, 1991. In the time since the Tiger Team review, ORNL has been actively completing those corrective actions that have adequate funding. Where funding is not available, it has been requested.

\subsubsection{Internal Reviews}

In addition to EPA, the state of Tennessee, and DOE audits and reviews, Energy Systems and ORNL 


\section{Environmental Report Vol. 1, Oak Ridge}

organizations external to the divisions and groups responsible for environmental concerns at ORNL performed numerous audits and reviews of the environmental program at ORNL.

These audits and reviews focused on the environmental program, record keeping, health and safety, QA, contingency plans, and storage of toxic and hazardous waste. In many cases, these audits and reviews led to improved operating procedures and management practices.

\subsubsection{K-25 Site}

The K-25 Site experienced numerous assessments during 1992. These assessments were performed by regulatory agencies such as the EPA and TDEC; DOE; Energy Systems; and by K-25 Site internal Environmental, Health, and Safety and Quality Assurance audit teams.

\subsubsection{External Regulatory Assessments}

Table 10.49 of Vol. 2 summarizes the major environmentally related assessments of the K-25 Site performed by outside agencies. All findings, negative observations, and other concerns have been addressed with corrective action plans and have been corrected or are progressing as scheduled.

\subsubsection{Internal Reviews}

In addition to EPA, TDEC, DOE, and Energy Systems, the K-25 Site performed audits and surveillances throughout the year that varied from walkdowns of facilities to extensive reviews of environmental programs, record keeping, and QA activities. As a result, many effective improvements were made to procedures and to management practices.

\subsubsection{Tiger Team Assessment}

Beginning in November 1991, the DOE-HQ Tiger Team Assessment subteam thoroughly reviewed the environmental management program at the K-25 Site for compliance to requirements. Corrective action plans in response to deficiencies found in the program were prepared considering existing plans to similar issues found at other sites. Each item is actively tracked in the Energy Systems Action Management System maintained by the K-25 Site QA organization. Status of completion may be obtained upon request. The most recently revised corrective action plan, $K-25$ Corrective Action Plan in Response to the Department of Energy 1992 Tiger Team Report Rev. 3, dated December 11, 1992, is awaiting signature of DOE Secretary O'Leary. 


\section{APPENDIXES}

Appendix A: Chemical Releases of the Oak Ridge

Reservation Facilities, 1992

Environmental Report . . . . . . . . . . . A-3

Appendix B: Errata for Oak Ridge Reservation

Environmental Report for 1991 . . . . . B-1

Appendix C: Statistical Treatment of Random

Uncertainties $\ldots \ldots \ldots \ldots \ldots \ldots \ldots$. . 1 


\section{Appendix A}

\section{Chemical Releases of the Oak Ridge Reservation Facilities, 1992 Environmental Report}

\section{Introduction}

In addition to indicating the concentrations of various chemicals present in the environment near DOE facilities, in recent years the annual environmental reports have contained an estimate of the quantities of certain chemicals being emitted to the environment. This appendix contains an expanded list of chemicals with information regarding the types of releases, the estimated quantities released, the major processes contributing to the releases, and a brief description of the basis of estimates for calendar year (CY) 1992. Radiological chemical releases for CY 1992 are not included in this appendix; they are reported in the applicable chapters of this report.

\section{Discussion}

Three categories of chemical releases at each DOE facility are reported in this appendix: (1) SARA 313, (2) other large-inventory chemicals, and (3) steam plant emissions. The SARA 313 chemicals are summarized from the information currently being compiled for the SARA Title III, Section 313, report required by SARA 1986. This report is submitted on July 1 of each year for the previous calendar year and contains chemicals on the EPA toxic substance list.

Currently, 309 specific chemicals and 20 chemical categories must be reviewed and possibly reported under SARA Section 313. If any of these chemicals were manufactured in excess of $25,000 \mathrm{lb}$, processed in excess of $25,000 \mathrm{lb}$, or "otherwise used" in excess of $10,000 \mathrm{lb}$ at a facility during CY 1992. the chemical must be reported. In many instances, the estimate of quantities released was obtained via material balance calculations, monitoring data, or engineering calculations. In some cases, no quantitative monitoring data, or emission factors were readily available, and release estimates were based on "best engineering judgment." Material balance calculation was the principal method used (1) derive the quantity released. Information obtained from air permits, rate of operation, quantities used, and known treatment efficiencies was used to estimate quantities released into the environment. Typically, assumptions based on enginecring judgment were required to perform the calculations when all variables were not known. Considerable manpower was expended reviewing chemical inventory information and estimating the quantities released to the environment.

Information contained in this appendix may not coincide with the information to be reported for all chemicals under SARA, Title III, Section 313. The SARA 313 report must be submitted to EPA and TEMA no later than July 1, 1993. The information for this appendix was generated in the March/April timeframe, and some additional refinements were in progress. It is imperative that the additional two months (May and June) be used to ensure compliance under SARA Title III, the community right-10-know law.

The second category of chemicals reported in this appendix is "other large-inventory chemicals." This listing is included to provide the reader with additional chemical information not reportable under SARA 313. Note that this is not a complete listing of all chemicals that may have been released at a site. This list was developed to better inform the reader of 


\section{Environmental Report Vol. 1, Oak Ridge}

additional chemicals used and released at each site and that may be of interest to the general public.

The third category, "steam plant emissions," is release estimates of certain pollutants from the coaland/or gas-fired steam plants located at each site.

Chemical release information is included for the Oak Ridge Y-12 Plant (Table A.1), ORNL

(Table A.2), and K-25 Site (Table A.3).

\section{Disclaimer}

Information contained within the 1992 Environmental Report (ER) pertaining to toxic chemical releases at the $Y-12$ Plant may not coincide with those to be reported under SARA, Title III, Section 313. The latter report, known as the Toxic Release Inventory (Form R), is to be submitted no later than July 1, 1993, to the EPA and TEMA. These forms furnish information on environmental releases (e.g., air, water, and land) of specific toxic chemicals manufactured, produced, or otherwise used at the Y.12 Plant during calendar year 1992. The data collection and review effort necessary to ensure that the numbers furnished for the ER in April will be identical to those submitted in July on the Toxic Release Inventory Forms cannot be made. It is imperative that the additional two months be utilized to ensure compliance under SARA, Title 111, the community right-10-know law. Elements requiring additional effort that may result in revision of release numbers are as follows:

- addressing mixtures (i.e., trade name products) containing toxic constituents at $1 \%$ or greater and carcinogens at $0.1 \%$ or greater;

- tracking bulk acid product distribution systems to identify sources of air emissions for comparison with waste effluents;

- cross-referencing SID numbers and RCRA waste stream numbers with process areas for material balance;

- confirming operational times of certain processes for use in air emission calculations; and

- cross-checking hazardous material purchases against reported material usage for each process area. 
1992 Environmental Report Vol. 1, Oak Ridge

Table A.1. Y-12 Plant chemical release information, CY 1992

\begin{tabular}{ccccc}
$\begin{array}{c}\text { Chemical } \\
\text { name }\end{array}$ & $\begin{array}{c}\text { Type of } \\
\text { environmental } \\
\text { release }\end{array}$ & $\begin{array}{c}\text { Quantity } \\
\text { relcased } \\
(\mathrm{lb} / \mathrm{kg})\end{array}$ & $\begin{array}{c}\text { Major } \\
\text { release } \\
\text { sources }\end{array}$ & $\begin{array}{c}\text { Basis of } \\
\text { estimate }\end{array}$ \\
\hline
\end{tabular}

SARA 313 reportable toxic chemicals

Freon 11

Hydrochloric acid

Methanol

Nitric acid

Perchloroethylene

Sulfuric acid

Chlorine
Freon 12
Freon 113
Hydrogen fluoride
Mercury
Trichloroethane

Nitrogen oxides (as nitrogen oxygen)

Sulfur oxides

(as sulfur dioxide)

Carbon monoxide

Non-Methane VOC

Particulates

$12,403 / 5,625$
$14,059 / 6,376$
$1,285 / 583$
$58,228 / 26,407$
$7,552 / 3,425$
$13,376 / 6,066$
$27,000 / 12,245$
$1,734 / 786$
$5,346 / 2,424$

\section{Air-fugitive}

Air-point

Air-fugitive

Air-fugitive

Air-point

Air-point

Air-point

Off-site

Air-point

Refrigeration
Stack/tank enissions
Neutralization
Cooling
Plating
Processing aid
Solvent/degreasing
Waste shipments
Plating

Other large inventory chemicals

SARA, Sect. 313 toxic chemicals below reporting threshold, of interest

$\begin{array}{lll}\text { Air-point } & 201 / 91 & \begin{array}{l}\text { Stack emissions } \\ \text { Water-E. Fork }\end{array} \\ \text { Air-fugitive } & 187 / 85 & \begin{array}{l}\text { Cooling waters } \\ \text { Process aid/ } \\ \text { refrigeration }\end{array} \\ \text { Air-fugitive } & 2,815 / 1,277 & \begin{array}{l}\text { Cleaning/solvent } \\ \text { Cleaning }\end{array} \\ \text { Air-fugitive } & 160 / 73 & \text { Stormwater runoff } \\ \text { Water-E. Fork } & 0.02 / 0.01 & \text { Cleaning/solvent } \\ \text { Air-fugitive } & 1,642 / 745 & \end{array}$

Steam plant emissions

$\begin{array}{llll}\text { Air-Point } & 1,430,484 / 648,746 & \text { Stack emissions } & \text { Emission factors } \\ \text { Air-Point } & 592,912 / 268,894 & \text { Stack emissions } & \text { Emission factors } \\ \text { Air-Point } & 81,160 / 36,807 & \text { Stack emissions } & \text { Emission factors } \\ \text { Air-Point } & 3,489 / 1,582 & \text { Stack emissions } & \text { Emission factors } \\ \text { Air-Point } & 3,474 / 1,576 & \text { Stack emissions } & \text { Emission factors }\end{array}$

\author{
Material balance \\ Engineering judgment \\ Engineering judgment \\ Material balance \\ Engineering judgment \\ Material balance \\ Material balance \\ Lab analysis \\ Engineering judgment
}

Engineering calculations

Monitoring

Material balance

Material balance

Material balance

Monitoring

Material balance 
1992 Environmental Report Vol. 1, Oak Ridge

Table A.2. ORNL Plant chemical release information, 1992

\begin{tabular}{ccccc}
\hline $\begin{array}{c}\text { Chemical } \\
\text { name }\end{array}$ & $\begin{array}{c}\text { Type of } \\
\text { environmental } \\
\text { release }\end{array}$ & $\begin{array}{c}\text { Quantity } \\
\text { released } \\
(\mathrm{lb} / \mathrm{kg})\end{array}$ & $\begin{array}{c}\text { Major } \\
\text { release } \\
\text { sources }\end{array}$ & $\begin{array}{c}\text { Basis of } \\
\text { estimate }\end{array}$ \\
\hline
\end{tabular}

SARA 313 chemicals

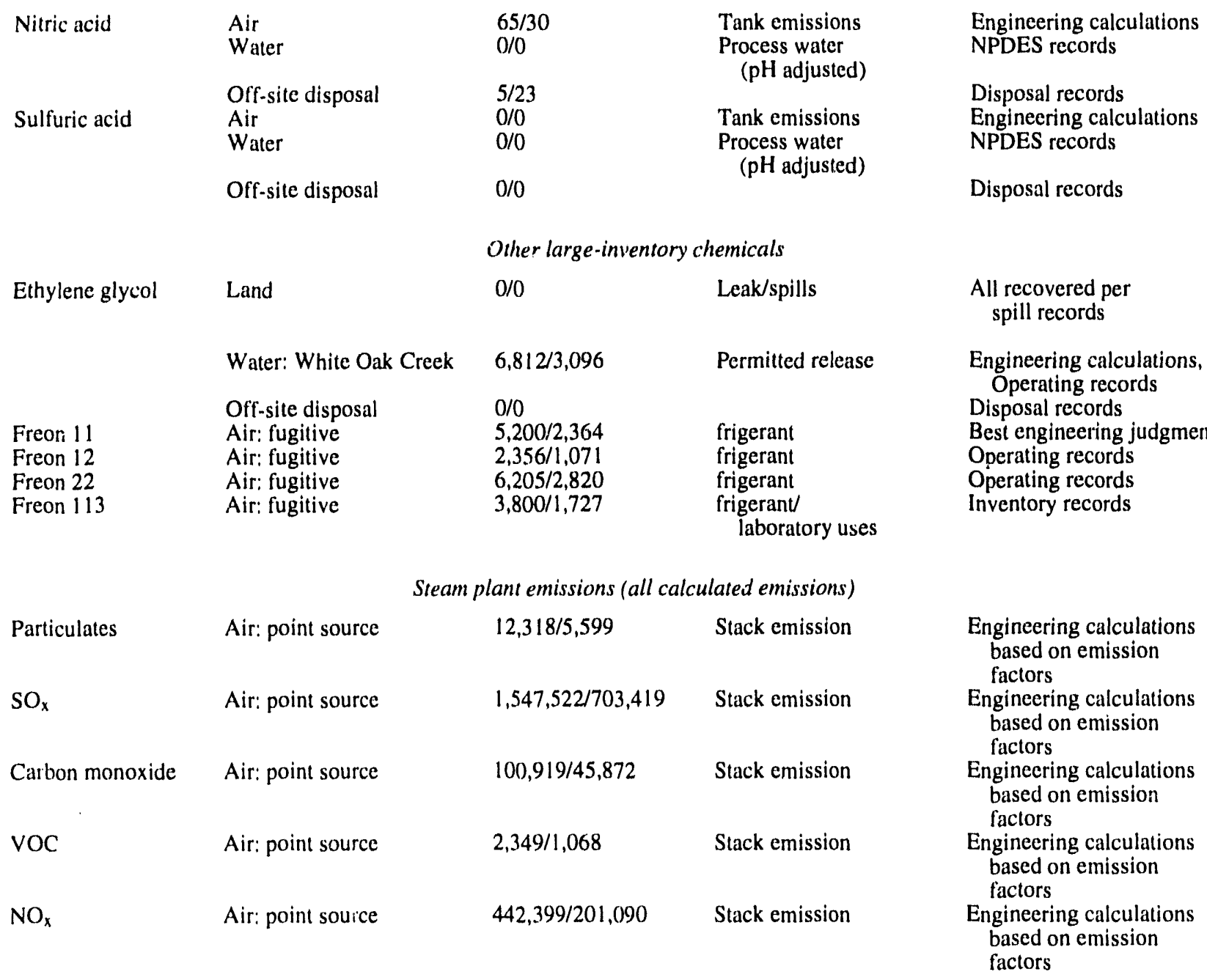


1992 Environmental Report Vol. 1, Oak Ridge

Table A.3. K-25 Site chemical release information, 1992

\begin{tabular}{|c|c|c|c|c|}
\hline $\begin{array}{l}\text { Chemical } \\
\text { name }\end{array}$ & $\begin{array}{l}\text { Type of } \\
\text { environmental } \\
\text { release }\end{array}$ & $\begin{array}{l}\text { Quantity } \\
\text { released } \\
(\mathrm{lb} / \mathrm{kg})\end{array}$ & $\begin{array}{l}\text { Major } \\
\text { release } \\
\text { sources }\end{array}$ & $\begin{array}{l}\text { Basis of } \\
\text { estimate }\end{array}$ \\
\hline \multicolumn{5}{|c|}{ SARA 313} \\
\hline \multirow[t]{6}{*}{ Chlorine } & Air: fugitive emission & $3,447 / 1,567$ & $\begin{array}{l}\text { Water purification cooling } \\
\text { towers }\end{array}$ & Other \\
\hline & Water: Poplar Creek & $111 / 50$ & Sanitary sewage treatment & Monitoring \\
\hline & $\begin{array}{l}\text { Water: Nameless tributary } \\
\text { of Clinch River }\end{array}$ & $450 / 206$ & Water purification & Monitoring \\
\hline & Water: Mitchell Branch & $27 / 12$ & Storm drains & Monitoring \\
\hline & Water: K-1007 P1 Pond & $7,705 / 3,502$ & Storm drains & Monitoring \\
\hline & Water: K-1007 P5 Pond & $152 / 69$ & Storm drains & Monitoring \\
\hline Sulfuric acid & Air: stack emissions & $66 / 130$ & TSCA incineration by-product & Other ${ }^{a}$ \\
\hline Hydrochloric acid & Air: stack emissions & $92 / 42$ & $\begin{array}{l}\text { TSCA incineration by-product } \\
\text { tank losses }\end{array}$ & Other ${ }^{a}$ \\
\hline \multicolumn{5}{|c|}{ Other large inventory chemicals } \\
\hline Freon 12 & Air: fugitive emissions & $1,570 / 714$ & $\begin{array}{l}\text { Refrigeration/ } \\
\text { systems cooling }\end{array}$ & Other ${ }^{a}$ \\
\hline Freon 22 & Air: fugitive emissions & $1,500 / 682$ & $\begin{array}{l}\text { Refrigeration/ } \\
\text { systems cooling }\end{array}$ & Other ${ }^{a}$ \\
\hline Freon 114 & Air: fugitive emission & $20,075 / 9,125$ & $\begin{array}{l}\text { Refrigeration/ } \\
\text { systems cooling }\end{array}$ & Other ${ }^{a}$ \\
\hline \multicolumn{5}{|c|}{ Steam plant emissions } \\
\hline Particulates & Air: stack emissions & $2,506 / 1,137$ & $\begin{array}{l}\text { Fossil fuels } \\
\text { combustion }\end{array}$ & Emission factors ${ }^{b}$ \\
\hline Sulfur dioxide & Air: stack emissions & $665 / 302$ & $\begin{array}{l}\text { Fossil fuels } \\
\text { combustion }\end{array}$ & Emission factors $^{b}$ \\
\hline Nitrogen oxide & Air: stack emissions & $44,235 / 20,065$ & $\begin{array}{l}\text { Fossil fuels } \\
\text { combustion }\end{array}$ & Emission factors ${ }^{b}$ \\
\hline Carbon monoxide & Air: stack emissions & $26,717 / 12,119$ & $\begin{array}{l}\text { Fossil fuels } \\
\text { combustion }\end{array}$ & Emission factors $^{b}$ \\
\hline Organics & Air: stack emission & $2,230 / 1,011$ & $\begin{array}{l}\text { Fossil fuels } \\
\text { combustion }\end{array}$ & Emission factors ${ }^{b}$ \\
\hline
\end{tabular}

${ }^{a}$ Based on best engineering judgment.

bAP-42. "Compilation of Air Pollutant Emission Factors" and boiler-specific emission factors. 


\section{Appendix B}

\section{Errata for Oak Ridge Reservation Environmental Report for 1991}

This appendix contains errata reported for the Oak Ridge Reservation Environmental Report for 1991 (Martin Marietta Energy Systems, Inc., ES/ESH-22, Vols. 1 and 2, Sept. 1991). A summary list is followed by corrected versions of the text, figures, and tables. Corrected values are indicated by a dagger $(\dagger)$. 
Volume 1

- P. xi: In Fig. 2, the K-25 Site dose equivalent should be 13 person-rem.

- P. xi: In Fig. 2, the total dose equivalent should be 29 person-rem.

- P. 2-6: The contribution of Y-12 Plant emissions should be $34 \%$ of the collective EDE.

- P. 2-6: The contribution of ORNL emissions should be $21 \%$ of the collective EDE.

- P. 2-14: In Sect. 2.1.7, the estimated collective committed EDE should be 29 person-rem.

Volume 2

- P. 4-5: Table 4.3 needs a footnote explaining that it does not contain fourth-quarter data.

- P. 4-8: In Table 4.6, the biochemical oxygen demand maximum should be 52.6; its average should be 29.4; its standard error should be 12 .

- P. 4-9: In Table 4.7, the vanadium max should be $<0.004$.

- P. 4-12: In Table 4.13, the cadmium average should be $<0.004$.

- P. 4-23: In Table 4.24, discharge point 604 , the chromium average should be $<0.01$.

- P. 4-23: In Table 4.24. discharge point 612, the copper average should be $<0.019$.

- P. 4-24: In Table 4.24, discharge point 618 , the following changes should be made:

$\begin{array}{lllll}\text { Parameter } & \text { Max } & \text { Min } & \text { Av } & \text { Stand } \\ \text { Temperature, }{ }^{\circ} \mathrm{C} & 25.6 & 24.1 & & 0.6 \\ \text { pH, standard units } & 8.5 & 7.9 & & \\ \text { Copper } & 0.026 & 0.018 & 0.023 & 0.003 \\ \text { Zinc } & 0.06 & 0.04 & & 0.01 \\ \text { Flow, gal/d } & 16,114 & 3,336 & & 4,935\end{array}$

- P. 4-65: In Table 4.55, the lead average should be followed by an asterisk.

- P. 4-66: In Table 4.55, the volatile organics should be revised as follows:

\begin{tabular}{|c|c|c|c|c|c|c|c|}
\hline Parameter & $\mathbf{n}$ & $\operatorname{Max}$ & Min & & Std error & CR av & $C R \max$ \\
\hline Chloroform & $0 / 11$ & & $<0.0050$ & $<0.0050$ & 0 & 0.041 & \\
\hline Trichloroethylene & $0 / 11$ & & $<0.0050$ & $<0.0050$ & 0 & 0.81 & \\
\hline
\end{tabular}

- PP. 4-76 to 4-89: All concentrations in Tables 4.72, 4.73, 4.74, 4.75, 4.76, 4.77, and 4.78 should be labeled in micrograms per liter $(\mu \mathrm{g} / \mathrm{L})$, except for $\mathrm{pH}$ values, which are in standard units.

- P. 4-97: The cadmium values in Table 4.83 should be labeled in milligrams per liter ( $\mathrm{mg} / \mathrm{L}$ ).

- P. 4-98: The settleable solids values in Table 4.84 should be labeled in milliliters per liter $(\mathrm{mL} / \mathrm{L})$.

- P. 4-101: The dissolved solids values in Table 4.88 should be labeled in milligrams per liter $(\mathrm{mg} / \mathrm{L})$.

- P. 4-102: The phenols values in Table 4.88 should be labeled in milligrams per liter $(\mathrm{mg} / \mathrm{L})$.

- P. 5-23: The magnesium average should be 17*.

- P. 5-24: In Table 5.15, the parameter ${ }^{489} \mathrm{Sr}+{ }^{99} \mathrm{Sr} "$ should read ${ }^{89} \mathrm{Sr}+{ }^{90} \mathrm{Sr} . "$

- P. 5-24: In Table 5.15, the reference value for ${ }^{89} \mathrm{Sr}+{ }^{90} \mathrm{Sr}$ should be 8 ; the reference footnote should be [2].

- P. 5-24: In Table 5.15, the reference value for ${ }^{3} \mathrm{H}$ should be 20,000; the reference footnote should be [2].

- P. 5-46: In Table 5.20, the reference value for ${ }^{89} \mathrm{Sr}+{ }^{90} \mathrm{Sr}$ should be 40; the reference footnote should be [4].

- P. 5-46: In Table 5.20, the reference value for ${ }^{3} \mathrm{H}$ should be 80,000; the reference footnote should be [4].

- P. 5-48: In Table 5.21, the reference value for ${ }^{89} \mathrm{Sr}+{ }^{90} \mathrm{Sr}$ should be 40 ; the reference footnote should be [4].

- P. 5-48: In Table 5.21, the reference value for ${ }^{3} \mathrm{H}$ should be 80,000; the reference footnote should be [4]. 
Vol. 1, page xi:

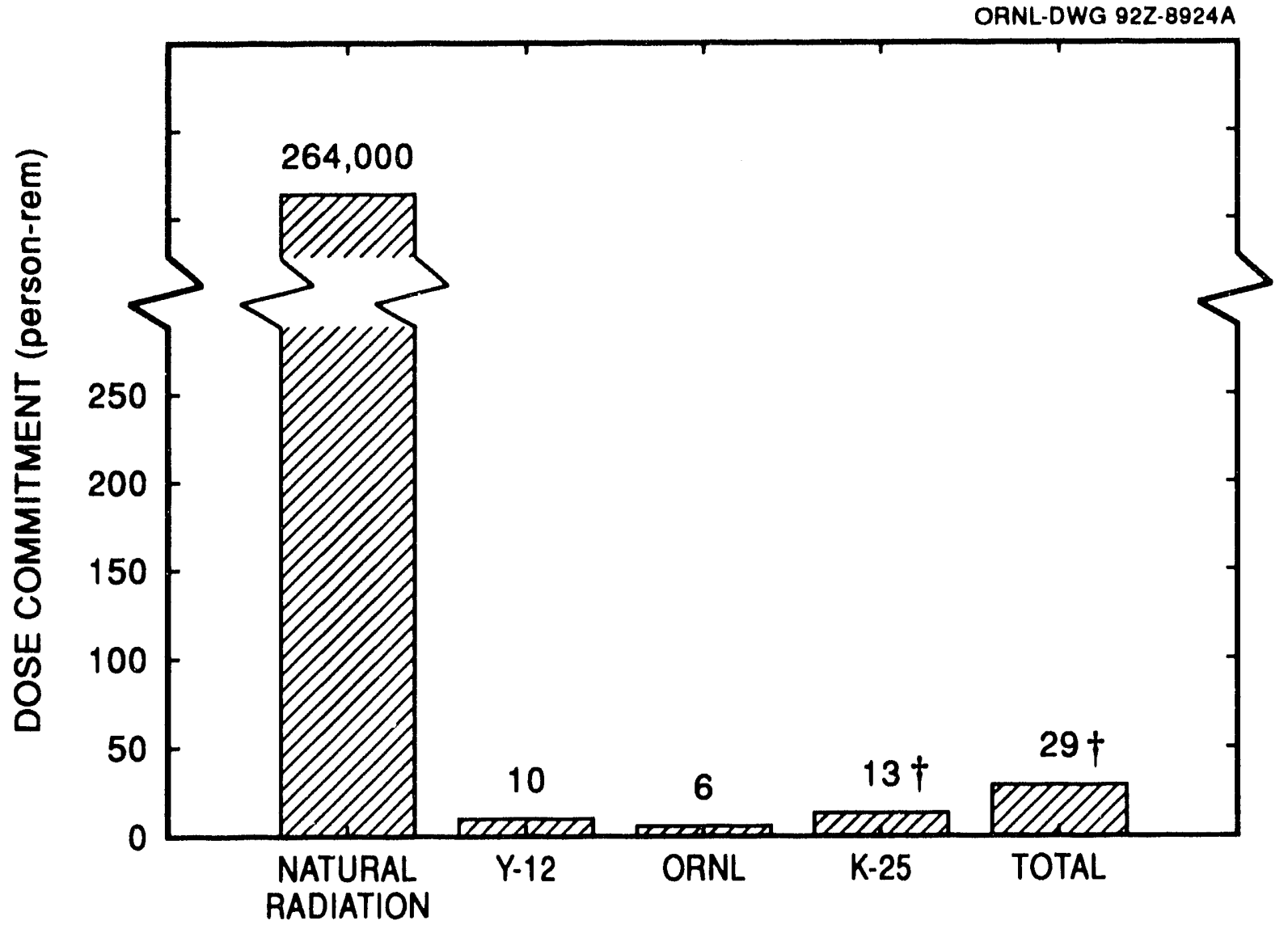

Fig. 2. The collective effective dose equivalent of the entire population within $80 \mathrm{~km}$ (50 miles) of the three installations.

Vol. 1, p. 2-6:

The EDE received by the hypothetical, maximally exposed individual for the $\mathrm{Y}-12$ Plant was calculated to be $1.4 \mathrm{mrem}(0.014 \mathrm{mSv})$. This individual is located approximately $1080 \mathrm{~m}(0.7 \mathrm{miles}) \mathrm{NNE}$ of the Y-12 Plant release point. Essentially, all of this dose is due to ingestion (2\%) and inhalation (98\%) of uranium, primarily ${ }^{234} \mathrm{U},{ }^{235} \mathrm{U}$, and ${ }^{238} \mathrm{U}$. The contribution of $\mathrm{Y}-12$ Plant emissions to the 50 -year committed collective EDE to the population residing within $80 \mathrm{~km}$ of the ORR was calculated to be approximately 10 person-rem ( 0.1 person-Sv), which is $34 \%$ of the collective EDE for the ORR.

The EDE received by the hypothetical, maximally exposed individual for ORNL was calculated to be $0.3 \mathrm{mrem}(0.003 \mathrm{mSv})$. This individual is located $4970 \mathrm{~m}$ ( 3.1 miles) SW of the 3039 stack and $5160 \mathrm{~m}$ (3.2 miles) WSW of the 7911 stack. Approximately $94 \%$ of this dose is due to ingestion and inhalation of ${ }^{3} \mathrm{H}$. The contribution of ORNL emissions to the collective EDE to the population residing within $80 \mathrm{~km}$ of the ORR was calculated to be 6 person-rem $\left(0.06\right.$ person-Sv), which is $21 \%^{\dagger}$ of the collective EDE for the ORR. 
Vol. 1, page 2-14:

\subsubsection{Findings and Conclusions}

The maximally exposed off-site individual could receive a 50-year committed EDE of approximately 2 mrem due to airborne effluents from the ORR. This dose is within the limit specified in the Clean Air Act for DOE facilities. The estimated collective committed EDE to the approximately $8.8 \times 10^{5}$ persons living within $80 \mathrm{~km}$ (50 miles) of the ORR is approximately $29 \dagger$ person-rem for 1991 airborne emissions. This represents about $0.01 \%$ of the $2.6 \times 10^{5}$ person-rem that the surrounding population would receive from all sources of natural radiation.

Vol. 2, p. 4-5:

Table 4.3. 1991 annual radiological summary Y-12 Plant diversion ditch ${ }^{a, b}$

\begin{tabular}{|c|c|c|c|c|c|c|}
\hline \multirow{2}{*}{ Parameter } & \multirow{2}{*}{$\begin{array}{c}\text { Number of } \\
\text { samples }\end{array}$} & \multicolumn{4}{|c|}{ Concentration ${ }^{c}$} & \multirow{2}{*}{$\begin{array}{c}\text { Percentage } \\
\text { of } \\
\text { DCG }\end{array}$} \\
\hline & & Max & Min & Av & $\begin{array}{l}\text { Standard } \\
\text { error }\end{array}$ & \\
\hline$U$, total & 52 & 0.074 & $<0.001$ & $<0.038$ & 0.002 & $d$ \\
\hline${ }^{235} \mathrm{U}(\%)$ & 51 & 0.630 & 0.180 & 0.422 & 0.013 & $d$ \\
\hline Th, total & 52 & $<0.011$ & $<0.003$ & $<0.003$ & 0.000 & $d$ \\
\hline
\end{tabular}

${ }^{a}$ See Fig. 4.2 in Vol. 1.

${ }^{b}$ Fourth-quarter data are not included in this table. $\dagger$

cUnits are in $\mathrm{mg} / \mathrm{L}$ unless otherwise noted.

${ }^{d}$ Not applicable. 
Vol. 2, p. 4-8:

Table 4.6. 1991 annual radiological and nonradiological data summary for East End Sewer, Y-12 Plant

\begin{tabular}{|c|c|c|c|c|c|c|}
\hline \multirow{2}{*}{ Parameter } & \multirow{2}{*}{$\begin{array}{c}\text { Number of } \\
\text { samples }\end{array}$} & \multicolumn{3}{|c|}{ Concentration $^{a}$} & \multirow{2}{*}{$\begin{array}{l}\text { Standard } \\
\text { error }\end{array}$} & \multirow{2}{*}{$\begin{array}{c}\text { Percentage } \\
\text { of } \\
\text { DCG }\end{array}$} \\
\hline & & $\operatorname{Max}$ & Min & $A v$ & & \\
\hline Mercury & 10 & 0.0045 & $<0.0002$ & $<0.0026$ & 0.106 & $b$ \\
\hline Oil and grease & 12 & 24.0 & $<2.0$ & $<6.1$ & 1.7 & $b$ \\
\hline Total suspended solids & 12 & 44.0 & 16.0 & 27.3 & 2.8 & $b$ \\
\hline Cyanide & 12 & 0.0070 & $<0.0020$ & $<0.0020$ & 0.0004 & $b$ \\
\hline Ammonia & 12 & 9.0 & 2.1 & 6.9 & 0.6 & $b$ \\
\hline Kjeldahl nitrogen & 12 & 16.0 & 7.8 & 11.7 & 0.6 & $b$ \\
\hline Sélenium & 12 & 0.0030 & $<0.0020$ & $<0.0021$ & 0.0001 & $b$ \\
\hline Biochemical oxygen demand $\dagger$ & 11 & $52.6 \dagger$ & 16 & $29.4 \dagger$ & $12+$ & $b$ \\
\hline Chemical oxygen demand & 12 & 150 & 23 & 68 & 9 & $b$ \\
\hline Chromium +6 & 12 & $<0.01$ & $<0.01$ & $<0.01$ & 0.00 & $b$ \\
\hline $\mathrm{pH}$, standard units & 10 & 7.9 & 6.9 & $b$ & 1.7 & $b$ \\
\hline Aluminum & 12 & 0.41 & 0.11 & 0.19 & 0.03 & $b$ \\
\hline Arsenic & 12 & $<0.04$ & $<0.04$ & $<0.04$ & 0.00 & $b$ \\
\hline Barium & 12 & 0.06 & 0.03 & 0.04 & 0.00 & $b$ \\
\hline Beryllium & 12 & $<0.0004$ & $<0.0004$ & $<0.0004$ & 0.0000 & $b$ \\
\hline Boron & 12 & 0.047 & 0.021 & 0.030 & 0.002 & $b$ \\
\hline Cadmium & 12 & $<0.004$ & $<0.004$ & $<0.004$ & 0.000 & $b$ \\
\hline Calcium & 12 & 39.6 & 34.4 & 36.8 & 0.5 & $b$ \\
\hline Cerium & 12 & $<0.02$ & $<0.02$ & $<0.02$ & 0.00 & $b$ \\
\hline Chromium & 12 & $<0.006$ & $<0.006$ & $<0.006$ & 0.000 & $b$ \\
\hline Cobalt & 12 & $<0.002$ & $<0.002$ & $<0.002$ & 0.000 & $b$ \\
\hline Copper & 12 & 0.037 & 0.008 & 0.015 & 0.002 & $b$ \\
\hline Gallium & 12 & $<0.02$ & $<0.02$ & $<0.02$ & 0.00 & $b$ \\
\hline Iron & 12 & 0.51 & 0.11 & 0.25 & 0.03 & $b$ \\
\hline Lanthanum & 0 & 0.0000 & 0.0000 & 0.0000 & 0.0000 & $b$ \\
\hline Lead & 12 & $<0.02$ & $<0.02$ & $<0.02$ & 0.00 & $b$ \\
\hline Lithium & 12 & $<0.02$ & $<0.02$ & $<0.02$ & 0.00 & $b$ \\
\hline Magnesium & 12 & 10.50 & 8.15 & 9.19 & 0.20 & $b$ \\
\hline Mangenese & 12 & 0.047 & 0.027 & 0.037 & 0.002 & $b$ \\
\hline Molybdenum & 12 & $<0.006$ & $<0.006$ & $<0.006$ & 0.000 & $b$ \\
\hline Nickel & 12 & $<0.008$ & $<0.008$ & $<0.008$ & 0.106 & $b$ \\
\hline Niobium & 12 & $<0.01$ & $<0.01$ & $<0.01$ & 0.11 & $b$ \\
\hline Phosphorus & 12 & 3.66 & 1.45 & 2.37 & 0.11 & $b$ \\
\hline Potassium & 12 & 6.9 & 4.5 & 5.7 & 0.2 & $b$ \\
\hline Scandium & 12 & $<0.0004$ & $<0.0004$ & $<0.0004$ & 0.0000 & $b$ \\
\hline Silver & 12 & 0.017 & $<0.006$ & $<0.008$ & 0.001 & $b$ \\
\hline Sodium & 12 & 16.7 & 8.9 & 12.5 & 0.6 & $b$ \\
\hline Strontium & 12 & 0.128 & 0.086 & 0.098 & 0.003 & $b$ \\
\hline Thorium & 12 & $<0.01$ & $<0.01$ & $<0.01$ & 0.00 & $b$ \\
\hline Titanium & 12 & $<0.01$ & $<0.01$ & $<0.01$ & 0.00 & $b$ \\
\hline Vanadium & 12 & $<0.004$ & $<0.004$ & $<0.004$ & 0.000 & $b$ \\
\hline Zinc & 12 & 0.27 & 0.07 & 0.14 & 0.01 & $b$ \\
\hline Zirconium & 12 & $<0.004$ & $<0.004$ & $<0.004$ & 0.000 & $b$ \\
\hline Alpha activity (pCi/L) & 12 & 5.8 & -2.4 & 1.6 & 0.8 & $b$ \\
\hline Beta activity (pCi/L) & 12 & 13.0 & 7.0 & 9.7 & 0.5 & $b$ \\
\hline${ }^{235} \mathrm{U}(\%)$ & 9 & 0.83 & 0.40 & 0.61 & 0.04 & $b$ \\
\hline $\mathrm{U}$, total & 12 & 0.003 & $<0.001$ & $<0.001$ & 0.000 & $b$ \\
\hline Gamma, total (pCi/L) & 12 & 190.0 & 3.5 & 62.0 & 15.2 & $b$ \\
\hline
\end{tabular}

${ }^{a}$ All units are in $\mathrm{mg} / \mathrm{L}$ unless noted otherwise.

${ }^{b}$ Not applicable. 
Vol. 2, p. 4-9:

Table 4.7. 1991 annual radiological and nonradiological data summary for the Biology Sewer, Y-12 Plant

\begin{tabular}{|c|c|c|c|c|c|c|}
\hline \multirow{2}{*}{ Parameter } & \multirow{2}{*}{$\begin{array}{c}\text { Number of } \\
\text { samples }\end{array}$} & \multicolumn{5}{|c|}{ Concentration ${ }^{a}$} \\
\hline & & $\operatorname{Max}$ & $\operatorname{Min}$ & Av & $\begin{array}{l}\text { Standard } \\
\text { error }\end{array}$ & $\begin{array}{c}\text { Percentage } \\
\text { of DCG }\end{array}$ \\
\hline Mercury & 12 & 0.0009 & $<0 .(0) 02$ & $<0.000) 3$ & 0.0001 & $b$ \\
\hline Oil and grease & 12 & 9 & $<2$ & $<3.0000$ & 0.6155 & $b$ \\
\hline Total suspended solids & 12 & 23 & $<5$ & $<7.1667$ & 1.5267 & $b$ \\
\hline Cyanide & 12 & 3 & $<0.002$ & $<0.2764$ & 0.2482 & $b$ \\
\hline Ammonia & 12 & 1.7 & $<0.2$ & $<0.7525$ & 0.1298 & $b$ \\
\hline Kjeldahl nitrogen & 12 & 4.3 & 0.7 & 1.6617 & 0.2937 & $b$ \\
\hline Selenium & 12 & $<0.002$ & $<0.002$ & $<0.0020$ & 0.0000 & $b$ \\
\hline Biochemical oxygen demand & 12 & 29 & 6.66 & 15.3742 & 2.2759 & $b$ \\
\hline Chemical oxygen demand & 12 & 86 & 15 & 35.1667 & 5.1696 & $b$ \\
\hline Chromium +6 & 12 & 0.01 & $<0.01$ & $<0.0100$ & 0.0000 & $b$ \\
\hline $\mathrm{pH}$, standard units & 12 & 9 & 7.2 & $b$ & 0.1474 & $b$ \\
\hline Aluminum & 12 & 0.64 & 0.05 & 0.1858 & 0.0472 & $b$ \\
\hline Arsenic & 12 & $<0.04$ & $<0.04$ & $<0.0400$ & 0.0000 & $b$ \\
\hline Barium & 12 & 0.0517 & 0.0246 & 0.0302 & 0.0022 & $b$ \\
\hline Beryllium & 12 & $<0.0004$ & $<0.0004$ & $<0.0004$ & 0.0000 & $b$ \\
\hline Boron & 12 & 0.311 & 0.009 & 0.0629 & 0.0234 & $b$ \\
\hline Cadmiunı & 12 & $<0.004$ & $<0.004$ & $<0.0040$ & 0.0000 & $b$ \\
\hline Calcium & 12 & 40.5 & 28.3 & 31.4917 & 0.9551 & $b$ \\
\hline Cerium & 12 & $<0.02$ & $<0.02$ & $<0.0200$ & 0.0000 & $b$ \\
\hline Chromium & 12 & 0.01 & $<0.006$ & $<0.0063$ & 0.0003 & $b$ \\
\hline Cobalt & 12 & 0.003 & $<0.002$ & $<0.0021$ & 0.0001 & $b$ \\
\hline Copper & 12 & 0.024 & $<0.006$ & $<0.0108$ & 0.0014 & $b$ \\
\hline Gallium & 12 & $<0.02$ & $<0.02$ & $<0.0200$ & 0.0000 & $b$ \\
\hline Iron & 12 & 0.57 & $<0.06$ & $<0.1033$ & 0.0424 & $b$ \\
\hline Lead & 12 & 0.02 & $<0.02$ & $<0.0200$ & 0.0000 & $b$ \\
\hline Lithium & 12 & 0.12 & $<0.02$ & $<0.0283$ & 0.0083 & $b$ \\
\hline Magnesium & 12 & 14 & 7.56 & 9.1408 & 0.5344 & $b$ \\
\hline Manganese & 12 & 0.066 & 0.003 & 0.0178 & 0.0049 & $b$ \\
\hline Molybdenum & 12 & $<0.007$ & $<0.006$ & $<0.0061$ & 0.0001 & $b$ \\
\hline Nickel & 12 & $<0.008$ & $<0.008$ & $<0.0080$ & 0.0000 & $b$ \\
\hline Niobium & 12 & $<0.01$ & $<0.01$ & $<0.0100$ & 0.0000 & $b$ \\
\hline Phosphorus & 12 & 7.34 & $<0.05$ & $<3.1790$ & 0.5212 & $b$ \\
\hline Potassium & 12 & 3.2 & 1.2 & 1.9417 & 0.1681 & $b$ \\
\hline Scandium & 12 & $<0.0004$ & $<0.0004$ & $<0,0004$ & 0.0000 & $b$ \\
\hline Silver & 12 & 0.259 & $<0.006$ & $<0.0448$ & 0.0256 & $b$ \\
\hline Sodium & 12 & 22.6 & 0.66 & 13.0142 & 1.5874 & $b$ \\
\hline Strontium & 12 & 0.109 & 0.038 & 0.0764 & 0.0052 & $b$ \\
\hline Thorium & 12 & $<0.01$ & $<0.01$ & $<0.0100$ & 0.0000 & $b$ \\
\hline Titanium & 12 & $<0.01$ & $<0.01$ & $<0.0100$ & 0.0000 & $b$ \\
\hline Vanadium & 12 & $<0.004 \uparrow$ & $<0.004$ & $<0.0040$ & 0.0000 & $b$ \\
\hline Zinc & 12 & 0.22 & 0.01 & 0.1200 & 0.0134 & $b$ \\
\hline Zirconium & 12 & $<0.004$ & $<0.004$ & $<0.0040$ & 0.0000 & $b$ \\
\hline Alpha activity (pCi/L) & 12 & 6.6 & -4 & 0.5358 & 1.0635 & $\dot{b}$ \\
\hline Beta activity $(\mathrm{pCi} / \mathrm{L})$ & 12 & 98 & 2.3 & 28.9250 & 9.1971 & $b$ \\
\hline${ }^{235} U(\%)$ & 2 & 0.42 & 0.35 & 0.3850 & 0.0350 & $b$ \\
\hline $\mathrm{U}$, total & 12 & $<0.001$ & $<0.001$ & $<0.0010$ & $0.0000)$ & $b$ \\
\hline Gamma, total (pCi/L) & 12 & 120 & 9.7 & 60.8920 & 12.1498 & $b$ \\
\hline
\end{tabular}

"All units are in $\mathrm{mg} / \mathrm{L}$ unless noted otherwise.

${ }^{b}$ Not applicable. 


\section{Environmental Report Vol. 1, Oak Ridge}

Vol. 2, p. 4-12:

Table 4.13. CY 1991 NPDES Permit Number TN 002968

Discharge Point 302, Y-12 Plant, Roger's Quarry

\begin{tabular}{|c|c|c|c|c|c|}
\hline \multirow[b]{2}{*}{ Parameter } & \multirow{2}{*}{$\begin{array}{l}\text { Number of } \\
\text { samples }\end{array}$} & \multicolumn{4}{|c|}{ Concentration (mg/L) } \\
\hline & & $\operatorname{Max}$ & Min & Av & $\begin{array}{c}\text { Standard } \\
\text { error }\end{array}$ \\
\hline Total suspended solids & 52 & 10 & 5 & 5 & 0 \\
\hline Chemical oxygen demand (COD) & 53 & 11 & 2.3 & 5.7 & 0.2 \\
\hline Sulfate & 53 & 38 & 15 & 22 & 1 \\
\hline Oil and grease & 53 & 12 & $<2$ & $<3$ & 0 \\
\hline Settleable solicis, $\mathrm{ml} / \mathrm{L}$ & 53 & 0.5 & $<0.1$ & $<0.1$ & 0.0 \\
\hline Selenium & 53 & 0.005 & $<0.0002$ & $<0.002$ & 0.000 \\
\hline Mercury & 53 & 0.0006 & $<0.0002$ & $<0.000$ & 0.000 \\
\hline Arsenic & 53 & $<0.2$ & $<0.04$ & $<0.04$ & 0.00 \\
\hline Cadmium & 53 & 0.005 & $<0.004$ & $<0.004 \dagger$ & 0.000 \\
\hline Chromium & 53 & $<0.006$ & $<0.006$ & $<0.006$ & 0.000 \\
\hline Copper & 53 & $<0.006$ & $<0.006$ & $<0.006$ & 0.000 \\
\hline Iron & 53 & 0.32 & $<0.06$ & $<0.08$ & 0.01 \\
\hline Nickel & 53 & $<0.008$ & $<0.008$ & $<0,008$ & 0.000 \\
\hline Zinc & 53 & $<0.01$ & 0.004 & $<0.009$ & 0.000 \\
\hline Lead & 53 & $<0.02$ & $<0.02$ & $<0.02$ & 0.00 \\
\hline $\mathrm{pH}$, standard units & 53 & 9.2 & 7.0 & $a$ & 0.1 \\
\hline Temperature, ${ }^{\circ} \mathrm{C}$ & 53 & 31.2 & 9.5 & 19.4 & 1.0 \\
\hline Turbidity, NTU & 53 & 7.6 & 0.34 & 1.60 & 0.21 \\
\hline Flow, $\mathrm{Mgd}^{b}$ & 365 & 12.76 & 0.07 & 0.89 & 0.08 \\
\hline
\end{tabular}

${ }^{a}$ Not applicable.

${ }^{b}$ Flow during operations and/or dischıarging. 
Vol. 2, p. 4-23:

Table 4.24. CY 1991 NPDES Permit Number TN 002968

Y-12 Plant cooling towers

\begin{tabular}{|c|c|c|c|c|c|c|}
\hline \multirow{2}{*}{ Parameter } & \multirow{2}{*}{$\begin{array}{l}\text { Number of } \\
\text { samples }\end{array}$} & \multirow{2}{*}{$\begin{array}{l}\text { Discharge } \\
\text { point }\end{array}$} & \multicolumn{4}{|c|}{$\begin{array}{c}\text { Concentration } \\
(\mathrm{mg} / \mathrm{L})\end{array}$} \\
\hline & & & Max & Min & Av & $\begin{array}{l}\text { Standard } \\
\text { error }\end{array}$ \\
\hline & & 602 & & & & \\
\hline Temperature, ${ }^{\circ} \mathrm{C}$ & 4 & & 26.7 & 21.3 & 24.7 & 1.3 \\
\hline $\mathrm{pH}$, standard units & 4 & & 8.5 & 7.7 & $a$ & 0.2 \\
\hline Free chlorine & 4 & & 0.02 & 0.01 & 0.015 & 0.003 \\
\hline Chromium & 4 & & $<0.01$ & $<0.01$ & $<0.01$ & 0 \\
\hline Copper & 4 & & 0.019 & 0.012 & 0.015 & 0.001 \\
\hline Zinc & 4 & & 0.06 & 0.03 & 0.04 & 0.01 \\
\hline \multirow[t]{2}{*}{ Flow, gal/d ${ }^{b}$} & 4 & & 9,936 & 3,512 & 6,873 & 1,322 \\
\hline & & 604 & & & & \\
\hline Temperature, ${ }^{\circ} \mathrm{C}$ & 4 & & 27.2 & 15.5 & 21.4 & 2.4 \\
\hline $\mathrm{pH}$, standard unita & 4 & & 8.4 & 8.1 & $a$ & 0.1 \\
\hline Free chlorine & 4 & & 0.02 & $<0.01$ & 0.015 & 0.003 \\
\hline Chromium & 4 & & 0.01 & $<0.01$ & $<0.01 \dagger$ & 0 \\
\hline Copper & 4 & & 0.016 & 0.006 & $<0.011$ & 0.002 \\
\hline Zinc & 4 & & 0.37 & 0.18 & 0.29 & 0.04 \\
\hline \multirow[t]{2}{*}{ Flow, gal/d $b$} & 4 & & 17,986 & 9,803 & 14,146 & 2,184 \\
\hline & & 606 & & & & \\
\hline Temperature, ${ }^{\circ} \mathrm{C}$ & 0 & & & & & \\
\hline $\mathrm{pH}$, standard units & 0 & & & & & \\
\hline Free chlorine & 0 & & & & & \\
\hline Chromium & 0 & & & & & \\
\hline Copper & 0 & & & & & \\
\hline Zinc & 0 & & & & & \\
\hline \multirow[t]{2}{*}{ Flow, gal/d $d^{b}$} & 0 & & & & & \\
\hline & & 610 & & & & \\
\hline Temperature, ${ }^{\circ} \mathrm{C}$ & 4 & & 31.5 & 24.8 & 28.3 & 1.4 \\
\hline $\mathrm{pH}$, standard units & 4 & & 8.5 & 8.2 & $a$ & 0.1 \\
\hline Free chlorine & 4 & & 0.006 & 0.01 & 0.036 & 0.014 \\
\hline Chromium & 4 & & $<0.07$ & $<0.01$ & $<0.01$ & 0.01 \\
\hline Copper & 4 & & 0.04 & 0.011 & 0.021 & 0.007 \\
\hline Zinc & 4 & & 0.19 & 0.04 & 0.09 & 0.04 \\
\hline \multirow[t]{2}{*}{ Flow, gal/d $\mathrm{d}^{b}$} & 4 & & 13,416 & 7,762 & 10,310 & 1,367 \\
\hline & & 612 & & & & \\
\hline Temperature, ${ }^{\circ} \mathrm{C}$ & 3 & & 24.9 & 23.5 & 24 & 0.5 \\
\hline $\mathrm{pH}$, standard units & 3 & & 8.3 & 7.9 & $a$ & 0.1 \\
\hline Free chlorine & 3 & & 0.15 & 0.02 & 0.067 & 0.042 \\
\hline Chromium & 3 & & 0.01 & $<0.01$ & $<0.01$ & 0 \\
\hline Copper & 3 & & $<0.022$ & 0.013 & $<0.019 \dagger$ & 0.003 \\
\hline Zinc & 3 & & 0.16 & 0.1 & 0.13 & 0.02 \\
\hline Flow, gal/d $b$ & 3 & & 30,272 & 8,072 & 18,014 & 6,512 \\
\hline
\end{tabular}


1992 Environmental Report Vol. 1, Oak Ridge

Table 4.24 (continued)

\begin{tabular}{|c|c|c|c|c|c|c|}
\hline \multirow{2}{*}{ Parameter } & \multirow{2}{*}{$\begin{array}{l}\text { Number of } \\
\text { samples }\end{array}$} & \multirow{2}{*}{$\begin{array}{c}\text { Discharge } \\
\text { point }\end{array}$} & \multicolumn{4}{|c|}{$\begin{array}{c}\text { Concentration } \\
(\mathrm{mg} / \mathrm{L})\end{array}$} \\
\hline & & & $\operatorname{Max}$ & $\operatorname{Min}$ & Av & $\begin{array}{l}\text { Standard } \\
\text { error }\end{array}$ \\
\hline & & 613 & & & & \\
\hline Temperature, ${ }^{\circ} \mathrm{C}$ & 4 & & 29.3 & 25.6 & 27.3 & 0.8 \\
\hline $\mathrm{pH}$, standard units & 4 & & 8.5 & 8.2 & $a$ & 0.1 \\
\hline Free chlorine & 4 & & 0.05 & 0.02 & 0.035 & 0.006 \\
\hline Chromium & 4 & & $<0.05$ & $<0.02$ & $<0.04$ & 0.01 \\
\hline Copper & 4 & & 0.014 & 0.012 & 0.013 & 0 \\
\hline Zinc & 4 & & 0.07 & 0.02 & 0.05 & 0.01 \\
\hline \multirow[t]{2}{*}{ Flow, gal/d $\mathrm{d}^{h}$} & 4 & & 41,835 & 14,275 & 29,001 & 6,055 \\
\hline & & 615 & & & & \\
\hline Temperature, ${ }^{\circ} \mathrm{C}$ & 4 & & 24.2 & 12.8 & 20.6 & 2.6 \\
\hline $\mathrm{pH}$, standard units & 4 & & 8.5 & 7.8 & $a$ & 0.2 \\
\hline Free chlorine & 4 & & 0.02 & 0.01 & 0.015 & 0.003 \\
\hline Chromium & 4 & & $<0.01$ & $<0.01$ & $<0.01$ & 0 \\
\hline Copper & 4 & & 0.315 & 0.058 & 0.142 & 0.06 \\
\hline Zinc & 4 & & 2.52 & 0.1 & 0.9 & 0.55 \\
\hline Flow, gal/d $\mathrm{d}^{b}$ & 4 & & 3,696 & 1,031 & 1,949 & 602 \\
\hline
\end{tabular}

Temperature, ${ }^{\circ} \mathrm{C}$

616

$\mathrm{pH}$, standard units

Free chlorine

Chromium

Copper

Zinc

Flow, gal/d $d^{b}$

617

Temperature, ${ }^{\circ} \mathrm{C}$

$\mathrm{pH}$, standard units

Free chlorine

Chromium

Copper

Zinc

Flow, gal/d $d^{b}$

0

0

0

0

0

0

Temperature, ${ }^{\circ} \mathrm{C}$

$\mathrm{pH}$, standard units

Free chlorine

Chromium

Copper

Zinc

Flow, gal/d ${ }^{h}$
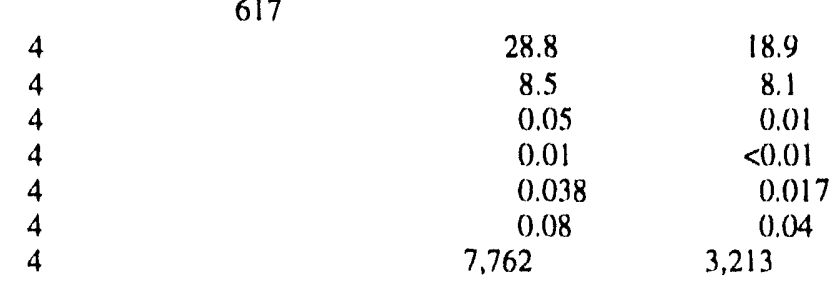
23.7
a
0.03
$<0.01$
0.025
0.06
5,395

$$
2
$$

0.1

0.0099

$$
\begin{aligned}
& 0 \\
& 0.0055
\end{aligned}
$$$$
0.01
$$

618

$\begin{array}{cc}25.6 \dagger & 24.1 \dagger \\ 8.5 \dagger & 7.9 \dagger \\ 0.02 & <0.01 \\ <0.01 & <0.01 \\ 0.026 \dagger & 0.018 \dagger \\ 0.06 \dagger & 0.04 \dagger \\ 16.114 \dagger & 3.336 \dagger\end{array}$

24.7
$a$
$<0.018$
$<0.01$
$0.023 \dagger$
0.05
10,031

$0.6 \dagger$
0.1
0.003
0
$0.003 \dagger$
$0.01 \dagger$
$4,935 \dagger$




\section{Environmental Report Vol. 1, Oak Ridge}

Table 4.24 (continued)

\begin{tabular}{|c|c|c|c|c|c|c|}
\hline \multirow{2}{*}{ Parameter } & \multirow{2}{*}{$\begin{array}{l}\text { Number of } \\
\text { samples }\end{array}$} & \multirow{2}{*}{$\begin{array}{l}\text { Discharge } \\
\text { point }\end{array}$} & \multicolumn{4}{|c|}{$\begin{array}{c}\text { Concentration } \\
(\mathrm{mg} / \mathrm{L})\end{array}$} \\
\hline & & & $\operatorname{Max}$ & Min & Av & $\begin{array}{l}\text { Standard } \\
\text { error }\end{array}$ \\
\hline & & 619 & & & & \\
\hline Temperature, ${ }^{\circ} \mathrm{C}$ & 4 & & 29.2 & 24 & 25.9 & 1.2 \\
\hline $\mathrm{pH}$, standard units & 4 & & 8.4 & 7.4 & $a$ & 0.2 \\
\hline Free chlorine & 4 & & 0.04 & 0.01 & 0.028 & 0.008 \\
\hline Chromium & 4 & & $<0.03$ & $<0.01$ & $<0.01$ & 0.01 \\
\hline Copper & 4 & & 0.118 & 0.008 & 0.05 & 0.024 \\
\hline Zinc & 4 & & 0.59 & 0.02 & 0.19 & 0.13 \\
\hline \multirow[t]{2}{*}{ Flow, gal/d $\mathrm{d}^{h}$} & 4 & & 11,798 & 6,900 & 8,274 & 1,178 \\
\hline & & 620 & & & & \\
\hline Temperature, ${ }^{\circ} \mathrm{C}$ & 4 & & 27.3 & 17.6 & 24.5 & 2.3 \\
\hline $\mathrm{pH}$, standard units & 4 & & 8.3 & 7.8 & $a$ & 0.1 \\
\hline Free chlorine & 4 & & 0.07 & 0.01 & 0.03 & 0.014 \\
\hline Chromium & 4 & & $<0.01$ & $<0.01$ & $<0.01$ & 0 \\
\hline Copper & 4 & & 0.135 & 0.038 & 0.087 & 0.022 \\
\hline Zinc & 4 & & 0.88 & 0.37 & 0.59 & 0.11 \\
\hline \multirow[t]{2}{*}{ Flow, gal/d ${ }^{b}$} & 4 & & 6,323 & 790 & 3,375 & 1,142 \\
\hline & & 622 & & & & \\
\hline Temperature, ${ }^{\circ} \mathrm{C}$ & 4 & & 31.8 & 26.8 & 29 & 1.1 \\
\hline $\mathrm{pH}$, standard units & 4 & & 8.5 & 8.2 & $a$ & 0.1 \\
\hline Free chlorine & 4 & & 0.2 & $<0.01$ & $<0.08$ & 0.043 \\
\hline Chromium & 4 & & $<0.01$ & $<0.01$ & $<0.01$ & 0 \\
\hline Copper & 4 & & 0.01 & 0.006 & 0.008 & $0 .(x) 1$ \\
\hline Zinc & 4 & & 0.04 & 0.02 & 0.03 & 0 \\
\hline \multirow[t]{2}{*}{ Flow, gal/d $d^{b}$} & 4 & & 14,950 & 9,810 & 12,803 & 1,287 \\
\hline & & 624 & & & & \\
\hline Temperature, ${ }^{\circ} \mathrm{C}$ & 0 & & & & & \\
\hline $\mathrm{pH}$, standard units & 0 & & & & & \\
\hline Free chlorine & 0 & & & & & \\
\hline Chromium & 0 & & & & & \\
\hline Copper & 0 & & & & & \\
\hline Zinc & 0 & & & & & \\
\hline \multirow[t]{2}{*}{ Flow, gal/d $\mathrm{d}^{b}$} & 0 & & & & & \\
\hline & & 626 & & & & \\
\hline Temperature, ${ }^{\circ} \mathrm{C}$ & 5 & & 21.4 & 9.9 & 13.9 & 2.1 \\
\hline pH, standard units & 5 & & 8.4 & 7.8 & $a$ & 0.1 \\
\hline Free chlorine & 5 & & 0.98 & $<0.01$ & $<0.214$ & 0.192 \\
\hline Chromium & 5 & & $<0.08$ & $<0.01$ & $<0.02$ & 0.01 \\
\hline Copper & 5 & & 0.059 & 0.009 & 0.035 & 0.009 \\
\hline Zinc & 5 & & 0.13 & 0.02 & 0.08 & 0.02 \\
\hline Flow, gal/d ${ }^{b}$ & 5 & & 26,000 & 923 & 7,449 & 4,696 \\
\hline
\end{tabular}


1992 Environmental Report Vol. 1, Oak Ridge

Table 4.24 (continued)

\begin{tabular}{|c|c|c|c|c|c|c|}
\hline \multirow{2}{*}{ Parameter } & \multirow{2}{*}{$\begin{array}{l}\text { Number of } \\
\text { samples }\end{array}$} & \multirow{2}{*}{$\begin{array}{l}\text { Discharge } \\
\text { point }\end{array}$} & \multicolumn{4}{|c|}{$\begin{array}{c}\text { Concentration } \\
(\mathrm{mg} / \mathrm{L})\end{array}$} \\
\hline & & & $\operatorname{Max}$ & Min & Av & $\begin{array}{l}\text { Standard } \\
\text { error }\end{array}$ \\
\hline & & 628 & & & & \\
\hline Temperature, ${ }^{\circ} \mathrm{C}$ & 4 & & 30.3 & 24.8 & 27.6 & 1.3 \\
\hline $\mathrm{pH}$, standard units & 4 & & 8.5 & 7.8 & $a$ & 0.2 \\
\hline Free chlorine & 4 & & 0.1 & 0.02 & 0.04 & 0.02 \\
\hline Chromium & 3 & & 0.07 & 0.01 & 0.03 & 0.02 \\
\hline Copper & 3 & & 0.054 & 0.012 & 0.027 & 0.013 \\
\hline Zinc & 3 & & 0.31 & 0.08 & 0.16 & 0.08 \\
\hline \multirow[t]{2}{*}{ Flow, gal/d $b$} & 4 & & 24,150 & 10,278 & 16,308 & 3,142 \\
\hline & & 630 & & & & \\
\hline Temperature, ${ }^{\circ} \mathrm{C}$ & 4 & & 28.3 & 20.7 & 24.8 & 1.6 \\
\hline $\mathrm{pH}$, standard units & 4 & & 8.5 & 8.1 & $a$ & 0.1 \\
\hline Free chlorine & 4 & & 0.1 & 0.02 & 0 & 0.019 \\
\hline Chromium & 4 & & 0.01 & $<0.01$ & $<0.01$ & 0 \\
\hline Copper & 4 & & 0.072 & 0.014 & 0.034 & 0.013 \\
\hline Zinc & 4 & & 0.1 & 0.02 & 0.07 & 0.02 \\
\hline \multirow[t]{2}{*}{ Flow, gal/d $\mathrm{d}^{b}$} & 4 & & 4,761 & 3,450 & 3,815 & 317 \\
\hline & & 632 & & & & \\
\hline Temperature, ${ }^{\circ} \mathrm{C}$ & 3 & & 28.1 & 18.9 & 23 & 2.7 \\
\hline $\mathrm{pH}$, standard units & 3 & & 8.3 & 8.3 & $a$ & 0 \\
\hline Free chlorine & 3 & & 0.05 & 0.015 & 0.028 & 0.011 \\
\hline Chromium & 3 & & $<0.01$ & $<0.01$ & $<0.01$ & 0 \\
\hline Copper & 3 & & 0.066 & 0.041 & 0.057 & 0.008 \\
\hline Zinc & 3 & & 0.1 & 0.07 & 0.09 & 0.01 \\
\hline \multirow[t]{2}{*}{ Flow, gal/d $b$} & 3 & & 6,037 & 3,080 & 4,066 & 986 \\
\hline & & 633 & & & & \\
\hline Temperature, ${ }^{\circ} \mathrm{C}$ & 0 & & & & & \\
\hline $\mathrm{pH}$, standard units & 0 & & & & & \\
\hline Free chlorine & 0 & & & & & \\
\hline Chromium & 0 & & & & & \\
\hline Copper & 0 & & & & & \\
\hline Zinc & 0 & & & & & \\
\hline \multirow[t]{2}{*}{ Flow, gal/d $d^{b}$} & 0 & & & & & \\
\hline & & 634 & & & & \\
\hline Temperature, ${ }^{\circ} \mathrm{C}$ & 4 & & 27.4 & 19.9 & 22.8 & 1.6 \\
\hline $\mathrm{pH}$, standard units & 4 & & 8.5 & 8.2 & $a$ & 0.1 \\
\hline Free chlorine & 4 & & 0.06 & 0.01 & 0.035 & 0.01 \\
\hline Chromium & 4 & & $<0.01$ & $<0.01$ & $<0.01$ & 0 \\
\hline Copper & 4 & & 0.021 & 0.01 & 0.017 & 0.003 \\
\hline Zinc & 4 & & 0.11 & 0.09 & 0.1 & 0 \\
\hline Flow, gal $/ \mathrm{d}^{b}$ & 4 & & 71,760 & 9,711 & 31,965 & 13,833 \\
\hline
\end{tabular}

"Not applicable.

bFlow during operation and/or discharging. 


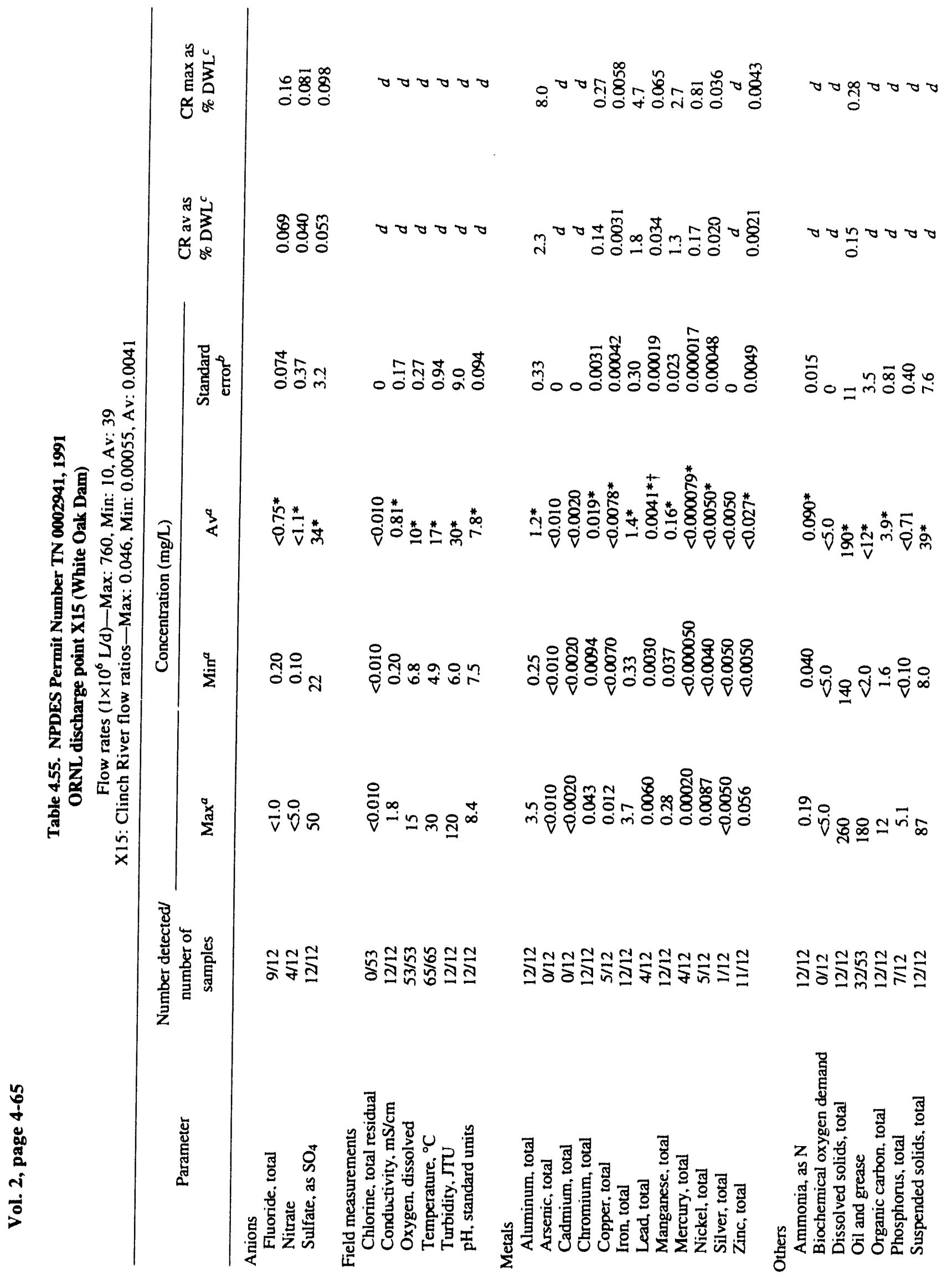




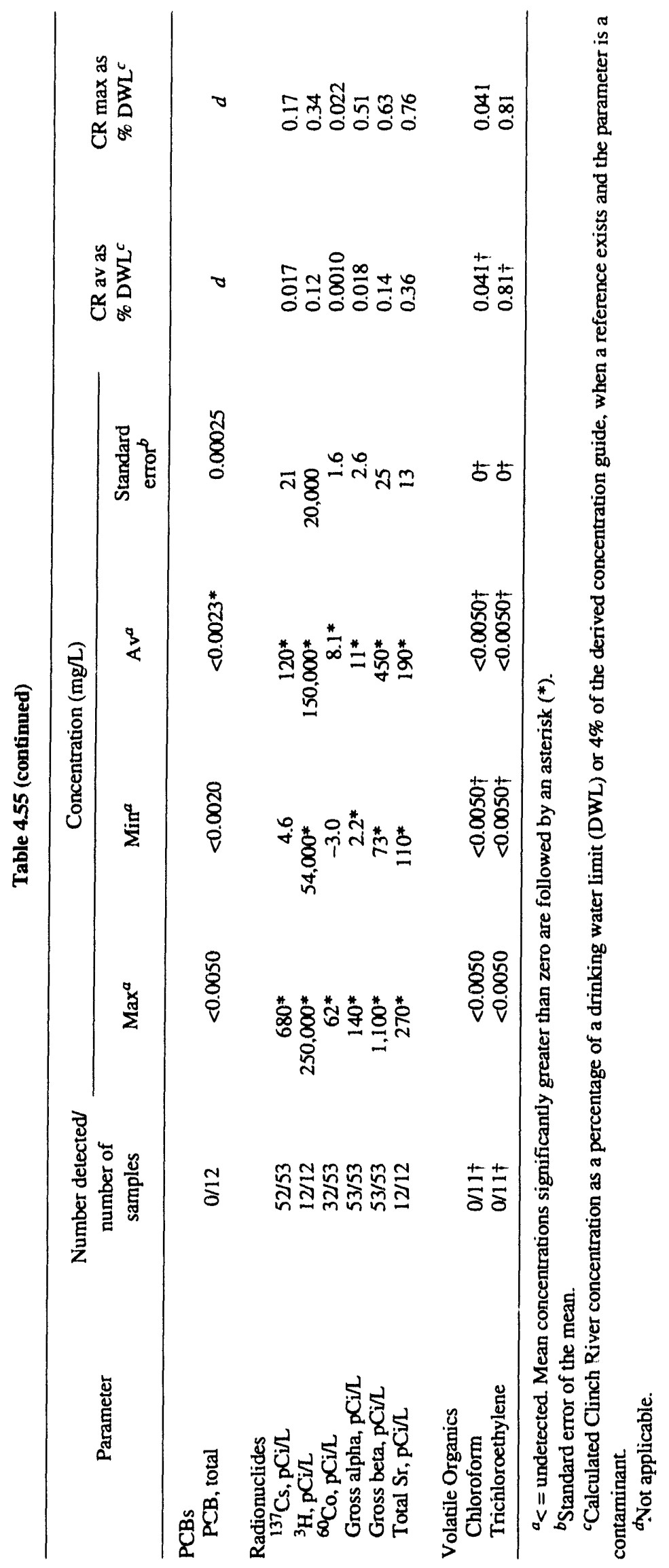


1992 Environmental Report Vol. 1, Oak Ridge

Vol. 2, p. 4-76:

Table 4.72. 1991 K-25 Site concentrations at West Fork Poplar Creek

\begin{tabular}{|c|c|c|c|c|}
\hline \multirow[b]{2}{*}{ Parameter } & \multicolumn{4}{|c|}{ Concentration $(\mu \mathrm{g} / \mathrm{L})^{a \dagger}$} \\
\hline & $\operatorname{Max}$ & Min & Av & $\begin{array}{l}\text { Standard } \\
\text { deviation }\end{array}$ \\
\hline 1,1,1-Trichloroethane & $<5$ & $<5$ & $<5$ & 0 \\
\hline $1,1,2,2$-Tetrachloroethane & $<5$ & $<5$ & $<5$ & 0 \\
\hline $1,1,2$-Trichloroethane & $<5$ & $<5$ & $<5$ & 0 \\
\hline 1,1-Dichloroethane & $<5$ & $<5$ & $<5$ & 0 \\
\hline 1,1-Dichloroethene & $<5$ & $<5$ & $<5$ & 0 \\
\hline 1,2,4-Trichlorobenzene & $<10$ & $<10$ & $<10$ & 0 \\
\hline 1,2-Dichlorobenzene & $<10$ & $<10$ & $<10$ & 0 \\
\hline 1,2-Dichloroethane & $<5$ & $<5$ & $<5$ & 0 \\
\hline 1,2-Dichloropropane & $<5$ & $<5$ & $<5$ & 0 \\
\hline 1,3-Dichlorobenzene & $<10$ & $<10$ & $<10$ & 0 \\
\hline 1,4-Dichlorobenzene & $<10$ & $<10$ & $<10$ & 0 \\
\hline 2,4,6-Trichlorophenol & $<10$ & $<10$ & $<10$ & 0 \\
\hline 2,4-Dichlorophenol & $<10$ & $<10$ & $<10$ & 0 \\
\hline 2,4-Dimethylphenol & $<10$ & $<10$ & $<10$ & 0 \\
\hline 2,4-Dinitrophenol & $<10$ & $<10$ & $<10$ & 0 \\
\hline 2,4-Dinitrotoluene & $<10$ & $<10$ & $<10$ & 0 \\
\hline 2,6-Dinitrotoluene & $<10$ & $<10$ & $<10$ & 0 \\
\hline 2-Chloroethylvinyl ether & $<10$ & $<10$ & $<10$ & 0 \\
\hline 2-Chloronaphthalene & $<10$ & $<10$ & $<10$ & 0 \\
\hline 2-Chlorophenol & $<10$ & $<10$ & $<10$ & 0 \\
\hline 2-Nitrophenol & $<10$ & $<10$ & $<10$ & 0 \\
\hline 3,3-Dichlorobenzidine & $<20$ & $<20$ & $<20$ & 0 \\
\hline 4,6-Dinitro-2-methylphenol & $<50$ & $<50$ & $<50$ & 0 \\
\hline 4-Bromophenyl-phenylether & $<10$ & $<10$ & $<10$ & 0 \\
\hline 4-Chloro-3-methylphenol & $<10$ & $<10$ & $<10$ & 0 \\
\hline 4-Chlorophenyl-phenylether & $<10$ & $<10$ & $<10$ & 0 \\
\hline 4-Nitrophenol & $<50$ & $<50$ & $<50$ & 0 \\
\hline Acenaphthene & $<10$ & $<10$ & $<10$ & 0 \\
\hline Acenaphthylene & $<10$ & $<10$ & $<10$ & 0 \\
\hline Ammonia nitrogen & $<200$ & $<200$ & $<200$ & 0 \\
\hline Anthracene & $<10$ & $<10$ & $<10$ & 0 \\
\hline Arsenic & $<5$ & $<5$ & $<5$ & 0 \\
\hline Benzene & $<5$ & $<5$ & $<5$ & 0 \\
\hline Benzidine & $<10$ & $<10$ & $<10$ & 0 \\
\hline Benzo(a)anthracene & $<10$ & $<10$ & $<10$ & 0 \\
\hline Benzo(a)pyrene & $<10$ & $<10$ & $<10$ & 0 \\
\hline Benzo(b)fluoranthene & $<10$ & $<10$ & $<10$ & 0 \\
\hline Benzo(g,h,i)perylene & $<10$ & $<10$ & $<10$ & 0 \\
\hline Benzo(k)fluoranthene & $<10$ & $<10$ & $<10$ & 0 \\
\hline bis(2-Chloroethoxy)methane & $<10$ & $<10$ & $<10$ & 0 \\
\hline bis (2-Chloroethyl)ether & $<10$ & $<10$ & $<10$ & 0 \\
\hline bis(2-Chloroisopropyl)ether & $<10$ & $<10$ & $<10$ & 0 \\
\hline bis(2-Ethylhexyl)phthalate & $<10$ & $<10$ & $<10$ & 0 \\
\hline Bromodichloromethane & $<5$ & $<5$ & $<5$ & 0 \\
\hline Rromoform & $<5$ & $<5$ & $<5$ & 0 \\
\hline Bromomethane & $<10$ & $<10$ & $<10$ & 0 \\
\hline Butylbenzylphthalate & $<10$ & $<10$ & $<10$ & 0 \\
\hline Cadmium & $<2$ & $<2$ & $<2$ & 0 \\
\hline Carbon tetrachloride & $<5$ & $<5$ & $<5$ & 0 \\
\hline Chemical oxygen demand (COD) & 21,000 & 7,000 & 13,000 & 5,571 \\
\hline Chlorobenzene & $<5$ & $<5$ & $<5$ & 0 \\
\hline Chloroethane & $<10$ & $<10$ & $<10$ & 0 \\
\hline
\end{tabular}


1992 Environmental Report Vol. 1, Oak Ridge

Table 4.72 (continued)

\begin{tabular}{|c|c|c|c|c|}
\hline \multirow[b]{2}{*}{ Parameter } & \multicolumn{4}{|c|}{ Concentration $(\mu \mathrm{g} / \mathrm{L})^{a \dagger}$} \\
\hline & Max & $\operatorname{Min}$ & Av & $\begin{array}{l}\text { Standard } \\
\text { deviation }\end{array}$ \\
\hline Chloroform & $<5$ & $<5$ & $<5$ & 0 \\
\hline Chloromethane & $<10$ & $<10$ & $<10$ & 0 \\
\hline Chromium & $<10$ & $<10$ & $<10$ & 0 \\
\hline Chrysene & $<10$ & $<10$ & $<10$ & 0 \\
\hline cis-1,3-Dichloropropene & $<5$ & $<5$ & $<5$ & 0 \\
\hline Copper & 8.6 & 8.6 & 8.6 & 0.0 \\
\hline Cyanide colorimetric & $<100$ & $<100$ & $<100$ & 0 \\
\hline Di-n-butylphthalate & $<10$ & $<10$ & $<10$ & 0 \\
\hline Di-n-octylphthalate & $<10$ & $<10$ & $<10$ & 0 \\
\hline Dibenz(a,h)anthracene & $<10$ & $<10$ & $<10$ & 0 \\
\hline Dibromochloromethane & $<5$ & $<5$ & $<5$ & 0 \\
\hline Diethylphthalate & $<10$ & $<10$ & $<10$ & 0 \\
\hline Dimethylphthalate & $<10$ & $<10$ & $<10$ & 0 \\
\hline Dissolved solids & 214,000 & 80,000 & 155,500 & 49,406 \\
\hline Ethylbenzene & $<5$ & $<5$ & $<5$ & 0 \\
\hline Fluoranthane & $<10$ & $<10$ & $<10$ & 0 \\
\hline Fluorene & $<10$ & $<10$ & $<10$ & 0 \\
\hline Flouride & IC & 100 & 100 & 0 \\
\hline Hexachlorobenzene & $<10$ & $<10$ & $<10$ & 0 \\
\hline Hexachlorobutadiene & $<10$ & $<10$ & $<10$ & 0 \\
\hline Hexachlorocyclopentadiene & $<10$ & $<10$ & $<10$ & 0 \\
\hline Hexachloroethane & $<10$ & $<10$ & $<10$ & 0 \\
\hline Ideno(1,2,3-cd)pyrene & $<10$ & $<\mathrm{rO}$ & $<10$ & 0 \\
\hline Isophorone & $<10$ & $<10$ & $<10$ & 0 \\
\hline Lead & 8.1 & 8.1 & 8.1 & 0.0 \\
\hline Manganese & 300.0 & 89.3 & 162.3 & 91.4 \\
\hline Mercury & $<0.2$ & $<0.2$ & $<0.2$ & 0.0 \\
\hline Methylene chloride & $<5$ & $<5$ & $<5$ & 0 \\
\hline $\mathrm{N}$-nitroso-di-n-propylamine & $<10$ & $<10$ & $<10$ & 0 \\
\hline $\mathrm{N}$-nitrpsodimethylamine & $<10$ & $<10$ & $<10$ & 0 \\
\hline $\mathrm{N}$-nitrodiphenylamine & $<10$ & $<10$ & $<10$ & 0 \\
\hline Naphthalene & $<10$ & $<10$ & $<10$ & 0 \\
\hline Nickel & $<10$ & $<10$ & $<10$ & 0 \\
\hline Nitrate nitrogen & 390 & 200 & 313 & 82 \\
\hline Nitrobenzene & $<10$ & $<10$ & $<10$ & 0 \\
\hline Pentachlorophenol & $<50$ & $<50$ & $<50$ & 0 \\
\hline $\mathrm{pH}$, standard units & 7.95 & 7.60 & 7.79 & 0.13 \\
\hline Phenanthrene & $<10$ & $<10$ & $<10$ & 0 \\
\hline Phenol & $<10$ & $<10$ & $<10$ & 0 \\
\hline Pyrene & $<10$ & $<10$ & $<10$ & 0 \\
\hline Sodium & 6,100 & 2,000 & 4,330 & 1,677 \\
\hline Sulfate & 51,000 & 27,000 & 38,000 & 7,720 \\
\hline Suspended solids & 28000 & 8000 & 18000 & 0 \\
\hline Tetrachloroethene & $<5$ & $<5$ & $<5$ & 0 \\
\hline Toluene & $<5$ & $<5$ & $<5$ & 0 \\
\hline trans-1,2-Dichloroethene & $<5$ & $<5$ & $<5$ & 0 \\
\hline trans-1,3-Dichloropropene & $<5$ & $<5$ & $<5$ & 0 \\
\hline Trichloroethene & $<5$ & $<5$ & $<5$ & 0 \\
\hline Trichlorofluoromethane & & & & 0 \\
\hline Uranium fluorometric & $<1$ & $<1$ & $<1$ & 0 \\
\hline Vinyl chloride & $<10$ & $<10$ & $<10$ & 0 \\
\hline Zinc & 12 & 6.5 & 8.8 & 2.3 \\
\hline
\end{tabular}

"The values for $\mathrm{pH}$ are in standard units. 
1992 Environmental Report Vol. 1, Oak Ridge

Vol. 2, p. 4-78:

Table 4.73. 1991 K-25 Site concentrations at Clinch River (Brashear Island)

\begin{tabular}{|c|c|c|c|c|}
\hline \multirow[b]{2}{*}{ Parameter } & \multicolumn{4}{|c|}{ Concentration $(\mu \mathrm{g} / \mathrm{L})^{a} \dagger$} \\
\hline & Max & $\operatorname{Min}$ & Av & $\begin{array}{l}\text { Standard } \\
\text { deviation }\end{array}$ \\
\hline 1,1,1-Trichloroethane & $<5$ & $<5$ & $<5$ & 0 \\
\hline $1,1,2,2$-Tetrachloroethane & $<5$ & $<5$ & $<5$ & 0 \\
\hline 1,1,2-Trichloroethane & $<5$ & $<5$ & $<5$ & 0 \\
\hline 1,1-Dichloroethane & $<5$ & $<5$ & $<5$ & 0 \\
\hline 1,1-Dichloroethene & $<5$ & $<5$ & $<5$ & 0 \\
\hline 1,2,4-Trichlorobenzene & $<10$ & $<10$ & $<10$ & 0 \\
\hline 1,2-Dichlorobenzene & $<10$ & $<10$ & $<10$ & 0 \\
\hline 1,2-Dichloroethane & $<5$ & $<5$ & $<5$ & 0 \\
\hline 1,2-Dichloropropane & $<5$ & $<5$ & $<5$ & 0 \\
\hline 1,3-Dichlorobenzene & $<10$ & $<10$ & $<10$ & 0 \\
\hline 1,4-Dichlorobenzene & $<10$ & $<10$ & $<10$ & 0 \\
\hline $2,4,6$-Tricillorophenol & $<10$ & $<10$ & $<10$ & 0 \\
\hline 2,4-Dichlorophenol & $<10$ & $<10$ & $<10$ & 0 \\
\hline 2,4-Dimethylphenol & $<10$ & $<10$ & $<10$ & 0 \\
\hline 2,4-Dinitrophenol & $<10$ & $<10$ & $<10$ & 0 \\
\hline 2,4-Dinitrotoluene & $<10$ & $<10$ & $<10$ & 0 \\
\hline 2,6-Dinitrotoluene & $<10$ & $<10$ & $<10$ & 0 \\
\hline 2-Chloroethylviny'l ether & $<10$ & $<10$ & $<10$ & 0 \\
\hline 2-Chloronaphthalene & $<10$ & $<10$ & $<10$ & 0 \\
\hline 2-Chlorophenol & $<10$ & $<10$ & $<10$ & 0 \\
\hline 2-Nitrophenol & $<10$ & $<10$ & $<10$ & 0 \\
\hline 3,3-Dichlorobenzidine & $<20$ & $<20$ & $<20$ & 0 \\
\hline 4,6-Dinitro-2-methylphenol & $<50$ & $<50$ & $<50$ & 0 \\
\hline 4-Bromophenyl-phenylether & $<10$ & $<10$ & $<10$ & 0 \\
\hline 4-Chloro-3-methylphenol & $<10$ & $<10$ & $<10$ & 0 \\
\hline 4-Chlorophenyl-phenylether & $<10$ & $<10$ & $<10$ & 0 \\
\hline 4-Nitrophenol & $<50$ & $<50$ & $<50$ & 0 \\
\hline Acenaphthene & $<10$ & $<10$ & $<10$ & 0 \\
\hline Acenaphthylene & $<10$ & $<10$ & $<10$ & 0 \\
\hline Ammonia nitrogen & $<200$ & $<200$ & $<200$ & 0 \\
\hline Anthracene & $<10$ & $<10$ & $<10$ & 0 \\
\hline Arsenic & $<5$ & $<5$ & $<5$ & 0 \\
\hline Benzene & $<5$ & $<5$ & $<5$ & 0 \\
\hline Benzidine & $<10$ & $<10$ & $<10$ & 0 \\
\hline Benzo(a)anthracene & $<10$ & $<10$ & $<10$ & 0 \\
\hline Benzo(a)pyrene & $<10$ & $<10$ & $<10$ & 0 \\
\hline Benzo(b)fluoranthene & $<10$ & $<10$ & $<10$ & 0 \\
\hline Benzo(g,h,i)perylene & $<10$ & $<10$ & $<10$ & 0 \\
\hline Benzo(k)fluoranthene & $<10$ & $<10$ & $<10$ & 0 \\
\hline bis(2-Chloroethoxy)methane & $<10$ & $<10$ & $<10$ & 0 \\
\hline bis(2-Chloroethyl)ether & $<10$ & $<10$ & $<10$ & 0 \\
\hline bis(2-Chloroisopropyl)ether & $<10$ & $<10$ & $<10$ & 0 \\
\hline bis(2-Ethylhexyl)phthalate & $<10$ & $<10$ & $<10$ & 0 \\
\hline Bromodichloromethane & $<5$ & $<5$ & $<5$ & 0 \\
\hline Bromoform & $<5$ & $<5$ & $<5$ & 0 \\
\hline Bromomethane & $<10$ & $<10$ & $<10$ & 0 \\
\hline Butylbenzylphthalate & $<10$ & $<10$ & $<10$ & 0 \\
\hline Cadmium & $<2$ & $<2$ & $<2$ & 0 \\
\hline Carbon tetrachioride & $<5$ & $<5$ & $<5$ & 0 \\
\hline Chemical oxygen demand (COD) & 16,000 & 15,000 & 15,500 & 500 \\
\hline Chlorobenzene & $<5$ & $<5$ & $<5$ & 0 \\
\hline Chloroethane & $<10$ & $<10$ & $<10$ & 0 \\
\hline
\end{tabular}


Table 4.73 (continued)

\begin{tabular}{|c|c|c|c|c|}
\hline \multirow[b]{2}{*}{ Parameter } & \multicolumn{4}{|c|}{ Concentration $(\mu \mathrm{g} / \mathrm{L})^{a \dagger}$} \\
\hline & $\operatorname{Max}$ & $\operatorname{Min}$ & Av & $\begin{array}{l}\text { Standard } \\
\text { deviation }\end{array}$ \\
\hline Chloroform & $<5$ & $<5$ & $<5$ & 0 \\
\hline Chloromethane & $<10$ & $<10$ & $<10$ & 0 \\
\hline Chromium & $<10$ & $<10$ & $<10$ & 0 \\
\hline Chrysene & $<10$ & $<10$ & $<10$ & 0 \\
\hline cis-1,3-Dichloropropene & $<5$ & $<5$ & $<5$ & 0 \\
\hline Copper & $<4.0$ & $<4.0$ & $<4.0$ & 0 \\
\hline Cyanide colorimetric & $<100$ & $<100$ & $<100$ & 0 \\
\hline Di-n-butylphthalate & $<10$ & $<10$ & $<10$ & 0 \\
\hline Di-n-octylphthalate & $<10$ & $<10$ & $<10$ & 0 \\
\hline $\operatorname{Dibenz}(\mathrm{a}, \mathrm{h})$ anthracene & $<10$ & $<10$ & $<10$ & 0 \\
\hline Dibromochloromethane & $<5$ & $<5$ & $<5$ & 0 \\
\hline Diethylphthalate & $<10$ & $<10$ & $<10$ & 0 \\
\hline Dimethylphthalate & $<10$ & $<10$ & $<10$ & 0 \\
\hline Dissolved solids & 158,000 & 134,000 & 142,000 & 9,381 \\
\hline Ethylbenzene & $<5$ & $<5$ & $<5$ & 0 \\
\hline Fluoranthane & $<10$ & $<10$ & $<10$ & 0 \\
\hline Fluorene & $<10$ & $<10$ & $<10$ & 0 \\
\hline Flouride IC & $<100$ & $<100$ & $<100$ & 0 \\
\hline Hexachlorobenzene & $<10$ & $<10$ & $<10$ & 0 \\
\hline Hexachlorobutadiene & $<10$ & $<10$ & $<10$ & 0 \\
\hline Hexachlorocyclopentadiene & $<10$ & $<10$ & $<10$ & 0 \\
\hline Hexachloroethane & $<10$ & $<10$ & $<10$ & 0 \\
\hline Ideno(1,2,3-cd)pyrene & $<10$ & $<10$ & $<10$ & 0 \\
\hline Isophorone & $<10$ & $<10$ & $<10$ & 0 \\
\hline Lead & $<4$ & $<4$ & $<4$ & 0 \\
\hline Manganese & 150 & 30.6 & 74.4 & 45.4 \\
\hline Mercury & $<0.2$ & $<0.2$ & $<0.2$ & 0.0 \\
\hline Methylene chloride & $<5$ & $<5$ & $<5$ & 0 \\
\hline $\mathrm{N}$-nitroso-di-n-propylamine & $<10$ & $<10$ & $<10$ & 0 \\
\hline $\mathrm{N}$-nitrpsodimethylamine & $<10$ & $<10$ & $<10$ & 0 \\
\hline $\mathrm{N}$-nitrodiphenylamine & $<10$ & $<10$ & $<10$ & 0 \\
\hline Naphthalene & $<10$ & $<10$ & $<10$ & 0 \\
\hline Nickel & $<10$ & $<10$ & $<10$ & 0 \\
\hline Nitrate nitrogen & 480 & 180 & 320 & 123 \\
\hline Nitrobenzene & $<10$ & $<10$ & $<10$ & 0 \\
\hline Pentachlorophenol & $<50$ & $<50$ & $<50$ & 0 \\
\hline $\mathrm{pH}$, standard units & 8.50 & 7.75 & 8.24 & 0.31 \\
\hline Phenanthrene & $<10$ & $<10$ & $<10$ & 0 \\
\hline Phenol & $<10$ & $<10$ & $<10$ & 0 \\
\hline Pyrene & $<10$ & $<10$ & $<10$ & 0 \\
\hline Sodium & 4,600 & 3,240 & 4,035 & 525 \\
\hline Sulfate & 21,000 & 18,000 & 19,250 & 0 \\
\hline Suspended solids & 76,000 & 8,000 & 26,500 & 1,090 \\
\hline Tetrachloroethene & $<5$ & $<5$ & $<5$ & 28,684 \\
\hline Toluene & $<5$ & $<5$ & $<5$ & 0 \\
\hline trans-1,2-Dichloroethene & $<5$ & $<5$ & $<5$ & 0 \\
\hline trans-1,3-Dichloropropene & $<5$ & $<5$ & $<5$ & 0 \\
\hline Trichlorocthene & $<5$ & $<5$ & $<5$ & 0 \\
\hline Trichlorofluoromethane & & & & 0 \\
\hline Uranium fluorometric & 1 & 1 & 1 & 0 \\
\hline Vinyl chloride & $<10$ & $<10$ & $<10$ & 0 \\
\hline Zinc & 22.00 & 3.44 & 10.16 & 7.11 \\
\hline
\end{tabular}

uThe values for $\mathrm{pH}$ are in standard units.

\section{B-18 Appendix}


1992 Environmental Report Vol. 1, Oak Ridge

Vol. 2, p. 4-80:

Table 4.74. 1991 K-25 Site concentrations at K-716 (Poplar Creek)

\begin{tabular}{|c|c|c|c|c|}
\hline \multirow{2}{*}{ Parameter } & \multicolumn{4}{|c|}{ Concentration $(\mu \mathrm{g} / \mathrm{L})^{\mathrm{a}} \dagger$} \\
\hline & $\operatorname{Max}$ & $\operatorname{Min}$ & Av & $\begin{array}{l}\text { Standard } \\
\text { deviation }\end{array}$ \\
\hline 1,1,1-Trichloroethane & $<5$ & $<5$ & $<5$ & 0 \\
\hline 1,1,2,2-Tetrachloroethane & $<5$ & $<5$ & $<5$ & 0 \\
\hline 1,1,2-Trichloroethane & $<5$ & $<5$ & $<5$ & 0 \\
\hline 1,1-Dichloroethane & $<5$ & $<5$ & $<5$ & 0 \\
\hline 1,1-Dichloroethene & $<5$ & $<5$ & $<5$ & 0 \\
\hline 1,2,4-Trichlorobenzene & $<10$ & $<10$ & $<10$ & 0 \\
\hline 1,2-Dichlorobenzene & $<10$ & $<10$ & $<10$ & 0 \\
\hline 1,2-Dichloroethane & $<5$ & $<5$ & $<5$ & 0 \\
\hline 1,2-Dichloropropane & $<5$ & $<5$ & $<5$ & 0 \\
\hline 1,3-Dichlorobenzene & $<10$ & $<10$ & $<10$ & 0 \\
\hline 1,4-Dichlorobenzene & $<10$ & $<10$ & $<10$ & 0 \\
\hline 2,4,6-Trichlorophenol & $<10$ & $<10$ & $<10$ & 0 \\
\hline 2,4-Dichlorophenol & $<10$ & $<10$ & $<10$ & 0 \\
\hline 2,4-Dimethylphenol & $<10$ & $<10$ & $<10$ & 0 \\
\hline 2,4-Dinitrophenol & $<50$ & $<50$ & $<50$ & 0 \\
\hline 2,4-Dinitrotoluene & $<10$ & $<10$ & $<10$ & 0 \\
\hline 2,6-Dinitrotoluene & $<10$ & $<10$ & $<10$ & 0 \\
\hline 2-Chloroethylvinyl ether & $<10$ & $<10$ & $<10$ & 0 \\
\hline 2-Chloronaphthalene & $<10$ & $<10$ & $<10$ & 0 \\
\hline 2-Chlorophenol & $<10$ & $<10$ & $<10$ & 0 \\
\hline 2-Nitrophenol & $<10$ & $<10$ & $<10$ & 0 \\
\hline 3,3-Dichlorobenzidine & $<20$ & $<20$ & $<20$ & 0 \\
\hline 4,6-Dinitro-2-methylphenol & $<50$ & $<50$ & $<50$ & 0 \\
\hline 4-Bromophenyl-phenylether & $<10$ & $<10$ & $<10$ & 0 \\
\hline 4-Chloro-3-methylphenol & $<10$ & $<10$ & $<10$ & 0 \\
\hline 4-Chlorophenyl-phenylether & $<10$ & $<10$ & $<10$ & 0 \\
\hline 4-Nitrophenol & $<50$ & $<50$ & $<50$ & 0 \\
\hline Acenaphthene & $<10$ & $<10$ & $<10$ & 0 \\
\hline Acenaphthylene & $<10$ & $<10$ & $<10$ & 0 \\
\hline Ammonia nitrogen & $<200$ & $<200$ & $<200$ & 0 \\
\hline Anthracene & $<10$ & $<10$ & $<10$ & 0 \\
\hline Arsenic & $<5$ & $<5$ & $<5$ & 0 \\
\hline Benzene & $<5$ & $<5$ & $<5$ & 0 \\
\hline Benzidine & $<50$ & $<50$ & $<50$ & 0 \\
\hline Benzo(a)anthracene & $<10$ & $<10$ & $<10$ & 0 \\
\hline Benzo(a)pyrene & $<10$ & $<10$ & $<10$ & 0 \\
\hline Benzo(b)fluoranthene & $<10$ & $<10$ & $<10$ & 0 \\
\hline Benzo( $g, h, i)$ perylene & $<10$ & $<10$ & $<10$ & 0 \\
\hline Benzo(k)fluoranthene & $<10$ & $<10$ & $<10$ & 0 \\
\hline bis(2-Chloroethoxy)methane & $<10$ & $<10$ & $<10$ & 0 \\
\hline bis(2-Chloroethyl)ether & $<10$ & $<10$ & $<10$ & 0 \\
\hline bis(2-Chloroisopropyl)ether & $<10$ & $<10$ & $<10$ & 0 \\
\hline bis(2-Ethylhexyl)phthalate & $<10$ & $<10$ & $<10$ & 0 \\
\hline Bromodichloromethane & $<5$ & $<5$ & $<5$ & 0 \\
\hline Bromoform & $<5$ & $<5$ & $<5$ & 0 \\
\hline Bromomethane & $<10$ & $<10$ & $<10$ & 0 \\
\hline Butylbenzylphthalate & $<10$ & $<10$ & $<10$ & 0 \\
\hline Cadmium & $<2$ & $<2$ & $<2$ & 0 \\
\hline Carbon tetrachloride & $<5$ & $<5$ & $<5$ & 0 \\
\hline Chemical oxygen demand (COD) & 41,000 & 7,000 & 20,250 & 11,214 \\
\hline Chlorobenzene & $<5$ & $<5$ & $<5$ & 0 \\
\hline Chloroethane & $<10$ & $<10$ & $<10$ & 0 \\
\hline
\end{tabular}


1992 Environmental Report Vol. 1, Oak Ridge

Table 4.74 (continued)

\begin{tabular}{|c|c|c|c|c|}
\hline \multirow[b]{2}{*}{ Parameter } & \multicolumn{4}{|c|}{ Concentration $(\mu \mathrm{g} / \mathrm{L})^{a \dagger}$} \\
\hline & Max & Min & Av & $\begin{array}{l}\text { Standard } \\
\text { deviation }\end{array}$ \\
\hline Chloroform & $<5$ & $<5$ & $<5$ & 0 \\
\hline Chloromethane & $<10$ & $<10$ & $<10$ & 0 \\
\hline Chromium & 13 & 13 & 13 & 0 \\
\hline Chrysene & $<10$ & $<10$ & $<10$ & 0 \\
\hline cis-1,3-Dichloropropene & $<5$ & $<5$ & $<5$ & 0 \\
\hline Copper & 14.00 & 4.60 & 8.37 & 3.01 \\
\hline Cyanide colorimetric & $<100$ & $<100$ & $<100$ & 0 \\
\hline Di-n-butylphthalate & $<10$ & $<10$ & $<10$ & 0 \\
\hline Di-n-octylphthalate & $<10$ & $<10$ & $<10$ & 0 \\
\hline Dibenz(a,h)anthracene & $<10$ & $<10$ & $<10$ & 0 \\
\hline Dibromochloromethane & $<5$ & $<5$ & $<5$ & 0 \\
\hline Diethylphthalate & $<10$ & $<10$ & $<10$ & 0 \\
\hline Dimethylphthalate & $<10$ & $<10$ & $<10$ & 0 \\
\hline Dissolved solids & 180,000 & 82,000 & 138,333 & 29,715 \\
\hline Ethylbenzene & $<5$ & $<5$ & $<5$ & 0 \\
\hline Fluoranthane & $<10$ & $<10$ & $<10$ & 0 \\
\hline Fluorene & $<10$ & $<10$ & $<10$ & 0 \\
\hline Flouride IC & 200 & 100 & 178 & 39 \\
\hline Hexachlorobenzene & $<10$ & $<10$ & $<10$ & 0 \\
\hline Hexachlorobutadiene & $<10$ & $<10$ & $<10$ & 0 \\
\hline Hexachlorocyclopentadiene & $<10$ & $<10$ & $<10$ & 0 \\
\hline Hexachloroethane & $<10$ & $<10$ & $<10$ & 0 \\
\hline Ideno(1,2,3-cd)pyrene & $<10$ & $<10$ & $<10$ & 0 \\
\hline Isophorone & $<10$ & $<10$ & $<10$ & 0 \\
\hline Lead & 14.0 & 4.6 & 7.8 & 3.2 \\
\hline Manganese & 500.0 & 84.1 & 208.8 & 146.4 \\
\hline Mercury & 3.60 & 0.23 & 1.10 & 1.07 \\
\hline Methylene chloride & $<5$ & $<5$ & $<5$ & 0 \\
\hline $\mathrm{N}$-nitroso-di-n-propylamine & $<10$ & $<10$ & $<10$ & 0 \\
\hline $\mathrm{N}$-nitrpsodimethylamine & $<10$ & $<10$ & $<10$ & 0 \\
\hline $\mathrm{N}$-nitrodiphenylamine & $<10$ & $<10$ & $<10$ & 0 \\
\hline Naphthalene & $<10$ & $<10$ & $<10$ & 0 \\
\hline Nickel & 17 & 12 & 15 & 3 \\
\hline Nitrate nitrogen & 700 & 110 & 476 & 145 \\
\hline Nitrobenzene, & $<10$ & $<10$ & $<10$ & 0 \\
\hline Pentachlorophenol & $<50$ & $<50$ & $<50$ & 0 \\
\hline $\mathrm{pH}$, standard units & 8.70 & 7.25 & 7.90 & 0.44 \\
\hline Phenanthrene & $<10$ & $<10$ & $<10$ & 0 \\
\hline Phenol & $<10$ & $<10$ & $<10$ & 0 \\
\hline Pyrene & $<10$ & $<10$ & $<10$ & 0 \\
\hline Sodium & 6,300 & 2,800 & 4,218 & 1,165 \\
\hline Sulfate & 33,000 & 19,000 & 24,667 & 5,019 \\
\hline Suspended solids & 243,000 & 9,000 & 91,750 & 81,618 \\
\hline Tetrachloroethene & $<5$ & $<5$ & $<5$ & 0 \\
\hline Toluene & $<5$ & $<5$ & $<5$ & 0 \\
\hline trans-1,2-Dichloroethene & $<5$ & $<5$ & $<5$ & 0 \\
\hline trans-1,3-Dichloropropene & $<5$ & $<5$ & $<5$ & 0 \\
\hline Trichloroethene & $<5$ & $<5$ & $<5$ & 0 \\
\hline Trichlorofluoromethane & $<5$ & $<5$ & $<5$ & 0 \\
\hline Uranium fluorometric & 8 & 1 & 3 & 0 \\
\hline Vinyl chloride & 10 & 8 & 9 & 0 \\
\hline Zinc & 60.0 & 15.3 & 26.6 & 13.0 \\
\hline
\end{tabular}

aThe values for $\mathrm{pH}$ are in standard units. 
1992 Environmental Report Vol. 1, Oak Ridge

Vol. 2, p. 4-82:

Table 4.75. 1991 K-25 Site concentrations at K-1513 (Clinch River)

\begin{tabular}{|c|c|c|c|c|}
\hline \multirow[b]{2}{*}{ Parameter } & \multicolumn{4}{|c|}{ Concentration $(\mu \mathrm{g} / \mathrm{L})^{a \dagger}$} \\
\hline & Max & $\operatorname{Min}$ & $A v$ & $\begin{array}{l}\text { Standard } \\
\text { deviation }\end{array}$ \\
\hline 1,1,1-Trichloroethane & $<5$ & $<5$ & $<5$ & 0 \\
\hline $1,1,2,2$-Tetrachloroethane & $<5$ & $<5$ & $<5$ & 0 \\
\hline 1,1,2-Trichloroethane & $<5$ & $<5$ & $<5$ & 0 \\
\hline 1,1-Dichloroethane & $<5$ & $<5$ & $<5$ & 0 \\
\hline 1,1-Dichloroethene & $<5$ & $<5$ & $<5$ & 0 \\
\hline 1,2,4-Trichlorobenzene & $<10$ & $<10$ & $<10$ & 0 \\
\hline 1,2-Dichlorobenzene & $<10$ & $<10$ & $<10$ & 0 \\
\hline 1,2-Dichloroethane & $<5$ & $<5$ & $<5$ & 0 \\
\hline 1,2-Dichloropropane & $<5$ & $<5$ & $<5$ & 0 \\
\hline 1,3-Dichlorobenzene & $<10$ & $<10$ & $<10$ & 0 \\
\hline 1,4-Dichlorobenzene & $<10$ & $<10$ & $<10$ & 0 \\
\hline 2,4,6-Trichlorophenol & $<10$ & $<10$ & $<10$ & 0 \\
\hline 2,4-Dichlorophenol & $<10$ & $<10$ & $<10$ & 0 \\
\hline 2,4-Dimethylphenol & $<10$ & $<10$ & $<10$ & 0 \\
\hline 2,4-Dinitrophenol & $<50$ & $<50$ & $<50$ & 0 \\
\hline 2,4-Dinitrotoluene & $<10$ & $<10$ & $<10$ & 0 \\
\hline 2,6-Dinitrotoluene & $<10$ & $<10$ & $<10$ & 0 \\
\hline 2-Chloroethylvinyl ether & $<10$ & $<10$ & $<10$ & 0 \\
\hline 2-Chloronaphthalene & $<10$ & $<10$ & $<10$ & 0 \\
\hline 2-Chlorophenol & $<10$ & $<10$ & $<10$ & 0 \\
\hline 2-Nitrophenol & $<10$ & $<10$ & $<10$ & 0 \\
\hline 3,3-Dichlorobenzidine & $<20$ & $<20$ & $<20$ & 0 \\
\hline 4,6-Dinitro-2-methylphenol & $<50$ & $<50$ & $<50$ & 0 \\
\hline 4-Bromophenyl-phenylether & $<10$ & $<10$ & $<10$ & 0 \\
\hline 4-Chloro-3-methylphenol & $<10$ & $<10$ & $<10$ & 0 \\
\hline 4-Chlorophenyl-phenylether & $<10$ & $<10$ & $<10$ & 0 \\
\hline 4-Nitrophenol & $<50$ & $<50$ & $<50$ & 0 \\
\hline Acenaphthene & $<10$ & $<10$ & $<10$ & 0 \\
\hline Acenaphthylene & $<10$ & $<10$ & $<10$ & 0 \\
\hline Ammonia nitrogen & $<200$ & $<200$ & $<200$ & 0 \\
\hline Anthracene & $<10$ & $<10$ & $<10$ & 0 \\
\hline Arsenic & $<5$ & $<5$ & $<5$ & 0 \\
\hline Benzene & $<5$ & $<5$ & $<5$ & 0 \\
\hline Benzidine & $<50$ & $<50$ & $<50$ & 0 \\
\hline Benzo(a)anthracene & $<10$ & $<10$ & $<10$ & 0 \\
\hline Benzo(a)pyrene & $<10$ & $<10$ & $<10$ & 0 \\
\hline Benzo(b)fluoranthene & $<10$ & $<10$ & $<10$ & 0 \\
\hline Benzo(g,h,i)perylene & $<10$ & $<10$ & $<10$ & 0 \\
\hline Benzo $(k)$ fluoranthene & $<10$ & $<10$ & $<10$ & 0 \\
\hline bis(2-Chloroethoxy)methane & $<10$ & $<10$ & $<10$ & 0 \\
\hline bis (2-Chloroethyl)ether & $<10$ & $<10$ & $<10$ & 0 \\
\hline bis(2-Chloroisopropyl)ether & $<10$ & $<10$ & $<10$ & 0 \\
\hline bis(2-Ethylhexyl)phthalate & $<10$ & $<10$ & $<10$ & 0 \\
\hline Bromodichloromethane & $<5$ & $<5$ & $<5$ & 0 \\
\hline Bromoform & $<5$ & $<5$ & $<5$ & 0 \\
\hline Bromomethane & $<10$ & $<10$ & $<10$ & 0 \\
\hline Butylbenzylphthalate & $<10$ & $<10$ & $<10$ & 0 \\
\hline Cadmium & $<2$ & $<2$ & $<2$ & 0 \\
\hline Carbon tetrachloride & $<5$ & $<5$ & $<5$ & 0 \\
\hline Chemical oxygen demand (COD) & 11,000 & 7,000 & 8,200 & 1,600 \\
\hline Chlorobenzene & $<5$ & $<5$ & $<5$ & 0 \\
\hline Chloroethane & $<10$ & $<10$ & $<10$ & 0 \\
\hline
\end{tabular}


Table 4.75 (continued)

\begin{tabular}{|c|c|c|c|c|}
\hline \multirow{2}{*}{ Parameter } & \multicolumn{4}{|c|}{ Concentration $(\mu \mathrm{g} / \mathrm{L})^{a t}$} \\
\hline & Max & Min & Av & $\begin{array}{l}\text { Standard } \\
\text { deviation }\end{array}$ \\
\hline Chloroform & $<5$ & $<5$ & $<.5$ & 0 \\
\hline Chloroinethane & $<10$ & $<10$ & $<10$ & 0 \\
\hline Chromium & $<10$ & $<10$ & $<10$ & 0 \\
\hline Chrysene & $<10$ & $<10$ & $<10$ & 0 \\
\hline cis-1,3-Dichloropropene & $<5$ & $<5$ & $<5$ & 0 \\
\hline Copper & $<4$ & $<4$ & $<4$ & 0 \\
\hline Cyanide colorimetric & 236 & 236 & 236 & 0 \\
\hline Di-n-butylphthalate & $<10$ & $<10$ & $<10$ & 0 \\
\hline Di-n-octylphthalate & $<10$ & $<10$ & $<10$ & () \\
\hline Dibenz(a,h)anthracene & $<10$ & $<10$ & $<10$ & () \\
\hline Dibromochloromethane & $<5$ & $<5$ & $<5$ & 0 \\
\hline Diethylphthalate & $<10$ & $<10$ & $<10$ & 0 \\
\hline Dimethylphthalate & $<10$ & $<10$ & $<10$ & 0 \\
\hline Dissolved solids & 166,000 & 78,000 & 142,666 & 23,028 \\
\hline Ethylbenzene & $<5$ & $<5$ & $<5$ & 0 \\
\hline Fluoranthane & $<10$ & $<10$ & $<10$ & () \\
\hline Fluorene & $<10$ & $<10$ & $<10$ & 0 \\
\hline Flouride IC & 200 & 200 & 200 & 0 \\
\hline Hexachlorobenzene & $<10$ & $<10$ & $<10$ & () \\
\hline Hexachlorobutadiene & $<10$ & $<10$ & $<10$ & 0 \\
\hline Hexachlorocyclopentadiene & $<10$ & $<10$ & $<10$ & 0 \\
\hline Hexachloroethane & $<10$ & $<10$ & $<10$ & 0 \\
\hline Ideno(1,2,3-cd)pyrene & $<10$ & $<10$ & $<10$ & 0 \\
\hline Isophorone & $<10$ & $<10$ & $<10$ & 0 \\
\hline Lead & 8.6 & 8.6 & 8.6 & 0.0 \\
\hline Manganese & 54 & 21 & 38 & 11 \\
\hline Mercury & $<0.2$ & $<0.2$ & $<0.2$ & 0.0 \\
\hline Methylene chloride & $<5$ & $<5$ & $<5$ & 0 \\
\hline $\mathrm{N}$-nitroso-di-n-propylamine & $<10$ & $<10$ & $<10$ & 0 \\
\hline $\mathrm{N}$-nitrpsodimethylamine & $<10$ & $<10$ & $<10$ & 0 \\
\hline $\mathrm{N}$-nitrodiphenylamine & $<10$ & $<10$ & $<10$ & 0 \\
\hline Naphthalene & $<10$ & $<10$ & $<10$ & 0 \\
\hline Nickel & 130 & 130 & 130 & 0 \\
\hline Nitrate nitrogen & 720 & 140 & 421 & 175 \\
\hline Nitrobenzene & $<10$ & $<10$ & $<10$ & 0 \\
\hline Pentachlorophenol & $<50$ & $<50$ & $<50$ & 0 \\
\hline pH, standard units & 8.60 & 7.50 & 8.03 & 0.33 \\
\hline Phenanthrene & $<10$ & $<10$ & $<10$ & 0 \\
\hline Phenol & $<10$ & $<10$ & $<10$ & 0 \\
\hline Pyrene & $<10$ & $<10$ & $<10$ & 0 \\
\hline Sodium & 5,600 & 3,210 & 4,209 & 804 \\
\hline Sulfate & 28,000 & 16,500 & 20,792 & 3,652 \\
\hline Suspended solids & 22,000 & 4,000 & 9,167 & 5,359 \\
\hline Tetrachloroethene & $<5$ & $<5$ & $<5$ & 0 \\
\hline Toluene & $<5$ & $<5$ & $<5$ & 0 \\
\hline trans-1,2-Dichloroethene & $<5$ & $<5$ & $<5$ & 0 \\
\hline trans-1,3-Dichloropropene & $<5$ & $<5$ & $<5$ & 0 \\
\hline Trichloroethene & $<5$ & $<5$ & $<5$ & 0 \\
\hline Trichlorofluoromethane & $<5$ & $<5$ & $<5$ & 0 \\
\hline Uranium fluorometric & $<1$ & $<1$ & $<1$ & 0 \\
\hline Vinyl chloride & $<10$ & $<10$ & $<10$ & 0 \\
\hline Zinc & 74.0 & 4.6 & 18.8 & 22.9 \\
\hline
\end{tabular}

${ }^{a}$ The values for $\mathrm{pH}$ are in standard units. 
1992 Environmental Report Vol. 1, Oak Ridge

Vol. 2, p. 4-84:

Table 4.76. 1991 K-25 Site concentrations at K-1710 (Poplar Creek)

\begin{tabular}{|c|c|c|c|c|}
\hline \multirow{2}{*}{ Parameter } & \multicolumn{4}{|c|}{ Concentration $(\mu \mathrm{g} / \mathrm{L})^{a \dagger}$} \\
\hline & Max & Min & Av & $\begin{array}{l}\text { Standard } \\
\text { deviation }\end{array}$ \\
\hline 1,1,1-Trichloroethane & $<5$ & $<5$ & $<5$ & 0 \\
\hline $1,1,2,2$-Tetrachloroethane & $<5$ & $<5$ & $<5$ & 0 \\
\hline 1,1,2-Trichloroethane & $<5$ & $<5$ & $<5$ & 0 \\
\hline 1,1-Dichloroethane & $<5$ & $<5$ & $<5$ & 0 \\
\hline 1,1-Dichloroethene & $<5$ & $<5$ & $<5$ & () \\
\hline 1,2,4-Trichlorobenzene & $<10$ & $<10$ & $<10$ & 0 \\
\hline 1,2-Dichlorobenzene & $<10$ & $<10$ & $<10$ & 0 \\
\hline 1,2-Dichloroethane & $<5$ & $<5$ & $<5$ & 0 \\
\hline 1,2-Dichloropropane & $<5$ & $<5$ & $<5$ & 0 \\
\hline 1,3-Dichlorobenzene & $<10$ & $<10$ & $<10$ & 0 \\
\hline 1,4-Dichlorobenzene & $<10$ & $<10$ & $<10$ & 0 \\
\hline 2,4,6-Trichlorophenol & $<10$ & $<10$ & $<10$ & 0 \\
\hline 2,4-Dichlorophenol & $<10$ & $<10$ & $<10$ & 0 \\
\hline 2,4-Dimethylphenol & $<10$ & $<10$ & $<10$ & 0 \\
\hline 2,4-Dinitrophenol & $<50$ & $<50$ & $<50$ & 0 \\
\hline 2,4-Dinitrotoluene & $<10$ & $<10$ & $<10$ & 0 \\
\hline 2,6-Dinitrotoluene & $<10$ & $<10$ & $<10$ & 0 \\
\hline 2-Chloroethylvinyl ether & $<10$ & $<10$ & $<10$ & 0 \\
\hline 2-Chloronaphthalene & $<10$ & $<10$ & $<10$ & 0 \\
\hline 2-Chlorophenol & $<10$ & $<10$ & $<10$ & 0 \\
\hline 2-Nitrophenol & $<10$ & $<10$ & $<10$ & 0 \\
\hline 3,3-Dichlorobenzidine & $<20$ & $<20$ & $<20$ & 0 \\
\hline 4,6-Dinitro-2-methylphenol & $<50$ & $<50$ & $<50$ & 0 \\
\hline 4-Bromophenyl-phenylether & $<10$ & $<10$ & $<10$ & 0 \\
\hline 4-Chloro-3-methylphenol & $<10$ & $<10$ & $<10$ & 0 \\
\hline 4-Chlorophenyl-phenylether & $<10$ & $<10$ & $<10$ & 0 \\
\hline 4-Nitrophenol & $<50$ & $<50$ & $<50$ & 0 \\
\hline Acenaphthene & $<10$ & $<10$ & $<10$ & 0 \\
\hline Acenaphthylene & $<10$ & $<10$ & $<10$ & 0 \\
\hline Ammonia nitrogen & 250 & 250 & 250 & 0 \\
\hline Anthracene & $<10$ & $<10$ & $<10$ & 0 \\
\hline Arsenic & 7.2 & 7.2 & 7.2 & 0.0 \\
\hline Benzene & $<5$ & $<5$ & $<5$ & 0 \\
\hline Benzidine & $<50$ & $<50$ & $<50$ & 0 \\
\hline Benzo(a)anthracene & $<10$ & $<10$ & $<10$ & 0 \\
\hline Benzo(a)pyrene & $<10$ & $<10$ & $<10$ & 0 \\
\hline Benzo(b)fluoranthene & $<10$ & $<10$ & $<10$ & 0 \\
\hline Benzo(g,h,i)perylene & $<10$ & $<10$ & $<10$ & 0 \\
\hline Benzo $(k)$ fluoranthene & $<10$ & $<10$ & $<10$ & 0 \\
\hline bis(2-Chloroethoxy)methane & $<10$ & $<10$ & $<10$ & 0 \\
\hline bis(2-Chloroethyl)ether, & $<10$ & $<10$ & $<10$ & 0 \\
\hline bis(2-Chloroisopropyl)ether & $<10$ & $<10$ & $<10$ & 0 \\
\hline bis(2-Ethylhexyl)phthalate & $<10$ & $<10$ & $<10$ & 0 \\
\hline Bromodichloromethane & $<5$ & $<5$ & $<5$ & 0 \\
\hline Bromoform & $<5$ & $<5$ & $<5$ & 0 \\
\hline Bromomethane & $<10$ & $<10$ & $<10$ & 0 \\
\hline Butylbenzylphthalate & $<10$ & $<10$ & $<10$ & 0 \\
\hline Cadmium & 2.4 & 2.4 & 2.4 & 0.0 \\
\hline Carbon tetrachloride & $<5$ & $<5$ & $<5$ & 0 \\
\hline Chemical oxygen demand (COD) & 23,000 & 7,000 & 14,071 & 5,571 \\
\hline $\begin{array}{l}\text { Chlorobenzene } \\
\text { S }\end{array}$ & $<5$ & $<5$ & $<5$ & ) \\
\hline Chloroethane & $<10$ & $<10$ & $<10$ & 0 \\
\hline
\end{tabular}


1992 Environmental Report Vol. 1, Oak Ridge

Table 4.76 (continued)

\begin{tabular}{|c|c|c|c|c|}
\hline \multirow{2}{*}{ Parameter } & \multicolumn{4}{|c|}{ Concentration $(\mu \mathrm{g} / \mathrm{L})^{a \dagger}$} \\
\hline & Max & Min & Av & $\begin{array}{l}\text { Standard } \\
\text { deviation }\end{array}$ \\
\hline Chloroform & $<5$ & $<5$ & $<5$ & 0 \\
\hline Chloromethane & $<10$ & $<10$ & $<10$ & 0 \\
\hline Chromium & 12 & 12 & 12 & 0 \\
\hline Chrysene & $<10$ & $<10$ & $<10$ & 0 \\
\hline cis-1,3-Dichloropropene & $<5$ & $<5$ & $<5$ & 0 \\
\hline Copper & 29.00 & 4.40 & 9.68 & 8.18 \\
\hline Cyanide colorimetric & $<100$ & $<100$ & $<100$ & 0 \\
\hline Di-n-butylphthalate & $<10$ & $<10$ & $<10$ & 0 \\
\hline Di-n-octylphthalate & $<10$ & $<10$ & $<10$ & 0 \\
\hline Dibenz $(a, h)$ anthracene & $<10$ & $<10$ & $<10$ & 0 \\
\hline Dibromochloromethane & $<5$ & $<5$ & $<5$ & 0 \\
\hline Diethylphthalate & $<10$ & $<10$ & $<10$ & 0 \\
\hline Dimethylphthalate & $<10$ & $<10$ & $<10$ & 0 \\
\hline Dissolved solids & 244,000 & 70,000 & 151,666 & 61,538 \\
\hline Ethylbenzene & $<5$ & $<5$ & $<5$ & 0 \\
\hline Fluoranthane & $<10$ & $<10$ & $<10$ & 0 \\
\hline Fluorene & $<10$ & $<10$ & $<10$ & 0 \\
\hline Flouride IC & 400 & 200 & 310 & 90 \\
\hline Hexachlorobenzene & $<10$ & $<10$ & $<10$ & 0 \\
\hline Hexachlorobutadiene & $<10$ & $<10$ & $<10$ & 0 \\
\hline Hexachlorocyclopentadiene & $<10$ & $<10$ & $<10$ & 0 \\
\hline Hexachloroethane & $<10$ & $<10$ & $<10$ & 0 \\
\hline Ideno(1,2,3-cd)pyrene & $<10$ & $<10$ & $<10$ & 0 \\
\hline Isophorone & $<10$ & $<10$ & $<10$ & 0 \\
\hline Lead & 49.0 & 4.1 & 16.6 & 18.8 \\
\hline Manganese & 2,000 & 97 & 378 & 662 \\
\hline Mercury & 16.00 & 0.22 & 2.77 & 5.42 \\
\hline Methylene chloride & $<5$ & $<5$ & $<5$ & 0 \\
\hline N-nitroso-di-n-propylamine & $<10$ & $<10$ & $<10$ & 0 \\
\hline N-nitrpsodimethylamine & $<10$ & $<10$ & $<10$ & 0 \\
\hline$N$-nitrodiphenylamine & $<10$ & $<10$ & $<10$ & 0 \\
\hline Naphthalene & $<10$ & $<10$ & $<10$ & 0 \\
\hline Nickel & 24.0 & 11.3 & 15.8 & 5.8 \\
\hline Nitrate nitrogen & 4500 & 300 & 1223 & 1,552 \\
\hline Nitrobenzene & $<10$ & $<10$ & $<10$ & 0 \\
\hline Pentachlorophenol & $<50$ & $<50$ & $<50$ & 0 \\
\hline $\mathrm{pH}$, standard units & 8.0 & 7.5 & 7.8 & 0.2 \\
\hline Phenanthrene & $<10$ & $<10$ & $<10$ & 0 \\
\hline Phenol & $<10$ & $<10$ & $<10$ & 0 \\
\hline Pyrene & $<10$ & $<10$ & $<10$ & 0 \\
\hline Sodium & 15,000 & 2,500 & 6,769 & 4,502 \\
\hline Sulfate & 45,000 & 6,000 & 31,417 & 10,574 \\
\hline Suspended solids & $1,230,000$ & 1,000 & 194,917 & 425,945 \\
\hline Tetrachloroethene & $<5$ & $<5$ & $<5$ & 0 \\
\hline Toluene & $<5$ & $<5$ & $<5$ & 0 \\
\hline trans-1,2-Dichloroethene & $<5$ & $<5$ & $<5$ & 0 \\
\hline trans-1,3-Dichloropropene & $<5$ & $<5$ & $<5$ & 0 \\
\hline Trichloroethene & $<5$ & $<5$ & $<5$ & 0 \\
\hline Trichlorofluoromethane & $<5$ & $<5$ & $<5$ & 0 \\
\hline Uranium fluorometric & 12 & 1 & 4 & 0 \\
\hline Vinyl chloride & $<10$ & $<10$ & $<10$ & 0 \\
\hline Zinc & 120.0 & 4.3 & 29.9 & 31.2 \\
\hline
\end{tabular}

${ }^{a}$ The values for $\mathrm{pH}$ are in standard units. 
1992 Environmental Report Vol. 1, Oak Ridge

Vol. 2, p. 4-86:

Table 4.77. 1991 K-25 Site concentrations at K-1770 (Clinch River)

\begin{tabular}{|c|c|c|c|c|}
\hline \multirow{2}{*}{ Parameler } & \multicolumn{4}{|c|}{ Concentration $(\mu \mathrm{g} / \mathrm{L})^{a \dagger}$} \\
\hline & $\operatorname{Max}$ & Min & Av & $\begin{array}{l}\text { Standard } \\
\text { deviation }\end{array}$ \\
\hline 1,1,1-Trichloroethane & $<.5$ & $<5$ & $<.5$ & () \\
\hline $1,1,2,2$-Tetrachloroethane & $<5$ & $<5$ & $<5$ & () \\
\hline $1,1,2$-Trichloroethane & $<5$ & $<5$ & $<.5$ & 0 \\
\hline 1,1-Dichloroethane & $<5$ & $<5$ & $<5$ & 0 \\
\hline 1,1-Dichloroethene & $<5$ & $<5$ & $<5$ & 0 \\
\hline 1,2,4-Trichlorobenzene & $<10$ & $<10$ & $<10$ & 0 \\
\hline 1,2-Dichlorobenzene & $<10$ & $<10$ & $<10$ & () \\
\hline 1,2-Dichloroethane & $<5$ & $<5$ & $<5$ & () \\
\hline 1,2-Dichloropropane & $<5$ & $<5$ & $<5$ & 0 \\
\hline 1,3-Dichlorobenzene & $<10$ & $<10$ & $<10$ & 0 \\
\hline 1,4-Dichlorobenzene & $<10$ & $<10$ & $<10$ & () \\
\hline 2,4,6-Trichlorophenol & $<10$ & $<10$ & $<10$ & 0 \\
\hline 2,4-Dichlorophenol & $<10$ & $<10$ & $<10$ & 0 \\
\hline 2,4-Dimethylphenol & $<10$ & $<10$ & $<10$ & 0 \\
\hline 2,4-Dinitrophenol & $<50$ & $<50$ & $<50$ & 0 \\
\hline 2,4-Dinitrotoluene & $<10$ & $<10$ & $<10$ & 0 \\
\hline 2,6-Dinitrotoluene & $<10$ & $<10$ & $<10$ & 0 \\
\hline 2-Chloroethylvinyl ether & $<10$ & $<10$ & $<10$ & () \\
\hline 2-Chloronaphthalene & $<10$ & $<10$ & $<10$ & 0 \\
\hline 2-Chlorophenol & $<10$ & $<10$ & $<10$ & 0 \\
\hline 2-Nitrophenol & $<10$ & $<10$ & $<10$ & 0 \\
\hline 3,3-Dichlorobenzidine & $<20$ & $<20$ & $<20$ & 0 \\
\hline 4,6-Dinitro-2-methylphenol & $<50$ & $<50$ & $<50$ & 0 \\
\hline 4-Bromophenyl-phenylether & $<10$ & $<10$ & $<10$ & () \\
\hline 4-Chloro-3-methylphenol & $<10$ & $<10$ & $<10$ & 0 \\
\hline 4-Chlorophenyl-phenylether & $<10$ & $<10$ & $<10$ & 0 \\
\hline 4-Nitrophenol & $<50$ & $<50$ & $<50$ & 0 \\
\hline Acenaphthene & $<10$ & $<10$ & $<10$ & 0 \\
\hline Acenaphthylene & $<10$ & $<10$ & $<10$ & 0 \\
\hline Ammonia nitrogen & $<200$ & $<200$ & $<200$ & 0 \\
\hline Anthracene & $<10$ & $<10$ & $<10$ & 0 \\
\hline Arsenic & $<5$ & $<5$ & $<5$ & 0 \\
\hline Benzene & $<5$ & $<5$ & $<5$ & 0 \\
\hline Benzidine & $<50$ & $<50$ & $<50$ & 0 \\
\hline Benzo(a)anthracene & $<10$ & $<10$ & $<10$ & 0 \\
\hline Benzo(a)pyrene & $<10$ & $<10$ & $<10$ & 0 \\
\hline Benzo(b)fluoranthene & $<10$ & $<10$ & $<10$ & 0 \\
\hline Benzo(g,h,i)perylene & $<10$ & $<10$ & $<10$ & 0 \\
\hline Benzo(k)fluoranthene & $<10$ & $<10$ & $<10$ & 0 \\
\hline bis(2-Chloroethoxy)methane & $<10$ & $<10$ & $<10$ & () \\
\hline bis(2-Chloroethyl)ether & $<10$ & $<10$ & $<10$ & 0 \\
\hline bis(2-Chloroisopropyl)ether & $<10$ & $<10$ & $<10$ & 0 \\
\hline bis(2-Ethylhexyl)phthalatc & $<10$ & $<10$ & $<10$ & 0 \\
\hline Bromodichloromethane & $<5$ & $<5$ & $<5$ & 0 \\
\hline Bromoform & $<5$ & $<.5$ & $<5$ & 0 \\
\hline Bromomethane & $<10$ & $<10$ & $<10$ & 0 \\
\hline Butylbenzylphthalate & $<10$ & $<10$ & $<10$ & 0 \\
\hline Cadmium & $<2$ & $<2$ & $<2$ & () \\
\hline Carbon tetrachloride & $<5$ & $<5$ & $<5$ & 0 \\
\hline Chemical oxygen demand (COD) & 27,500 & $5,(00)$ & 11,071 & 7,174 \\
\hline Chlorobenzene & $<5$ & $<5$ & $<5$ & () \\
\hline Chloroethane & $<10$ & $<10$ & $<10$ & 0 \\
\hline
\end{tabular}


Table 4.77 (continued)

\begin{tabular}{|c|c|c|c|c|}
\hline \multirow{2}{*}{ Parimeter } & \multicolumn{4}{|c|}{ Concentration $(\mu \mathrm{g} / \mathrm{L})^{a \dagger}$} \\
\hline & Max & $\operatorname{Min}$ & Av & $\begin{array}{l}\text { Standard } \\
\text { deviation }\end{array}$ \\
\hline Chlorotorm & $<5$ & $<5$ & $<.5$ & () \\
\hline Chloromethane & $<10$ & $<10$ & $<10$ & 0 \\
\hline Chromium & $<10$ & $<10$ & $<10$ & 0 \\
\hline Chrysene & $<10$ & $<10$ & $<10$ & 0 \\
\hline cis-1,3-Dichloropropene & $<5$ & $<5$ & $<5$ & 0 \\
\hline Copper & 5.5 & 4.9 & 5.2 & 0.3 \\
\hline Cyanide colorimetric & $<100$ & $<100$ & $<100$ & 0 \\
\hline Di-n-butylphthalatc & $<10$ & $<10$ & $<10$ & () \\
\hline Di-n-octylphthalate & $<10$ & $<10$ & $<10$ & 0 \\
\hline Dibenz(a,h)anthracene & $<10$ & $<10$ & $<10$ & 0 \\
\hline Dibromochloromethane & $<5$ & $<5$ & $<5$ & 0 \\
\hline Dicthylphthalate & $<10$ & $<10$ & $<10$ & 0 \\
\hline Dimethylphthalate & $<10$ & $<10$ & $<10$ & 0 \\
\hline Dissolved solids & $174,000)$ & $64,0(0)$ & 140,000 & 27,092 \\
\hline Ethylbenzene & $<5$ & $<5$ & $<5$ & 0 \\
\hline Fluoranthane & $<10$ & $<10$ & $<10$ & 0 \\
\hline Fluorene & $<10$ & $<10$ & $<10$ & () \\
\hline Flouride IC & 100 & 100 & 100 & () \\
\hline Hexachlorobenzene & $<10$ & $<10$ & $<10$ & 0 \\
\hline Hexachlorobutadiene & $<10$ & $<10$ & $<10$ & () \\
\hline Hexachlorocyclopentadiene & $<10$ & $<10$ & $<10$ & 0 \\
\hline Hexachlorocthane & $<10$ & $<10$ & $<10$ & 0 \\
\hline Ideno(1,2,3-cd)pyrene & $<10$ & $<10$ & $<10$ & 0 \\
\hline Isophurone & $<10$ & $<10$ & $<10$ & 0 \\
\hline Lead & $<4$ & $<4$ & $<4$ & 0 \\
\hline Manganese & 88.3 & 26.0 & 49.3 & 19.8 \\
\hline Mercury & 0.24 & 0.24 & 0.24 & 0.00 \\
\hline Methylene chloride & $<5$ & $<5$ & $<5$ & 0 \\
\hline $\mathrm{N}$-nitroso-di-n-propylamine & $<10$ & $<10$ & $<10$ & 0 \\
\hline $\mathrm{N}$-nitrosodimethylaminc & $<10$ & $<10$ & $<10$ & () \\
\hline $\mathrm{N}$-nitrodiphenylamine & $<10$ & $<10$ & $<10$ & 0 \\
\hline Naphthalene & $<10$ & $<10$ & $<10$ & 0 \\
\hline Nickel & $<10$ & $<10$ & $<10$ & 0 \\
\hline Nitrate nitrogen & 600 & 130 & 373 & 1.37 \\
\hline Nitrobenzene & $<10$ & $<10$ & $<10$ & () \\
\hline Pentachlorophenol & $<50$ & $<50$ & $<50$ & 0 \\
\hline ph, standard units & 8.40 & 7.65 & $8 .(04$ & (0. 22 \\
\hline Phenanthrene & $<10$ & $<10$ & $<10$ & () \\
\hline Phenol & $<10$ & $<10$ & $<10$ & 0 \\
\hline Pyrene & $<10$ & $<10$ & $<10$ & 0 \\
\hline Sodium & 6,390 & 3,500 & 4,393 & 836 \\
\hline Sulfate & $28,(0) 0$ & 17,000 & 21,333 & 2,953 \\
\hline Suspended solids & 63,000 & 4,000 & 17,917 & 17,100 \\
\hline Tetrachloroethene & $<5$ & $<5$ & $<5$ & 0 \\
\hline 'Toluene & $<5$ & $<5$ & $<5$ & () \\
\hline trans-1,2-Dichloroethene & $<5$ & $<5$ & $<5$ & 0 \\
\hline trans-1,3-Dichloropropene & $<5$ & $<5$ & $<5$ & 0 \\
\hline Trichloroethene & $<5$ & $<5$ & $<5$ & () \\
\hline Trichlorofluoromethane & $<5$ & $<5$ & $<5$ & 0 \\
\hline Uranium fluorometric & 1 & 1 & 1 & 0 \\
\hline Vinyl chloride & $<10$ & $<10$ & $<10$ & () \\
\hline Zinc & 14.00 & 4.24 & 8.05 & 3.38 \\
\hline
\end{tabular}

"The values for pH are in standard units. 
1992 Environmental Report Vol. 1, Oak Ridge

Vol. 2, p. 4-88:

Table 4.78. 1991 K-25 Site concentrations at Mitchell Branch

\begin{tabular}{|c|c|c|c|c|}
\hline \multirow[b]{2}{*}{ Parameter } & \multicolumn{4}{|c|}{ Concentration $(\mu \mathrm{g} / \mathrm{L})^{a \dagger}$} \\
\hline & Max & Min & Av & $\begin{array}{l}\text { Standard } \\
\text { deviation }\end{array}$ \\
\hline 1,1,1-Trichloroethane & $<5$ & $<5$ & $<5$ & 0 \\
\hline $1,1,2,2$-Tetrachloroethane & $<5$ & $<5$ & $<5$ & 0 \\
\hline 1,1,2-Trichloroethane & $<5$ & $<5$ & $<5$ & 0 \\
\hline 1,1-Dichloroethane & $<5$ & $<5$ & $<5$ & 0 \\
\hline 1.1-Dichloroethene & $<5$ & $<5$ & $<5$ & 0 \\
\hline 1,2,4-Trichlorobenzene & $<10$ & $<10$ & $<10$ & 0 \\
\hline 1,2-Dichlorobenzene & $<10$ & $<10$ & $<10$ & 0 \\
\hline 1,2-Dichloroethane & $<5$ & $<5$ & $<5$ & 0 \\
\hline 1,2-Dichloropropane & $<5$ & $<5$ & $<5$ & 0 \\
\hline 1,3-Dichlorobenzene & $<10$ & $<10$ & $<10$ & 0 \\
\hline 1,4-Dichlorobenzene & $<10$ & $<10$ & $<10$ & 0 \\
\hline $2,4,6$-Trichlorophenol & $<10$ & $<10$ & $<10$ & 0 \\
\hline 2,4-Dichlorophenol & $<10$ & $<10$ & $<10$ & 0 \\
\hline 2,4-Dimethylphenol & $<10$ & $<10$ & $<10$ & 0 \\
\hline 2,4-Dinitrophenol & $<10$ & $<10$ & $<10$ & 0 \\
\hline 2,4-Dinitrotoluene & $<10$ & $<10$ & $<10$ & 0 \\
\hline 2,6-Dinitrotoluene & $<10$ & $<10$ & $<10$ & 0 \\
\hline 2-Chloroethylvinyl ether & $<10$ & $<10$ & $<10$ & 0 \\
\hline 2-Chloronaphthalene & $<10$ & $<10$ & $<10$ & 0 \\
\hline 2-Chlorophenol & $<10$ & $<10$ & $<10$ & 0 \\
\hline 2-Nitrophenol & $<10$ & $<10$ & $<10$ & 0 \\
\hline 3,3-Dichlorobenzidine, & $<20$ & $<20$ & $<20$ & 0 \\
\hline 4,6-Dinitro-2-methylphenol & $<50$ & $<50$ & $<50$ & 0 \\
\hline 4-Bromophenyl-phenylether & $<10$ & $<10$ & $<10$ & 0 \\
\hline 4-Chloro-3-methylphenol & $<10$ & $<10$ & $<10$ & 0 \\
\hline 4-Chlorophenyl-phenylether & $<10$ & $<10$ & $<10$ & 0 \\
\hline 4-Nitrophenol & $<50$ & $<50$ & $<50$ & 0 \\
\hline Acenaphthene & $<10$ & $<10$ & $<10$ & 0 \\
\hline Acenaphthylene & $<10$ & $<10$ & $<10$ & 0 \\
\hline Ammonia nitrogen & $<200$ & $<200$ & $<200$ & 0 \\
\hline Anthracene & $<10$ & $<10$ & $<10$ & 0 \\
\hline Arsenic & $<5$ & $<5$ & $<5$ & 0 \\
\hline Benzene & $<5$ & $<5$ & $<5$ & 0 \\
\hline Benzidine & $<10$ & $<10$ & $<10$ & 0 \\
\hline Benzo(a)anthracene & $<10$ & $<10$ & $<10$ & 0 \\
\hline Benzo(a)pyrene & $<10$ & $<10$ & $<10$ & 0 \\
\hline Benzo(b)fluoranthene & $<10$ & $<10$ & $<10$ & 0 \\
\hline Benzo(g,h,i)perylene & $<10$ & $<10$ & $<10$ & 0 \\
\hline Benzo(k)fluoranthene & $<10$ & $<10$ & $<10$ & 0 \\
\hline bis(2-Chluroethoxy)methane & $<10$ & $<10$ & $<10$ & 0 \\
\hline bis(2-Chloroethyl)ether & $<10$ & $<10$ & $<10$ & 0 \\
\hline bis(2-Chloroisopropyl)ether & $<10$ & $<10$ & $<10$ & 0 \\
\hline bis(2-Ethylhexyl)phthalate & $<10$ & $<10$ & $<10$ & 0 \\
\hline Bromodichloromethane & $<5$ & $<5$ & $<5$ & 0 \\
\hline Bromoform & $<5$ & $<5$ & $<5$ & 0 \\
\hline Bromomethane & $<10$ & $<10$ & $<10$ & 0 \\
\hline Butylbenzylphthalate & $<10$ & $<10$ & $<10$ & 0 \\
\hline Cadmium & $<2$ & $<2$ & $<2$ & 0 \\
\hline Carbon tetrachloride & $<5$ & $<5$ & $<5$ & 0 \\
\hline Chemical oxygen demand (COD) & 21,000 & 7,000 & 14,000 & $7,0(0)$ \\
\hline Chlorobenzene & $<5$ & $<5$ & $<5$ & 0 \\
\hline Chloroethane & $<10$ & $<10$ & $<10$ & 0 \\
\hline
\end{tabular}


1992 Environmental Report Vol. 1, Oak Ridge

Table 4.78 (continued)

\begin{tabular}{|c|c|c|c|c|}
\hline \multirow[b]{2}{*}{ Parameter } & \multicolumn{4}{|c|}{ Concentration $(\mu \mathrm{g} / \mathrm{L})^{a \dagger}$} \\
\hline & Max & $\operatorname{Min}$ & Av & $\begin{array}{l}\text { Standard } \\
\text { deviation }\end{array}$ \\
\hline Chloroform & $<5$ & $<5$ & $<5$ & 0 \\
\hline Chloromethane & $<10$ & $<10$ & $<10$ & 0 \\
\hline Chromium & $<10$ & $<10$ & $<10$ & 0 \\
\hline Chrysene & $<10$ & $<10$ & $<10$ & 0 \\
\hline cis-1,3-Dichloropropene & $<5$ & $<5$ & $<5$ & 0 \\
\hline Copper & 8.6 & 8.6 & 8.6 & 0.0 \\
\hline Cyanide colorimetric & $<100$ & $<100$ & $<100$ & 0 \\
\hline Di-n-butylphthalate & $<10$ & $<10$ & $<10$ & 0 \\
\hline Di-n-octylphthalate & $<10$ & $<10$ & $<10$ & 0 \\
\hline Dibenz $(a, h)$ anthracene & $<10$ & $<10$ & $<10$ & 0 \\
\hline Dibromochloromethane & $<5$ & $<5$ & $<5$ & 0 \\
\hline Diethylphthalate & $<10$ & $<10$ & $<10$ & 0 \\
\hline Dimethylphthalate & $<10$ & $<10$ & $<10$ & 0 \\
\hline Dissolved solids & 132,000 & 68,000 & 108,000 & 24,351 \\
\hline Ethylbenzene & $<5$ & $<5$ & $<5$ & 0 \\
\hline Fluoranthane & $<10$ & $<10$ & $<10$ & 0 \\
\hline Fluorene & $<10$ & $<10$ & $<10$ & 0 \\
\hline Flouride IC & $<100$ & $<100$ & $<100$ & 0 \\
\hline Hexachlorobenzene & $<10$ & $<10$ & $<10$ & 0 \\
\hline Hexachlorobutadiene & $<10$ & $<10$ & $<10$ & 0 \\
\hline Hexachlorocyclopentadiene & $<10$ & $<10$ & $<10$ & 0 \\
\hline Hexachloroethane & $<10$ & $<10$ & $<10$ & 0 \\
\hline Ideno(1,2,3-cd)pyrene & $<10$ & $<10$ & $<10$ & 0 \\
\hline Isophorone & $<10$ & $<10$ & $<10$ & 0 \\
\hline Lead & 8.1 & 8.1 & 8.1 & 0.0 \\
\hline Manganese & 620 & 13 & 210 & 270 \\
\hline Mercury & $<0.2$ & $<0.2$ & $<0.2$ & 0.0 \\
\hline Methylene chloride & $<5$ & $<5$ & $<5$ & 0 \\
\hline $\mathrm{N}$-nitroso-di-n-propylamine & $<10$ & $<10$ & $<10$ & 0 \\
\hline $\mathrm{N}$-nitrpsodimethylamine & $<10$ & $<10$ & $<10$ & 0 \\
\hline$N$-nitrodiphenylamine & $<10$ & $<10$ & $<10$ & 0 \\
\hline Naphthalene & $<10$ & $<10$ & $<10$ & 0 \\
\hline Nickel & 14 & 14 & 14 & 0 \\
\hline Nitrate nitrogen & $<20$ & $<20$ & $<20$ & 0 \\
\hline Nitrobenzene & $<10$ & $<10$ & $<10$ & 0 \\
\hline Pentachlorophenol & $<50$ & $<50$ & $<50$ & 0 \\
\hline ph, standard units & 8.10 & 7.15 & 7.76 & 0.35 \\
\hline Phenanthrene & $<10$ & $<10$ & $<10$ & 0 \\
\hline Phenol & $<10$ & $<10$ & $<10$ & 0 \\
\hline Pyrene & $<10$ & $<10$ & $<10$ & 0 \\
\hline Sodium & 830 & 461 & 640 & 145 \\
\hline Sulfate & 4,000 & 2,000 & 2,667 & 943 \\
\hline Suspended solids & 177,000 & 9,000 & 65,333 & 78,961 \\
\hline Tetrachloroethene & $<5$ & $<5$ & $<5$ & 0 \\
\hline Toluene & $<5$ & $<5$ & $<5$ & 0 \\
\hline trans-1,2-Dichloroethene & $<5$ & $<5$ & $<5$ & 0 \\
\hline trans-1,3-Dichloropropene & $<5$ & $<5$ & $<5$ & 0 \\
\hline Trichloroethene & $<5$ & $<5$ & $<5$ & 0 \\
\hline Trichlorofluoromethane & & & & 0 \\
\hline Uranium fluorometric & $<1$ & $<1$ & $<1$ & 0 \\
\hline Vinyl chloride & $<10$ & $<10$ & $<10$ & 0 \\
\hline Zinc & 13.0 & 3.8 & 8.1 & 3.8 \\
\hline
\end{tabular}

${ }^{a}$ The values for $\mathrm{pH}$ are in standard units. 
1992 Environmental Report Vol. 1, Oak Ridge

Vol. 2, p. 4-97:

Table 4.83. 1991 NPDES Permit Number TN 0002950

Discharge Point K-1700, Mitchell Branch, K-25 Site

\begin{tabular}{|c|c|c|c|c|c|}
\hline \multirow{2}{*}{ Parameter } & \multirow{2}{*}{$\begin{array}{l}\text { Number of } \\
\text { samples }\end{array}$} & \multicolumn{3}{|c|}{ Concentration } & \multirow{2}{*}{$\begin{array}{c}\text { Standard } \\
\text { error }\end{array}$} \\
\hline & & Max & Min & $\mathrm{Av}$ & \\
\hline 1,1,1-Trichloroethane, $\mu \mathrm{g} / \mathrm{L}$ & 89 & $<5$ & $<5$ & $<5$ & 0 \\
\hline 1,1,2,2-Tctrachloroethane, $\mu \mathrm{g} / \mathrm{L}$ & 89 & $<5$ & $<5$ & $<5$ & 0 \\
\hline 1,1-Dichloroethane, $\mu \mathrm{g} / \mathrm{L}$ & 188 & $<5$ & $<5$ & $<5$ & 0 \\
\hline 1,2-7ichloroethane, $\mu \mathrm{g} / \mathrm{L}$ & 85 & $<5$ & $<5$ & $<5$ & 0 \\
\hline 1,2-Dichlorobenzene, $\mu \mathrm{g} / \mathrm{L}$ & 14 & $<5$ & $<5$ & $<5$ & 0 \\
\hline 1,2,-Dichloropropeine, $\mu \mathrm{g} / \mathrm{L}$ & 89 & $<5$ & $<5$ & $<5$ & 0 \\
\hline 2-Chlorovinyl ether, $\mu \mathrm{g} / \mathrm{L}$ & 89 & $<10$ & $<10$ & $<10$ & 0 \\
\hline Aluminum, $\mathrm{mg} / \mathrm{L}$ & 108 & 3.5 & 0.031 & 0.287 & 0.42 \\
\hline Benzene, $\mu \mathrm{g} / \mathrm{L}$ & 89 & $<5$ & $<5$ & $<5$ & 0 \\
\hline Beryllium, mg/L & 89 & 0.003 & 0.0003 & 0.0011 & 0 \\
\hline Bromodichloromethane, $\mu \mathrm{g} / \mathrm{L}$ & 89 & $<5$ & $<5$ & $<5$ & 0 \\
\hline Bromoform, $\mu \mathrm{g} / \mathrm{L}$ & 89 & $<5$ & $<5$ & $<5$ & 0 \\
\hline Bromomethane, $\mu \mathrm{g} / \mathrm{L}$ & 89 & $<10$ & $<10$ & $<10$ & 0 \\
\hline Cadmium $\mathrm{mg} / \mathrm{L} \dagger$ & 89 & 0.049 & 0.002 & 0.0026 & 0.0049 \\
\hline Carbon tetrachloride, $\mu \mathrm{g} / \mathrm{L}$ & 89 & $<5$ & $<5$ & $<5$ & 0 \\
\hline Chemical oxygen demand (COD), mg/L & 224 & 36 & $<5$ & 6.46 & 4.44 \\
\hline Chloroberizene, $\mu \mathrm{g} / \mathrm{L}$ & 97 & $<5$ & $<5$ & $<5$ & 0 \\
\hline Chloroethane, $\mu \mathrm{g} / \mathrm{L}$ & 89 & $<10$ & $<10$ & $<10$ & 0 \\
\hline Chloroform, $\mu \mathrm{g} / \mathrm{L}$ & 89 & $<5$ & $<5$ & $<5$ & 0 \\
\hline Chloromethane, $\mu \mathrm{g} / \mathrm{L}$ & 89 & $<10$ & $<10$ & $<10$ & 0 \\
\hline Chromium, mg/L & 111 & 0.055 & 0.01 & 0.011 & 0.0046 \\
\hline Cis-1,3-dichloropropene, $\mu \mathrm{g} / \mathrm{L}$ & 89 & $<5$ & $<5$ & $<5$ & 0 \\
\hline Dibromochloromethane, $\mu \mathrm{g} / \mathrm{L}$ & 89 & $<5$ & $<5$ & $<5$ & 0 \\
\hline Dissolved solids, $\mathrm{mg} / \mathrm{L}$ & 114 & 1,080 & 74 & 218.9 & 108.49 \\
\hline Ethyl benzene, $\mu \mathrm{g} / \mathrm{L}$ & 89 & $<5$ & $<5$ & $<5$ & 0 \\
\hline Flow, MGD & 365 & 7.4246 & 0.0632 & 0.7183 & 2.589 \\
\hline Fluoride, $\mathrm{mg} / \mathrm{L}$ & 113 & 0.9 & 0.1 & 0.1863 & 0.0924 \\
\hline Lead, $\mathrm{mg} / \mathrm{L}$ & 112 & 0.026 & 0.004 & 0.00487 & 0.0029 \\
\hline Mercury, mg/L & 90 & 0.00051 & 0.0002 & 0.00021 & 0.00004 \\
\hline Methylene chloride, $\mu \mathrm{g} / \mathrm{L}$ & 90 & $<17$ & $<5$ & 5.4 & 2.14 \\
\hline Nitrate nitrogen, $\mathrm{mg} / \mathrm{L}$ & 111 & 1.13 & 0.04 & 0.3515 & 0.145 \\
\hline Oil and grease, $\mathrm{mg} / \mathrm{L}$ & 113 & 10.98 & 2 & 2.16 & 1.05 \\
\hline $\mathrm{pH}$, standard units & 365 & 8.5 & 6.95 & $a$ & $a$ \\
\hline Selenium, mg/L & 94 & 0.013 & 0.005 & 0.0051 & 0.0008 \\
\hline Silver, $\mathrm{mg} / \mathrm{L}$ & 94 & 0.077 & 0.01 & 0.011 & 0.0068 \\
\hline Tetrachloroethene, $\mu \mathrm{g} / \mathrm{L}$ & 89 & $<5$ & $<5$ & $<5$ & 0 \\
\hline Toluene, $\mu \mathrm{g} / \mathrm{L}$ & 89 & $<5$ & $<5$ & $<5$ & 0 \\
\hline Total suspended solids, $\mathrm{mg} / \mathrm{L}$ & 220 & 1,080 & 1 & 6.4 & 9.572 \\
\hline Trans-1,2-dichloroethane, $\mu \mathrm{g} / \mathrm{L}$ & 89 & 50 & $<5$ & 25.08 & 14.816 \\
\hline Trans-1,3-dichloroethane, $\mu \mathrm{g} / \mathrm{L}$ & 85 & $<5$ & $<5$ & $<5$ & 0 \\
\hline Trichloroethelene, $\mu \mathrm{g} / \mathrm{L}$ & 87 & 69 & $<5$ & 41,773 & 15.64 \\
\hline Trichlorofluoromethane, $\mu \mathrm{g} / \mathrm{L}$ & 8 & $<5$ & $<5$ & $<5$ & 0 \\
\hline Țurbidity, NTU & 222 & 72 & 0.85 & 6.91 & 7.41 \\
\hline Vinyl chloridu, $\mu_{z} !$ & 89 & $<10$ & $<10$ & $<10$ & 0 \\
\hline
\end{tabular}

${ }^{a}$ Not applicable. 
1992 Environmental Report Vol. 1, Oak Ridge

Vol. 2, p. 4-98:

Table 4.84. 1991 NPDES Permit Number TN 0002950

Discharge Point K-1203 Sewage Treatment Plant, K-25 Site

\begin{tabular}{|c|c|c|c|c|c|}
\hline \multirow{2}{*}{ Parameter } & \multirow{2}{*}{$\begin{array}{c}\text { Number of } \\
\text { samples }\end{array}$} & \multicolumn{3}{|c|}{ Concentration } & \multirow{2}{*}{$\begin{array}{c}\text { Standard } \\
\text { error }\end{array}$} \\
\hline & & $\operatorname{Max}$ & Min & Av & \\
\hline Ammonia nitrogen, $\mathrm{mg} / \mathrm{L}$ & 174 & 1.61 & 0.2 & 0.215 & 0.1148 \\
\hline Antimony, mg/L & 1 & $<0.05$ & $<0.05$ & $<0.05$ & 0 \\
\hline Arsenic, $\mathrm{mg} / \mathrm{L}$ & 2 & $<0.05$ & $<0.05$ & $<0.05$ & 0 \\
\hline Beryllium, mg/L & 1 & $<0.001$ & $<0.001$ & $<0.001$ & 0 \\
\hline Biological oxygen demand (BOD), mg/L & 175 & 12 & 2.7 & 5.291 & 1.08 \\
\hline Boron, $\mathrm{mg} / \mathrm{L}$ & 1 & 0.027 & 0.027 & 0.027 & 0 \\
\hline Cadmium, mg/L & 1 & 0.003 & 0.003 & 0.003 & 0 \\
\hline Calcium, mg/L & 1 & 35 & 35 & 35 & 0 \\
\hline Chemical oxygen demand (COD), mg/L & 220 & 159 & 5 & 12,109 & 12.23 \\
\hline Chromium, mg/L & 1 & 0.01 & 0.01 & 0.01 & 0 \\
\hline Cobait, $\mathrm{mg} / \mathrm{L}$ & $i$ & $<0.1$ & $<0.1$ & $<0.1$ & 0 \\
\hline Copper, mg/L & 1 & 0.0081 & 0.0081 & 0.0081 & 0 \\
\hline Fecal coliform, col/100 mL & 174 & $>5,000$ & 0 & 125.469 & 598.4935 \\
\hline Flow, MGD & 365 & 2.787 & 0.1915 & 0.4479 & 0.83919 \\
\hline Iron, $\mathrm{mg} / \mathrm{L}$ & 1 & 0.41 & 0.41 & 0.41 & 0 \\
\hline Lead, mg/L & 2 & 0.05 & $<0.004$ & 0.027 & 0.023 \\
\hline Magnesium, mg/L & 1 & 9.9 & 9.9 & 9.9 & 0 \\
\hline Manganese, $\mathrm{mg} / \mathrm{L}$ & 1 & 0.15 & 0.15 & 0.15 & 0 \\
\hline Mercury, mg/L & 1 & 0.00022 & 0.00022 & 0.00022 & 0 \\
\hline Molybdenum, mg/L & 1 & $<0.01$ & $<0.01$ & $<0.01$ & 0 \\
\hline Nickel, mg/L & 1 & $<0.05$ & $<0.05$ & $<0.05$ & 0 \\
\hline Nitrate nitrogen, $\mathrm{mg} / \mathrm{L}$ & 125 & 226 & 0.65 & 8.083 & 19.7543 \\
\hline $\mathrm{pH}$, standard units & 365 & 8.9 & 6.8 & $a$ & $a$ \\
\hline Potassium, mg/L & 1 & 3.3 & 3.3 & 3.3 & 0 \\
\hline Selenium, mg/L & 2 & 0.05 & $<0.005$ & 0.0275 & 0.0225 \\
\hline Settleable solids, mL/ $\dagger$ & 307 & 4 & 0.1 & 0.119 & 0.2241 \\
\hline Silicon, $\mathrm{mg} / \mathrm{L}$ & 1 & 1.9 & 1.9 & 1.9 & 0 \\
\hline Silver, $\mathrm{mg} / \mathrm{L}$ & 1 & $<0.01$ & $<0.01$ & $<0.01$ & 0 \\
\hline Sodium, mg/L & 1 & 13 & 13 & 13 & 0 \\
\hline Suspended solids, mg/L & 173 & 230 & 2 & $9.54 i$ & 17.242 \\
\hline Total organic carbon, $\mathrm{mg} / \mathrm{L}$ & 43 & 9 & 1 & 3.725 & 1.896 \\
\hline Total residual chlorine, $\mathrm{mg} / \mathrm{L}$ & 455 & 13 & 0.003 & 0.066 & 0.03195 \\
\hline Vanadium, $\mathrm{mg} / \mathrm{L}$ & 1 & $<0.5$ & $<0.5$ & $<0.5$ & 0 \\
\hline Zinc, $\mathrm{mg} / \mathrm{L}$ & 1 & 0.049 & 0.049 & 0.049 & 0 \\
\hline
\end{tabular}

${ }^{a}$ Not applicable. 
1992 Environmental Report Vol. 1, Oak Ridge

Vol. 2, p. 4-100:

Table 4.88. 1991 NPDES Permit Number TN 0002950

Discharge Point K-1407-J Treatment Pond at K-25 Site

\begin{tabular}{|c|c|c|c|c|c|}
\hline \multirow{2}{*}{ Parameter } & \multirow{2}{*}{$\begin{array}{c}\text { Number of } \\
\text { samples }\end{array}$} & \multicolumn{3}{|c|}{ Concentration } & \multirow{2}{*}{$\begin{array}{c}\text { Standard } \\
\text { error }\end{array}$} \\
\hline & & $\operatorname{Max}$ & Min & Av & \\
\hline 1,1,1-Trichloroethane, $\mu \mathrm{g} / \mathrm{L}$ & 230 & $<5$ & $<5$ & $<5$ & 0 \\
\hline 1,1,2,2-Tetrachloroethane, $\mu \mathrm{g} / \mathrm{L}$ & 230 & $<5$ & $<5$ & $<5$ & 0 \\
\hline 1,1,2-Trichloroethane, $\mu \mathrm{g} / \mathrm{L}$ & 230 & $<5$ & $<5$ & $<5$ & 0 \\
\hline 1,1-Dichloroethane, $\mu \mathrm{g} / \mathrm{L}$ & 230 & $<5$ & $<5$ & $<5$ & 0 \\
\hline 1,1-Dichloroethene, $\mu \mathrm{g} / \mathrm{L}$ & 230 & $<5$ & $<5$ & $<5$ & 0 \\
\hline 1,2,4-Trichlorobenzene, $\mu \mathrm{g} / \mathrm{L}$ & 66 & $<40$ & $<10$ & 10.45 & 3.66 \\
\hline 1,2-Dichlorobenzene, $\mu \mathrm{g} / \mathrm{L}$ & 99 & $<40$ & $<10$ & $<10.3$ & 3.0 \\
\hline 1,2-Dichloroethane, $\mu \mathrm{g} / \mathrm{L}$ & 229 & $<5$ & $<5$ & $<5$ & 0 \\
\hline 1,2-Dichloropropane, $\mu \mathrm{g} / \mathrm{L}$ & 229 & $<5$ & $<5$ & $<5$ & 0 \\
\hline 1,3-Dichlorobenzene, $\mu \mathrm{g} / \mathrm{L}$ & 100 & $<40$ & $<10$ & $<10.3$ & 3.5 \\
\hline 1,4-Dichlorobenzene, $\mu \mathrm{g} / \mathrm{L}$ & 103 & $<40$ & $<10$ & $<10.3$ & 3.5 \\
\hline 2,4,6-Trichlorophenol, $\mu \mathrm{g} / \mathrm{L}$ & 67 & $<40$ & $<10$ & $<10.5$ & 3.6 \\
\hline 2,4-Dichlorophenol, $\mu \mathrm{g} / \mathrm{L}$ & 67 & $<40$ & $<10$ & $<10.5$ & 3.6 \\
\hline 2,4-Dimethylphenol, $\mu \mathrm{g} / \mathrm{L}$ & 67 & $<40$ & $<10$ & $<10.5$ & 3.6 \\
\hline 2,4-Dinitrophenol, $\mu \mathrm{g} / \mathrm{L}$ & 67 & $<40$ & $<10$ & $<10.5$ & 3.6 \\
\hline 2,4-Dinitrotoluene, $\mu \mathrm{g} / \mathrm{L}$ & 67 & $<40$ & $<10$ & $<10.5$ & 3.6 \\
\hline 2,6-Dinitrotoluene, $\mu \mathrm{g} / \mathrm{L}$ & 67 & $<40$ & $<10$ & $<10.5$ & 3.6 \\
\hline 2-Chloroethylvinyl ether, $\mu \mathrm{g} / \mathrm{L}$ & 228 & $<10$ & $<10$ & $<10$ & 0 \\
\hline 2-Chloronaphthalene, $\mu \mathrm{g} / \mathrm{L}$ & 70 & $<40$ & $<10$ & $<10.5$ & 3.6 \\
\hline 2-Chlorophenol, $\mu \mathrm{g} / \mathrm{L}$ & 70 & $<40$ & $<10$ & $<10.4$ & 3.6 \\
\hline 2-Nitrophenol, $\mu \mathrm{g} / \mathrm{L}$ & 70 & $<40$ & $<10$ & $<10.4$ & 3.6 \\
\hline 3,3'-Dichlorobenzidine, $\mu \mathrm{g} / \mathrm{L}$ & 70 & $<80$ & $<20$ & $<28.9$ & 7.17 \\
\hline 4,6-Dinitro,2-methylphenol, $\mu \mathrm{g} / \mathrm{L}$ & 70 & $<200$ & $<50$ & $<52.17$ & 17.93 \\
\hline 4-Bromophenyl-phenylether, $\mu \mathrm{g} / \mathrm{L}$ & 70 & $<40$ & $<10$ & $<10.4$ & 3.6 \\
\hline 4-Chloro-3-methylphenol, $\mu \mathrm{g} / \mathrm{L}$ & 70 & $<40$ & $<10$ & $<10.4$ & 3.6 \\
\hline 4-Chlorophenyl-phenylether, $\mu \mathrm{g} / \mathrm{L}$ & 70 & $<40$ & $<10$ & $<10.4$ & 3.6 \\
\hline 4-Nitrophenol, $\mu \mathrm{g} / \mathrm{L}$ & 70 & 200 & 50 & 52.17 & 17.9 \\
\hline Acenaphthene, $\mu \mathrm{g} / \mathrm{L}$ & 70 & $<40$ & $<10$ & $<10.4$ & 3.6 \\
\hline Acenaphthylene, $\mu \mathrm{g} / \mathrm{L}$ & 70 & $<40$ & $<10$ & $<10.4$ & 3.6 \\
\hline Aluminum, $\mathrm{mg} / \mathrm{L}$ & 96 & 1.9 & 0.095 & 0.205 & 0.23 \\
\hline Ammonia nitrogen, $\mathrm{mg} / \mathrm{L}$ & 47 & 0.25 & $<0.2$ & 0.201 & 0.007 \\
\hline Anthracene, $\mu \mathrm{g} / \mathrm{L}$ & 55 & $<40$ & $<10$ & $<10.5$ & 3.9 \\
\hline Antimony, $\mathrm{mg} / \mathrm{L}$ & 103 & $<0.05$ & $<0.05$ & $<0.05$ & 0 \\
\hline Arsenic, $\mathrm{mg} / \mathrm{L}$ & 129 & $<0.005$ & $<0.005$ & $<0.005$ & 0 \\
\hline Barium, mg/L & 160 & 0.33 & 0.022 & 0.098 & 0.0297 \\
\hline Benzene, $\mu \mathrm{g} / \mathrm{L}$ & 231 & $<5$ & $<5$ & 5 & 0 \\
\hline Benzidine, $\mu \mathrm{g} / \mathrm{L}$ & 69 & 40 & $<10$ & 10.43 & 3.6 \\
\hline Benzo(a)anthracene, $\mu \mathrm{g} / \mathrm{L}$ & 69 & $<40$ & 10.43 & 3.6 & 3.6 \\
\hline Benzo(a)pyrene, $\mu \mathrm{g} / \mathrm{L}$ & 69 & 40 & $<10$ & 10.43 & 3.6 \\
\hline Benzo(b)fluoranthene, $\mu \mathrm{g} / \mathrm{L}$ & 69 & 40 & $<10$ & 10.43 & 3.6 \\
\hline Benzo(g,h,i)perylene, $\mu \mathrm{g} / \mathrm{L}$ & 69 & 40 & $<10$ & 10.43 & 3.6 \\
\hline $\operatorname{Benzo}(k)$ fluoranthene, $\mu \mathrm{g} / \mathrm{L}$ & 69 & 40 & $<10$ & 10.43 & 3.6 \\
\hline Beryllium, mg/L & 99 & $<0.003$ & $<0.0003$ & $<0.00097$ & 0.0003 \\
\hline Bis(2-chloroethoxy)methane, $\mu \mathrm{g} / \mathrm{L}$ & 68 & $<40$ & $<10$ & 10.4 & 3.6 \\
\hline Bis(2-chloroethyl)ether, $\mu \mathrm{g} / \mathrm{L}$ & 68 & $<40$ & $<10$ & 10.4 & 3.6 \\
\hline Bis(2-chloroisopropyl)ether, $\mu \mathrm{g} / \mathrm{L}$ & 67 & $<40$ & $<10$ & 10.4 & 3.6 \\
\hline Bis(2-ethylhexyl)phthalate, $\mu \mathrm{g} / \mathrm{L}$ & 68 & $<40$ & $<10$ & $<10.4$ & 3.6 \\
\hline Boron, $\mathrm{mg} / \mathrm{L}$ & 95 & 1.6 & 0.019 & 0.367 & 0.4 \\
\hline
\end{tabular}


Table 4.88 (continued)

\begin{tabular}{|c|c|c|c|c|c|}
\hline \multirow{2}{*}{ Parameter } & \multirow{2}{*}{$\begin{array}{c}\text { Number of } \\
\text { samples }\end{array}$} & \multicolumn{3}{|c|}{ Concentration } & \multirow{2}{*}{$\begin{array}{l}\text { Standard } \\
\text { error }\end{array}$} \\
\hline & & Max & $\operatorname{Min}$ & Av & \\
\hline Bromide, $\mathrm{mg} / \mathrm{L}$ & 44 & 10 & 1 & 2.39 & 1.7 \\
\hline Bromodichloromethane, $\mu \mathrm{g} / \mathrm{L}$ & 230 & 7 & $<2$ & 4.996 & 0.238 \\
\hline Bromoform, $\mu \mathrm{g} / \mathrm{L}$ & 230 & $<5$ & $<5$ & $<5$ & 0 \\
\hline Bromomethane, $\mu \mathrm{g} / \mathrm{L}$ & 230 & $<10$ & $<10$ & $<10$ & 0 \\
\hline Butylbenzylphthalte, $\mu \mathrm{g} / \mathrm{L}$ & 69 & $<40$ & $<10$ & $<10.4$ & 3.6 \\
\hline Cadmium, mg/L & 126 & 0.0057 & $<0.002$ & $<0.0021$ & 0.0004 \\
\hline Carbon tetrachloride, $\mu \mathrm{g} / \mathrm{L}$ & 231 & $<5$ & $<5$ & $<5$ & 0 \\
\hline Chemical oxygen demand, $\mathrm{mg} / \mathrm{L}$ & 167 & 343 & $<5$ & $<15.5$ & 28.04 \\
\hline Chloride, $\mathrm{mg} / \mathrm{L}$ & 34 & 3090 & $<20$ & 626.21 & 638.988 \\
\hline Chlorobenzene, $\mu \mathrm{g} / \mathrm{L}$ & 231 & $<5$ & $<5$ & $<5$ & 0 \\
\hline Chloroethane, $\mu \mathrm{g} / \mathrm{L}$ & 231 & $<10$ & $<10$ & $<10$ & 0 \\
\hline Chloroform, $\mu \mathrm{g} / \mathrm{L}$ & 214 & 52 & $<1$ & $<5.86$ & 6.76 \\
\hline Chloromethane, $\mu \mathrm{g} / \mathrm{L}$ & 230 & $<10$ & $<10$ & $<10$ & 0 \\
\hline Chromium, mg/L & 123 & 0.1 & $<10$ & 0.014 & 0.012 \\
\hline Chrysene, $\mu \mathrm{g} / \mathrm{L}$ & 69 & $<40$ & $<10$ & $<10.4$ & 3.6 \\
\hline Cis-1,3-dichloropropene, $\mu \mathrm{g} / \mathrm{L}$ & 230 & $<5$ & $<5$ & $<5$ & 0 \\
\hline Cobalt, $\mathrm{mg} / \mathrm{L}$ & 103 & $<0.1$ & $<0.1$ & $<0.1$ & 0 \\
\hline Copper, mg/L & 120 & 0.081 & $<0.004$ & $<0.014$ & 0.013 \\
\hline Cyanide, $\mathrm{mg} / \mathrm{L}$ & 59 & 0.33 & $<0.1$ & $<0.11$ & 0.032 \\
\hline Di-n-butylphthalate, $\mu \mathrm{g} / \mathrm{L}$ & 69 & $<40$ & $<10$ & $<10.4$ & 3.6 \\
\hline Di-n-octylphthalate, $\mu \mathrm{g} / \mathrm{L}$ & 69 & $<40$ & $<10$ & $<10.4$ & 3.6 \\
\hline Dibenz(a.h)anthracene, $\mu \mathrm{g} / \mathrm{L}$ & 69 & $<40$ & $<10$ & $<10.4$ & 3.6 \\
\hline Dibromochloromethane, $\mu \mathrm{g} / \mathrm{L}$ & 231 & $<5$ & $<5$ & $<5$ & 0 \\
\hline Diethylphthalate, $\mu \mathrm{g} / \mathrm{L}$ & 68 & $<40$ & $<10$ & $<10.4$ & 3.6 \\
\hline Dimethylphthalate, $\mu \mathrm{g} / \mathrm{L}$ & 68 & $<40$ & $<1.0$ & $<10.4$ & 3.6 \\
\hline Dissolved solids mg/L† & 177 & 7322 & 260 & 2077.2 & 1374.6 \\
\hline Ethyl benzene, $\mu \mathrm{g} / \mathrm{L}$ & 229 & $<5$ & $<5$ & $<5$ & 0 \\
\hline Fluoranthene, $\mu \mathrm{g} / \mathrm{L}$ & 69 & $<40$ & $<10$ & $<10.4$ & 3.6 \\
\hline Fluorene, $\mu \mathrm{g} / \mathrm{L}$ & 69 & $<40$ & $<10$ & $<10.4$ & 3.6 \\
\hline Fluoride, $\mathrm{mg} / \mathrm{L}$ & 164 & 71 & 0.2 & 13.2 & 17.3 \\
\hline Hexachlorobenzene, $\mu \mathrm{g} / \mathrm{L}$ & 69 & $<40$ & $<10$ & $<10.4$ & 3.6 \\
\hline Hexachlorobutadiene, $\mu \mathrm{g} / \mathrm{L}$ & 69 & $<40$ & $<10$ & $<10.4$ & 3.6 \\
\hline Hexacylopentadiene, $\mu \mathrm{g} / \mathrm{L}$ & 69 & $<40$ & $<10$ & $<10.4$ & 3.6 \\
\hline Hexachloroethane, $\mu \mathrm{g} / \mathrm{L}$ & 69 & $<40$ & $<10$ & $<10.4$ & 3.6 \\
\hline Indeno(1,2,3-cd)pyrene, $\mu \mathrm{g} / \mathrm{L}$ & 69 & $<40$ & $<10$ & $<10.4$ & 3.6 \\
\hline Iron, $\mathrm{mg} / \mathrm{L}$ & 119 & 3.3 & 0.099 & 0.68 & 0.73 \\
\hline Isophorone, $\mu \mathrm{g} / \mathrm{L}$ & 70 & $<40$ & $<10$ & $<10.4$ & 3.6 \\
\hline Kjeldahl nitrogen, $\mathrm{mg} / \mathrm{L}$ & 45 & 2.74 & 0.84 & 1.08 & 0.3 \\
\hline Lead, $\mathrm{mg} / \mathrm{L}$ & 125 & 0.016 & $<0.004$ & $<0.0046$ & 0.002 \\
\hline Magnesium, mg/L & 95 & 0.47 & 8.9 & 17.36 & 13.73 \\
\hline Manganese, $\mathrm{mg} / \mathrm{L}$ & 118 & 0.342 & $<0.01$ & 0.034 & 0.036 \\
\hline MBAS, mg/L & 57 & 0.3 & $<0.2$ & $<0.203$ & 0.015 \\
\hline Methylene chloride, $\mu \mathrm{g} / \mathrm{L}$ & 102 & 19 & $<2$ & 5.66 & 2.36 \\
\hline Molybdenum, $\mathrm{mg} / \mathrm{L}$ & 99 & $<0.1$ & $<0.01$ & $<0.016$ & 0.018 \\
\hline $\mathrm{N}$-nitroso-di-N-propylamine, $\mu \mathrm{g} / \mathrm{L}$ & 69 & $<40$ & $<10$ & $<10.4$ & 3.6 \\
\hline$N$-nitrosodimethylamine, $\mu \mathrm{g} / \mathrm{L}$ & 69 & $<40$ & $<10$ & $<10.4$ & 3.6 \\
\hline $\mathrm{N}$-nitrosodiphenylamine, $\mu \mathrm{g} / \mathrm{L}$ & 69 & $<40$ & $<10$ & $<10.4$ & 3.6 \\
\hline Naphthalene, $\mu \mathrm{g} / \mathrm{L}$ & 69 & $<40$ & $<10$ & $<10.4$ & 3.6 \\
\hline Nickel, mg/L & 125 & 0.5 & $<0.01$ & $<0.06$ & 0.06 \\
\hline Nitrate nitrogen, mg/L & 98 & 23 & $<0.2$ & $<2.02$ & 2.5 \\
\hline Nitrobenzene, $\mu \mathrm{g} / \mathrm{L}$ & 70 & $<40$ & $<10$ & $<10.4$ & 3.6 \\
\hline Oil and grease, $\mathrm{mg} / \mathrm{L}$ & 109 & 14.5 & $<2$ & $<2.3$ & 1.8 \\
\hline
\end{tabular}


1992 Environmental Report Vol. 1, Oak Ridge

Table 4.88 (continued)

\begin{tabular}{|c|c|c|c|c|c|}
\hline \multirow{2}{*}{ Parameter } & \multirow{2}{*}{$\begin{array}{c}\text { Number of } \\
\text { samples }\end{array}$} & \multicolumn{3}{|c|}{ Concentration } & \multirow{2}{*}{$\begin{array}{c}\text { Standard } \\
\text { error }\end{array}$} \\
\hline & & Max & Min & Av & \\
\hline \multicolumn{6}{|l|}{ РCB } \\
\hline Aroclor-1016, $\mu \mathrm{g} / \mathrm{L}$ & 63 & $<0.5$ & $<0.5$ & $<0.5$ & 0 \\
\hline Aroclor $-1221, \mu \mathrm{g} / \mathrm{L}$ & 63 & $<0.5$ & $<0.5$ & $<0.5$ & 0 \\
\hline Aroclor $-1232, \mu \mathrm{g} / \mathrm{L}$ & 63 & $<0.5$ & $<0.5$ & $<0.5$ & 0 \\
\hline Aroclor-1242, $\mu \mathrm{g} / \mathrm{L}$ & 63 & $<0.5$ & $<0.5$ & $<0.5$ & 0 \\
\hline Aroclor $-1248, \mu \mathrm{g} / \mathrm{L}$ & 63 & $<0.5$ & $<0.5$ & $<0.5$ & 0 \\
\hline Aroclor $-1250, \mu \mathrm{g} / \mathrm{L}$ & 63 & 1.4 & $<1$ & 1.01 & 0.05 \\
\hline Aroclor $-1260, \mu \mathrm{g} / \mathrm{L}$ & 63 & $<1$ & $<1$ & $<1$ & 0 \\
\hline Pentachlorophenol, $\mu \mathrm{g} / \mathrm{L}$ & 70 & $<200$ & $<50$ & $<52.14$ & 17.8 \\
\hline $\mathrm{pH}$, standard units & 365 & 8.9 & 6.7 & $a$ & $a$ \\
\hline Phenanthrene, $\mu \mathrm{g} / \mathrm{L}$ & 70 & $<40$ & $<10$ & $<10.4$ & 3.6 \\
\hline Phenol, $\mu \mathrm{g} / \mathrm{L}$ & 70 & $<40$ & $<10$ & $<10.4$ & 3.6 \\
\hline Phenols, mg/L $\dagger$ & 46 & 1.5 & 0.03 & $<0.07$ & 0.21 \\
\hline Phosphorus, mg/L & 95 & 3.7 & $<0.2$ & $<3.06$ & 6.12 \\
\hline Pyrene, $\mu \mathrm{g} / \mathrm{L}$ & 69 & $<40$ & $<10$ & $<10.4$ & 3.6 \\
\hline Selenium, $\mathrm{mg} / \mathrm{L}$ & 130 & $<0.025$ & $<0.005$ & $<0.00538$ & 0.0025 \\
\hline Silver, $\mathrm{mg} / \mathrm{L}$ & 129 & 0.06 & $<0.01$ & $<0.011$ & 0.0078 \\
\hline Sulfate, $\mathrm{mg} / \mathrm{L}$ & 61 & 1500 & 135 & 553.23 & 284.4 \\
\hline Sulfide, $\mathrm{mg} / \mathrm{L}$ & 43 & 2 & $<1$ & $<1.02$ & 0.151 \\
\hline Sulfite, $\mathrm{mg} / \mathrm{L}$ & 41 & 2 & $<0.1$ & $<1.38$ & 0.73 \\
\hline Suspended solids, $\mathrm{mg} / \mathrm{L}$ & 218 & 36 & 0.1 & 7.18 & 5.68 \\
\hline Tetrachloroethene, $\mu \mathrm{g} / \mathrm{L}$ & 230 & $<5$ & $<5$ & $<5$ & 0 \\
\hline Thallium, $\mathrm{mg} / \mathrm{L}$ & 104 & $<0.01$ & $<0.01$ & $<0.01$ & 0 \\
\hline Tin, $\mathrm{mg} / \mathrm{L}$ & 101 & 0.05 & $<0.01$ & $<0.02$ & 0.017 \\
\hline Titanium, $\mathrm{mg} / \mathrm{L}$ & 101 & 0.03 & $<0.003$ & $<0.0053$ & 0.0056 \\
\hline Toluene, $\mu \mathrm{g} / \mathrm{L}$ & 229 & 11 & $<5$ & $<5.03$ & 0.396 \\
\hline Total organic carbon, $\mathrm{mg} / \mathrm{L}$ & 83 & 19 & $<1$ & $<4.05$ & 2.52 \\
\hline Phosphate, $\mathrm{mg} / \mathrm{L}$ & 40 & 92 & 0.6 & 9.32 & 15.2 \\
\hline Total residual chlorine, $\mathrm{mg} / \mathrm{L}$ & 39 & 0.22 & $<0.02$ & $<0.072$ & 0.04 \\
\hline Trans-1,2-dichloroethene, $\mu \mathrm{g} / \mathrm{L}$ & 219 & 8 & $<5$ & $<5.04$ & 0.3 \\
\hline Trans-1,3-dichloropropene, $\mu \mathrm{g} / \mathrm{L}$ & 231 & $<5$ & $<5$ & $<5$ & 0 \\
\hline Trichloroethene, $\mu \mathrm{g} / \mathrm{L}$ & 231 & $<5$ & $<5$ & $<5$ & 0 \\
\hline Vinyl chloride, $\mu \mathrm{g} / \mathrm{L}$ & 231 & $<10$ & $<10$ & $<10$ & 0 \\
\hline Zinc, $\mathrm{mg} / \mathrm{L}$ & 122 & 0.29 & $<0.002$ & $<0.028$ & 0.03 \\
\hline Trichlorofluoromethane, $\mu \mathrm{g} / \mathrm{L}$ & 51 & $<5$ & $<5$ & $<5$ & 0 \\
\hline
\end{tabular}

"Not applicable. 
Vol. 2, p. 5-23:

Table 5.15. Constituents in Waste Area Grouping (WAG) 1 groundwater at ORNL, March 7-26, 1991

\begin{tabular}{|c|c|c|c|c|c|c|c|}
\hline \multirow{2}{*}{ Analyte } & \multirow{2}{*}{$\begin{array}{l}\text { Number } \\
\text { detected }\end{array}$} & \multirow{2}{*}{$\begin{array}{c}\text { Number } \\
\text { of } \\
\text { samples }\end{array}$} & \multicolumn{3}{|c|}{ Values above the detection limit } & \multirow{2}{*}{$\begin{array}{l}\text { Reference } \\
\text { value }^{c}\end{array}$} & \multirow{2}{*}{$\begin{array}{l}\text { Number of values } \\
\text { exceeding } \\
\text { reference [ref] }\end{array}$} \\
\hline & & & $\operatorname{Max}^{a}$ & $\operatorname{Min}^{a}$ & $A v^{b}$ & & \\
\hline
\end{tabular}

Anions, unfiltered (mg/L)

Fluoride
Nitrate
Phosphate
Sulfate as $\mathrm{SO}_{4}$

Field measurements, unfiltered

Conductivity $(\mathrm{mS} / \mathrm{cm})$

Dissolved oxygen (ppm)

Redox (mV)

Temperature $\left({ }^{\circ} \mathrm{C}\right)$

Turbidity (JTU)

$\mathrm{pH}$ (standard units)

Metals, filtered (mg/L)

Aluminum
Barium
Beryllium
Boron
Calcium
Chromium
Iron
Magnesium
Mangat:e:
Nickel
Potassium
Silicon
Silver
Sodium
Strontium
Vanadium
Zinc

Metals, unfiltered $(\mathrm{mg} / \mathrm{L})$

Aluminum

Barium

Beryllium

Calcium

Chromium

Iron

Magnesium

Manganese

Nickel

Potassium

Silver

Sodium

Vanadium

Zinc
Downgradient wells

$\begin{array}{rrrlccr}23 & 23 & 68 & 1.5 & 19^{*} & 250 & 0[3] \\ 20 & 23 & 3.4 & 0.10 & 0.52^{*} & 4.0 & 0[2] \\ 4 & 23 & 8.3 & 1.6 & 5.4^{*} & 10 & 0[2] \\ 1 & 23 & 2.2 & 2.2 & 2.2 & e & {[e]} \\ 22 & 23 & 110 & 2.0 & 36^{*} & 250 & 0[3]\end{array}$

$\begin{array}{ll}23 & \\ 23 & \\ 23 & 23 \\ 23 & 23 \\ 23 & 23 \\ 23 & 23\end{array}$

0.96
5.4
210
18
910
9.0

0.15
0.010
-200
10
110
6.6

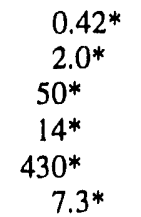

$e$

$e$

31

1.0

$(6.5,8.5)$

$[e]$
$[e]$
$[e]$
$0[1]$
$23[2]$
$1[3]$

\subsection{6}

0.43

0.00092

1.0

170

0.019

19

31

7.2

0.0062

7.5

5.6

0.0061

260

1.3

0.0032

0.019

0.071

0.023

0.00042

1.0

1.3

0.0055

0.067

0.47

0.0019

0.0043

0.35

5.6

0.0054

5.8

1.3

0.0021

0.0052

0.15
$0.14^{*}$
$0.00065^{*}$
1.0
$89^{*}$
$0.013^{*}$
$4.8 *$

0.20

1[3]

$2.0 \quad 0[2]$

$e$

e

e

0.050

0.30

$17^{*} \dagger$

$1.7 *$

$0.0049 *$

$1.8^{*}$

5.6

$0.0058 *$

$41^{*}$

1.3

$0.0027^{*}$

$0.0079 *$

e

0.050

0.10

$e$

$e$

0.050

$e$

$e$

$e$

5.0

$0[1]$

9[3]

[e]

$10[3]$

0[1]

[e]

[e]

$0[1]$

[e]

[e]

[e]

$[e]$
$0[1]$

$\begin{array}{cl}0.29 & 0.059 \\ 0.33 & 0.025 \\ 0.00082 & 0.00052 \\ 170 & 1.5 \\ 0.019 & 0.0054 \\ 18 & 0.054 \\ 30 & 0.55 \\ 6.4 & 0.0017 \\ 0.0078 & 0.0040 \\ 7.0 & 0.40 \\ 0.0068 & 0.0056 \\ 300 & 5.2 \\ 0.0038 & 0.0023 \\ 0.024 & 0.0054\end{array}$

0.20

3[3]

$0.12 *$

$0.00068^{*}$

88*

$0.013^{*}$

$3.0^{*}$

$16 *$

1.3*

$0.0053^{*}$

$1.7 *$

$0.0062 *$

43*

$0.0032 *$

$0.011^{*}$
2.0

$e$

e

0.050

0.30

e

0.050

0.10

e

0.050

$e$

e

5.0
0[2]

$0[1]$

12[3]

[e]

$10[3]$

0[1]

[e]

o[1]

$[e]$
$[e]$

0[1] 
Table 5.15 (WAG 1 continued)

\begin{tabular}{|c|c|c|c|c|c|c|c|}
\hline \multirow{2}{*}{ Analyte } & \multirow{2}{*}{$\begin{array}{l}\text { Number } \\
\text { detected }\end{array}$} & \multirow{2}{*}{$\begin{array}{c}\text { Number } \\
\text { of } \\
\text { samples }\end{array}$} & \multicolumn{3}{|c|}{ Values above the detection limit } & \multirow{2}{*}{$\begin{array}{l}\text { Reference } \\
\text { value }^{c}\end{array}$} & \multirow{2}{*}{$\begin{array}{l}\text { Number of } \\
\text { exceeding } \\
\text { reference } 1 \text { ro }\end{array}$} \\
\hline & & & $\operatorname{Max}^{a}$ & $\operatorname{Min}^{a}$ & $A v^{b}$ & & \\
\hline \multicolumn{8}{|c|}{ Downgradient wells (continued) } \\
\hline \multicolumn{8}{|l|}{ Others, filtered } \\
\hline Solids, total dissolved $(\mathrm{mg} / \mathrm{L})$ & 23 & 23 & 720 & 180 & $400^{*}$ & 500 & $6[1]$ \\
\hline \multicolumn{8}{|l|}{ Others, unfiltered } \\
\hline Alkalinity (mg/L) & 23 & 23 & 450 & 150 & $300^{*}$ & $e$ & {$[e]$} \\
\hline Carbon, total organic (mg/L) & 23 & 23 & 4.3 & 0.70 & $1.9^{*}$ & $e$ & {$[e]$} \\
\hline Halides, total organic $(\mu \mathrm{g} / \mathrm{L})$ & 12 & 23 & 44 & 5.0 & $16^{*}$ & $e$ & {$[e]$} \\
\hline Nitrogen, total Kjeldahl (mg/L) & 13 & 23 & 3.1 & 0.13 & $0.92 *$ & $e$ & {$[e]$} \\
\hline Solids, total suspended ( $\mathrm{mg} / \mathrm{L})$ & 12 & 23 & 39 & 5.0 & $14^{*}$ & $e$ & {$[e]$} \\
\hline Sulfide, total $(\mathrm{mg} / \mathrm{L})$ & 15 & 23 & 4.5 & 0.16 & $0.68^{*}$ & $e$ & {$[e]$} \\
\hline \multicolumn{8}{|l|}{ Pesticides and PCBs, unfiltered $(\mu \mathrm{g} / \mathrm{L})$} \\
\hline Endosulfan sulfate & 2 & 23 & JB 0.040 & JB 0.010 & 0.025 & $e$ & {$[e]$} \\
\hline Heptachlor & 2 & 23 & $\mathrm{~J} 0.033$ & JB 0.010 & 0.022 & $e$ & {$[e]$} \\
\hline gamma-BHC (Lindane) & 1 & 23 & JB 0.030 & JB 0.030 & 0.030 & $e$ & {$[e]$} \\
\hline \multicolumn{8}{|l|}{ Radionuclides, filtered ( $\mathrm{g} / \mathrm{L}$ ) } \\
\hline U-Total & 1 & 1 & 0.000021 & 0.000021 & 0.000021 & $e$ & {$[e]$} \\
\hline \multicolumn{8}{|l|}{ Radionuclides, unfiltered ( $\mathrm{g} / \mathrm{L}$ ) } \\
\hline U-Total & 1 & 1 & 0.000031 & 0.000031 & 0.000031 & $e$ & {$[e]$} \\
\hline \multicolumn{8}{|l|}{ Radionuclides, filtered ( $\mathrm{pCi} / \mathrm{L}$ ) } \\
\hline${ }^{60} \mathrm{Co}$ & 2 & 23 & 86 & 46 & 66 & 200 & $0[4]$ \\
\hline Gross alpha & 9 & 23 & 300 & 1.3 & 35 & 15 & $1[2]$ \\
\hline Gross beta & 15 & 23 & 14,000 & 3.0 & 950 & 50 & $3[2]$ \\
\hline${ }^{89} \mathrm{Sr}+{ }^{90} \mathrm{Sr}$ & 8 & 18 & 6,500 & 3.2 & 840 & 8 & $5[2]$ \\
\hline${ }^{234} \mathrm{U}$ & 1 & 1 & 300 & 300 & 300 & 20 & $1[4]$ \\
\hline${ }^{235} \mathrm{U}$ & 1 & $i$ & 1.1 & 1.1 & 1.1 & 24 & $0[4]$ \\
\hline${ }^{238} \mathrm{U}$ & 1 & 1 & 7.0 & 7.0 & 7.0 & 24 & $0[4]$ \\
\hline \multicolumn{8}{|l|}{ Radionuclidesf, unfiltered ( $\mathrm{pCi} / \mathrm{L}$ ) } \\
\hline${ }^{60} \mathrm{Co}$ & 1 & 23 & 57 & 57 & 57 & 200 & $0[4]$ \\
\hline${ }^{137} \mathrm{Cs}$ & 1 & 23 & 54 & 54 & 54 & 120 & $0[4]$ \\
\hline Gross alpha & 11 & 23 & 260 & 1.4 & 26 & 15 & $1[2]$ \\
\hline Gross beta & 12 & 23 & 14,000 & 3.2 & 1,200 & 50 & $3[2]$ \\
\hline${ }^{3} \mathrm{H}$ & 14 & 23 & 6,500 & 840 & $2,400^{*}$ & $20,000 \dagger$ & $0[2] \dagger$ \\
\hline${ }^{89} \mathrm{Sr}+{ }^{90} \mathrm{Sr} \dagger$ & 9 & 17 & 6,800 & 3.5 & 770 & $8.0 \dagger$ & $4[2] \dagger$ \\
\hline${ }^{234} \mathrm{U}$ & 1 & 1 & 300 & 300 & 300 & 20 & $1[4]$ \\
\hline${ }^{235} \mathrm{U}$ & $i$ & 1 & 1.6 & 1.6 & 1.6 & 24 & $0[4]$ \\
\hline${ }^{238} \mathrm{U}$ & 1 & 1 & 10 & 10 & 10 & 24 & $0[4]$ \\
\hline \multicolumn{8}{|c|}{ Tentatively identified compounds, unfiltered $(\mu \mathrm{g} / \mathrm{L})$} \\
\hline Toluene-solvent in std. solns, -7.07 & 1 & 1 & JB 470 & JB 470 & 470 & $e$ & {$[e]$} \\
\hline Toluene-solvent in std. solns. -7.08 & 1 & 1 & JB 490 & JB 490 & 490 & $e$ & {$[e]$} \\
\hline Toluene-solvent in std. solns. -7.09 & 2 & 2 & JB 230 & JB 190 & $210^{*}$ & $e$ & {$[e]$} \\
\hline Toluene-solvent in std. solns. -7.1 & 2 & 2 & JB 470 & JB 270 & 370 & $e$ & {$[e]$} \\
\hline Toluene-solvent in std. solns.-7.11 & 1 & 1 & JB 180 & JB 180 & 180 & $e$ & {$[e]$} \\
\hline Unknown-10.3 & $i$ & 1 & J 140 & J 140 & 140 & $e$ & {$[e]$} \\
\hline Unknown-25.16 & 1 & 1 & $\mathrm{~J} 17$ & J 17 & 17 & $e$ & {$[e]$} \\
\hline Unknown-7.95 & 1 & 1 & $\mathrm{~J} 33$ & J 33 & 33 & $e$ & {$[e]$} \\
\hline Unknown-8.16 & 2 & 2 & $\mathrm{~J} 220$ & J 13 & 120 & $e$ & {$[e]$} \\
\hline Unknown-8.17 & 1 & 1 & $\mathrm{~J} 28$ & $\mathrm{~J} 28$ & 28 & $e$ & {$[e]$} \\
\hline Unknown-8.9 & 1 & 1 & J 12 & $\mathrm{~J} 12$ & 12 & $e$ & {$[e]$} \\
\hline Unknown-9.1 & 1 & 1 & J 9.0 & J 9.0 & 9.0 & $e$ & {$[e]$} \\
\hline
\end{tabular}


Table 5.15 (WAG 1 continued)

\begin{tabular}{|c|c|c|c|c|c|c|c|}
\hline \multirow{2}{*}{ Analyte } & \multirow{2}{*}{$\begin{array}{l}\text { Number } \\
\text { detected }\end{array}$} & \multirow{2}{*}{$\begin{array}{c}\text { Number } \\
\text { of } \\
\text { samples }\end{array}$} & \multicolumn{3}{|c|}{ Values above the detection limit } & \multirow{2}{*}{$\begin{array}{c}\text { Reference } \\
\text { value }^{c}\end{array}$} & \multirow{2}{*}{$\begin{array}{l}\text { Number of values } \\
\text { exceeding } \\
\text { reference }[\mathrm{ref}]^{d}\end{array}$} \\
\hline & & & $\operatorname{Max}^{a}$ & $\operatorname{Min}^{a}$ & $A v^{b}$ & & \\
\hline \multicolumn{8}{|c|}{ Downgradient wells (continued) } \\
\hline \multicolumn{8}{|c|}{ Volatile organics, unfiltered $(\mu \mathrm{g} / \mathrm{L})$} \\
\hline 1,2-Dichloroethene & 1 & 23 & $\mathrm{~J} 3.0$ & J 3.0 & 3.0 & $e$ & [e] \\
\hline Carbon disulfide & 1 & 23 & J 3.0 & J 3.0 & 3.0 & $e$ & {$[e]$} \\
\hline Carbon tetrachloride & 1 & 23 & $\mathrm{~J} 2.0$ & $\mathrm{~J} 2.0$ & 2.0 & 5.0 & $0[2]$ \\
\hline Chloroform & 3 & 23 & 8.0 & $\mathrm{~J} 3.0$ & 4.7 & 100 & $0[2]$ \\
\hline Methylene chloride & 2 & 23 & JB 1.0 & JB 1.0 & 1.0 & $e$ & {$[e]$} \\
\hline Trichloroethene & 4 & 23 & 6.0 & $\mathrm{~J} 2.0$ & $3.8^{*}$ & 5.0 & $1[2]$ \\
\hline \multicolumn{8}{|c|}{ Upgradient wells } \\
\hline \multicolumn{8}{|l|}{ Anions, unfiltered $(\mathrm{mg} / \mathrm{L})$} \\
\hline Chloride & 3 & 3 & 11 & 2.3 & 5.8 & 250 & $0[3]$ \\
\hline Fluoride & 3 & 3 & 0.60 & 0.10 & 0.43 & 4.0 & $0[2]$ \\
\hline Nitrate & 1 & 3 & 5.5 & 5.5 & 5.5 & 10 & $0[2]$ \\
\hline Sulfate (as $\mathrm{SO}_{4}$ ) & 3 & 3 & 36 & 20 & $27^{*}$ & 250 & $0[3]$ \\
\hline \multicolumn{8}{|l|}{ Field measurements, unfiltered } \\
\hline Conductivity $(\mathrm{mS} / \mathrm{cm})$ & 3 & 3 & 0.41 & 0.28 & $0.33^{*}$ & $e$ & {$[e]$} \\
\hline Dissolved oxygen (ppm) & 3 & 3 & 6.7 & 0.70 & 2.7 & $e$ & {$[e]$} \\
\hline Redox $(\mathrm{mV})$ & 3 & 3 & 200 & -200 & 62 & $e$ & {$[e]$} \\
\hline Temperature $\left({ }^{\circ} \mathrm{C}\right)$ & 3 & 3 & 15 & 14 & $15^{*}$ & 31 & $0[1]$ \\
\hline Turbidity (JTU) & 3 & 3 & 1,000 & 140 & 650 & 1.0 & $3[2]$ \\
\hline $\mathrm{pH}$ (standard units) & 3 & 3 & 7.8 & 6.9 & $7.4^{*}$ & $(6.5,8.5)$ & $0[3]$ \\
\hline \multicolumn{8}{|l|}{ Metals, filtered (mg/L) } \\
\hline Barium & 3 & 3 & 0.30 & 0.037 & 0.17 & 2.0 & $0[2]$ \\
\hline Calcium & 3 & 3 & 110 & 49 & $84^{*}$ & $e$ & {$[e]$} \\
\hline Chromium & 3 & 3 & 0.018 & 0.0041 & 0.012 & 0.050 & $0[1]$ \\
\hline Cobalt & 1 & 3 & 0.0047 & 0,0047 & 0.0047 & $e$ & {$[e]$} \\
\hline Iron & 1 & 3 & 0.25 & 0.25 & 0.25 & 0.30 & $0[3]$ \\
\hline Magnesium & 3 & 3 & 31 & 7.5 & $21^{*}$ & $e$ & {$[e]$} \\
\hline Manganese & 2 & 3 & 0.0069 & 0.0034 & 0.0052 & 0.050 & $0[3]$ \\
\hline Potassium & 3 & 3 & 1.1 & 0.66 & $0.88 *$ & $e$ & {$[e]$} \\
\hline Sodium & 2 & 3 & 18 & 5.7 & 12 & $e$ & {$[e]$} \\
\hline Vanadium & 2 & 3 & 0.0035 & 0.0021 & 0.0028 & $e$ & {$[e]$} \\
\hline Zinc & 3 & 3 & 0.0087 & 0.0069 & $0.0075^{*}$ & 5.0 & $0[1]$ \\
\hline \multicolumn{8}{|l|}{ Metals, unfiltered $(\mathrm{mg} / \mathrm{L})$} \\
\hline Barium & 3 & 3 & 0.24 & 0.11 & $0.18^{*}$ & 2.0 & $0[2]$ \\
\hline Calcium & 3 & 3 & 110 & 45 & $86^{*}$ & $e$ & {$[e]$} \\
\hline Chromium & 3 & 3 & 0.015 & 0.0052 & $0.012^{*}$ & 0.050 & 0[1] \\
\hline Iron & 2 & 3 & 0.055 & 0.054 & $0.055^{*}$ & 0.30 & $0[3]$ \\
\hline Magnesium & 3 & 3 & 29 & 8.0 & $21^{*}$ & $e$ & {$[e]$} \\
\hline Manganese & 2 & 3 & 0.0058 & 0.0027 & 0.0042 & 0.050 & $0[3]$ \\
\hline Nickel & 1 & 3 & 0.0042 & 0.0042 & 0.0042 & 0.10 & $0[1]$ \\
\hline Potassium & 3 & 3 & 1.2 & 0.68 & $0.96^{*}$ & $e$ & {$[e]$} \\
\hline Sodium & 2 & 3 & 17 & 7.9 & 13 & $e$ & {$[e]$} \\
\hline Zinc & 2 & 3 & 0.013 & 0.0060 & 0.0093 & 5.0 & $0[1]$ \\
\hline
\end{tabular}


1992 Environmental Report Vol. 1, Oak Ridge

Table 5.15 (WAG 1 continued)

\begin{tabular}{|c|c|c|c|c|c|c|c|}
\hline \multirow{2}{*}{ Analyte } & \multirow{2}{*}{$\begin{array}{l}\text { Number } \\
\text { detected }\end{array}$} & \multirow{2}{*}{$\begin{array}{c}\text { Number } \\
\text { of } \\
\text { samples }\end{array}$} & \multicolumn{3}{|c|}{ Values above the detection limit } & \multirow{2}{*}{$\begin{array}{l}\text { Reference } \\
\text { value }^{i^{\prime}}\end{array}$} & \multirow{2}{*}{$\begin{array}{l}\text { Number of values } \\
\text { exceeding } \\
\text { reference [ref] }\end{array}$} \\
\hline & & & $\operatorname{Max}^{a}$ & $\operatorname{Min}^{a}$ & $A v^{b}$ & & \\
\hline \multicolumn{8}{|c|}{ Upgradient wells (continued) } \\
\hline \multicolumn{8}{|l|}{ Others, filtered } \\
\hline Solids, total dissolved (mg/L) & 3 & 3 & 400 & 300 & $340^{*}$ & 500 & $0[1]$ \\
\hline \multicolumn{8}{|l|}{ Others, unfiltered } \\
\hline Alkalinity $(\mathrm{mg} / \mathrm{L})$ & 3 & 3 & 350 & 250 & $280^{*}$ & $e$ & {$[e]$} \\
\hline Carbon, total organic $(\mathrm{mg} / \mathrm{L})$ & 3 & 3 & 1.2 & 0.80 & $1.0 *$ & $e$ & {$[e]$} \\
\hline Nitrogen, total Kjeldahl (mg/L) & 1 & 3 & 0.45 & 0.45 & 0.45 & $e$ & {$[e]$} \\
\hline Sulfide, total (mg/L) & 2 & 3 & 0.64 & 0.16 & 0.40 & $e$ & {$[e]$} \\
\hline \multicolumn{8}{|l|}{ Pesticides and PCBs, unfiltered $(\mu \mathrm{g} / \mathrm{L})$} \\
\hline beta-BHC & 1 & 3 & 1.7 & 1.7 & 1.7 & $e$ & {$[e]$} \\
\hline delta-BHC & 1 & 3 & 0.29 & 0.29 & 0.29 & $e$ & {$[e]$} \\
\hline \multicolumn{8}{|l|}{ Radicnuclidesf, filtered (pCi/L) } \\
\hline Gross alpha & 1 & 3 & 1.8 & 1.8 & 1.8 & 15 & $0[2]$ \\
\hline Gross beta & 2 & 3 & 3.8 & 3.5 & $3.6^{*}$ & 50 & $0[2]$ \\
\hline \multicolumn{8}{|l|}{ Radionuclidesf, unfiltered $(\mathrm{pCi} / \mathrm{L})$} \\
\hline${ }^{60} \mathrm{Co}$ & 2 & 3 & 68 & 46 & 57 & 200 & $0[4]$ \\
\hline Gross alpha & 1 & 3 & 2.4 & 2.4 & 2.4 & 15 & $0[2]$ \\
\hline${ }^{3} \mathrm{H}$ & 3 & 3 & 3,200 & 1,300 & $2,400^{*}$ & 20,000 & $0[2]$ \\
\hline${ }^{89} \mathrm{Sr}+{ }^{90} \mathrm{Sr}$ & 1 & 3 & 3.2 & 3.2 & 3.2 & 8.0 & $0[2]$ \\
\hline \multicolumn{8}{|l|}{ Volatile organics, unfiltered $(\mu \mathrm{g} / \mathrm{L})$} \\
\hline Chloroform & 1 & 3 & $\mathrm{~J} 1.0$ & J 1.0 & 1.0 & 100 & $0[2]$ \\
\hline
\end{tabular}

${ }^{a}$ Prefixes J, B, and E mean that the value was estimated, found in the laboratory blank, or exceeded the calibration range, respectively.

${ }^{b}$ An asterisk $\left(^{*}\right)$ follows each mean that is significantly greater than zero.

cIf a reference limit exists, the source is coded as:

1. Rules of Tennessee Department of Environment and Conservation, Bureau of Environment, Division of Water Pollution Control, Chapter 1200-4-3, General Water Quality Criteria, as amended.

2. 40 CFR Part 141-National Primary Drinking Water Regulations, Subparts B and G, as amended.

3. 40 CFR Part 143-National Secondary Drinking Water Regulations, as amended.

4. DOE Order 5400.5, Chapter III, Derived Concentration Guides for Air and Water, as amended.

${ }^{d}$ The source of the reference limit is enclosed within brackets.

eNot applicable.

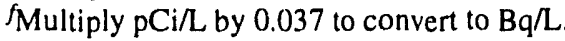


Vol. 2, p. 5-46:

Table 5.20. Constituents in Solid Waste Storage Area (SWSA) 6 groundwater at ORNL semi-annual assessment wells,

February 14-March 1, September 4-October 14, and December 9-18, 1991

\begin{tabular}{|c|c|c|c|c|c|c|c|}
\hline \multirow{2}{*}{ Analyte } & \multirow{2}{*}{$\begin{array}{l}\text { Number } \\
\text { detected }\end{array}$} & \multirow{2}{*}{$\begin{array}{l}\text { Number of } \\
\text { samples }\end{array}$} & \multicolumn{3}{|c|}{ Detected values } & \multirow{2}{*}{$\begin{array}{c}\text { Reference } \\
\text { value }^{c} \dagger\end{array}$} & \multirow{2}{*}{$\begin{array}{l}\text { Number of values } \\
\text { exceeding } \\
\text { relerence [ref]'t }\end{array}$} \\
\hline & & & $\operatorname{Max}^{a}$ & $\operatorname{Min}^{a}$ & $A v^{b}$ & & \\
\hline
\end{tabular}

Downgradient wells

Ficld measurements, unfiltered Conductivity $(\mathrm{mS} / \mathrm{cm})$ Dissolved oxygen (ppm) Redox (mV)

Temperature $\left({ }^{\circ} \mathrm{C}\right)$

Turbidity (JTU)

$\mathrm{pH}$ (standard units)

Others, unfiltered

Alkalinity (mg/L)

Carbon, total organic ( $\mathrm{mg} / \mathrm{L})$

9

5

Radionuclides, filtered $(\mathrm{pCi} / \mathrm{L})^{e}$

${ }^{60} \mathrm{Co}$

Gross alpha

Gross beta

${ }^{3} \mathrm{H}$

${ }^{89} \mathrm{Sr}+{ }^{90} \mathrm{Sr}$

$\begin{array}{ll}18 & 18 \\ 18 & 18 \\ 18 & 18 \\ 18 & 18 \\ 18 & 18 \\ 18 & 18\end{array}$

0.42
9.5
280
21
420
7.7

0.013
0.20
160
12
40
4.8

$0.20^{*}$
$4.4^{*}$
$210^{*}$
$16^{*}$
$130^{*}$
$6.2^{*}$

$d$
$d$
$d$

30

1.0

$(6.5,8.5)$
$[d]$
[d]
[d]
$0[1]$
$18[2]$
$9[3]$

$250 \quad 5$.

3.4

5.0
0.55

$120 *$

$1.2 *$

$d$

[d]

[d]

29

$\begin{array}{rr}2 & 9 \\ 6 & 18\end{array}$

3
6

18
9

9
18

18
9

3

5.4
3.5
7.3
30,000

3.2

2.5

3.8

30,000

9.7

860

5.9

4.3
$2.9^{*}$
$5.0^{*}$
$12,000^{*}$
$8.4^{*}$

8.0
2.0
2.0

200

15

0[4]

$0[2]$

$0[2]$

$80,000 \dagger$

$40 \dagger$

$0[4] \dagger$

$0[4] \uparrow$

Volatile organics, unfiltered $(\mu \mathrm{g} / \mathrm{L})$

Carbon disulfide

Chloroform

Methylene chloride

$\begin{array}{rr}8.0 & 8.0 \\ \mathrm{~J} 2.0 & \mathrm{~J} 2.0 \\ \mathrm{~J} 2.0 & \mathrm{~J} 2.0\end{array}$

8.0
2.0

2.0

$d$
100
$d$

[d]

$0[2]$

Tentatively identified compounds, unfiltered $(\mu \mathrm{g} / \mathrm{L})$

Ethane, 1, 1'-oxybis- 12.82

1

J 300

$\mathrm{J} 300$

300

$d$

$[d]$

Upgradient wells

Field measurements, unfiltered

Conductivity $(\mathrm{mS} / \mathrm{cm})$
Dissolved oxygen $(\mathrm{ppm})$
Redox $(\mathrm{mV})$
Temperature $\left({ }^{\circ} \mathrm{C}\right)$
Turbidity $(\mathrm{JTU})$
pH (standard units)

$\begin{array}{ll}14 & 14 \\ 13 & 13 \\ 14 & 14 \\ 14 & 14 \\ 13 & 13 \\ 14 & 14\end{array}$

0.84
11
280
16
930
8.5

0.023
3.0
17
12
53
4.9
$0.33^{*}$ $6.0^{*}$
$190^{*}$
$14^{*}$
$180^{*}$
$7.3^{*}$

$d$
$d$
$d$
30
1.0
$(6.5,8.5)$

[d]

[d]

[d]

$0[1]$

13[2] 
1992 Environmental Report Vol. 1, Oak Ridge

Table 5.20 (SWSA 6 continued)

\begin{tabular}{|c|c|c|c|c|c|c|c|}
\hline \multirow{2}{*}{ Analyte } & \multirow{2}{*}{$\begin{array}{l}\text { Number } \\
\text { detected }\end{array}$} & \multirow{2}{*}{$\begin{array}{c}\text { Number of } \\
\text { samples }\end{array}$} & \multicolumn{3}{|c|}{ Detected values } & \multirow{2}{*}{$\begin{array}{c}\text { Reference } \\
\text { valuec }\end{array}$} & \multirow{2}{*}{$\begin{array}{l}\text { Number of values } \\
\text { exceeding } \\
\text { reference }[\mathrm{ref}]^{c}\end{array}$} \\
\hline & & & $\operatorname{Max}^{a}$ & $\operatorname{Min}^{a}$ & $A v^{b}$ & & \\
\hline \multicolumn{8}{|c|}{ Upgradient wells (continued) } \\
\hline \multicolumn{8}{|l|}{ Others, unfiltered } \\
\hline Alkalinity $(\mathrm{mg} / \mathrm{L})$ & 7 & 7 & 430 & 7.5 & $210^{*}$ & $d$ & $\lfloor d]$ \\
\hline Carbon, total organic $(\mathrm{mg} / \mathrm{L})$ & 3 & 7 & 1.1 & U 0.73 & $0.90^{*}$ & $d$ & {$[d]$} \\
\hline Halides, total organic $(\mu \mathrm{g} / \mathrm{L})$ & 1 & 7 & U 5.9 & U 5.9 & 5.9 & $d$ & {$[d]$} \\
\hline \multicolumn{8}{|l|}{ Radionuclides, filtered $(\mathrm{pCi} / \mathrm{L})^{e}$} \\
\hline${ }^{137} \mathrm{Cs}$ & 1 & 7 & 4.3 & 4.3 & 4.3 & 120 & $0[4]$ \\
\hline Gross alpha & 5 & 14 & 2.6 & 2.0 & $2 . .3 *$ & 15 & $0[2]$ \\
\hline Gross beta & 4 & 7 & 13 & 5.7 & $8.4^{*}$ & 50 & $0[2]$ \\
\hline${ }^{3} \mathrm{H}$ & 2 & 14 & 1,000 & 810 & $910^{*}$ & $80,000 \dagger$ & $0[4] \dagger$ \\
\hline
\end{tabular}

"Prefixes J, B, and E mean that the value was estimated, found in the laboratory blank, or exceeded the calibration range, respectively.

${ }^{h}$ An asterisk (*) follows each mean that is significantly greater than zero.

${ }^{c}$ If a reference limit exists, the source is enclosed in brackets and coded as:

1. Rules of Tennessee Department of Health and Environment, Bureau of Environment, Division of Water Pollution Control, Chapter 1200-4-3, General Water Quality Criteria, February 1987.

2. 40 CFR (7-1-1990 edition) Part 141-National Primary Drinking Water Regulations, Subparts B and G, as amended. Applicable reference standard as required by RCRA regulations.

3. 40 CFR (7-1-1990 edition) Part 143-National Secondary Drinking Water Regulations, as amended.

4. DOE Order 5400.5, Chapter III, Derived Concentration Guides for Air and Water, as amended.

${ }^{d}$ Not applicable.

${ }^{e}$ Multiply $\mathrm{pCi} / \mathrm{L}$ by 0.037 to convert to $\mathrm{Bq} / \mathrm{L}$. 
Vol. 2, p. 5-48:

Table 5.21. Constituents in Solid Waste Area (SWSA) 6 groundwater

at ORNL quarterly assessment wells,

February 14-March 1, September 4-October 14, and December 9-18, 1991

\begin{tabular}{|c|c|c|c|c|c|c|c|}
\hline \multirow{2}{*}{ Analyte } & \multirow{2}{*}{$\begin{array}{l}\text { Number } \\
\text { detected }\end{array}$} & \multirow{2}{*}{$\begin{array}{l}\text { Number of } \\
\text { samples }\end{array}$} & \multicolumn{3}{|c|}{ Detected values } & \multirow{2}{*}{$\begin{array}{c}\text { Reference } \\
\text { value't }\end{array}$} & \multirow{2}{*}{$\begin{array}{l}\text { Number of } \\
\text { values } \\
\text { exceeding } \\
\text { reference } \\
\text { [ref|ct }\end{array}$} \\
\hline & & & $\operatorname{Max}^{a}$ & $\operatorname{Min}^{a}$ & $A v^{b}$ & & \\
\hline \multicolumn{8}{|c|}{ Field measurements, unfiltered } \\
\hline Conductivity $(\mathrm{mS} / \mathrm{cm})$ & 30 & 30 & 0.83 & 0.10 & $0.48^{*}$ & $d$ & {$[d]$} \\
\hline Dissolved oxygen (ppm) & 30 & 30 & 12 & 0.010 & $4.8^{*}$ & $d$ & {$[d]$} \\
\hline Redox $(\mathrm{mV})$ & 30 & 30 & 660 & 150 & $210^{*}$ & $d$ & {$[d]$} \\
\hline Temperature $\left({ }^{\circ} \mathrm{C}\right)$ & 30 & 30 & 16 & 11 & $14^{*}$ & 30 & $0[1]$ \\
\hline Turbidity (JTU) & 30 & 30 & 760 & 6.3 & $150^{*}$ & 1.0 & $30[2]$ \\
\hline $\mathrm{pH}$ (standard units) & 30 & 30 & 8.3 & 5.9 & $7.3^{*}$ & $(6.5,8.5)$ & $1[3]$ \\
\hline \multicolumn{8}{|l|}{ Others, unfiltered } \\
\hline Alkalinily (mg/L) & 30 & 30 & 480 & 30 & $290^{*}$ & $d$ & {$[d]$} \\
\hline \multicolumn{8}{|c|}{ Radionuclides, filtered ( $\mathrm{pCi} / \mathrm{L})^{e}$} \\
\hline${ }^{60} \mathrm{Co}$ & 12 & 30 & 970 & 4.3 & $340^{*}$ & 200 & $6[4]$ \\
\hline${ }^{137} \mathrm{Cs}$ & 1 & 30 & 3.2 & 3.2 & 3.2 & 120 & $0[4]$ \\
\hline Gross alpha & 12 & 30 & 26 & 1.4 & $4.8^{*}$ & 15 & $1[2]$ \\
\hline${ }^{3} \mathrm{H}$ & 28 & 30 & $2,100,000$ & 490 & $360,000^{*}$ & $80,000 \dagger$ & $15[4] \dagger$ \\
\hline${ }^{89} \mathrm{Sr}+{ }^{90} \mathrm{Sr}$ & 14 & 30 & 54 & 1.9 & $13^{*}$ & $40 \dagger$ & $1[4] \dagger$ \\
\hline \multicolumn{8}{|c|}{ Volatile organics, unfiltered $(\mu \mathrm{g} / \mathrm{L})$} \\
\hline $1,1,1$-Trichloroethane & 1 & 30 & $\mathrm{~J} 1.0$ & J 1.0 & 1.0 & 200 & $0[2]$ \\
\hline 1,1-Dichloroethane & $i$ & 30 & $\mathrm{~J} 2.0$ & $\mathrm{~J} 2.0$ & 2.0 & $d$ & {$[d]$} \\
\hline 1,2-Dichloroethane & 3 & 30 & 19 & 11 & $15^{*}$ & 5.0 & $3[2]$ \\
\hline 1,2-Dichloroethene & 6 & 30 & 10 & $\mathrm{~J} 4.0$ & $6.7^{*}$ & $d$ & {$[d]$} \\
\hline 4-Methyl-2-pentanone & 1 & 30 & J 5.0 & J 5.0 & 5.0 & $d$ & {$[d]$} \\
\hline Acetone & 4 & 30 & JB 5.0 & JB 3.0 & $3.8^{*}$ & $d$ & {$[d]$} \\
\hline Benzene & 1 & 30 & J 3.0 & J 3.0 & 3.0 & 5.0 & $0[2]$ \\
\hline Carbon disulfide & 2 & 30 & 160 & B 33 & 97 & $d$ & {$[d]$} \\
\hline Carbon tetrachloride & 3 & 30 & 65 & 40 & $52 *$ & 5.0 & $3[2]$ \\
\hline Chloroform & 4 & 30 & 60 & $\mathrm{~J} 2.0$ & $40^{*}$ & 100 & $0[2]$ \\
\hline Methylene chloride & 1 & 30 & J 2.0 & J 2.0 & 2.0 & $d$ & {$[d]$} \\
\hline Styrene & 1 & 30 & J 1.0 & $\mathrm{~J} 1.0$ & 1.0 & $d$ & {$[d]$} \\
\hline Trichloroethene & 6 & 30 & E 330 & J 1.0 & $140^{*}$ & 5.0 & $4[2]$ \\
\hline
\end{tabular}


1992 Environmental Report Vol. 1, Oak Ridge

Table 5.21 (SWSA 6 continued)

\begin{tabular}{|c|c|c|c|c|c|c|c|}
\hline \multirow{2}{*}{ Analyte } & \multirow{2}{*}{$\begin{array}{l}\text { Number } \\
\text { detected }\end{array}$} & \multirow{2}{*}{$\begin{array}{l}\text { Number } \\
\text { of } \\
\text { samples }\end{array}$} & \multicolumn{3}{|c|}{ Detected values } & \multirow{2}{*}{$\begin{array}{c}\text { Reference } \\
\text { value }{ }^{c} \dagger\end{array}$} & \multirow{2}{*}{$\begin{array}{l}\text { Number of values } \\
\text { exceeding } \\
\text { reference [ref]' }\end{array}$} \\
\hline & & & $\operatorname{Max}^{a}$ & $\operatorname{Min}^{a}$ & $A v^{h}$ & & \\
\hline \multicolumn{8}{|c|}{ Tentatively identified compounds, unfiltered $(\mu \mathrm{g} / \mathrm{L})$} \\
\hline 1,2,2-Trifluoro-chloro-7.83 & 1 & 1 & $\mathrm{~J} 12$ & $\mathrm{~J} 12$ & 12 & $d$ & {$[d]$} \\
\hline 1-Hexanol,2-ethyl-28.66 & 2 & 2 & $\mathrm{~J} 5.0$ & J 5.0 & 5.0 & $d$ & {$[d]$} \\
\hline Ethane,1,1,2-trichloro-7.85 & 1 & 1 & J 8.0 & J 8.0 & 8.0 & $d$ & [d] \\
\hline Methane,trichlorofluoro-6.9 & 1 & 1 & $\mathrm{~J} 7.0$ & J 7.0 & 7.0 & $d$ & [d] \\
\hline Methane,trichlorofluoro-6.91 & 1 & 1 & $\mathrm{~J} 8.0$ & J 8.0 & 8.0 & $d$ & [d] \\
\hline Methane,trichlorofluoro-6.94 & 1 & 1 & $\mathrm{~J} 8.0$ & J 8.0 & 8.0 & $d$ & {$[d]$} \\
\hline Unknown-18.78 & 1 & 1 & $\mathrm{~J} 23$ & $\mathrm{~J} 23$ & 23 & $d$ & [d] \\
\hline Unknown-22.87 & 1 & 1 & J 160 & J 160 & 160 & $d$ & {$[d]$} \\
\hline Unknown-25.36 & 1 & 1 & $\mathrm{~J} 9.0$ & J 9.0 & 9.0 & $d$ & {$[d]$} \\
\hline Unknown-25.37 & 2 & 2 & $\mathrm{~J} 8.0$ & $\mathrm{~J} 7.0$ & $7.5^{*}$ & $d$ & [d] \\
\hline Unknown-26.64 & 1 & 1 & $\mathrm{~J} 200$ & J 200 & 200 & $d$ & [d] \\
\hline Unknown-30.12 & 1 & 1 & J 6.0 & $\mathrm{~J} 6.0$ & 6,0 & $d$ & {$[d]$} \\
\hline Unknown-30.13 & 2 & 2 & J 8.0 & J 6.0 & $7.0^{*}$ & $d$ & {$[d]$} \\
\hline
\end{tabular}

aPrefixes J, B, and E mean that the value was estimated, found in the laboratory blank, or exceeded the calibration range, respectively.

${ }^{b}$ An asterisk $\left({ }^{*}\right)$ follows each mean that is significantly greater than zero.

$c^{c}$ If a reference limit exists, the source is enclosed in brackets and coded as:

1. Rules of Tennessee Department of Health and Environment, Bureau of Environment, Division of Water Pollution Control, Chapter 1200-4-3, General Water Quality Criteria, February 1987.

2. 40 CFR (7-1-1990) Part 141-National Primary Drinking Water Regulations, Subparts B and G, as amended. Applicable reference standard as required by RCRA regulations.

3. 40 CrR (7-1-1990) Part 143-National Secondary Drinking Water Regulations, as amended.

4. DOE Order 5400.5, Chapter III, Derived Concentration Guides for Air and Water, as amended.

Not applicable.

eMultiply pCi/L by 0.037 to convert to $\mathrm{Bq} / \mathrm{L}$. 


\section{Table C.1. Commonly used population parameters and sample statistics}

\begin{tabular}{|c|c|}
\hline Population parameters & $\begin{array}{l}\text { Sample statistics } \\
\text { (Estimators of parameters) }\end{array}$ \\
\hline$\mu_{x}($ mean-first moment $)$ & $X=\frac{1}{n} \sum_{i=1}^{n} x_{i}$ \\
\hline$\sigma_{x}^{2}($ variance-second central moment) & $s_{x}^{2}=\frac{1}{n-1} \sum_{i=1}^{n}\left(x_{i}-\bar{x}\right)^{2}$ \\
\hline$\sigma_{x}$ (standard deviation of $x$ about $\mu_{x}$ ) & $s_{x}=\sqrt{s_{x}^{2}}$ \\
\hline $\begin{array}{l}\sigma_{\bar{x}} \text { (standard error of the mean, or } \\
\text { standard deviation of the average) }\end{array}$ & $s_{x}=\frac{1}{\sqrt{n}} s_{x}$ \\
\hline$\sigma_{x y}=\sigma_{y x}($ covariance $)$ & $s_{x y}=s_{y x}=\frac{1}{n-1} \sum_{i=1}^{n}\left(x_{i}-\bar{x}\right)\left(y_{i}-\bar{y}\right)$ \\
\hline $\begin{array}{l}\frac{\sigma}{\mu}(100) \text { (coefficient of variation, or } \\
\begin{array}{l}\text { relative standard deviation, } \\
\text { expressed in percent) }\end{array}\end{array}$ & $v_{x}=\frac{s_{x}}{\bar{x}}(100)$ \\
\hline
\end{tabular}

examination of the data for any marked departures from normality. There are some simple procedures to do this. They include construction of a histogram or graphical test using probability paper. The discussion of random uncertainties that follows assumes that a normal distribution is justifiable. It can be shown that this subsequent treatment is not absolutely dependent on a normal population distribution. The Central Limit Theorem states this, provided the departures are not too great, and further predicts that the convolution or folding together of nonnormal distributions tends to form normal distributions. The probabilities for some typical intervals in the normal distribution are provided in Table B.2. As stated before, an analysis of the observed values will be used to estimate $\mu$ and $\sigma^{2}$

Table C.2. Probabilities for same typical intervals in normal distribution

\begin{tabular}{cc}
$\begin{array}{c}\text { Interval } \\
\left(\mu-\zeta \sigma_{x}\right) \text { to }\left(\mu+\zeta \sigma_{x}\right) \\
(\zeta)\end{array}$ & $\begin{array}{c}\text { Percentage of the } \\
\text { population within } \\
\text { this interval } \\
(\%)\end{array}$ \\
\hline 0.6745 & 50 \\
1.000 & 68.269 \\
1.960 & 95 \\
2.000 & 95.450 \\
2.576 & 99 \\
3.000 & 99.73 \\
\hline
\end{tabular}

\section{C-2 Appendix}




\section{Sample Mean and Standard Deviation}

For $n$ measurements of $x$, the best estimate of the parameter $\mu$ is obtained from the mean $(\bar{x})$ of the sample, and the best estimate of $\sigma^{2}$ from the variance $\left(s_{x}^{2}\right)$, where

$$
\bar{x}=\frac{1}{n} \sum_{i=1}^{n} x_{i} \rightarrow \mu
$$

and

$$
s_{x}^{2}=\frac{1}{n-1} \sum_{i=1}^{n}\left(x_{1}-\bar{x}^{2} \rightarrow \sigma_{x}^{2}\right.
$$

The sample standard deviation is the square root of the variance, or the quantity $s_{x}$. It refers to the standard deviation computed from a sample of measurements.

\section{Standard Error of the Mean}

Any mean $\bar{x}$ is determined from a finite number of measurements. If the determination is repeated, one can obtain a series of slightly different $\bar{x}$ values. According to the Central Limit Theorem, for large $n$, the distribution of these $\bar{x}$ values will be close to normal for any distribution of $x$ that has at least two finite moments. Thus, a standard deviation of this distribution could be obtained from repeated determinations of $\bar{x}$. It may, however, also be estimated from just the measurements used in a single determination of $\bar{x}$. This estimate of the precision on the mean is termed the standard error of the mean $\left(s_{x}^{2}\right)$, which is given by

$$
s_{x}^{2}=\frac{s_{x}^{2}}{n}=\frac{1}{n(n-1)} \sum_{i=1}^{n}\left(x_{i}-\bar{x}\right)^{2}
$$

The quantity $s_{x}^{2}$ is termed the variance of the mean. The standard error of the mean $\left(s_{x}\right)$ must not be confused with the sample standard deviation $\left(s_{\mathrm{x}}\right)$. The standard deviation $s_{\mathrm{x}}$ is only dependent on the measurement precision, whereas $s_{x}$ depends on both the precision and the number of observations.

\section{Statistical Treatment of Data Below the Detection Limit}

Results obtained in the laboratory are often reported as "less than" or "below detection." In these situations the detection limit is reported along with the "less than" designation. The sample mean and standard error of the mean are affected by these values; they become "biased" - biased high for the mean and low for the standard error of the mean. That is, the sample standard error of the mean is estimating something smaller than the true standard error.

A further cunsequence of the bias is an increased likelihood that a population mean will be declared greater than zero in a statistical test using the biased sample mean and standard error. A statistically significant result may be a consequence of the number of values below the detection limit. If, however, there were a number of values above the detection limit, the conclusion that the true mean is greater than zero may be valid even though the estimate of true mean is biased. 


\section{Internal Distribution}

\author{
1. T. A. Acox \\ 2. W. A. Alexander \\ 3. D. I. Allen \\ 4. G. E. Anderson \\ 5. A. D. Arms \\ 6. D. L. Armstrong \\ 7. D. L. Ashburn \\ 8. T. L. Ashwood \\ 9. J. B. Atwater \\ 10. M. L. Baker \\ 11. B. D. Barkenbus \\ 12. F. P. Baxter \\ 13. D. E. Beck \\ 14. H. C. Beeson \\ 15. B. A. Berven \\ 16. C. R. Bieber \\ 17. R. M. Bishop \\ 18. T. J. Blasing \\ 19. D. M. Borders \\ 20. D. J. Bostock \\ 21. K. L. Brady \\ 22. C. W. Broughton \\ 23. T. R. Butz \\ 24. S. A. Carnes \\ 25. W. W. Chance \\ 26. R. B. Clapp \\ 27. D. E. Conrad \\ 28. K. W. Cook \\ 29. R. B. Cook \\ 30. L. M. Cuddy \\ 31. N. H. Cutshall \\ 32. M. P. DeLozier \\ 33. R. J. Devol \\ 34. F. Dickens \\ 35. L. C. Dolan \\ 36. J. G. Dorsey \\ 37. R. C. Durfee \\ 38. T. O. Early \\ 39. J. M. Eaton \\ 40. H. L. Fellers \\ 41. C. J. Ford \\ 42. J. M. Forstrom \\ 43. M. W. Francis
}

44. D. W. Frazier

45. R. E. Frounfelker

46. C. E. Frye

47. J. W. Garber

48. C. T. Garten, Jr.

49. R. W. Glass

50. H. A. Glovier, Jr.

51. G. A. Goslow

52. P. S. Gouge

53. P. A. Gourieux

54. R. L. Grant

55. J. T. Grumski

56. M. G. Guhy

57. L. E. Hall

58. J. L. Haymore

59. J. C. Henderson

60. D. D. Herr

61. S. G. Hildebrand

62. C. C. Hill

63. D. A. Hill

64. R. M. Hill

65. R. L. Hinzman

66. J. W. Hodge

67. F. Homerosky, Jr.

68. K. Horsley

69. R. L. Howell

70. D. D. Huff

71. W. K. Jago

72. T. G. Jett

73. C. G. Jones

74. K. G. Kahl

75. R. J. Keeling

76. J. E. Keyes

77. R. M. Keyser

78. C. W. Kimbrough

79. R. H. Kingrea

80. A. F. Kiriluk

81. M. E. Kirker

82. K. L. Kliewer

83. W. S. Koncinski

84. O. C. Kopp

85. F. C. Kornegay

86. E. H. Krieg, Jr. 


\author{
87. S. Y. Lee \\ 88. D. A. Levine \\ 89. J. M. Loar \\ 90. L. W. Long \\ 91. P. Y. Lu \\ 92. F. C. Maienschein \\ 93. A. P. Malinauskas \\ 94. W. D. Malis \\ 95. F. K. Martin \\ 96. J. C. Massey \\ 97. R. A. McCord \\ 98. J. G. McDonald \\ 99. R. J. McElhaney \\ 100-114. L. W. McMahon \\ 115. N. G. McRae \\ 116. S. A. Meacham \\ 117. A. R. Merrill, Jr. \\ 118. L. J. Mezga \\ 119. D. Milan \\ 120. J. L. Miranda \\ 121. G. K. Moore \\ 122. J. J. Morello, Jr. \\ 123. G. L. Murphy \\ 124-138. J. B. Murphy \\ 139. F. R. Mynatt \\ 140. C. E. Nix \\ 141. M. J. Norris \\ 142. F. R. O'Donnell \\ 143. W. F. Ohnesorge \\ 144. P. E. Osborne \\ 145. P. D. Parr \\ 146. S. E. Payne \\ 147. D. C. Pentecost \\ 148. M. J. Peterson \\ 149. G. V. Pierce \\ 150. P. Potter \\ 151. J. E. Powell \\ 152. R. E. Pudelek \\ 153. R. M. Reed \\ 154. D. E. Reichle \\ 155. J. B. Richard \\ 156. R. Richmond \\ 157-161. J. G. Rogers \\ 162. P. S. Rohwer \\ 163. R. T. Roseberry \\ 164. R. H. Ross \\ 165. T. H. Row \\ 166. R. M. Rush \\ 167. G. E. Rymer \\ 168. L. B. Ryon
}

169. E. M. Schilling

170. T. E. Shannon

171. J. Sheffield

172. C. W. Sheward

173-187. L. G. Shipe

188. D. S. Shriner

189. B. F. Siefken

190. C. S. Sims

191. S. P. N. Singh

192. N. L. Sinor

193. E. L. Smith, Jr.

194-195. M. C. Smith

196. M. L. Socolof

197. G. R. Southworth

198. R. J. Spence

199. E. G. St. Clair

200. D. L. Stansberry

201. A. J. Stewart

202. L. E. Stokes

203. J. E. Stone

204. J. D. Story

205. S. H. Stow

206. M. F. Tardiff

207. F. G. Taylor, Jr.

208. N. A. Teasley, Jr.

209. W. A. Thomas

210. P. B. Thompson

211. W. W. Thompson, Jr.

212. K. M. Tomko

213. J. R. Trabalka

214. R. R. Turner

215. C. J. Van Meter

216. L. O. Vaughan

217. P. R. Wasilko

218. J. S. Wassom

219. C. W. Weber

220. R. W. Weigel

221. L. Welch

222-271. D. C. West

272. D. A. White

273. M. G. White

274. R. K. White

275. M. C. Wiest, Jr.

276-277. C. K. Williams, III

278. J. K. Williams

279. W. R. Williams

280. A. R. Wilson

281. S. L. Winters

282. Central Research Library

283. DOE K-25 Site Office 
284. DOE Y-12 Site Office

285. ESD Library

286-288. ORNL Laboratory Records

289. ORNL Laboratory Records-RC

290. ORNL Patent Section
291. ORNL Y-12 Technical Library

292. PGDP Library

293. PORTS Library

294. K-25 CEP Document Center

295. K-25 Site Library

\section{External Distribution}

296. Office of Assistant Manager for Energy Research and Development, U.S. Department of Energy Oak Ridge Field Office, P. O. Box 2001, Oak Ridge, TN 37831-8600.

297-298. Office of Scientific and Technical Information, P. O. Box 62, Oak Ridge, TN 37831.

299-700. This report is distributed widely by the Department of Energy's Oak Ridge Operations Office to local, state, and federal government agencies, the Congress, the public, and the news media. 

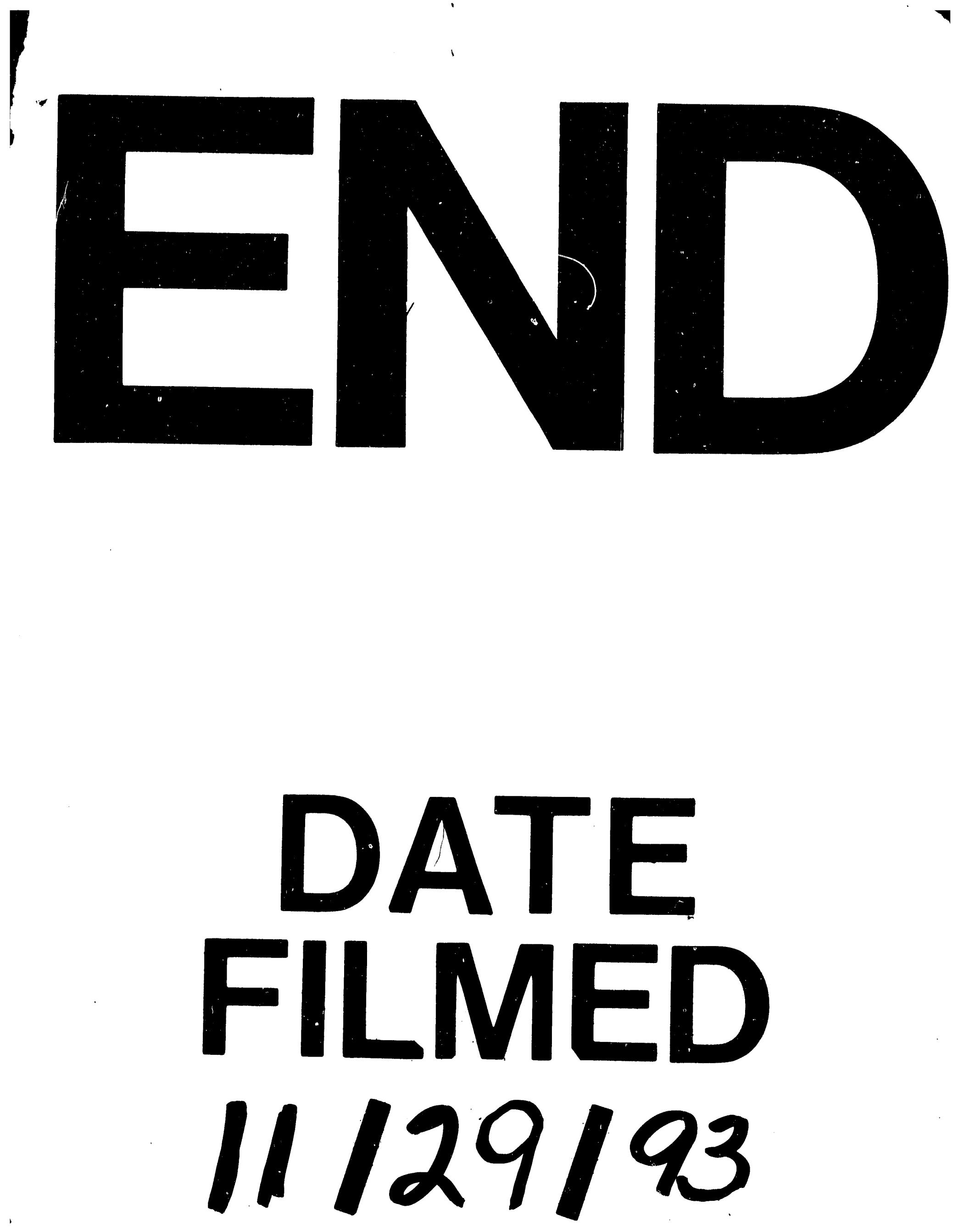
